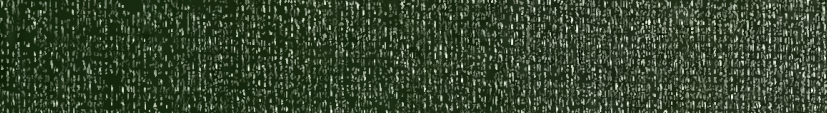

-

1.5. 4. T.7.

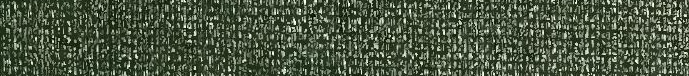
t. 2.

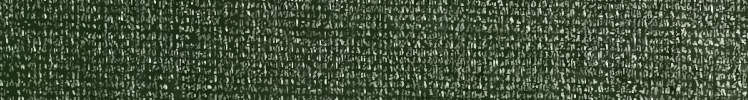
2. 6. 4. 4. 1.7. 4.

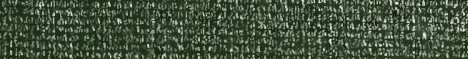

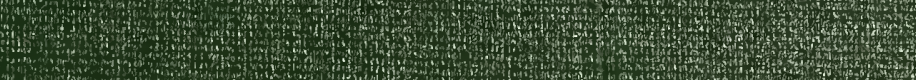

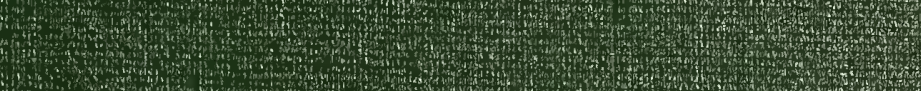

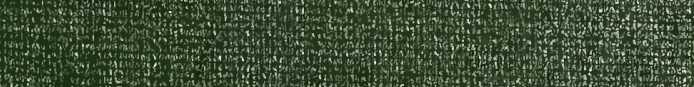
(1)

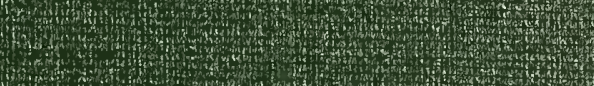

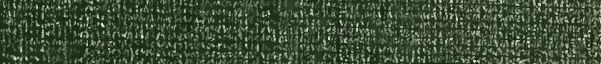

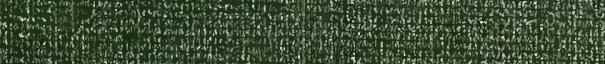

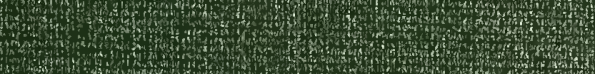

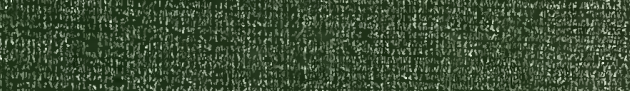

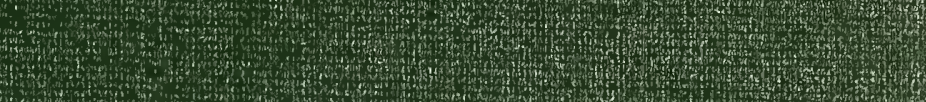
2.7.

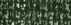

(1)

然

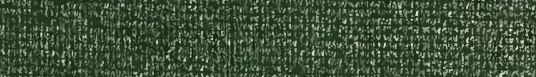
4. 1.

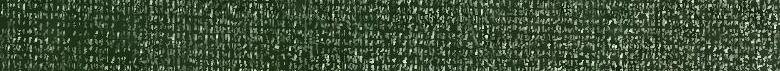
(1) 4

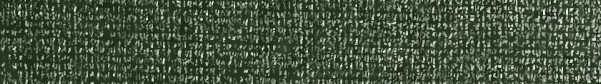
4.

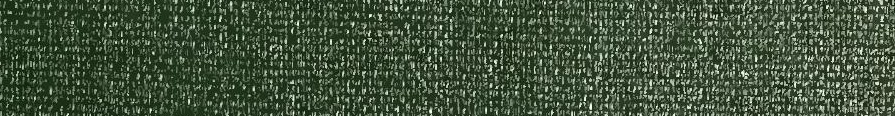
1.4.

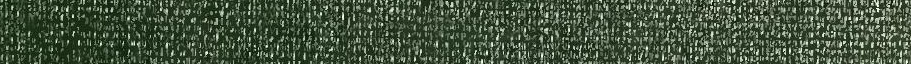
1.7.4. 7

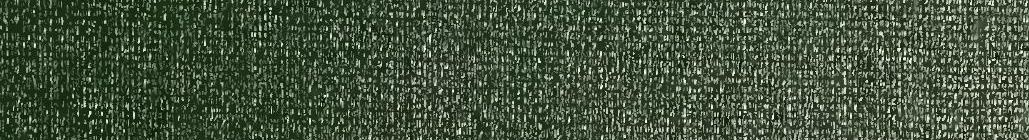

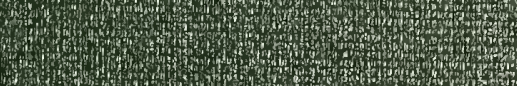





Jniuersity of Atlichiqan Studies

HUMANISTIC SERIES

VOLUME XIII

FRAGMENTS FROM THE CAIRO

GENIZAH IN THE FREER

COLLECTION 


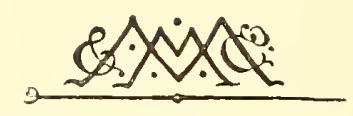

THE MACMILLAN COMPANY:

NEW YORK - BOSTON - CHICAGO

DALLAS - SAN FRANCISCO

MACMILLAN AND CO., LIMITED

LONDON · BOMBAY • CALCUTTA - MADRAS MELBOURNE

THE MACMILLAN CO. OE CANADA, LtD. TORONTO 


\section{FRAGMENTS}

FROM THE

\section{CAIRO GENIZAH}

IN THE

\section{FREER COLLECTION 08.44}

EDITED BY

RICHARD GOTTHEIL

COLUMBIA UNIVERSITY

AND

WILLIAM H. WORRELL

UNIVERSITY OF MICHIGAN

涩ew Pork

THE MACMILLAN COMPANY

LONDON: MACMILLAN AND COMPANY, LTD.

I 927

All rights reserved

Ereer Gallery of Are

Washington, D. C. 
COPXRIGHT, I927,

BY FRANCIS W. KELSEY, EdITOR.

Published May r927.

PRINTED IN GREAT BRITAIN

BY W. LEWIS, M.A., AT THE UNIVERSITY PRESS, CAMBRIDGE. 


\section{PREFACE}

The documents from the Cairo Genizah published in this volume were obtained by Mr Charles L. Freer in Egypt in 1908. They now form a part of the collections in the Freer Gallery of Art in Washington, D.C.

In December, I 906, Mr Freer had purchased at Gizeh the now well-known Greek manuscripts of Deuteronomy and Joshua, the Gospels and the Psalms, and fragments of a manuscript of the Epistles of Paul. A report upon them was made by Professor Henry A. Sanders at the meeting of the Archaeological Institute of America in Chicago at the end of December, ig07. Much interest was aroused; and since it seemed probable that the manuscripts had been found in the ruins of a monastery and had formed a part of a monastic library, Mr Freer resolved to spare no effort to obtain other portions of the same collection in case such should have been brought to light. With this in mind, he made a special trip to Egypt in I 908. The most diligent inquiry, however, failed to elicit information that would lead to the recovery of other Greek manuscripts of value; but in his quest Mr Freer did secure some Coptic parchments, in which was included a Psalter, and the Genizah fragments.

The Coptic Psalter was handed to me by Mr Freer in Detroit on September 15, 1908. A few days later his Curator brought to me at the University of Michigan the remaining Coptic leaves and the Genizah documents. All this material was at once examined by Dr William H. Worrell. The Coptic Psalter and the other leaves afterwards were published by Mr Worrell in Volume X of the Humanistic Series of the University of Michigan Studies; in the same series, Volumes VIII and IX, Mr Sanders had already published the Greek manuscripts.

Learning of the presence of the Genizah documents in Detroit, and appreciating, as few scholars would, their value as source material for the history of an obscure but important period, Professor Richard Gottheil in I 9 I 2 undertook to prepare them for publication. He had accomplished the extremely difficult task of transcribing the texts when the war broke out. Responding to the call of duty, with much personal sacrifice and risk to health, he devoted himself to humanitarian work in New York until the Armistice, and beyond. 
Resuming his preparation of the Genizah material as soon as possible, he finished the first draft of the translation of nearly all the documents, and had commenced the preparation of notes, when an accumulation of work, due to having been called to spend an academic year at the University of Strasbourg, obliged him to ask to be relieved from further responsibility for the completion of the volume.

Very reluctantly the request of Professor Gottheil was granted, and he placed all the material in the hands of Professor Worrell in November, 1924. It is not possible to distinguish by marks the work of the two scholars, but for the final form of the volume Professor Worrell is alone responsible. Professor Gottheil personally examined certain Genizah documents in the TaylorSchechter, Bodleian, British Museum and Paris Consistoire collections; and his name is therefore given with the observations bearing upon these collections. Similarly his name is mentioned in a number of other instances in which $\mathrm{Mr}$ Worrell was unable to verify sources or to express a personal opinion. Dr Samuel Feigin worked out No. XLIV independently, and that number has been printed just as it came from his pen, entirely upon his responsibility.

Professor A. Marx, Professor Ginzberg, and Professor Israel Davidson, all of the Jewish Theological Seminary of America, Mr David Yellin, of Jerusalem, and Mr B. Chapira, of Paris, assisted Professor Gottheil with particular matters which have been acknowledged in their place. Mr Leon Nemoy, of Yale University, verified references to books in distant libraries. Anne MacKenzie Worrell gave vital assistance with references, analyses, manuscript, and proof. The Jewish Institute of Religion, New York, the Case Memorial Library, Hartford, Ct., the Hebrew Union College, Cincinnati, and the University of Michigan, loaned books of reference. To all of these the editors unite in expressing their indebtedness.

The heliotype plates of the volume were executed by the Heliotype Company, in Boston, under the direction of $\mathrm{Mr} \mathrm{W}$. C. Ramsay. The cost of publication was defrayed from the Freer Research and Publication Fund of the University of Michigan.

UNIVERSITy OF Michigan,

FRANCIS W. KELSEY. July го, 1926. 


\section{CONTENTS}

INTRODUCTION :

PAGE

i. The Cairo Genizah

ii. The Freer Collection .

iii. The Paper .

iv. The Handwriting

v. The Dating

vi. 'The Language and Languages

vii. Arabic

viii. Hebrew and Aramaic .

ix. Contents

x. Geography

xi. Biography

xii. Jew and Gentile.

xiii. Marriage

xiv. Religion, Learning, Superstition

xv. Commerce and Manufacture

xvi. Proper Names

xvii. Purpose and Plan of Publication

Texts, Translations and Notes:

II. Letter

III. Letter

IV. Letter

V. Letter

VI. Halachic Fragment

VII. Memorandum .

VIII. Letter

IX. Letter

X. A Leaf from a Prayer-Book

XI. Bill of Divorce

XII. Letter

XIII. List of Tax-Payers .

XIV. Leaf from a Merchant's Note-Book .

XV. Charm

XVI. Document

XVIII. Leaf from a Merchant's Note-Book .

Poetic Fragments upon the Back of an Arabic Document

XX. Leaf from a Book of Poems . . . . . . 90

XXI. Letter . . . . . . . . 94

XXII. A Business Letter . . . . . . . . 96

XXIII. Notes on the Back of a Letter . . . . . 100

$\mathrm{xi}$

xiv

xiv

xiv

$\mathrm{xvi}$

xvi

xviii

xxii

xxiii

xxiv

xxiv

xxvi

xxvii

xxvii

xxviii

xxix

$\mathrm{XXX}$$$
\text { 100 }
$$ 
Texts, Translations and Notes (contd.): XXIV. Charm

XXV. A Scrap of Paper . . . . . . . . Iо8

XXVI. Letter . . . . . . . . . . II

XXVII. Letter . . . . . . . . . . 116

XXVIII. Part of a Letter . . . . . . . . . 130

XXIX. Pizmōnīm . . . . . . . . . . . I34

XXX. Part of a Letter . . . . . . . . ${ }_{1} 3^{8}$

XXXI. Part of a Letter . . . . . . . . 142

XXXIl. Part of a Letter . . . . . . . . 146

XXXIII. Letter. . . . . . . . . . 150

XXXIV. Letter . . . . . . . . . ${ }^{156}$

$\mathrm{XXXV}$, Letter . . . . . . . . . 160

XXXVI. An Accounting . . . . . . . . ${ }^{164}$

XXXVII. Letter. . . . . . . . . 170

XXXVIII. Poetic Biblical Paraphrases . . . . . . 172

XXXIX. Fragment of Maimonides . . . . . 176

XL. Leaves from the Note-Book of a Marriage Broker . . $\quad$ I 78

XLI. Letter . . . . . . . . . . 190

XLII. Liturgical Memoranda . . . . . . . I94

XLIII. Agreement in Regard to the Academy at al-Ramlah . I96

XLIV. Halachic Fragment . . . . . . . 202

XLV. Leaves from a Note-Book . . . . . . 218

XLVI. A Page from a Prayer-Book . . . . . . 226

XLVII. Letter. . . . . . . . . . 228

XLVIII. Letter . . . . . . . . . 236

XLIX. Letter from a Lady . . . . . . . 242

L. Three Letters of Complaint . . • . . . 246

INDEXES :

Index of Subjects . . . . . . . . . . 267

Index of Proper Names : . . . . . . . . 269

Arabic and Hebrew . $\quad . \quad$. . . . . . . 273 


\section{LIST OF PLATES}

PLATE

FACING PAGE

I. Fragment i a

II. Fragment $\mathrm{I} b$

III. Fragment 2 a

IV. Fragment $2 \mathrm{~b}$

V. Fragment $3 \mathrm{a}$

VI. Fragment $3 b$

VII. Fragment 4 .

VIII. Fragment $5 \mathrm{a}$

IX. Fragment $5 \mathrm{~b}$

X. Fragment 7 .

XI. Fragment 8a

XII. Fragment $8 \mathrm{~b}$

XIII. Fragment 9a

XIV. Fragment $9 \mathrm{~b}$

XV. Fragment I 2

XVI. Fragment I4a

XVII. Fragment $\mathrm{i}_{4} \mathrm{~b}$

XVIII. Fragment I $_{5}$ a

XIX. Fragment I $5 \mathrm{~b}$

XX. Fragment 16 a

XXI. Fragment $16 \mathrm{~b}$

XXII. Fragment $2 \mathrm{I}$

XXIII. Fragment 22

XXIV. Fragment 23

XXV. Fragment 26

XXVI. Fragment $27 \mathrm{a}$

XXVII. Fragment $27 \mathrm{~b}$

XXVIII. Fragment 28

XXIX. Fragment 30

XXX. Fragment $3 \mathrm{I}$

XXXI. Fragment $3^{2}$

XXXII. Fragment $33 \mathrm{a}$

XXXIII. Fragment $33 \mathrm{~b}$

XXXIV. Fragment 34 a

XXXV. Fragment $34 \mathrm{~b}$

XXXVI. Fragment 35 a

XXXVII. Fragment $35 \mathrm{~b}$

XXXVIII. Fragment 36

XXXIX. Fragment 37

XI. Fragment 40a

XLI. Fragment $40 \mathrm{~b}$ 


\section{LIST OF PLATES}

PLATE

XLII. Fragment 4I

XLIII. Fragment $42 \mathrm{a}$

XLIV. Fragment $42 \mathrm{~b}$

XLV. Fragment $43 \mathrm{a}$

XLVI. Fragment $43 \mathrm{~b}$

XLVII. Fragment $45 \mathrm{a}$

XLVIII. Fragment $45 \mathrm{~b}$

XLIX. Fragment 47

L. Fragment 48

LI. Fragment 5oa

LII. Fragment 5ob 


\section{INTRODUCTION $^{1}$}

\section{i. The Cairo Genizah}

$\mathrm{T}$ HE Hebrew word geñzāh means "safe-keeping," "hiding," "archive," "treasury," "hiding-place." Specifically it means a depository where worn-out, heretical, or disgraced books, written or printed, useless documents and letters, or other objects of pious solicitude, are stored.

Genizahs among Jews, and similar institutions among Christians, owe their origin doubtless to the feeling that objects hallowed by religious or personal use and association may not be destroyed even though they have ceased to be useful. Fear of profanation leads to the practice of hiding them, in walls or attics, in the ground, or with the dead, in order that, like the beloved dead, they may remain forever safe until obliterated by Time, under the dispensation of Providence. In Europe and elsewhere a corner of the graveyard was set apart for this purpose ${ }^{2}$. There is such a place in Florence ${ }^{3}$, marked by an appropriate inscription. In the ancient Coptic "Red Monastery" at Sohaj worn-out prayer-books, vestments, and altarparaphernalia are thrown into a pit. The theological motivation among the Jews is the protection of the Divine Name from desecration. Genizah papers are indeed sometimes called shemoth, "names." Islam shows a similar solicitude for any piece of writing or printing, because it almost certainly contains the Name of God ${ }^{4}$.

The word geniza $\bar{a} h$ has now become a proper name, designating the literary limbo of the ancient Synagogue of Elijah ${ }^{5}$ in Old Cairo. The Genizah and its contents have had a long history which unfortunately cannot yet be written because of the incompleteness and hear-say character of the evidence. From the account of Mr E. N. Adler in the Jezvish Encyclopedia, vol. v, pp. 6 I 2 ff., we learn that the Synagogue was originally a Christian church, bearing the name of St Michael. Chosroes, partly as an enemy of the faith of Byzantium, and partly no doubt as the heir of Cyrus, in 6 I 6 turned the Synagogue over to the Jews. Benjamin of Tudela visited it in the twelfth century, and thought it a very ancient place. The great Egyptian

1 Large Roman numerals in parentheses indicate the fragments in the Freer collection; and Arabic numerals in parentheses indicate the pages of the present volume.

2 For genizah ceremonies see Revue des Écoles de l'Alliance, I901, p. Io3.

3 Cf. Gionale della Societì Asiatica, 1918-20, p. 97.

4 Lane, Manners and Customs of the Modern Egyptians, ch. xiii.

5 Or Ezra, or Moses. See also the Jewish Encyclopedia, vol. v, pp. 60 ff.; Encyclopaedia of Religion and Ethics, vol. vi, pp. I87 ff.; Steinschneider in Zeitschrift fiir hebräische Bibliographie, vol. x, p. 89; also the many articles in the Jewish Quarterly Review. 
antiquary, al-Maḳīzī (A.D. I 364-I 442), writes : "Synagogue of the Syrians: This synagogue is in the street of Kașr al-Sham', of the city of Cairo, and it is ancient. There is an inscription above its door, in the Hebrew writing, engraven in the wood, to the effect that it was built in the year 336 of Alexander (A.D. 24), which is about 45 years before the second destruction of Jerusalem, by Titus (A.D. 7O), and 600 years before the Hijrah (A.D. 622). And in this synagogue there is a copy of the Law which all agree to be entirely in the handwriting of the Prophet Ezra." No doubt Mann is right, and we are to understand that the inscription read " ( 1 ) 336 " of the Seleucid Era, which is A.D. IO24 (The Jezes in Egypt and in Palestine, vol. ii, p. 375). Simon van Geldern at about I750, and Jacob Saphir in I864, both saw the Synagogue and its genizah, and recognised the value of their treasures.

Mrs Agnes Smith Lewis tells us casually ${ }^{6}$ that the first known Genizah leaves were brought to Europe by Dr Lansing; but there appears to be no support for the statement. Mr E. N. Adler in I 888 visited the Synagogue; but he did not succeed in seeing the contents of the Genizah, for he was told that they had been buried. In the early nineties Professor Gottheil used to see the desk of Dr Neubauer, the sub-librarian of the Bodleian Library at Oxford, covered with portions of books which Dr Neubauer told him had come from the East, his professional discretion not permitting him to disclose their exact source. The Bodleian catalogue makes the statement that in I 890 the Rev. J. Chester bought some leaves in Cairo for the Bodleian Library, and adds that "the credit of first recognising their possible value to Hebrew literature belongs to Dr Neubauer." In Anecdota Oxoniensia (Semitic Series, parts 4-6, Medieval Jewish Chronicles II, I 895) Dr Neubauer published a chronicle which had evidently come from the Cairo Genizah? ? In January, I896, Mr Adler again came to Egypt, and, with the knowledge and help of the Chief Rabbi of Egypt, he took away a sackful of parchment and paper leaves.

On May I 3 th, I 897 , Dr Schechter observed in a bundle of fragments brought from southern Palestine by Mrs Lewis and Mrs Gibson, a timeworn leaf of the lost Hebrew original of Ecclesiasticus ${ }^{8}$. With the promptness which was characteristic of him, Professor Schechter set out immediately for Cairo with the single purpose of bringing back the entire contents of the Genizah to Cambridge. Armed with an introduction to Lord Cromer he went to Egypt. A word from the latter to the Jewish authorities in Cairo opened up the old chamber. Professor Schechter was able to take away with him in sacks, at his own estimate, not less than one hundred thousand pieces of vellum and paper. He has given an account of this visit in his article, "A Horde of Hebrew Manuscripts9."

One doubts, however, whether Schechter brought back all that was in the Genizah. Undoubtedly the place had been plundered before his

${ }_{6}$ Zeitschrift der deutschen morgenländischen Gesellschaft, vol. 1xi, p. 631.

7 P. xi.

${ }^{8}$ S. Schechter and C. Taylor, The W'isdom of Ben Sira, Cambridge, I899, page v.

${ }_{9}$ Studies in Judaism, Second Series, I908, pp. 9 ff. 
coming $^{10}$, and he was cheated by the men who worked with and for him. Mrs Lewis ${ }^{6}$ tells us that leaves were somehow stolen between the packing and unpacking; and that she personally bought some of these from dealers in Cairo. At any rate, a lot of the material had escaped. The Jews themselves had taken the overflow of the Genizah proper, and buried it in their cemetery in the desert, called al-Basātinn, where they had constructed several underground chambers for the purpose. From this place Professor Gottheil in 1910 secured fragments, both early and late. So much had escaped that there is hardly a large library in Europe that is without its collection of Genizah fragments. Of first importance in this respect are the British Museum, the Bodleian, the Jewish Consistory of Paris, the Royal Library of Berlin, the Municipal Library of Frankfurt and the library of the Archduke Rainer, in Vienna. Many private collections also possess them. Dropsie College, Philadelphia, is the custodian of some four hundred and fifty documents, apparently from the Cairo Genizah ${ }^{11}$.

No list has ever been made, nor is one likely soon to be made, of all the places where Genizah fragments have found a resting-place.

The contents of Mr Adler's famous "sack" were brought to the Jewish Theological Seminary of America, in New York, where they are at the disposition of American scholars; and the great mass of material removed officially by Professor Schechter is now the Taylor-Schechter collection at Cambridge.

It seems certain that the Genizah, once filled to overflowing-literally overflowing into the community cemetery-is now emptied of everything of value. The three most recent visits disclosed nothing but printed matter. But a great deal may still be in the hands of dealers.

10 The Synagogue had been repaired some time before Schechter's visit, most probably about I 890 , shortly after which date the Genizah material began to appear at the Bodleian. To quote from a reliable correspondent, whose name cannot be mentioned: "Before the late Dr Schechter transferred its remains to Cambridge, many dealers helped themselves to small bundles of fragments which they would obtain by bakhshish from the beadle of the old Synagogue at Fustāt (Old Cairo), where the Genizah had been discovered in an attic as a result of the work of repairing the Synagogue. The workmen on tearing down the roof dumped all the contents of this attic into the court-yard, and there the MSS were lying for several weeks in the open. During these weeks many dealers could obtain bundles of leaves for nominal sums. They later sold these bundles at good prices to several tourists and libraries."

But the Genizah was known in 1750 and $\mathbf{1} 864$, as we have seen, and hence could not be "discovered." Also, if "all the contents" were dumped into the court-yard, they must have been restored, in part at least, to the Genizah before Schechter's visit in I897, for he found them there. In view of all the statements, perhaps the contents of the Genizah and the entrance to it, were always known to the Synagogue authorities. They deceived Adler upon his first visit, in I888, with a conventional answer: The contents of a genizah are regularly buried. Before the repairs, the contents and their whereabouts were well known, but not their value. That fact appeared to the Synagogue authorities only after they had seen the beadle sell to the dealers.

11 Formerly in the (Cyrus) Adler, Sulzberger, Amram, Friedenwald, and Cobern collections. These, together with other Genizah material in Philadelphia, are characterised by the late Dr B. Halper in his Descriptive Catalogue (1924). 
The Genizah documents which have thus far been examined have contributed immensely to the history of the Jews in the eastern Mediterranean, especially in Egypt. Before the discovery little was known of the government of the communities, their tastes and activities, their daily lives. The article "Egypt" in the Jewish Encyclopedia, written in I903, in the absence of a second edition of that work has been overtaken by the excellent book of Dr Jacob Mann, The Jews in Egypt and in Palestine under the Fätimid Caliphs (Oxford, I920-22). It is hoped, however, that some day all the Genizah material will be published in the original texts, and with logical or chronological sequence, in a Corpus Geniziacorum; and that before long some body of scholars and some Maecenas will be found to undertake the task.

\section{ii. The Freer Collection}

The Genizah documents edited in the present volume were purchased by Mr Charles L. Freer of Detroit in the year I908, from a dealer in Gizeh. Nothing further is known of their provenance. They were probably picked up by the curious or the speculative at the time when the Synagogue was being repaired. Every Egyptian knows the negotiable value of antiquities, particularly of inscribed leaves. It is, of course, also possible that they were dug up by natives after being regularly buried by the authorities of the Synagogue. It is even possible that they never were in the Synagogue, but that they were obtained from some ancient cemetery, where they had been originally buried with the dead.

The Freer collection of Genizah documents has been placed in the Freer Gallery of the Smithsonian Institution at Washington, D.C.

\section{iii. THE PAPER}

All the fragments are written upon Paper.

Nos. V, VI, VII, VIII, IX, X, XII, XIII, XV, XIX, XXIII, XXIV, XXV, XXVI, XXVII, XXVIII, XXX, XXXI, XXXII, XXXIV, XXXV, XXXVIII, XXXIX, XLII, XLIII, XLIV, XLV, and XLVI are without screen-marks. Nos. I, II, III, IV, XI, XIV, XVI, XVII, XVIII, XX, XXI, XXIX, XXXIII, XXXVI, XL, XLVIII, and XLIX have coarse, and Nos. XXII, XXXVII, XLI, XLVII, and L, fine screen-marks.

Watermarks are to be found on Nos. XXVII and L. The former is apparently a mailed torso, and the latter a hand-and-star such as was employed by manufacturers in France, Switzerland, and Sicily, between A.D. I 490 and I 590, according to Briquet, Les Filigranes (I907).

\section{iv. The Handwriting}

Although some of the hands betray a familiarity with Arabic writing (XXVII), there is very little of Arabic writing to be found in the collection. The instances are: Nos. XVI (entire), XXVII and XXXV (addresses), II and XIX (scrawls on the back which we have not attempted to explain). 
The Coptic numerals employed in No. XL would seem to indicate some contact with the Coptic-Arabic fiscal system.

The collection as a whole is written in Hebrew characters. There is nothing remarkable in the use of the Hebrew alphabet by the Jews when writing Arabic. They have done similarly in Persia, Spain, the Slavic countries, and America. So also the Greeks and Armenians use their national alphabets for writing Turkish. For a time the Jacobite Christians of the Lebanon wrote Arabic in Syriac characters, the so-called Karshūnī. Just as the use of the Arabic script quite generally follows the adoption of Islam, so the use of the Latin or the Greek alphabet shows historical and cultural relationship to the Latin church or the Greek church respectively. It is perhaps not that the letters are more sacred than the language; but that the letters can still be taught after it becomes impossible to continue the tradition of the language.

The variety and difficulty of the hands present at once the chief problem of the editors; although Hebrew writing, in the very nature of the case, is not usually so difficult as the freely ligatured Arabic. One group in particular, Nos. III, XII, XXII, XXXIII, XXXIV, and XXXV, is written in a very bad Hebrew hand in which similar letters are scarcely differentiated at all. Even for a Jew of that time and place these letters could not have been more legible than the proverbial scrawls of Horace Greeley are to us. As modern analogies to these memoranda-slips and leaves from note-books, we are to think of the slips which are issued to us by our grocers, or the personal memoranda and agenda which we carry about in our pockets.

It has been difficult to find a satisfactory standard for the classification of hands ${ }^{12}$. The traditional terms, "square," "half-square," and "cursive," have no definitive and generally accepted meaning. "Square" is used to designate the group of hands most nearly like the standard type of our Hebrew bibles. "Half-square" means usually the group resembling the "rabbinic" or "Rashi" type of the printers; "cursive" means perhaps a running hand with ligatures. But "square" hands become careless, and begin to look like "rabbinic"; while truly "cursive" hands can hardly be found at all. In this collection, in spite of the carelessness of many of the hands, there is only one (XXI) really "cursive" hand, in the sense of being freely ligatured.

Under these circumstances it has been thought best to invent a system, if only for the purposes of this volume; and to give the three traditional terms a definite meaning. As the letter $\mathfrak{N}$ is the most variable in the alphabet, and as its variation stands in a certain relation to the classes, "square," "half-square," and "cursive," we need only to define these classes in terms of the form of $\boldsymbol{\aleph}$. In very few cases is the result belied by the general impression of the writing.

12 Bernheimer, Paleografia Ebraica, Florence, 1924, has come to hand too Iate for consideration. 
The square type is made with five strokes: $\mathbf{\aleph}$.

The half-square type is made with three strokes, and still resembles the square: $\boldsymbol{N} \times \boldsymbol{\mu}$.

The cursive type is made with three or even two strokes, and does not much resemble the square: $K N \leqslant \& \varepsilon$.

Nineteen of the documents may be dated, exactly or approximately. If these be arranged in chronological order no definite development is apparent. E.g. No. XLVII, of A.D. I067, has the same cursive form as No. XLI, which is certainly later than I4 I2. On the other hand, it appears that while cursive hands are commonest in letters and memoranda, square and half-square hands are employed in legal documents (XI, XIIII) and in other formal (XXXI, XXXII, XL) writing, and by persons writing letters from Jerusalem ( $\mathrm{V}, \mathrm{XXVII})$.

\section{v. The Dating}

Unfortunately only nineteen of the fifty fragments can by any means be dated. Of these the earliest appears to be No. V (c. Io I6?) or No. XLIII (IO43), and the latest No. L (c. I53O?) or No. XL (I5I1). The undated ones may, of course, fall outside these limits. General considerations make it likely that nearly all of the collection belongs to the early or middle part of this period; and it is disappointing not to find some reference to the Crusades or the Mongol invasions.

\section{vi. The Language and Languages}

The interpretation of many of the letters is made peculiarly difficult by a certain characteristic vagueness, incoherence, and obscurity of language (I8). The editors are well aware of their failure in many instances to grasp the meaning of the texts (139 ff.). Some of the trouble arises from pure slovenliness of thought and expression. Confusion between two possible forms or constructions, which present themselves simultaneously to the mind of the writer, are very common $(36,46$, I I9-I 26 , I 38 , I 52 , I 53,158$)$. To the obscurities of very bad Arabic ( 5 I) and Arabic under some strong foreign influence (XXXIII) are added the inelegancies of speech-mixture. Hebrew and Arabic are often frankly combined in a single document, even of some pretensions (XLIII). But Arabic and Hebrew are combined in the same words $(\mathrm{XV})$; Arabic words are used in a Hebrew sense, and Hebrew words in an Arabic sense (39, I62); and the Arabic and Hebrew articles are even combined (IO4).

One cannot escape the impression, however, that there is a considerable element of deliberate geheimthuerei; "My letter has gone forward to you with the 'dogs,' who will tell you about it" (I9). "And the 'Elephant'God keep him !- did not wish to give colors" (95). "The writer of it is the slave, your insignificant servant, Genesis-Exodus" (I33). Some of this is due to fear of the interception of letters, no doubt: "And it is not possible for me to explain to you..." (I5I). Much of it arises from the trade-slang of a forgotten age: No. XXXVI is an excellent exampie of this. Some of 
it may be humor: "Bought a slave" means "became the father of a son" ( $5 \mathrm{I})$. "The bed is the most important thing in the house" (2 I). "I needed first of all a tailor" ( 5 I).

The elaborate ceremonial of address in the letters, whether in Hebrew or in Arabic, suggests some relationship with the highly developed epistolary technique of the Arabs, as set forth in such books as the Suble al-A'shā of al-Kalkạāhandī (died A.D. I4 I 8) ${ }^{13}$.

The languages used are Arabic, Hebrew, and Aramaic.

Except in the few cases where the language is bad, we may assume that Arabic was the mother tongue of the vriters of all these documents. It is used for most of the personal letters, notes, and memoranda ; and documents in Hebrew have a tendency to lapse into it. Hebrew is the language of formal letters, or letters written by proficient persons with a motive for emphasising the bond that united the Jews. Hebrew is the language of the poetic pieces, all more or less religious, and Aramaic the language of documents (XI); but words from both languages are often introduced into Arabic texts, especially where Jewish institutions are concerned.

It is perhaps unnecessary, except for completeness, to remark here that Hebrew was properly the language of Canaan (Isaiah xix, I8). Themselves a part of the Aramaean migration, and in contact with Aramaic (Gen. xxxi, 47 ; II Sam. x, 6 ; Jud. xviii, 28), the Jews must have become more familiar with Aramaic after the deportations of Israelites and importation of Aramaeans in 734 and 722 B.C. (II Kings xv, 29; xvii, 6, 24; Ezra iv, 2, IO). Aramaic was understood by Judaeans of the upper classes as early as 7O I B.C. (II Kings xviii, 26; Isaiah xxxvi, I I). During the fifty years of exile in an Aramaic-speaking Babylon the Jews must have learned that language thoroughly, as the steady process of aramaisation in post-exilic Hebrew testifies. The writer of Ezra (end of fourth century B.C.) and the writer of Daniel (about I67 B.C.) not only include Aramaic documents and reports, but themselves use Aramaic within the body of a Hebrew book, intended for Jewish readers. With the beginning of Hellenistic times Hebrew seems to have perished as a spoken language. It was replaced by Aramaic and Greek. After the decline of Greek in the fourth century, Aramaic, in various forms, continued to be the language of Jews in the orient until the Muslim conquests, in the latter part of the seventh century A.D. Medieval and modern Hebrew have so strong an infusion of Aramaic at times, that they may be said to consist of a mixture of the two. This did not occur with Arabic, probably because of the greater difference between Arabic and Hebrew; although Arabic became the chief language of the Jews in the East.

13 Cf. a similar work in Zeitschr. der deutschen morg. Gesell., vol. 1xx, pp. $7 \mathrm{ff}$. British Museum I 82, Hebrew A3, gives suggestions for writing to a superior for assistance. 


\section{vii. ARABIC}

At times the Arabic used approximates to the classical idiom. The suffix -kumu occurs in a rajaz-verse (I33); and there are instances of the $i^{\prime} r \bar{a} b$ and the tanwin (4I). But for the most part the Arabic is colloquial in some degree. The type is usually Egyptian; but it is often Palestinian or Syrian, or even Maghribi (VII). This colloquialism varies from a slight coloring or an occasional slip, to an out-and-out use of the vernacular (IX, XII, XXVI, XXVII, XXVIII, XXX, XXXIII, XXXIV, XLV). In the two letters (or two parts of one letter?) written by a slave (or servant?) to his master (XXVIII, XXX) we have perhaps the oldest existing specimens of colloquial, howbeit Jewish Arabic. The writer spells both his Arabic and his Hebrew words phonetically. No. XXVI is most peculiar, if indeed we have read it properly.

Orthography and phonology must be treated together, as we cannot always know whether we are dealing with peculiarities of spelling or peculiarities of pronunciation. Some of the texts are more phonetic than others, writing the consonants and long vowels apparently as heard and spoken ( I 30), and even occasionally indicating the short vowels (63, I 39).

The Hebrew letters employed in expressing the Arabic sounds are those which etymologically correspond to the Arabic letters; but some cases require special comment :

$$
\begin{aligned}
& ت \text { and } \dot{H}=\pi \\
& \text { b } \\
& \text { s and } \dot{j}=7 \\
& \dot{\omega} \quad=\dot{\xi}
\end{aligned}
$$

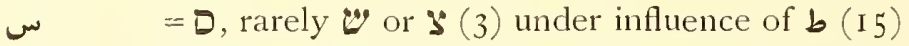

$$
\begin{aligned}
& \text { ص } \quad=\$ \text {, rarely } i(5 \mathrm{I}) \\
& \text { j } \quad=i \text {, rarely } \mathbf{Y}(\mathbf{I} 38) \\
& \text { b) } \quad=\dot{0} \\
& \tau=\dot{j} \text {, indicating a non-Cairene pronunciation } \\
& \dot{\tau}=9 \text {, rarely } \pi \text {, as in Europe }(122,138) \\
& \dot{\varepsilon}=\dot{y} \\
& \text { ق }=\text { P, rarely } \mathrm{A} \text { ( I } 52 \text { ), or omitted, because }=\text { hamzah (I 54) } \\
& \tau=\pi \text {, rarely } \pi(50,140) \text {, or } y \text { under influence of } \pi(63) \\
& \varepsilon=y \text {, rarely omitted, in numerals (I } 38 \text { ) } \\
& =\pi \text {, rarely omitted, in } f i[h i] \text { ( I I } 2) \\
& \sim \quad=" \text {, passim. Short } i \text { also? (1 } 38,230)
\end{aligned}
$$

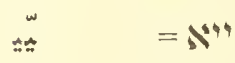

$$
\begin{aligned}
& \text { : } \quad=\text { ᄀ, rarely } \$(12 \text { ff., I 59) }
\end{aligned}
$$

In the way of forms and syntactic peculiarities not necessarily colloquial :

' lis for (14, 1 52 )

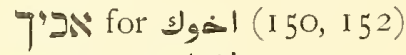

דיפ for (38) 
Also the frequent omission of the article, the strange use of prepositions, and the redundant "it" (XXVII especially).

Peculiarities of vocabulary not necessarily colloquial :

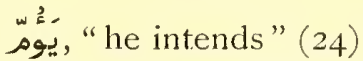

$$
\begin{aligned}
& \text { إِبْراء, "acquittal " (35) } \\
& \text { أَهِ, "business" (I62) } \\
& \text { بَيْنَ, "by agreement" (43) }
\end{aligned}
$$

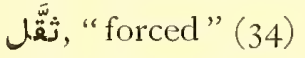

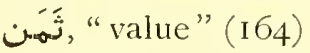

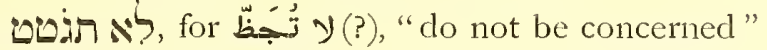

$$
\begin{aligned}
& \text { (9), "shipment" (97) } \\
& \text { حديث, "business" (37) } \\
& \text {, , "matter" (63) }
\end{aligned}
$$

, يُحرِّرص " " he should urge" (39)

$$
\text { 审, "judiciable claim" "? (43) }
$$$$
\text { 囟, “mouldiness”. (I 22) }
$$$$
\text { خأُ " "risked" (I } 52 \text { ) }
$$

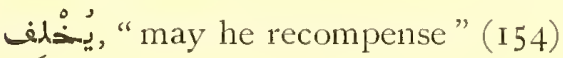

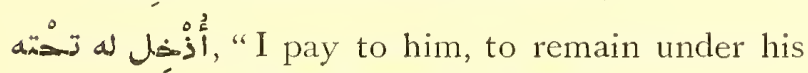
management"? (32 ff.)

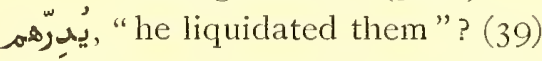

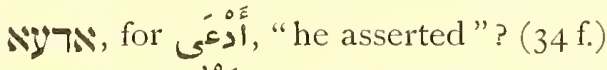

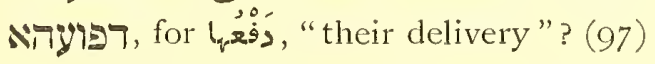

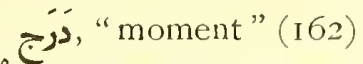

دفعت

زَٔ, "he said" (34 ff. et passim)

راسى, " راسى, "myself” (I 40)

olقر. "embroidery" (I 52 2)

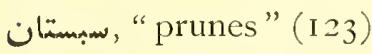

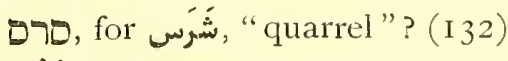

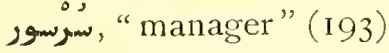

年, “despatcher" (228)

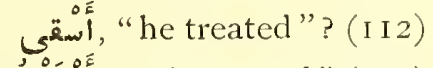

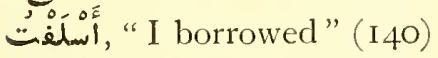

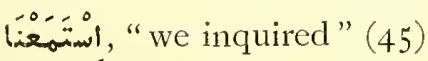

$$
\begin{aligned}
& \text { سعرe, "purchase-price "? (I64) }
\end{aligned}
$$




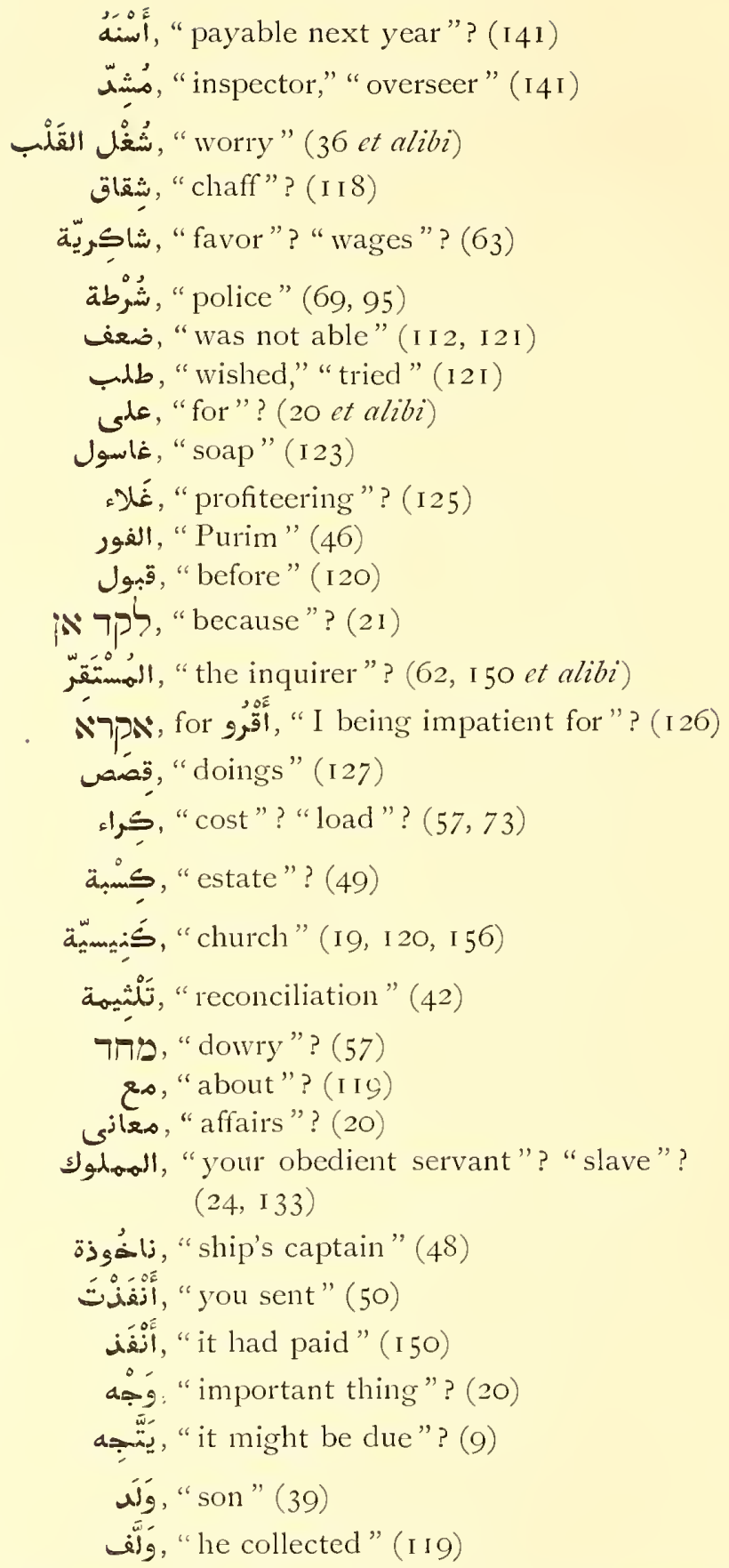

Of especial interest are the instances of colloquial phonology (Egyptian, unless otherwise stated):

Loss of ' in numerals ( I I 4, I38, I6 3 et alibi).

Loss of final - hi ( I I 2).

New' arising out of $k$ (I 54 bis), or triliterality (I99).

Change of "to ! $t$ before the voiceless stop $t\left(6_{3}\right)$. 
Change of $s$ to $s$ before the emphatic stop $t$ (I 5 ).

Loss of final short vowel of verbal forms, resulting in shortening of preceding vowel (34), or (when the root ends with $l$ ) assimilation to the $l$ of the preposition $(46$, I 38, I 40, I 56 ).

Accent on first syllable in broken plurals of the form foithl, with consequent shortening of second syllable, so as to produce the form fáalïl ( 160 et passim).

Maghribi accent on last syllable with consequent loss of initial vowel in $i b n$ and $a b \bar{u}(32,4 \mathrm{I}, 69)$.

Colloquial forms are frequent:

wilàd for azulàd (40).

Characteristic forms of numerals ( 138 ).

Maghribī hà $m \bar{\alpha}$ for hum (I 40).

tè and ilō for lahu (Palestinian and Syrian, 33).

hädi for hadha (Palestinian and Syrian, I 52).

dì for hìdha (162).

$\bar{e} s h$ for $m \bar{\alpha}$ (Palestinian and Syrian, 2 I, 39, 52, I 24, I 52 ).

hêk for hākadhà (Palestinian and Syrian, I 52 ).

The negative suffix $-\operatorname{sh}[e](54,65$, I 2 I, I 40, I 50 , I 5 I $)$, at times still objective and not yet adverbial ( 150 , I 5 I).

The present-tense-prefix $b i$ - with the imperfect (39, I I 2, I 52 ).

The Maghribi first-person-singular (sic!) prefix with the imperfect, $n$, if it be not a mere use of "we" for "I." (Spanish-Moroccan? I 52 et alibi.)

The external $t$ in the VIIIth form of the verb (5I, $52,53, \mathrm{I} 60$ ).

Metathesis of first vowel in verbs whose third radical is $y$, e.g. illket for hakaitu (Palestinian, I40).

Inflection of verbs whose third radical is ' (47) and verbs whose second and third radicals are identical ( 155 ), as though they were verbs whose third radical is $y$.

Simplification of yutma'inn to yutémmin (47).

The pseudo-verb $f i[/ 2](\mathrm{I} 5 \mathrm{I})$.

The conjunctions walla (125) and ila wa (56).

The adverb lissa $(65)$.

Syntactic peculiarities of the colloquial:

The relative pronoun alladhi is at times used as a conjunction in the manner in which its colloquial counterpart, illi, is used in Cairene vernacular at the present day. This is precisely the history of the Germanic demonstrative (English that) which becomes relative and then conjunctive: "That book that denies that such is the case" (45, I 30).

The Hebrew letters $\boldsymbol{N}$ occur many times in such a way as to appear to be the Arabic conjunction $a n$, used as an indefinite relative pronoun (45, 5 I, 54, 96, I 30). As everyone knows, Arabic has no indefinite relative pronoun. This an would seem therefore to be used in the manner of Hebrew - At times it stands between an undetermined noun and its attributive adjective $(45,54,96)$.

The conjunction $a n$ is omitted (I $2 \mathrm{I}$ ).

The participle is used for a finite verb (? $5 \mathrm{I}$ ). 
Vocabulary and idioms which are like modern colloquial:

\begin{tabular}{|c|c|}
\hline batțāl, & "worthless," "bad" (34) \\
\hline$b a \ddot{k} a$ & "he became"? $(44,63)$ \\
\hline$i \bar{a} b$ & "he brought" (38) \\
\hline yejīb, & "that he bring" (I 2I) \\
\hline $\bar{a} b u$ & "they would bring [a price]" (39) \\
\hline & "letter" (62) \\
\hline$\langle 2 \bar{\alpha} j$ & $\begin{array}{l}\text { "thing" (19, 63, I 20, I60), plural, } \\
\text { havwarij (I 54, I 87) }\end{array}$ \\
\hline & "story" (47) \\
\hline & "he gave" (56) \\
\hline $\bar{a} h$, & "he went" (46) \\
\hline fì hạalì, & "I went about my business" (I 40 \\
\hline & "cleverer" (I60) \\
\hline & "rascal" (I I 3) \\
\hline & us" (46) \\
\hline$k a b a d \bar{n}$ & "they have received" (I 20) \\
\hline ti[k]rá 'ammi. & $\begin{array}{l}\text {.....as-saläm, "give my greetings } \\
\text { to......" (I 54) }\end{array}$ \\
\hline rak & "with your favor" (I4I) \\
\hline & "half" (1 22) \\
\hline
\end{tabular}

viii. HEBREW AND ARAMAIC

The few Hebrew words which are spelled phonetically after the Arabic fashion (I 30 ) indicate the Sephardic value of the vowel ${ }_{\mathrm{r}}: \bar{\alpha}$ (I 30 ). In No. XV,

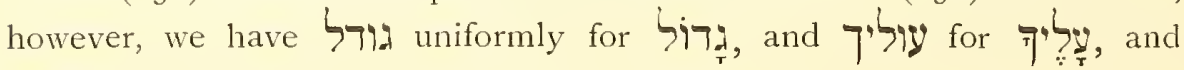
อיפוy for the accent rested upon the penult. Both of these peculiarities are foreign to the present pronunciation of Hebrew by Jews of Sephardic origin in Arabic-speaking lands, and characteristic of the pronunciation of Jews of Ashkenazic, Yememite, Persian, and Caucasian origin. There is no reason for suspecting Ashkenazic influence more than the others.

Arabic ابو frequently becomes 'IN' (I42) on the analogy of ancient names, such as Abimelech (142).

Very few unusual meanings appear. "ק? "? which generally means "picture," must mean "copy" (29). "גגר :-1, "Hagarene," a biblical word, referring to a certain Arab tribe, stands for "Arabic" in general (27), instead of appears in the vision seen by a crystal-gazer (76). The poet, in quest of rimes, invents new words (173, 175). 


\section{ix. Contents}

Of theological material there is only an unimportant fragment of Maimonides (XXXIX), an equally poor one of Simeon Kayyāra (VI), and an extremely problematic jumble of halachic notes of very doubtful origin and purpose (XLIV).

Poetry (pizmōnīm) is represented by a panegyric of Abraham Maimunī (XXIX), religious poems or hymns (pizmōnīm) and fragments (XVII, XIX, XX), including a biblical paraphrase (XXXVIII).

The liturgy is found in two specimens (X, XLVI), and liturgical notes in three (XXIII, XXV, XLII). None of these, except possibly XLVI, is of any interest. Nos. XXIII, XXV, and XLII are not only extremely difficult to translate and explain, but very difficult to account for.

There are two interesting magical texts or amulets ( $\mathrm{XV}, \mathrm{XXIV}$ ), the former to be used in connection with some "scrying" or crystal-gazing ceremony.

Four of the items are documents in the precise legal sense: the extremely important formal agreement about the order of precedence in the Academy at al-Ramlah (XLIII), an interesting bill of divorce (XI), two documents recording the settlement of an indebtedness incurred in a partnership undertaking (I), and an all but completely unintelligible receipt in Arabic script (XVI). No. VII is the memorandum of an indignation meeting held by a defrauded investor, and hardly a legal document. The same may be 'said of the list of tax-payers (XIII), leaves from merchants' note-books (XIV, XVIII), and an accounting of expenses incurred by a business expedition (XXXVI). Two records of marriage-settlements, with long lists of articles belonging to the bride (XL, XLV), and a record of the sale of a slave (XLV), are probably informal documents.

Of the fifty numbers in the collection twenty-four contain letters. Nos. XXX and XXVIII probably are parts of the same letter, and XXXI and XXXII are certainly such; while No. L contains three distinct communications. We thus have twenty-four letters also. Not only do the letters constitute nearly half of the collection, but they are by far the most interesting part of it. In the picture which they give of Jewish life in Egypt from about A.D. 1000 to I 500 , there is much that is characteristic of Jewish life and of life everywhere.

Letters were carried by travellers (47) or runners (XLVII) over vast distances, and arrived infrequently (47). Anxious relatives at home beg the young man to write oftener, and he replies that he is too busy ( $5 \mathrm{I}$ ). Every sort of letter is represented. There is the family-letter, mostly about personal trials and troubles (III, IX, XXVII, XXVIII, XXX); the begging: letter of an aunt (XLIX); the appeal of a worthy man to the munificent al-Tustarī (XXXI-XXXII); the wheedling, half-threatening, plea for assistance in behalf of another (XLVIII); on the loss of a friend (XXI); the trivial polite letter (XXVI); to a departed guest (XXXIV); upon fleeing to Alexandria (XXXVII); on general business matters (XXII); to a business associate (XII, XXXIII); complaining to a business partner of 
his timidity (XXXV); from a wily old man in Jerusalem who knows better than to speculate in sugar (XLI); from a half heat-stricken man held up at a lonely caravan-station in Sinai (XLVII); about the adjustment of a debt (IV); about a real-estate controversy (VIII); about a case of divorce (V); complaint of political intrigue against the writer (II); exposure of a corrupt and tyrannical judge $(\mathrm{L})$. From these letters, supplemented by the other material in the collection, we derive the data underlying the following sections.

\section{x. GEOGRAPHY}

The geographical range of the documents is from Aleppo and Turkey in the north to Aden in the south, and from Spain and France in the west to Colombo and India in the east.

Most important is Egypt, the home of prosperous Jewry. A number of Egyptian places are mentioned. At al-Fusțatt (Old Cairo) was the congregation and Synagogue of Elijah, in whose archives were kept important letters received, and copies of important letters sent. Perhaps the Canal mentioned in No. IX is the ancient water-way which gave its name to the street al-Khalig in modern Cairo (54). Alexandria is spoken of, and appears in several personal and family names.

Palestine, and particularly Jerusalem, are objects of concern. There is an allusion to the Jewish Quarter, to the Rubāìyah (Müristān?) and the Church (of the Holy Sepulchre?). There has been an earthquake, or similar catastrophe, and the "Glorious Place" has collapsed, and must be rebuilt (3I). In the Holy City the chief necessities of life, then as now, were fuel-wood and olive oil, for heat and light (I2I), except when there was actual want of food (I25). No. XXVII gives the familiar picture of Jewish misery in Jerusalem. Other places in Palestine and Syria are mentioned: Hebron? (I I 8), al-Ramlah (20I), Safed, Kafr Yāsîf, 'Ain alZaitūn (L), Tyre (I27), Aleppo (IO3, XLVII). All the stations on the caravan route between Cairo and Damascus are mentioned in No. XXX. Caravans from Aleppo and Damascus stop at Kațyah in Sinai (XLVII).

There seems to have been a group of Cairene Jews, settled at Aden, South Arabia, and engaged in the trade with India and Ceylon. They even occasionally went to Colombo (IX).

Spanish Jews are often alluded to (I 79, L), and Spanish ships (I 23) are once mentioned; also people of Sicily (75) and commerce with that country (123); perhaps even France (99). The writers of XXI and XXVII were probably of Moroccan origin, as were doubtless others (153).

\section{xi. BIOGRAPHY}

A great many personal names appear; but most of them are not to be identified, and many of them are as indefinite as "Abraham Cohen" would be in modern New York, or "Muhammad" in Cairo.

The following are a few of the names which seem to be more or less certainly placed. The references in each case are to Mann, The Jezes in Egypt and Palestine under the Fätimids, vol. i (1920); vol. ii (1922). 
I. Abraham Maimūnī (135), son of the great Maimonides, born I I86, died 1237.

2. Abraham, son of Shema'yāh the Hābēr, descendant of Shema'yāh Gầōn (7), signatory of many documents, alive in Io8s (Mann, ii, 232).

3. Abū al-Faraj (25), perhaps the same as Abū al-Faraj, son of Abū Zakarī, a judge at al-Fustạțt, alive in I zOI. Both father and son bore the title "ra'îs" (Mann, i, 246).

4. Halfōn ha-Lēvī, son of Manasseh (I I), signatory of documents in conjunction with No. 2, and therefore contemporary (Mann, ii, 232).

5. The Hazzān Bayyān (53) - a strange form and word-order-perhaps the same as Abū 'l-Bayyān the Hazzān, about ı050 (Mann, i, 242; ii, 308).

6. Immanuel, son of Yehì êl (6I), perhaps a descendant of the Yehì'el who lived in the twelfth (?) century (Mann, ii, $303 \mathrm{ff}$.).

7. Jacob, son of Joseph ha-Hasidh (26), perhaps the same as the head of the Jewish court who signed documents at al-Fustaț in IOI 6 and IOI8, and at Aleppo in Io28 (Mann, i, 37, I 50).

8. Judah ha-Kōhēn, son of Eleazar (I3), was dayyān at Bilbais from I I 87 onward (Mann, ii, 3 I 7 ).

9. Mebōrākh, son of Nathan ( I I), a known signatory of twelfth-century documents (Mann, i, 222, 227 ; ii, 293).

IO. Nahrai, son of Nissim (I29), perhaps the same as the famous scholar by that name who died between I050 and Iog8 (Mann, i, 204 ff.; ii. $240 \mathrm{ff}$.). But the prefixed "Abū Yahyā" would refer to a supposedly well-known son, of which there is no record.

I I. Nathan, son of Abraham (I99), usurper of power in the Palestinian Academy (XLIII), becoming "Father of the Law Court," or "Second," in place of the rightful aspirant, Tobiah, son of Daniel (Mann, i, I4I-I 52 ; also pp. 7I, 75, I I 5, I 29, I 30, 193, 273).

I2. Nathan, son of Samuel (35), perhaps the same as the secretary to the nāgìd about I I 40 (Mann, i, 225).

13. Shabbatai, son of Abraham the Dayyān the Hābēr (I 7$)$, signed documents in I I 54 (Mann, ii, 259).

I4. Solomon, son of Judah (I99), the Gä'ōn, or "First," in the Palestinian Academy. See No. I I.

I 5. Tobiah, son of Daniel (I99), the "Third" who should have been "Second" in the Palestinian Academy. See No. I I.

I6. al-Tustarī, Abū Sa'd, Abraham, son of Abū al-Faḍl, Sahl (I43), the wealthy dealer in rarities who through the mother of the Sultan Ma'add, a slave-girl from his market, exercised great influence at court until his assassination in I048 (Mann, i, 76, 79, I22; Lane-Poole, $A$ History of Egypt in the Middle Ages [1901], pp. I37, I49).

I 7. 'Ulāh ha-Lēvī, son of Joseph (3), probably the "Parnās of Babylon," about i i 6 (Mann, i, I96).

I 8. Yepheth, son of David (7), perhaps the same as Yepheth the Hazzān, son of David, son of Shekhanya (Mann, ii, 97, 246). But he signed documents in IO20, ninety-six years before our own. 
19. Abraham Castro $(237,24 \mathrm{I})$, may be the one mentioned by Sambari and Solomon Hazzān. If so, he was alive in A.D. I606.

20. Joseph Sarakossī (Saragossī, L), organised the Safed community in A.D. I492. See Jervish Encyclopedia, s.v.

21. Moses di Trani (? L), Dayyān of Safed, 1525-35. See Jewish Encyclopedia, s.v.

\section{xii. Jew AND Gentile}

The student of the Law who refuses to invest in sugar (193) speaks casually of a neighbor as "the uncircumcised one-May his name and memory be blotted out!" (I9I). The melancholic Abū Zubair, writing from Jerusalem, complains that a certain other Jew is found at the houses of Muslims, and does not understand the difference between "inside and outside" (127). A Jew excuses himself for resorting to gentiles (19). A proselyte is perhaps mentioned in a list of Jewish tax-payers (69). Two Muslim formulae: "Praise be to God, the Lord of the Worlds" (I6I), and "In the name of God, the Merciful, the Compassionate" (I63), occur in one letter. Arabic script is occasionally used, and in one instance Coptic numerals (XL).

Considering the complaining tone of many of the letters, we hear surprisingly little about persecution. There is difficulty between Jewish landlord and gentile tenant (2I), or between Muslim landlord and Jewish tenant (I2I), of the kind usual in the Near East, and not necessarily influenced by religious or racial feelings. In Nos. XXXI and XXXII Tobiah asks al-Tustarī for a letter: "For I fear that evil may overtake me on the way, even as it overtook me at Hānēs. Had it not been for the mercies of the Almighty and the favor of my Lord, the honored Elder, I should be today in prison. In those days I had money in my hand, and I gave a bribe" ( $147 \mathrm{f}$.). There seems to be a veiled allusion to persecution in XXII: "I inform you" by this letter "of the condition of Būṣir and its pain and travail; and that it is a city of great trouble and travail" (97). No. XXXVII seems to tell of persecution or similar disorders: The writer's son-in-law (or father-in-law?) has rented a "tower" at a place called Sikat (?), or near Alexandria ; and the whole family intends to live together in it. At his present place of residence "there are people rejoicing, and many people dead-yet there is no trustworthy information." He would "like to go away from here." "Perhaps God will have mercy, and His anger will depart from His people Israel-even though there are some who say that the towers are untrustworthy" (I7I). A synagogue is destroyed by Muslims (233).

Piracy, the capture of Jewish merchants and other travellers, and the necessity of ransoming them, laid a heavy burden both upon those who ventured abroad and upon those who stayed at home (50, note; $5 \mathrm{I}$ ). The pirates were Muslims (5I). Such captures were made purely in view of ransom. "The captive, Esther" ( 183 ) is ransomed by the man who is to marry her, for fifty dīnārs (183), a rather large sum. There were, of course, 
the usual slaves (I 59, $223 \mathrm{f}$.). It was probably the ability of the Jews to pay, and their faithfulness in ransoming their brethren, that made them the particular victims of this practice. Labor requisitions (23I) need not have been made upon Jews especially.

The Jews paid a poll-tax (23). Number XIII is a list of the names of tax-payers with amounts $(67 \mathrm{ff}$.). It is not clear why the Sultan took a third of a certain estate (4I). Jews adjusted their differences successfully before Jewish courts ( $3 \mathrm{ff}$, , 43). In one case two dishonest men defraud a business partner successfully by resorting to a Muslim court (35).

\section{xiii. MARriage}

Women owned and inherited property $(39,47,55)$. A girl might marry when only twelve years old (I87). The economic side of the agreement was arranged by a marriage-broker, who made note of the facts ( $\mathrm{XL}, \mathrm{XLV}$ ). The betrothal, with its "advanced payment" (mukdam), and the marriage proper, with its "delayed payment" (me'utharr), were probably celebrated in quick succession (XL, XLV). In the interim the lady was sometimes supported by the fiancé (I 87 ). The bride brought a dowry (nedunyāh). This consisted of a great variety of goods. In both Nos. XL and XLV we find remarkable lists of articles of clothing and personal adornment, jewelry, cosmetics, and sweetmeats (187), which will well repay study. Some of the names belong evidently to the fanciful nomenclature of the day. What indeed is a "trembler" (I 8 I), or a "dancer" (I 79)? Others, though strange, are intelligible and interesting, such as the color, "gazelles' blood," and the many articles from Hormuz (I8I, I85). Property arrangements are also 'frequently stated, particularly that the husband shall possess the wife's handiwork, but must provide her with clothing (I79, I83, I87), and the inheritance rights of the children are protected $\left(\mathrm{I} 8_{3}\right)$.

The last mentioned arrangements are made not merely in view of death, but also of divorce (I83); and this was apparently not difficult. In No. XI we have a bill of divorce in which no grounds are stated, while great pains are taken with phraseology, attestation, and delivery of the document. In No. $\mathrm{V}$ the grounds are that the wife has refused to follow her husband to another city, to which he has transferred his domicile. That there may sometimes have been extreme grounds for divorce appears from the mention of two cases of adultery $(53,55)$, where the husbands were away from home for long periods. The unfortunate, illegitimate offspring was refused the customary blessings at circumcision ( 55 ). Neither ḥazzān nor dayyān would attend, and certain less sensitive Byzantine Jews managed to collect the necessary quorum (55). Great fondness for children is revealed in the letter to a departed guest (I57), where we have perhaps one word of infantile Hebrew.

\section{xiv. Religion, Learining, Superstition}

Religion and learning are not fairly represented in the present small collection of Genizah documents. For evidence of these one must refer, e.g., to the description of still uninvestigated materials enumerated by 
Bacher in the Hastings Encyclopaedia of Religion and Ethics (s.v. Genizah). Our collection consists of humbler remains of the past, overlooked or rejected by seekers after literary texts. Nevertheless, we have a few pizmōnim, liturgical fragments and notes, halachic bits, and a portion of Maimonides besides occasional references to books and an interest in study, pamphlets on Hebrew grammar and theological controversy ( $123 \mathrm{ff}$.). Books were hard to get, and loaned books hard to recover (125). A borrowed copy of the Prophets cannot be returned, because the boys are reading it (I53)! Only one really unworthy exponent of religion appears $(\mathrm{L})$, although the ethics of a certain transaction in grain are at least doubtful (1 23). There are some maxims of merit ( 127, I 75 ).

It is quite natural that we should find some evidence of the pursuit of magic and pseudo-science. No. XXIV is a charm or amulet, such as those elsewhere alluded to (23, I 25). No. XV, while it may be a charm, is certainly the recipe for a "scrying" ceremony, with the well-known reference to "princes" which are wont to appear in the vision (76). Elsewhere there is reference to a "magic circle" (IO7). Cabbalistic names are used (IO7), in-

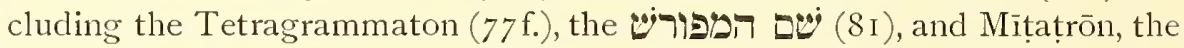
angel (77). The purpose of magic may be protection from disease and accident (IO7), or the cure of disease and decay (23), or the discovery of hidden treasure (79 ff.). The Song of Songs will cure "dry patches" or a drying up of the body, or boils (23). Psalm cxxi, 5-8, and Exodus xiv, I9 also have magic potency (IO7). People live in fear of magic, diseases, ghosts, and all sorts of catastrophy (IO7). The Latin word succuba perhaps occurs (IO7), instead of the Hebrew Lilith, for the vampire-demoness. If the boy's name, 'Allān, means "stupid," it is applied to avert the evil eye from a particular shining mark (9, I I, I9). A vindictive statement about one who is dead is hastily retracted: "But woe unto us! For we are not unmindful of our own condition!" (I27).

\section{xv. Commerce and Manufacture}

The Jews of al-Fustāt and their correspondents dealt in many wares, both staple and fancy: tartar and resin (25), saffron and coral (75), pepper (87), flax, linen, and indigo (99), wool and woollen goods (I2I), wheat, prunes, gum-arabic, almonds, soap, and earthen pots (I23, 23I), alum, candied roses (?), and spikenard (I 53), sugar (I9I), swords (I93), and other commodities. They advanced money for the purchase of material and the maintenance of workmen, taking and selling the finished product. They were in fact manufacturers of colored silks (73), cloth (I6I), and yarn ( I 53).

The Jews also entered into partnerships (7), a thing which Moslems in Egypt even nowadays seldom dare to do. These, to be sure, were not always successful, because of the indifference (63), or timidity (I6I), or dishonesty (33, I9I) of the partners. The risks of commerce were great. Then as now, goods were perishable and prices fluctuated (I9I). But clients in those days were exposed to unusual dangers and uncertainties. Tips, taxes, fees, bribes, presents, obligations, contributions, and gratuities, 
to agents, porters, sailors, ferrymen, gate-keepers, camel-drivers, inspectors, revenue-officers and what not (XXXVI), by which the Jews avoided molestation, must have taken much of the profit and all of the pleasure out of commercial pursuits.

Of the coins mentioned, the dinàr gets its name from the Roman denārius, but it is a gold coin weighing between 66 and $684 / 7$ grains. The American five-dollar gold-piece weighs 129 grains at 900 fine; so that a dinnar of the same fineness would lack only a few grains of being equal to half that coin, or $\$ 2.50$. Its purchasing power at the time, however, has been estimated at about $\$ 7.50$. The ashrafi (I39 ff., I 87 ) succeeded the dinār in Egypt toward the end of the fourteenth century A.D. (I87). It weighed 53.8 grains.

The dirham gets its name from the Greek $\delta \rho a \chi \mu \eta$. The Arabs took over this word, in the form darahim, as though a broken plural from an imaginary singular, dirham. It was equal to about $1 / 15$ of a dinzer or an ashrafī. A special dirham nāsirì is mentioned (I I I).

Other coins are, the rubäi, or "quarter" of a dinàr (I67); the musf faddah, or "half a silver-piece" ( I 39); the maiyadi or mi aiyadì, coined after" A.D. I4I2-I42I (I92); and the habbah, mentioned among other small coins (i65). The Hebrew words 59 (193) and 597 (183, 232) are used perhaps to mean dinärs. Moroccan money was used (169). Mithkàl and kivàt $(3,33,73)$ are names for weights primarily, but are used apparently in reference to coins or coined money. The former may mean dinar (33, 73). The latter is $1 / 24$ of a $\operatorname{din} \bar{a} r(3,69)$.

In the way of weights and measures we have the kintaxr, which now equals about $99 \mathrm{lbs}$. and $4 / 5 \mathrm{oz}$. avoir., the rotl, a little less than I lb. avoir., and the wikizalh, about 1.32 oz. avoir. The kintär contains roo rotls, and the rotl contains 12 wikizyahs. Kintār is derived from Latin centenarius, "containing a hundred," a word which has passed into many languages in the sense of "a hundredweight," or "a hundred pounds." Rotl seems to coine from Greek $\lambda i \tau \rho a$, related to Latin libra, "a pound," and wikiyah from Latin uncia, "an ounce," the twelfth part of a libra. The kașabah is a measure of length, at present equal to I I ft. 7.766. The equivalents in the above have been taken from Baedeker, Egypt and the Sudan, I908. IV azn (12 I) seems to be a unit of weight, not "weight" in general. Kafas (193) and k̊afiz (II9) are evidently grain measures.

\section{xvi. Proper NAMes}

The many interesting proper names which are to be found in these texts deserve more than the few observations which are here accorded them; but adequate treatment must await further investigation. No. XIII is especially important.

No doubt the Jews of al-Fustāt, like Jews in other lands, bore double names, one Hebrew and the other gentile. Fortunately, however, in the case of Egypt, many names were more or less the same in both languages. We have therefore not only Hebrew names and Arabic names, but such as 
might be either if necessary. When a Hebrew name resembled an Arabic one in sense but not in sound, it was translated instead of being phonetically modified: e.g. Näthan became Hibah (27, 69), while Abhrāhām became Ibrāhim (22); just as Kêphà became Petros (John i, 43), while Shä ül became Paulus (Acts xiii, 9).

The patronymics are most interesting, as they show that certain namemotifs, which are commonly supposed to be of recent European origin, are medieval and oriental. Bin Asad (32), "Löwensohn," Ibn al-Bahwari (67), "Son of the Lion-like," Siba" (67), "Lion," are all members of the large group of "lion-names," which may have started with Genesis xlix, 9, as a cryptogram for Judah. In Europe the German translation, Löwe, seems to have been associated with Hebrew ?? and 2?. The permutations, through translation and paranomasia, are very numerous. Al-Dhahabi (7I) is "Goldmann"; al-Fidd (7 I) is "Silbermann"; al-Sukkarī (67) is "Zuckermann"; al-Safir (I 3 I), though it means "sapphire," stands doubtless for

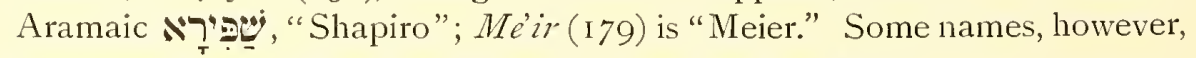
have come back to the orient from Europe, such as Māyō (I9I).

\section{xvii. Purpose and Plan of Publication}

For many years the content of Genizah material, particularly the Hebrew material, has been studied, while the form, especially of the Arabic material, has been neglected. This is easily explicable; for the chief interest undoubtedly lies, and should lie, in the life and times of the Fustạt community, rather than in their language; and the language of these documents, at least on the Arabic side, presents peculiar difficulties.

In attempting to interpret documents written in a vulgar or barbarous form of some well-known language, there is always the question, first of all, as to whether they should receive grammatical and lexicographical treatment. It used to be thought that such was unnecessary, or indeed impossible, because there was no grammar. Now-a-days no one will doubt that vulgar and barbarous texts have, after all, grammatical peculiarities; and that these can and must be studied for an understanding of the content of these texts. But the discharge of this duty is more difficult than its recognition; for vulgar dialects must be studied without prejudice, mostly in the light of their own evidence; and barbarous documents require at the same time constant watchfulness to detect the intrusion of "educated speech" in its varying degrees of corruption.

It is the purpose of the present volume to explain the texts, particularly those in Arabic, in such a way that anyone having a fair knowledge of the ordinary idiom may learn to read them; and to call attention to the peculiarities of language in such a way as to benefit those whose chief interest is philological. The translations have been made so that, by including the bracketed words, the reader will have a free rendering, and, by excluding them, a literal one. This is of course not entirely true everywhere. At the expense of beauty and brevity, and with some violence to 
English at times, he will, however, usually be able to see what the editors understood the text to mean, and how they arrived at that understanding. The Arabic student will thus be assisted without seriously inconveniencing the general reader, who wishes to acquaint himself with the content of the documents. In a very few instances parentheses have been used to indicate words in the original which cannot stand in the translation. Bracketed restorations in the text of No. I are by Professor Gottheil; others have been explained in each case.

The treatment of proper names presents a problem. There are purely Hebrew names, or names written clearly as Hebrew; there are Arabic names; but there are also names which belong equally to the Hebrew and the Arabic languages, such as the interchangeable Abhrō $h \bar{x} m-1 b r \bar{a} / z \bar{m}$, and names which may be pronounced either as Hebrew or as Arabic, such as Sedhāka $\bar{c} h$-Sadakah. Doubtless the Jews of al-Fusțāt used these pairs interchangeably. For this reason, and for the sake of simplicity, all familiar names have been given their ordinary English form, regardless of whether they are Hebrew or Arabic in a particular case: e.g. Abraham, Isacc, Judah, Nathan, Samuel, Joseplı. Less familiar ones have been transliterated as Hebrew or as Arabic; and sometimes the assignment to the one or the other has been rather arbitrary.

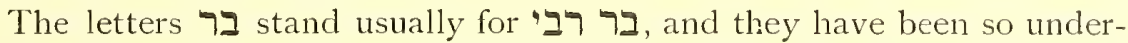
stood in most cases. Occasionally, however, they seem to be Aramaic 7 בפר (179), particularly when they do not have the dots of abbreviation over them. Ibn, Bin, Ben, Bar, Bint, and Bath have all been spelled with capitals, since often they must stand as the first part of a name. Sometimes they have been retained, and sometimes they have been translated. No fixed rule could be observed, as epithets and blessings attached to the end of a patronymic would in English seem to refer to the son, while in reality referring to the father. The innumerable abbreviations of formulae of blessing have sometimes been translated, sometimes paraphrased, and sometimes entirely omitted, as seemed best in each case.

The order of the fragments in this publication is that of the originals in the Freer Gallery at the Smithsonian Institution, Washington; not chronological, nor with reference to the contents. A chronological order would have been difficult, because so few of the fragments can be dated even approximately; and as to subject-matter, they admit of many arrangements. It is unfortunate that No. XXVIII is separated from XXX, and XXXI from XXXII. One might wish also that the more interesting ones could have been placed at the beginning of the volume, instead of some that are rather dull and obscure.

This work has been done under rather unusual difficulties. In spite of great effort, it doubtless contains many inconsistencies. Both subjectmatter and language are such as to provoke controversy. The editors will be content if they have contributed anything to the understanding of Genizah documents. 



\section{INTRODUCTION TO FIRST FRAGMENT}

Paper $12 \frac{3}{5} \times 8$ inches.

Written in a fairly good Hebrew cursive, in Arabic with Hebrew intermingled.

The fragment is, in places, very much torn; but with the exception of a few words, the text can be recovered entirely.

It contains two documents relating to one and the same affair. It seems that two parties were concerned in some business venture in al-YemenAbū al-Âlā Șāiid 'Ulāh and Abū al-Afrāḥ 'Arūs al-Ajawānī. Difficulties seem to have arisen and 'Arūs owes 'Ulāh the sum of four dīnārs and one carat. Upon the recto we have a document, fully attested, to the effect that 'Arūs owes this money to 'Ulāh. Upon the verso we have a second document to say that the money owed by 'Arūs has been paid, in the manner specified in the first document, into court; and 'Ulāh releases 'Arūs from all further indebtedness in the matter.

Being official documents they are extraordinarily prolix; but such verbosity and tautology are characteristic not only of these Judeo-Arabic court papers, but of such instruments at all times-even in the courts and law-offices of our own day. It has been no easy matter to translate this verbiage and to find the English terms corresponding to the Aramaic or Arabic expressions.

And, being official documents, they contain a great many Aramaic expressions and sentences. Jewish law goes back to Talmudic days, when the ordinary language of the people was Aramaic. As they passed into Arabic speaking lands, or as the Arabic cultural invasion engulfed them, their language of intercourse became Arabic; but the formulae as laid down in the Talmudic law held their own against this invasion, in exactly the same manner as Latin did in European lands, and as French did when it replaced Latin as the culture-language of Europe.

The documents here published bear a striking resemblance in their whole form and tenor to the two published by the late Adalbert Merx of Heidelberg University in his Documents de Paléographie Hébraïque et Arabe (Leiden, I 894). One of them, in fact, bears the date A.D. I I I4, one year previous to one of our documents and two years previous to the second (A.D. III 5 and III6). The names of the witnesses, being those of the members of the Court of Justice at Fustaat, are common in documents of this period. See Mann, The Jews in Egypt and Palestine under the Fatimio? Caliphs, Oxford, I920, Index. 


\section{TWO DOCUMENTS}

A

Recto:

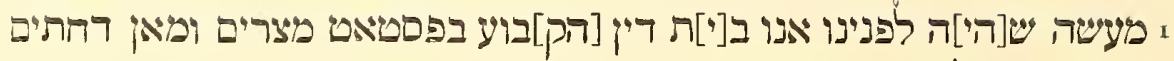

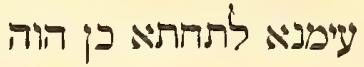

2

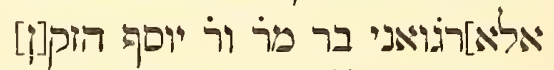

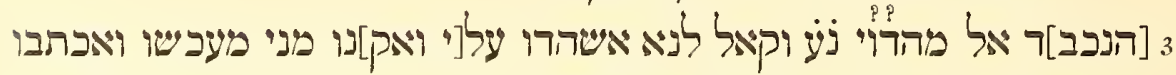

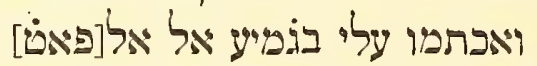

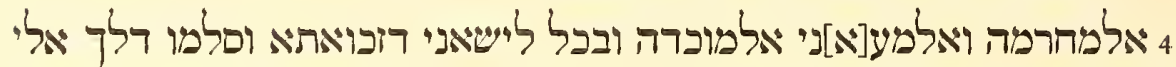

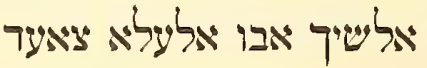

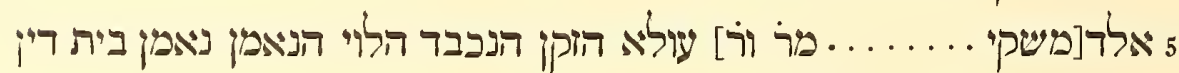

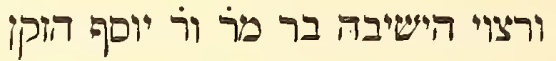

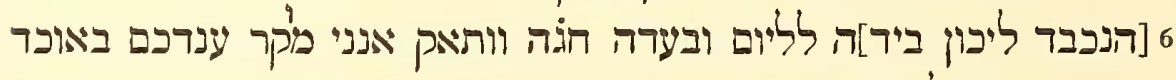

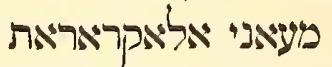

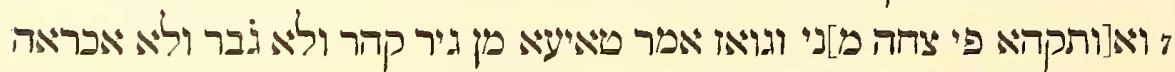
ולא סהו ולא גל[ט] וליא

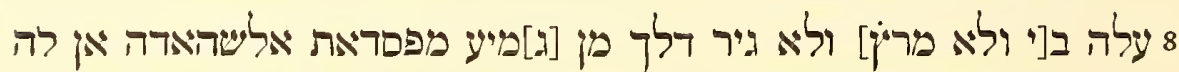

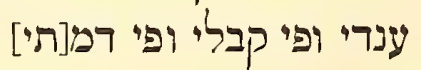

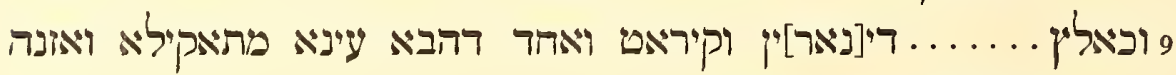

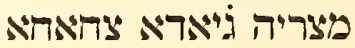

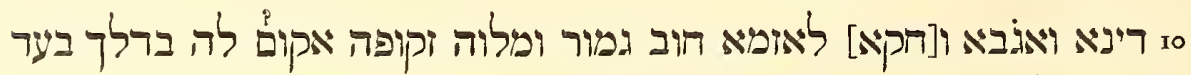

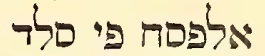

A

${ }^{1}$ Reading מעy, though the text is not quite plain. Sometimes simply the word מה is used. Cf. Cambridge University Library, Taylor-Schechter I3 (Ji . No. 7). . מיה שהיה בפנינו.

${ }^{2}$ Followed by one of the expressions usually accompanying the names of prominent individuals: כבור גדולת קדוישת. Cf. Mann, The Jerws in Egypt, vol. ii, p. 383.

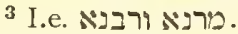

4 I.e. "purple."

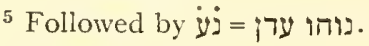

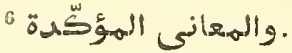

7 The Aramaic expression very often occurs in the simpler form כתבו לי זכות. 


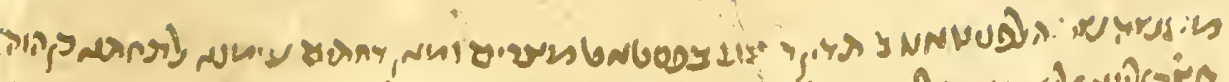

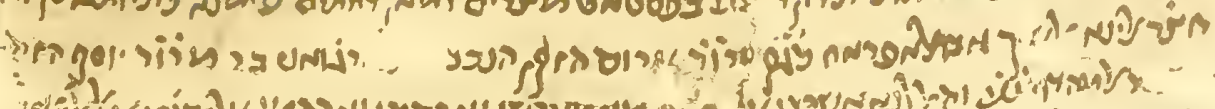

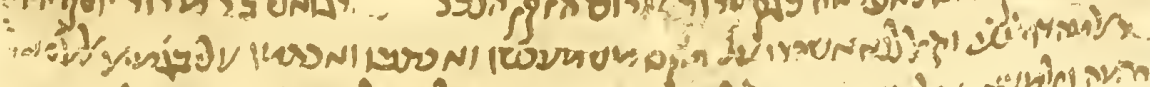

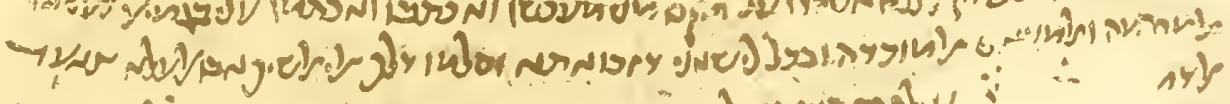

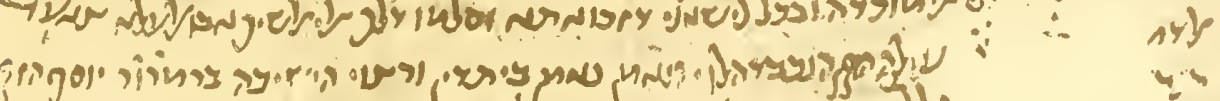
1

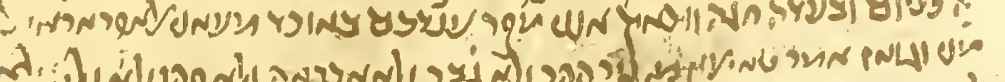

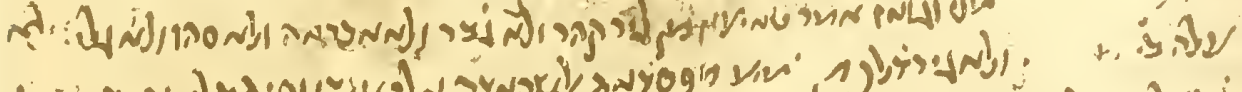

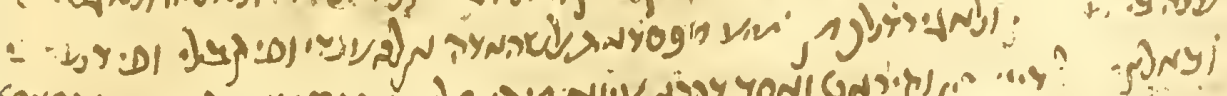

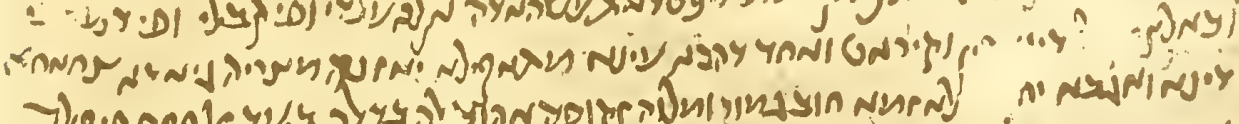

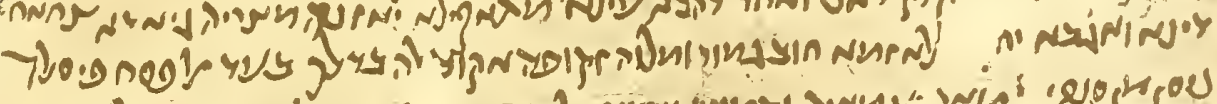

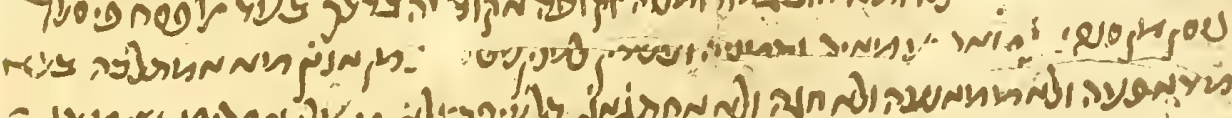
- Ly.

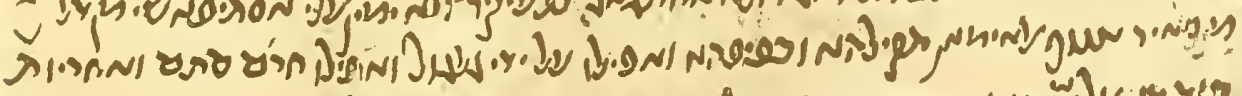

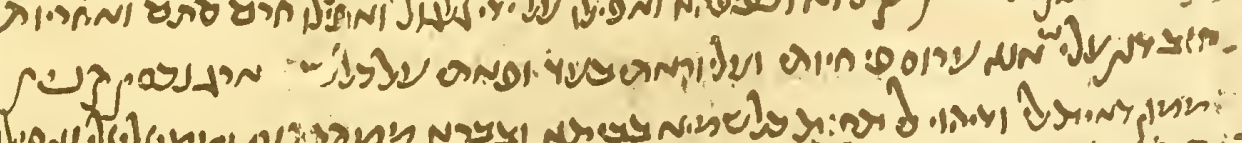

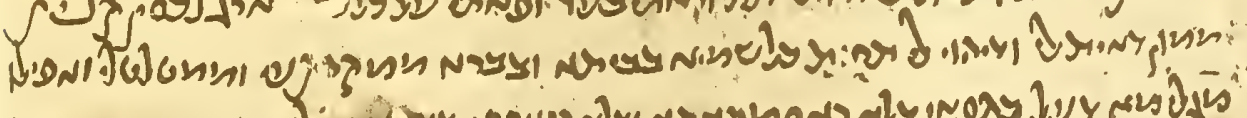
j:

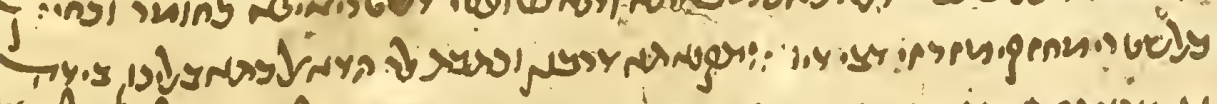

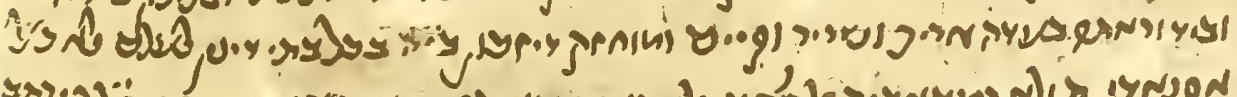

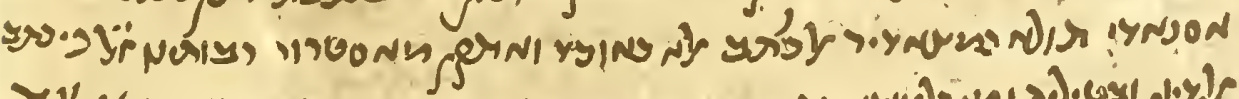

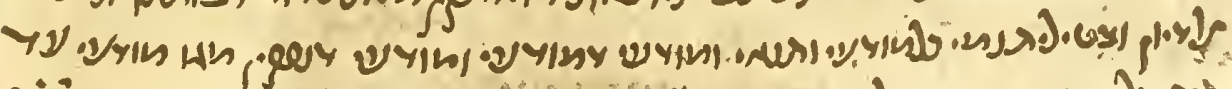

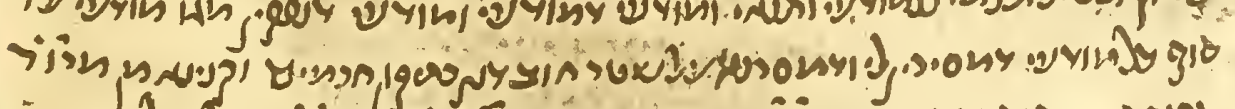

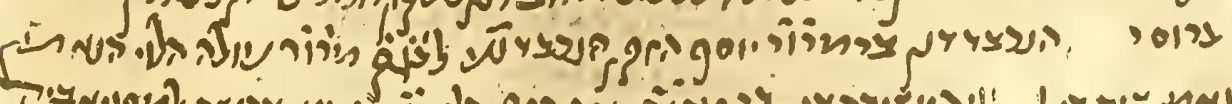

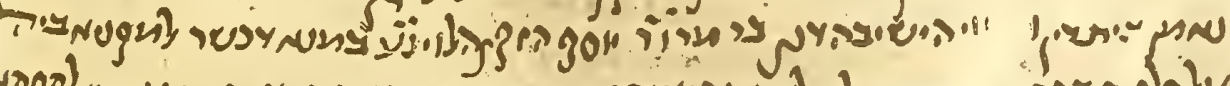
עaras

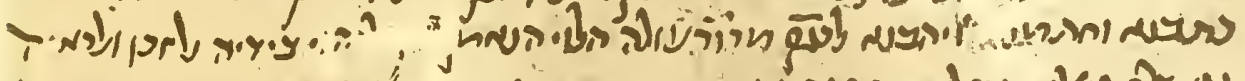
ל

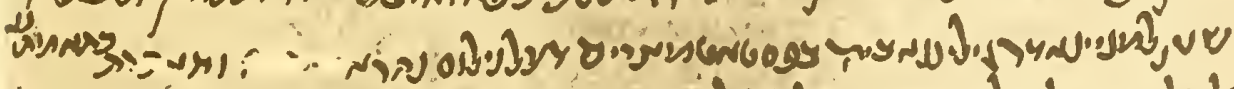
D"gi "

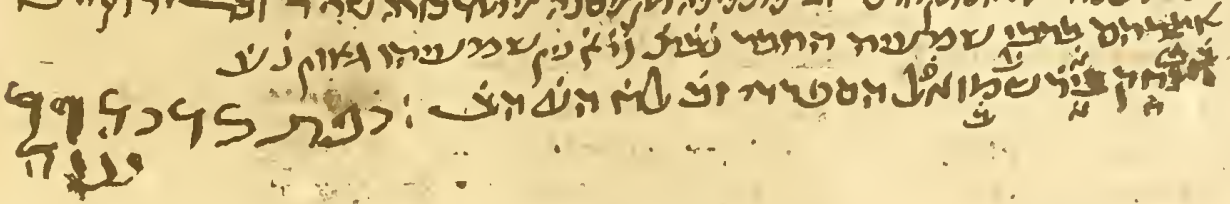




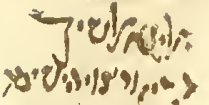

spingeriph

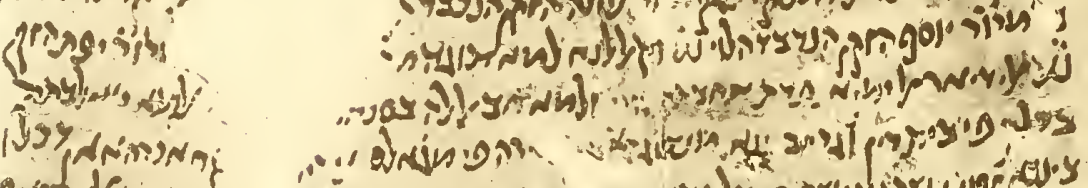

jisy

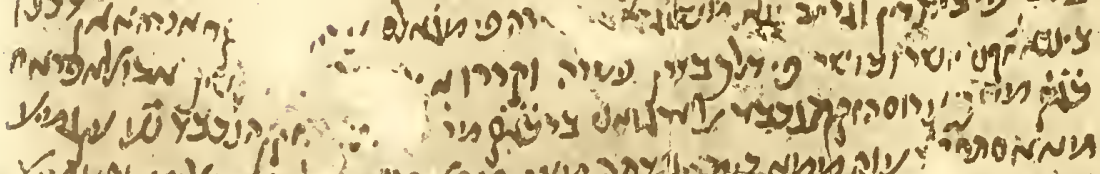

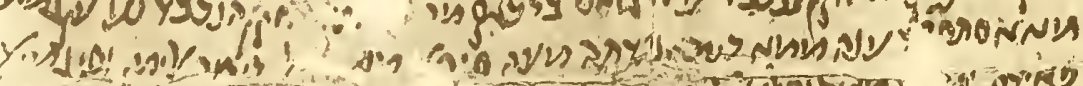

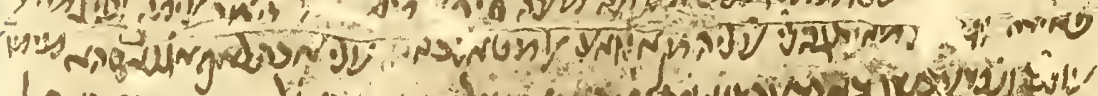

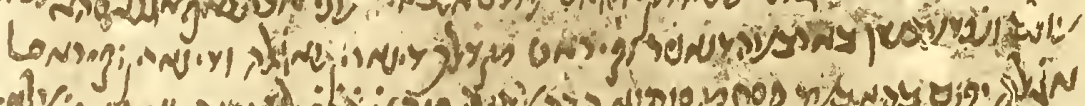

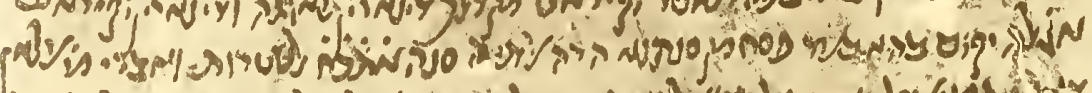

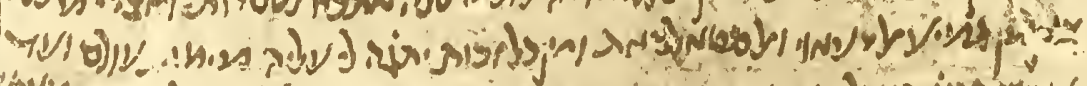

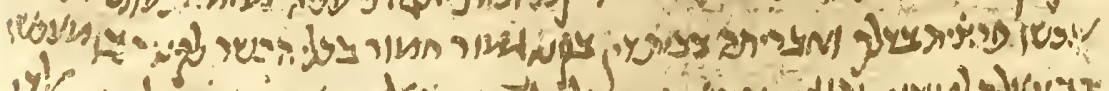

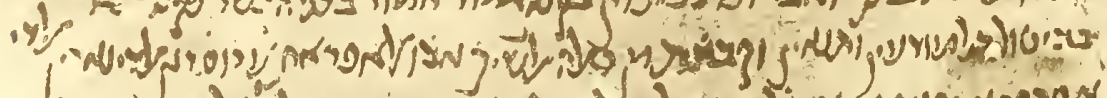

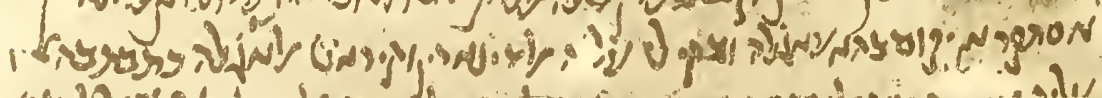

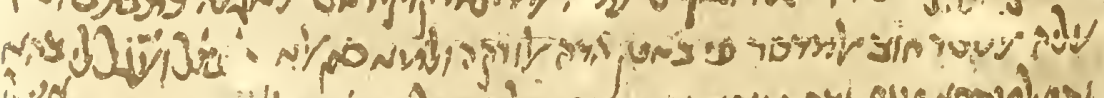

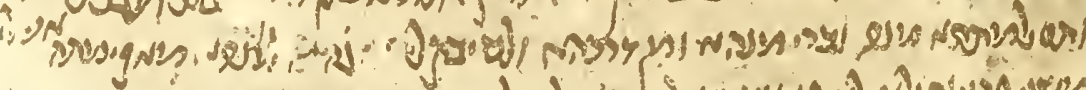

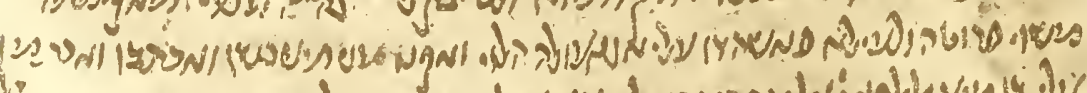

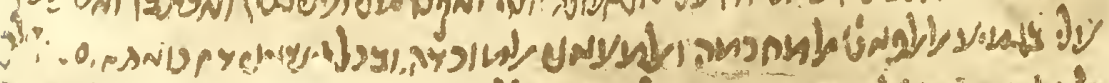

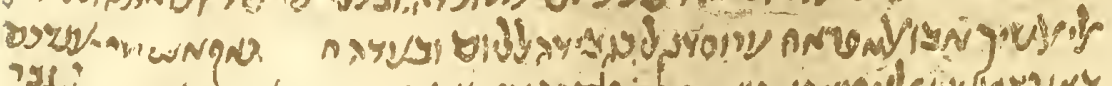

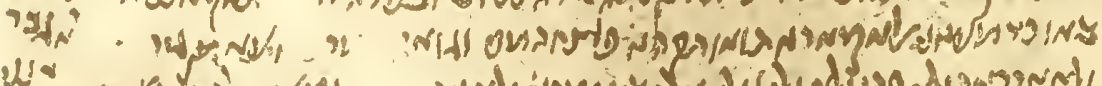

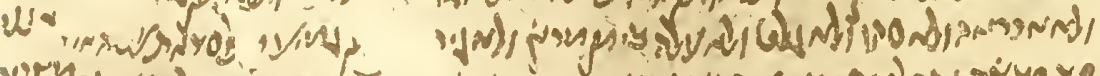

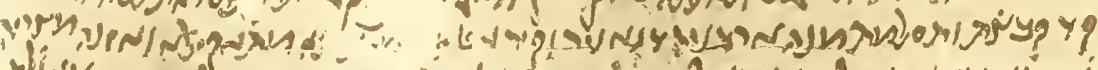

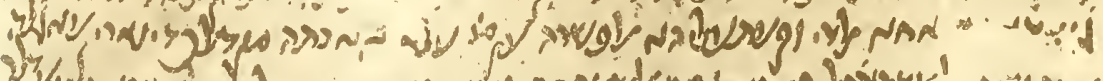

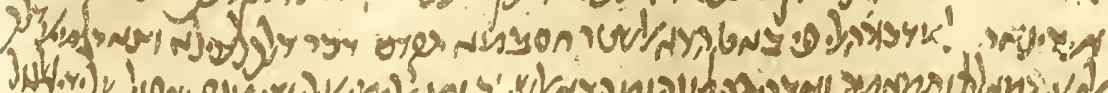

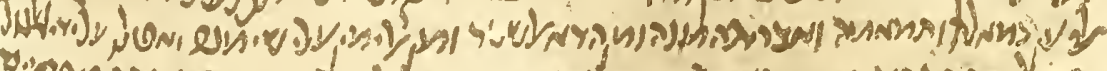
y.on (a)

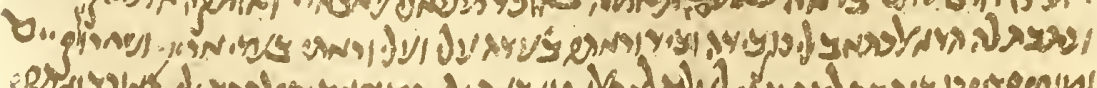

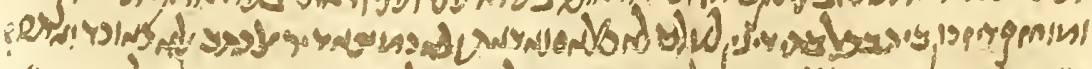

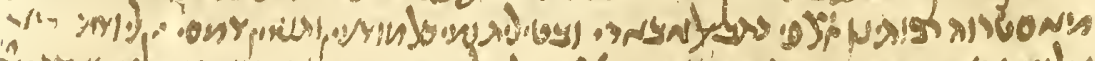

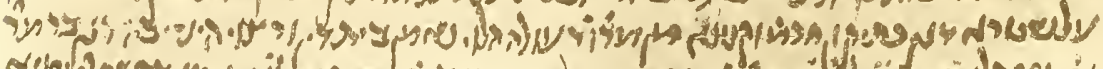

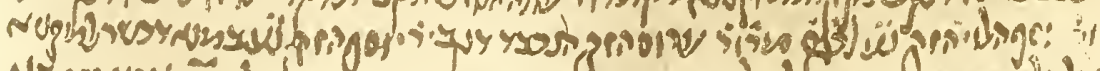

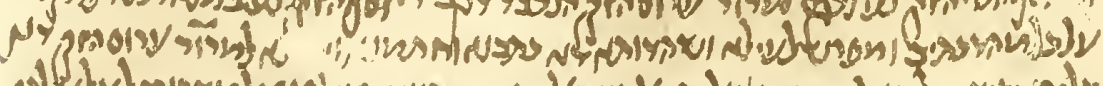

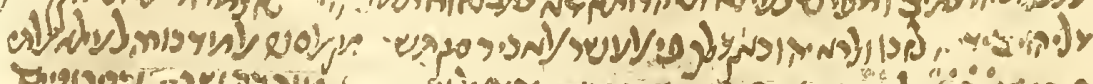

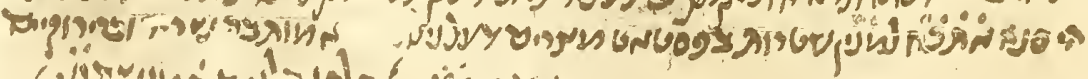

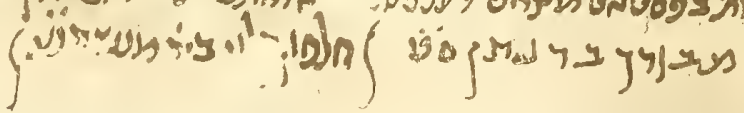




\section{TWO DOCUMENTS}

A

Recto:

I The following ${ }^{1}$ occurred before us the Bēth Dīn [Court of Justice] properly appointed in Fusțāt, Egypt, and in the presence of those whose names are signed below. Thus it was:

2. There appeared before us the Sheikh Abū al-Afrāḥ ${ }^{2}$, our lord and master $^{3}$ 'Arūs, the honored elder al-Arjawānī', son of our lord and master Joseph, the honored

3 elder, al-Mihdāwi $\overline{1}^{5}$, and said to us: Take my testimony, and ratify it on my part at this moment, write it down and have it signed for me, using all the sacred

+ terms and the hallowed expressions ${ }^{6}$, and in language that will fully exempt me $e^{7}$, and hand this [document] to the Sheikh Abū al-'Alā Să'id ${ }^{8}$ 5 of $\mathrm{Da}[$ mascus...... ' Ulāh ha-Lēvì, the honored elder, the trusted Levite, trusted of the Bēth Dīn and accredited of the Yeshïbhah, son of our lord and master Joseph,

6 [the honored elder, that it remain in his possession] from now on and afterwards, as a document and a bond. Behold, I acknowledge before you in the most positive

7 and binding form of acknowledgment, being [in good health] ${ }^{9}$, in full possession of my will, voluntarily, not being forced, without constraint, coercion, without inadvertence or error,

8 or any infirmity in [me or illness] or any of the many [conditions] that make it impossible for me to give testimony, that I owe him, and have in my possession and in my care

9 and separate......dīnārs and one kị̂āt ${ }^{10}$ of fine gold in mithḳāls ${ }^{11}$ of Egyptian weight of good quality and true,

Io a legitimate debt and a binding liability ${ }^{12}$. I shall pay ${ }^{13}$ him this after the Passover festival at the end of ${ }^{14}$

8 The use of the letter $y$ for $\mathrm{w}$ is quite possible in these documents. The same person is mentioned in another document cited by Worman in the Jewish Quarterly Review,

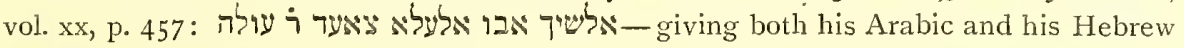
name.

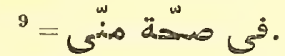

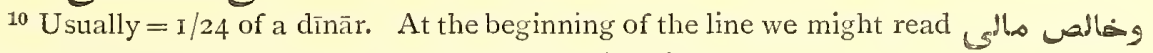
were it not necessary to suppose a number at this point.

11 The mithka $\bar{l}$ had various values. Here the word is probably used for "coin" in general.

12 These Arabic words are followed by their equivalent in Hebrew.

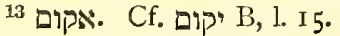

14 "in the course of"? 


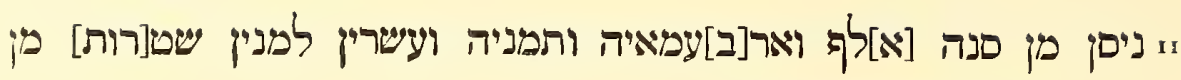

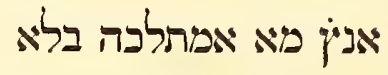

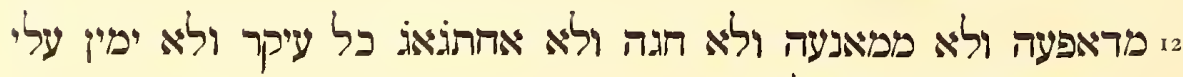

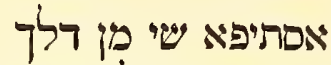
3י פן סאיר צנוף אלאימאי תמא תקילהא וכפיפהא ואפילו על ידי גלגול ואפילו חרם סתם ואחריות אית צמות

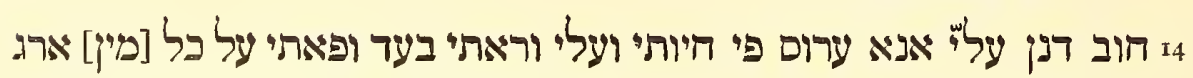

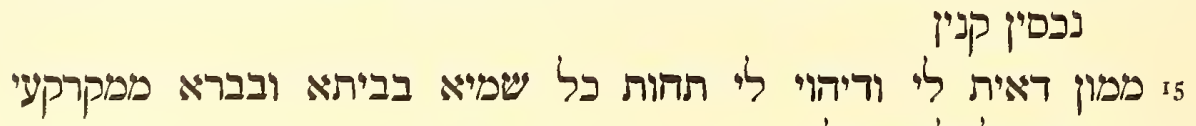

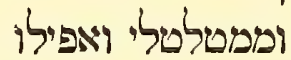

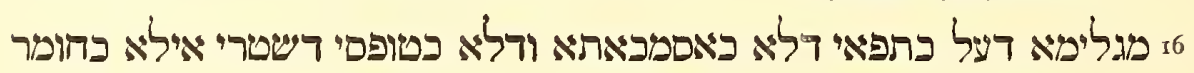
ופדזים

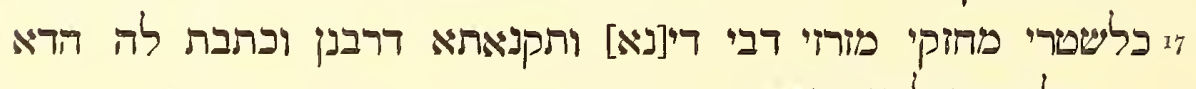

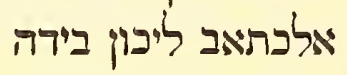

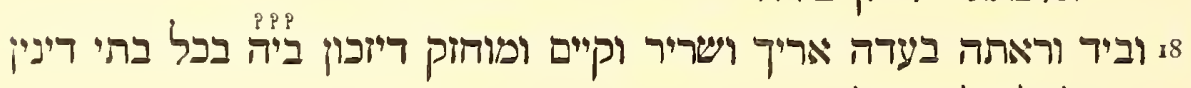
לעלם לאי פאל

19 אשנאדאת ולא כמצזאדיר אלכיתב אלא פ'אוכד ואתקן מא סטרו[ה] רבותינו i

ס אלדייון ובטילית נמי פל מודעי ותנאי ומורעי דמודעי ומודעי דנפקין מגו מודעי עיד ובעירית

ז2 סוף כל מודעי דמסירין לי ודמסרנא על שטר דוב דני בתיקון חבמים

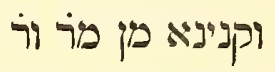

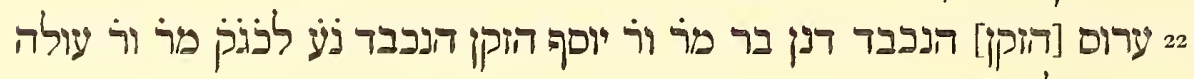
הללי הנאמשי

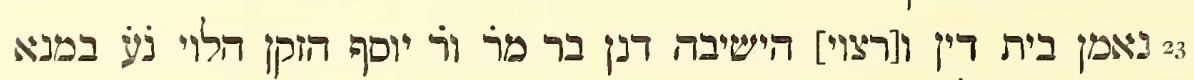

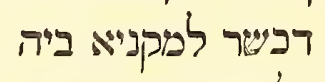

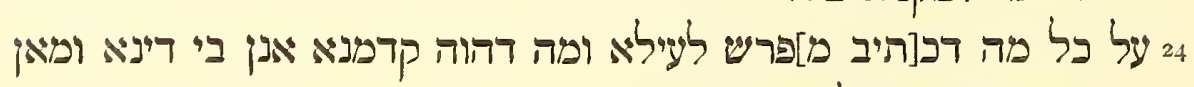

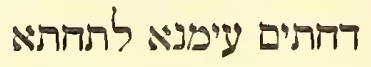

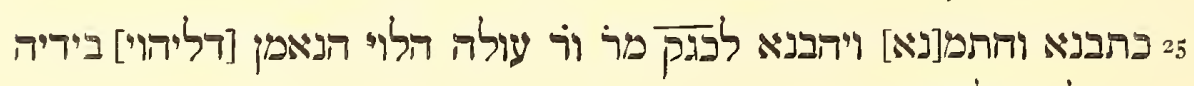
לזכו ולראיה ותמאיה

\footnotetext{
15 The Seleucid Era, beginning 3 I2 B.C.

${ }^{16}$ Literally: "light or heavy."
} 
I Nisan of the year one thousand four hundred and twenty-eight according to the Era of Documents ${ }^{15}$, in the same good coin which he possessed. [He does this] without

12 any constraint or restraint, argument or discussion at all, or any oath for the carrying-out of any part of this [agreement],

I3 from among all the various kinds of oaths, unimportant or capital ${ }^{16}$; not even by means of an oath of implication, nor by any unqualified vow. [The return

${ }^{+}+$of this money] is an obligation upon me, 'Arūs, during my lifetime, and upon my heirs after my death, upon anything worth while that I may possess-property, possessions

I5 or money that is mine or that I may possess under all the heavens, at home or abroad, real or personal property, even to the covering that is I6 upon my shoulders: not like simple acts of recovery or mere contract formularies, but like full and valid documents :

I 7 invincible, irresistible writs of the court of justice, and the ordinances of the rabbis. I have written this document in his favor, that it may be in his possession

I8 and in the possession of his heirs after him: a document lasting, stable and durable; it being understood that they can make use of it in any court of justice and for all time to come: not like

I9 simple acts of recovery ${ }^{17}$ or mere contract-formularies ${ }^{18}$, but as the most binding and stable documents that our rabbis ${ }^{19}$ have laid down for documents

2o acknowledging debts. I declare void all protests and conditions and protests of protests, and protests that may be developed from protests to the $n^{\text {th }}$

21 degree that may be made for me, or that we may have made in connection with this deed of claim-[all] in accordance with the statutes of the wise men. We have received from our lord and master, this ${ }_{22}$ 'Arūs, the honored [elder], son of our lord and master Joseph, the honored elder, for our lord and master 'Ulāh ha-Lèvī, the trusted one ${ }^{20}$, 23 this one trusted of the Bēth Dinn and accredited of the Yeshibah, this son of our lord and master Joseph ha-Lēvi the elder ${ }^{21}$, [a guarantee] in current money

${ }_{24}$ according to all that is set forth explicitly above, and which has been brought before us, the Court of Justice, and before those whose names are signed for us below.

${ }_{25}$ We have written this, sealed it, and given it to our lord and master 'Ulāh ha-Lēvi the trusted one, that he keep it as evidence and as proof.

\footnotetext{
17 There is a hole in the paper here.

18 isliwl.

19 See Merx, Documents de Paléographie Hébrä̈que et Arabe, p. 32, note.

$20 \%$. Words of blessing following names are omitted in the translation.

21 See Mann, op. cit., vol. i, p. 196.
} 
26 ופיאן דלך פי אלעישר אליאביר מן חדש תמטו דשנת אלפא ו"ארבעמאה ועיה ועשרין וישבעה דיער

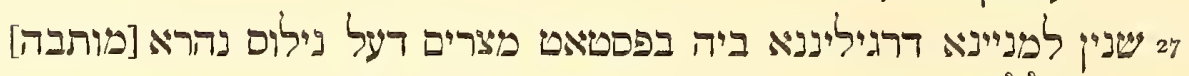

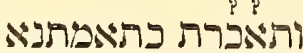
28 אלי אלעשר אליאול פן חדש אב אלתמאלי לה פן אלפנה אלמדכורה שריר

וברירי וקיים

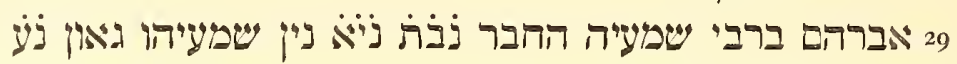
מ.

ה

Verso:

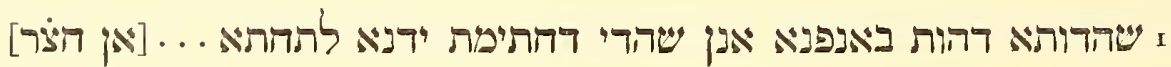

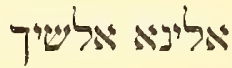

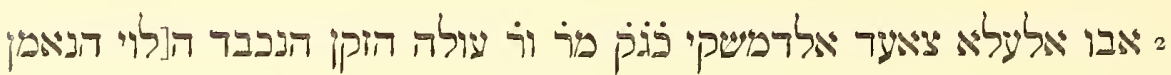

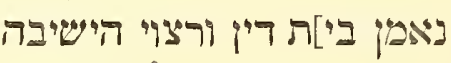

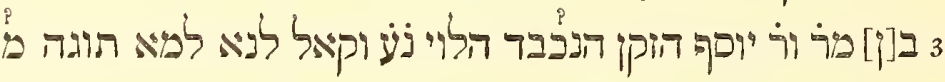
i

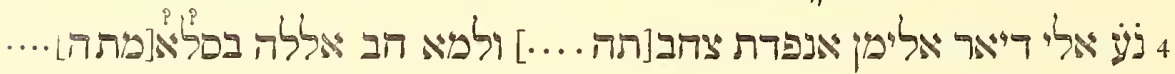
ה ה

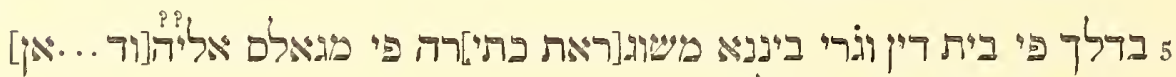

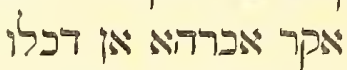

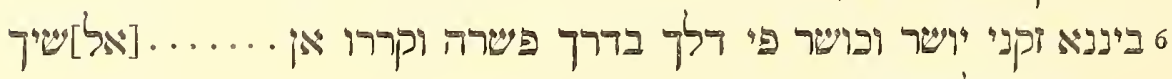

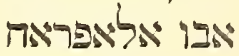

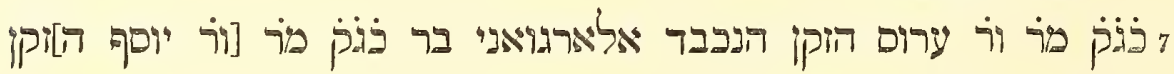
המברב

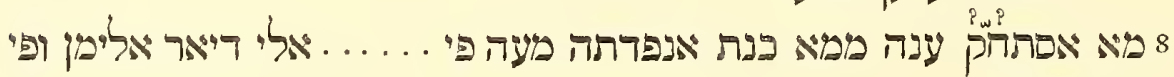
y"y.s

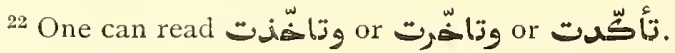

${ }^{23}$ I.e. the Passover festival.

${ }^{24}$ The letters placed above names sometimes spell a title, e.g. המלמד = "the teacher." (Taylor-Schechter 13, J I. No. I.) Sometimes they spell the name of the person's father. See Mann, op. cit., vol. ii, p. Io2. At other times they are the initials of 
26 This happened during the last ten days of the month Tammuz, of the year one thousand four hundred and twenty-seven,

27 according to the era that we are accustomed to use in Fusțāt of Egypt, situate upon the river Nile. Our signature was affixed [only] ${ }^{22}$

28 upon the tenth day of the month of $\mathrm{Ab}$, that follows it ${ }^{23}$, of the aforementioned year.

Certain! Clear! Established!

29 Abraham son of Rabbi Shema'yah, the Hābēr, descendant of Shema'yah Gāōn.

30 [Signed by] Isaac, son of R. Samuel ${ }^{24}$ ha-Sefardī.

Yepheth, son of R. David (?)......

$\mathrm{B}$

Verso:

I Testimony in regard to the affair that was treated before us-we who have placed our signature below :...... [There appeared] before us the Sheikh

2 A $\mathrm{b} \bar{u}$ al-'Alā Șāiid of Damascus, our lord and master 'Ulāh, the revered elder ha-[Lंēvi, the trusted one, trusted of the court] of justice and accredited of the Yeshībhah,

3 son of our lord and master Joseph, the revered elder ha-Lēvi, and said to us: When............our lord and master Yepheth, the elder

4 went to the country of al-Yemen, a partner[ship] was agreed upon between us (?) ${ }^{1}$; and, when God was gracious enough to permit him to return to us in health ${ }^{2}$, when the case was brought

5 before the Court of Justice, many difficulties ${ }^{3}$ arose between us...... in the end an agreement (?) was reached that there should come between us

6 righteous and God-fearing elders in this matter, in order that a settlement ${ }^{4}$ might be arrived at. So, there came to an agreement.....the Sheikh Abū al-Afrāh,

7 our lord and master 'Arūs, the honored elder al-Arjawānī, son of our lord [and master Joseph the] honored elder, in respect to all that to which I

8 have a right of that which $\mathbb{I}$ had given (?) to him [to take with him] ${ }^{5}$ to the districts of al-Yemen, and in regard to

words making up a pious wish. The last signature is badly written. Perhaps Yepheth was a very old man at this time. In Mann, op. cit., ii, 97, we find Yepheth the Hazzān, son of Rabbi David, identical with Yepheth b. David b. Shekhanya, who signed documents as early as A.D. IO2O, ninety-six years before our document.

B

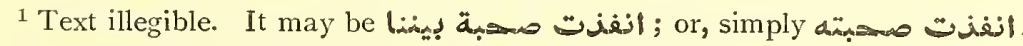

${ }^{2}$ The sense is quite certain, but the text is not easily restored.

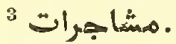

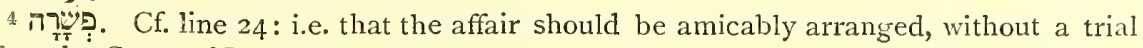
before the Court of Law.

${ }^{5}$ Perhaps insert في في 


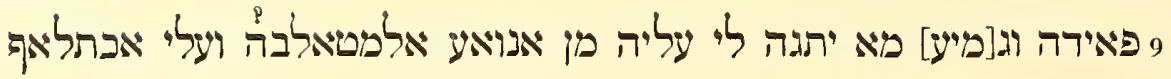

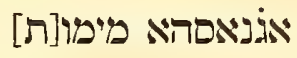

10

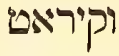
יי אגלה יקום בהא בעף פסה פן סנתנא הדה אלתי הי סנה התכז למטרות

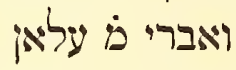

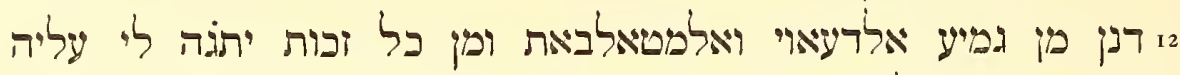

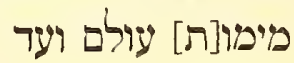

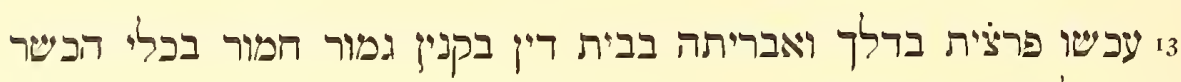

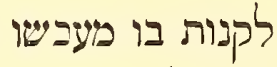

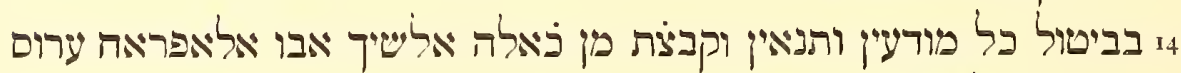

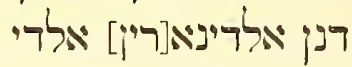

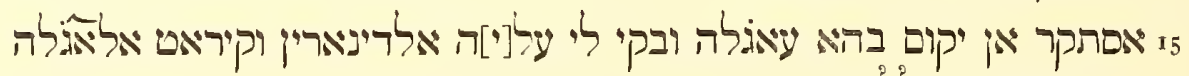
כתבת בה אין

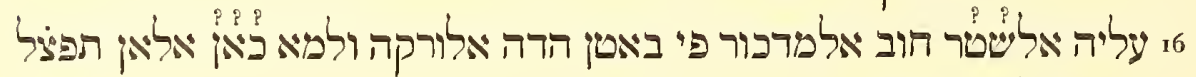

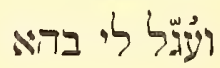

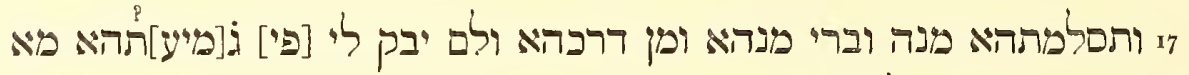

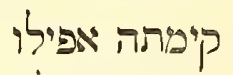

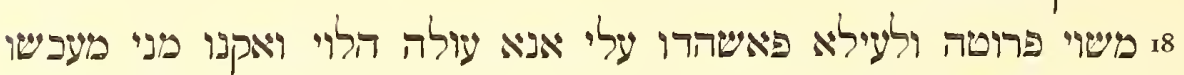

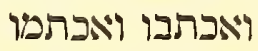

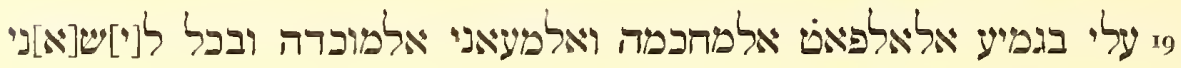

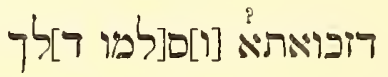

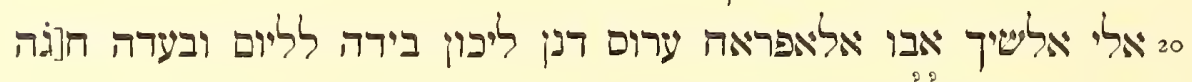

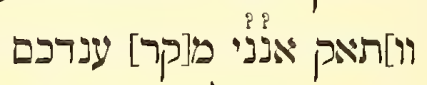

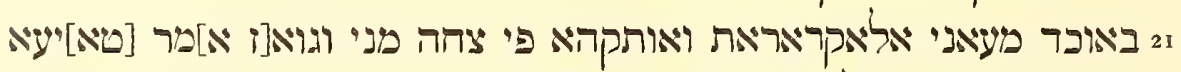

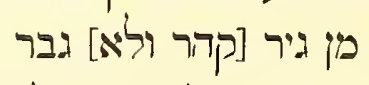
22 וליא אבראה ולא סהו ולא פלט ולא עלה בי מן מריץ ולאי ג'ר [דלך מן]

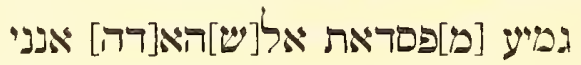

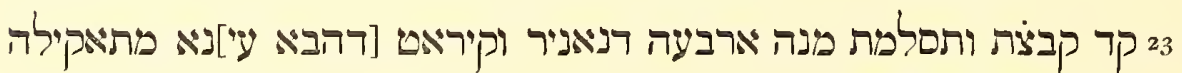
ואינה מצריה آَجِلَة 6. 
9 all that had been gained, and in regard to all that belonged (?) ${ }^{7}$ to me from him of the different things that I had the right to demand of him, in their various kinds, from the days

ro of old until now: that it amounted to four dīnārs and a ḳirāṭ. Of these, two dīnārs were to be paid at once; and two dīnārs and a kị̂năt

in should be kept ${ }^{6}$ and paid by him after the Passover festival of this year which is the year I 428 according to the Era of Documents. This Mar 'Allān was declared free

I 2 from any further claims or demands, or from any gain that might be due (?) ${ }^{7}$ to me from days of old until

${ }_{3}$ today. Now I have agreed to this and have given him a quittance in the Court of Justice, by means of a perfect, all-comprising, bill of sale, with all the legal apparatus with which it is customary to make such quittance at this time,

It by declaring void any provisions and conditions. I have received from his maternal uncle, Sheikh Abū al-Afrāh the two dīnārs which

$I_{5}$ it was agreed should be paid at once on his account. There remained owing to me from him the two dīnārs and a kịirạt to be paid afterwards; for which ${ }^{8}$ I

I 6 had drawn up the promissory note mentioned in this paper. And now that he has been kind enough, and the payment of this sum has been accelerated to me,

If and I have received it from him, and he is free from it and from any liability in regard to it; and since I have no longer any pecuniary interest at all in it, even

is that of a penny or more, receive, therefore, this testimony from me, 'Ulāh ha-Lêvì, and ratify it on my part at this moment. Write it down, and have it signed for me,

ig using all the sacred terms and the binding expressions, and in language that will fully exempt him, and hand this statement

zo to this Sheikh Abū al-Afrăh 'Arūs, that it remain in his possession from now on and afterwards as a document and a bond. Behold! I acknowledge before you,

21 in the most positive and binding form of acknowledgment, being in good health, in full possession of my will-power, voluntarily, not being forced, without coercion and

22 constraint, without inadvertence or error, or any hindrance arising from illness, or any of the many [conditions] that might make it impossible for me to give testimony-that I

${ }_{23}$ received and accepted from him four dīnārs and one ${ }^{9}$ kịrāt of fine gold in mithḳāls of Egyptian weight

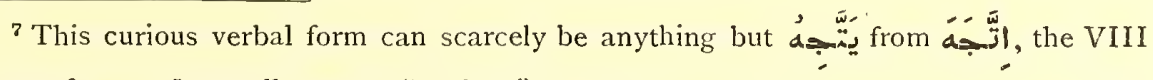
form of وجه. It usually means "to face."

8 There are two very strange characters at the end of the line. Perhaps $\mathbf{k}$ (אל, "now."

${ }^{9}$ There is no room for וזהח. Cf. A, line 9. 


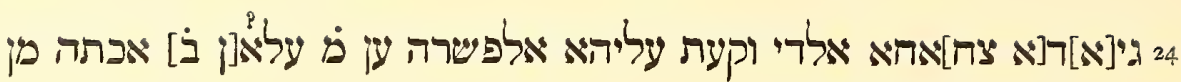

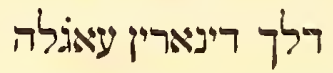

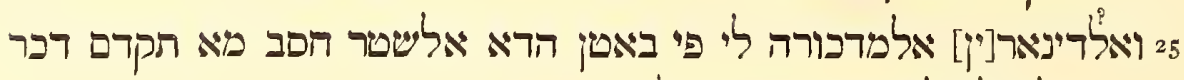

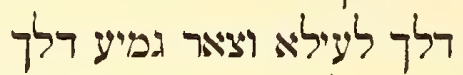

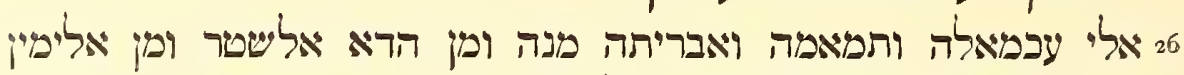

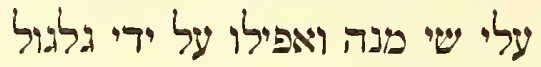

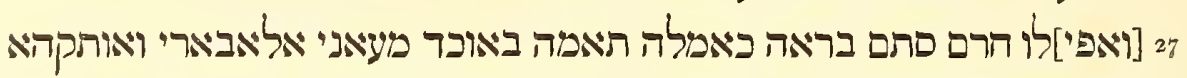

$$
\text { וכתיקון חכמים }
$$

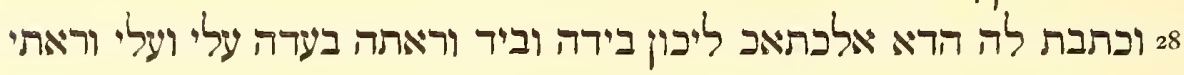

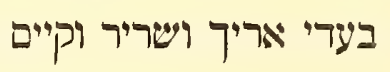

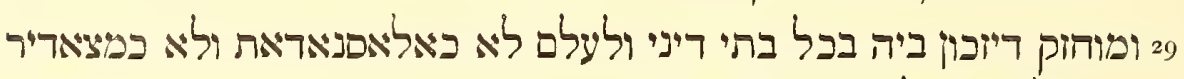

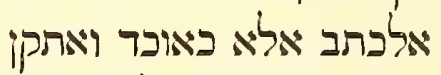

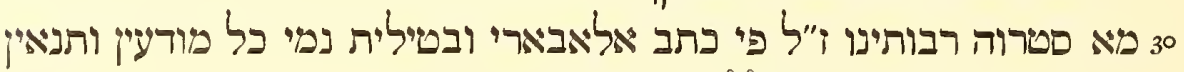

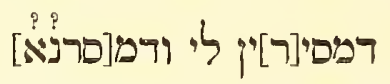

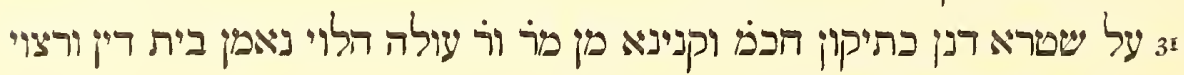

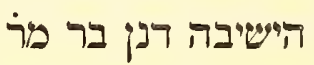

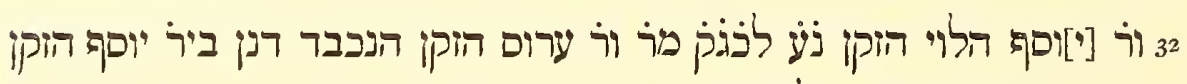

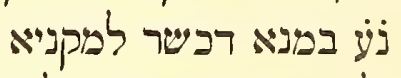

33 על כל מה רכתיב ומפרש לעילא ושהדותא דא כתבנאיא וחתמנא וי[הב]ניא

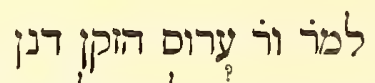

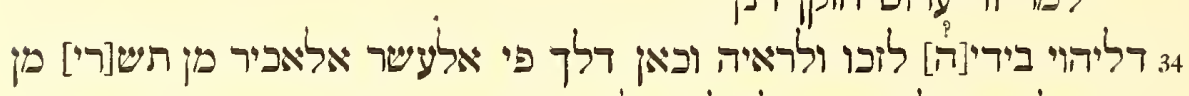

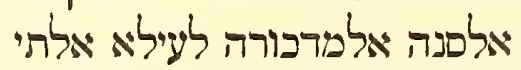

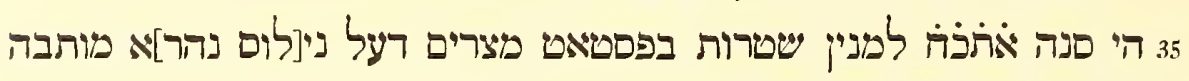

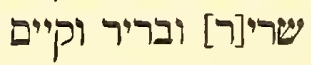

מבורך בר נתן טּט 
${ }_{2}$ of good quality and true, according to the agreement reached with Mar 'Allān his nephew in regard to these two dinnārs which were to be paid at once

25 and the two dinārs mentioned by me in this paper, as has been stated above. All this has come

26 to me completely and in its entirety. I now free him from this [debt] and from [the provision of] this document, and from taking an oath in regard to any part of it, even a compulsory oath

${ }_{27}$ - a complete and entire release, in the widest and fullest sense of that term and according to the statutes of the wise men.

${ }_{28}$ I have written this document in his favor, that it may be in his possession and in the possession of his heirs after him : binding upon me and my heirs after me; lasting, stable, and durable:

29 it being understood that they can make use of it in any court of justice and for all time to come; not like simple acts of recovery, or mere contract-formularies, but as the most binding and stable documents

30 that our rabbis have laid down for us in regard to the documents of release. I, further, declare void any protests or conditions which may have been made for me or which I may have made

$3^{\mathrm{I}}$ in regard to this document, in accordance with the statutes of the wise men. We have received from this our lord and master 'Ulāh ha-Lèvī, the trusted one of the Court of Justice, and accredited of the Yeshibhah, the son of our master

$3^{2}$ and lord Joseph ha-Lēvī, for our lord and master this 'Arūs, the honored elder, son of Rabbi Joseph, the elder, in current money, according to all 33 that is set out explicitly above. This testimony we have written down and signed, and have handed over to our lord and master this 'Arūs the elder, that it remain with him

$3+$ as proof and as evidence. This occurred during the last ten days of Tishri, of the year mentioned above, which is

35 the year I428, according to the Era of Documents, in Fustạt of Egypt, situate upon the river Nile. Certain! Clear! Established!

$3^{6}$ [Signed] Mebōrākh, son of Nathan

Halfōn ha-Lēvī, son of Menasseh. 


\section{LETTER}

Paper I I $\frac{5}{8} \times 8 \frac{3}{4}$ inches.

Arabic and Hebrew, in fairly legible cursive Hebrew characters.

Recto:

אפי "'

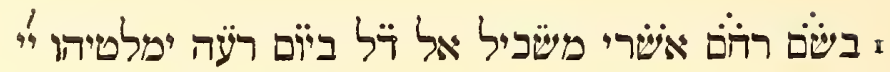

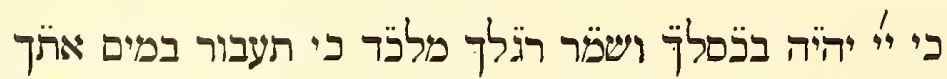

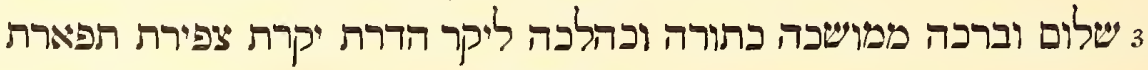

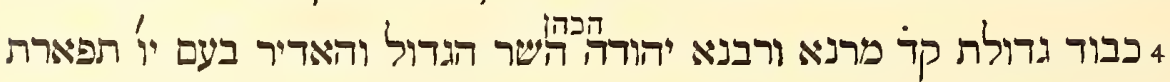
השרים

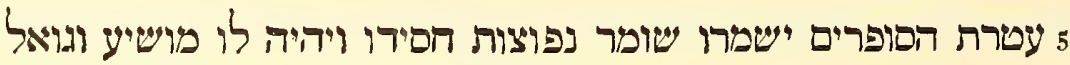

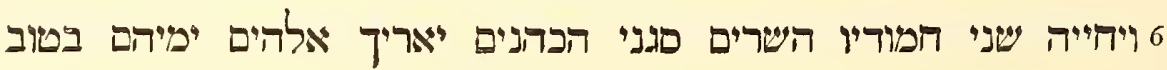
9שים

ז בנעיפים בר כג' מרנ ורבj אלי[ע]זר השר הכהן האדיר שר הנריבים

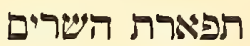

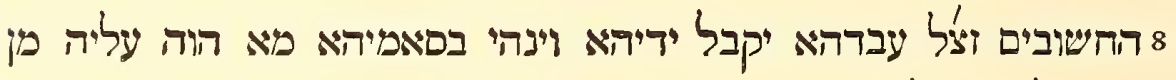

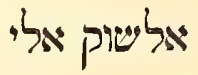

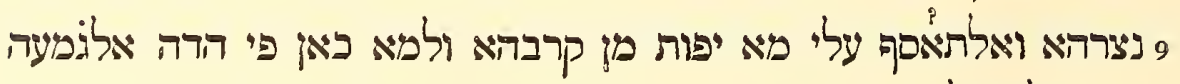

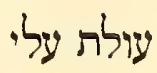

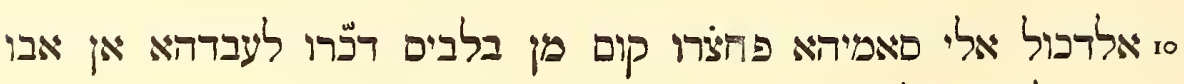

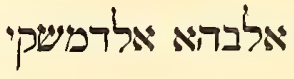

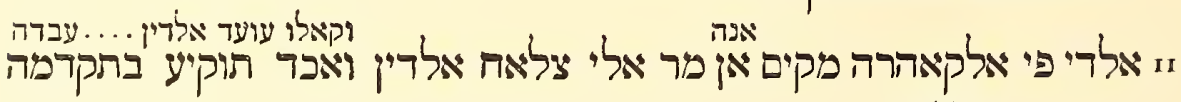

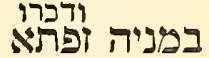

1 This seems to be a Jewish replica of the usual Muslim introduction بسم الله الرومهن الرهيم. Cf. also Steinschneider, Die Arabische Literatur der Juden, p. xxxi.

2 Psalm xli, 2.

${ }^{3}$ Proverbs iii, $26 . \quad{ }^{4}$ Isaiah xliii, 2.

${ }^{5}$ For the use of "דi in the sense of "son," cf. Mann, op. cit., vol. ii, pp. 54, 1. 8, 58 .

${ }^{6}$ This alludes to the fact that the family was of priestly descent.

7 Refers to Judah ha-Kōhēn in line 4 .

${ }^{8}$ The feminine suffix here and in the following words is quite inexplicable-except as referring to תפארת in line 7. 
แु

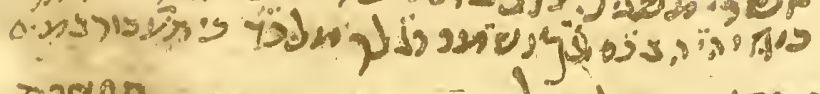

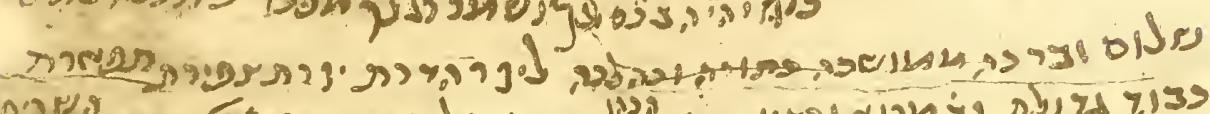

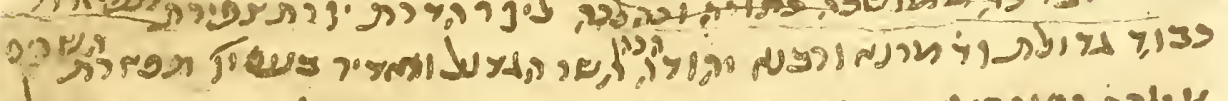

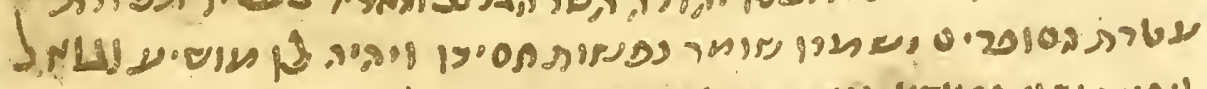

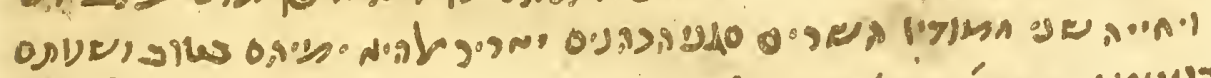

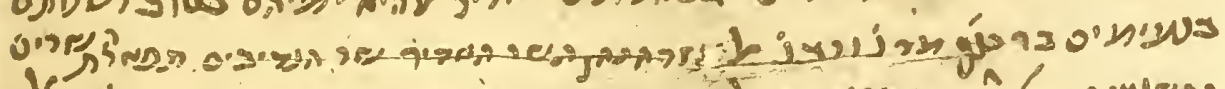

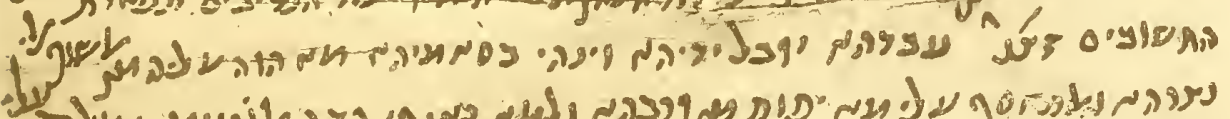

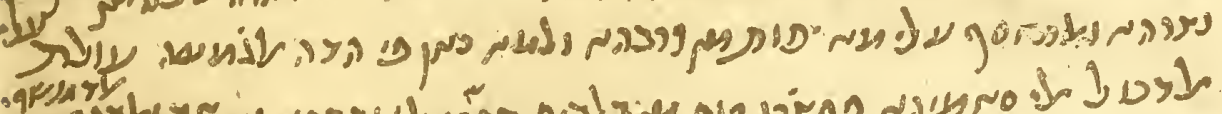

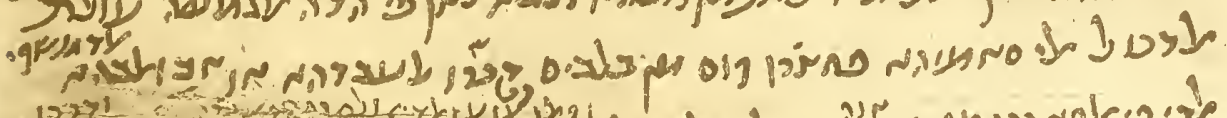
1331.

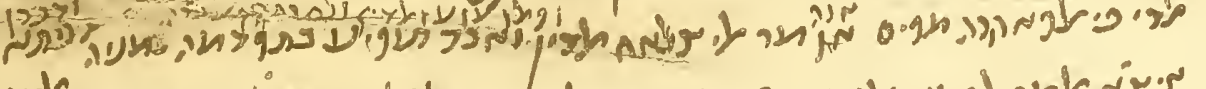

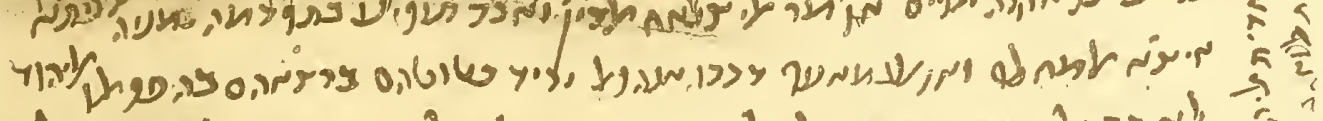

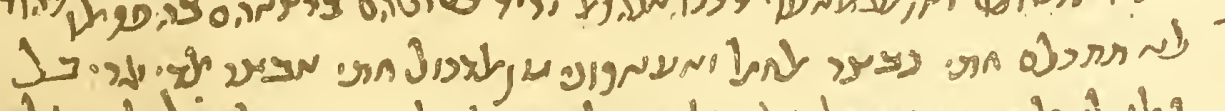

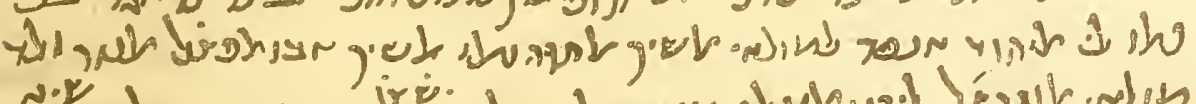

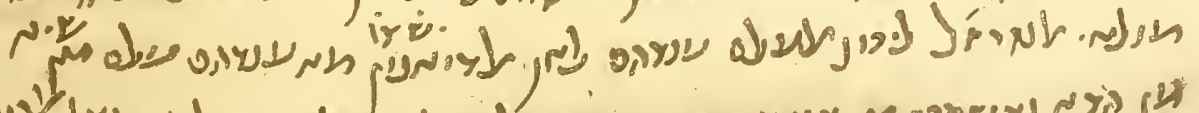

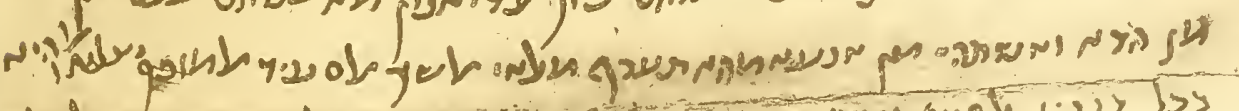

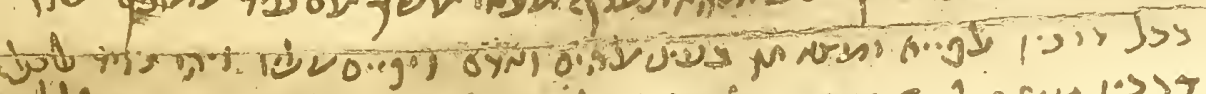

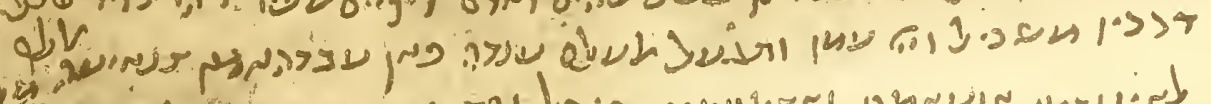

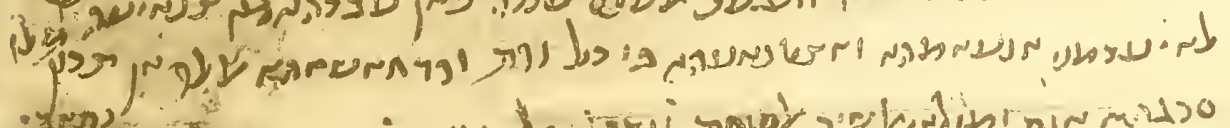

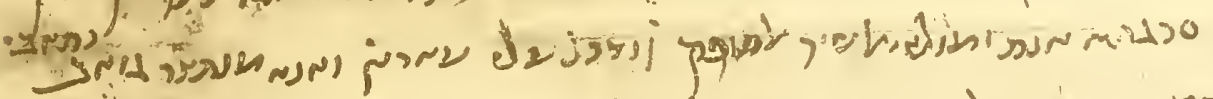

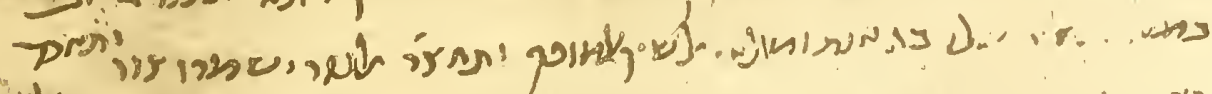
ist)

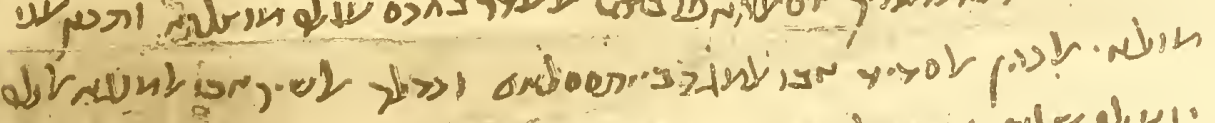

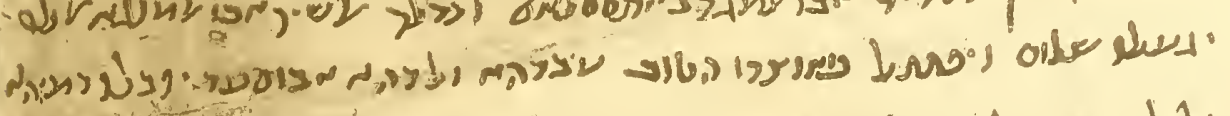

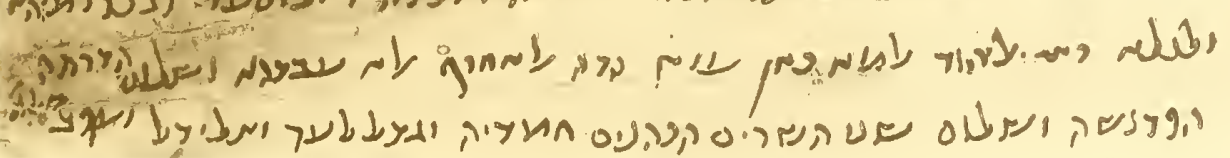




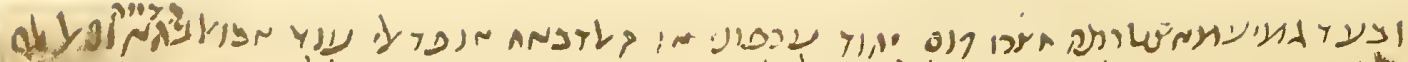

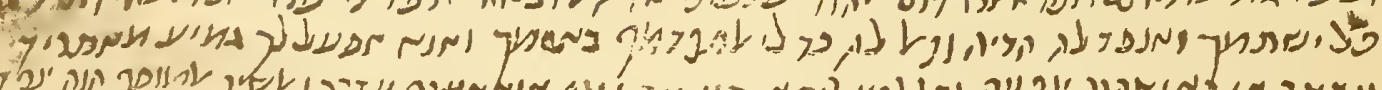

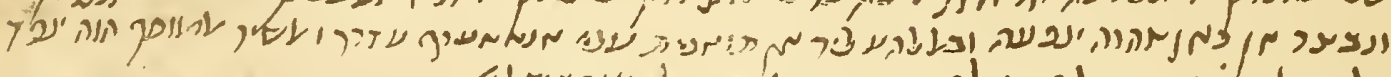

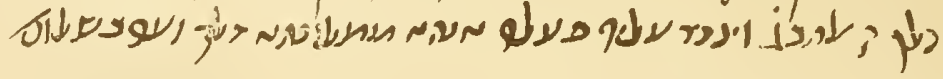
:

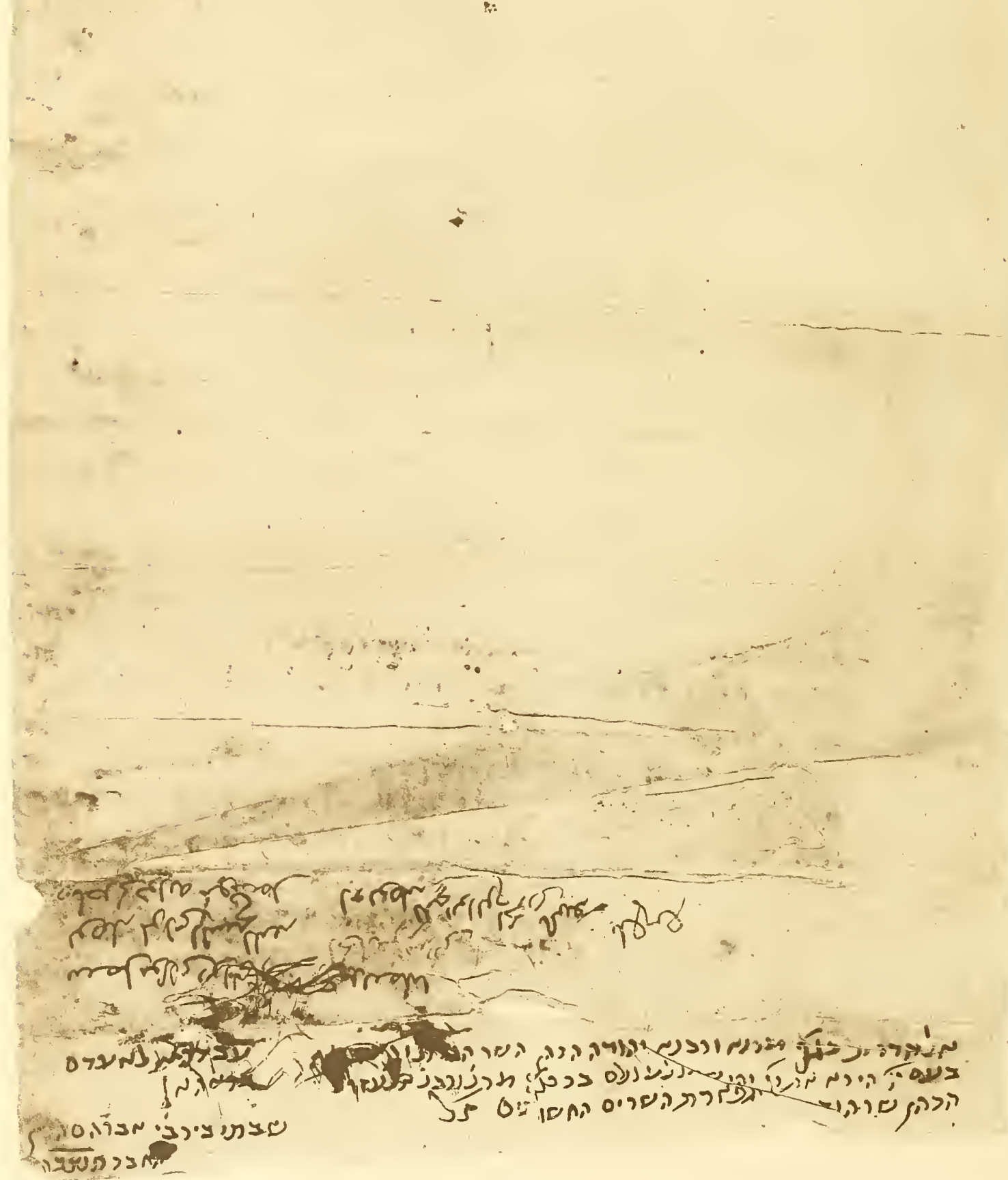




\section{LETTER}

A letter from Shabbatai, son of Abraham, Hābēr, of Minyat Zifta, to Judah ha-Kōhēn, the son of Eleazar, Dayyān of Bilbais, complaining that Jews of Bilbais are injuring his position in Minyat Zifta.

Shabbatai signed documents in A.D. I I 54. Judah was appointed Dayyān in I 87 , after which date our letter was probably written.

Recto :

I In the name of Mercy ${ }^{1}$ ! Happy is he who takes cognizance of the poor; on the day of evil God will deliver him².

2 For God will be thy hope and will keep thy feet from stumbling ${ }^{3}$, [as it is said :] "When thou goest through the water, I am with thee"."

3 Peace and prolonged blessing, as [promised in] the Law and in tradition, to the Honorable Crown of Glory,

4 his Illustrious Greatness, our Lord and Master, Judah ha-Kōhēn, the Great and Mighty Prince among the People of God, the Glory of Princes,

5 the Diadem of Scribes. May He preserve him who preserves his scattered pious ones, and may He be unto him a healer and deliverer!

6 May he also preserve in life his two sons ${ }^{5}$, the princes, the assistant priests ${ }^{6}$. May God lengthen their days in the [enjoyment of] good things, and their years

7 in pleasantness-son of ${ }^{7}$ our Lord and Master Eleazar ha-Kōhēn, the Prince, the Glorious, Chief among Princes, the Glory of Worthy

8 Princes. His slave kisses his hands ${ }^{8}$, and brings to the attention of his Highness ${ }^{9}$ how ardent his desire is for

9 his well being, and his regret (?) at the length of time during which he is away from him ${ }^{10}$. Now when it occurred in this week that I was boorishly denied entrance

Io to his Highness, people came from Bilbais and mentioned to his slave ${ }^{11}$ that $\mathrm{Abū}$ al-Bahā of Damascus,

I who was living in Cairo, had come to Salāh al-Dīn ${ }^{12}$, and had taken a promise from him of promotion in Minyat $\mathrm{Zifta}^{13}$, and they mentioned

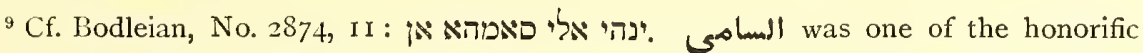
titles used in Egyptian protocols. See the interesting discussion of these titles, from which come many of our Hebrew ones in these documents, in al-Kalkashandī, Subh alA'shā, vol. vi, p. I 5, and Max van Berchem, Corpus Inscriptionum Arabicarum, I, 446.

10 The translation is a suggestion merely: ما يفوت من قربه

11 I.e. to himself, the writer.

12 Between the lines there has been inserted: "And some say "Awwād (written עועד) al-Din...his slave."

${ }^{13}$ Ibn Duḳmāk, Description de l'Egypte (Vollers), v, I09; Mann, op. cit., Index s.v. 


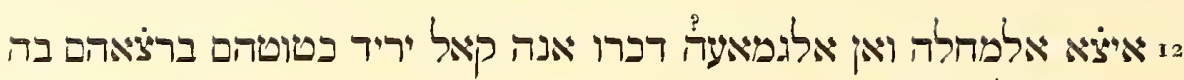
פקאזלו אליהוד אלמד

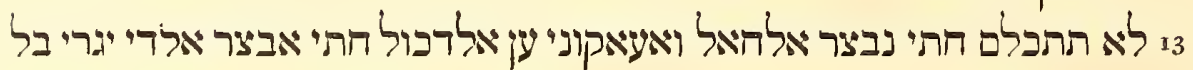

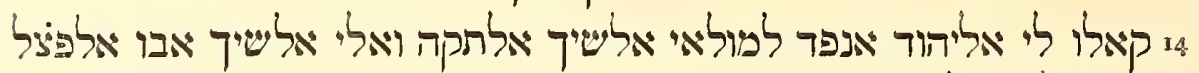
אלנור ולדי אליד

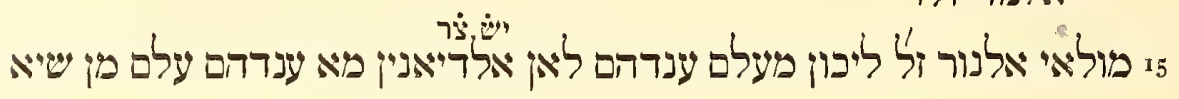

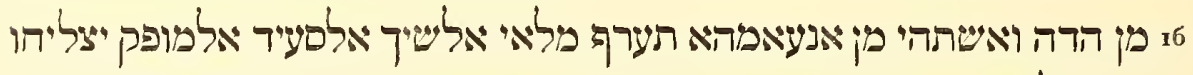

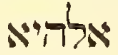

7י בכל דרכיו אלקיִים ימצ"א חן בעיני אלהים ואדם ויקי"ם עליו ויהי דויד לפל

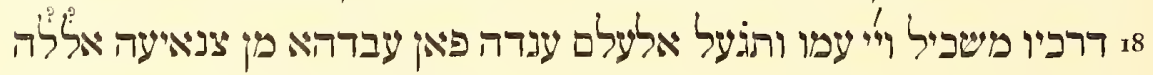

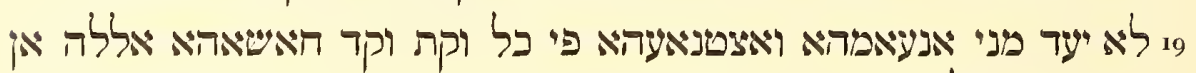

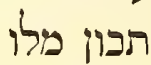

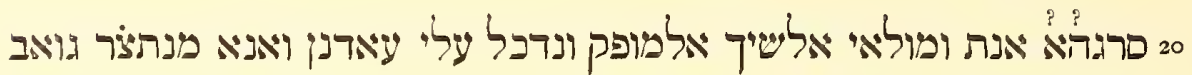

בתאבי

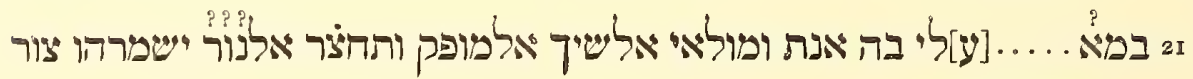

ותאכר

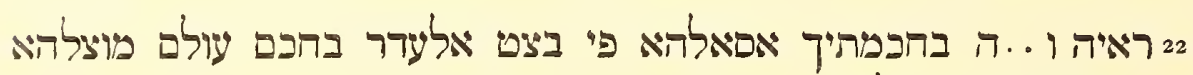

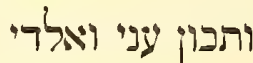

23 מולאי אלכהן אלסריד אבו אלמגרבי יתם סלאם וכדלך אלשיך אבו אלמנגיא ה

24

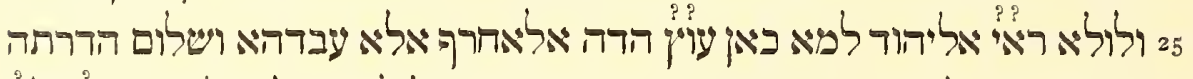

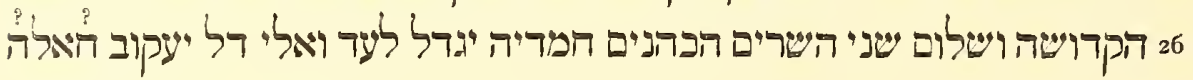
Margin:

אלא חדית אליהודי אלדין פין בלבים

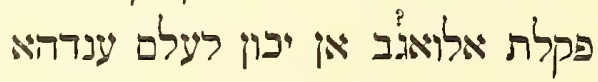

\footnotetext{
${ }_{11}$ Between Alexandria and Damietta. See Jewish Encyclopedia, vol. v, p. 62.

15 مولى

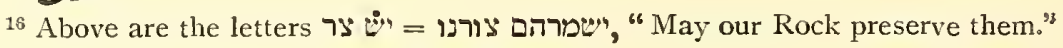

17 تُعرّف

${ }^{18}$ Written מליא צורנו

19 After Nehemiah ii, 20.

20 Or אלפיים.

${ }^{21}$ Proverbs iii, 4 .
} 
s2 also al-Mahallah ${ }^{\mathbf{1 4}}$, and a lot of them added that he had said that he wished their signature, expressing their satisfaction with him. The Jews answered:

I3 "Do not say anything until we have looked into the matter." They prevented me from coming, so as to learn what had happened. But

I 4 the Jews said to me, "Write to our master ${ }^{15}$, the Sheikh al-Thikah and to Sheikh Abū al-Faḍl al-Nūr, son of

15 our master al-Nūr, that he become a teacher among them, because the judges ${ }^{16}$ have no knowledge whatsoever

I6 concerning the matter." I desire that his Grace should inform ${ }^{17}$ our master $^{18}$ the Sheikh al-Sa'id al-Muwaffik-may God prosper him ${ }^{19}$

${ }_{17}$ in all his ways . . . ${ }^{20}$ - may he find grace in the eyes of God and of man ${ }^{21}$, and may there be applied to him the Biblical verse: "And David was

I 8 intelligent in all his doings, and God was with him ${ }^{22}$ "- and make the matter known to him. Now his slave ${ }^{23}$ - the least of God's children-

I9 has not been lacking his ${ }^{24}$ favor and his good will at all times. God forbid that you should be in a divided state of mind ${ }^{25}$,

2o you and my master al-Sheikh al-Muwaffik! Let us return to our usual custom. I am awaiting an answer to my letter

${ }_{21}$ in regard to what [you reply to ${ }^{23} \mathrm{me}-$ you and my master the Sheikh al-Muwaffik. Bring al-Nür-may the Rock preserve him !-and get

22 his view....... and...... in thy wisdom ${ }^{27}$. I would ask you boldly ${ }^{28}$ for help for all time to come; and that you serve me in the place of a father.

${ }_{23} \mathrm{My}$ best greetings to my master the righteous priest al-Maghrabī; and so also to the Sheikh Abū al-Munajja ${ }^{29}$. May God

24. grant him peace! May God open for him His good treasure ${ }^{30}$ ! His slave and his [slave's] son ${ }^{31}$ kiss his feet.

25 And were it not for the opinion of the Jews, these words would not have been written so mysteriously about ${ }^{32}$ your slave. Greetings to his 26 Holiness, and greetings to the two priestly princes, his sons. May he be exalted forever, and the poor of Jacob.......

Margin:

In regard to ${ }^{32}$ the case of the Jew [and] the Dayyān of Bilbais, I said: "It is right that he should be informed."

22 I Samuel xviii, I 4. After this long interruption, the text is taken up from line I6 as if nothing had intervened.

23 The writer. 24 The addressee's.

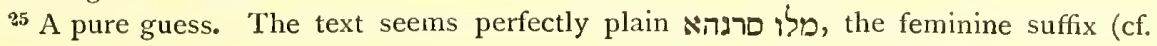
note 8. $\mathrm{N}=\boldsymbol{o}_{-}=-\mathrm{u}$ in this text) referring to the addressee. Lane (p. I343) notes an old

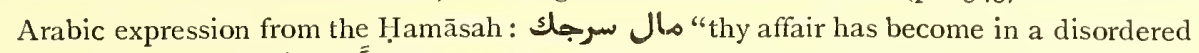

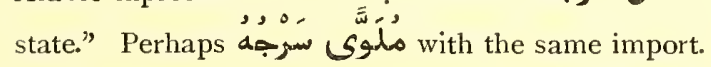

26 The words are all blurred here. $\quad 27$ Plural.

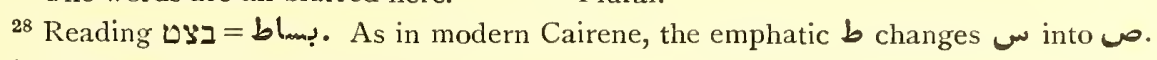

${ }^{29}$ Cf. Mann, op. cit., vol. i, p. 2 I 5 .

30 Cf. Deut. xxviii, I2. 31 Read

عל means "concerning," and probably stands for على 32. 
Verso:

r ובעד גמיע מא צ'טרתה הצירו קום יהוד ערפוני אן קאל דבאח אנפר אלי

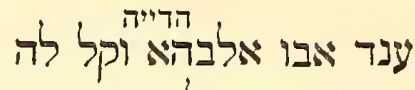

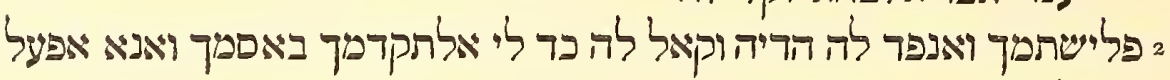
לך גפיעי מא תריד

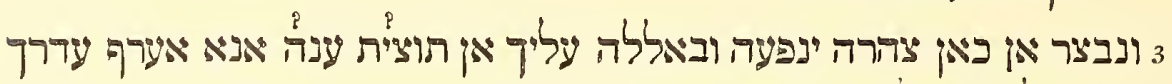

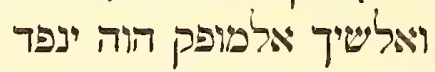

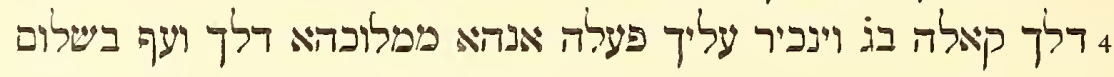
Address :

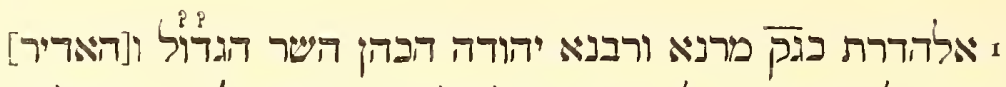

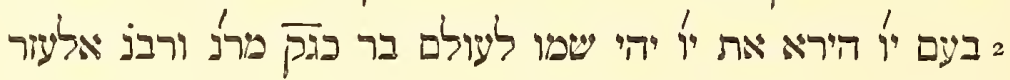

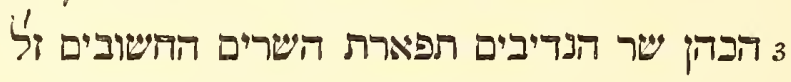

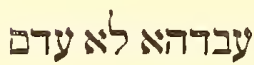

בקאהזאיא

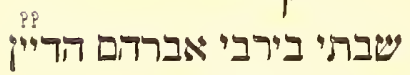

החבר תנצבה ירבי

33 . C. Cf. note 28.

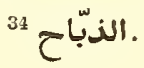


Verso:

I And after all that I have written ${ }^{33}$ a number of Jews came and informed me that Dabbāh ${ }^{34}$ said "Send to Abū al-Bahā a present, and say to him :

2 "May it not insult you." "So he sent him a present, and said : "Get the promotion for me in your name, and I shall do for you all that you wish."

3 We shall see if his brother-in-law will help him. By Allah! It is for you to command concerning him. I know your excuse. The Sheikh al-Muwaffik-let him send.

${ }_{4}$ This he said...... ${ }^{35}$ And let him find fault with him for what he has done. Verily this is your servant. Good luck!

\section{Address:}

I To our Glorious Lord and Master, Judah ha-Kōhēn, the Great and Mighty Prince

2 among the people of God, who fear God-May his name be remembered forever-son of our Lord and Master Eleazar

3 ha-Kōhēn, Prince of the Noble, Glory of Renowned Princes,

4 [Signed:] Shabbatai, son of Rabbi Abraham the Judge, the Hābēr, his slave. May he never be bereft of him ${ }^{36}$ !

\footnotetext{
35 Do i stand for $2=\infty \div$ " in all"?

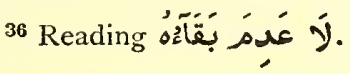




\section{LETTER}

Paper I I $\frac{1}{4} \times 7$ inches.

Arabic in cursive Hebrew characters.

The paper is now much damaged, and the ink pale. The handwriting is so slovenly that whole groups of letters assume the same form. On the other hand, the same letter of the alphabet may assume many forms. The number of possible readings is thus very great, and their value correspondingly small. If the language were even tolerably pure and the thought connected, translation might still be possible. But the writer is vague and incoherentperhaps even intentionally cryptic and mysterious. One doubts that Arabic is his natural tongue at all. It may be safely said that this letter would not have been clear even to a contemporary Egyptian acquainted with the secret diplomacy of the situation. Cf. Nos. XII, XXII, XXXIII, XXXIV, and XXXV.

Recto:

ו כתאבי יאבי וסי[די] אלעויו עלי אטאל אללה בקאך ואדאם סל [אמתר]

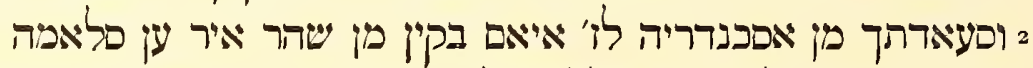

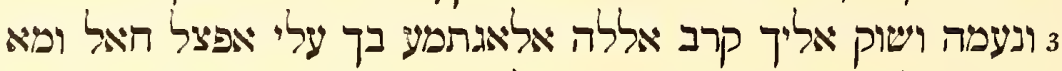

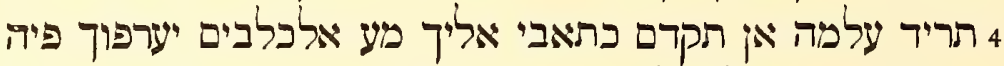

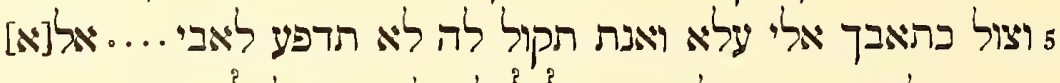

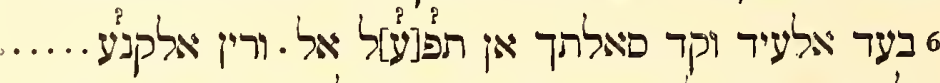

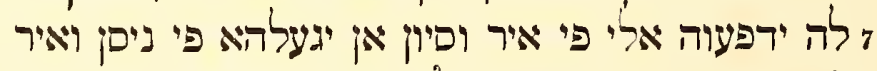

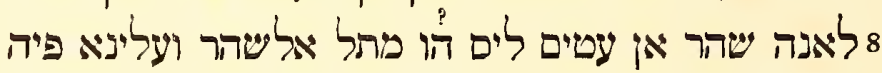

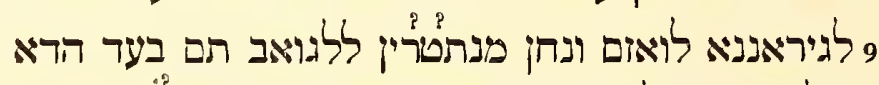

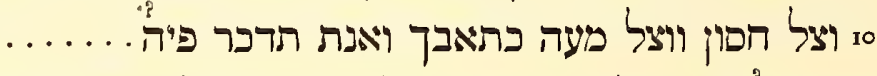

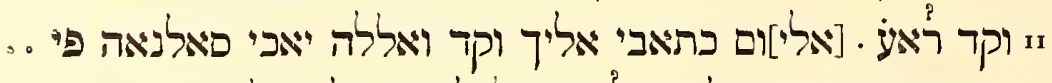

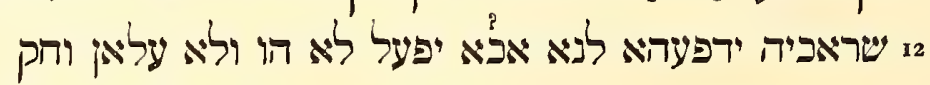

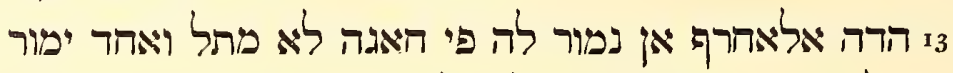

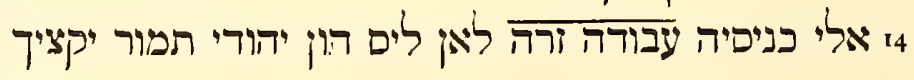

1 Quite plainly, Hebrew כלבים, meaning "rascals"? Cf. No. XXI, recto, line 5

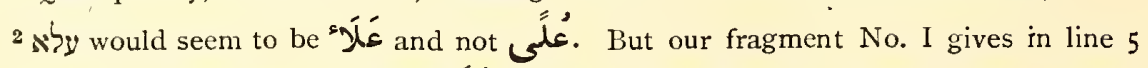

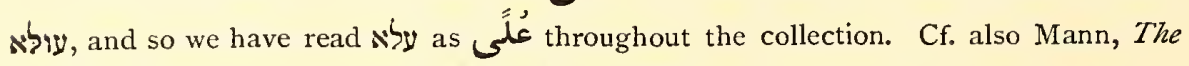
Jeres in Egypt and in Palestine under the Fatimids, p. 283, col. 3, line 8.

${ }^{3}$ I.e. Nisan.

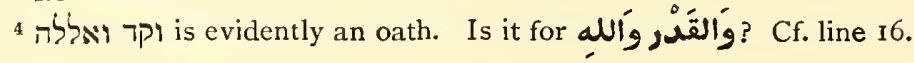

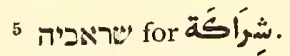

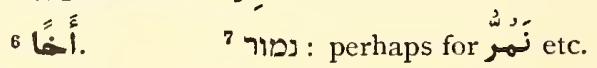




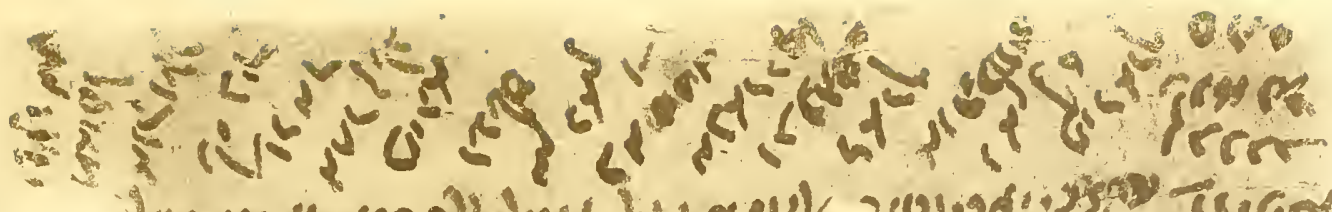

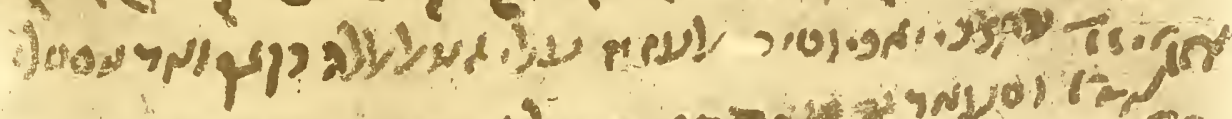

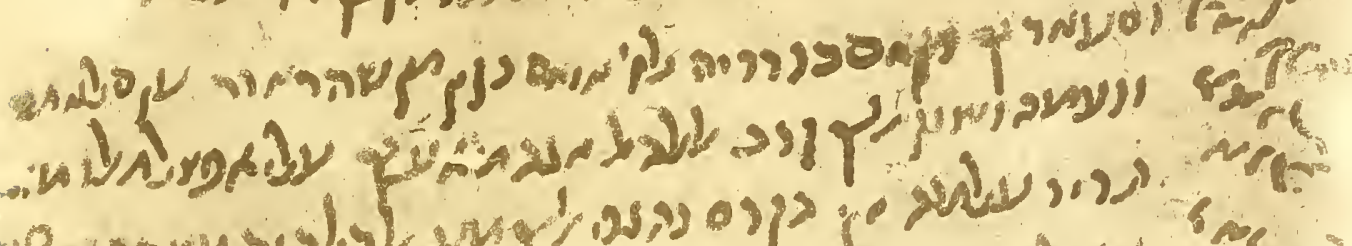

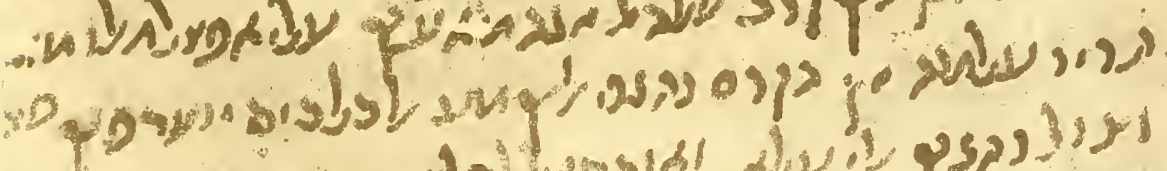

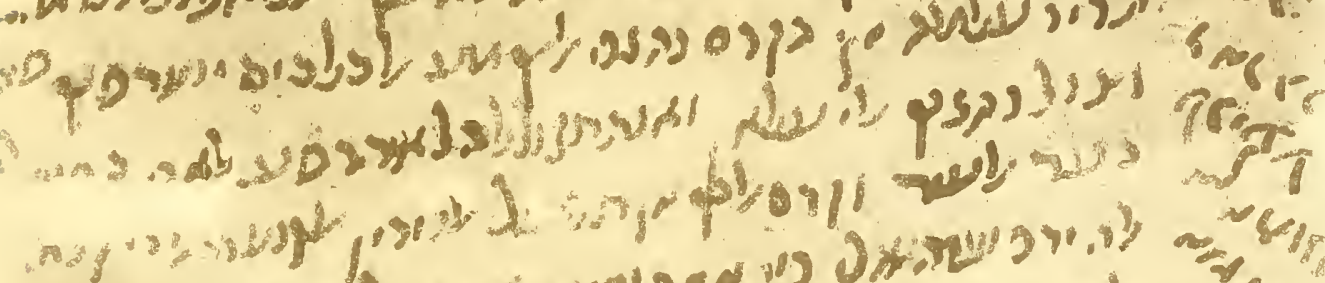

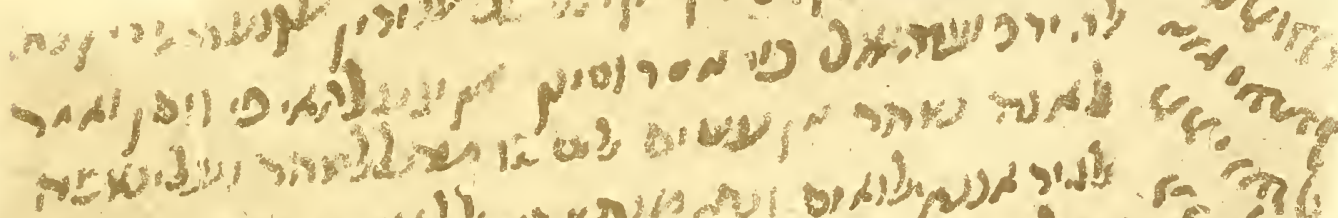

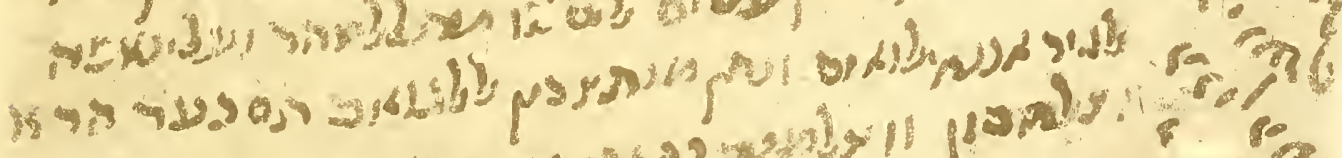

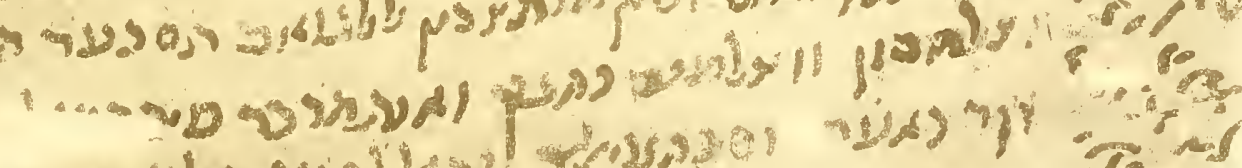

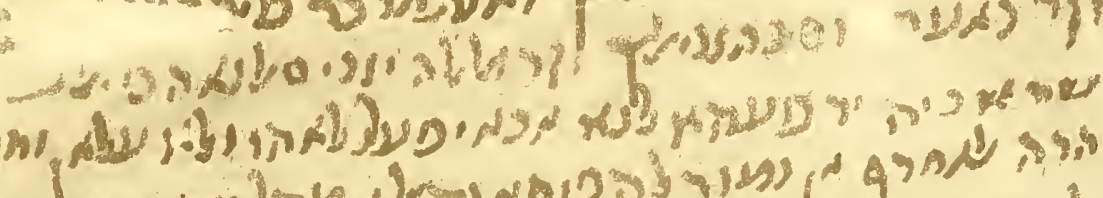

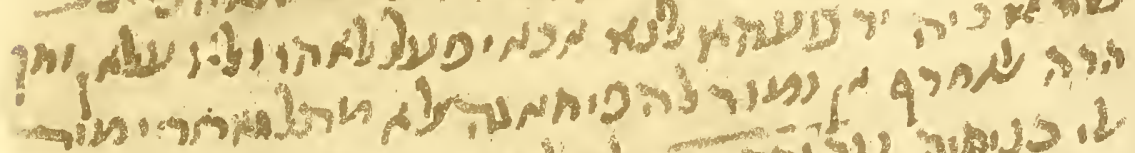

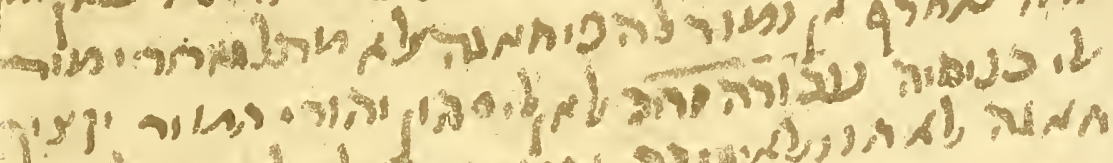

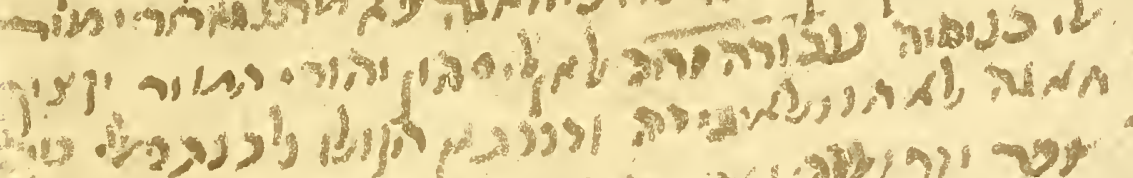

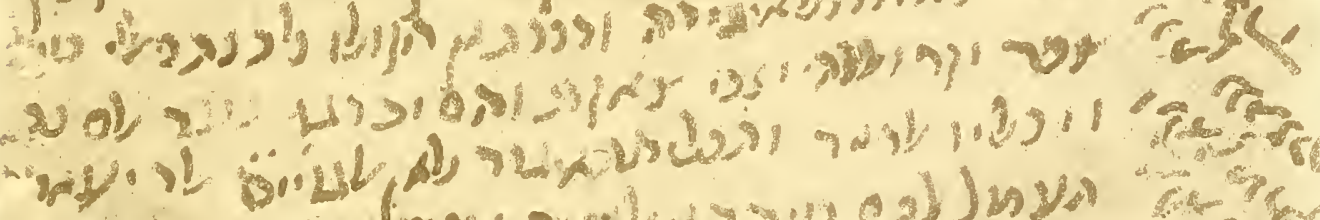
$\log _{0}$

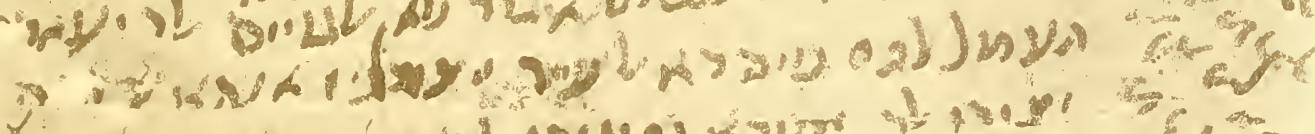

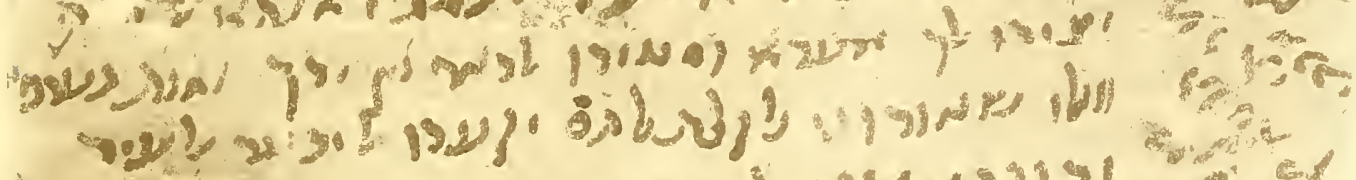

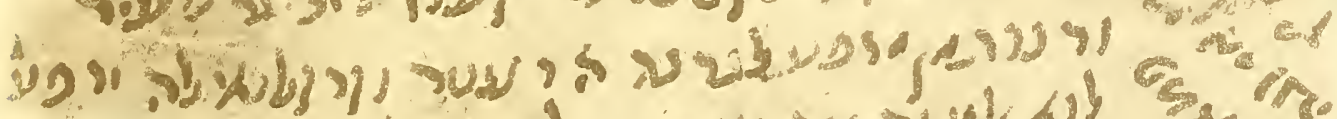

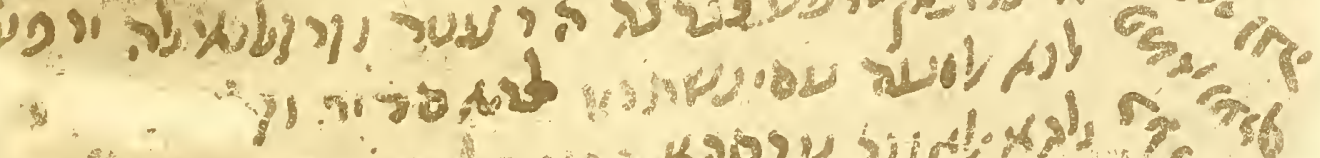

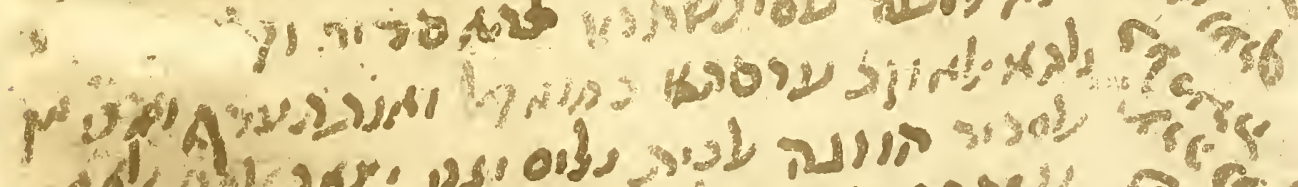

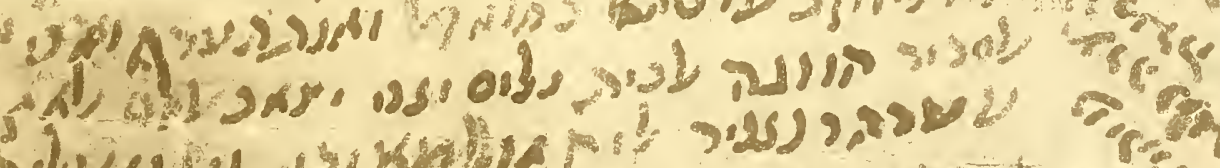

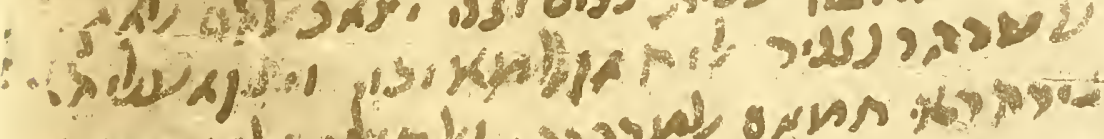
- as

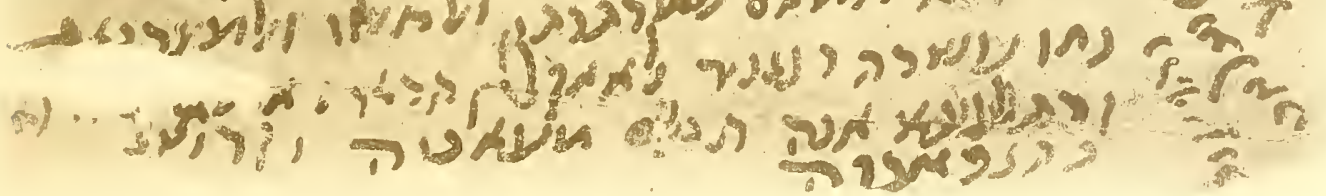




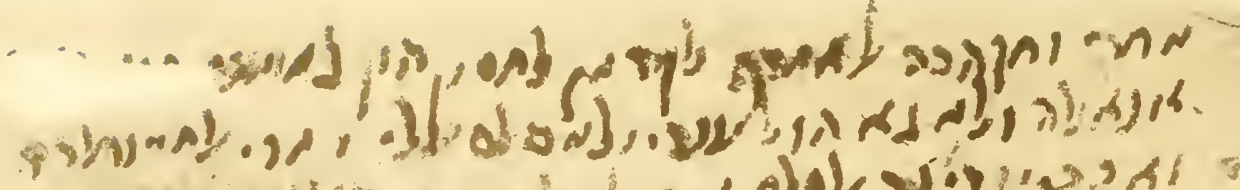

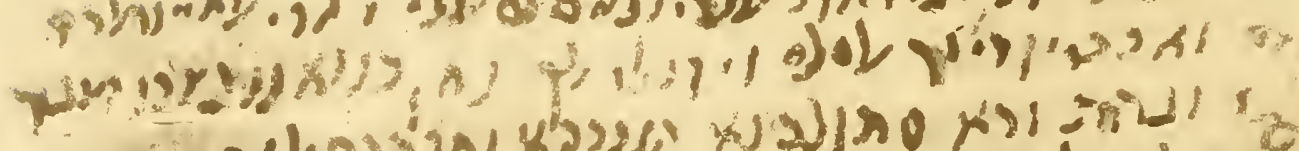

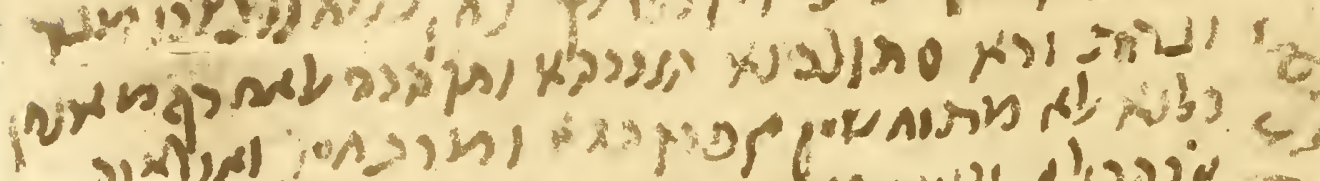

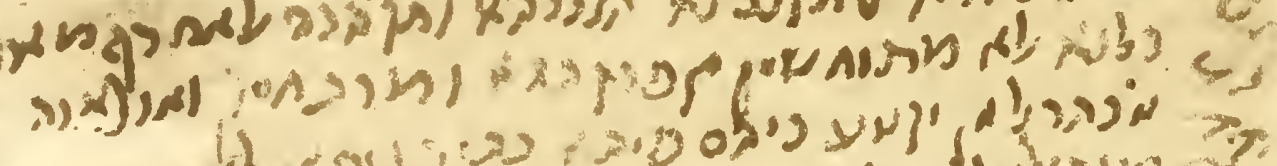

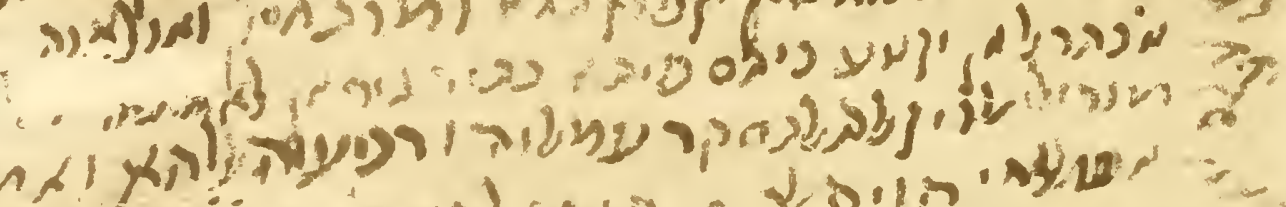
सh

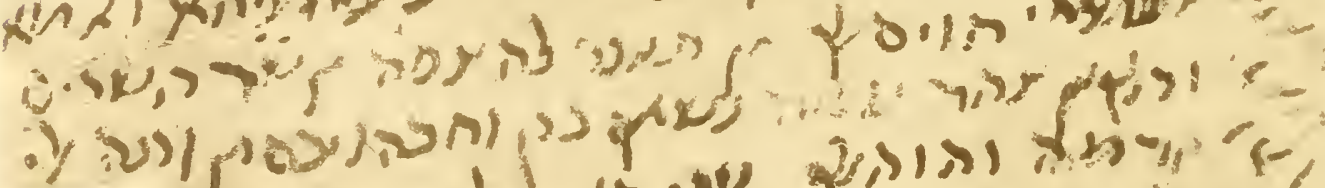

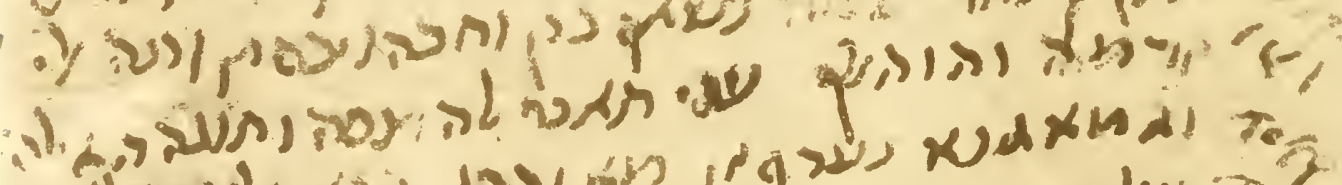

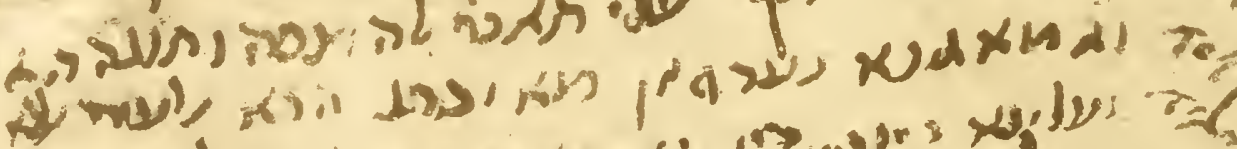

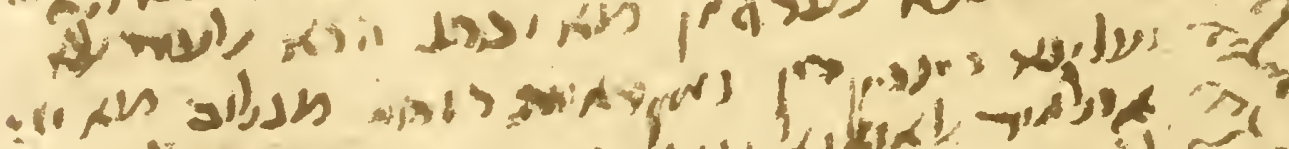

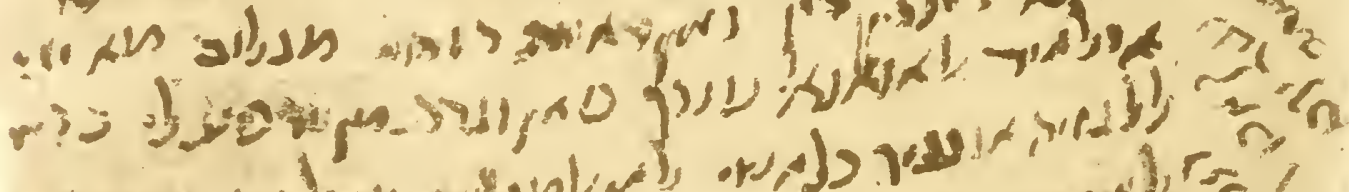

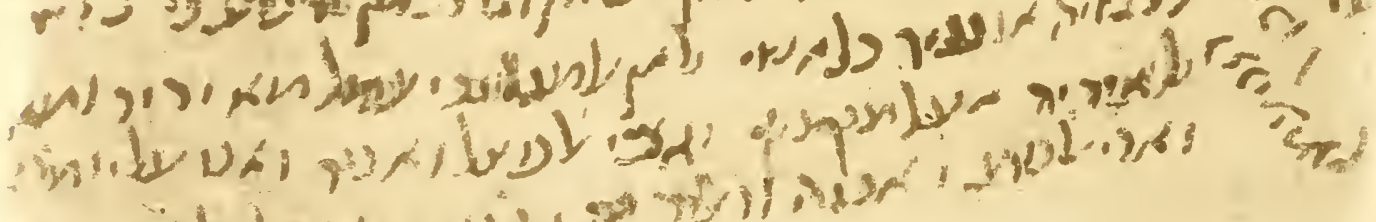

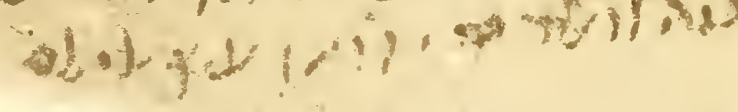

- Trofez rovermorim

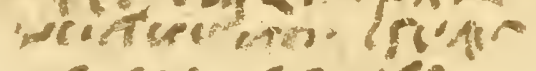
sore race Troute?

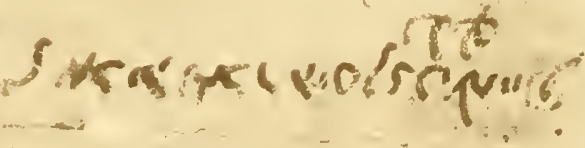




\section{LETTER}

A letter from a certain Abraham, "Reader of the Law," probably stopping in Alexandria, to his brother, 'Ulā Abū 'Umrān Moses, "Reader of the Law," probably living in Fustāț. There is no date.

There is mention of business concerns and troubles; especially difficulties arising from the circumstance that a heavy poll-tax was being levied on a small number of Jews. We learn incidentally that bedsteads were scarce; and that passages from the Song of Solomon were used-in what manner we are not told-to cure a drying up of the body, and boils. Some female relatives and children have outstayed their welcome and are quarrelling with one another; and similar tittle-tattle.

\section{Recto:}

I My letter to [you], O my Brother and my Lord! God prolong your life and continue your health

2 and your prosperity! From Alexandria, 7 days remaining of the month of Iyyar. About health

3 and well-being and yearning for you! God grant a speedy reunion with you under the most propitious circumstances! And what

4 you wish to know: My letter has gone forward to you with the dogs ${ }^{1}$ who will tell you about it.

5 The arrival of your letter to 'Ulā! And you say to him: "Do not pay Abū......until

6 after the festival." And I have already asked you to make the...

7 for it, they paying it to me in Iyyar and Sivan, if they will make them in Nisan and Iyyar,

8 because it $^{3}$ is an important month: It is not like the month [of Iyyar]. And we are responsible in [the matter]

9 to our neighbors for necessary expenses, and we are waiting for the answer. Then, after this

ıo arrived Hassūn, and your letter arrived with him. And you mention in it.........

I But my letter has already......to you today. By Allah, my Brother ${ }^{4}$ ! We asked him about.

I 2 collectively ${ }^{5}$ pay it to us as a brother ${ }^{6}$ : Neither he nor 'Allān should do it [singly]. And by

I 3 these very words [which I am writing]: If we go ${ }^{7}$ to him about any thing 8 , it is not as though one went

I 4 to a church ${ }^{9}$ of "Idol Worship ${ }^{10}$," because there is no Jew here [for] you [to] go [to to have him] do [something] for you :

\footnotetext{
8 حابه is modern Egyptian colloquial for "thing."

9 S. Cf. No. XXVII, note 32.

10 The Hebrew title of a Mishnah tractate.
} 


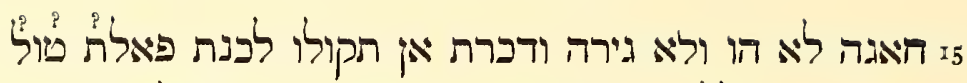

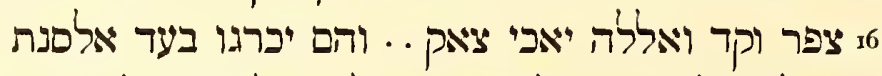

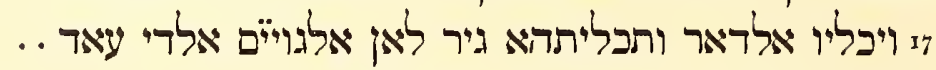

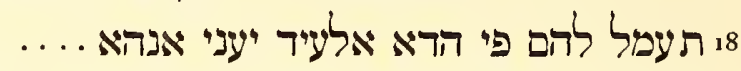

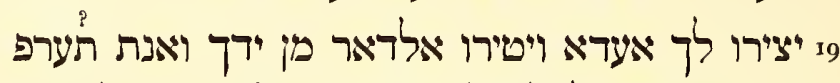
20

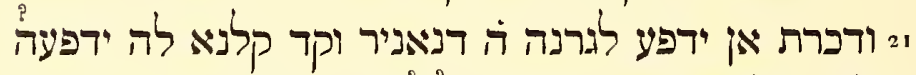

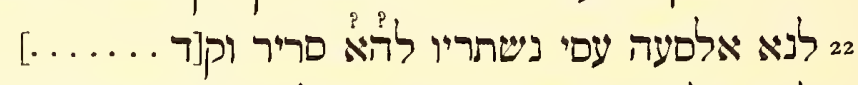

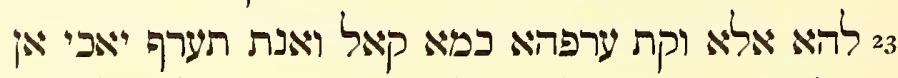

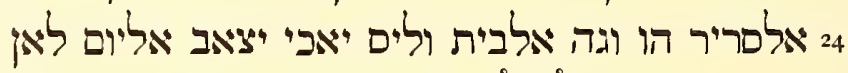

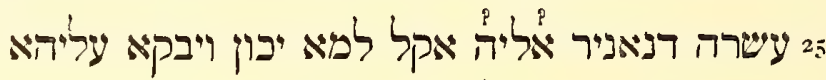

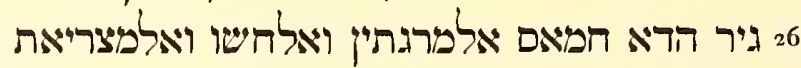

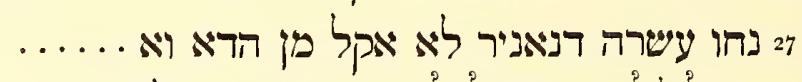

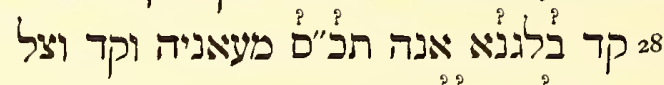

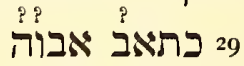

Margin:

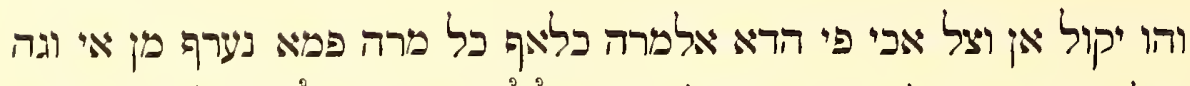

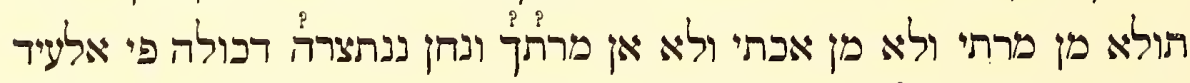

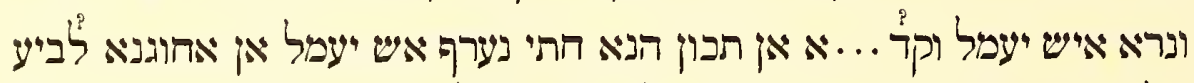

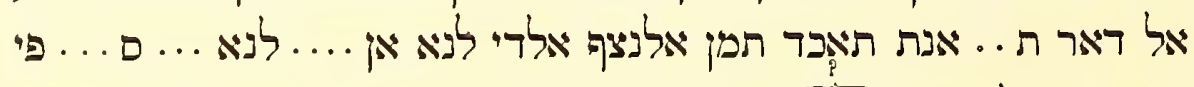

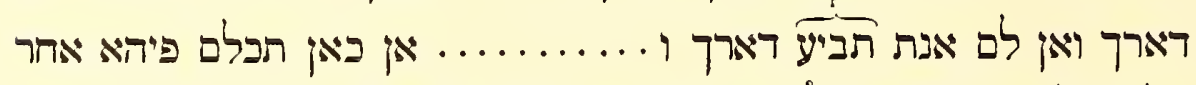

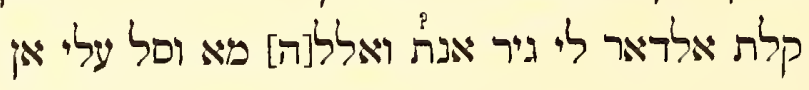

Verso: ז אחר וחקה בה לא יכף לקד אן לחםין הון ............

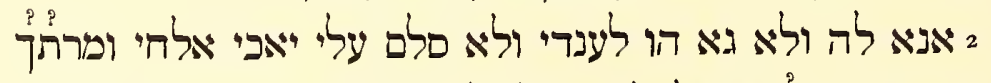

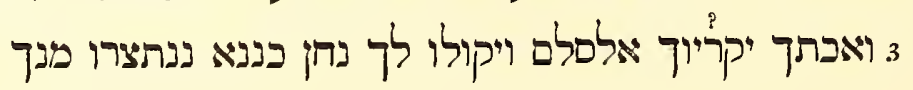

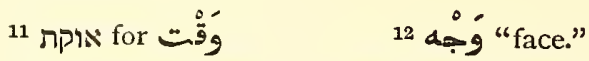

13 y 13 carelessly used as elsewhere in these fragments.

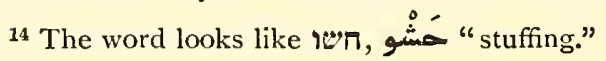

15 مَعَانِيه, plural of with suffix.
} 
I5 neither he nor anyone else [is a Jew]. And you have remarked in your letter: "If you say.........

r6 .......By Allah, my Brother !..........and they go after the year [is up]

${ }_{7} z$ and leave the house ; and its abandonment is otherwise [than you might expect or wish], because the gentiles who......

I8 you do for them during this festival. That is to say: It...

ig and become enemies, and tear the house to pieces out of your hand, and you know......

2o But if they had consulted me I should have said to them [that] they should remain until after the festival.

21 And you mentioned that he should pay to our neighbor 5 dināars, and we had told him that he should pay it

22 to us at once. Perhaps we can buy for her a bed and...

${ }_{23}$ for her at the time ${ }^{11}$ of her wedding, as he said. And you know, my Brother, that

24 the bed is the most important thing ${ }^{12}$ in the house. And it is not [easily] got nowadays, my Brother, because...

25 ten dinārs to him at the very least. And there remains for ${ }^{13}$ her

26 besides this: pigeons, the two pearls, the...... ${ }^{14}$ and the Egyptian [goldpieces]-

27 about ten dīnārs, not less than this, and

28 News has reached us that he. his affairs ${ }^{15} . "$

And there arrived

29 the letter of his father.

Margin:

And he says that my brother has arrived this time contrary to every [other] time. And we do not know for what reason he turns away from my wife and not from my sister, and not from your wife. And we await his coming at the [time of the] festival, and we shall see what ${ }^{16}$ he will do. And.........that you be here until we know what ${ }^{16}$ he will do: whether he will compel us to sell the house......you take the value of the half which belongs to us. If...... to us............ in your house. And if not, you sell your house.................. if you speak about it after I have said : "The house is mine, not you[rs]-By Allah $1 . . . \ldots \ldots . .$.

Verso:

I other...... and his equity in it. Let him not be afraid because ${ }^{17}$ al-Husein is here.........

2 I......to him. But he did not come to my house, nor did he salute me, O my living Brother, and your wife

3 and your sister...........the salutation. And they say to you : We have been expecting it of you,

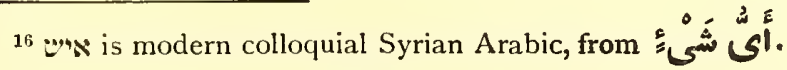

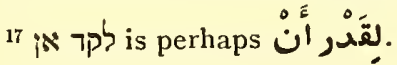


4 וגהת ורא סת ולכנא תזכרתא ומן הדה אלאחרך מא נהן

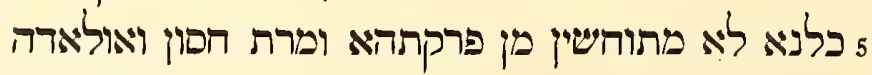

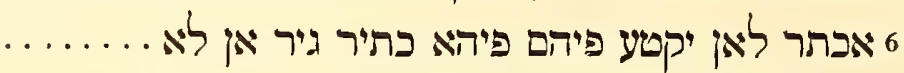

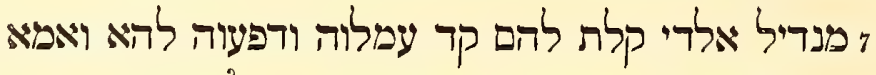

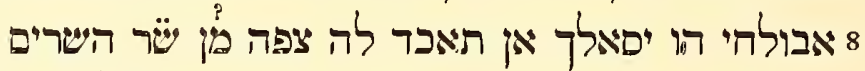

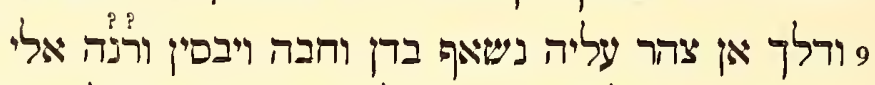

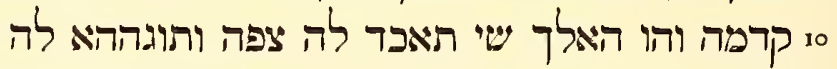

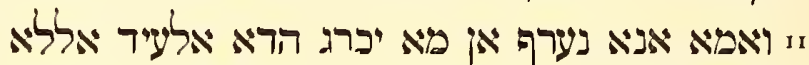

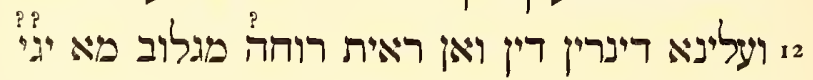

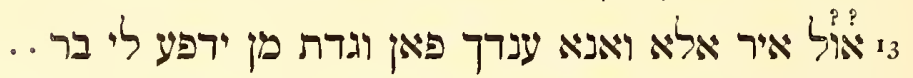

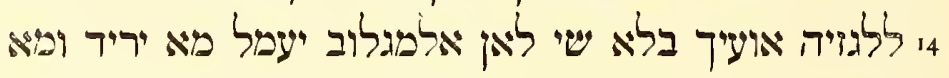

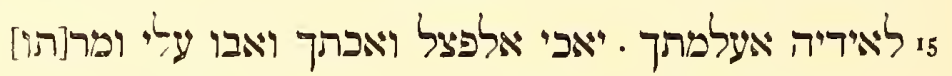

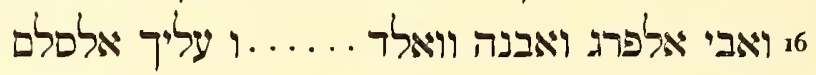

There is some further writing on the right-hand margin; but only a word here and there can be made out.

\section{Margin :}

לאבי עמראן בן אבו.....

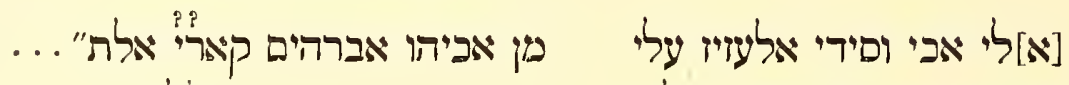
אללה אבי עמראן מסי קארי אלת וסיד אלויז עלי אטאל אללה בקאה ו"אראם עזי מאי אית

${ }^{18}$ He meant to write תזכרנא. 19 نشُاف 
${ }_{4}$ behind a lady's back. But we remember ${ }^{18}$." And by these words [which I am writing], not we,

5 any of us, will be desolated by the pain of separation from her; and the wife of Hassūn and his children

6 still more! Because there is no estrangement between them and her; very much so, without.........

7 handkerchief which I said to them they had made it and paid for it. And as for

8 Abū al-Hayy, he asks you to take for him a description from the Song of Solomon.

${ }_{9}$ For there appeared upon him a drying up ${ }^{19}$ of the body, and a boil, and dry patches, and a...........

so of his foot. And he is perishing......you take him a description [from the Song of Solomon], and send it to him ${ }^{20}$.

I But we know that this festival will not pass without

12 our being in debt two dinārs. And if I see him bankrupt (?), he will not come

13 on the first of Iyyar, unless I am at your house. And if I could find someone who would pay me......

If for the poll-tax, I would take care of you for nothing, because the bankrupt does what he wishes and what comes

${ }_{15}$ to hand. And I have informed you...O my Brother most excellent, and your sister, and Abū 'Ulā, and his wife,

I 6 and $A b \bar{u}$ al-Faraj, and his son, and the parents of......... And upon you be the Peace!

\section{Margin:}

To Abū 'Umrān Ibn Abū.

To my Brother and Lord the Beloved, 'Ulā Abū 'Umrān Moses, Reader of the Law.........God lengthen his life, and continue his strength!

From his brother, Abraham, Reader of the Law..... [If it please] God.

${ }^{20}$ I.e. as an aphrodisiac amulet? Skin diseases and their cure by bathing at Tiberias are mentioned by Mann, op. cit., vol. i, p. I66, and ref. 


\section{LETTER}

Paper $9 \frac{1}{2} \times 6 \frac{3}{4}$ inches.

A business letter in Arabic, in a clear, cursive Hebrew hand.

זי מגלם סיידנא אלריים ירום הדו ויגרל כבדו ואלממלוך

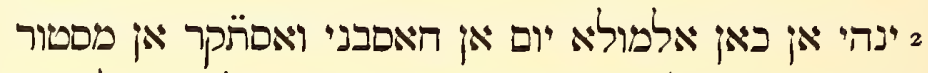

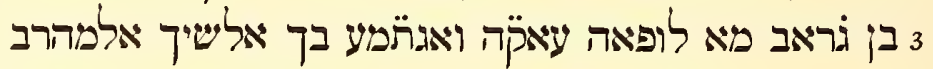

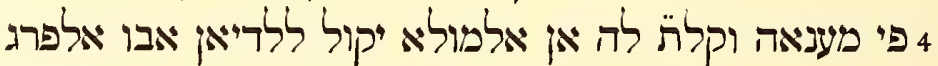

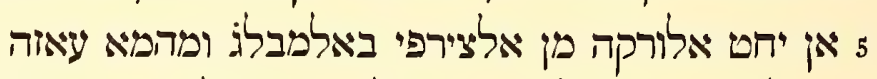

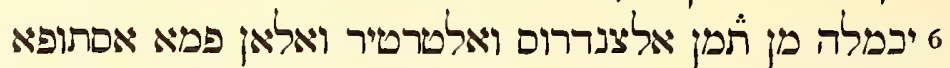

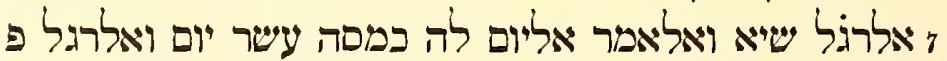

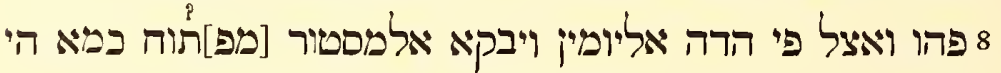

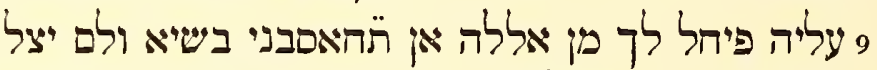

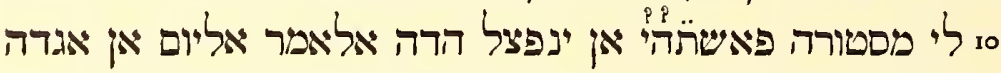

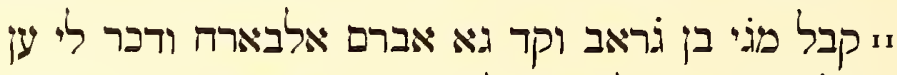

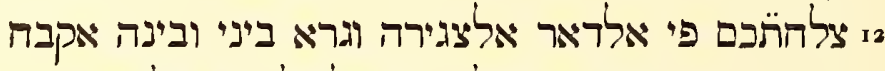

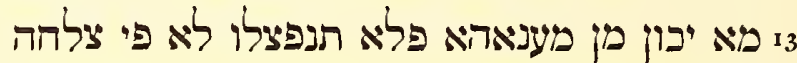

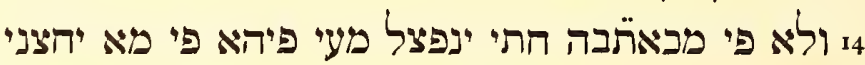

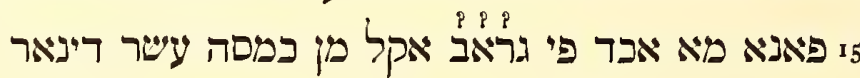

\section{Margin:}

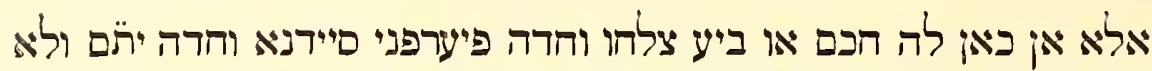

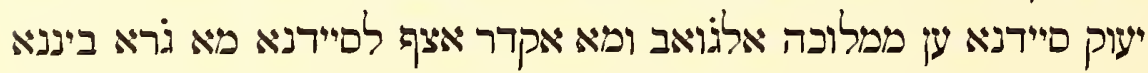

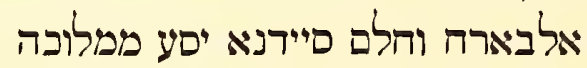

${ }^{1}$ On the use of stals in this sense, see Dozy, Supplement, s.v.; Oriental. Lit. Zeitung, I906, p. 362. It is probable that the Hebrew מושב is merely a translation from the Arabic. See, further, Mann, The Jews in Egypt, vol. ii, Index, p. 419.

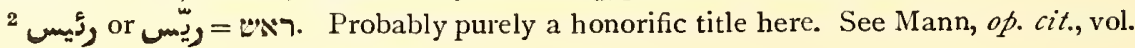
i, pp. 262, 266.

4 الم-A A term of servility very often used in letters. Cf. Brit. Mus. Or. 5542, No. 23 : אלממלוך אבן סעיר יקבל אלאריץ בין ידי אלמולי אלשישיך .......

which ends :

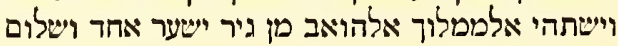

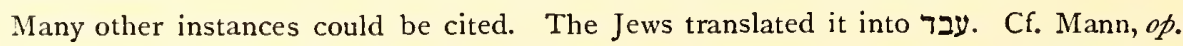
cit., vol. ii, p. 330, note I.

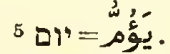
${ }^{6}$ Read יחאסבני. Cf. line 9. " document."
${ }^{8}$ Punctuated according to al-Dhahabi's Mushtabih, (de Jong), p. 384. 


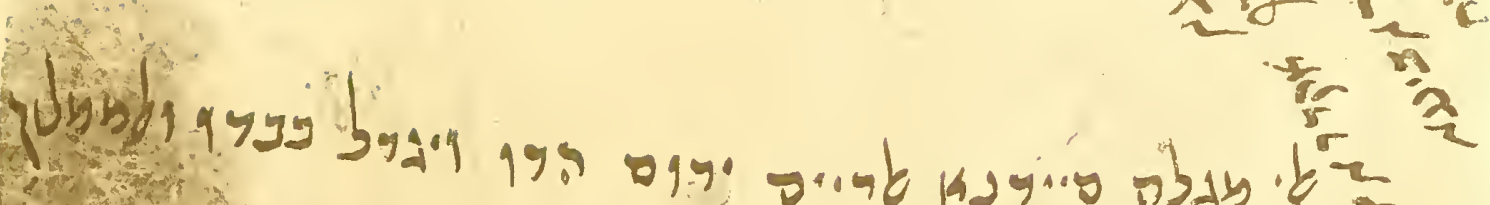
ying obsy.

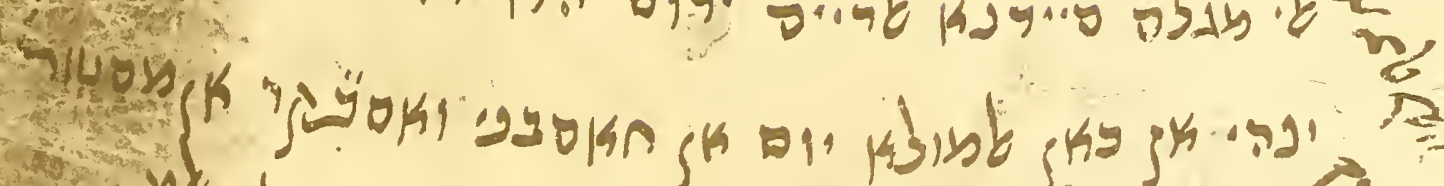

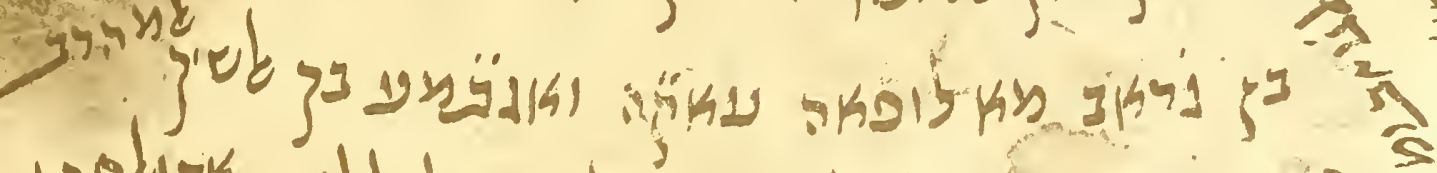

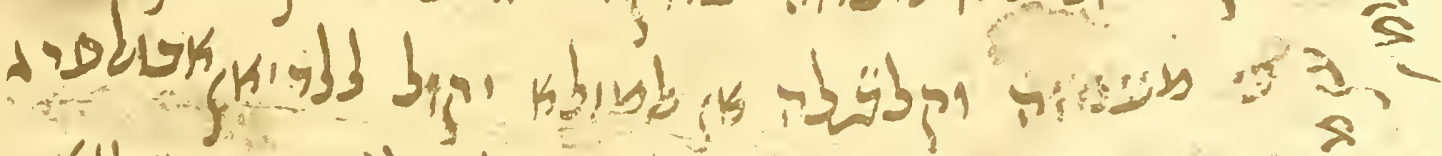

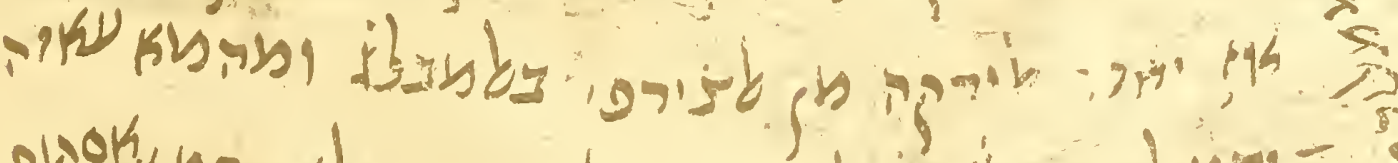

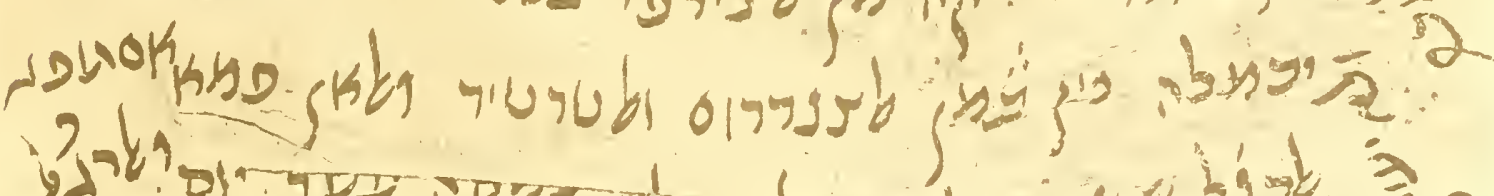

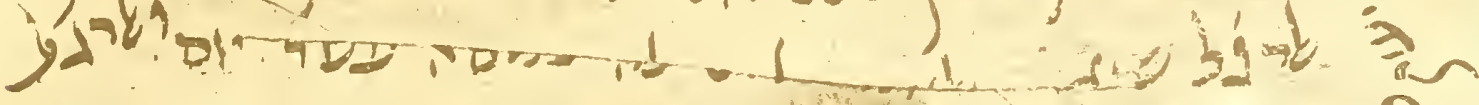

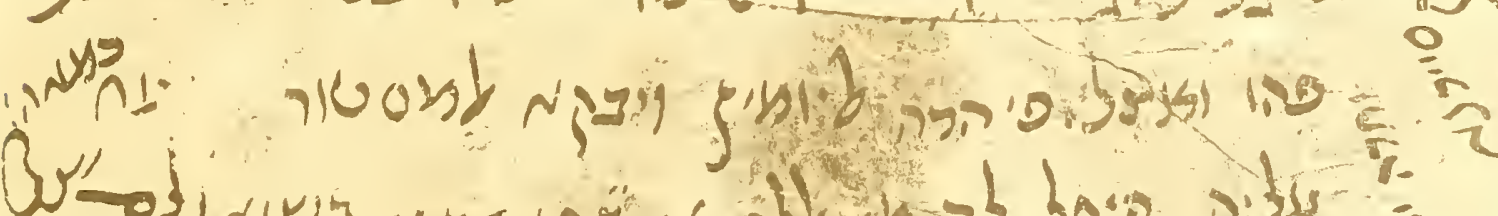

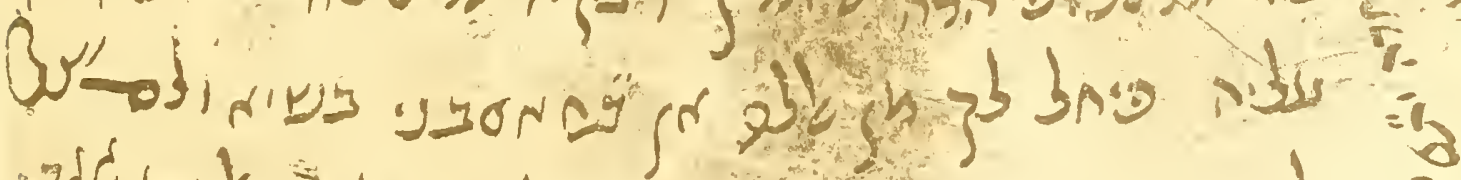

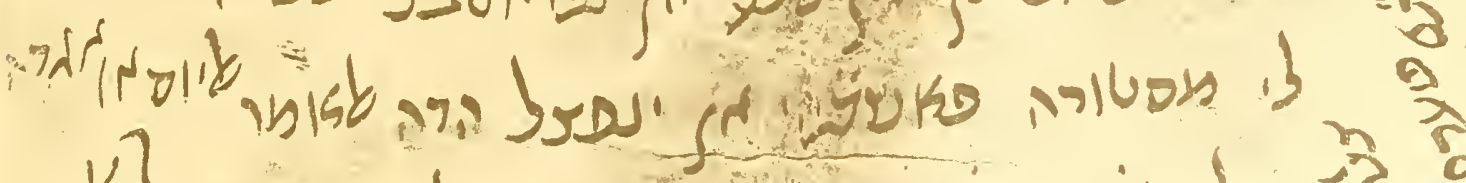

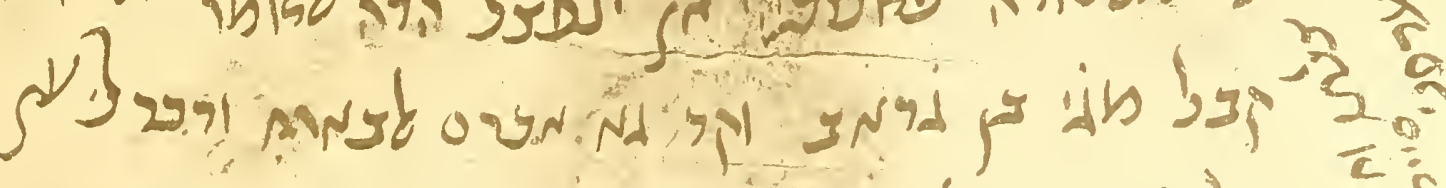

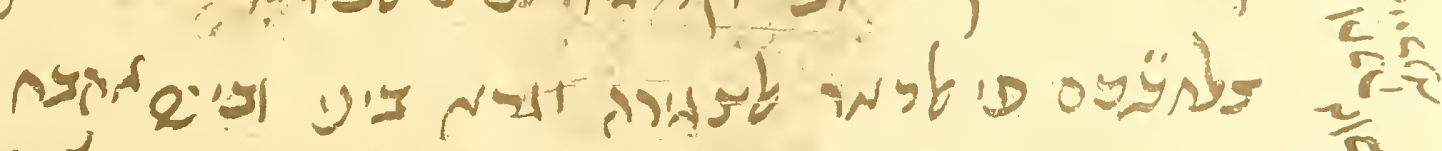

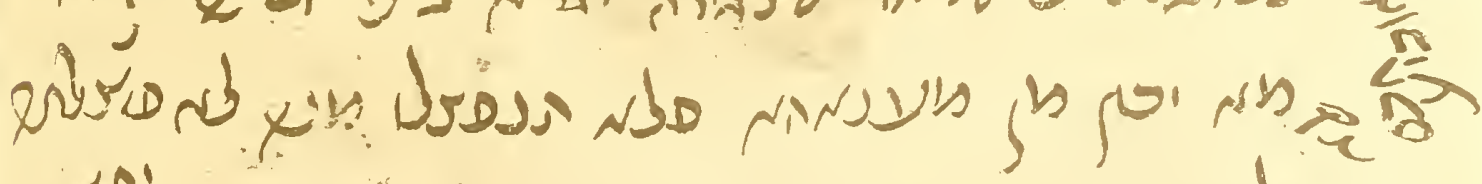

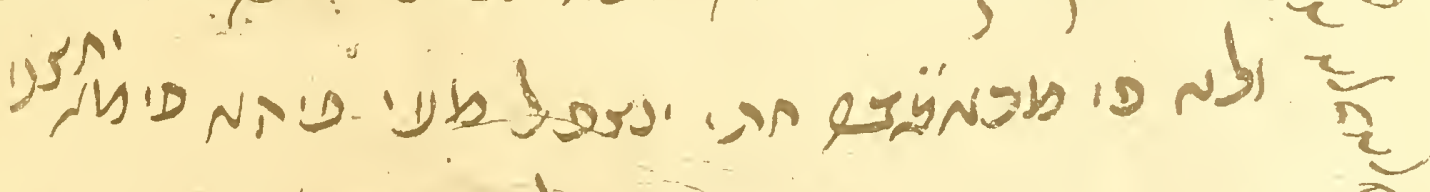

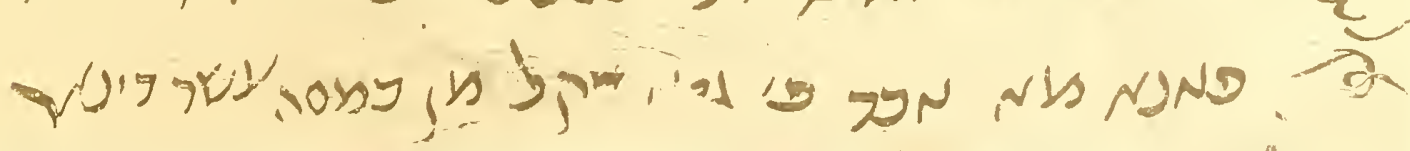


. 


\section{LETTER}

A certain Ibn Ghurāb has borrowed money of the writer of the letter, and cannot repay it, although he has merchandise on hand. The addressee, an unnamed prominent man (ra'iss), is now asked to assume the debt, take over the merchandise, and arrange matters with the judge, Abū al-Faraj, and the money-changer or banker, as he has promised to do. There has also been some trouble about a certain piece of real-estate. There seems to be no way of dating this letter.

I To his Excellence ${ }^{1}$, our Master, the Ra'̄̄s ${ }^{2}$, may his glory ${ }^{3}$ be exalted and his honor extolled. The servant ${ }^{4}$ begs to say that

${ }_{2}$ if the Master intends ${ }^{5}$ to settle accounts with $\mathrm{me}^{6}$, it is certain that in regard to the account ${ }^{7}$ of

3 Ibn Ghurāb ${ }^{8}$, there will be no difficulty in collecting it. The Sheikh al-Muharrab met with you [to consult]

4 about his affair and you promised him that the Master would speak to the judge, Abū al-Faraj,

5 that he [write] the document from the money-changer ${ }^{9}$ for the [entire] amount, and that whatsoever was wanting

6 he would make good from the sale ${ }^{10}$ of the resin and the tartar ${ }^{11}$. Now, the man has not paid

z any part of it. The matter has been going on now for fifteen days. The man

8 is coming within the next two days. The account will be left open as it stands

9 against him. It is permitted you by God that you settle with me in some manner. No account

ro has come to me. I wish today that this affair be settled, that I may have ${ }^{12}$ [the account]

I before Ibn Ghurāb comes. Now yesterday, Abram came and mentioned to me your

12 agreement about the small dwelling. Between him and me there arose

13 the worst kind of discussion. Do you not settle with him, either by agreement

I 4 or by written document, until he has settled with me about it, in regard to the share that is to come to me.

$x_{5}$ I shall not accept for ${ }^{13}$ Ghurāb(?) less than fifteen dīnārs.

Margin:

But, if he has a judgment or has made a sale, do you make an agreement with him alone. In such a case, may my Master acquaint me of it. It is all right [to settle with him] alone(?). May my Master not withhold from his servant an answer. I am not able to describe to my Master what happened between us yesterday. May the kindness of our Master encompass his servant!

\footnotetext{
9 Or "banker."

${ }^{10}$ Literally: "price."

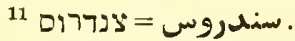

12 Literally: "find it."

13
} 


\section{LETTER}

Paper $11 \frac{1}{8} \times 7 \frac{3}{8}$ inches.

Carefully written in half-square Hebrew characters, in fairly good mediaeval Hebrew. The paper is torn and the writing illegible in many places.

On the verso there is an address, but it is illegible save for the words:

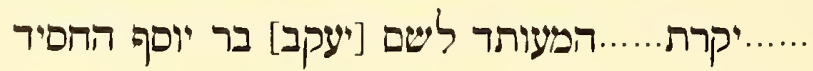

Also on the verso, but upside-down, in very faded script which appears to be older than that on the recto, are portions of verses from the Bible, as

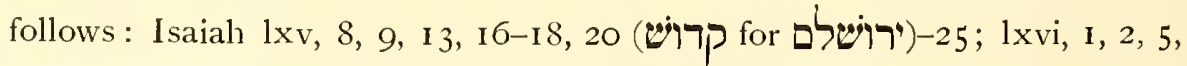
7-14, I8-23. Judges xv, I5-19; xvi, 28. We cannot imagine their purpose.

At the top of the recto are a few scrawled Arabic letters of no apparent import.

This letter was written to a Gā'ōn Jacob Ben Joseph ha-Hasīdh, perhaps the Jacob Ben Joseph Ab-Bēth-Dīn who as rabbi signed documents at Fustạt in A.D. IOI6 and IOI8, and did the same at Aleppo in IO28. Cf. Mann, op. cit., vol. i, pp. 37, I50. The writer of the letter is an important person in Jerusalem. At the time when this Jacob was in Fusțāt the chief dignitary in Jerusalem was Josiah Gā'ōn. Cf. Mann, op. cit., vol. i, pp. 7 I ff. His letters are not unlike this in their opening words. The "glorious place" which collapsed was probably a synagogue; and the cause may have been the earthquake of A.D. IOI6. Cf. Mann, op. cit., vol. i, pp. 72, I 56.

Recto:

ו ל.........

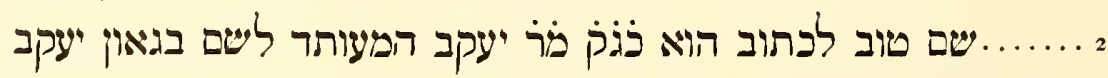

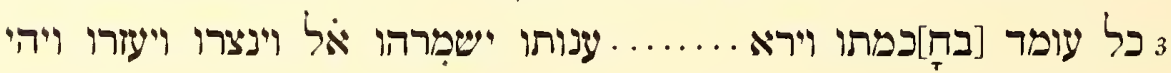

בעורו

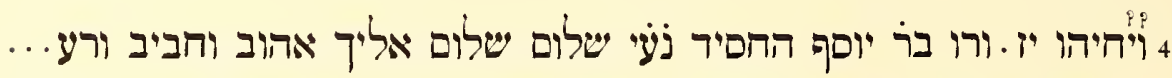
5 מאדון השלום ומעיר השלום ומנתיבותיה ושלום גם ממני אוהבך נפש יח ישים

כנפט

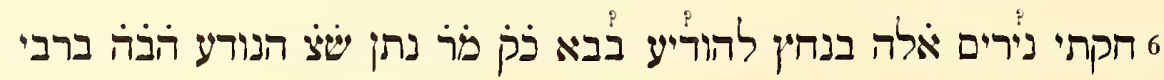
7 זכריה נעי ובידו ספר פק[דונ]ות הגרי וחותפיה יני ייתבע את שלפה בי פלף

אלבוקי

\section{8 עבור אשתו ואומרה אליי אין זה טענה גם לא ראיה לתבוע בו ואפר האיש}

${ }^{1}$ I.e. Ha-Me'uttadh. Early in the eleventh century the Egyptian Jews broke away from the authority of their brethren in Palestine and established a religious and legal school (Yeshībhah) that went by this name "Ge'ōn Ya'kōb." See Mann, op. cit., vol. i, p. 191 . 


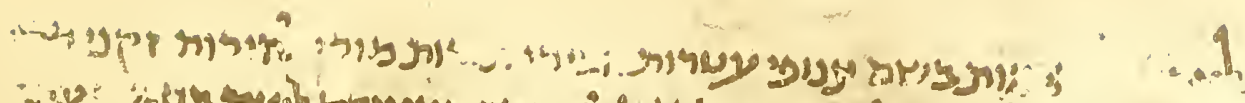

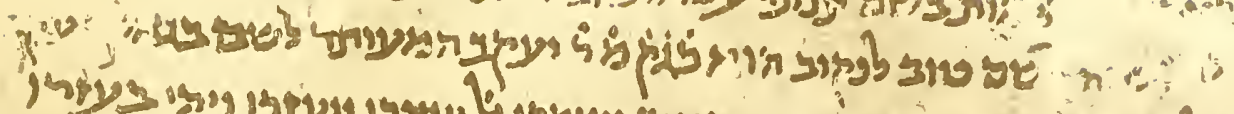

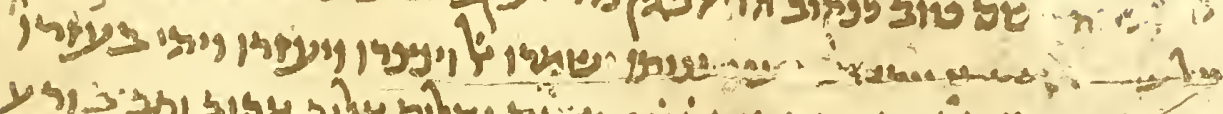

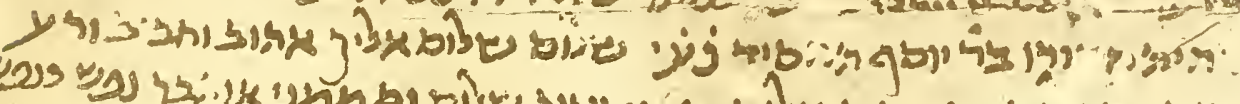

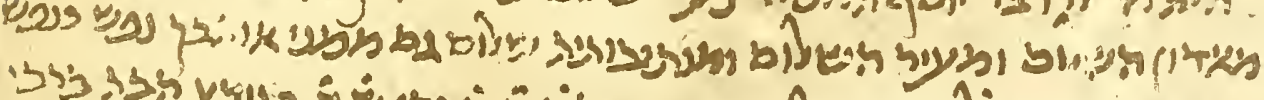

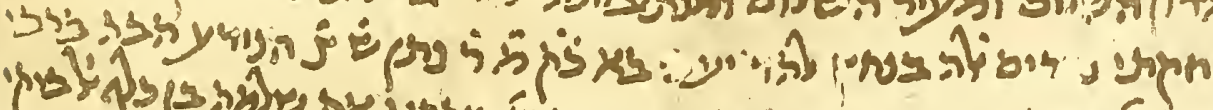

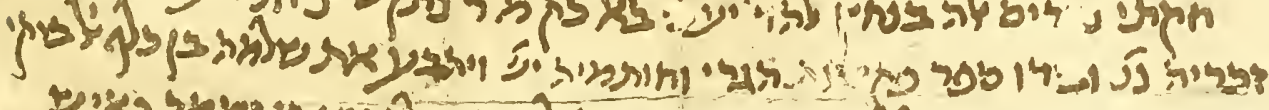

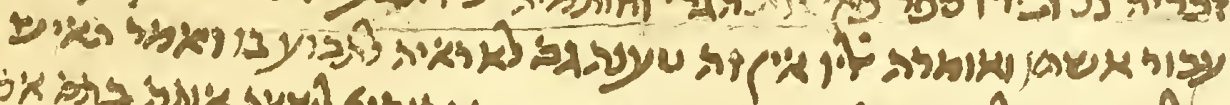

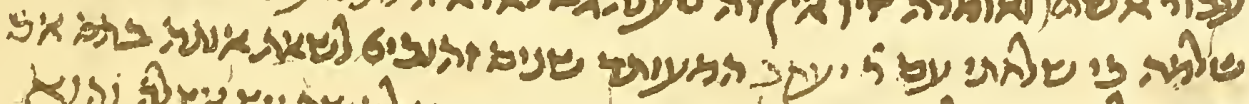

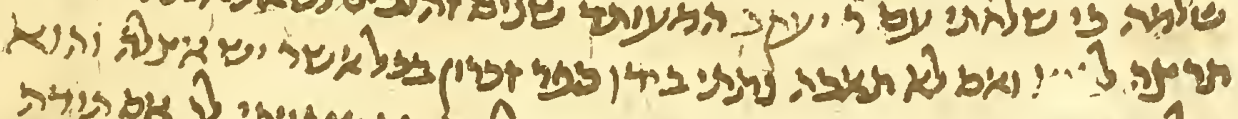

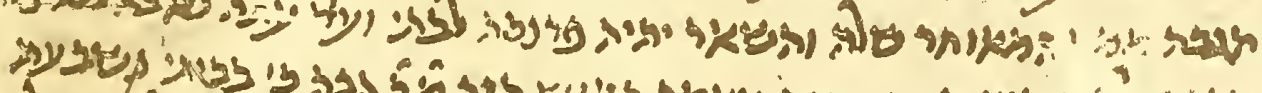

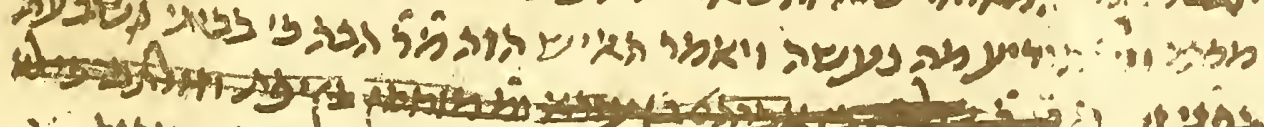

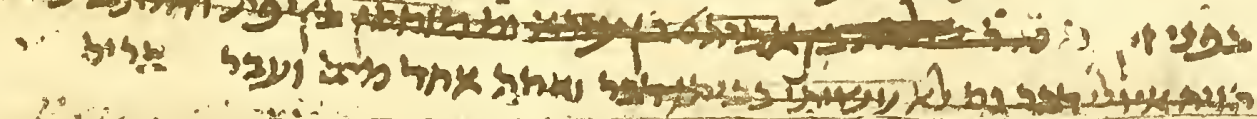

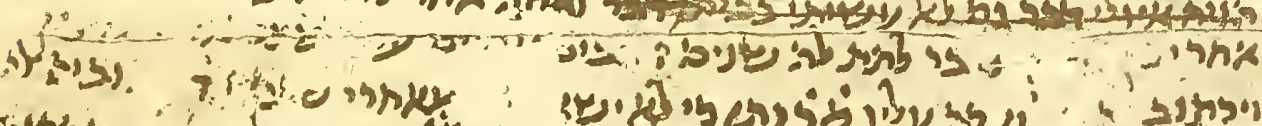

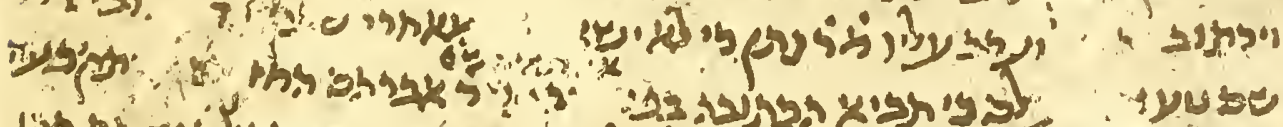

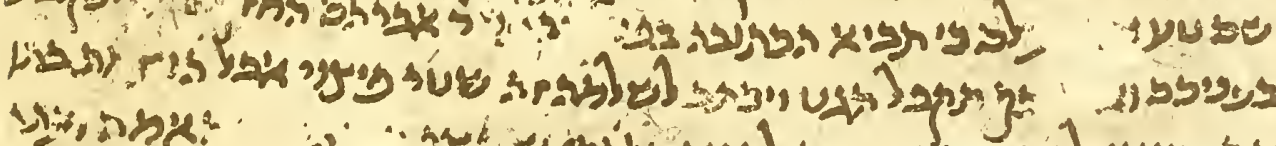

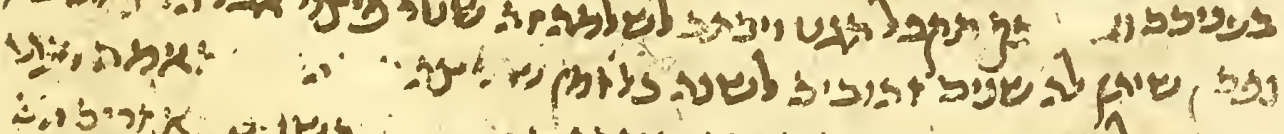
:

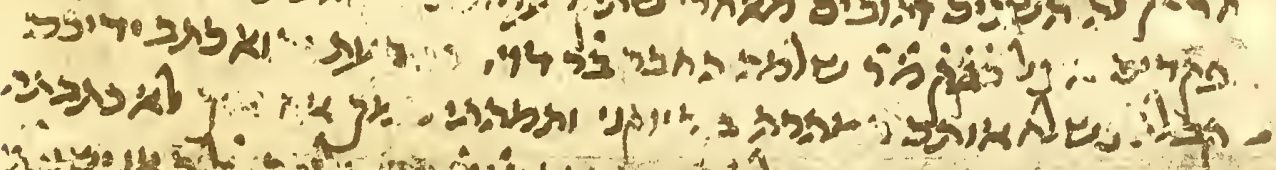

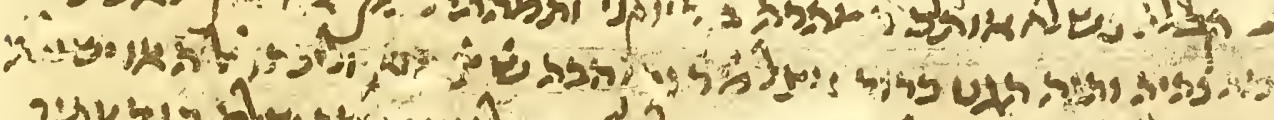

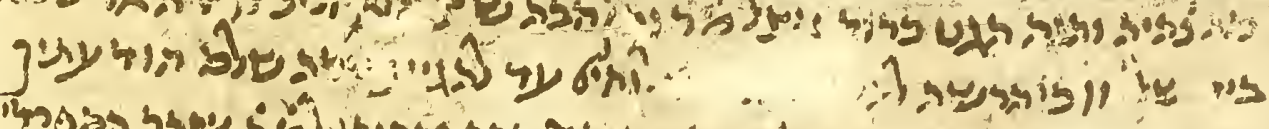

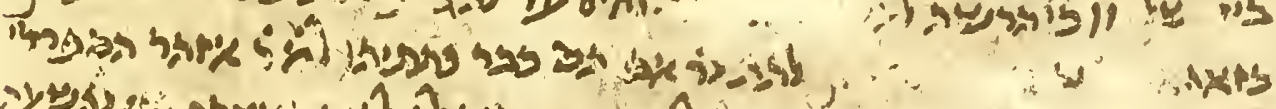

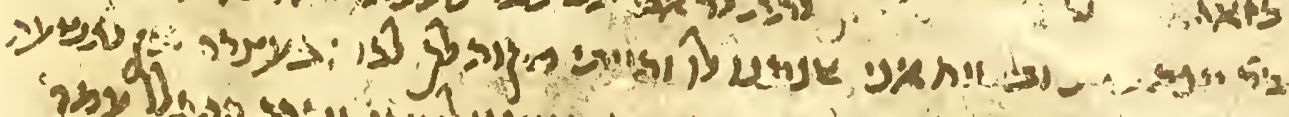

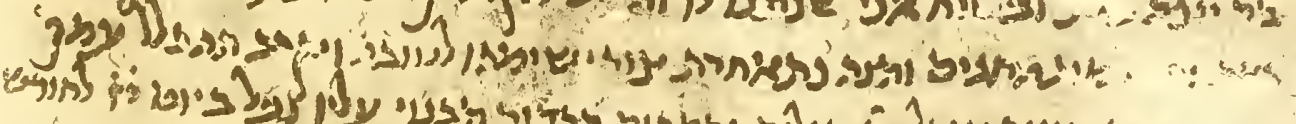

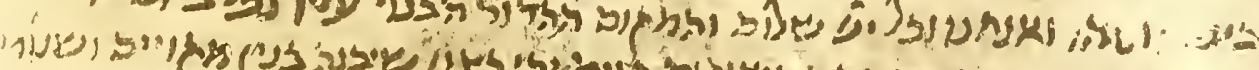

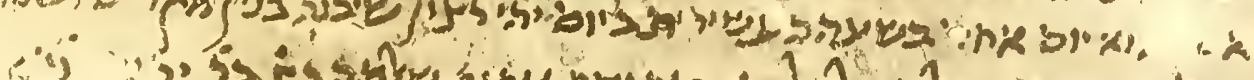

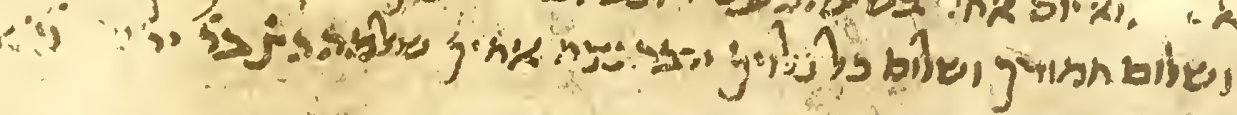




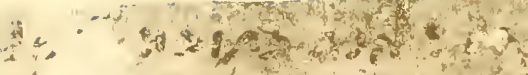

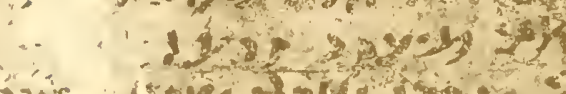

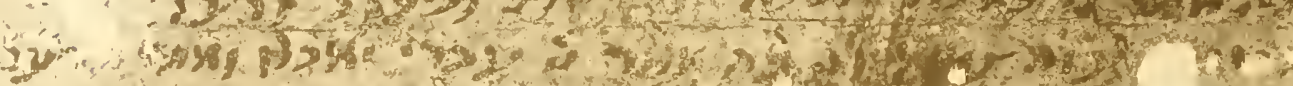
urr

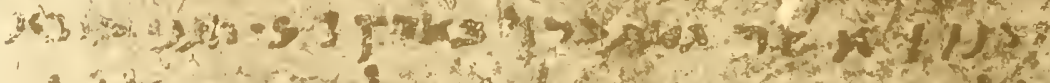

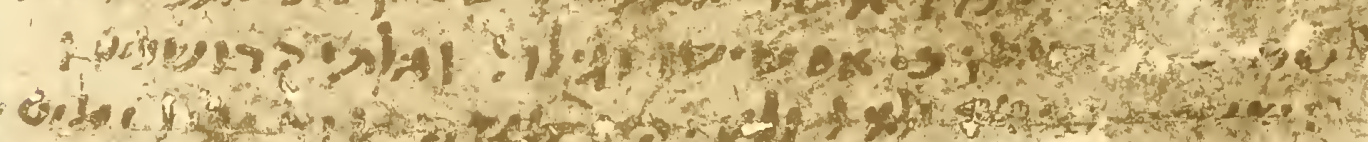

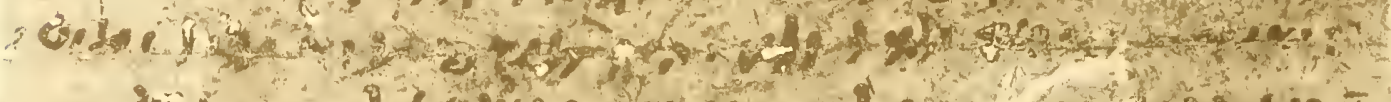

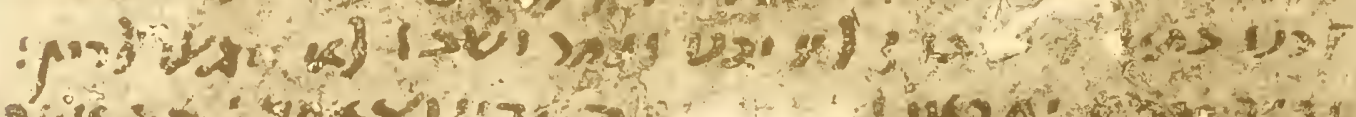

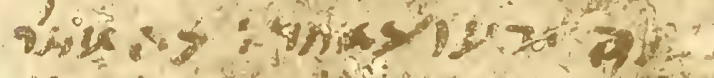

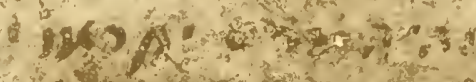

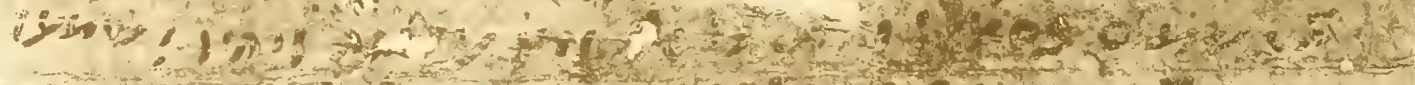

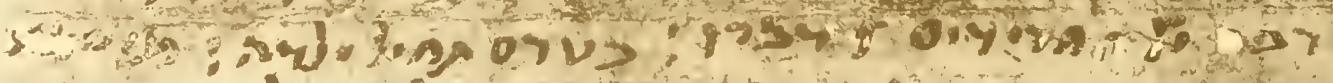

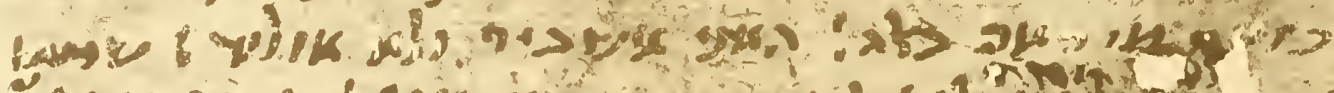

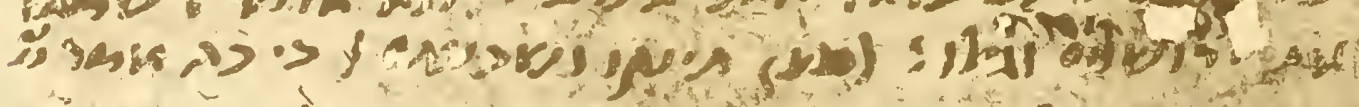

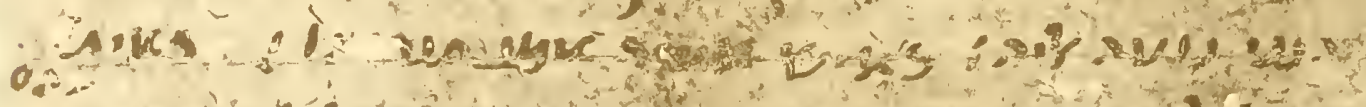

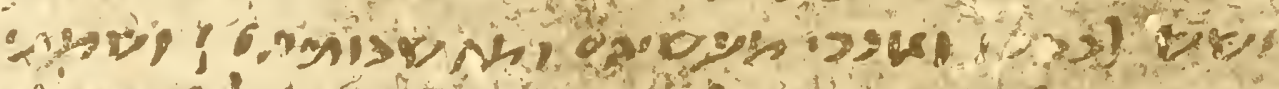

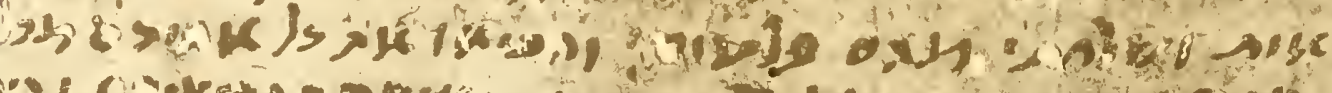

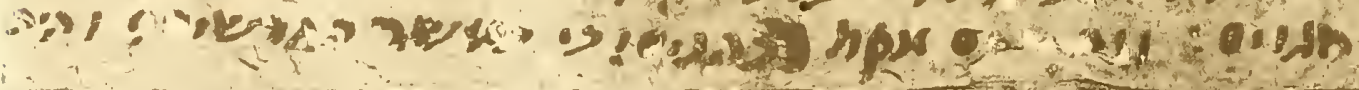

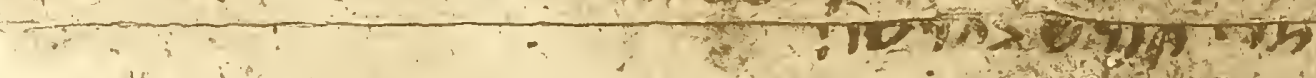
Fis

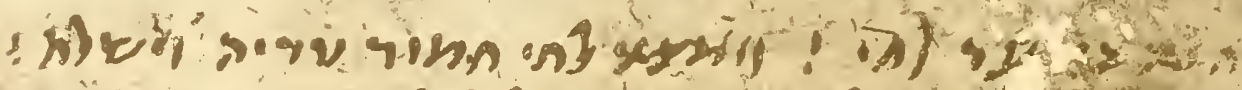

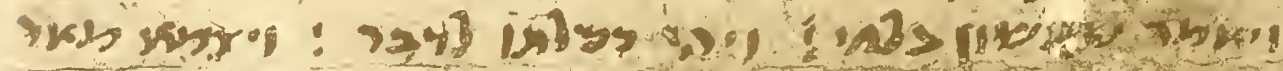

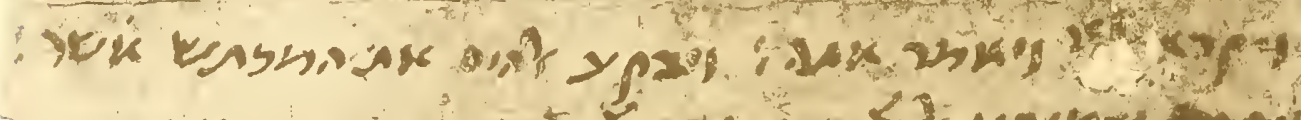

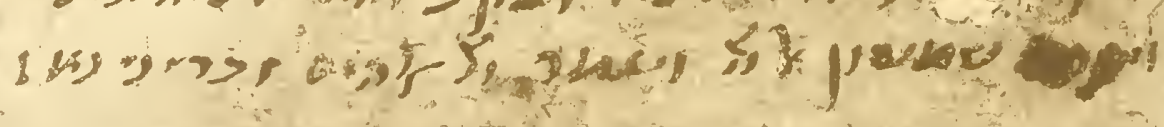

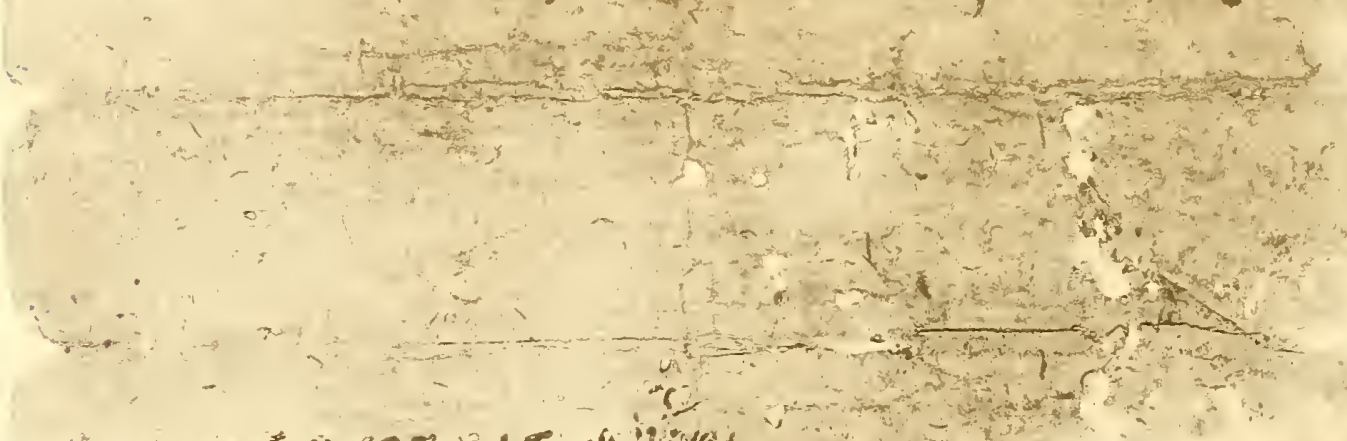

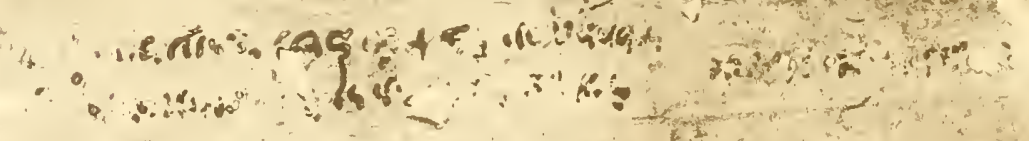




\section{LETTER}

Apparently Jacob had left Jerusalem some time before, bearing a commission from Solomon Ben Khalaf al-Būkși in Jerusalem to his wife in Fusțāt. Solomon had given Jacob two gold-pieces with which to pay her way to Jerusalem. Evidently he expected trouble, for he gave to Jacob a statement of his possessions in his house at Fusțăt and directions to take possession of these. The only response that came was another messenger, Nathan or Hibah by name, son of Zachariah, who arrived in Jerusalem with a protest from the wife that Solomon had no grounds for his action. Nathan next undertook to carry to the wife in Fustat a letter of divorce, which he promised to deliver to her in the presence of a certain Abraham the Hazzān.

Nathan appears with all the documents and with Solomon's statement that it was in the house of the writer that Jacob had sworn to carry the original message to the wife. The writer is equally certain that nothing of the kind ever took place under his roof, nor had he heard of the affair at all. He now writes in great haste to Jacob and tells him that he is sending by a Spaniard, al-Azhar, a copy of the wife's protest, which is to be delivered to Abraham, the intended witness of the divorce proceedings. Incidentally it is said that a certain "glorious place" in Jerusalem has collapsed.

Recto:

I To......in the name of those who are enwrapped in turbans, Hāaērs of doctrines, teachers of doctrines, elders......

2......a good name to write it is: Master Jacob, "The Appointed ${ }^{1 "}$ to be called by [the title] Ge'on Jacob!

3 Everyone who tastes of his wisdom and beholds (?)..... his humility. May God keep him, and preserve him and assist him, and be his help,

+ and enliven him (?)...... son of Joseph the Pious. Peace! Peace be upon you! Beloved and dear, and friend (?).

5 From the Lord of Peace and from the City of Peace, and from her paths! And peace also from me who love you as my own life!

6 I write these pages earnestly, to inform [you] of the arrival of Master Nathan, messenger of the congregation ${ }^{2}$, known [in Arabic as] $\mathrm{Hibah}^{3}$, son of Rabbi

7 Zachariah, bringing an Arabic ${ }^{4}$ document of deposits and its seals. And it makes demands of Solomon Ben Khalaf al-Būḳi $\overline{1}^{5}$

8 about his wife. And she says to him [in the document] "This [document of yours which you have sent me] is not a [proper] complaint, nor does it contain proof [justifying] a demand." And the man Solomon said :

2 a

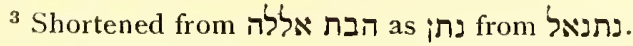

4 " הגרי " of Hagar."

${ }^{5}$ From Būks, the name of a river near Baghdad. See Yāḳūt, Geogr. Wörterbuch, vol. i, p. $762 ;$ Muschtarik, p. $7 \mathrm{I}$. 
9 שלמה כי שלחתי עם ר יעקב המעותר שנים זהובים לשאת אותה בהם אם

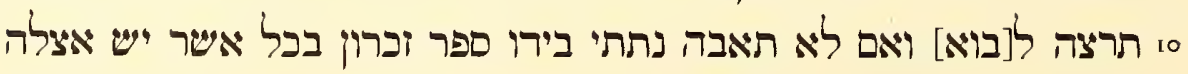

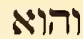

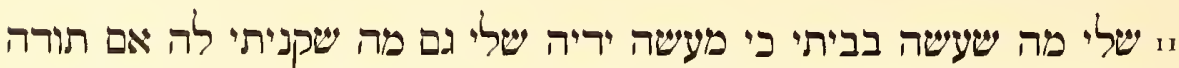

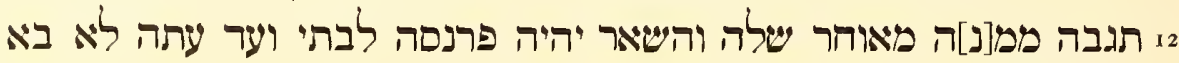

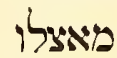

3י מכ[תב] ול[א] הודיע מה נעשה ויאמר האיש הוה מר הבה כי בביתי נשבעה

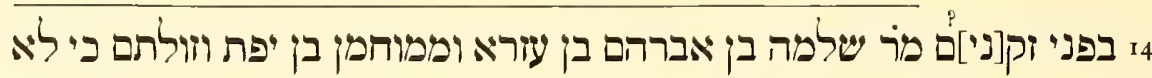
5י הויה אצלי דבר גם לא עשיתי בביתי דבר ואתה אחר מהם ועבר]י

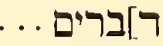

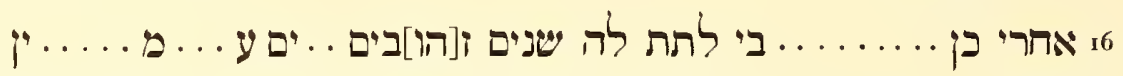

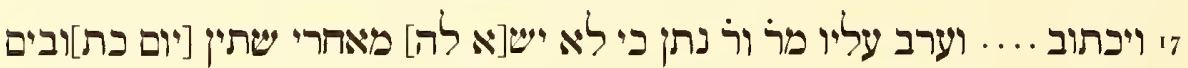
אלי

8. שם טע[נה] ... לם כי תביא הכתובה בפנייו ו]בפניר אברהם החהן... תקרעה

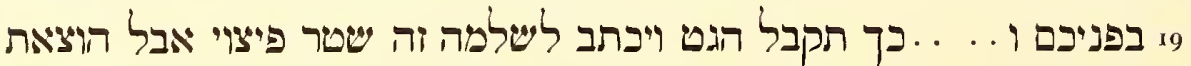

בתו 20 נפס[ה] שית; לה שנים זהובים לשנה כל ומן שרצה ....... אמה ועתה?

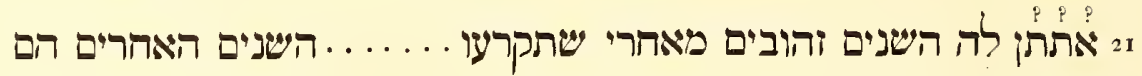

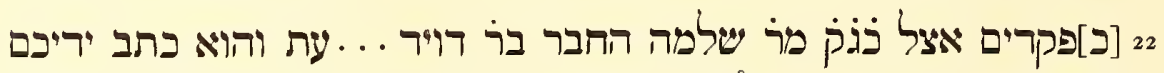

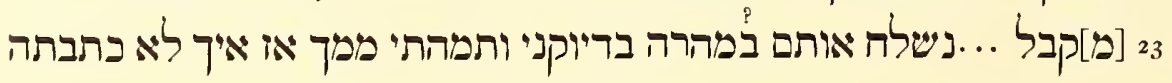

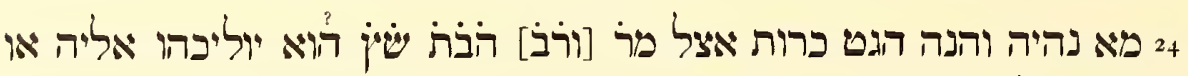

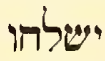

25 בי[ר] של[וח] בי הרשה ל[נו לשלוח ש[לוחים ער להגיע לירה שרם הודעתיך

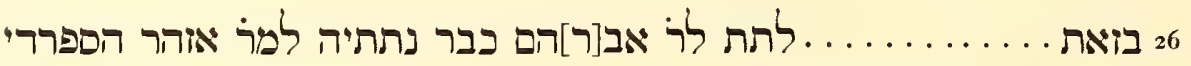

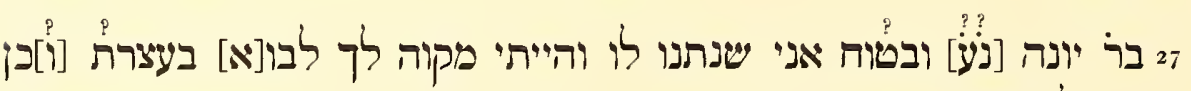
לת לתשר

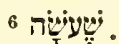

7 מאודר has no article; but that is not uncommon in our texts.

8 This passage was deleted.

${ }^{9}$ ธתל-1i??

${ }^{10}$ About eight illegible letters are written above the line here. 
9 "I sent by Rabbi Jacob Ha-Me'uttadh" two gold-pieces, with which to bring her, if

to she were willing to come; and, if she did not desire [to come], I gave into his hand a document of memorandum as to all that was in her possession, namely:

II 'Mine is that which she made ${ }^{6}$ in my house, for the work of her hands is mine as well as that which I bought for her. If she admits the claim,

is collect from her her overdue ${ }^{7}$ [debt], then the remainder shall be the support of my daughter.' But up to the present there has not come from him

13 any letter nor has he let [me] know what has been done." And this man, our Master Hibah, says that in my house an oath was taken

${ }_{4} 4$ in the presence of elders, ${ }^{8}$ our Master Solomon Ben Abraham Ben Ezra, and Memühamän Ben Yapheth, and others ${ }^{9}$. But never

${ }^{5} 5$ did there happen in my presence anything [like this,] nor did I do in my house anything [like this,] and [that] you [Rabbi Jacob] were one of them. And things happened.

16 After this........ by me to give her two pieces of gold

17 and he write......... And our Master Rabbi Nathan became surety for him that he would bring to her(?) after two days(?) documents thith-

I 8 er [as a] complaint.........she should produce the [marriage ?] document, in his presence and in the presence ${ }^{10}$ of Rabbi Abraham the Hazzān... .......and tear it up

${ }_{19}$ in your presence. And.........she should receive the letter of divorce. ......And [that] he would write for this Solomon a document of damages. But [as for] the expenses of his daughter

so herself(?), that he would give her two gold-pieces the year for as long as she wished.................her mother. And now

2I I shall give her the two gold-pieces after she has torn it up.........the later years

22 as a deposit with our Master Solomon the Hābēr, son of Rabbi David. And it is the writing of your hands

${ }_{23}$ accepting......We are sending them in haste with a duplicate ${ }^{11}$ [for return]. And I was astonished at you then that you did not write

${ }_{24}$ what was to happen. And behold [here is] the executed bill of divorce in the possession of our Master, Rabbi Hibah. He will take it to her or send it

25 by the hand of his messenger, for he has authorised [us to send] messengers, so that it may reach her safely. I have acquainted you

26 with this..............to give to Rabbi Abraham. I have already given it to our Master Azhar the Spaniard ${ }^{12}$,

27 son of Rabbi Jonah, and I am confident that they have been given to him. And I have been hoping that you would come at the feast [of Weeks] and so also on the Ninth of

11 generally means "picture."

12 งาจด. 


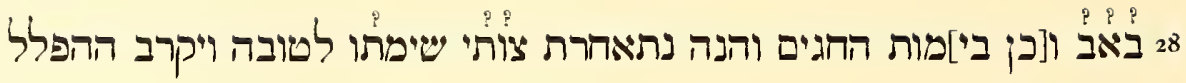
עמכו....

29 ב ....... הו ואנהנו וכל יני שלום והמקום ההדור הבנוי עליו נפל ביום י; לושי לחדוש

30 א[ב וה][יא יום אחר בשעה העשירית ביום יהי רצון שיבנה בנין מקויים

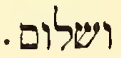

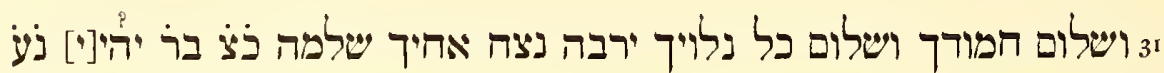

13 "My hearing of his situation for good has been delayed."

\section{HALACHIC FRAGMENT}

Paper I I $\frac{3}{8} \times 6 \frac{1}{2}$ inches.

Four pages of Hebrew in square Hebrew writing.

The orthography is poor, and many words and passages are omitted.

The variants are probably not worth noting; and the text has accordingly not been printed here. This fragment has been studied by Professor Gottheil only. 
$28 \mathrm{Ab}$, and so also at the [other] feast days. And behold I have had to wait for good news of it ${ }^{13}$. And may the...... with you be near!

$29 \ldots \ldots$. And we and all...... ${ }^{14}$ are well. But the glorious ${ }^{15}$ place, which had been built upon, fell on the I 7 th of the month

30 of $\mathrm{Ab}($ ?), and it was a Sunday, at the tenth hour of the day. May it be His pleasure to build a firm building! Greetings!

$3^{x}$ And greetings [to] your son, and greetings [to] all your relatives!

[God] prolong the life of your brother Solomon, son of Rabbi Yahyā (?) [May] his rest [be in] Eden!

14 This abbreviation occurs in line 7 also. Does it mean "etc."?

15 Or "steep," or "spiral."

\section{HALACHIC FRAGMENT}

From the Halākhōth Gedhōototh of Simeon Kayyāra, a Babylonian rabbinical authority of the ninth century.

In the edition of Hildesheimer, Halachoth Gedoloth nach dem Texte der Handschrift der Vaticana, Berlin, I888, this text covers p. I38, lines 9-20; line 30-p. I 39, line I3; p. I40, lines 6-24. 


\section{MEMORANDUM}

Paper $10 \frac{3}{8} \times 7$ inches.

Arabic in Hebrew characters, cursive and not easily read, since the writer has apparently written quickly and automatically, without looking at the resulting forms of the letters. The Arabic has a strong vernacular coloring. Some of the names have Maghrabī, or north African forms. A little Aramaic phraseology is introduced.

Certain witnesses, whose names are signed at the end in square characters, testify to their belief in the truth of Bin Asad's account of his transactions with Abū al-'Ulā Bin Bu al-Faraj and Șadaḳah Bin Jacob, his partner: all apparently Jews.

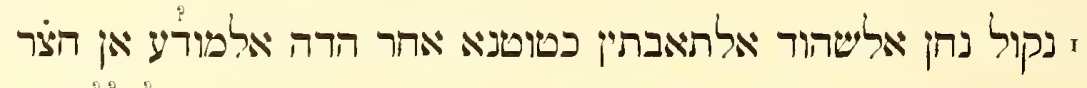

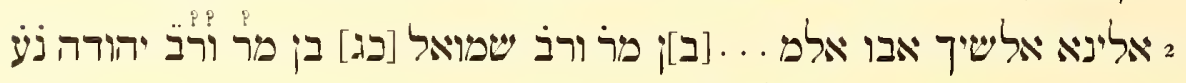

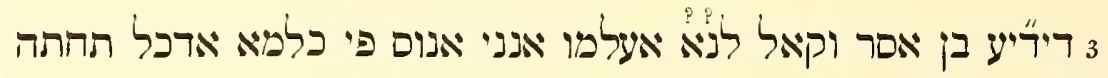

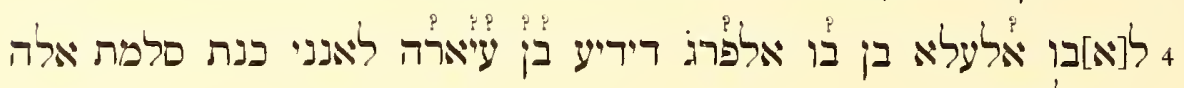
וליצרקה

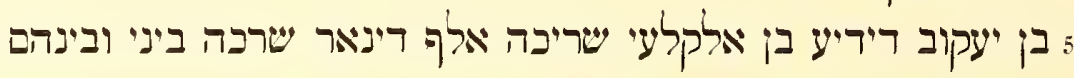

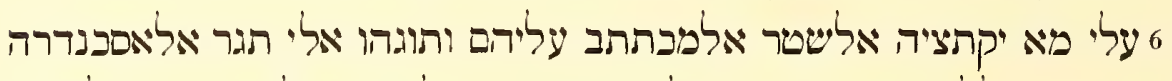

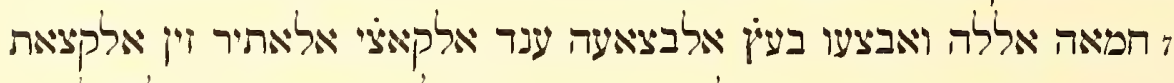

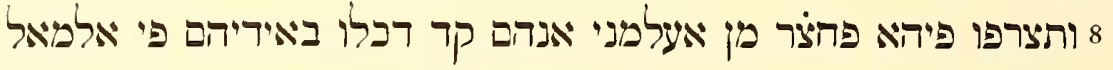
9 ואפלוה פחצרת אלי תגר אלאסבנריה ואלתמסת פי אבו עלא בי בו มา

1 I.e. الثَابتين خطوطُنها, if one should seek to justify the expression grammatically.

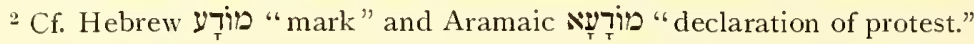

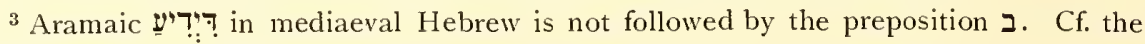
same phrase infra, 11. 4, 5 .

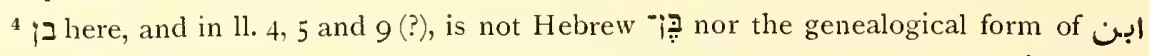
in names, but the Maghrabī (Tunisian, Algerian, Moroccan, Spanish) إبْن =بِن also ב أبو This 11. 4, 9, for also a Maghrabī form. Both arise from the ultima-accent

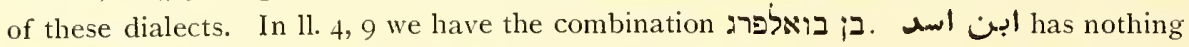
to do with the tribe of Asad. It means "Son of a Lion" and is a play upon Gen. xlix, 9, and a substitute for "Jew" or "Judah," as in this case. Cf. the Western Benari, Loewensohn, Loewe, Loew, Lowe, Lieure, Loeb, Léon, Leo, Lion, and variations. There is some confusion with "!? and hence Herz, Leben, etc.

5 אוֹ is a very violently emotional Hebrew expression, used of rape and highway robbery.

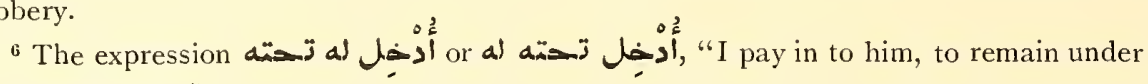
his management." 
בנים

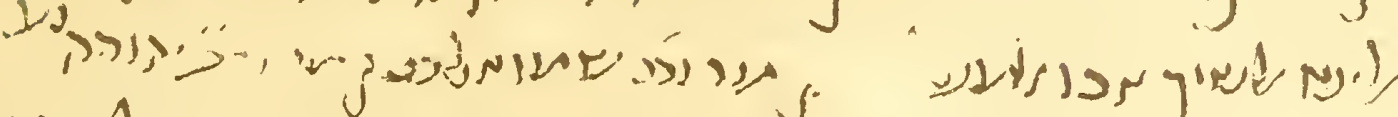

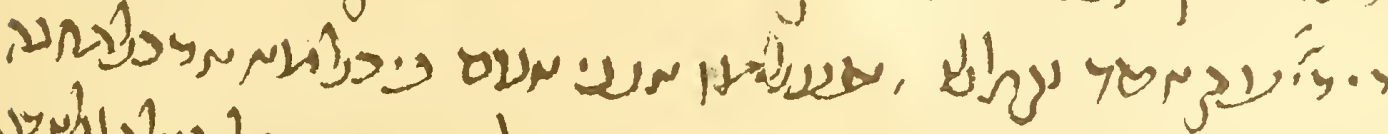
3) א"

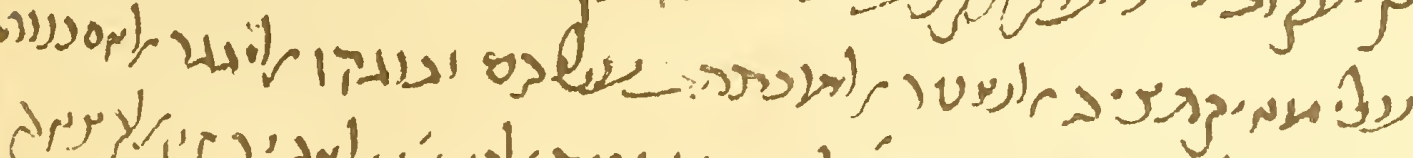

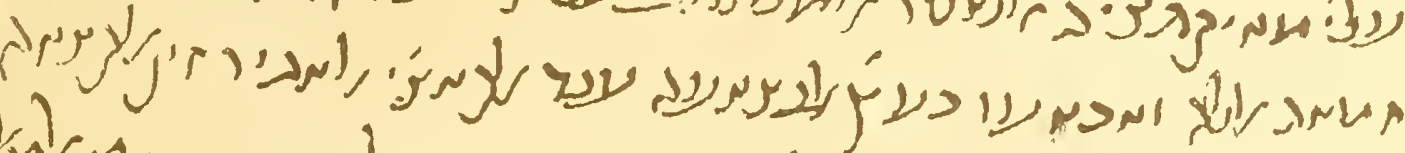

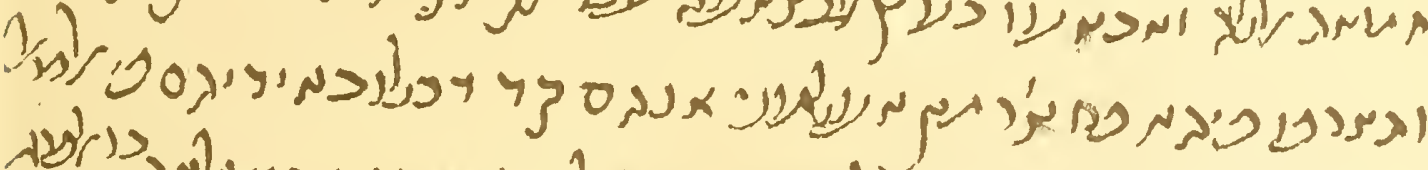

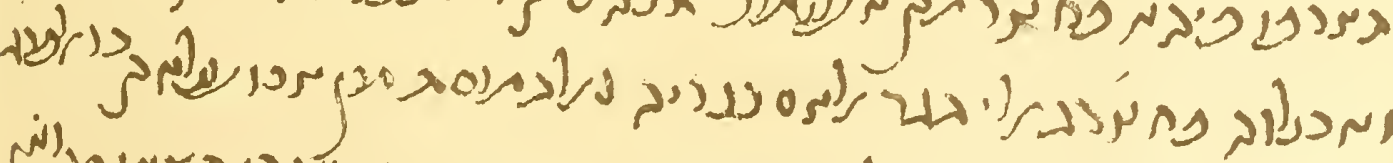

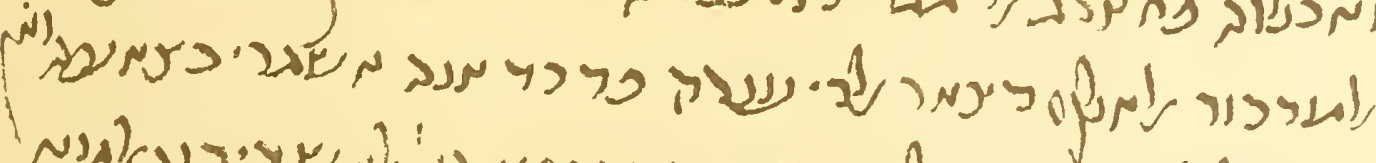

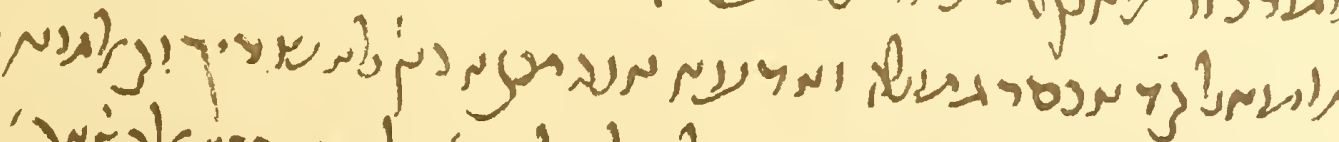

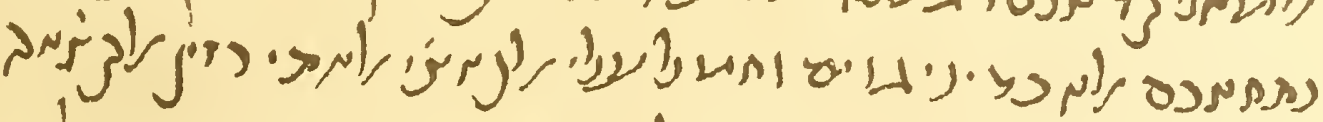

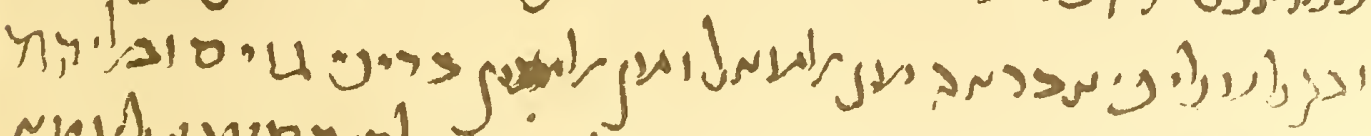
יע

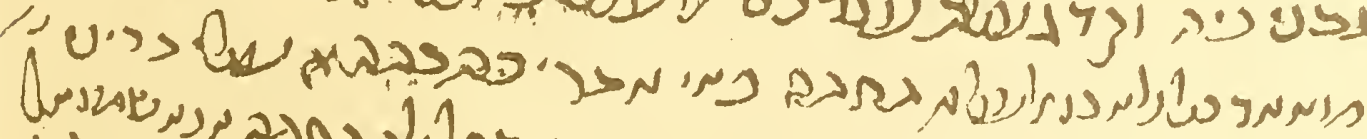

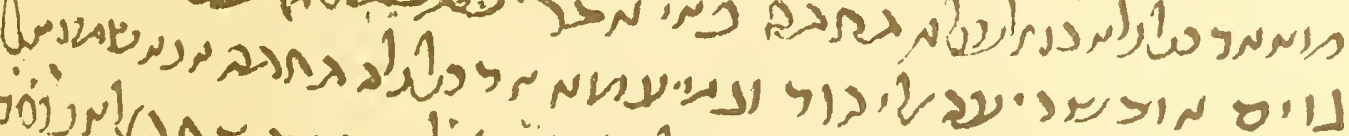

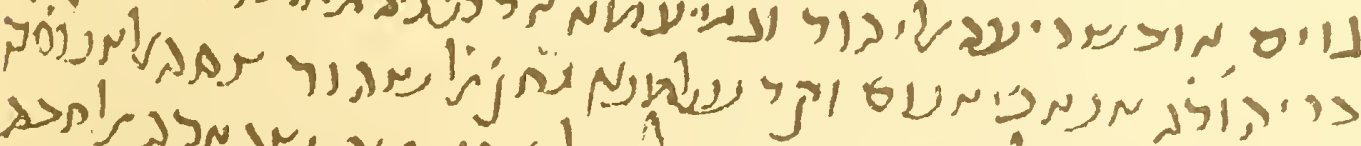

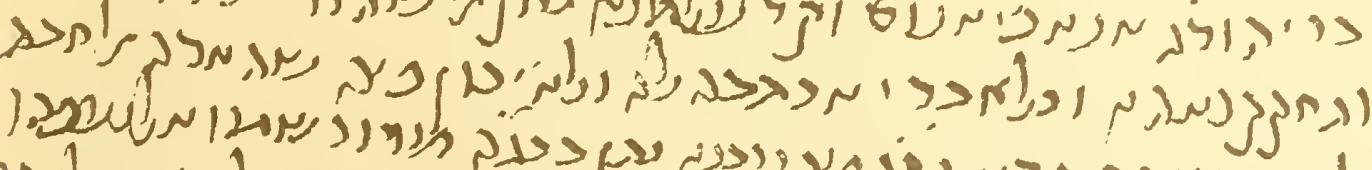

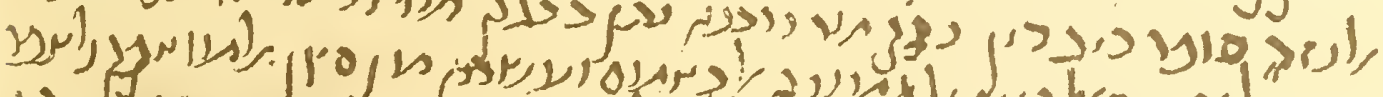

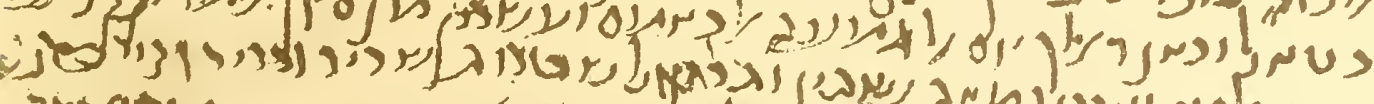

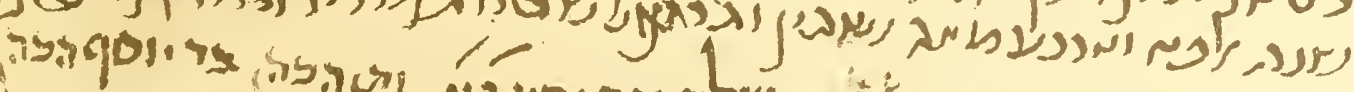

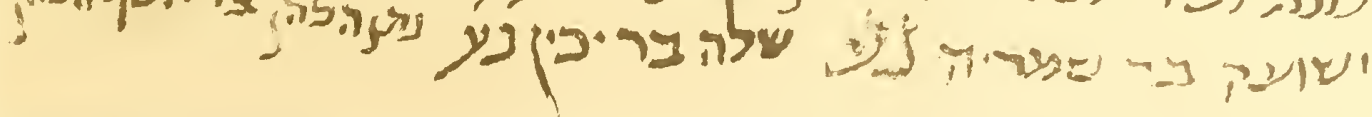




$$
\text { - }
$$




\section{MEMORANDUM}

It appears that Bin Asad loaned a large sum of money to Abũ al-'Ulã and Sadaḳah Bin Jacob to invest at Alexandria, on terms that were stated in a document, and understood by Bin Asad to constitute a partnership. Some of the money was invested. Of the remainder a large part or all was either lost in speculation or stolen outright. Abū al-'Ulā asserted that some money had been lost, but that he was not liable for it, as he was merely an agent and not a partner. The matter was brought before a Muslim court, where Bin Asad was bullied by the Kādi and by his enemy, and confused with technicalities with which he is thoroughly disgusted. The court evidently decided against Bin Asad, and issued some document which put his case in a bad light. He goes to certain Jewish friends and tells his tale. He knows that he has lost the money: that is all. The fragment is the record of an indignation meeting held sometime in June of the year A.D. I I 5 O.

I We, the witnesses, whose signatures $\operatorname{stand}^{1}$ at the end of this declaration ${ }^{2}$, say that there appeared

2 before us the Sheikh Abū al....., son of our lord and master Samuel, son of our lord and master Judah,

3 who is known as $^{3}$ Bin $\mathrm{Asad}^{4}$, and said to us: I have been robbed ${ }^{5}$ in respect to all that $I$ intrusted for investment

4 to $^{6}$ Abū al-'Ulā Bin Bū al-Faraj, known as Bin 'Ayyāra(?), because I turned over to him ${ }^{7}$ and to Sadakah

5 Bin Jacob, known as Bin al-Kal'⿳亠̄, his partner, a thousand dīnārs ${ }^{8}$, as a partnership between me and them

6 according to what the document required which was drawn up ${ }^{9}$ concerning them. And they went to the city of Alexandria

7 -God defend it! - and invested some of the capital in the presence of the Kādīine, al-Athīr, Ornament of the Kādīis,

8 and they got control of it $^{11}$. And someone came and informed me that they had already gone into the property with their hands

9 and had eaten it up. And I went to the city of Alexandria ${ }^{12}$ and I entreated Abū al-'Ulā Bin Bū al-Faraj,

7 אל for á, as in Syrian vernacular ito.

${ }^{8}$ The dinnār, according to the Misbäh̆ of al-Faiyūmī (about A.D. 1333/4-we quote through Lane, Arabic-English Lexicon), was a gold coin weighing $7 \mathrm{I} \frac{1}{2}$ or $68 \frac{4}{7}$ grains of wheat, the same as the mithḳāl. The American five-dollar gold-piece weighs I29 grains at 900 fine.

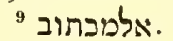

${ }^{10}$ I.e. the judge.

11 I.e. the thousand dīnārs.

$12 \mathrm{M}$ isspelled as before, but differently. 
o אלמדכור אלאלפ דינאר אלדי ענרה פרכר אנד אשתרי בצאעה ואן

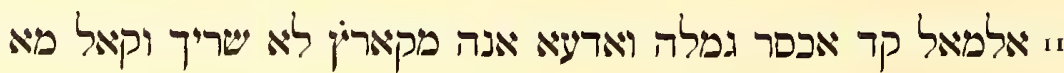

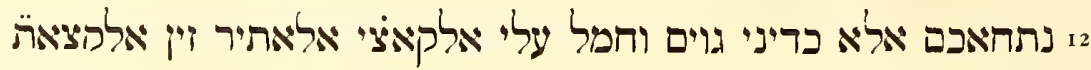

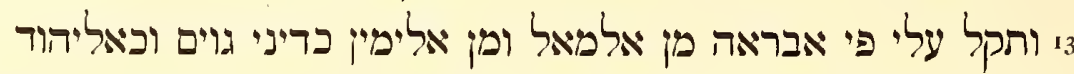

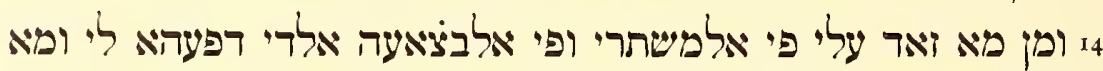

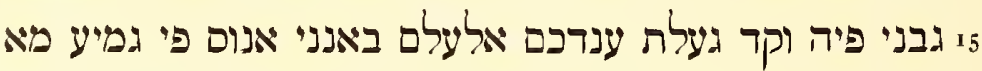

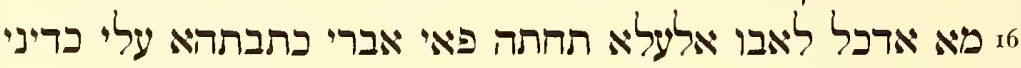

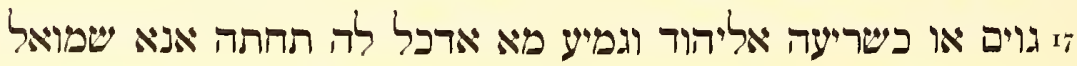

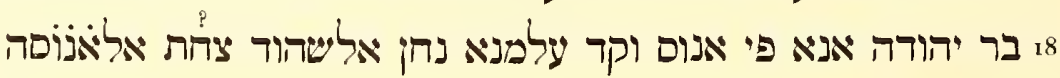

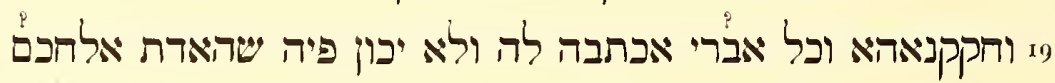

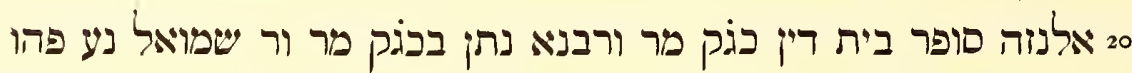

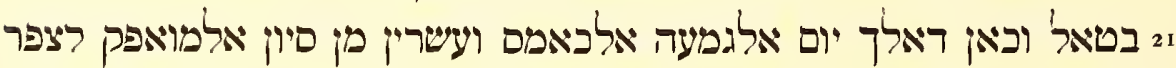

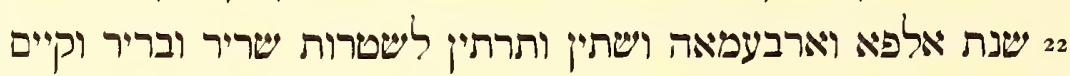
23

13 ذكر in these texts means simply "to say."

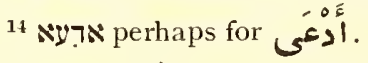

${ }^{15} \mathrm{~A}$ مُقَارِ is an agent, intrusted with capital for business purposes, on the condition that the gain shall be divided between the agent and the investor, and that the loss, if any, shall fall upon the investor. See Lane, Arabic-English Lexicon, part 7, p. 2515.

${ }^{16}$ He must have been a Jew, however ; else why say this at all? Cf. also 1. I 3 .

17 ثَقَّلَ

${ }^{18} \mathrm{He}$ was confused with technicalities.

أَجِابْنى must be first $\bar{a}$ is absorbed by $m \bar{a}$, the second $\bar{a}$ is shortened in the shut syllable of the vernacular form.

20 אברי 20 perhaps though we find no instance.

21 Singular, and probably impersonal, or meaning his enemy.

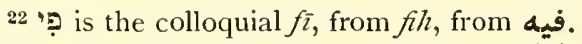

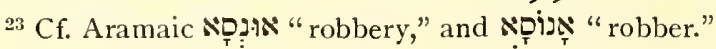


Io the aforementioned, for the thousand dinnārs which he had. And he said ${ }^{13}$ that he had bought goods, and that the

in property had been decreased by a certain amount. And he asserted ${ }^{14}$ that he was [merely] an agent ${ }^{15}$, [and] not a partner. And he said :

I2 "We shall not litigate except according to the laws of the Gentiles"16." And he urged the Kādīi, al-Athīr, Ornament of the Kădīis;

${ }_{1} 3$ and he forced ${ }^{17}$ me to clear him concerning the property and the oath ${ }^{18}$ according to the laws of the Gentiles and according to the Jews-

I4 and about what had accrued to me through the transaction, and through the capital which he had paid me, and about what

${ }_{15}$ answer he had given $\mathrm{me}^{19}$ in [the matter]. And now I have informed you that $I$ have been robbed in respect to all

I6 I intrusted to Abū al-'Ulā for investment: whatever be the acquittal ${ }^{20}$ which you ${ }^{21}[\mathrm{O}$ Abū al-'Ulā] have written against me, according to the laws of

I 7 the Gentiles or the canon law of the Jews. All that I intrusted to him for investment I, [the son of] Samuel

I8 Bar Judah, I, have been robbed of it ${ }^{22}$. And we, the witnesses, know that the robbery ${ }^{23}$ is a fact.

I9 And we have verified it. And [as to] every acquittal ${ }^{20}$ which he [Abū al'Ulā] had written against him [Bin Asad]: there is no unobjectionable legal evidence in it.

zo The scribe of the [Jewish] court, our lord and master Nathan, son of our lord and master Samuel-he is

21 a worthless ${ }^{24}$ fellow. And this occurred ${ }^{25}$ on Friday, the twenty-fifth of Sivan, the equivalent to Safar.

22 The year [is] one thousand four hundred and sixty-two of [the Era of] Documents ${ }^{26}$. [Be it] certain, clear and abiding ${ }^{27 !}$

23 [Signed:] Joshua Bar Shemaryah, Shēlāh Bar Yakīn, Nathan ha-Kōhēn Bar Joseph ha-Kōhēn.

24 Very nearly the modern colloquial sense of the word.

25 I.e. the memorandum was written.

${ }^{26}$ The Seleucid Era, beginning October Ist, 3 I 2 B.C. It is called in these fragments the Era of Documents. The Jews continued to use this manner of dating almost exclusively until well into the eleventh century A.D. Then they began to use the Jewish Era, which starts with October 7th, 376r B.c. Wislicenus, Der Kalendar, Leipzig, 1905, p. 74. Our fragment is dated some time in June, A.D. I I 5 O.

27 This line is in Aramaic. 


\section{LETTER}

Paper $12 \frac{3}{8} \times 4 \frac{5}{8}$ inches.

Arabic in cursive Hebrew characters.

The five bits of writing are from the hands of three individuals. The longest, recto (a), is rather clearly written; though the language is bad and mixed with Hebrew, and the style vague and ornate. The next longest, verso $(a)$, is crabbed and angular, as though from the hand of someone unaccustomed to the pen; but the language is good, and the style concise and to the point. Recto $(b)$ is merely a false beginning of the same. Verso (a) dates itself and recto (b) on Monday, the eighth of Marheshwān, Seleucid Era, I 543, which is A.D. I23I. Verso $(b)$ and $(c)$ are in a cultivated but difficult cursive hand, which becomes worse as it proceeds. The language is very much better than usual in our texts. There are even pedantic nominal case-endings and certain orthographic peculiarities of the Arabic in its own alphabet which the writer no doubt was accustomed to use. We do not know who he was. The first of the two is dated Thursday, the eleventh of Marheshwān, Seleucid Era, I 543, which is three days later than verso $(a)$. The second is not dated, but may be assumed to have been written at the expiration of the ten days from the eleventh of Marheshwān, or the twenty-first of that month.

Recto: $(a)$

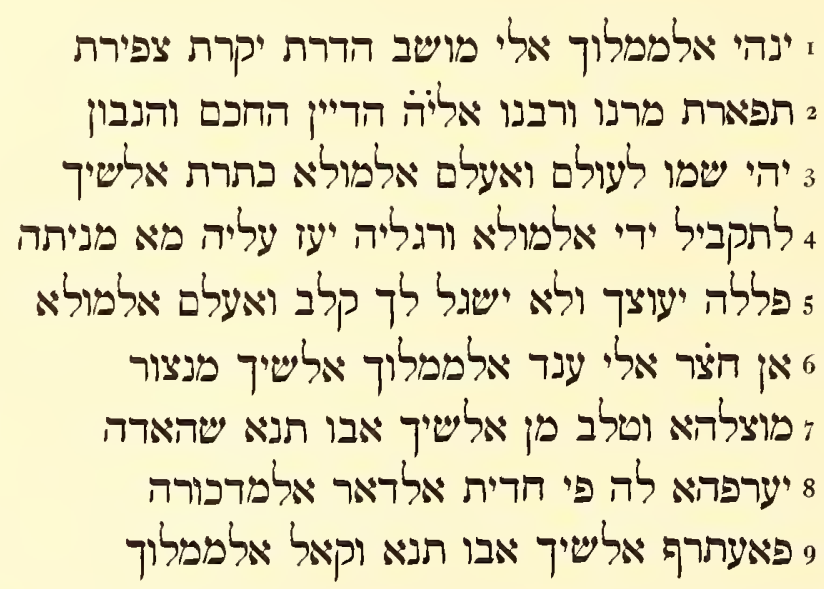

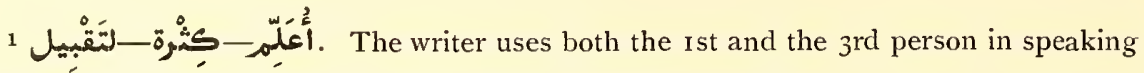
of himself. We have translated everywhere with the Ist person.

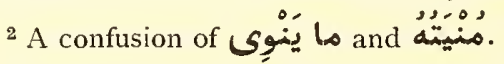

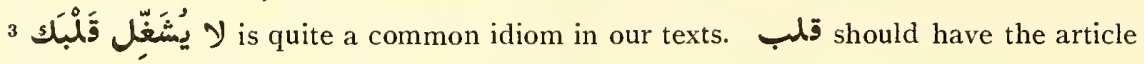
here.

4 The woman in question, not yet named. From lines I5, I6 we learn that she is the wife of the Sheikh Sarür and sister of the wife of the Sheikh Manșūr.

${ }^{5}$ Here, as in modern colloquial, the second object of a verb is indicated by the preposition : شهادة يُعِرِفها له فيى 


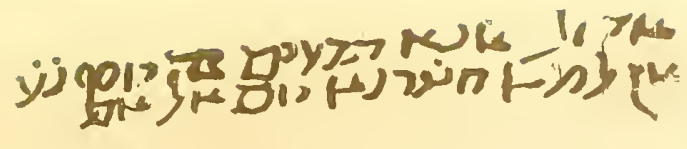

תח

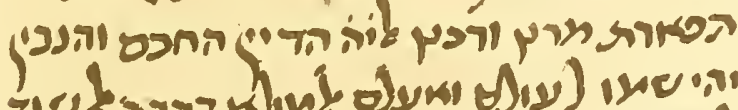

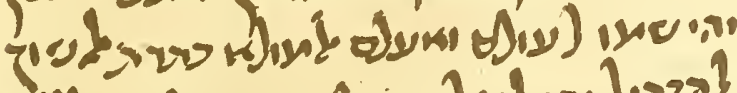
ה

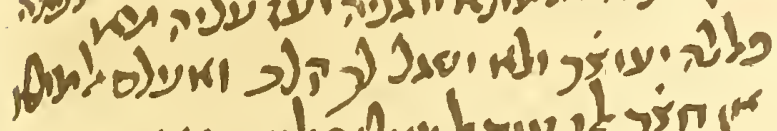

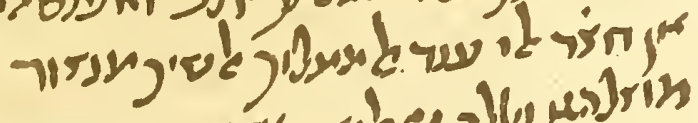

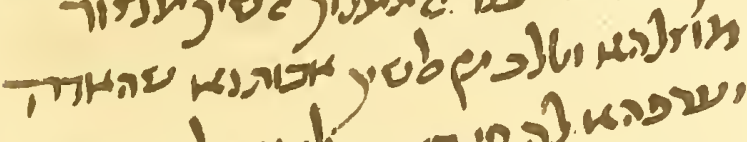
פ

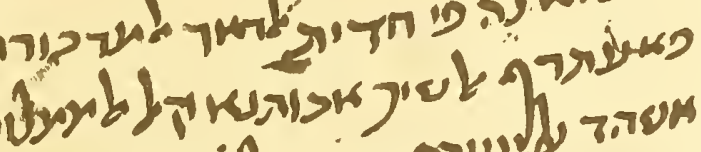

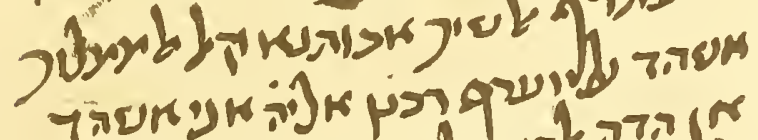

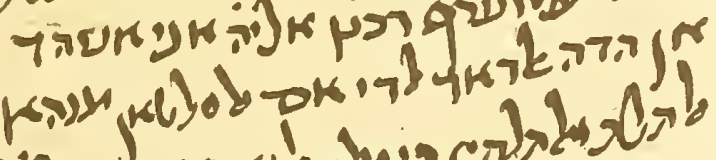

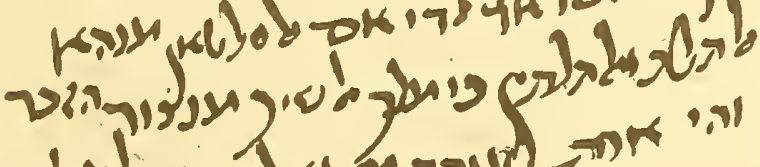
.

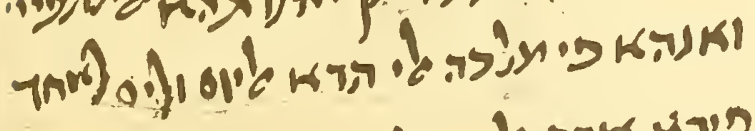

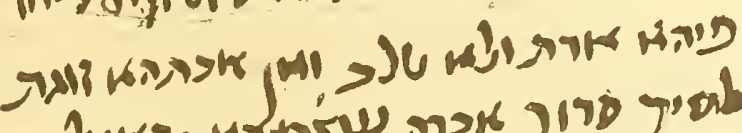

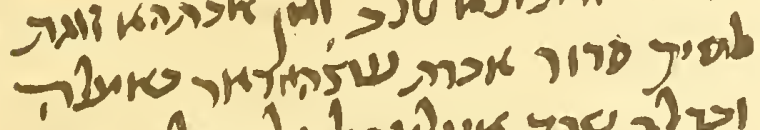

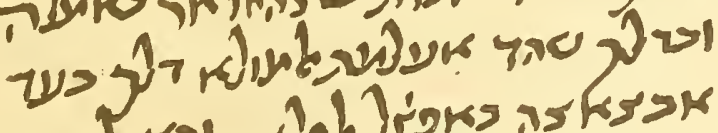

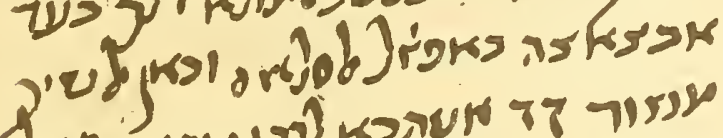

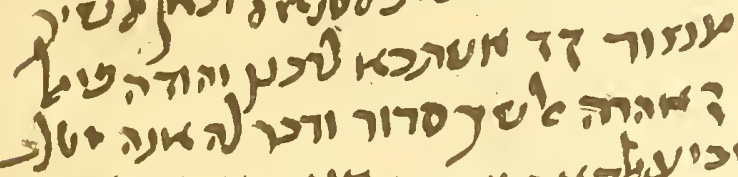

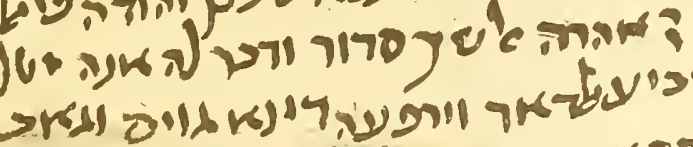

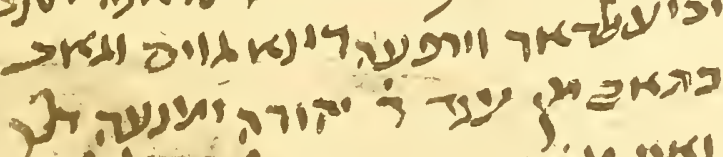

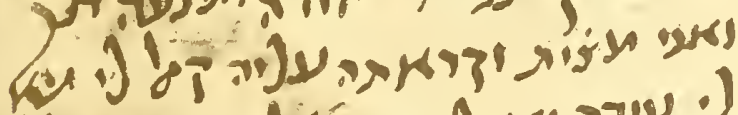

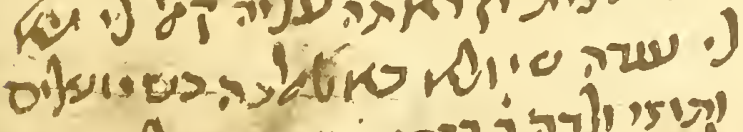

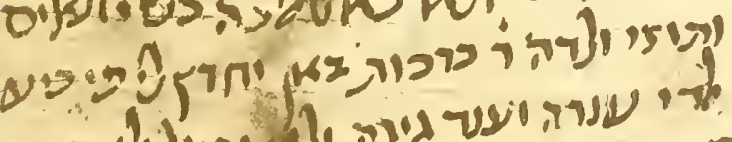

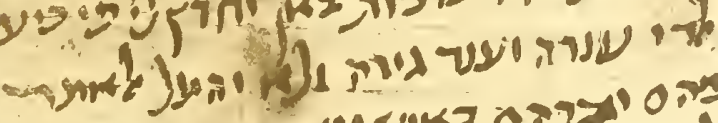

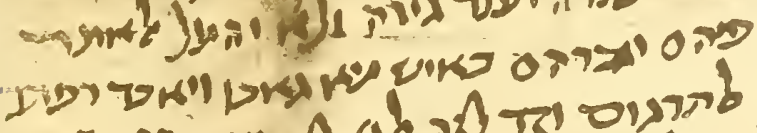

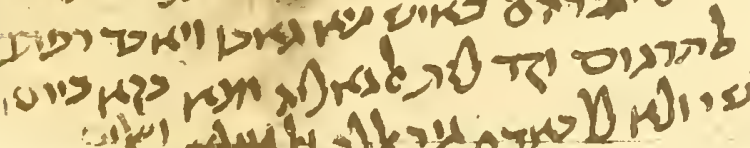

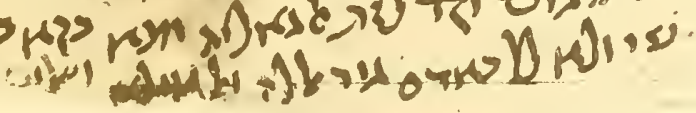




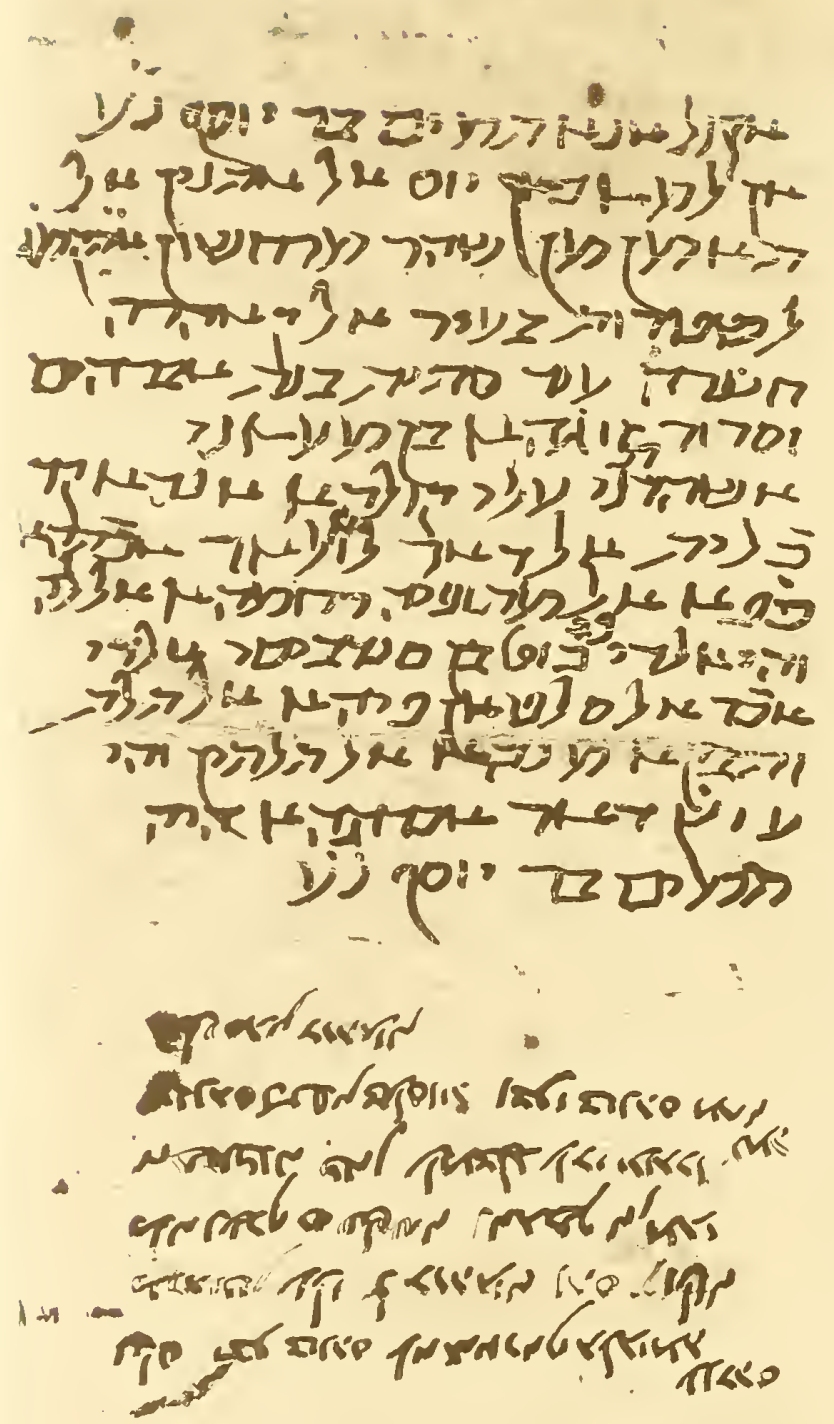

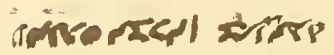

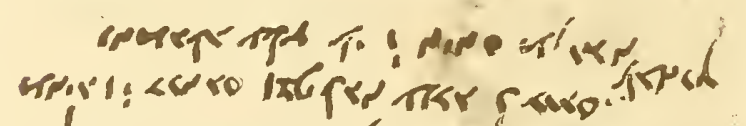

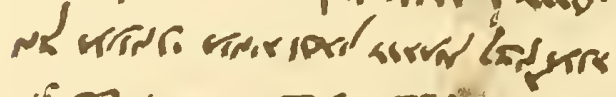

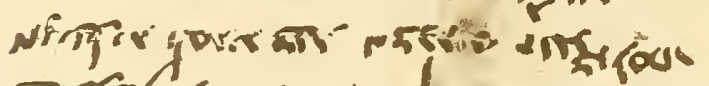

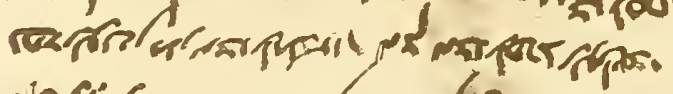

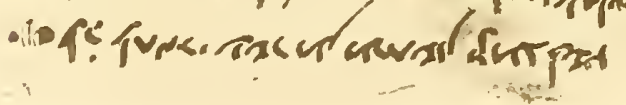




\section{LETTER}

Recto $(a)$ is a letter from one Abū al-Thanā to a judge, Rabbi Elijah, probably both in Kalyūb, just north of Cairo. He seeks with flattery to represent that his friend, Abū al-Manșūr, of Kalyūb, the son of Abū alFaraj, has been driven into exile and destitution because he was prevented from selling his house by a sister-in-law, Sutait, the daughter of Abraham, and her husband, Abū al-Sarūr, the son of Ma'ānī. The house belongs to Mansūr, and the other family have nothing to do with it. Abū al-Thanā sold the movable property at the request of Manșür's son. All the harmless facts are admitted, but the others are suppressed. Evidently Mansūr's wife, Kifā', has died, and Manșūr has tried to defraud his children by selling their estate; and has defrauded Sutait in some manner, possibly by the sale of the movable property. Abū al-Thanā is the agent of Manșūr and not of his son. Manșūr is not destitute; and probably would not have been evicted if he had not attempted the sale. We learn from verso $(a)$ the other side of the story through the witness Tamim, son of Joseph. Sutait and Kifā' were sisters and joint heirs to two estates. After the larger of the two had been reduced by confiscation, Sutait took the smaller as her own, and Kifā' the larger, which she willed to her children. Verso (a) tells us that Manșūr was evicted, and made to pay damages to Sutait, which he could do in part only. Verso $(c)$ states that the two parties agreed to a payment of the balance at convenience, without court-action, but with an added 20 per cent.

Recto: (a)

I [I,] the slave, approach the Presence of the Beauty of the Dignity of the Crown of

2 Splendor of our Master and Rabbi, Elijah, the wise and intelligent Judge.

3 May his name endure forever! And I assure the Master that [I,] the Sheikh, many times

${ }_{4}$ kiss $^{1}$ the hands and feet of the Master. My desire ${ }^{2}$ oppresses me;

5 but may God reward you, and may it not perplex you ${ }^{3}$. And I inform the Master

6 that the Sheikh Manșür, her ${ }^{4}$ go-between, came to [me,] the slave, 7 and demanded of [me,] the Sheikh Abū Thanā, testimony

8 of which he might inform her ${ }^{4}$, touching ${ }^{5}$ the case $^{6}$ of the estate ${ }^{7}$ in question $^{8}$.

9 And [I,] the Sheikh Abū Thanā, made acknowledgment and said: "[I,] the slave,

6 حديث "négociation, conférence," or perhaps "autorité, juridiction," Dozy, Supplément aux Dictionnaires Arabes, vol. i, p. 258.

'Cf. the long list of dārs in Lower Egypt, Ibn Dukmāke, Description de l'Égypte (ed. Vollers, Cairo, I893), pp. 56 ff. Ibn Dukmāk died in 1406, a hundred and seventyfive years after the date of our text.

${ }^{8}$ I.e. "mentioned." But the estate, like the woman in line 7 , is still unmentioned. Evidently there has been discussion of the matter. 


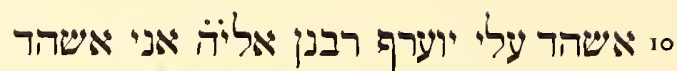

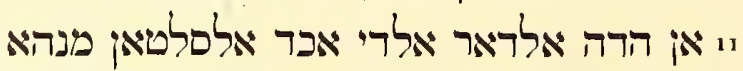

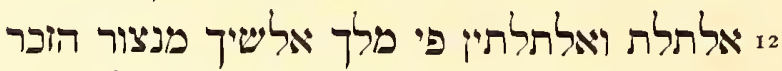

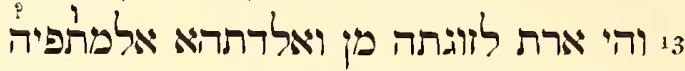

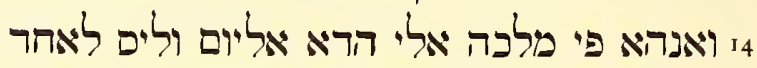

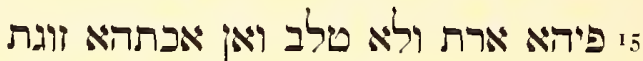

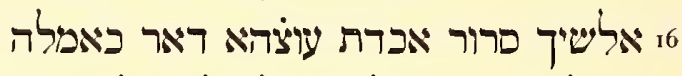

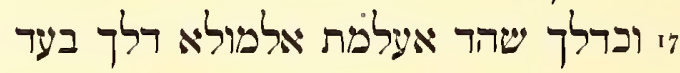
18 אבצאצה באפצל אלסלאם ובאי אלשי וכיך

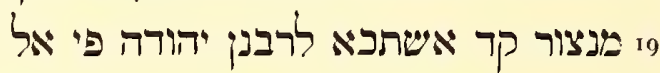

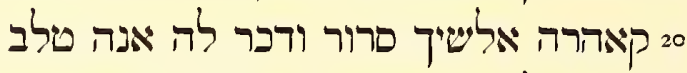

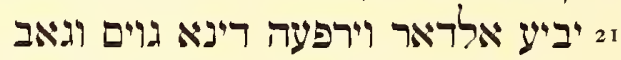
22 בתאב מן ענר ל' יהודה ומנעה רליך

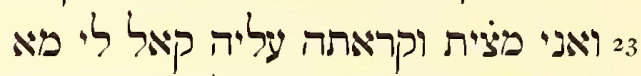

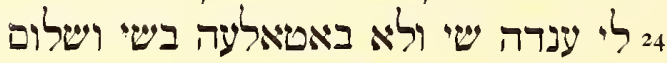

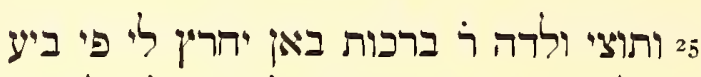

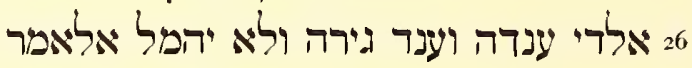

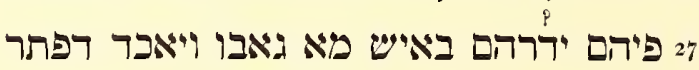

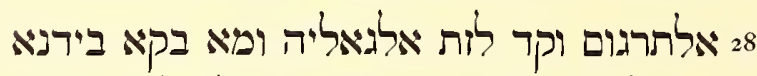
29 שי ולא ללכאדם גיר אללה ואלמולא ושלום. Recto: $(b)$, written after recto $(a)$, but above it, by the same hand as verso $(a)$ :

\section{אקול אנא תמים בר יוסף כלע.}

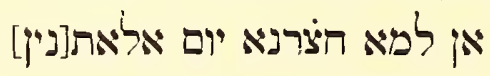

9.e. على [آَنْ [يْرَفَ.

${ }^{10}$ Kāmil, the Ayyubid, A.D. 1218-1238, at this time. But more likely an earlier ruler is meant.

11 הזכור = 11.

12 for מתופיה 12.

${ }^{13}$ I.e. the estate or the two-thirds remaining of it.

14 I.e. Manșūr 15 I.e. Sarūr.

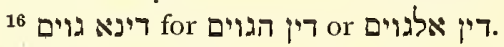

17 The modern colloquial verb - -

${ }^{18}$ I.e. the writ of Rahbi Judah, or the injunction of the Muslim judge, issued on the basis of the same. 
Io testify - that our Rabbi Elijah may be informed ${ }^{9}$ - I testify Ir that this [is] the estate ${ }^{7}$ from which the Sultan ${ }^{10}$ took away

I 2 a third; and [that] the two-thirds [remaining] are under the control of the Sheikh Manșūr, mentioned ${ }^{11}$;

$I_{3}$ and [that] it is an inheritance of his wife, from her deceased ${ }^{12}$ mother;

$I_{4}$ and that it ${ }^{13}$ [has remained] under his control until this day: and [that] no one [else] has

${ }_{5} 5$ any inheritance in it, nor any [right to make] demand; and that her sister, the wife of

I6 the Sheikh Sarūr, took in place of it a complete estate.

${ }_{17}$ And thus I testified. [So now] I have informed the Master of this, after I 8 paying compliment to him with special salutations. And the Sheikh

19 Manșūr has already complained, to Rabbi Judah in

20 Cairo, of the Sheikh Sarūr. And he ${ }^{14}$ told him that he had tried

2 I to sell the estate; and he ${ }^{15}$ informed the gentile judge ${ }^{16}$ of it, and brought ${ }^{17}$

22 a writ from Rabbi Judah, and enjoined him ${ }^{14}$ from [doing] this.

${ }_{23}$ And I went and read $i^{18}$ to him $^{14}$. He said to me [in reply]: " $\mathrm{He}^{15}$ owes me

${ }_{2}+$ nothing, and I have nothing to explain to him ${ }^{19}$. Adieu!'

${ }_{25}$ And his son ${ }^{20}$, Rabbi Berākhōth, was commissioned to urge ${ }^{21}$ me to sell

26 [the movable effects] which he had in his possession and in the possession of others; and the command

27 in regard to them was not neglected; [for I, the slave,] liquidated ${ }^{22}$ them for whatsoever ${ }^{23}$ [price] they would bring ${ }^{24}$. And [I, the slave,] was given a letter ${ }^{25}$

28 which said in substance ${ }^{26}$ : 'And I have fled into exile. And we have nothing left ${ }^{27}$,

29 nor has [our] servant either, save only God and [you,] the Master. Farewell!'”

Recto: $(b)$

I, Tamim Bar Joseph, say

that after we had appeared on Mon[day $]^{28} \ldots . . .$.

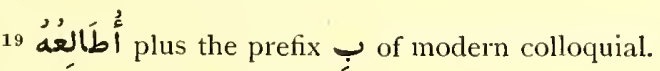

20 ginstead of أبن

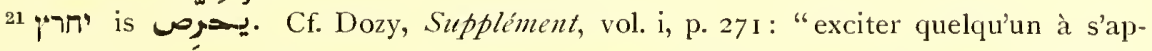
pliquer à."

22 The $ב$ has been changed to 7 . Although we know of no instance of the kind, we should $0, \sin ^{2}$,

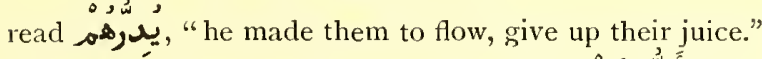

23 is the modern vernacular ês $h$, for

24 We know of no other instance of this precise meaning. Cf. note 17 .

25 The Arabic word is used in the Hebrew sense.

26 The Hebrew word is used in the Arabic sense.

27 They had the cash proceeds of the sale of their effects.

28 Tamim began to write on the recto of the paper, and was interrupted at this point. He then wrote verso $(a)$. 
Verso: (a)

ז אקול אנא תמים בר יוסף ذע

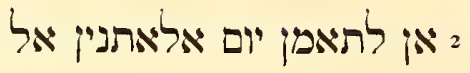

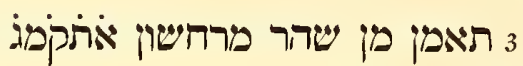
4

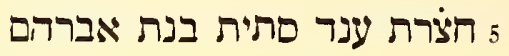
6 וסרור זוגהא בן מעאני ענות

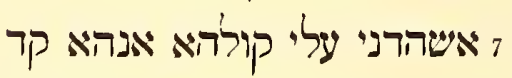
8 פَלית אלדאר לולאר אבَתהאי קולרא אנראי

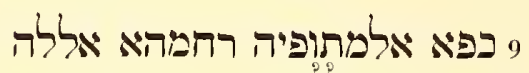

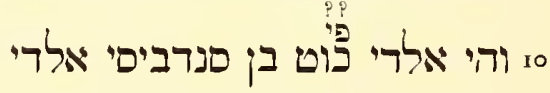

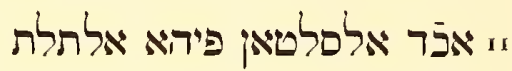

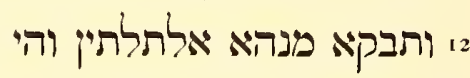

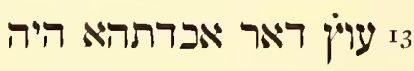

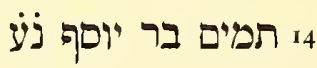

Verso: (b), upside down:

זיום אלה אלחארי עשר מן מרחשון קמג לשט

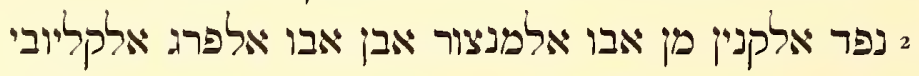

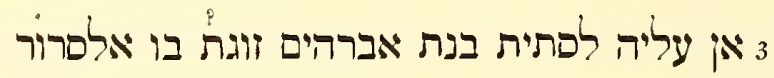

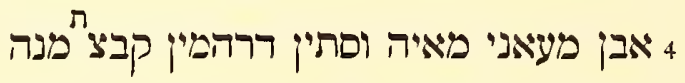

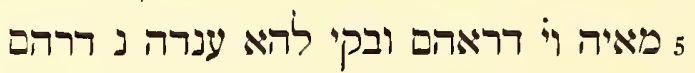
6 ואמפהלת עליה: אלי ; 7 ואנהם אבראו בעצהם עליה ואיות

${ }^{29}$ Beginning Oct. Ist, 3 I 2 B.C. This date does fall on a Monday, according to Schram, Kalendariographische und Chronologische Tafeln, Leipzig, 1908, p. 235, col. 7D, line 25. Our document was written in A.D. I23I.

${ }^{30}$ I.e. diminutive of the colloquial sitt, "lady," but we find only ${ }^{3}$ in the dictionaries.

31 Or "vacated"? The $\supset$ has a raphe to show that it stands for $\dot{\zeta}$.

$32 \mathrm{I}^{3}$ is the modern colloquial form of the plural.

${ }^{33}$ I.e. "my." 
Verso: $(a)$

I I, Tamim Bar Joseph, say

2 that on the eighth, Monday, the

3 eighth of the month Marheshwān, I 543,

4 [Era of] Documents ${ }^{29}$, in the city of Cairo,

5 I was present with Sutait ${ }^{30}$ Bint Abraham,

6 and Sarūr Ibn Ma‘ānī, her husband,

7 [who] called me to witness her statement. Behold it was:

8 "The estate was left" to the children ${ }^{32}$ of her ${ }^{33}$ sister" $^{31}$

$9 \mathrm{Kifā}^{-34}$, deceased ${ }^{13,35}$ _ God have mercy on her!

10 And it is [the estate] which........... Ibn Sandabīis $\bar{i}^{36}$, from which

I the Sultan took a third.

12 And there remain two-thirds of it; and it is

${ }_{3}$ the estate for which she took a substitute."

${ }_{4}$ [Signed:] Tamīm Bar Joseph.

\section{Verso: $(b)$}

I Thursday, the eleventh of Marheshwān, I 543, [Era] of Documents ${ }^{37}$,

2 the property ${ }^{38}$ passed from Abū al-Manșūr Ibn Abū al-Faraj al-Kalyūbīīis.

${ }_{3}$ He owes Sutait Bint Abraham, wife of $\mathrm{Bu}^{\mathbf{4 0}}$ al-Sarūr

${ }_{4} \mathrm{Ibn} \mathrm{Ma}^{6} \mathrm{a} n \overline{1}$, a hundred ${ }^{41}$ and sixty dirhams ${ }^{41}$. She received from him

5 a hundred and ten dirhams; and there remained, of what he owed her,

fifty dirhams.

6 And she granted him a respite of ten days from this date.

; And they declared each other free [of further obligation].

31 s "similar," to the parent.

35 This tells us why there was trouble in the first place. The wife of Manșur had died; and the wife's sister wished to prevent Manșūr from defrauding his children by selling the house for his own enrichment.

${ }^{36}$ I.e. from Sandabīs, a village in the Kalyūb district. Cf. Ibn Duḳmāk, op. cit., v, 49; Ibn Haukal (de Goeje), p. 93, and the other authors cited by de Goeje, ad loc.

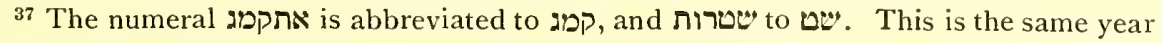
as verso $(a)$, and probably also as verso $(b)$.

38 قنْيان is "property" or "income."

${ }^{39}$ I.e. from Kalyūb, just north of Cairo.

40 The north African form of Abū. Cf. No. XIII, note 32.

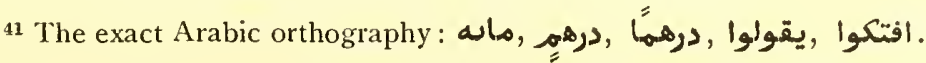


Verso: $(c)$

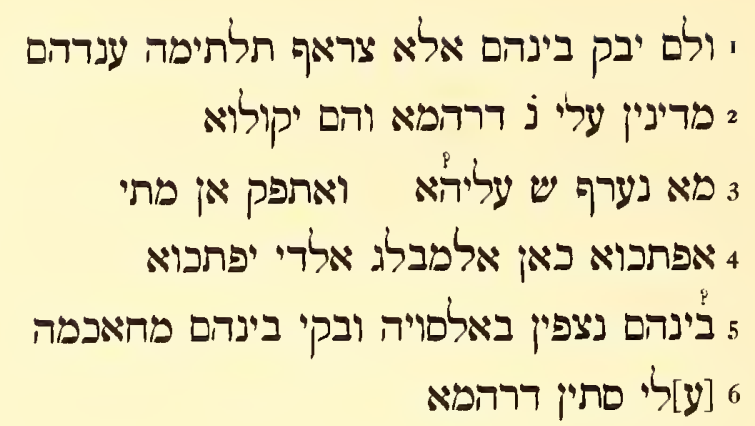

42 تَلْنَيَْمَ.

${ }^{43}$ I.e. Sutait and Sarūr agreed to regard the remaining fifty dirhams as a debt of honor, never to be mentioned again between them; and the two parties were reconciled, and settled their case out of court. The $\boldsymbol{w}$ is modern colloquial: $m a \bar{a} n a^{2} r a f s h$, from "We do not know." 
Verso: $(c)$

I And there remained between them nothing but to accomplish a reconciliation $^{42}$ among them,

2 making a debt of [the] 50 dirhams ${ }^{41}$, and saying

3 "We know nothing about them ${ }^{43}$." And he agreed that, when

4 they were paid ${ }^{41}$, the sum which would be paid

5 [would be, by tacit agreement] between them ${ }^{44}$, two equal parts. So there remained, [by tacit agreement] between them, a judiciable claim ${ }^{45}$ 6 amounting to sixty dirhams ${ }^{46}$.

44 بَيْنَه seems to mean idiomatically "by agreement"

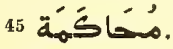

46 I.e. ten dirhams extra for the privilege of private settlement by reconciliation? 


\section{LETTER}

Paper $6 \frac{3}{4} \times 20 \frac{1}{2}$ inches, made up of two sheets pasted together.

This long strip is completely covered with writing. The top, margin and bottom, originally left for the sake of appearance, were afterwards filled with postscripts; just as the margins of Oriental printed books are filled out with other material, for good measure, "pressed down and running over." Unfortunately twenty-three lines have been mutilated by the removal of one corner.

The writing is in cursive Hebrew characters, quite legible on the whole.

The language is Arabic, without any admixture of Hebrew or Aramaic, at times elegant, but in general colloquial, with strange constructions and strange meanings of ordinary words.

Recto :

1 בישריז

2 כתאבי אליך יא אכי ואלעזיי עלי וענרי אטאל אללה בקאך ואראם

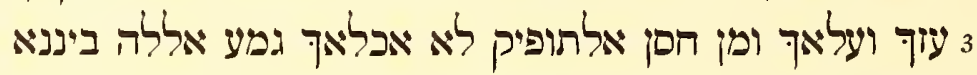

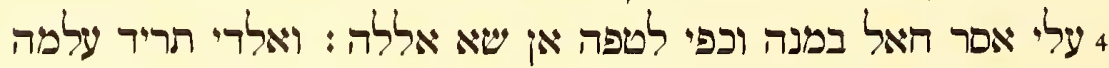

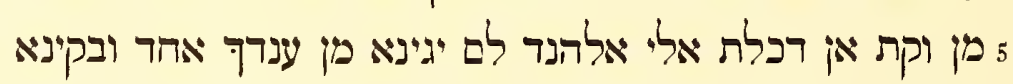

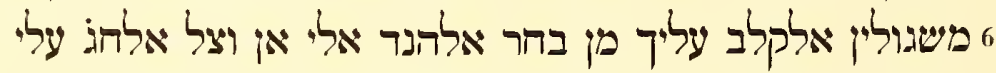
7 אלרי יקאל לה אב; אלקורירי פאשתמענא בה ו"אכברנא

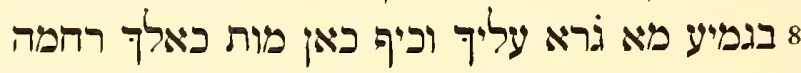

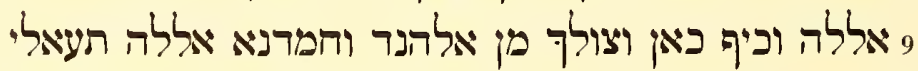

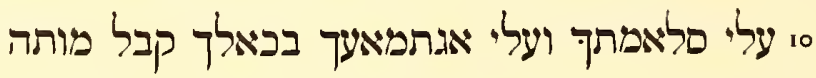

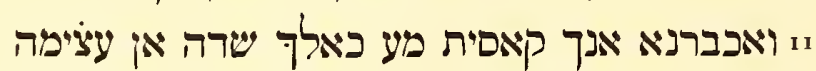

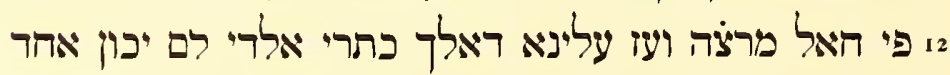

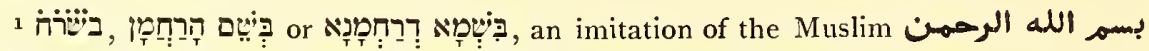
الرهيم and close to the original from which the latter was taken.

عَزِيز 2 means both "mighty" and "dear," according to the preposition used ; hence this clever play upon the word.

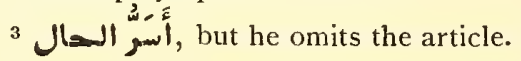

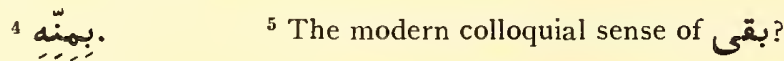

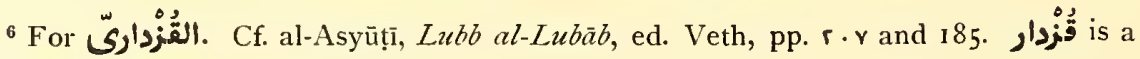
district of India. 


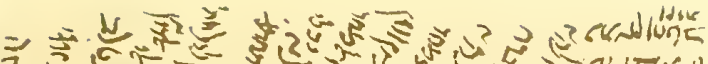

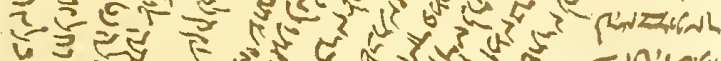
2
ये र्वे

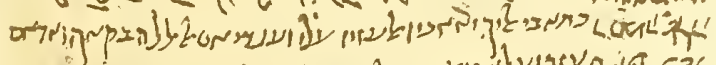

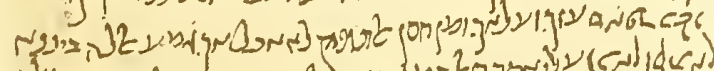
is

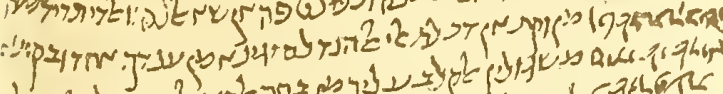

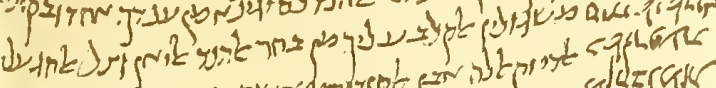

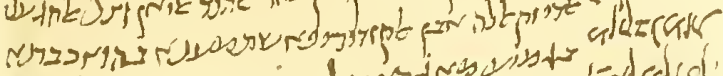

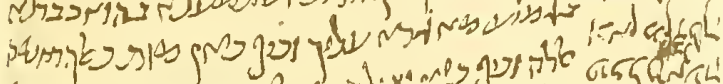

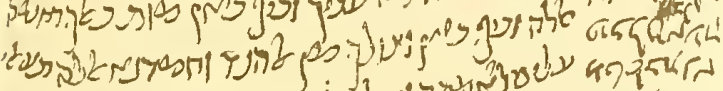

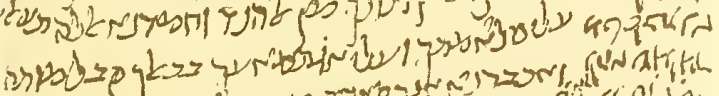

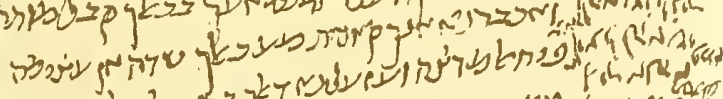
"ro

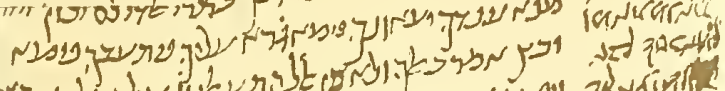

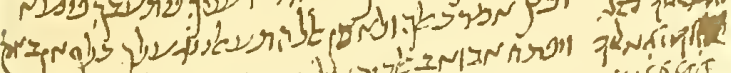
by restiver b) res a (2)

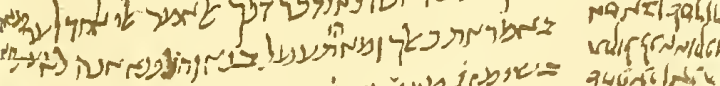

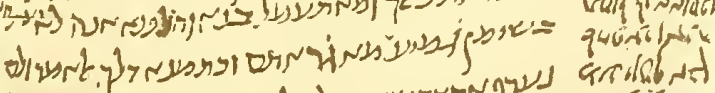

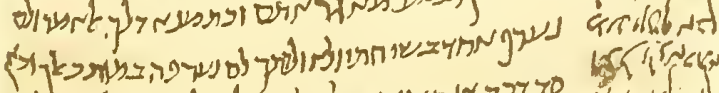
16 1. ט

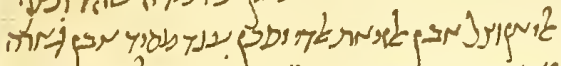
年

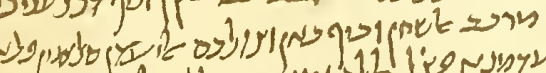

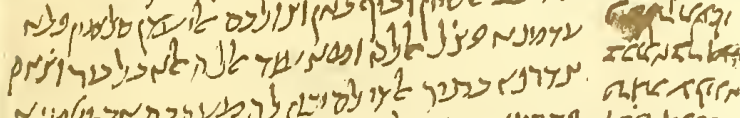

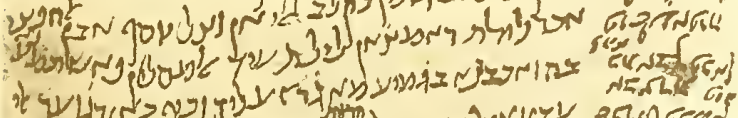

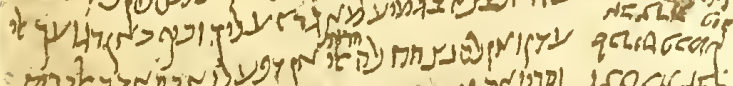

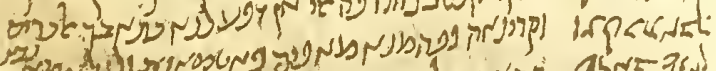

1. $\because \rightarrow 0$.

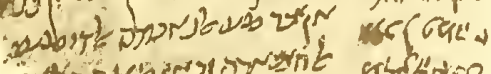

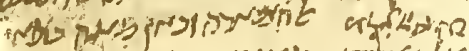

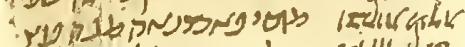

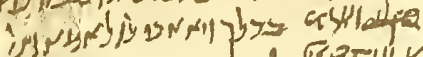

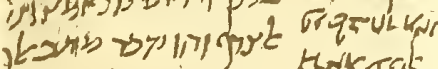

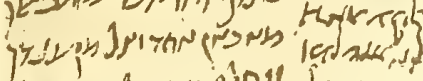

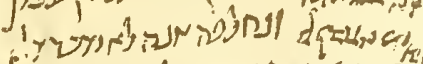
D) 710 व 2)

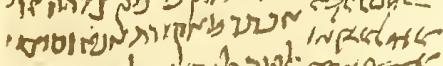

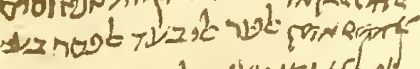

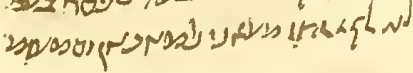




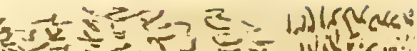
3 है:

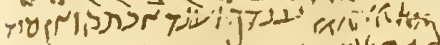

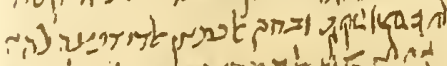

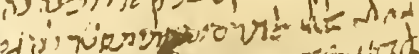
i N

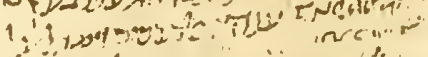

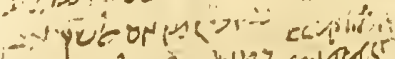

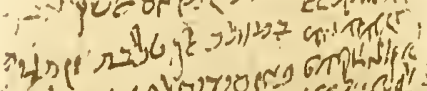

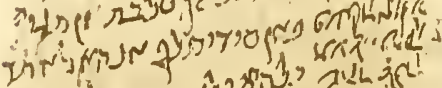
- de

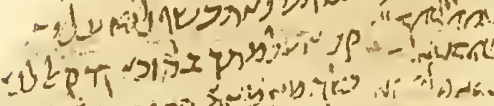
ن jo

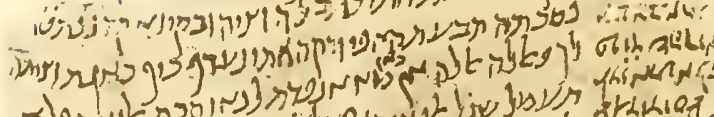

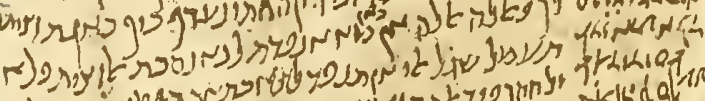
Af 75y ט

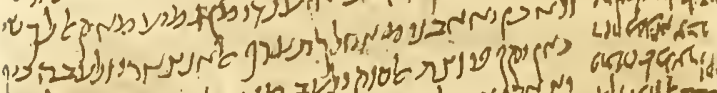

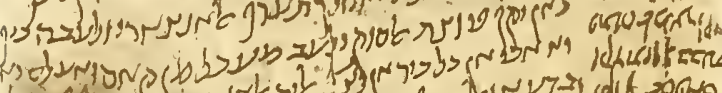

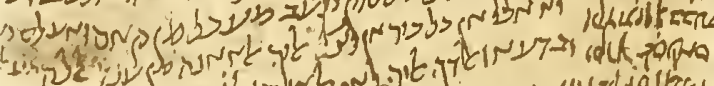

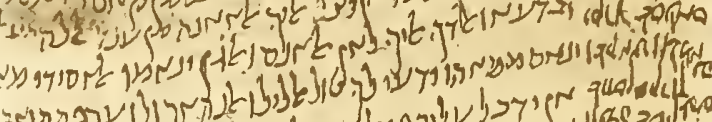
3rim $r 2$ (s)

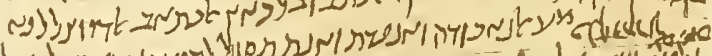

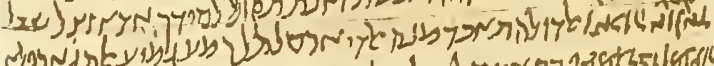
Nghndrey is 4 ys

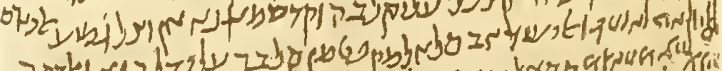

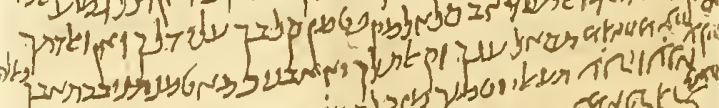

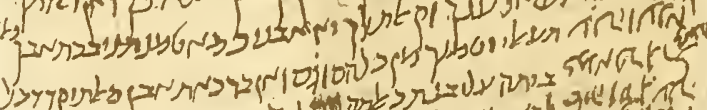
צ 年

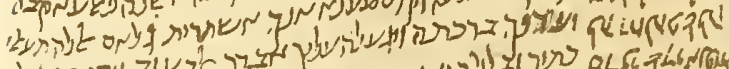

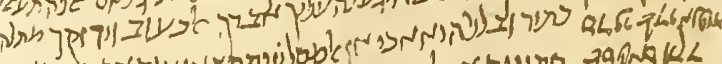

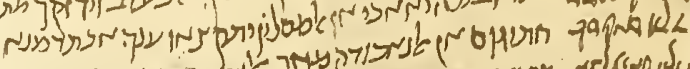

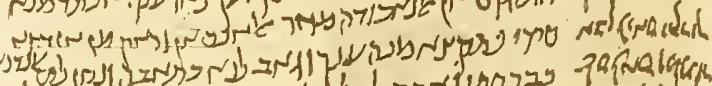

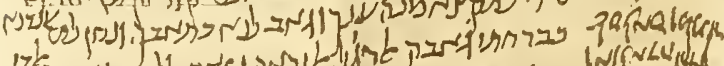

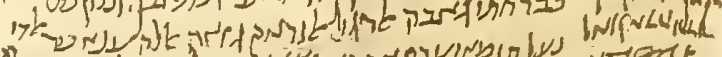

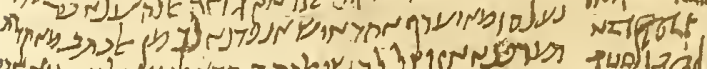

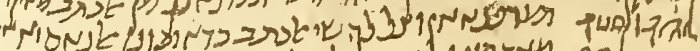

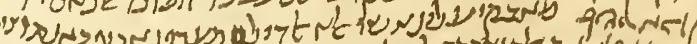

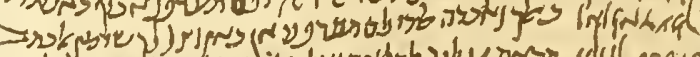

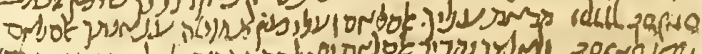

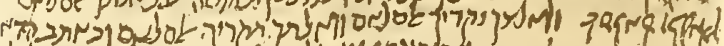

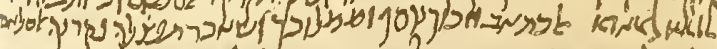

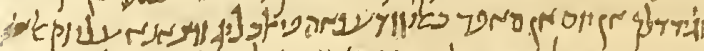

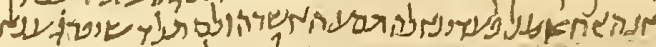

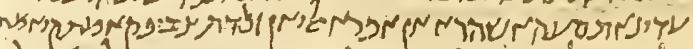

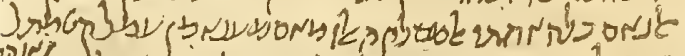

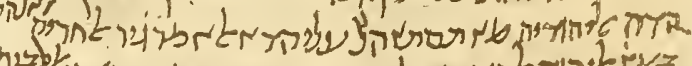

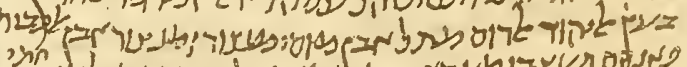

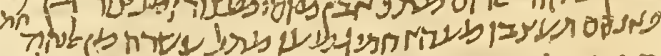

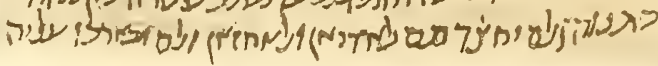




\section{LETTER}

It appears that a certain Joseph, who lives in Fustạt with many relatives, is writing to a brother(?), who lives in Aden, South Arabia, with a few other persons from the Fustatt community. The father of these two brothers is the patriarchal head of the family. The brother in Aden is a merchant, and has made two trips to India, particularly to Colombo in Ceylon, on one of which he was captured by pirates and ransomed by his relatives at home. A maternal uncle, who went from Fustât to India on business undertaken by the father, has died there; and there is great uncertainty about his will, especially because the wife of this uncle is a grasping creature and has also had an illegitimate child in his absence. A similar case is mentioned in the letter.

There is no address. The letter was to be intrusted to a friend for discreet delivery.

There is no date. But a certain hazzān Abū 'l-Bayyān, is mentioned in Mann, op. cit., vol. i, p. 242, vol. ii, p. 308, which is a letter considered by Mann to belong to about I I 50 .

\section{Recto :}

I In the name of the Compassionate ${ }^{1 !}$

2 My letter to you, O my Brother, mightier ${ }^{2}$ than I and dear ${ }^{2}$ to me. May God lengthen your life and prolong

3 your strength and your dignity, and not deprive you of the beauty of success! May God reunite us

4 under the most happy ${ }^{3}$ circumstances, in His grace ${ }^{4}$ and the abundance of His kindness : if it please God! And what you would like to know [is that]

5 from the time when you entered India no one came to us from you, and we became ${ }^{5}$

6 troubled in regard to you on account of the Indian Ocean until the Hājj 'Alī arrived,

7 who is called Ibn al-Kuzdīri ${ }^{6}$. And we enquired ${ }^{7}$ of him; and he informed us

8 of all that had befallen you, and the manner of your [maternal] uncle's death-God have mercy on him!-

9 and how you arrived [back] from India. And we praised God the Exalted Io for your safety, and your being able to reach your uncle before his death. is And he told us that you had endured great hardships ${ }^{8}$ with your uncle I2 while he was sick; and that was very ${ }^{9}$ difficult for us [to bear, namely ${ }^{10}$ : [that] no one of us

7 The VIII form of سهی usually means "listened to."

8 أن أن used as a relative with indefinite antecedent.

9 כor כתיר.

10 The vernacular use of $\mathfrak{G}$ ill as a conjunction. Cf. Spiro, Arabic-English Vocabulary,

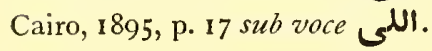


3ו מנא ענרך יעאונך פימא גרא עליף פי תעבך פימא

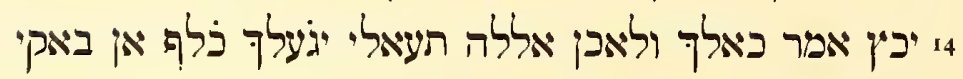

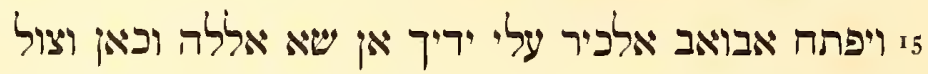

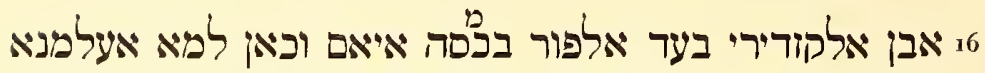

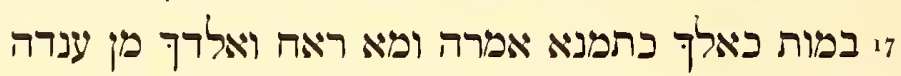

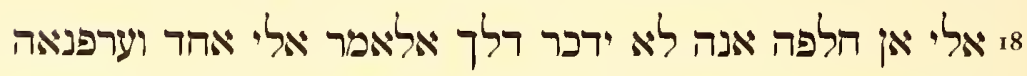

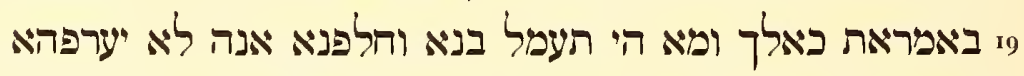

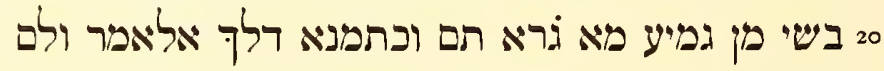

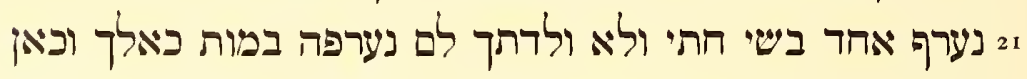

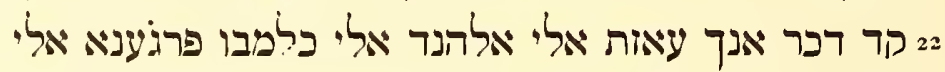

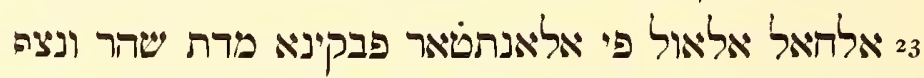

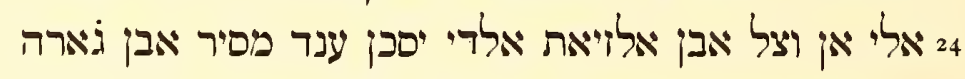

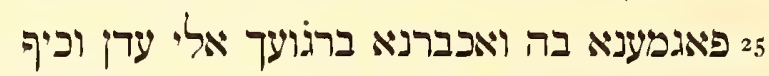

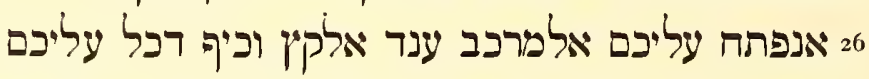

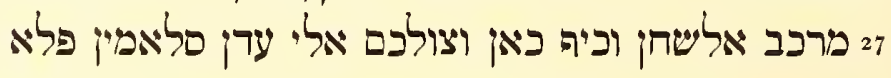

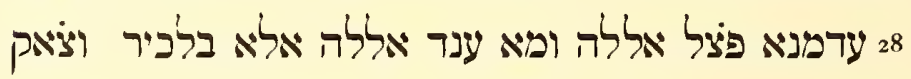
29

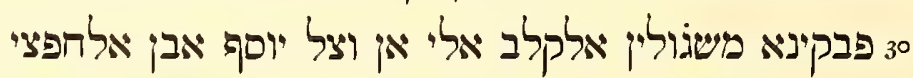

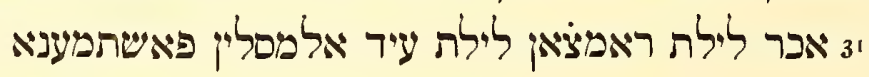

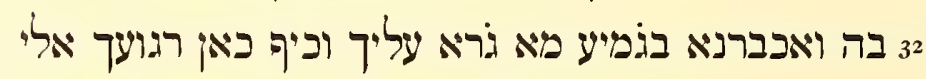

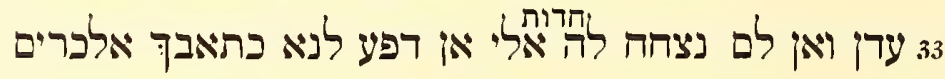

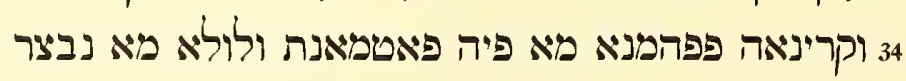

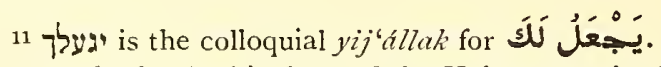

12 פור is the Arabic form of the Hebrew word. Cf. line 46 and al-Ḳalkāshandī, Subh al-A`shā, II, 427, where the printed edition has فوز however.

${ }^{13} \tau^{\prime}$ in the colloquial sense.

${ }^{11} \mathrm{Cf}$. the bottom of verso.

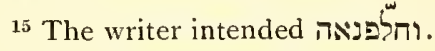

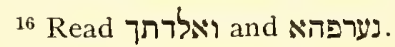

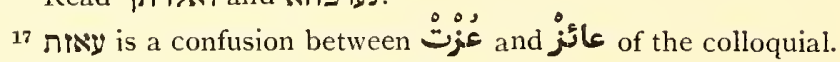

18 Perhaps for إِجَارَّة, "protection." 
13 was at your side to help you in what befell you when you were worn out with

I 4 the concerns of your uncle's case. But God the Exalted will make for you ${ }^{11}$ a lasting change ${ }^{8}$

15 and open the gates of fortune to your hands: if it please God!

I6 Now Ibn al-Ķuzdīin arrived five days after Pūrīm ${ }^{12}$. And, after he had told us

17 of the death of your uncle, we made a secret of his case. And your father did not leave ${ }^{\mathbf{1 3}}$ his presence

18 until he had made him swear that he would not mention this matter to anyone; and we informed him

19 about the wife ${ }^{\mathbf{1 4}}$ of your uncle, and what she was doing to us. And we made him swear ${ }^{15}$ that he would not tell her

20 anything of all that had happened. Then we made a secret of that matter. And

${ }_{21}$ we shall not tell anyone about anything: indeed not even your wife ${ }^{16}$ shall we inform of the death of your uncle.

22 And [al-Kuzdīin] had said that you wan ted ${ }^{17}$ [to go] to India, to Colombo; so, we returned to

23 [our] former state of suspense; and remained [so] for the space of a month and a half :

${ }_{24}$ until Ibn al-Zaiyāt arrived, wholives at the house of Musayyar Ibn Jārah ${ }^{18}$. ${ }_{25}$ Then we met together with him, and he told us of your return to Aden, and how

26 the ship was captured when [you were] attacked, and how there came to you

27 a cargo ship, and how you arrived at Aden, safe and sound. So we did not 28 lack the grace of God: and with God there is no [possibility of anything] but [affairs going] well. But we

29 were much distressed because ${ }^{10}$ there was no letter of yours with him, reassuring us ${ }^{19}$.

3o So, we remained anxious until Joseph Ibn al-Hafși arrived

${ }_{3}$ l late on the night of Ramadān, the night of the festival of the Muslims ${ }^{20}$. And we met together with

32 him. And he told us of all that had befallen you, and how you returned to

${ }_{33}$ Aden. But we did not believe [his] story ${ }^{21}$ until he had handed us your good letter.

${ }_{34}$ And we read ${ }^{22}$ it, and understood what was in it. So, I was at peace. But if we had not seen

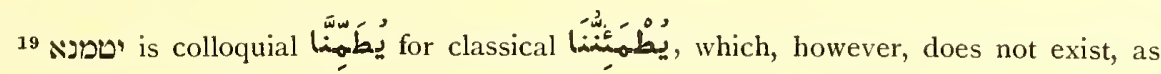
the classical verb is always intransitive and cannot take an object. Cf. the classical form and sense in lines 34, $35 \quad 20$ Read מסלמין.

21 חרות (which needs the article) is not classical, but probably equivalent to the modern colloquial haddüta, plural hawāait, "fairy story."

22 קרינה 2 is the colloquial form of 
35 כתאבך למא כאן יטמאן לנא קלב

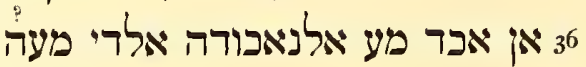

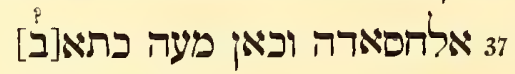
83 מוסי פאבדנאה מנה פוצ[ל] .

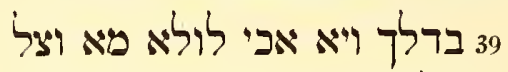

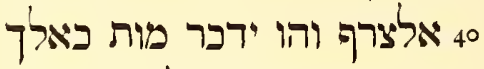

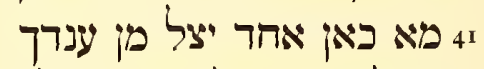
24 ונחלפה אנה לא ידבר דלד.

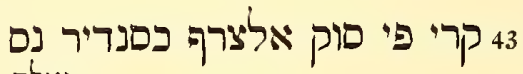

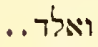

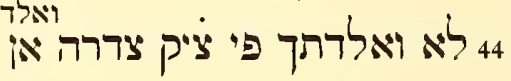
45 אכתר מא קדרת אנא וסידי.

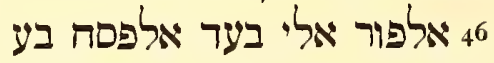

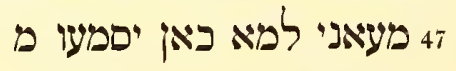

Verso:

ז ענרך וענד אכתה ואן סיד?:

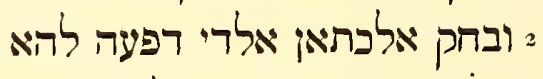

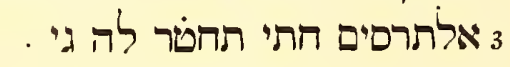

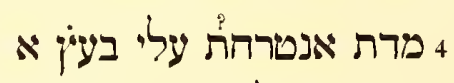

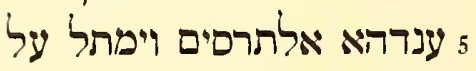

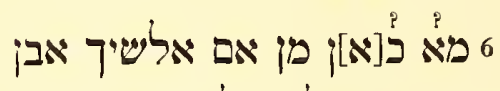
7

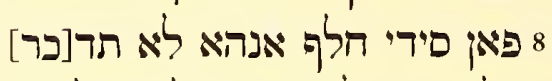

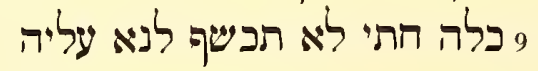

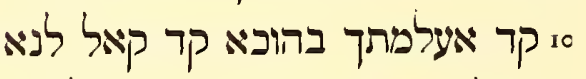

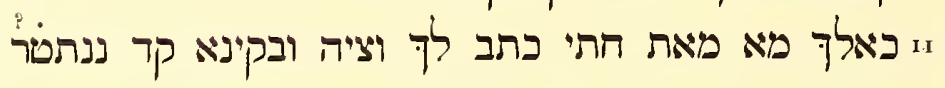

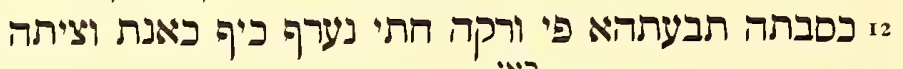

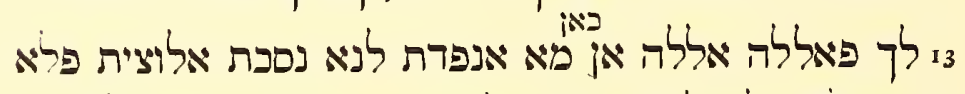

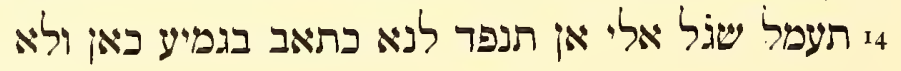

23 מע perhaps for té.

${ }^{21}$ Persian ناخوذة. Cf. Dozy, Supplément, p. 648.

${ }^{25} \aleph$ erased and $\square$ written. 
35 your letter, why should [our] heart have been tranquil ?........

$3^{6}$ that he took along ${ }^{23}$ the ship's captain ${ }^{24}$ who [had been] with him......... 37 envy $^{25}$. And he had the letter......

${ }_{3} 8$ Moses. So we received it from him, and there arrived........

39 about that. And, $\mathrm{O}$ my brother, if he had not arrived......... [Market of]

${ }_{4} \circ$ Exchange ${ }^{26}$. And it mentions the death of your uncle........

${ }_{41}$ no one arrived from [the place] where you [were]

$4^{2}$ and we made him swear not to mention that [matter].....

43 was read ${ }^{27}$ in the Market of Exchange ${ }^{28} \ldots \ldots \ldots . .$.

44 not [your mother] ${ }^{29}$ in his anxiety, that your mother......

45 as much as I was able and my master ${ }^{30} \ldots \ldots \ldots . .$.

${ }_{4}^{6}$ Pūrìm ${ }^{12}$ until after the Passover...........

47 affairs ${ }^{31}$ after they had heard......

Verso:

I with you and his sister; and that my Master.........

2 and about the linen which he delivered to her...........

3 the specification ${ }^{32}$ until...... she forbade him........

4 while it was being relegated to some one of.........

5 with her the specification ${ }^{32}$; and he described.........

6 what was the matter with the mother of the Sheikh Ibn........

7 about the death of your uncle, she tried to come.....

8 And the Master ${ }^{30}$ swore that she would not mention.

9 all of it, so that she should not enlighten us about it.....

ro she had informed you of.........(?) He said to us................

I your uncle did not die until he had written for you a testament. And we continued to await [a statement of]

r2 his estate ${ }^{33}$, sent by you, on paper, so that we might know how the will stood in relation

${ }_{3}$ to you. But Allah! Allah! If you do not have executed for us a copy of the will, then do not

$I_{4}$ do any business until you have executed for us a document with everything there is ${ }^{34}$. And do not

\footnotetext{
${ }^{26}$ Supplied from line 43.

${ }_{28}^{28}$ For this Sük al-Ṣarf see Ibn Duḳmāk, op. cit., v, p. 38 et alibi; and Casanova, Essai de Reconstruction Topographique de la Ville d'al-Foustât ou Misr, tome I, in Mémours par les nembres de l'Institut Français du Caire, vol. xxxv, Index.

29 is has been deleted.

${ }^{30} \mathrm{He}$ is the one referred to as "סיר "the master" in lines 8, I6, and elsewhere.

31 Cf. No. IV, line 4.

32 "description"? "placing under guard"? "stamping"?

33 This is a strange meaning for 34 .
} 
6.5 ילחקך פי ראלך תואניא פהרא אכבר וציתנא ענדך

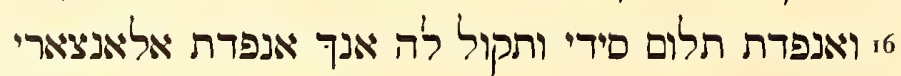

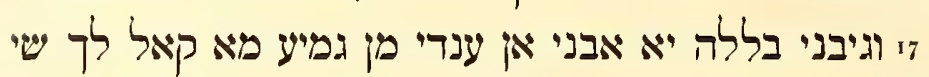

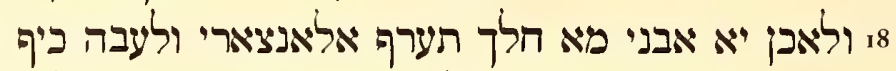

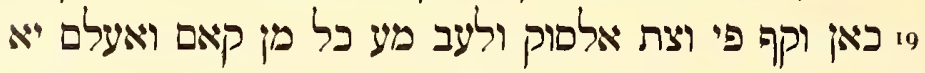

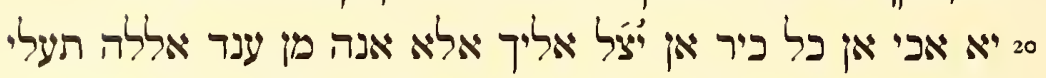

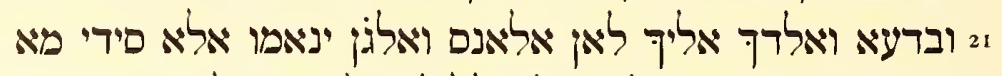

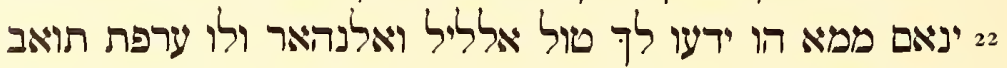

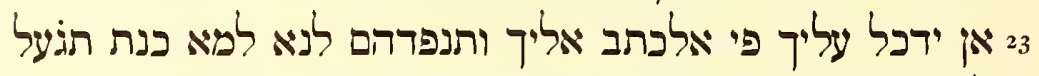

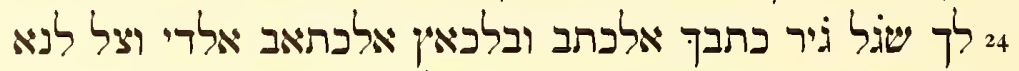

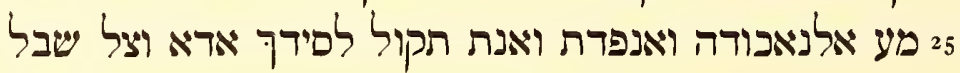

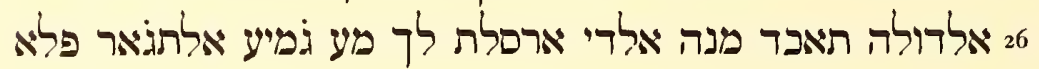

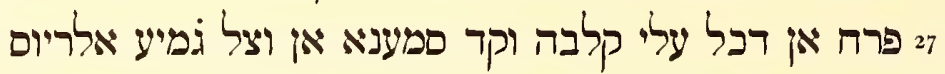

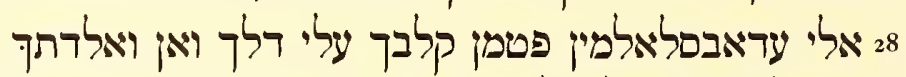

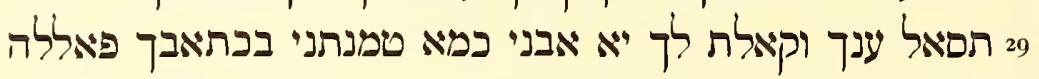

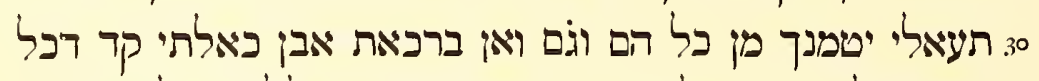

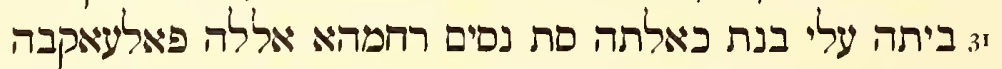

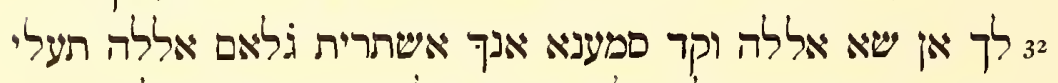

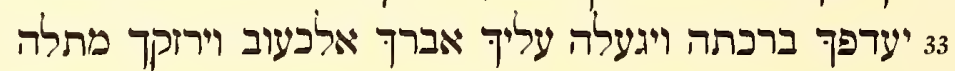

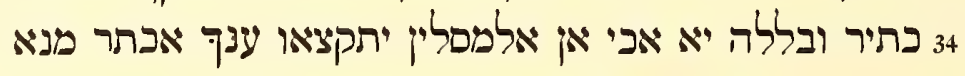

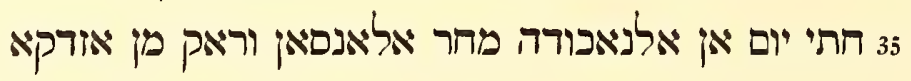

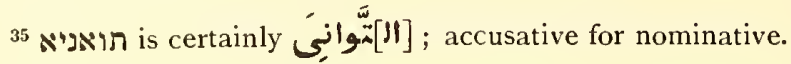

36 is is both "testament" and "command"; hence the play upon the word.

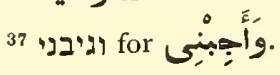

${ }^{38}$ I.e. either he "made fools of," or "trifled with," or "gambled with."

${ }^{39}$ He intended to write

תואו 40 is apparently

${ }^{41}$ Cf. al-Dhāhabī, Mìzzàn al-I'tidāl (Cairo, I 325), i, 440.

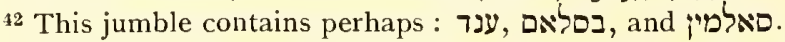

${ }^{43}$ Humorous? Although the text says "bought a slave," the context refers to a son.

44 The same correction of the text as in recto, 1. $3 \mathrm{I}$. But here we have a reference to pirates, and the ransoming of captive Jews. Cf. Mann, op. cit., vol. i, pp. 87 ff. Muslims captured Christians and Jews, and Christians captured Muslims (and Jews?). The price of ransom was $33_{3}^{1}$ dinnārs, the dinnār being worth about $\$ 2.50$ in gold, with a purchasing power of about $\$ 7.50$ at that time. 
${ }_{15}$ let carelessness ${ }^{35}$ overtake you in that [matter]; for this is our supreme "will" 36 in regard to you.

16 And you sent [a letter] complaining [to] the Master ${ }^{30}$ and saying to him that you had sent to al-Anșārī.

if But answer $\mathrm{me}^{37}$, by Allah, my Son: Have I anything of all [the property] he told you of?

I8 But, my Son, aren’t you free to recognize al-Anșārī and his little game: how

ig he stood in the market-place and played ${ }^{38}$ with anyone who happened to be standing there? And know,

2o $\mathrm{O}$ my Brother, no good-fortune is sent ${ }^{39}$ to you except that it comes from God the Exalted.

21 And about your father's ${ }^{30}$ calling out to you-for men and demons may sleep, but the Master ${ }^{30}$ does not

22 sleep, because he keeps calling to you, all night and all day long. And if you only knew shame ${ }^{40}$ :

23 that it might enter into you through the letters to you! And you send [letters] to us about having

$2_{4}$ other business to do than writing letters : and especially the letter which reached us

25 with the ship's captain. And you sent word, and you said to your Master ${ }^{30}$ : "When Shbl al-Daulah"1

26 arrives get from him what I have sent to you as well as to the other merchants." And he did not

${ }_{27}$ rejoice. It made a deep impression on him. And we heard that all the dignitaries arrived

28 at............. ${ }^{42}$ But calm yourself ${ }^{19}$. Your mother

29 asked after you and said to you : "O my Son, just as you have relieved ${ }^{19}$ me with your letter, so may God

30 the Exalted relieve ${ }^{19}$ you from every care." And also Barakāt the son of my [maternal] aunt, has taken possession of

${ }_{31}$ his house with the daughter of his [maternal] aunt, Sitt Nissim-God have mercy upon her:-[as bride]. But you have

$3^{2}$ offspring-if it please God. We have heard that you have bought ${ }^{43} \mathrm{a}$ boy. May God the Exalted

33 teach you what a blessing he is, and make him the most blessed of honors, and grant you many more

34 like him! And, by Allah, my Brother, the Muslims ${ }^{44}$ exacted $^{45}$ for you[r ransom still] more from us;

35 until one day ${ }^{46}$ the ship's captain set free ${ }^{47}$ a rich man, [one] of the friends ${ }^{48}$

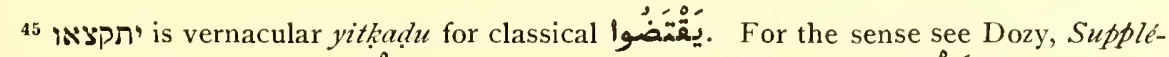
ment, p. 362. With this verb نs denotes the payer of the ransom, and $\dot{\mathcal{L}}$ the ransomed person. $\quad 46$ יום C. Cf. note 8.

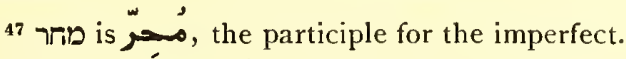

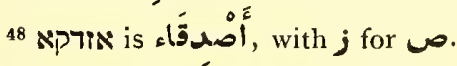


36 םירי פתקצא מנה ענך וגאב לנא כתאבך ונחן לים ענרנא

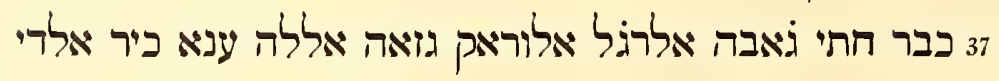

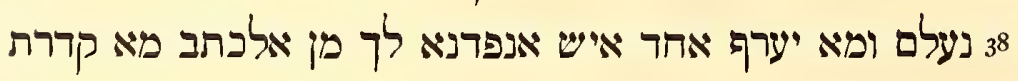

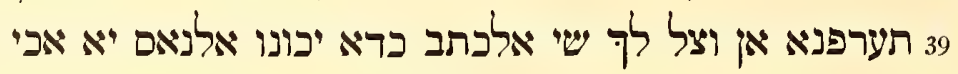

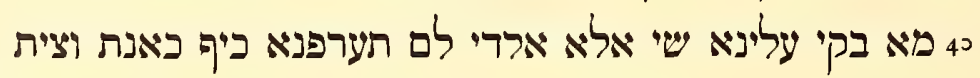

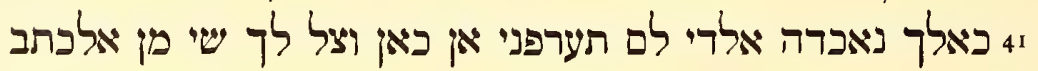

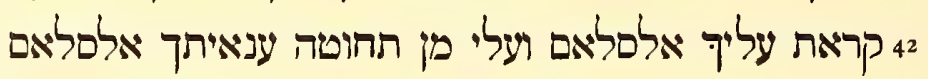

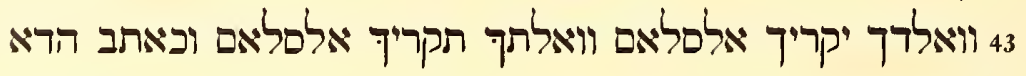

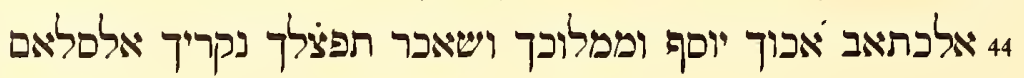

\section{Margin of verso:}

וכואתך יקרוך | אלםלאם וכלאתך | יקרוך אלםלאם | ואולאר עמך |אלשיך

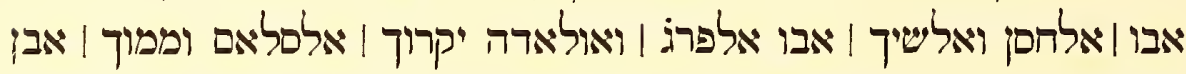

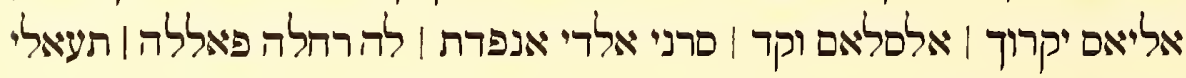

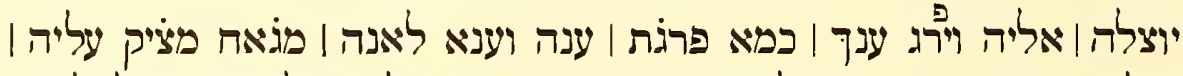

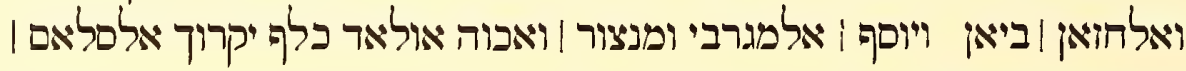

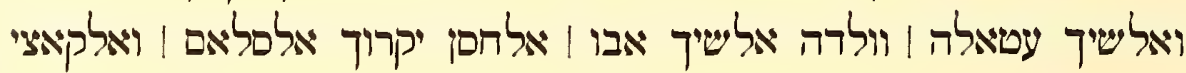

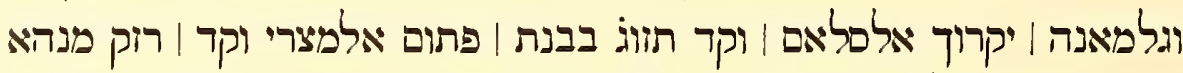

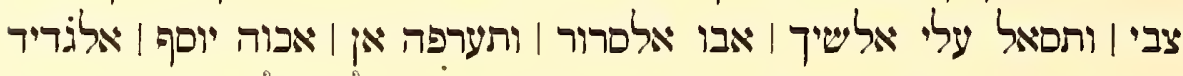

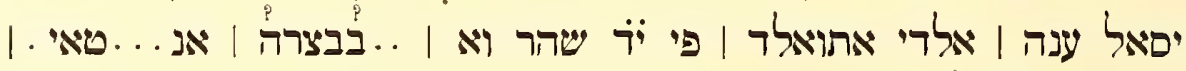

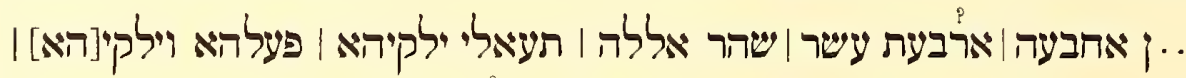

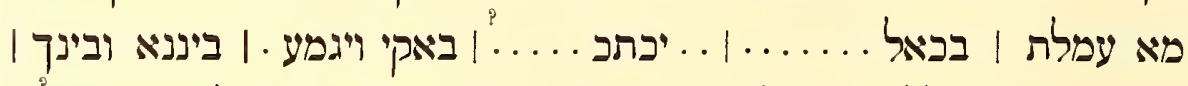

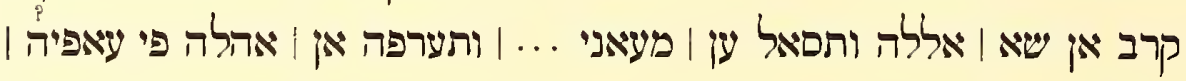

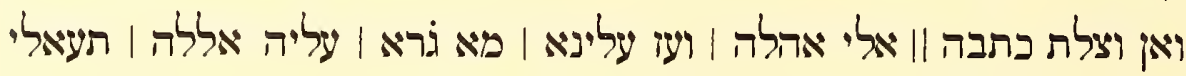

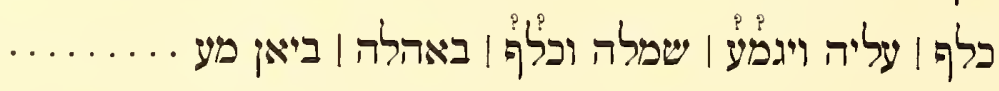

\footnotetext{
${ }^{49}$ I.e. the ship's captain.

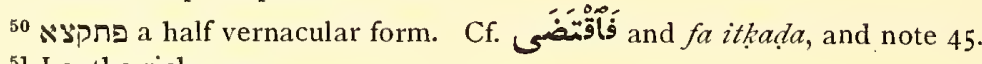

${ }^{51}$ I.e. the rich man.

52 The recipient of the letter is actually or supposedly in captivity somewhere. Cf. lines 24-36.

${ }^{53}$ The forms $\bar{e} s h$ and wasalláksh are vernacular.
} 
$3^{6}$ of the Master ${ }^{30}$, and he ${ }^{49}$ demanded ${ }^{50}$ from him ${ }^{51}$ [an additional ransom] for you ${ }^{52}$. And he ${ }^{51}$ brought your letter to us. And we did not have any

37 news until the rich man brought it-May God requite him with good from us, [now] that ${ }^{10}$ we

38 know. And no one knows what ${ }^{53}$ we sent you in [the way of] letters. As far as you are able,

39 inform us whether the letters reached you ${ }^{53}$. [Well!] That is how people are, my Brother ${ }^{54}$ !

40 Nothing remains for us [to say] except that ${ }^{10}$ you did not inform us how it was [with] the testament

${ }^{+}$of your uncle. We object to your ${ }^{10}$ not informing me as to whether any of the letters reached you.

$4^{2}$ I send you greeting, and to [all] whom your grace and favor protect, [I send] greeting.

43 And your father sends you greeting; and your mother sends you greeting; and the writer of this

${ }_{44}$ letter, your brother and slave, Joseph, who is grateful for your favor : we send you greeting!

Margin of verso:

And your sisters send you greeting; and your [maternal] aunts send you greeting; and the sons of your [paternal] uncle, the Sheikh Abu al-Hasan and the Sheikh Abū al-Faraj, and his children, send you greeting ; and your father-in-law ${ }^{55}$ Ibn Elias, sends you greeting. I am glad that you wrote to him [while on his] journey. And God the Exalted will cause [your letter] to reach him; and it will comfort you just as you comforted him and us. For he is ruined, he is in straits ${ }^{56}$. And the Hazzān Bayyān, and Joseph al-Maghribī, and Manșūr, and his brother, the children of Khalaf, send you greeting. And the Sheikh 'Ațāllāh ${ }^{57}$ and his son ${ }^{16}$, the Sheikh Abū al-Hasan, send you greeting. And the Kadi and his [male] slaves send you greeting. He has married the daughter of Futūh the Egyptian; and has been blessed [with] a boy from her. And you make inquiry in behalf of the Sheikh Abū al-Sarūr: [Please] inform him that his brother, Joseph al-Jadid, asks after [the child] which was born ${ }^{58}$ on the $14^{\text {th }}$ of the month... ...... fourteenth of the month. May God the Exalted requite her [with] her deed, and requite her [with] what she wrought !......write......remainder... ... and bring us together soon, if it please God. And you ask after the affairs of...... [Please] inform him that his family are in health, and that his letters have reached his family. But we were grieved by what happened to hin. May God the Exalted make up to him [what he lost], and set his affairs in order, and make up to him by his family [what he lost]........

\footnotetext{
54 Exactly the German expression of resignation : "So sind die Menschen!"

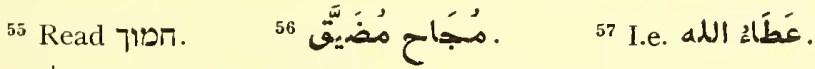

58 אתומאלד is the colloquial form itwalad, of the VIII stem. Cf. note 50.
} 
Bottom of verso:

ו וגיר דלך אן יום אן סאפר כאלי וורענאה פי אלכליג ותאגא עלי וקאל...

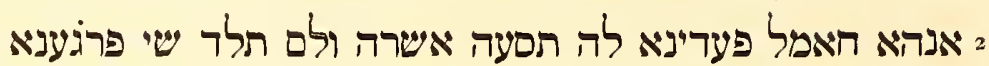

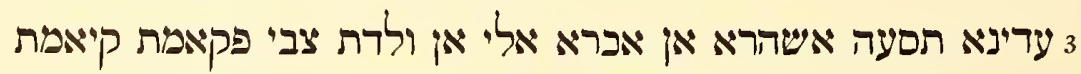

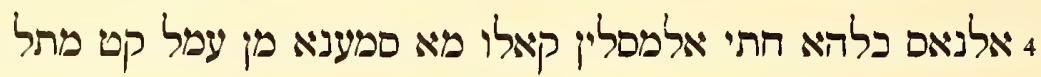

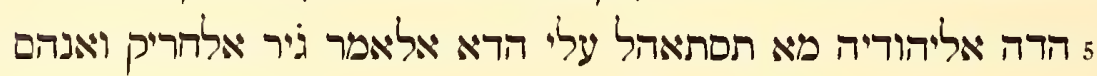

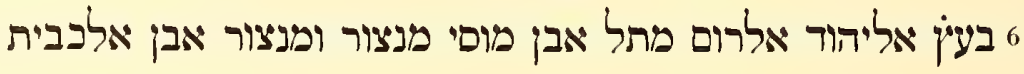

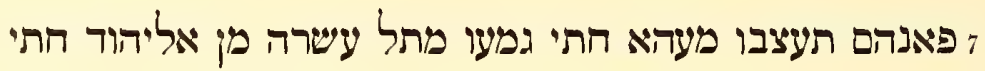

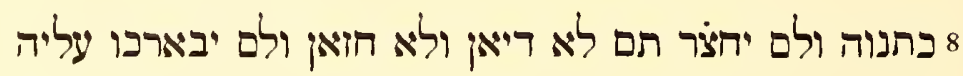

\section{Margin of recto:}

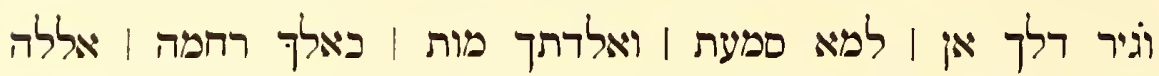

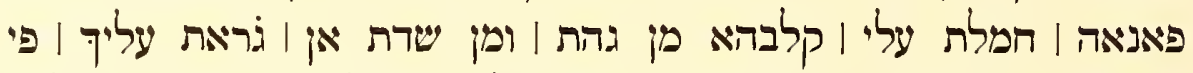

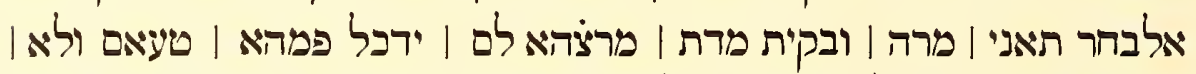

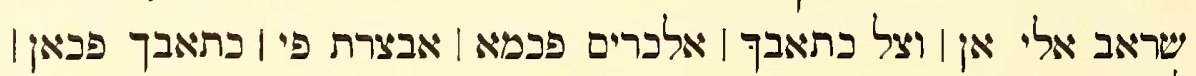

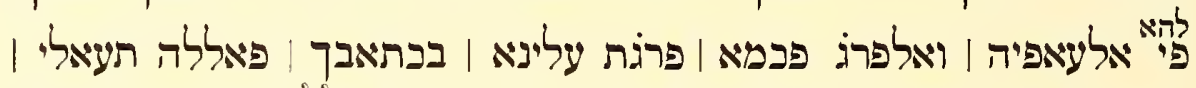

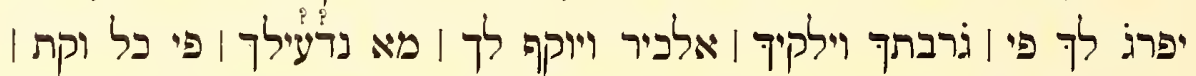

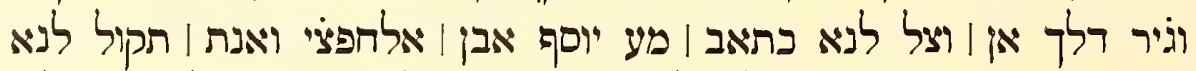

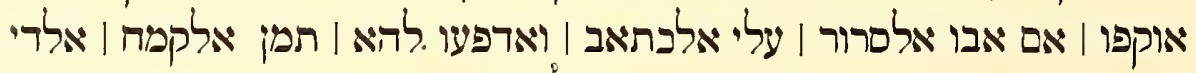

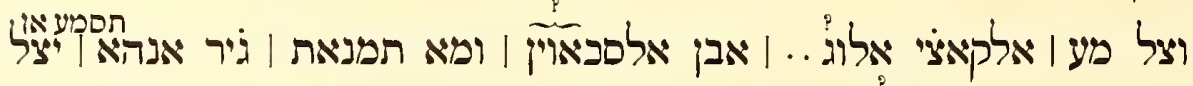

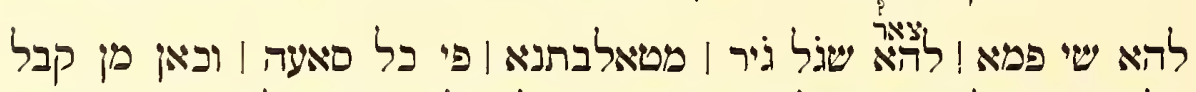

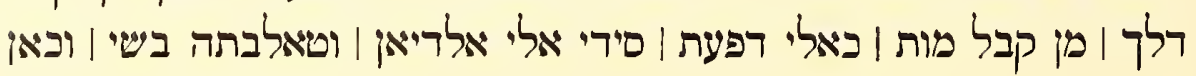

\footnotetext{
59 Read אישה

60 לם תלדשי 6 , lam tulidshe, with the negative -she of modern vernacular.

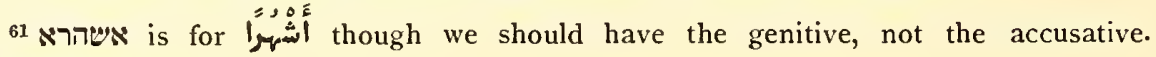
Cf. note 8.

${ }^{62}$ Read מסלמין.

${ }^{63}$ I.e. "corrupt." This must be an epithet, not an acceptable name.

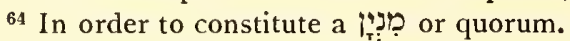

${ }^{65}$ Is this the child referred to above as born "on the I4th of the month"?

${ }_{66}^{6}$ Read פהנהא.

68 שית אים. Cf. note 8.

${ }_{69}$ The words ואואן לם have been written and deleted.
} 
Bottom of verso:

I And another matter: On the day ${ }^{46}$ when my [maternal] uncle went on a journey and we took leave of him at the canal, he took me aside and said :

${ }_{2}$ "She is with child." And we let nine months ${ }^{59}$ go by for it [to happen]; but she did not bear ${ }^{60}$. And again

3 we let another nine months ${ }^{61}$ go by, until she bore a boy. And there was an uprising of

4 all the people, until [even] the Muslims ${ }^{62}$ said: "We never in our lives heard of a deed like [the deed of]

5 this Jewess! She deserves for this thing nothing less than burning!" And 6 some of the Jews--Byzantine Jews, such as Manșūr Ibn Moses, and Manșūr Ibn al-Khabīth ${ }^{63}$

7 defended her cause, until they had collected something like ten of the Jews ${ }^{64}$, in order to

8 circumcise [the child]. But neither dayyān nor hazzān was present. And they did not [therefore] say the [necessary] blessings over him ${ }^{65}$.

\section{Margin of recto:}

And another matter: After your mother had heard [of] the death of your [maternal] uncle-God have mercy on him!-she ${ }^{66}$ was heavy-hearted because of you ${ }^{67}$ and some hardship ${ }^{68}$ which you might have encountered at sea the second time ${ }^{69}$. And while she was sick [from this worry] neither food nor drink entered her mouth, until your good letter reached her. And just as she looked at it-your letter-and felt well and happy [again], and just as you relieved us by your letter ${ }^{70}$ : so may God the Exalted relieve you in your trial ${ }^{71}$, and make good-fortune meet you and stay with you. [That is] what we pray for you always.

And another matter: Joseph Ibn al-Hafși brought us a letter [from you $^{72}$;] "Keep the mother of Abū al-Sarūr from writing; and pay her the price of the grain which arrived with the Kadi...... Ibn al-S...., and what she expects, without her hearing that anything has come to her." She has come to have no other occupation than begging of us continually. And before that-before the death of my [maternal] uncle-she brought the Master ${ }^{30}$ before the dayyān ${ }^{73}$ and made a demand upon him. And at the time my [maternal] uncle went on the journey ${ }^{74}$ - God have mercy on him $^{75}$ - he recommended to the Master $^{30}$ that he buy for her a dinār's

70 The word ועלי has been written and deleted.

71 תגרבתך.

72 This person's letter and visit are spoken of in lines 30-35. A Joseph Ibn Șadōk, grandson of Ibn Hafș, of the house of Hafș, is mentioned in a genealogy in Mann, op. cit., ii, 318 , 1. I 5 .

73 Apparently $\boldsymbol{\varepsilon}$ 's means "to summon to court."

74 Mentioned at the bottom of the verso.

${ }^{75} \mathrm{He}$ did not return from this journey, but died. 


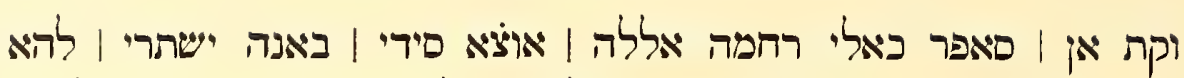

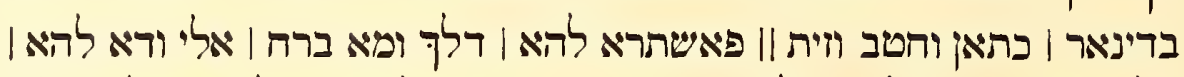

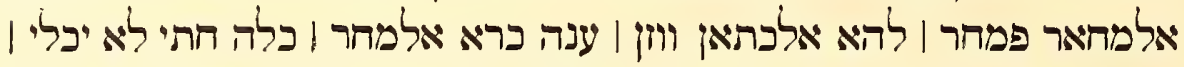

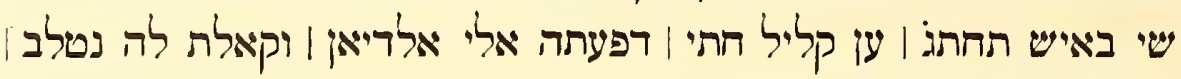

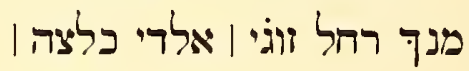

76 Cf. note 44.

${ }_{77}$ Colloquial ila wa-. $\quad{ }^{\mathbf{7 8}}$ Colloquial $d a$.

${ }^{79}$ This root occurs three times here (and perhaps in verso, 1. 35), and is plainly written

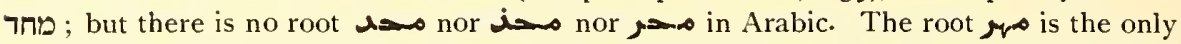
one that will give sense. The 7 presents no difficulty; but the $\pi$ can be accounted for only by the assumption of an actual dialectical difference.

\section{A LEAF FROM A PRAYER-BOOK}

Paper $8 \frac{1}{2} \times 6$ inches.

Hebrew in half-square Hebrew characters, partly vocalized, and not always correctly so.

The many abbreviations and omissions, in the manner of No. XLII, suggest that this may be merely a memorandum of prayers. 
worth ${ }^{76}$ of linen, and fuel-wood and olive oil. And he bought her that. And he continued [to give her things] until ${ }^{77}$ he gave ${ }^{78}$ her the dowry ${ }^{79}$. And he gave her the linen for a dowry; and he paid ${ }^{80}$ from [the sale of] it the $\cos ^{81}$ of the dowry ${ }^{82}$, all of it ; so that nothing remained that she could have [even] the slightest need of. And then she brought him before the dayyăn; and she said to him: "We want from him [the profits of] my husband's journey, which he completed."

80 Dozy, Supplément.

81.5 is usually "rent." $\quad 82$ She married again.

X. A LEAF FROM A PRAYER-BOOK

Like No. XLVI, this fragment has to do with the prayers for the Day of Atonement.

Recto begins with the words :

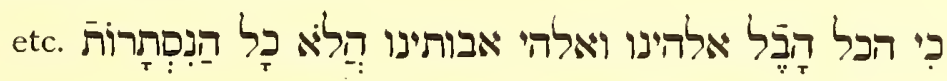

Verso begins with the words:

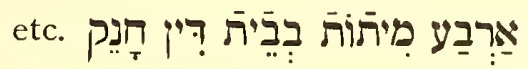




\section{BILL OF DIVORCE}

Paper $7 \frac{3}{8} \times 5 \frac{1}{2}$ inches.

In half-square Hebrew characters, but in the Aramaic language, so often used in Jewish documents.

There are some places where the writing has been effaced or the paper destroyed; but the complete text can be recovered from the context.

Recto:

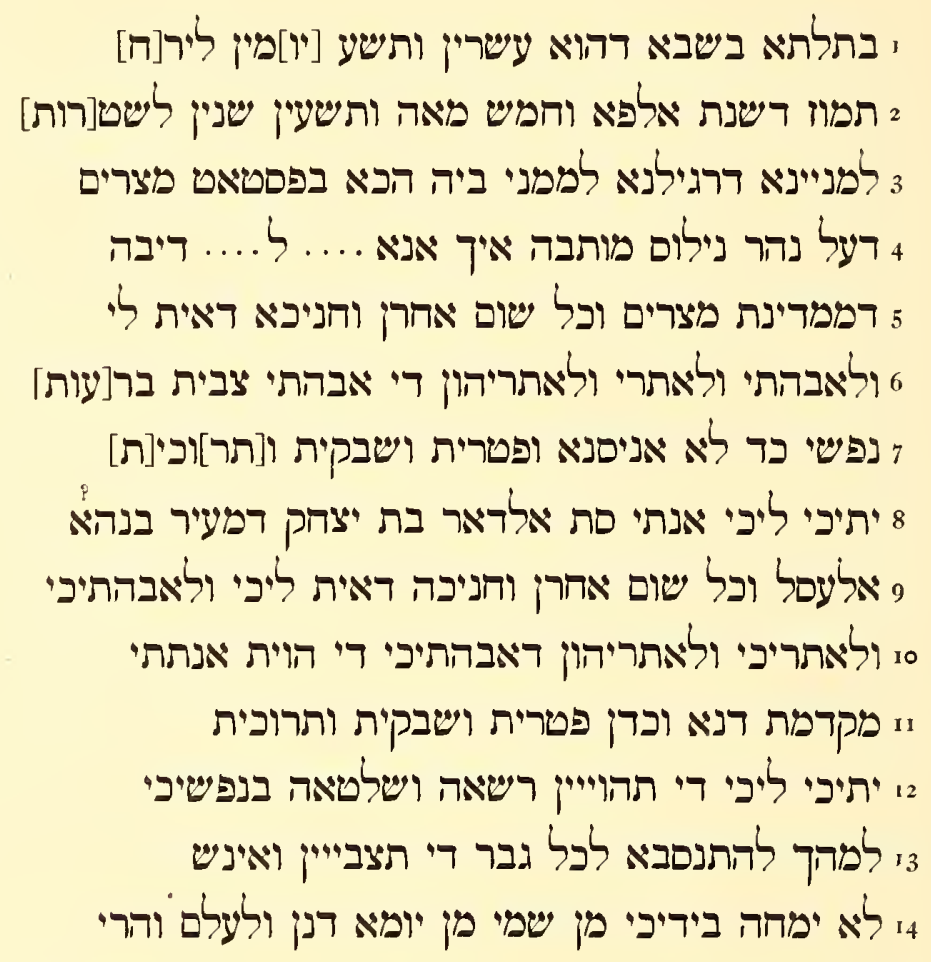

1 Such bills of divorce could be drawn up in other languages than Aramaic, though this seems to have been the prevailing language since 500 B.C. A number of such bills have been found in the Genizah. See e.g. Moise Schwab in Revue des Études Juives, vol. lvi, p. I28; and especially the excellent treatise of Ludwig Blau, Die Jïdische Ehescheidung und der Jüdische Scheiderbrief, Budapest, Igr I (two facsimiles are given there from the Elkan Adler collection). See another facsimile in the Jezwish Encyclopedia, vol. iv, p. 624. Though the general expressions were fixed from of old, extra words could be added in order to give greater importance to that which was being said. The present bill is as long as any that we have seen of this early period.

${ }^{2}$ A.D. I278. ${ }^{3}$ We take = Fusțāt.

${ }^{4}$ In none of the bills of divorce that we have seen is the precaution in regard to the name taken to this length. The usual expression is simply : ובל שום דאית לי לי

5 Notice the redundancy of the expression יתיבי ליבי which, however, is found elsewhere. Cf. Blau, loc. cit., part ii, p. 99.

6 ס אלד אר 6 would mean "lady of the house." See Steinschneider, Jewish Quarterly Review, vol. xi, p. 330. 


\section{BILL OF DIVORCE ${ }^{1}$}

A bill of divorce given to Sitt al-Dār, daughter of Isaac, of the village of Benha al-'Asal, by her husband-whose name may have been Shilyāin the city of Fustāt.

It is dated 1590 of the Era of Documents, i.e. A.D. I 278.

On the verso the witnesses have testified to having handed the bill of divorce to the woman in question.

Recto :

I On the third day of the week, [Tuesday], which is the twenty-ninth day of the month

z Tammūz, of the year one thousand five hundred and ninety of [the

Era of] Documents ${ }^{2}$,

3 according to the method of dating by which we are accustomed to count

here in Fustăt of Egypt,

+ which is situate upon the river Nile, I . ..... ${ }^{11}$

5 of the city of Fusta $t^{3}$ - and any other name or surname that I may possess, 6 my father may possess, my place of dwelling or the places of dwelling of

my fathers may possess ${ }^{4}$ - I desire,

7 in perfect free-will, and without being compelled: to free thee, to let thee go, and to cause thee ${ }^{5}$ to depart-

8 thee my wife, Sitt al-Dār ${ }^{6}$, daughter of Isaac, of the city of Benha 9 al-'Asal-or any other name or surname that thou mayest possess, that thy fathers may possess,

to or thy place of dwelling, or the places of dwelling of thy fathers ${ }^{8}$ [may

give thee], thou who wert my wife

I prior to this. In such manner I release thee, I send thee forth, and I let I 2 thee depart, that thou mayest be free and have the right, of thine own

will,

13 to go and marry any man thou wilt.

If No one can oppose thee in my name ${ }^{9}$, from this day onward and forever.

Behold!

${ }^{7}$ Yāḳūt, Geographisches Wörterbuch, vol. i, p. 748, gives both pronunciations, Binha and Banha. The word הלעם was added to it, because the best honey in Egypt came from the place. See, also, Ibn Dulṣmāk, Description de l'Égypte, vol. v, p. 59. It occurs in other Genizah documents; see Mann, The Jezes in Egypt, vol. ii, general index, s.z.

${ }^{8}$ See above, line 6 . The meaning seems to be that he wishes to cover any name that she or he may have coming from family possessions in other places.

${ }^{9}$ I.e. "saying that thou bearest my name." The addition of "מפ see Blau, loc. cit., part ii, p. Ioo. 
ז את מותרת לכל ארם ודן דיהוי ליכי מני ספר

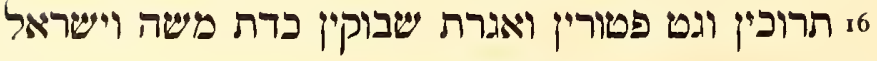

7 עמנואל ביר וחיאל נבתויא ש[ל]ה בר עמרם زעי

Verso:

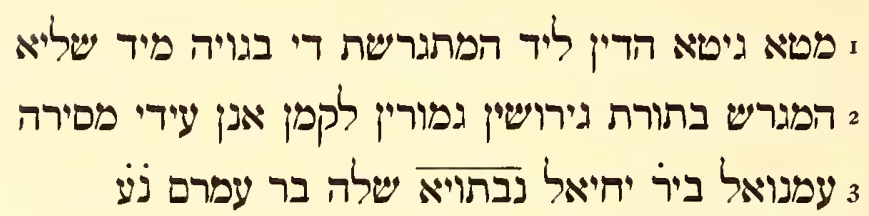

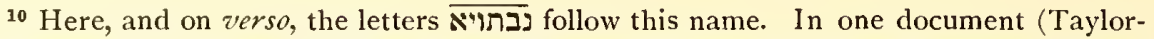
Schechter, I3. J6, No. I I) we find them after the very name which has been signed to our own : עימנואל ביר יחיאל נבתויא. See other examples of this combination of letters in Mann, op. cit., vol. ii, p. 236. It is not uncommon. Evidently it contains the first letters of some pious wish. 
15 Thou art free to every man. It is proper that thou shouldst receive from me a document

I6 of freedom, a bill of divorce, and a letter of dismissal, according to the law of Moses and of Israel.

$1_{7}$ [Witnesses] Immanuel, son of Rabbi Yehīēe ${ }^{10}$.

Shēlāh Bar 'Amram.

Verso:

I This bill of divorce has reached the divorcee, who is among her people, from the hand of Shilyā ${ }^{\mathbf{1 1}}$,

2 the divorcer, according to the law of complete divorce. Below we the witnesses of the delivery [sign our names]:

3 Immanuel, son of Rabbi Yehīel Shēlāh Bar 'Amram.

11 If this reading is correct, one may restore recto, line 4 thus:

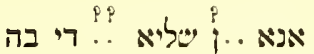

and translate: "I,...... Shilyā..., who [live] in the city of Cairo," etc. 


\section{LETTER}

Paper $8 \times 6 \frac{5}{8}$ inches.

Arabic in Hebrew characters. Cf. III, XXII, XXXIII, XXXIV, XXXV.

Written with a scratchy pen and gummy ink in a degenerate cursive Hebrew hand of which the similar letters are usually entirely undifferentiated.

Recto:

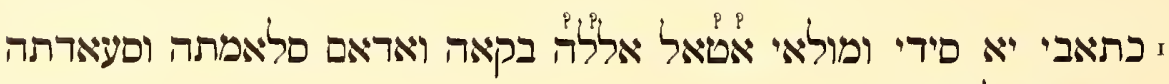
אי אילמסתקר

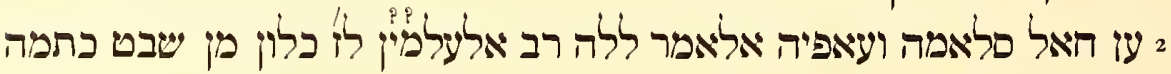

3 עלינא ועליך בכיר אעלמך יא פולאי אן תקדפת מני אליך ערה כתב ארגו

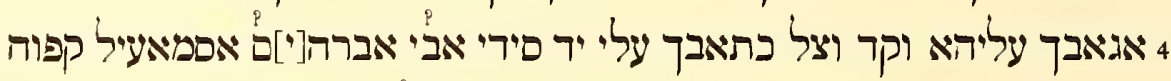

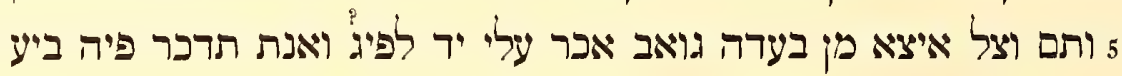

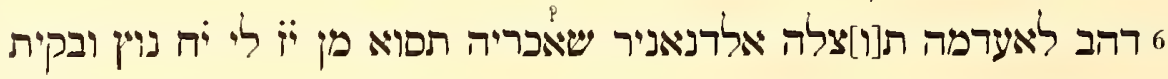

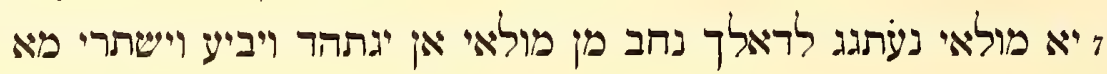

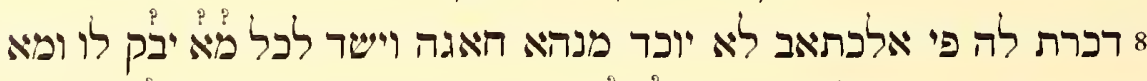

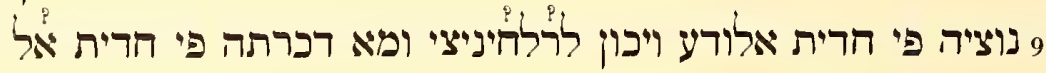

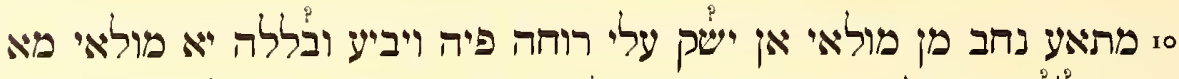

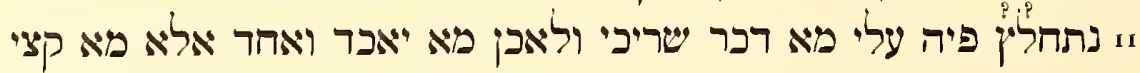

1 בתתאבי Many letters begin with the simple word. Cf. MS. Paris Consistoire VII. E. I8:

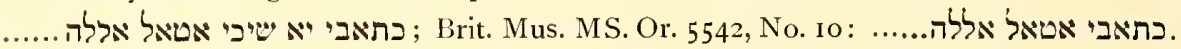

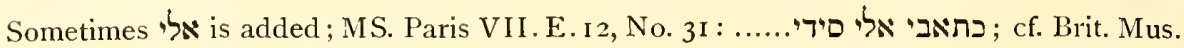
MS. Or. 5542, No. 2I. Sometimes the verb is used, in the first person or in the third person ; e.g. Taylor-Schechter, 5. 7, No. 6: ....... כתבת אטאל אללה מולה ; Bodl. MS. Hebr. c. 28,

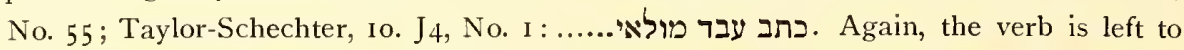
be understood; e.g. MS. Paris VII.E.24. For the forms of address in Genizah letters, see Worman in the Jewish Quarterly Review, vol. xix, pp. 72 I ff., and Goldziher, in Revue des Études Juives, vol. lv, pp. $54 \mathrm{ff}$.

${ }^{2}$ So the words should perhaps be rendered in this letter, instead of by "Lord and Master."

${ }^{3}$ In our texts there is a habit of using interchangeably the second and third persons, when speaking to the addressee; and the singular and plural of the first person, when the writer speaks of himself. In our translation we use one form only in each case.

${ }^{4}$ This formula gives some trouble because of its indefiniteness.

${ }^{5}$ Cf. the Koran, ch. i, verse I. ل 
g gavel

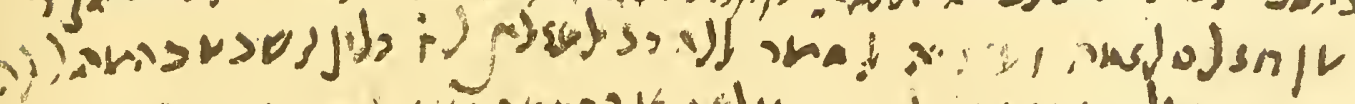

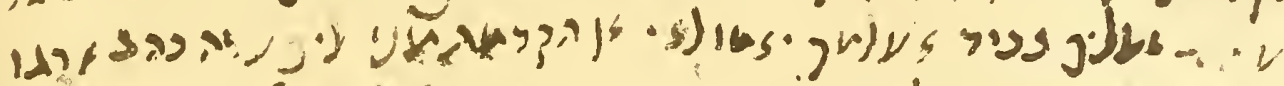

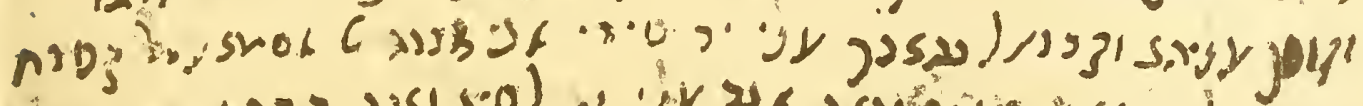

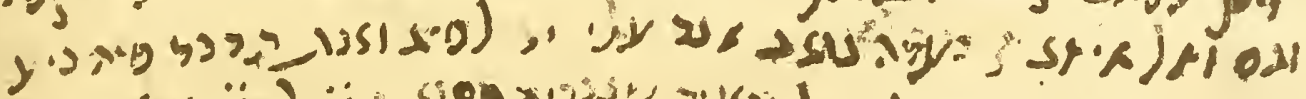
s.

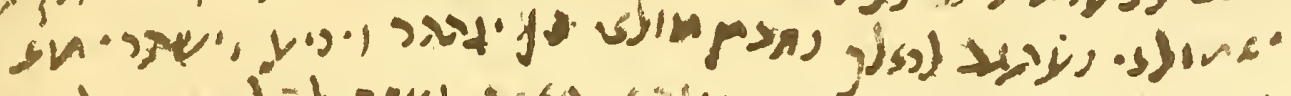

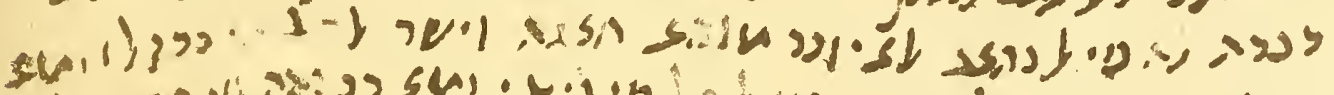

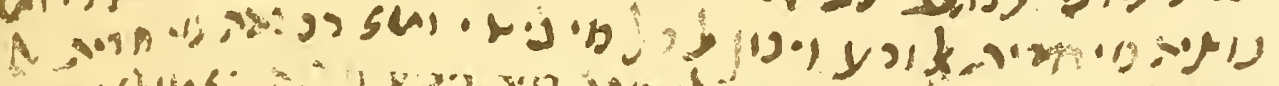

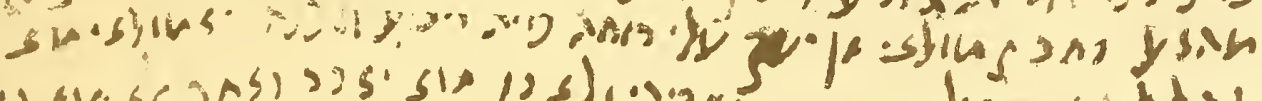

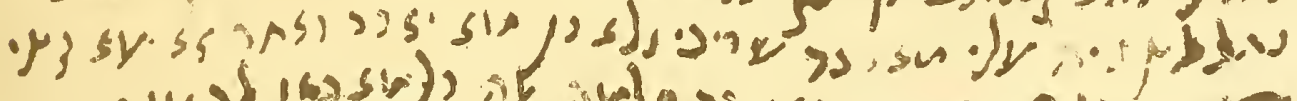

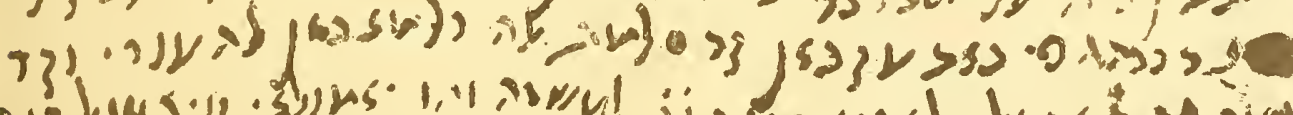

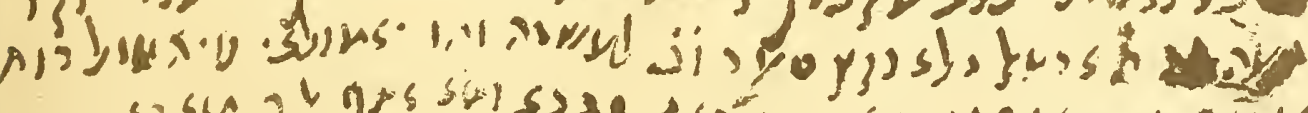

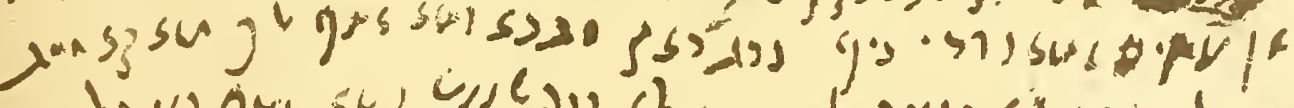

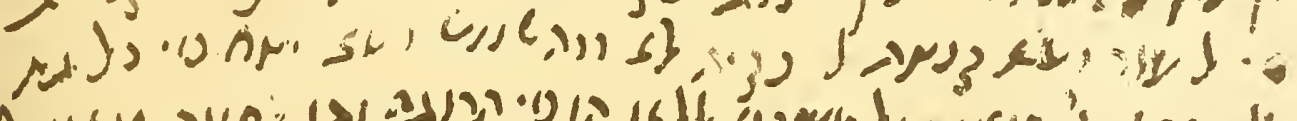

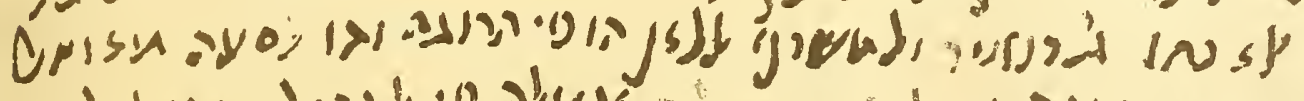

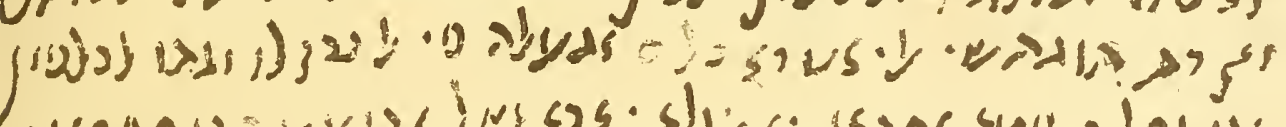

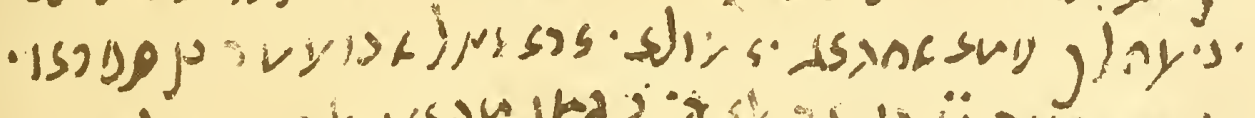

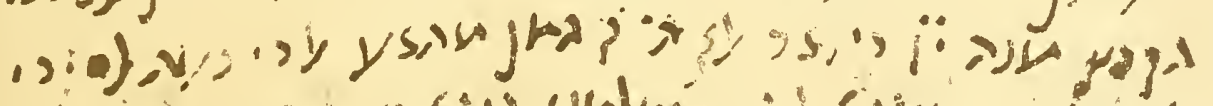

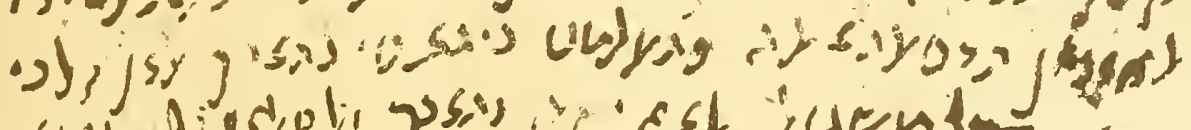

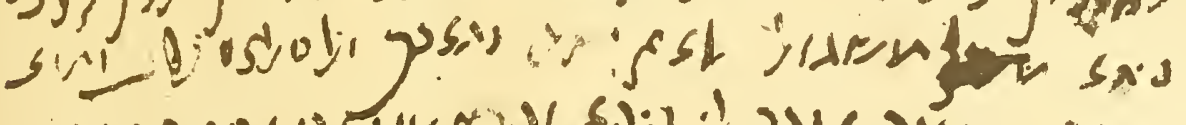

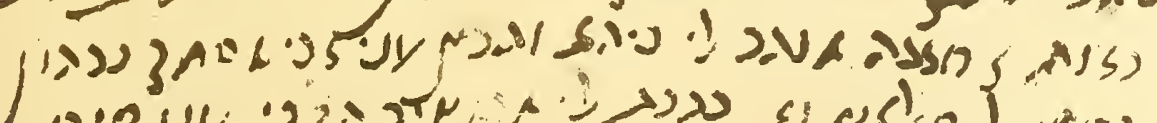

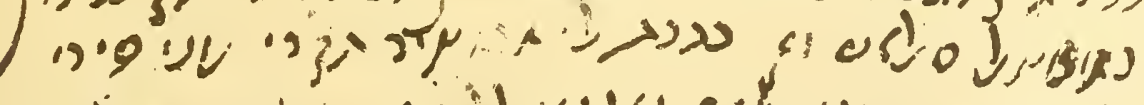
- 3,4

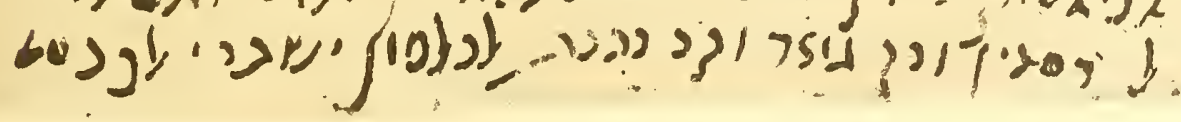





\section{LETTER}

The Arabic is as slovenly as the script, and shows strong colloquial tendencies. The style is abbreviated and technical, perhaps intentionally cryptic. As he goes on the writer becomes more and more incoherent.

A letter from an unknown man to one whose name we read uncertainly as Abū Yahyā Nathaniel Ibn Nissīm, urging him to attend to certain business matters the nature of which is not clear.

\section{Recto :}

I [This is] my letter ${ }^{1}, \mathrm{Sir}^{2}$, [to you]. May God lengthen your ${ }^{3}$ life and prolong your ${ }^{3}$ health and happiness! Behold [in me] the inquirer ${ }^{4}$

2 after the state of your health and fortunes. God, the Lord of the Worlds ${ }^{5}$, disposes [our affairs]. [There are now] 7 [days] remaining of [the month of] Shebhāt. May God complete it

3 auspiciously for you and us! I am informing you, Sir, a number of letters

have gone forward from me to you. I hope [to receive]

+ your answer to them. Your letter arrived by the hand of master Abū Ibrāhīm Ismā‘il Ḳfwh (?).

5 And then arrived, after it, another letter ${ }^{6}$, by the hand of Lfyj(?). And you say in it: "Sell

6 gold to whoever needs it most. Send him the dinārs as a favor? ${ }^{7}$, [the dīnār] equalling from I 7 to I8 [and a] half [dirhams] $]^{8 . " ~ A n d ~ I ~ a m ~}$ still $^{9}$ in need ${ }^{10}$ of [doing] this,

7 Sir. I desire of you, Sir, that you display some zeal, and sell and buy what

8 I told you to in the letter: not selecting some [one] thing ${ }^{11}$ from it, but strictly doing everything that remains for you [to do], and what

9 I directed you [to do] in the matter ${ }^{12}$ of the deposit. And may it become...... And what I said in the matter ${ }^{12}$ of the

Io [personal] effects. I desire of [you], Sir, that you discipline yourself in this matter, and sell. And by Allah, Sir,

II we are not going to save ourselves in [the business] according to what my partner says. But let no one take anything except what was decided upon

7 شاكريّة usually means "wages"; etymologically "thankfulness."

${ }^{8}$ Reading 'نُص tenth centuries the dinār was worth about 15 dirhams. See Le Strange, Palestine under the Muslims, 1890 , p. 43 .

${ }^{9}$ Or in the modern colloquial sense: "I have come to be."

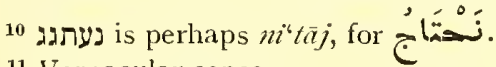

11 Vernacular sense.

12 חדית can hardly have any other meaning here. Cf. Dozy, Suppl., vol. i, p. 258, col. 2, line 4 from below. 


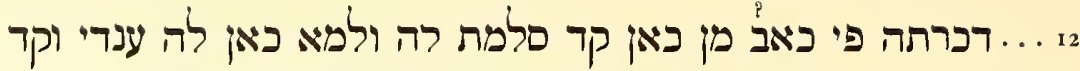

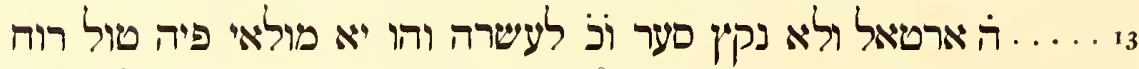

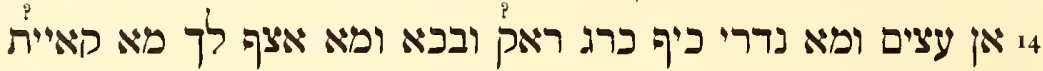

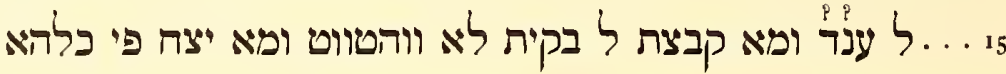

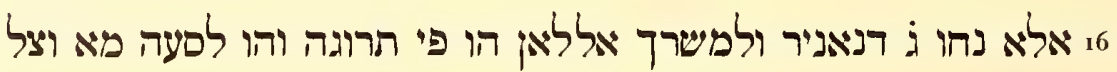

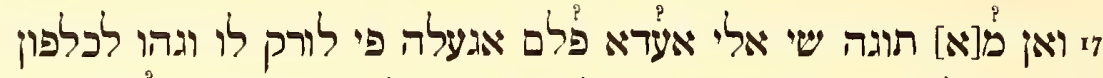
18 19 20

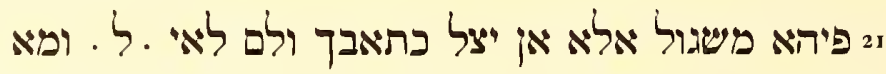

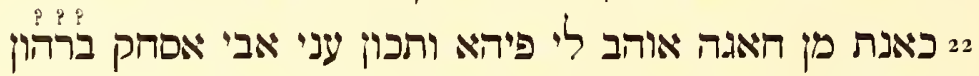

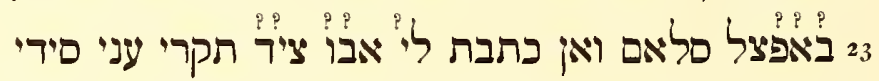

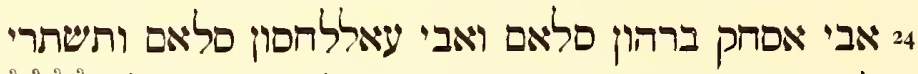
25

\section{Address:}

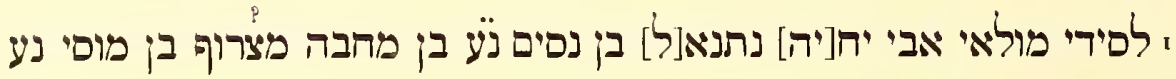

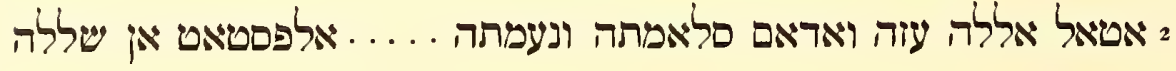
13 Reading בתก.
14 Reading מן ממא
15 סעl for ?

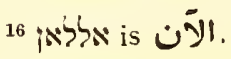

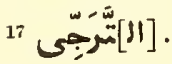
${ }^{18}$ Colloquial, lissa. 
12 ...... I said in [the] letter ${ }^{13}$ about what ${ }^{14} \mathrm{I}$ have turned over to him and what I had of his [property]. And

13 ........5 roțls, and not less, amount to ${ }^{15} 26$ for ten. And it [requires] patience,

14 great [patience]. And we do not know how it went.......and weeping. And I cannot describe to you what

$15 \ldots \ldots \ldots \ldots \ldots \ldots$........... for all of it not [less]

I6 than about 3 dinārs would be proper. And the man who has taken [me] as partner is at present ${ }^{16}$ hoped for ${ }^{17}$ but has not yet ${ }^{18}$ arrived.

${ }_{17}$ But he is not ${ }^{19}$ going to [our] enemies. But I did not put it on paper.

If they had only gone to Halfōn

I8 to sell it for you. And what I require of you, Sir, [is that] when Abū 'Ițr Ibn Sufrāwī arrives,

I9 you take from him 16 dinnārs.........[personal] effects which belonged to master

20......you deliver them to him and then notify me of it in your letter. At present I am

2I worried $^{20}$ about them-until your letter arrives ;....... and I

22 had nothing of my own remaining among them. And let there be from me [to] ${ }^{21}$ Abū Isaac Brhōn(?)

23 the most excellent ${ }^{22}$ of greetings! And I have written to Abū Saa ${ }^{\natural} \overline{1} d(?)$.

Give my greetings [to $]^{21}$ master

${ }_{2}+\mathrm{Abū}$ Isaac Brhōn(?) and Abü al-Husain(?). And buy

${ }_{25}$ for me two books of paper of the best quality. I have written to Halfōn to buy the pickles(? ${ }^{23}$.

\section{Address :}

To master Abū Yahyā(?) Nathaniel Ibn Nissīm Ibn Mahabbah(?) Mașrūf(?) Ibn Moses. May God prolong his vigor and continue his health and prosperity! Fusțāt -if it please God!

19 Colloquial suffix, $-s h$.

20 bes written and deleted. $\quad 21 \zeta$ omitted.

22 The scribe corrected the first two or three letters, and we can read neither the original nor the correction. He may have intended אפיצ.

23 Sُ 23 , plural of 


\section{LIST OF TAX-PAYERS}

A long strip of paper I I $\frac{1}{4} \times 4 \frac{1}{16}$ inches.

Arabic in half-square Hebrew characters.

\section{Recto :}

י אדבאקי פן פסקה אלכראג

ามา

רינר

רינר

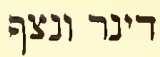

דינריין נצינף דינר רינר

בינר

רבע רינר

נציפ רינר

רבע רינר

רבע רינר רבער

רבע רינר

רבע רינר

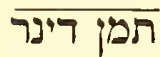

רבע רינר רינר
רפע

2 אלטייך אבו אל כיר אלבמארין

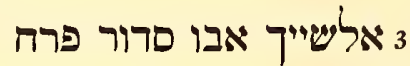

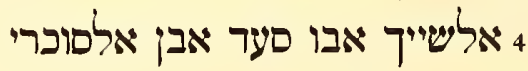
5

6 אלשייך אבו מנצור אבי היים

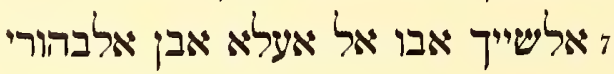

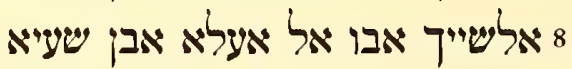

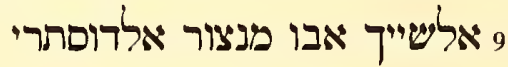
ס אלכאתב אלרי דאר למאט

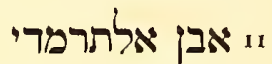

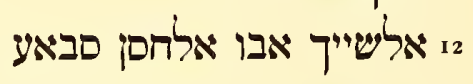

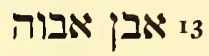

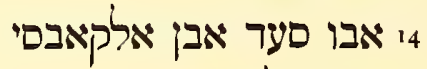

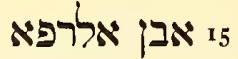

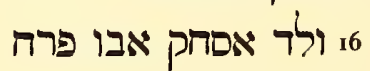
ז צרר נסים 8 אבין עמראי אלטרי נסים

" "Good-luck."

${ }^{2}$ We omit the vowels when they are not known.

3 "Lotus tree." $\quad$ "Joy." " 5 "Good-luck."

6 "Sugary." Cf. Zuckermann, Suessmann, Suesskind, etc.

7 Or lbn 'Ammō. $\quad 8$ Hebrew, "Life."

9 "Lion-like." Cf. No. VII, note 4 ; or else जُ" "جهورى " of victories." The words "he has paid" were written above this name, then blotted out.

10 Perhaps 


\section{LIST OF TAX-PAYERS}

The title and contents indicate that we have here a register of tax-payers in some Jewish community, probably in Fusțāt, with the amounts that they have paid-not the balance to be paid (as 1. I states) - of the fiscal tax.

Interest centers in the personal names. One must remember, however, that these people were often no more conscious of the meaning and implication of their names than we ourselves are of ours. There are ArabMuslim, Jewish and double names, epithets and descriptive identifications. The Jewish names already include well-known modern motifs.

Recto:

I The Remainder of the Government Poll-Tax :

Paid by

2 The Sheikh Abū al-Khairi al-Bmārīn ${ }^{2}$

- a dīnār.

3 The Sheikh Abū Sudūr ${ }^{3}$ Farah $^{4}$

+ The Sheikh Abū Sa‘d ${ }^{5}$ Ibn al-Sūkkarī ${ }^{6}$

- a dīnār.

- a dīnār.

5 His cousin?

6 The Sheikh Abū Manșūr Ibn Hayyīm ${ }^{8}$

- a dīnār and a half.

7 The Sheikh Abū al-A 'lā Ibn al-Bahwarī⿳9

— two dīnārs.

- a half dīnār.

8 The Sheikh Abū al-A'lā Ibn Sha'yā'10

- a half dīnār.

9 The Sheikh Abū Manșūr, the registrar ${ }^{11}$

- a dīnār.

Io The Scribe who [lives in the] house of Lmāt

- a half dīnār.

II Ibn al-Tirmidhī 12

12 The Sheikh Abū al-Hasan Sibā'13

- a quarter dīnār.

— a half dīnār.

13. Ibn Abūh ${ }^{14}$

${ }_{4} \mathrm{Abū} \mathrm{Sa} \mathrm{S}^{5} \mathrm{Ibn}$ al-Ḳ̂ābisī

— a quarter dīnār.

- a quarter dinnār.

15 Ibn al-Rifā ${ }^{15}$

16 Walad Isaac ${ }^{16}$ Abū Farah ${ }^{4}$

— a quarter dīnār.

I7 The brother-in-law ${ }^{17}$ of Nissīm ${ }^{18}$

— a quarter dīnār.

- an eighth dīnār.

I8 Ibn 'Umrān'19, the physician

— a quarter dīnār.

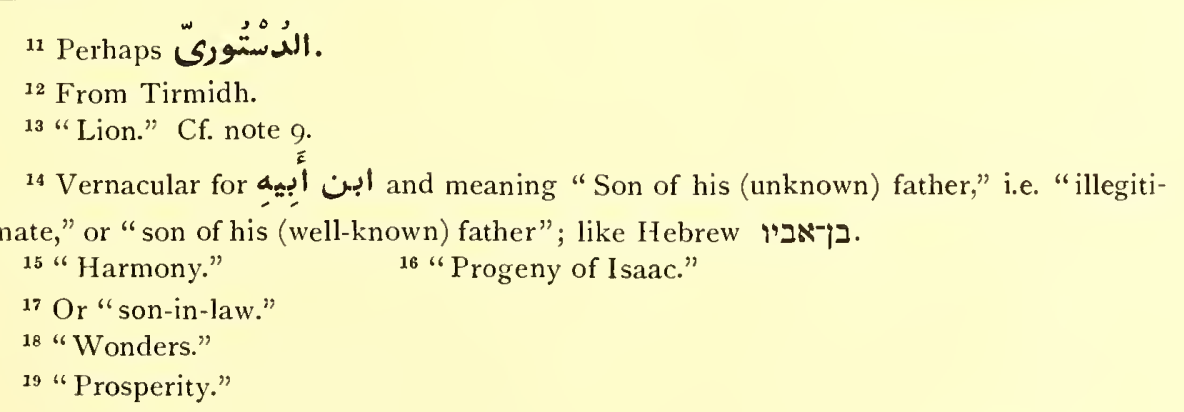




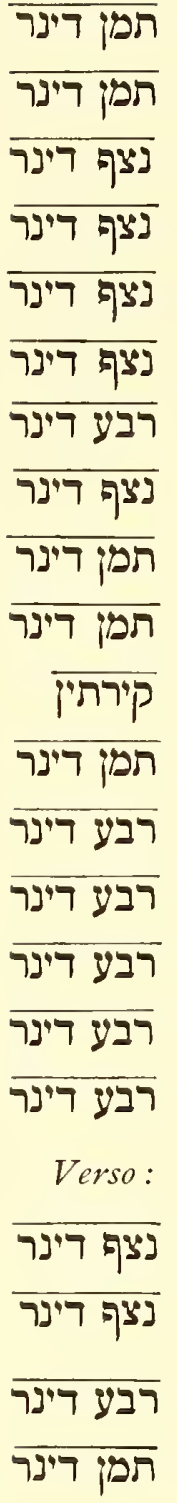

נצבע
9י אבן סהר ארשראבי

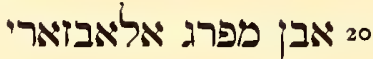
21 אבן בושיר 2 22 אלשייך אבו אלחסן צדקה

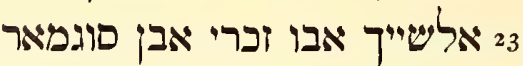

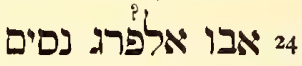
25 אבו זכרי אבן מנשה אכופי נסים

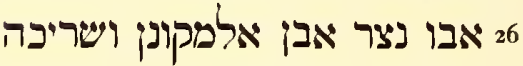
27 מוםי אבן אלמגאני נצי אבי אימקי 28 נסים אלמגרבי אים אימני 29 אבו אלביר אלצ'רפי אלפרי 30

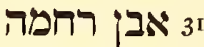
32 אבו עמראן בן צגיר 33 אבו עמראן 34 אבו נצר בן מכתאר 35 אבו אלכיר אלגיר נצר מכתר

36 מולאי אלשיך אבו מנצור 37 אבו סער אבן אל קטאיף אל אבוך מצור רבע,תמן איאו 38 39 אבו אל חי עמרי אי אי

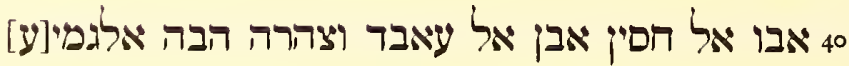

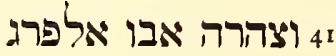

\footnotetext{
20 "Easy," i.e. of birth, or wished-for future.

21 "Comforter."

${ }^{22}$ From Buzār, a village about two parasangs distant from Nīsāpūr, Persia. Cf. alAsyūțī, Lubb al-Lubāb, ed. Veth, pp. 6, 30, rq.

23 "Little messenger of good."

24 Hebrew "צighteousness."

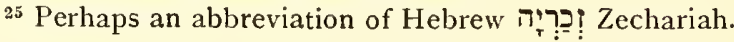


r9 Ibn Sahl ${ }^{20}$ the wine-dealer

20 Ibn Mufarrij ${ }^{21}$ al-Ubzārīi22

2r Ibn Bushair ${ }^{23}$

22 The Sheikh Abū al-Hasan Sadaḳah²4

${ }_{23}$ The Sheikh Abū Zekharāi ${ }^{25}$ Sūjmār

${ }_{24} \mathrm{Abu}$ al-Faraj Nissīm ${ }^{18}$

${ }_{25}$ Abū Zekharāi ${ }^{25}$ Ibn Manasseh

${ }_{26} \mathrm{Abu}$ Naṣr the son of the public mourner ${ }^{26}$, and his

partner

${ }_{27}$ Moses Ibn al-Majānīi ${ }^{27}$

${ }_{28}$ Nissīm $^{18}$ al-Maghribīi ${ }^{28}$

29 Abū al-Khair ${ }^{1}$ the money-changer

30 Abū 'Umrān ${ }^{19}$, with the police ${ }^{30}$

31 Ibn Raḥmah ${ }^{31}$

${ }^{32}$ Abū 'Umrān ${ }^{19} \mathrm{Bin}^{32}$ Ṣaghīr ${ }^{33}$

33 Abū 'Umrān' 19

${ }_{34}$ Abū Naṣr Bin ${ }^{32}$ Mukhtār

$35 \mathrm{Abu}$ al-Khair ${ }^{1}$ the proselyte ${ }^{34}$

Verso:

${ }_{3} 6 \mathrm{My}$ lord the Sheikh Abū Manșūr

37 Abū Sa'd ${ }^{5}$ Ibn al-Katā'if ${ }^{35}$

$3^{8} \mathrm{Abū}$ 'Umrān, son of the tailor ${ }^{36}$

39 Abū al-Hayy ${ }^{37}$

$40 \mathrm{Abu}$ al-Husain Ibn al- ${ }^{\mathrm{A}} \mathrm{bid}^{38}$ and his brother-inlaw $^{17}$, Hibah $^{39}$

$4^{\mathrm{r}}$ And the brother-in-law ${ }^{17}$ of Abū al-Faraj
— an eighth dīnār.

- an eighth dīnār.

— a half dīnār.

— a half dīnār.

- a half dīnàr.

- a half dīnār.

— a quarter dīnār.
- a half dīnār.

— an eighth dīnār.

— an eighth dīnār.

- two carats ${ }^{20}$.

- an eighth dīnār.

- a quarter dīnār.

— a quarter dīnār.

- a quarter dīnār.

- a quarter dīnār.

— a quarter dīnār.
- a half dīnār.

- a half dīnār.

— a quarter dīnār.

— an eighth dīnār.

- the whole.

- a half and a quarter dīnār.

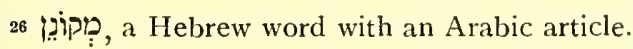

27 "Profit." 28 "From the Barbary States."

${ }^{29}$ I.e. one-twelfth dīnār.

30 شُطَراء "strangers." 31 " "Mercy."

${ }^{32}$ Here written 1 a and not אבר Hebrew orthography.

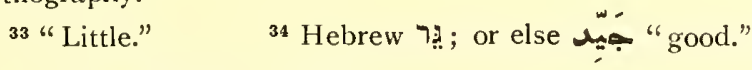

35 "Sweetmeats." Cf. note 6.

${ }^{36}$ Or Ibn al-Khayyāṭ. Over this name there is written in small letters, "a quarter", an eighth."

37 "Living." Cf. note 8.

38 "Pious." 39 "Gift." 


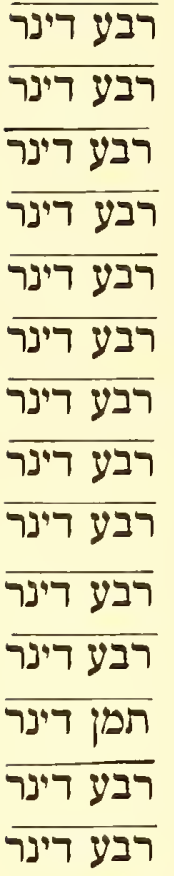

42

43 44 אבו אל חוסין אלרהבי איאי 45 טיבאי 45 46 אבו אל חסן צרקה בן שמען

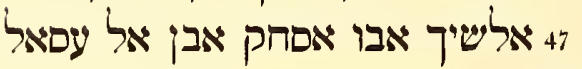

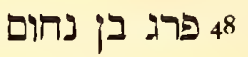

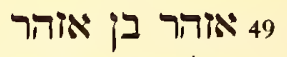

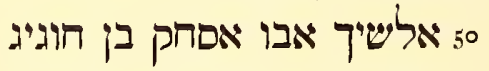

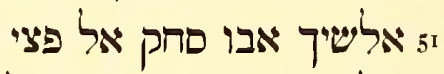

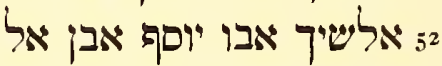

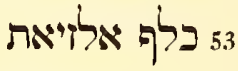

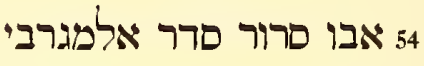
55 אבו מוםי הרון אלגהבר פרד אלמרי
40 "Hidden Treasure."
41 The same as Husain, of course.
42 "Golden." Cf. Goldmann, Goldstein, Goldberg, etc.
${ }^{43}$ Pedantic as it would be, perhaps it is طَيَّ" "well done !" 
42 Șadaḳah ${ }^{24}$ al-Ṣafīn ${ }^{40}$

43 Sadakah $^{24}$ the glazier

${ }_{44}$ Abū al-Hūsain ${ }^{41}$ al-Dhahabī ${ }^{42}$

45 Ṭayyibān ${ }^{43}$

${ }_{4} 6 \mathrm{Abū}$ al-Hasan Șadaḳah ${ }^{24} \mathrm{Bin}^{32}$ Simon

${ }_{47}$ The Sheikh Abū Isaac Ibn al-'Assāl ${ }^{44}$

${ }_{48}^{8}$ Faraj Bin ${ }^{32}$ Nahum

49 Azhar Bin ${ }^{32}$ Azhar ${ }^{45}$

50 The Sheikh Abū Isaac Bin ${ }^{32}$ Hūjaij ${ }^{46}$

${ }_{51}$ The Sheikh Abū Isaac ${ }^{47}$ al-Fiḍ̣i ${ }^{48}$

${ }_{52}$ The Sheikh Abū Joseph Ibn al-......

$53 \mathrm{Kalaf}^{49}$ the oil-dealer

${ }_{54} \mathrm{Abu}^{50}$ Sarūr Sidr ${ }^{51}$ al-Maghribī ${ }^{28}$

${ }_{55} \mathrm{Abū}$ Moses Aaron the money-changer
- a quarter dīnār.

— a quarter dīnār.

- a quarter dīnār.

- a quarter dīnār.

- a quarter dīnār.

_- a quarter dīnār.

- a quarter dīnār.

- a quarter dīnār.

- a quarter dīnār.

- a quarter dīnār.

- a quarter dīnār.

- an eighth dīnār.

- a quarter dīnār.

- a quarter dīnār.

\footnotetext{
44 "Sweet as honey." Cf. note 6.

45 "Very brilliant." Cf. Glanz, Finkelstein, etc.

46 "Little ear-ring."

47 The $x$ has been omitted.

18 "Silvery." Cf. Silbermann, Silberstein, etc.

49 "Love," or perhaps مَلْف "progeny."

50 There seems to have been something before this, blotted out.

51 "Lotus tree."
} 


\section{LEAF FROM A MERCHANT'S NOTE-BOOK}

Paper. One double page, $8 \frac{3}{8} \times 5 \frac{7}{8}$ inches.

Arabic in half-square Hebrew characters. On the verso much has been blurred and effaced.

$$
\text { Recto : (a) }
$$

ז שרח אלרי וקע עלי אלחריר אלמצבוג 2 אלאצל כאם סו רטל אלתמן שי רינר

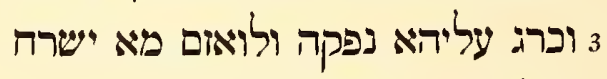
4 אולא נקיץ אלסו רטל ذ דינר 5 ופי קרמו ללצבאג פה ניה רינר

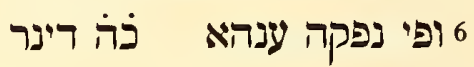

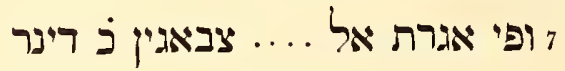

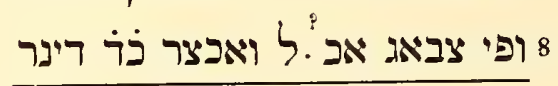
9 דאלך אלגמלה קעד דינר ס איגמלתין תעד דינר זי צח פיה מצבוג פג רטל תמר רינר Recto: (b)

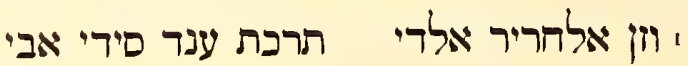

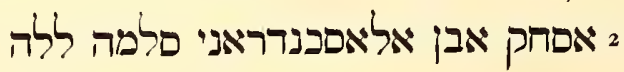

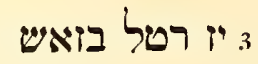

Verso: $(a)$

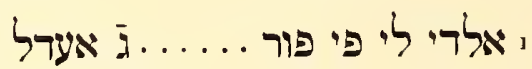

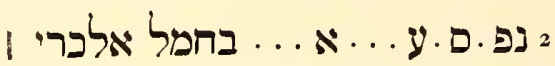
3 מתקאלין ונצפ ואיצא עדל חי הריר

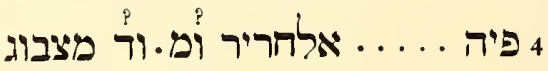
5 ורזמתין לי עתיק ובםאטט כביר

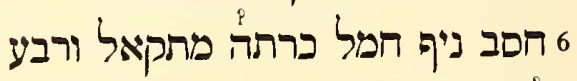

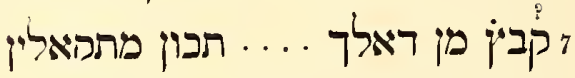
8 בקי עלי מ[תקא]לין אלי רבע ידפעהא

1 A roțl is equal to about 12 ounces.

${ }^{2}$ Cf. No. VII, note 8.

3 Perhaps some mistake had been made in the weighing, or the quality was not what it should have been.

"He had written [ץ"צ] תלאל "polishers." 


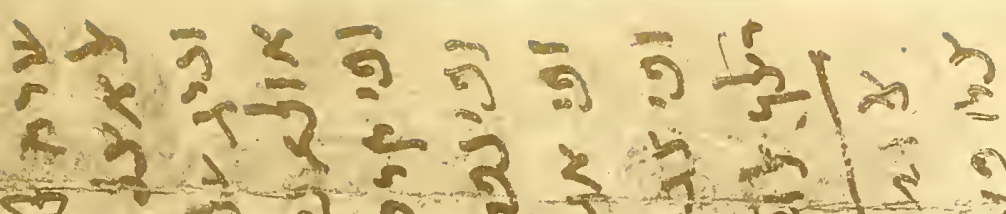
क 2 है $\div 2525$ s

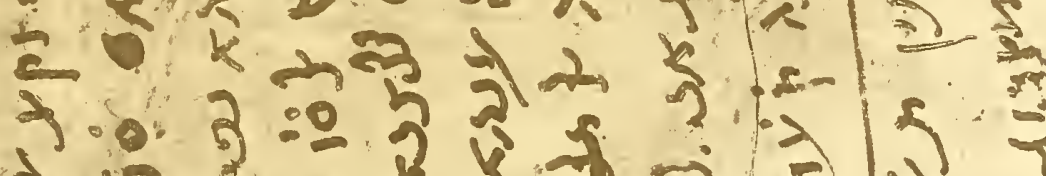

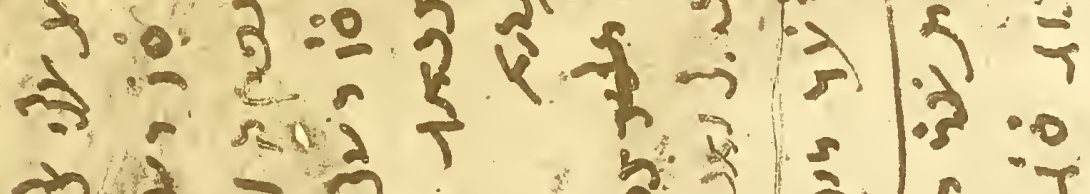

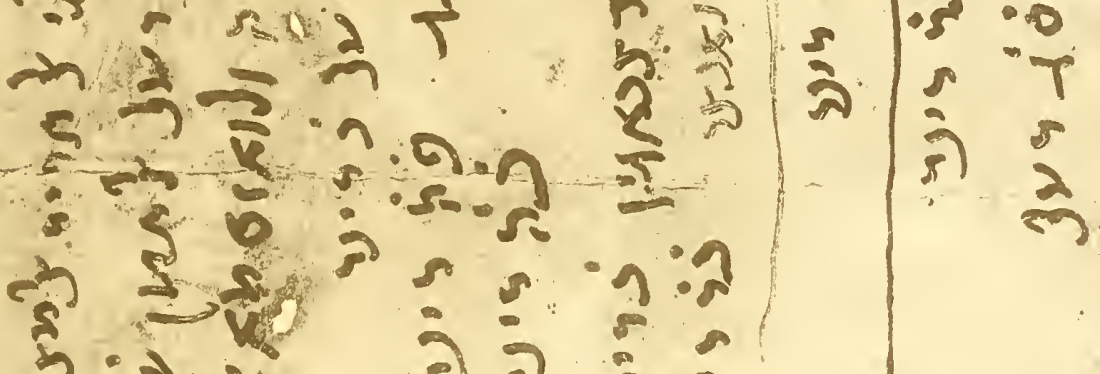

Tे

厂

$\sum z^{2}=$

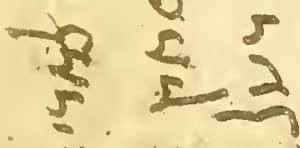

5 a

का 5

齐淛

23

is

- $\frac{5}{5}$ में 


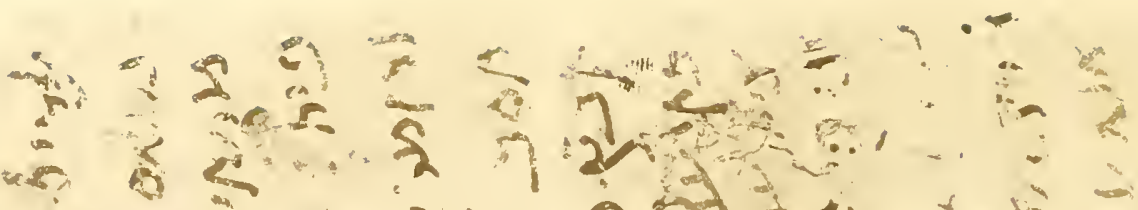

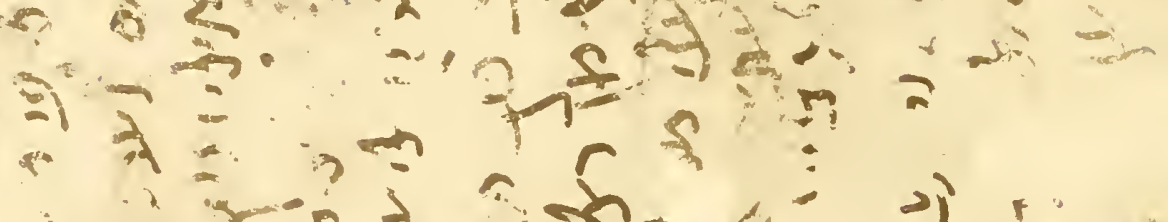

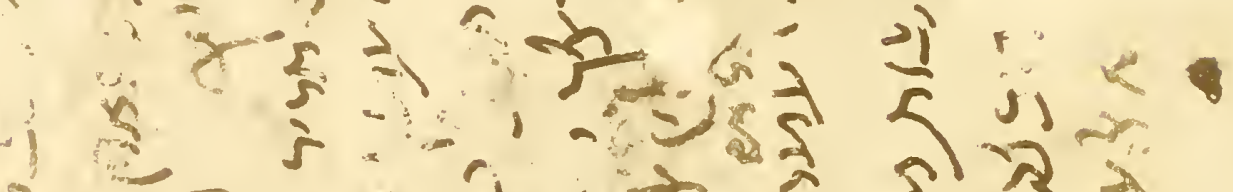
5. रद

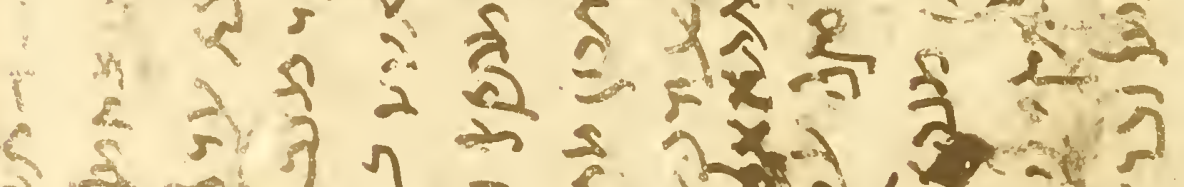

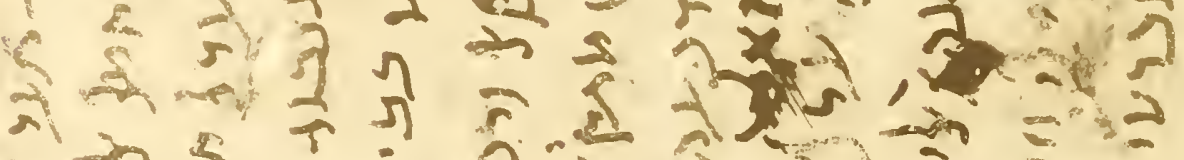

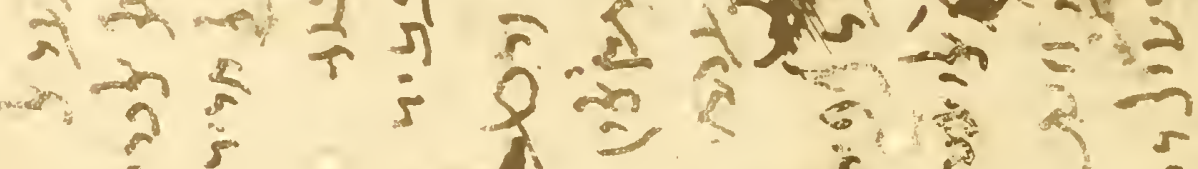

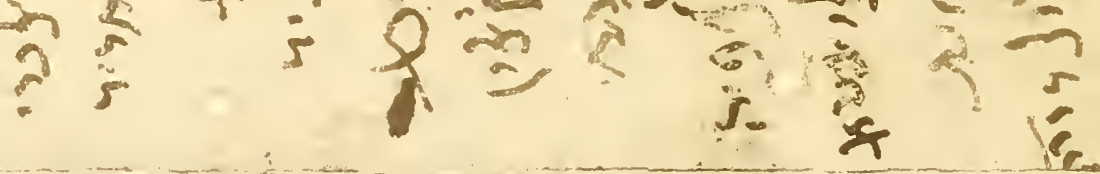

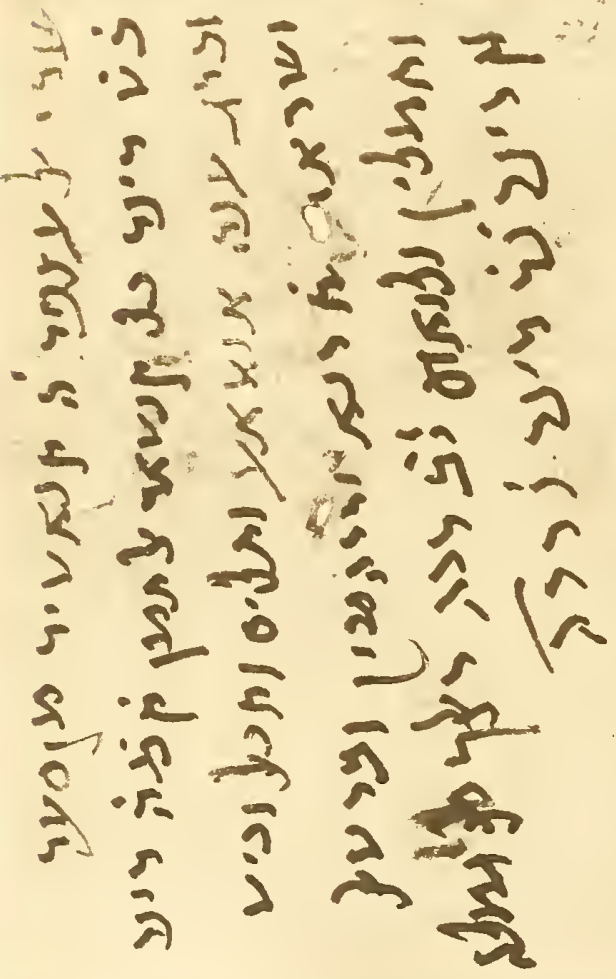




\section{LEAF FROM A MERCHANT'S NOTE-BOOK}

Recto: $(a)$

I Detail of the sum spent for the dyed silk:

2 The stock, unbleached, 66 roțls ${ }^{1}$; price

- 300 dīnārs².

3 Expenses and other necessaries paid out as follows:

${ }_{4}$ Firstly, diminution in the value of the 66 roṭls $^{3}-20$ dinnarrs.

5 And in crimson dye for the dyer $\quad-85$ dinnārs.

6 And in expenses connected with this $\quad-25$ dinnārs.

7 And in wages for the dyers ${ }^{4} \quad-20$ dinnārs.

8 And in...... ${ }^{5}$ and green dyes $\quad-24$ dīnārs.

9 The whole sum equals

- I74 dīnārs.

ro The two sums equal

- 474 dīnārs.

II There resulted actually of dyed goods, 63 roțls.

Recto : (b)

I Weight of the silk which I left with my lord Abū

2 Isaac al-Iskandarānī-God grant him grace !-

3 is 17 roṭls......(? $)^{6}$

Verso: $(a)$

I .......which belongs to me in......... 3 bales

2 ..............by the load ${ }^{\text {? }}$

3 two mithkāals ${ }^{8}$ and a half, and also a bale of silk, + in which......the silk, and dyed.

5 and two bundles of clothes belonging to me, old ${ }^{9}$, and a large rug ${ }^{10}$

6 enough for more than the load of.......... mithkāa and a quarter

; taken off from this...... becomes two mithkà̀ls.

8 There remains on two mithkâals as muıch as a quarter which he will pay

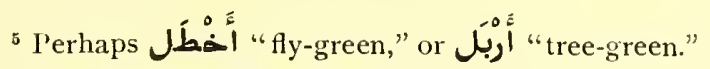

6 A word of four letters follows.

? ברי = p. 340 .

${ }^{8}$ Cf. No. VII, note 8.

9 We should have expected a dual.

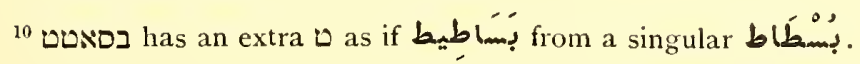


9 אליד .............. דפעתרא אליד

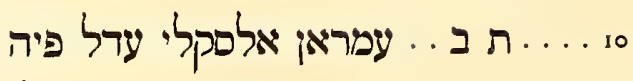

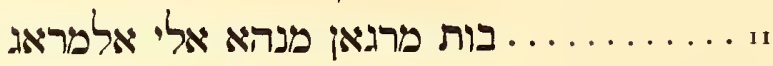

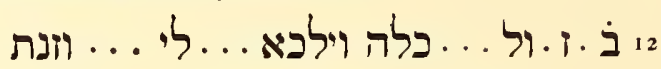
3י אנא ען . .. . אלעדל חמל וברטיל דירה]ם?]

Verso: $(b)$

ו ששרי אלעצפר ה קנאטיר פן סער 2 כלט דינר בל קנטאר אלתפי קפוה דינר 3 וכרג ענר אנטאע ותלים ותכאר וכיט

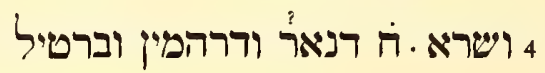
5 6

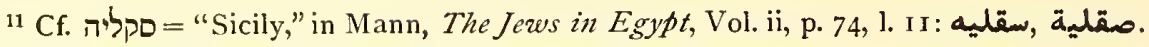
Ibn Khurdādhbih (de Goeje, Bibl. Geogr. Arab., Vol.vi), p. 9I. 
g to him........ I have paid them to him

ro ......... Umrān the Sicilian ${ }^{11}$, a sack in which is

is ............corals, some of them belonging to the coral-gatherer ${ }^{12}$

I $2 . . . . . . . . . . .$. I have weighed

I3 I from......the sack, the porterage and the bakshish of a dirham.

Verso: $(b)$

I He has bought 5 hundredweight of saffron from Sa'd

2 [paying] 29 dinārs for every hundredweight [which makes] the price

145 dīnārs

3 and [these should be] deducted from this [for] leather table-cloths, and .......and.......and string

4 and......8 dīnārs and 2 dirhams, and bakshish

5 and [for] porters ${ }^{13}$ and [other] necessary expenses 12 dirhams. This [to be taken] from the sum

6 ......dīnārs, 24 dīnārs, 6 dirhams.

12 مَرَّiَ instead of the usual

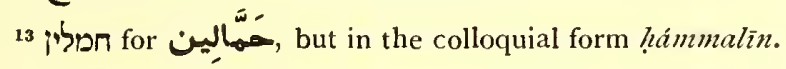




\section{CHARM}

Paper $9 \frac{1}{2} \times 3 \frac{5}{16}$ inches.

Hebrew in cursive Hebrew characters, not easily read. Vowel points are occasionally inserted, but ignorantly. The spelling is bad, and may represent a peculiar pronunciation: Moroccan, Persian, Yemenite or Ashkenazic. The Arabic article and imperative have crept in.

Recto:

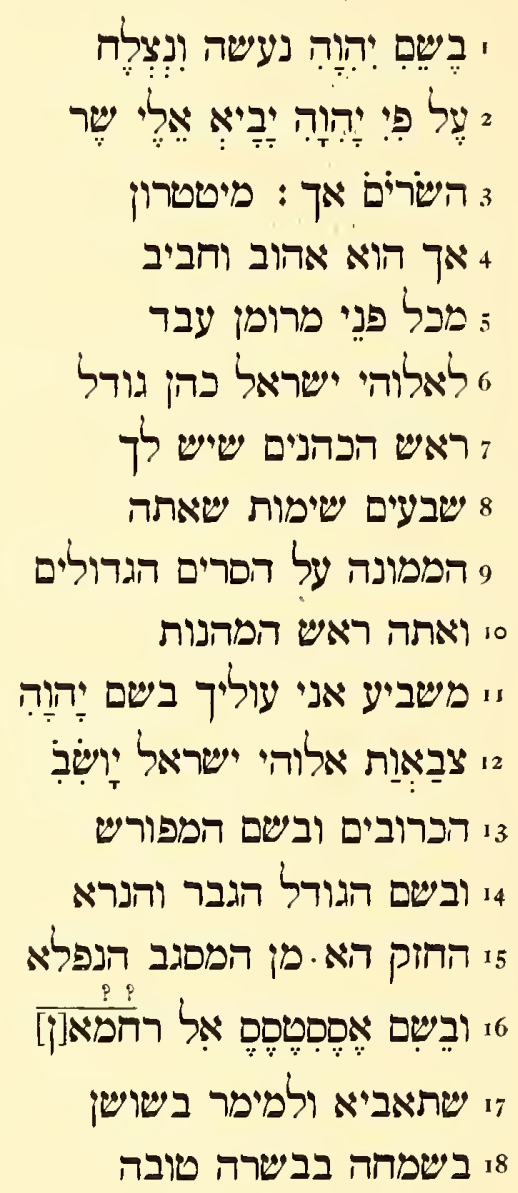

1 Or perhaps שר הישרים, "the Prince of demons." In any case "prince" is the technical term for the figures seen by the "scryer," or gazer into crystals, ink-pools, and the like. The Arabs call them "kings." In the Journal of the American Oriental Society, vol. xxxvi, pp. $37 \mathrm{ff}$., there is abundant material on this subject. See also Daiches, Babylonian Oil Magic in the Talmud and in Later Jewish Literature, London, I9I3; and Blau, Altjüdisches Zauberwesen, Strassburg, 1898, p. I1. Sanhedrin, Iог says: "One is allowed to ask the princes of oil and the princes of eggs; only they lie. One whispers a spell over oil in the vessel, but does not whisper over oil in the hand....." Blau fails to understand that this refers to scrying with oil and with eggs, broken into a cup or plate. Rashī (I Ith cent.) on the passage, explains the "princes of oil" as "princes of the thumb." They are figures seen in the oiled thumbnail. 
dy

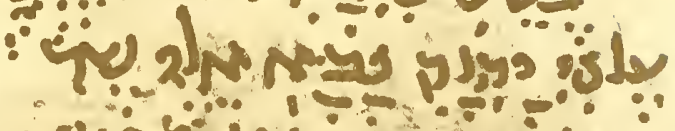

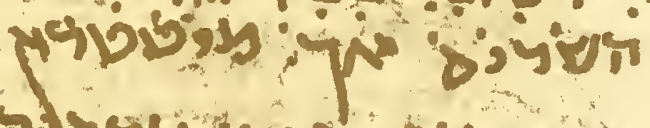

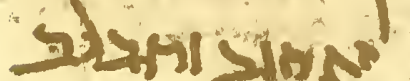

apse pissososo do

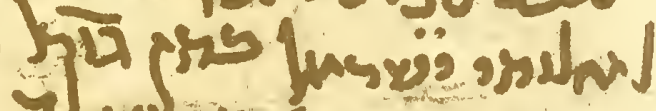

Vo vosiss enas

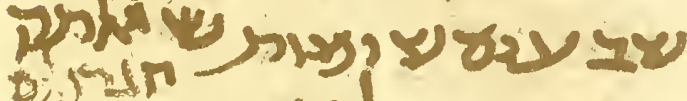
oxomly intess

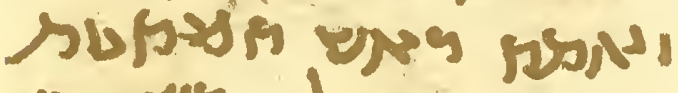

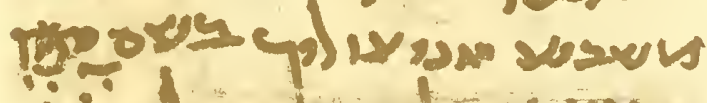

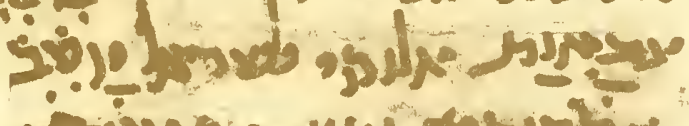
Dijun ory tersisn Nund yly dy des oves

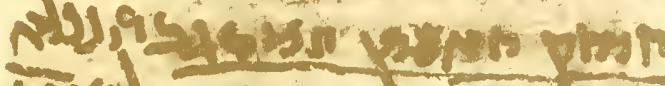
Now heppopoys motionli weres

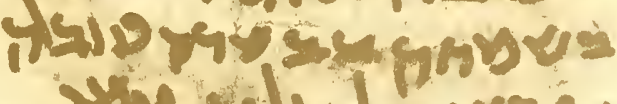

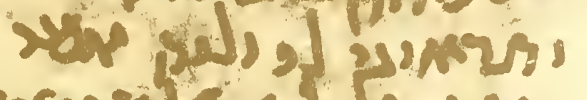

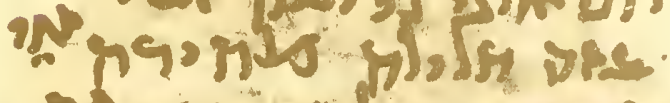

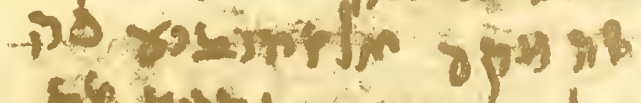
pe pares nosos inlow zovon ass ofor

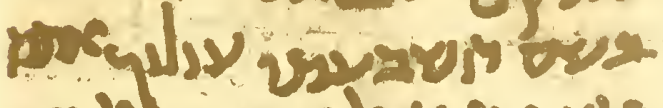

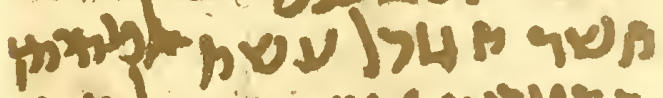
trobsos nes ritore

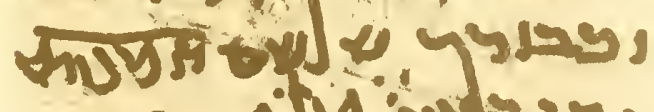
poposojus proms

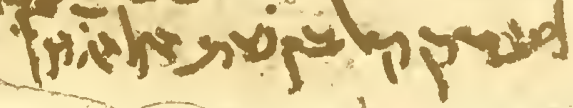




\section{yompos biontroods.}

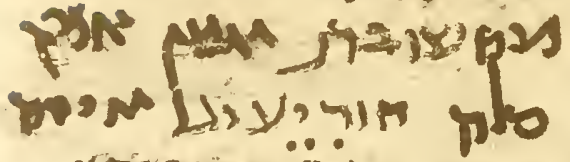

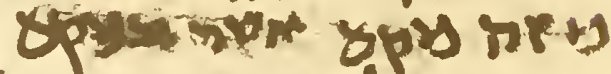

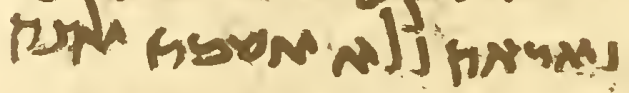

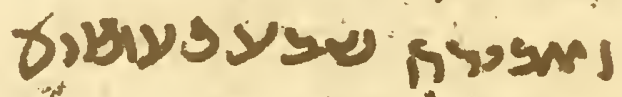
silvos ins of iogs Loses plo viveres pis

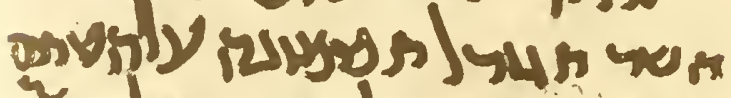

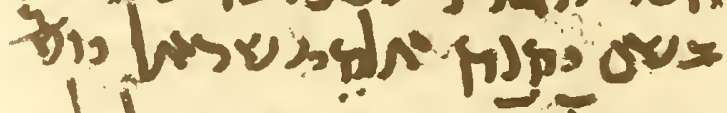

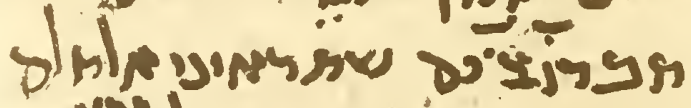

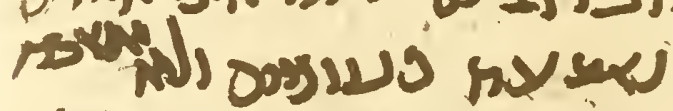

40o on y y

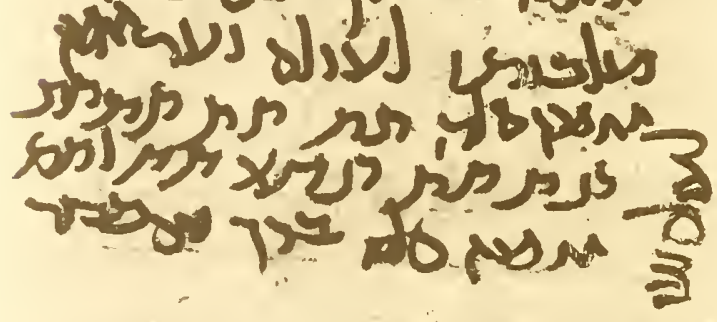

Tor y y pren

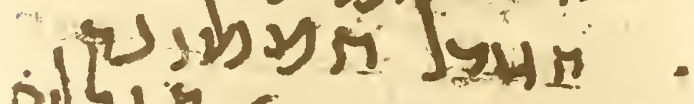
i) यो 6,4

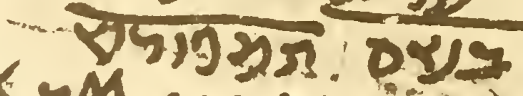
$\gamma$ Yo UNं N) $x$ ing

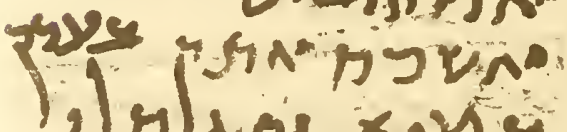
9) probsionso news तit jort pas." 


\section{CHARM}

This is a magical text, to be used in "scrying," or self-hypnotic gazing, at some bright surface. The angel Mittatrōn is adjured by the Ineffable Name, with the will of God, to reveal through an apparition, or "prince," the location of hidden gold pieces, to one Sedhāḳāh Ben Sitt al-Ahl, and his mother, Sitt al-Ahl. The magic is kept "white" by reference to the God of Israel; but His Name is nevertheless taken in vain. Scrying with oil, ink, egg, and bright objects was common among Jews and A rabs in the Orient, then as now.

\section{Recto:}

I In the Name of YHWH may we do and prosper!

2 According to the word of YHWH may it bring to me the Prince of

3 the princes ${ }^{1}, \mathrm{Akh}^{2}$ ! Mittatrōn ${ }^{3}$ !

${ }_{+} \mathrm{Akh}^{2}$ ! He is more beloved ${ }^{4}$ and dear

5 than all the faces of His heaven. A servant ${ }^{5}$

6 unto the God of Israel! High Priest ${ }^{6}$ !

7 Chief of the Priests, unto whom belong

8 seventy names! [You] who are

9 the appointed one over the great princes!

ro You, the chief of the appointed ones!

in I adjure you ${ }^{7}$ by the Name YHWH

12 Sebhā'ōth, the God of Israel, seated

I3 above the Cherubim ${ }^{8}$ ! And by the Ineffable Name!

I+ And by the Great, Mighty, Awful Name?

${ }_{5}$ The Strong, Steadfast ${ }^{10}$, Exalted, Gigantic [Name]!

16 And by the name Eses! Teses ${ }^{11}$ ! Rahmānn ${ }^{12}$ !

I 7 That you bring and [make] to speak, gladly ${ }^{13}$, I 8 with rejoicing and good tidings;

\footnotetext{
2 A proper name or a magical word of power.

${ }^{3}$ The highest of the angels. See Levy, Wörterbuch über die Talmudim und Midraschim.

4 This is "white" magic. The possible evil of resorting to it is averted by considering the spiritual agent as merely the deputy of God, or as a blessed agency.

5 After עבר was written "deputy high priest."

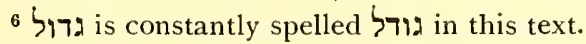

על עליך עor. The t was deflected toward $o$.

${ }^{8}$ From I Samuel iv, 4 .

9 The writer intended הגרול הגבור הנורה.

10 There is a deleted letter in האמרורמר.

11 Magical words of power. On the margin: "Forever and ever."

12 Arabic as well as Hebrew.

13 There would be danger in dealing with unwilling spirits.
} 
פ ותראיני לי וליה אמר

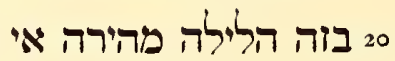

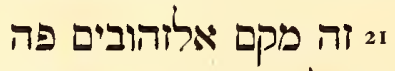
22 אלכה עינינו נראה וה מה אים 23 המקם תמים תמים 24 בשם השבעתי עוליך אתה תמים תמים

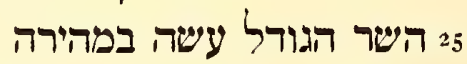

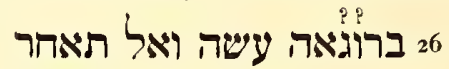
27 28

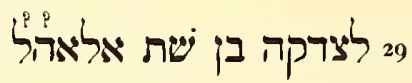

Verso :

30

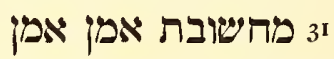
32

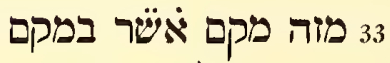
34 ואראה ולא אשכה מתי אתר במקה 35 ואכירה שבע פעומים ואנר ולא

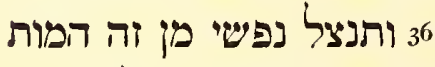
37 הזה השבעתי עוליך 38 אשר הגודל הממונה על השרים עולים

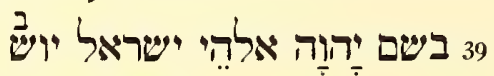
40

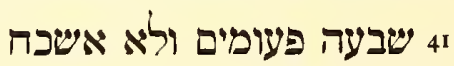

42 43 מלכותו לעיולם וער אמُן 44  אמן

14 For ?ִ? ? (Aramaic).

${ }^{15}$ Arabic article with a Hebrew word.

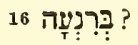


19 and that you cause me to see: [cause] me [to see] it ${ }^{14}$ !

[This, O magician,] say:

${ }_{20}$ "In this night! Quickly! Where is

21 this - the place of the ${ }^{15}$ gold pieces? Here?

22 Let me go! [With] our eyes let us see this-

${ }_{23}$ the place! Perfectly! Perfectly!

${ }_{2}+$ By the Name I have adjured you? ${ }^{2}$ You,

25 the Great Prince! Act quickly,

26 instantly ${ }^{16}$ ! Act, and delay not !

${ }_{27}$ And [by] your honor, which is [the honor of] the Ineffable Name!

28 Let it be a favor from the presence of YHWH,

29 unto Ședhāḳāh Ben Sitt al-Ahl ${ }^{17}$.

Verso:

30 and unto Sitt al-Ahl! And may he make known

$3^{1}$ thoughts ${ }^{18}$ ! Amen! Amen!

32 Selah! Inform us! Where is this-

33 what is this place which is somewhere ${ }^{19}$ !

34 And let me see; and do not you forget [, O Prince ${ }^{20 ! "}$

35 And [this is] the end ${ }^{21}$, [of the spell, which you say] seven times ${ }^{22}$.

36 And may my soul escape this-this

${ }_{37}$ death $^{23}$ ! I adjure you ${ }^{7}$,

38 who are the great one, appointed over the princes,

39 by the name of $\mathrm{YHWH}$, the God of Israel, seated above

${ }_{4}$ o the Cherubim, that you show me the ${ }^{15}$ dream ${ }^{24}$ !

${ }_{4}$ [ [The following say] seven times ${ }^{22}$, and do not forget ${ }^{20}$ :

$4^{2}$ "Thou art blessed, Name of Honor!

${ }_{43}$ His rule is forever and ever! Amen!

${ }_{44}$ Amen! Selah! TT TT TTTT

${ }_{45}$ TT TT TT. TT and TT11

${ }_{4} 6$ Amen! Selah! Blessed is the Name of Honor!

17 I.e. "Lady of the Family." Cf. the Arabic name Sitt al-Dār in No. XI, and Sitt al-

Bahā, Mann, op. cit., ii, p. 363 .

18 For מחשבות.

19 The disjointed construction may be due to confusion.

${ }^{20}$ An Arabic imperative of a Hebrew word.

21 Arabic.

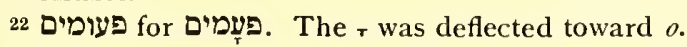

${ }^{23}$ I.e. the result of attempting the spell, or of not ridding oneself of its influence at the conclusion. Cf. p. 49 of the article in J.A.O.S. cited. Professor Campbell Bonner suggests reading "מ̣ת = מית "dead"; and understands here a reference to a necrodaemon.

24 I.e. the vision in the crystal. 
74 השבעתי עליך השר 48 הגודל הממונה 4 השעתי עליך 49 על השרים הגרלים

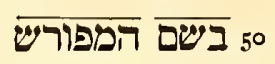
יש שתראיני מקם המרש 25 אלזהובים ולה מיאים 53 אשבה אתה בערק 54 תמים ותגלידה לי 55 לי אנא סורה במהרה 54 65 אמן אמן סלה סורה 
${ }_{47} \mathrm{I}$ adjure you, $\mathrm{O}$ Great

48 Prince, the appointed one

49 over the great princes,

5o by the Ineffable Name!

5I that you show me the place

$5^{2}$ of the gold pieces. And do not

53 you forget ${ }^{20}$ ! [It is] in a box!

${ }_{54}$ Perfectly! And reveal to me!

${ }_{55}$ To me! Me! SWRH! Quickly!

56 Amen! Amen! Selah!" 


\section{DOCUMENT}

A small sheet of paper, $5 \frac{3}{4} \times 5 \frac{1}{2}$ inches, containing a document in Arabic script and language.

The script is atrociously bad; and for the full deciphering, it would need the vision of the late Professor J. Karabacek ${ }^{1}$. In two or three places only are dots used to distinguish one letter from several of its fellows.

The scrawl at the end of line 8 can only be imagined to stand for six hundred. If this is correct, the document is dated Monday, the and of Shawwāl, 654 A.H., or the 23 rd of October, A.D. I 256.

On the verso are three more lines of the same sort, and above these at least one preceding line. Of these scarcely a word can be read.

The difficulty of deciphering such writing as this might be compared to what would be encountered centuries hence by anyone who tried to read the strange marks now made by salesmen on their sales-slips in our department stores.

Grateful acknowledgment of assistance is here made to M. Casanova of Paris, to Mr David Yellin of Jerusalem, and to Mr Raja F. Howrani.

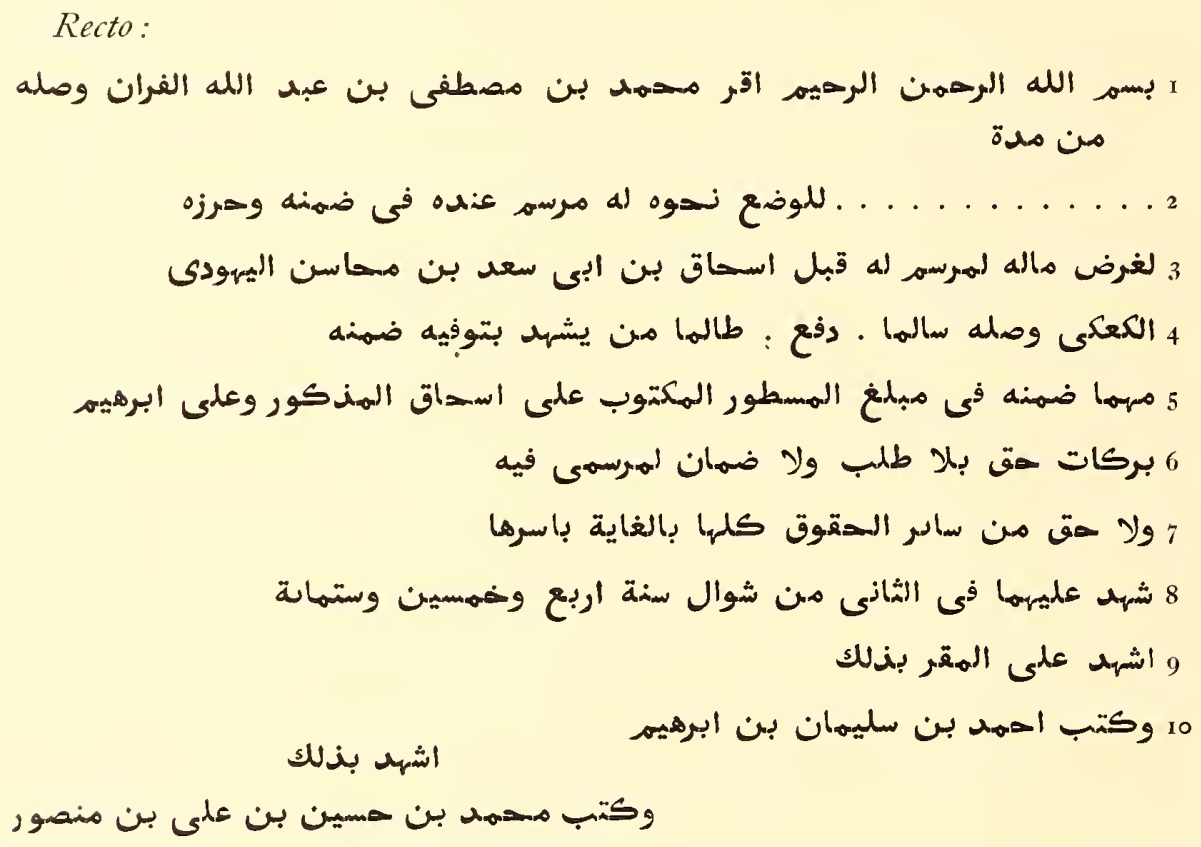

1 See, e.g., his publication of specimens from Arabic documents in Mittheilungen aus der Sammlung der Papyrus Erzherzog Rainer, vols. ii and iii, pp. 87 seq., his Fïhrer durch die Ausstellung, p. 259, and al-Kalkâshhandì's Subhh al-A'shä, vol. iii, pp. 55-142. 


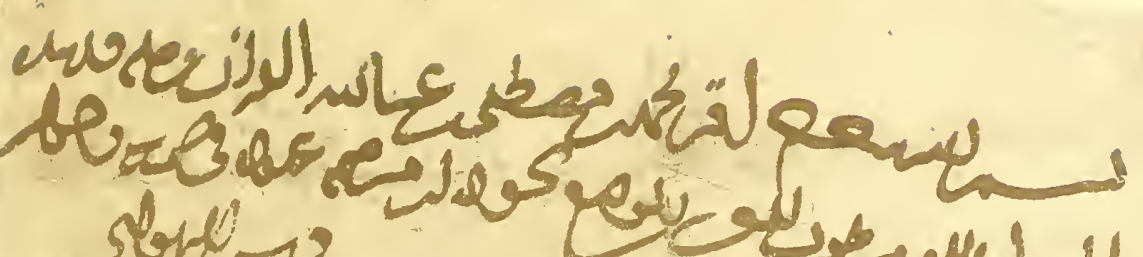

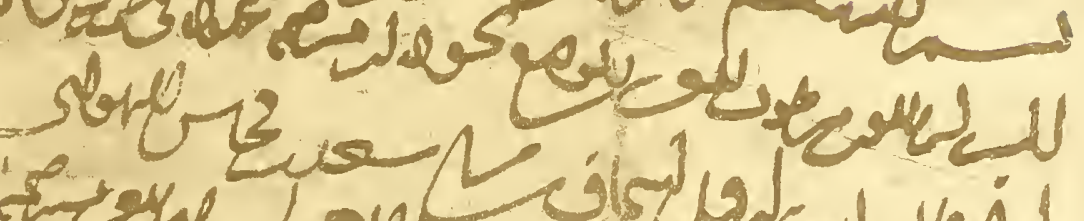

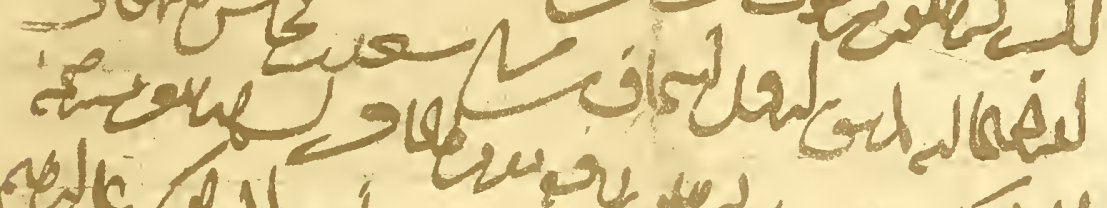

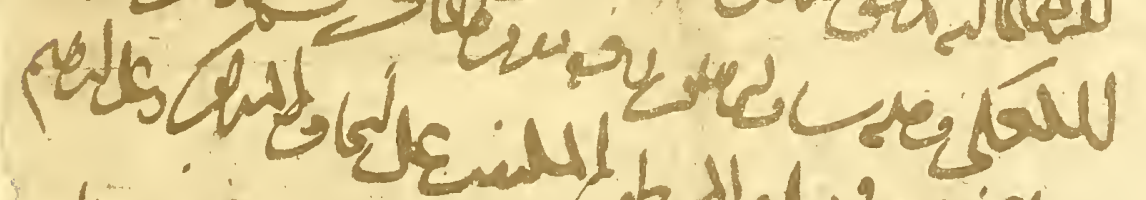

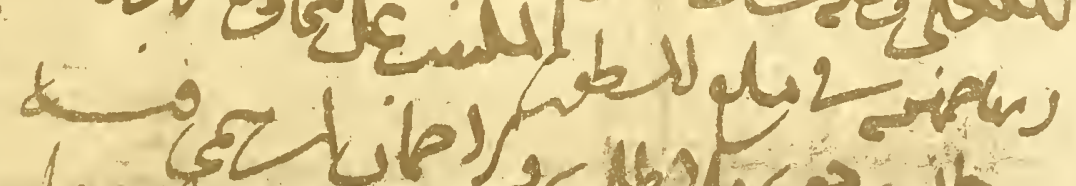

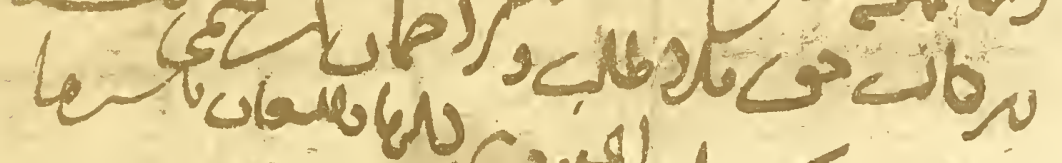

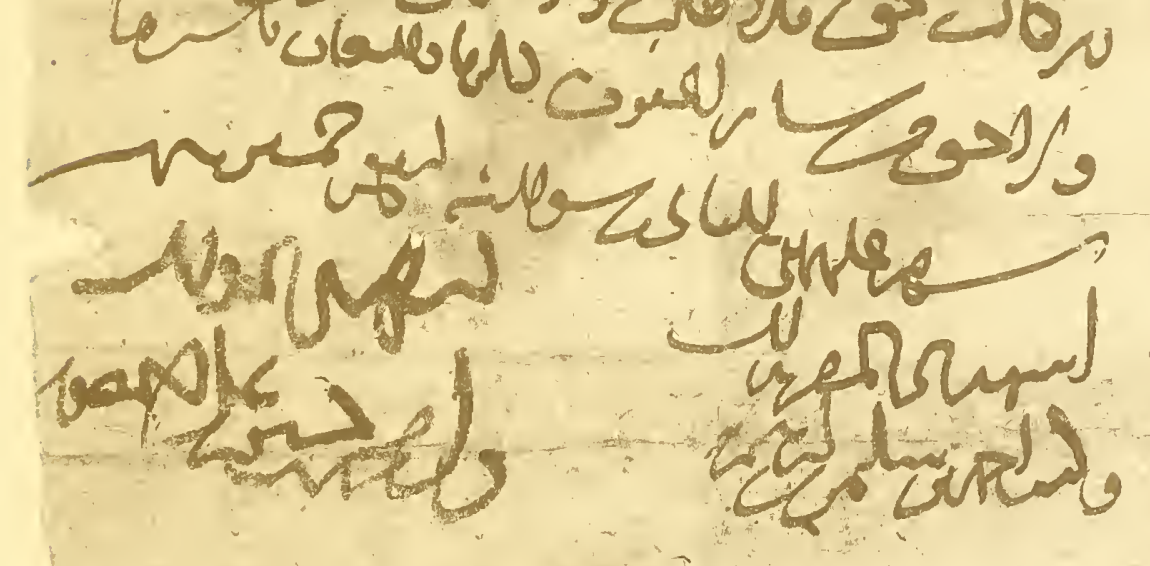

Genizah Fragment 16 a 


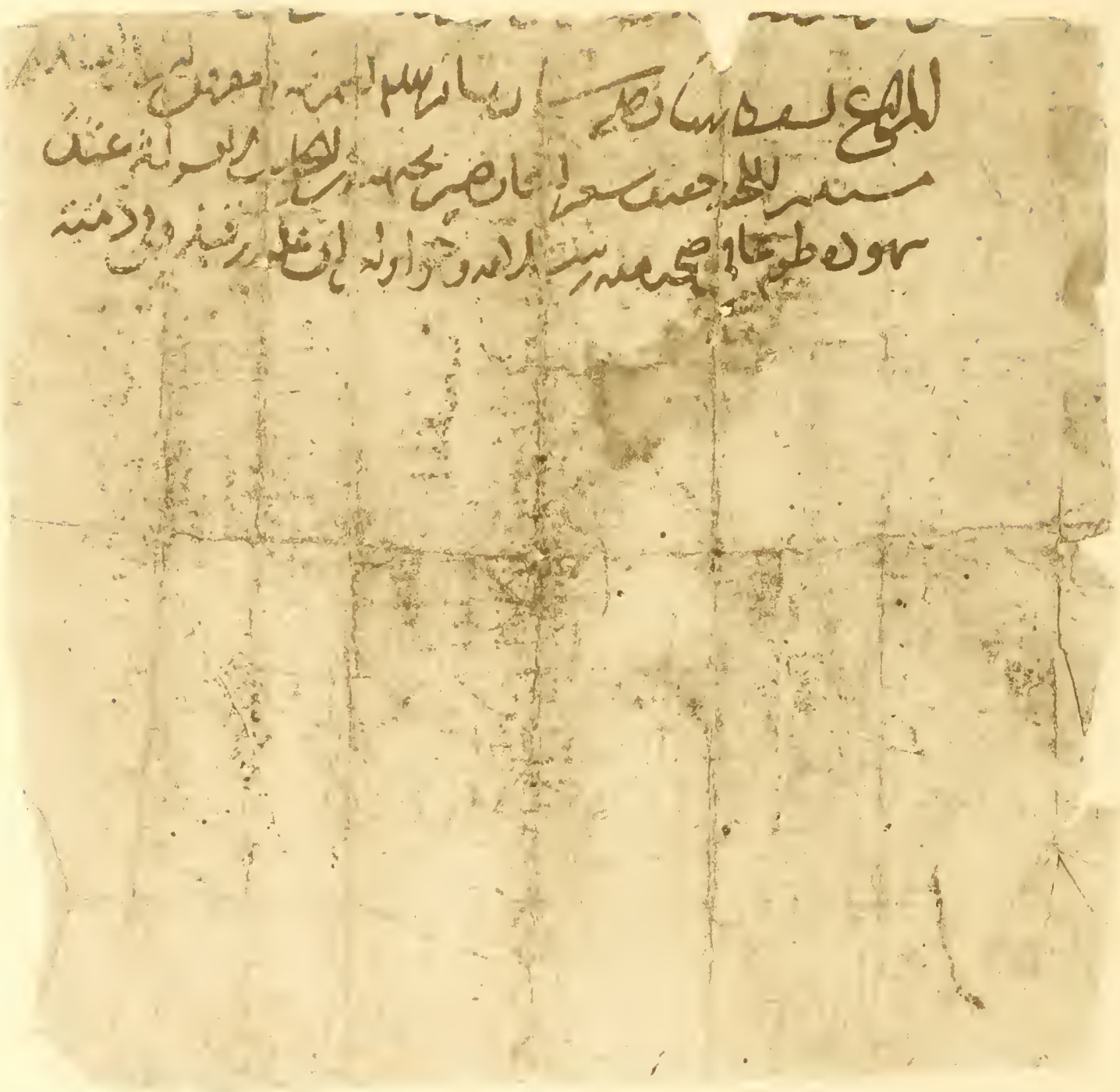

Genizah Fragment $16 \mathrm{~b}$ 


\section{DOCUMENT}

A document in which a Muslim, Muhammad Ibn Muștaphā, acknowledges that he has received from two Jews, Isaac Ibn Abū Sa'd and Abraham Barakat, the value of money which they owe him. Isaac and Abraham are released from any further responsibility for this. Isaac seems to have transacted the business. Two Muslims sign their names as witnesses of the acknowledgment. Muhammad Ibn Muștaphā does not himself sign. The words "he wrote" before the signatures show that we have here only a copy of the document. Perhaps this is often the case with our fragments.

Recto :

I In the Name of God, the Merciful, the Compassionate! Muhammad Ibn Muṣtaphā Ibn 'Abdallāh, the Baker, acknowledges [that] he received some time ago

2 .............. as a deposit and so forth ${ }^{3}$, belonging to him, itemized, in his possession, in his responsible custody,

3 as something belonging to him, documented as his, in the presence of Isaac Ibn Abū Sa'd Ibn Muhāsin the Jew,

${ }_{4}$ the pastryman, [that] he has received safely......payment.......as long as anyone witnesses the complete payment of his responsibility,

5 whatever his responsibility, in the sum documented and written down against the aforementioned Isaac and against Abraham

6 Barakāt, a right without question and without responsibility for the things explicitly mentioned ${ }^{4}$

7 or any claim of all the remaining [possible] claims, at the utmost, in their entirety.

8 He testified regarding the two of them on the second of Shawwāl, [of] the year six hundred and fifty-four.

9 I testify regarding him who acknowledged this : And he wrote ${ }^{5}$ : Ahmad Ibn Sulaimān Ibn Ibrahīm." I testify regarding this :

ro And he wrote ${ }^{5}$ : Muhammad Ibn Huṣain Ibn 'Alī Ibn Manșūr."

2 Evidently certain articles are named here, or sums of money. The second word in this line occurs again as the fourth word in line 4 .

3 ; 30 , abbreviating some documentary formula.

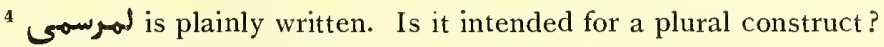

5 Equivalent to our bracketed word "Signed." 


\section{XVII, PENITENTIAL HYMN}

Paper $\operatorname{IO}_{5}^{5} \times 3^{\frac{3}{4}}$ inches, written upon both sides.

Hebrew in rude, cursive Hebrew letters.

The strophe is of four lines, the first three of which rime, while the fourth line contains the general rime of the hymn. The first line in the fragment contains the end of one stanza. There follow three stanzas, and then comes one line containing a few words of supplication that are often used as a mark of division between one poem and another one succeeding it. After these stanzas come two stanzas of two different pizmōnīm; but these contain only two lines each, so-called "sheniyyah," though the same rime ends each half-line. A later hand has copied and fully punctuated these two stanzas.

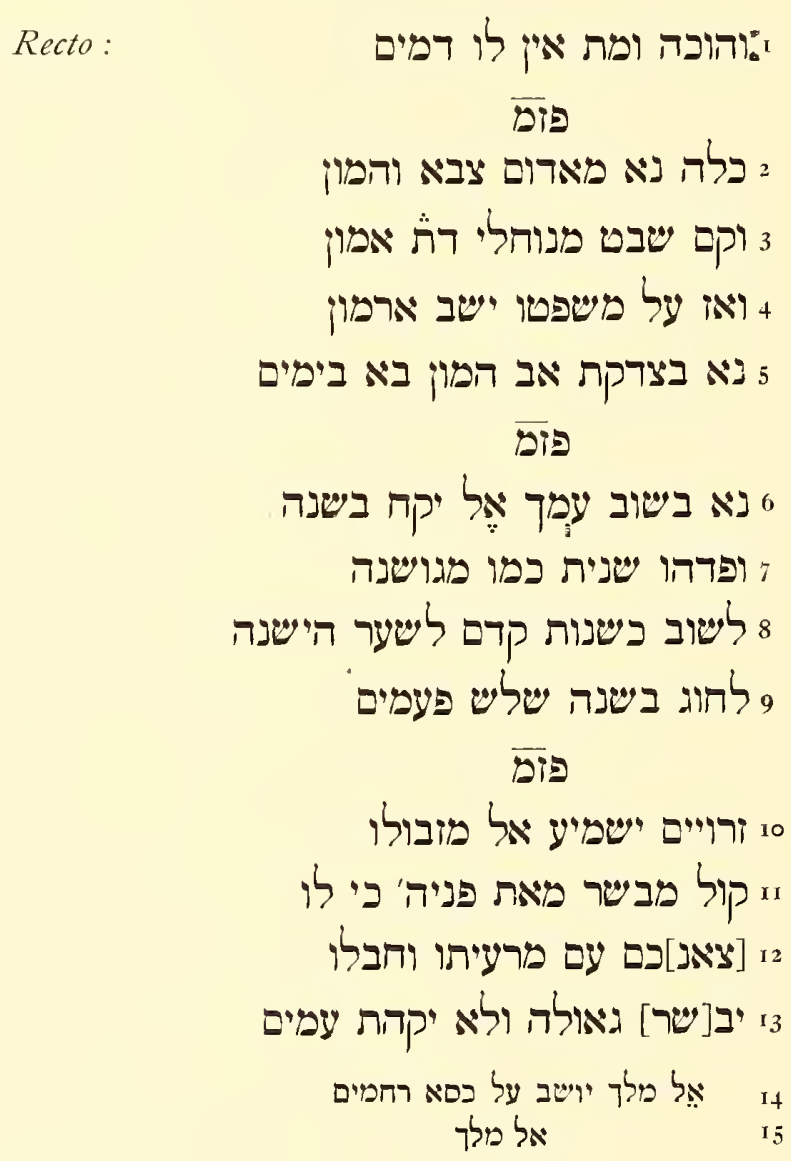

1 Cf. Exodus xxii, I.

${ }^{2}$ I.e. Rome or the Byzantine Empire.

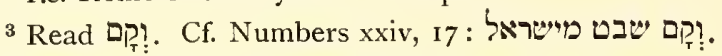

${ }^{4}$ The reference is, of course, to Egypt. The original reading of the third word was מגאון. This has been smudged out and beneath it מנוחלי written. 


\section{PENITENTIAL HYMN}

A portion of a Pizmōn, i.e. a hymn with a refrain, forming a part of the extensive Selihah, or penitential, literature, which was composed by the Jews during the early Middle Ages, and graced the Synagogal liturgy upon days set apart for invoking the forgiveness and the clemency of God.

Acknowledgments are due to Professor Israel Davidson for his help with some of the faded places, and with the literature.

\section{Recto:}

I And be smitten that he die, there shall be no blood shed for him ${ }^{1}$.

\section{Pizmōn.}

2 Make an end, now, in Edom ${ }^{2}$ of host and legion,

3 And a sceptre shall rise ${ }^{3}$ out of [Israel,] the inheritors of [subjection to] the law of Ammon".

+ And then in judgment may He sit in His palace-

5 Because of the righteousness of the Father of Nations, stricken in age ${ }^{5}$.

Pizmōn.

$6 \mathrm{O}$, when Thy people repenteth, let it not receive shame ${ }^{6}$.

7 Redeem it a second time as Thou didst from Goshen,

8 That it may return, as in days of yore, to the Old Gate?

9 To celebrate Thy festivals three times a year.

\section{Pizmōn.}

ro May God cause His scattered ones to hear His voice from on high,

Ir A voice of good tidings from God himself, that to Him belongs

I2 Your flock ${ }^{8}$, together with its pasture-place and its land,

I3 Proclaiming redemption ${ }^{9}$. To Him the people shall gather.

It O God, King, that sittest upon the seat of mercy.

I $_{5} \mathrm{O}$ God, King !

${ }^{5}$ I.e. Abraham; cf. Genesis xviii, II ; xxiv, I. The scribe wrote at first באימין, which he then corrected.

${ }^{6}$ Cf. Hosea x, 6:

7 Cf. Nehemiah iii, 6.

${ }^{8}$ Reading quite uncertain. Professor Davidson suggests as a possible reading עדריכם.

${ }^{9}$ Professor Davidson disagrees with the reading, and believes that only four letters fill the space, i.e. גולה. It is peculiar that ול ולא ול though in the passage (Gen. xlix, 10) there is no Kere and Kethibh. 
Verso:

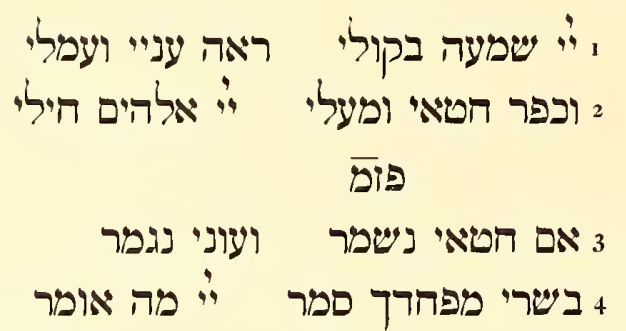

XVIII. LEAF FROM A MERCHANT'S NOTE-BOOK

Paper $9 \frac{5}{8} \times 3 \frac{1}{4}$ inches.

Leaf from a merchant's note-book.

Arabic in Hebrew characters : written in a hurried cursive hand, similar to that on the verso of No. XXXVI, and very difficult to read.

Recto:

, אבו זכרי קפו וה' כו יאו

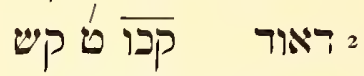

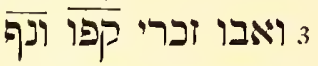

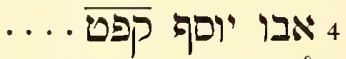

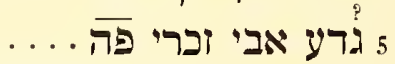

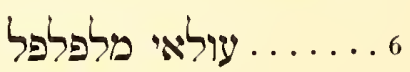

שי מוֹ

7

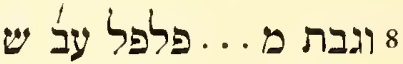

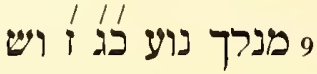

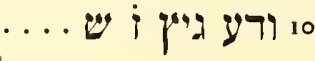

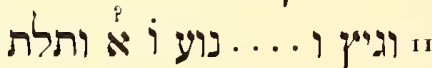

12

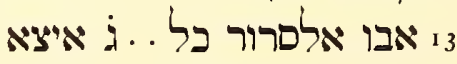

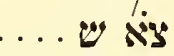

I4

15 ועריה צרת תצל בכלט ...

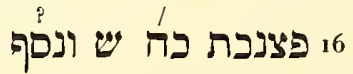


Verso:

I $\mathrm{O}$ God, listen to my voice, understand my affliction and my travail.

2 Forgive my sins and my faithlessness. The Lord God is my strength ${ }^{\mathbf{1 0}}$.

Pizmōn.

3 If my $\sin$ is to be remembered, if my iniquity is to be completed, 4 From fear of Thee my flesh would creep; O God! What shall I say ${ }^{11}$ ?

\section{LEAF FROM A MERCHANT'S NOTE-BOOK}

It is impossible to give a connected translation, or even to transcribe more than these first two sections of the recto. The remaining section of the recto, and the verso, which has two sections running from opposite ends to the center, are in the same hand, though more carelessly written.

Below we print a few of the expressions which are recognizable.

Recto:

I Abū Zachariah, I 26 and 5, 26

2 David, I 26 9, 100, 300

3 and $A b \bar{u}$ Zachariah, I 86 and a half

+ Abū Joseph, I I $89 . . . . \ldots . .$. .

5 Abū Zachariah's boy, $85 \ldots \ldots \ldots$

6 ...................tith pepper,

7 97,300

8 And I brought.........pepper, 72, 300

$9 \ldots \ldots .$. variety, 23,7 and 300

10 ............., 300

r ...........variety, 6, I and a third.

12 ............thousand.

I3 Abū al-Sarūr, all...3 also

149 I, 300

I5 and he owes......combined with $29 . . .$. .

16 .........28, 300 and a half

${ }^{10}$ Cf. Habakkuk iii, I9. $\quad 11 \mathrm{Cf}$. Joshua vii, 8. 
XIX. POETIC FRAGMENTS UPON THE BACK OF AN ARABIC DOCUMENT

Paper $4 \frac{1}{2} \times 3 \frac{7}{8}$ inches.

Portion of a book (?) made up of long strips of paper which had been used once before. Upon the back there are some lines in a hopelessly difficult Arabic script.

Recto:

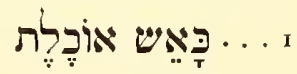

!

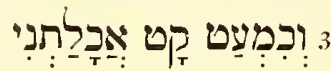

4

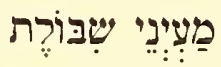

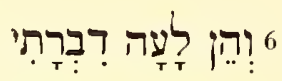

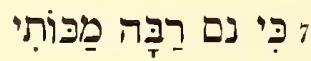

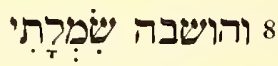

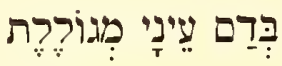

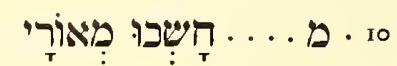

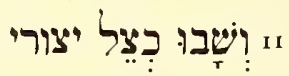

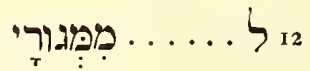

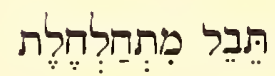

13

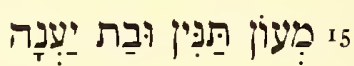

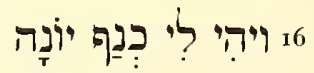

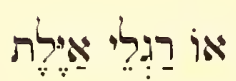

17

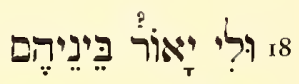

18 18

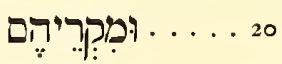

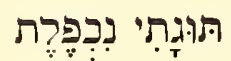

2 I

.... . רנד

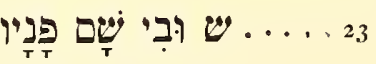

1 Cf. Ezekiel xvi, 47. 


\section{POETIC FRAGMENTS UPON THE BACK OF AN ARABIC DOCUMENT}

The Hebrew of the recto is written in half-square characters, and is a portion of some dìwan or collection of poems. It is, however, written continuously, without any consideration for the form of the poem.

Professor Israel Davidson has very kindly gone over the fragment and made some useful suggestions. The text has been rearranged and pointed by Professor Gottheil.

\section{Recto :}

I....... as a fire that devoureth.

2 And a burning fire of grief.

${ }_{3}$ And, as if that were only a little thing ${ }^{1}$, it hath devoured me.

+ And how it burneth, and hath ground me in pieces!

5 [Like the] sources of a torrent.

6 And behold, my utterance stammereth.

; For my wounds [are] a great wonder(?)

8 And my garment hath been cut(?)

9 Rolled in the blood of mine eyes.

$10 . .$. . And my lights have grown dark

I And my creations(?) have become like a shadow.

I $2 \ldots \ldots$ from my neighbourhood.

I3 A shaken world.

It And ....... let me dwell.

I5 The haunt of jackals ${ }^{2}$ and the ostrich.

i6 And let me have the wing of a dove

${ }_{17}$ Or the legs of a hind.

I8 And I shall have light in their midst.

19 To dwell ........ among them.

$20 . . . \ldots$ and their accidents.

2s My grief is doubled.

22 And I shall wander.........

$23 \ldots \ldots \ldots$ and in me there $\mathrm{His}$ face ......

${ }^{2}$ Cf. Jeremiah ix, Io 


\section{LEAF FROM A BOOK OF POEMS}

Paper $5 \frac{3}{8} \times 3 \frac{3}{4}$ inches.

A leaf, in a half-square hand, from a book of Hebrew poems.

It begins with the last verse of a poem by Abraham Ibn Ezra (I092I 167), the acrostic of whose name, Abraham, can be followed at the beginning of the four verses that remain out of the five. The first stanza must have been rimed with a mun. Each stanza is separated from its successor by the word pisis.

Recto:

$\overline{s i g}$

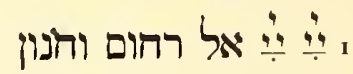

$$
\begin{aligned}
& \text { 2 יִי בצל ידך כל כםית } \\
& 3 \\
& 4
\end{aligned}
$$

$\overline{9 i 2}$

5

6 6

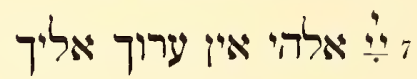

מפ

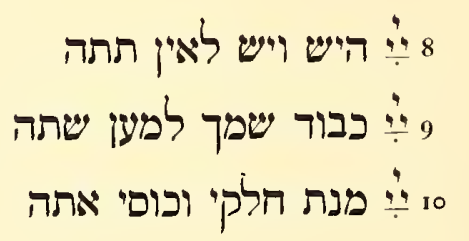

$\overline{\text { Dig }}$

יי יִי ממרום שלח קחיני

Verso:

$$
\text { 12 } 12
$$

${ }^{1}$ Cf. Isaiah li, I6.

2 Cf. Psalm civ, 24.

${ }^{3}$ Cf. Psalm xl, 6. The word $\lceil " \aleph$ is badly written 


\section{LEAF FROM A BOOK OF POEMS}

The second poem, as Professor Davidson was quick to detect, is by Judah ha-Lèvi (b. IO35). The acrostic of his name can be discerned in the last six of these eight verses of the poem, the whole of which can be found in the Diwān des Abu-l-Hasan Jehuda ha-Levi (ed. H. Brody), vol. iii, p. I64. The writer of our fragment calls it : פis according to the opening words. Brody's edition furnishes our emendations and restorations.

\section{Recto :}

r Lord, Lord God, Merciful and Compassionate.

\section{Pizmōn}

2 O Lord, Thou hast covered everything with the shadow of Thy Hand ${ }^{1}$ !

${ }_{3} \mathrm{O}$ Lord, over dark waters Thou hast raised a light.

4 O Lord, in wisdom Thou hast made them all².

\section{Pizmōn}

5 O Lord, Thou art very high-placed and who can comprehend Thee?

6 O Lord, Thou hast made everything dependent upon Thee.

${ }_{7}$ O Lord, my God, there is nothing that can be compared unto Thee ${ }^{3}$.

Pizmōn

8 O Lord, Existence, [who bringest] existence to nought".

${ }_{9} \mathrm{O}$ Lord, for the honour of Thy name [Thou hast caused] the year [to be.] Io $\mathrm{O}$ Lord, the portion of mine inheritance and my cup art Thou ${ }^{5}$.

\section{Pizmōn}

ir O Lord, send from above and take $\mathrm{me}^{6}$.

\section{Verso:}

$12 \mathrm{O}$ Lord, lead me whilst in this life, by Thy counsel.

${ }_{3}$ O Lord, chasten me not in Thy hot displeasure?

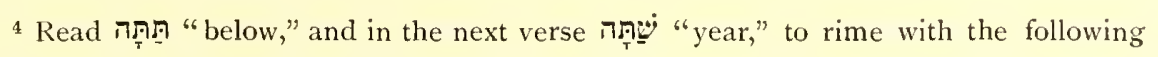
הฺָุ.

5 Cf. Psalm xvi, 5.

6 Psalm xviii, 17.

7 Psalm vi, 2. 
פופ זיז

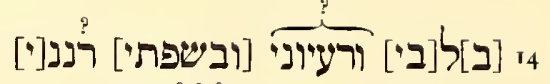

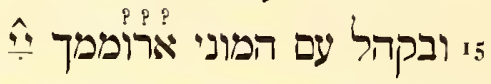
6ו ירידי בשיחרים קחו נא הישרים

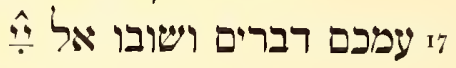
פופ בלבי

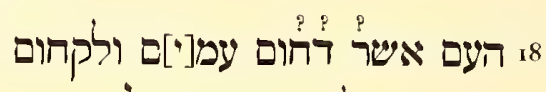

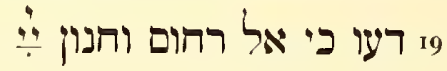
פוזמ בלבי 20 ואחת שיאלתי יבשר סלחתי

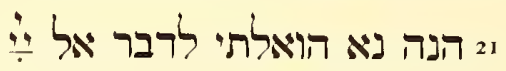
sis

${ }^{8}$ Read 'צומו and $\mathrm{cf}$. II Samuel xx, I9.

9 Hosea xiv, 3. 


\section{Another Pizmōn}

${ }_{14}$ In my heart and in my thoughts and upon my lips is my rejoicing.

${ }_{15}$ In the congregation of my faithful people ${ }^{8}$, will I praise Thee O Lord.

ז6 $\mathrm{O}$ my beloved ones, at early morn take now the righteous.

${ }_{7}$ [Take] with you words, and return unto the Lord ${ }^{9}$.

\section{Pizmōn "In My Heart"}

I8 $\mathrm{O}$ people, whom [other] peoples have oppressed and taken captive,

${ }_{19}$ Know that gracious and full of compassion is the Lord ${ }^{10}$.

$$
\text { Pizmōn “In My Heart” }
$$

20 One favor I ask, Speak the word 11 "I have forgiven ${ }^{12}$."

21 Behold now, I have taken it upon me to speak unto the Lord ${ }^{13}$.

\footnotetext{
10 Psalm cxi, 4 .

11 Read תבשר.

${ }^{12}$ Numbers xiv, 20.

${ }^{13}$ Genesis xviii, 27
} 


\section{LETTER}

Paper $7 \times 6 \frac{1}{4}$ to $7 \frac{1}{4}$ inches.

Arabic in peculiar, perhaps Maghribi ${ }^{1}$, cursive Hebrew characters, at times difficult to read. The last line, and two words elsewhere, are in Arabic characters.

\section{Recto:}

ו יא מולאי וסירי אראם אללה עיךך ואטאל מרתך כתבתה לילה אלאדר

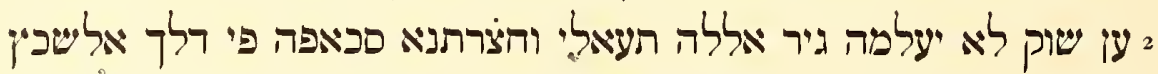

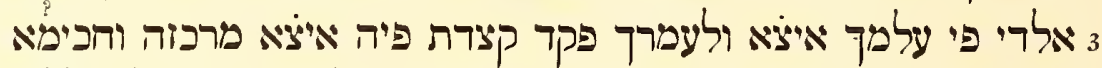

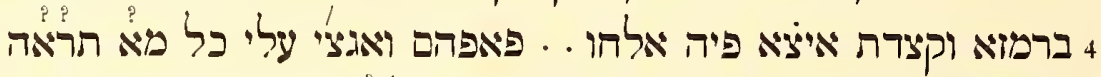

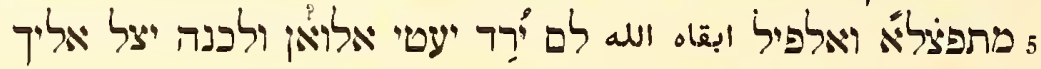

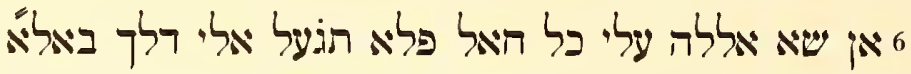

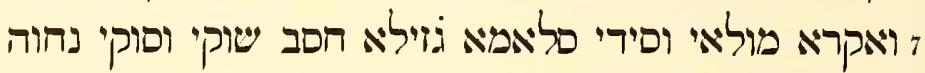

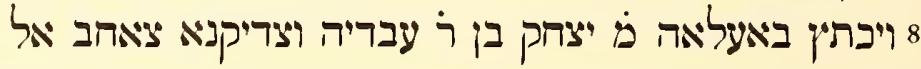

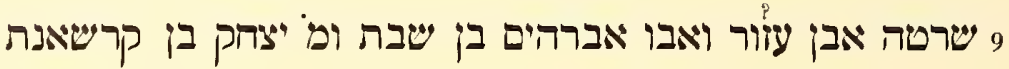
o וסאיר אלאבואן תם עלי מולאי מעאראי ورحمة الله تعلى وبركته لائه I J

Margin:

\section{וכתבת עלי חפי שריד פעדרני אלי פציל מולאי}

Verso:

\section{אלחכם אלאגל אלריים אלאבמל רב חלפון הלוי زרו}

1 "Letters in a similar script I have come across in Bodleian MS. Heb. c. 28 ; 51 r. (addressed to a certain Abū Sa ${ }^{t} \bar{i} d$ ); in Bodleian MS. Heb. d. 66, No. 8o, as well as in a letter belonging to the collection of the Paris Consistoire (No. VII, E. 24)-which the Grand Rabbin M. Israel Lévi was kind enough to send to me-sent by a certain Hayyim Ibn Hānī of Ispahan. Evidently, the last had made use of a Maghribī scribe while, probably, in Morocco." (Professor Gottheil.)

2 I.e. "you." "I do not wish to bias you." 


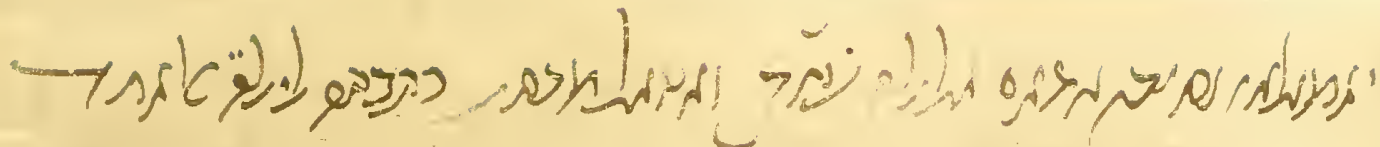
Fo⿰⿺乚一匕 的

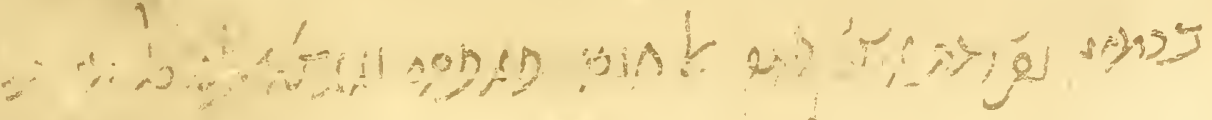

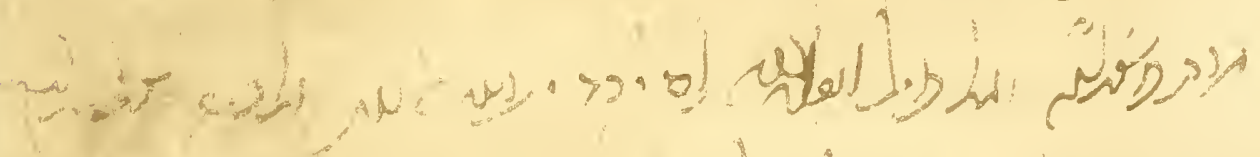

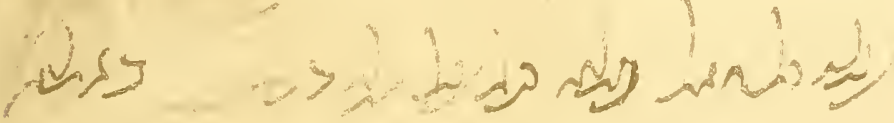

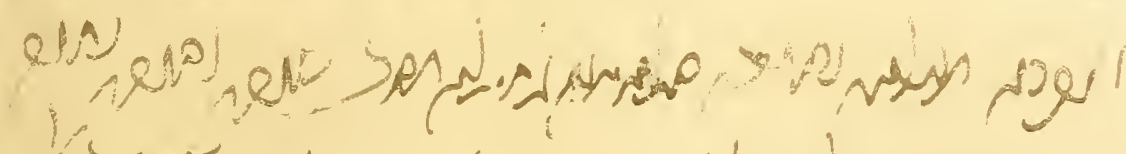

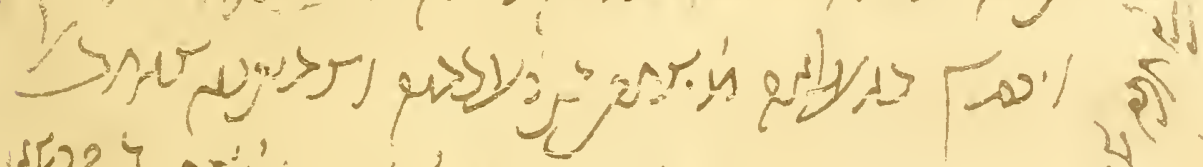

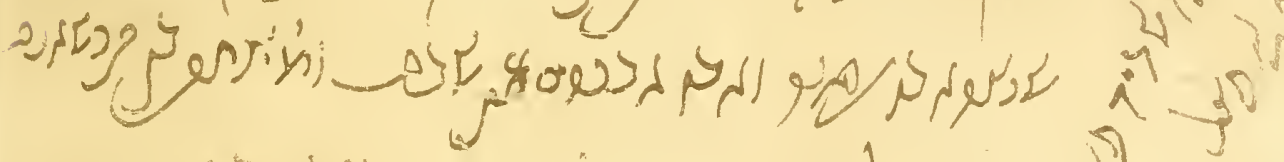

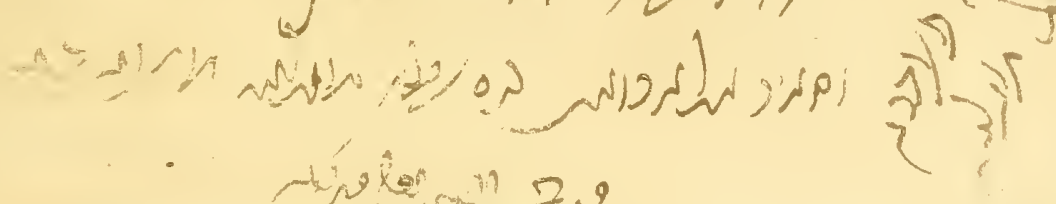




$$
\text { - }
$$




\section{LETTER}

A polite and elegant letter from an unnamed person to the ra'îs, Rabbi Halfōn ha-Lēvī, who may be one of those mentioned in Mann, op. cit., vol. ii, pp. 232, 237 ; Jewish Quarterly Review, vol. xix, pp. 730, 733.

\section{Recto :}

i O my Lord and Master! May God continue your strength and lengthen your life! I have written [this] on Saturday night

2 with the wish [that] none but God Most High should instruct him². Well, we have suffered a $\operatorname{loss}^{3}$ in this individual.

3 as you also know. For, by your life, you also sought in him a support, and a wise man

4 among [the] wise ${ }^{4}$. And you also sought in him........ But understand, and close your eyes to all that you see,

5 if you will be so kind ${ }^{5}$. And the elephant-God keep him!-did not wish to give colors; but he will reach you,

6 if it please God, in any case $^{6}$. So give no thought to that matter.

7 And I greet my Lord and Master becomingly, according to my desire and my inclination toward him.

8 And this applies in the highest degree to Master Isaac, son of Rabbi Obadiah, and our friend, the Chief of the

9 Police, Ibn 'Azūr (?), and Abū Abraham Ibn Shbt, and Master Isaac Krshänt,

Io and the rest of the brethren. Then [greetings] to my Master once more, 1 and the Mercy of God Most High, and His Blessing!

\section{Margin :}

And I have written in great haste ${ }^{7}$, so excuse me to his Excellency, my Master.

Verso:

[To] the Most Glorious Judge, the Most Perfect Chief, Rabbi Halfōn ha-Lēvī.

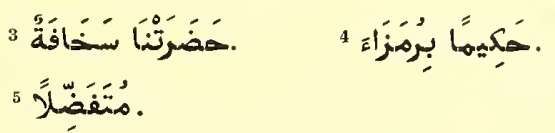

${ }^{6}$ Quite plainly written. Is this a reference to some person? Cf. p. I8, note I.

7.e. Iَفْند. 


\section{A BUSINESS LETTER}

Paper $7 \frac{1}{2} \times 5 \frac{1}{2}$ inches.

Arabic in cursive Hebrew characters, like those of III, XII, XXXIII, XXXIV, XXXV, all very difficult to read because of the levelling of many letters to the same form. The writer relied upon muscular sensation, more than upon sight. When the connection is lost reliable translation becomes impossible.

Recto:

ו תקדם כתאבי אליך יאבי ואלעיזי אטאל אללה בקאך ואראם תאירך

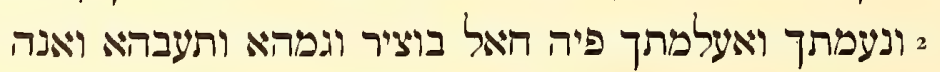

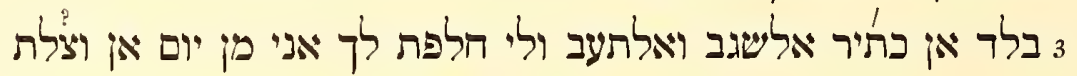

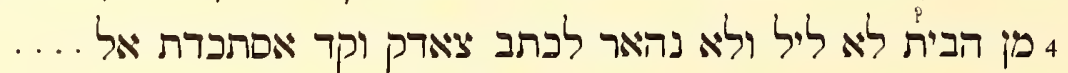

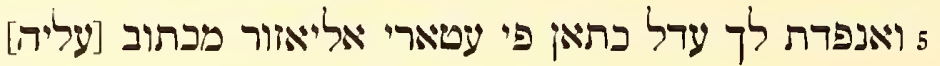

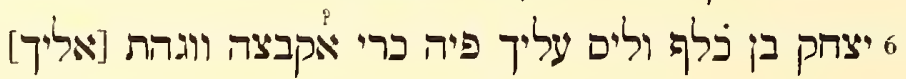

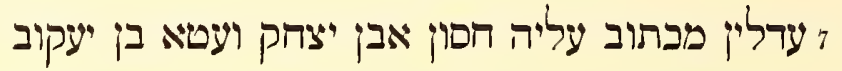

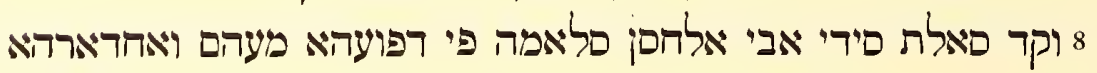

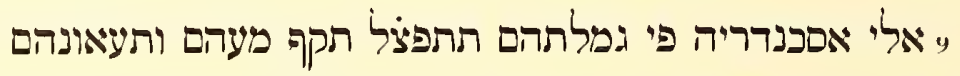

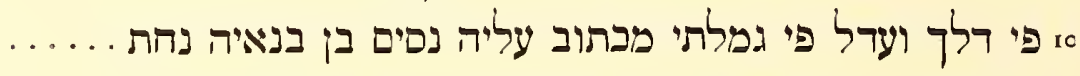

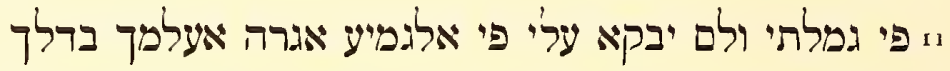

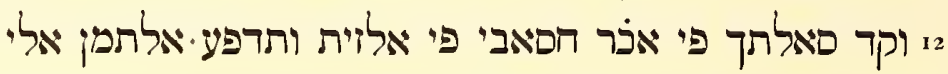

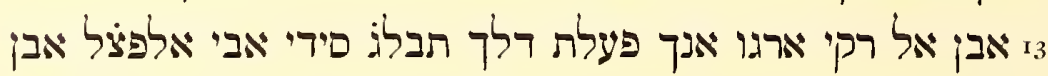

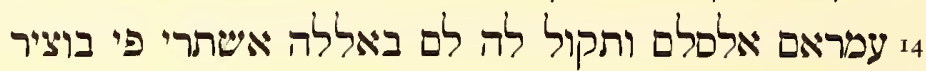

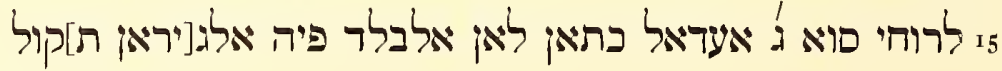

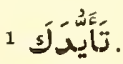

2 Cf. Yâkūut, sub voce بُوصير, vol. i, p. 760, who says it is the name of four towns in Egypt: (1) near Eshmunēn, (2) near Gīzeh, (3) in the Fayyūm, (4) near Samanūd. It might be Taposiris Magna, near Alexandria, now called Abūṣîr.

3 غَمَّه. The reference is possibly to persecution of Jews.

4 í used as a relative with indefinite antecedent, as in No. IX, recto, I. I I; verso, 1. 35 ; bottom of verso, 1.3 .

5 i here is أََ in the sense of German "da": "Seit dem Tage da ich..."

'בית המקריט. 


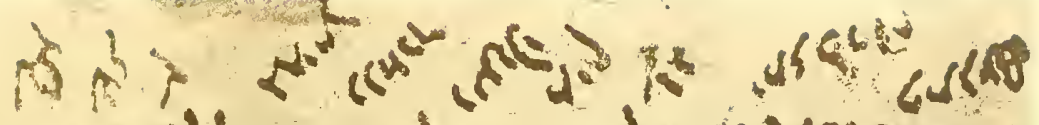

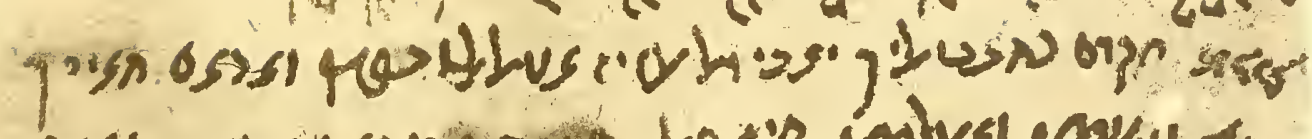

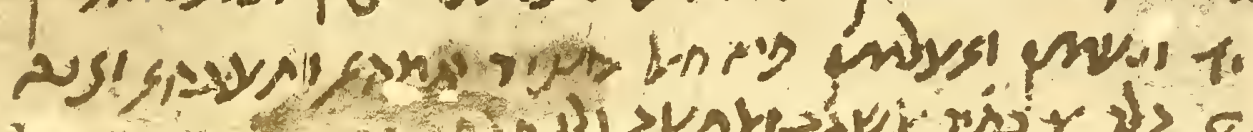

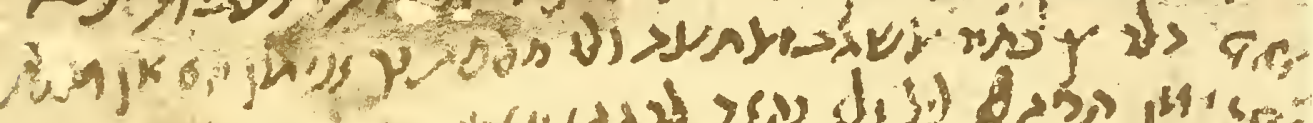

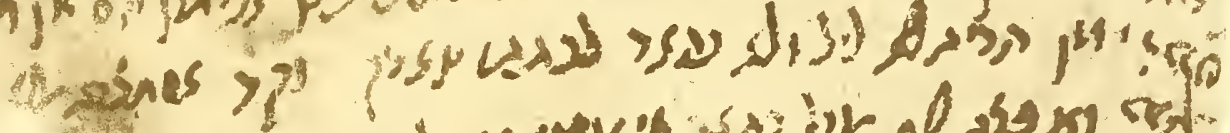

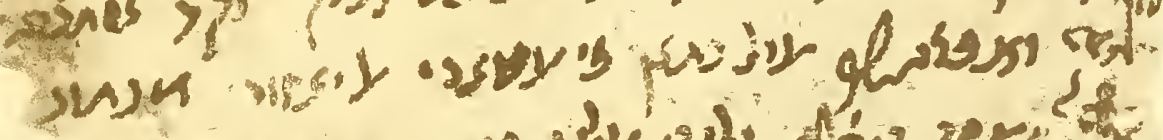

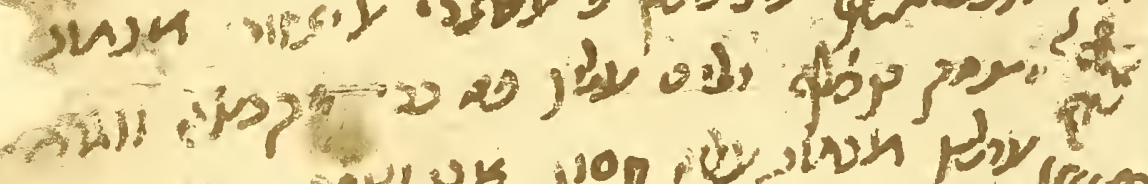
(19)

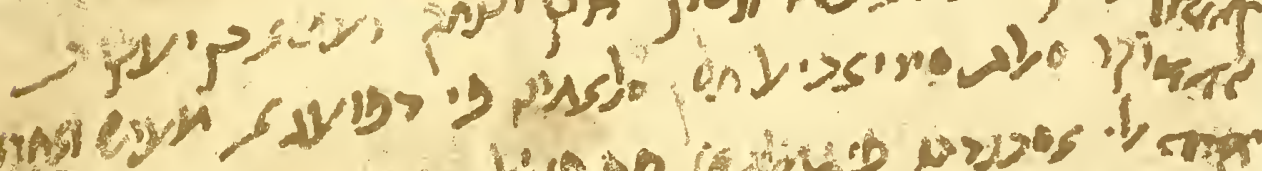

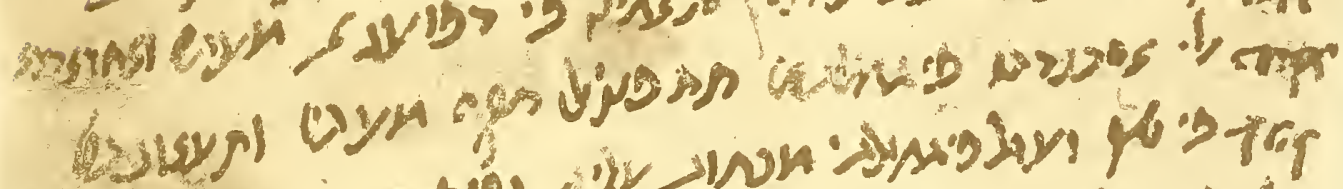

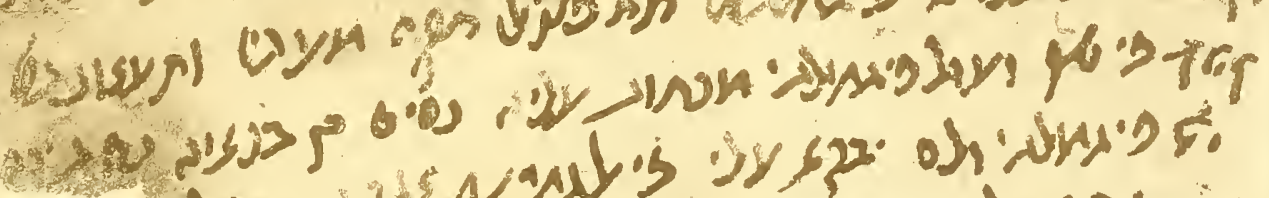

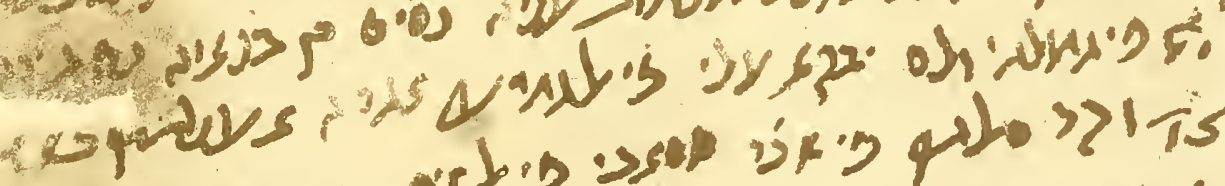

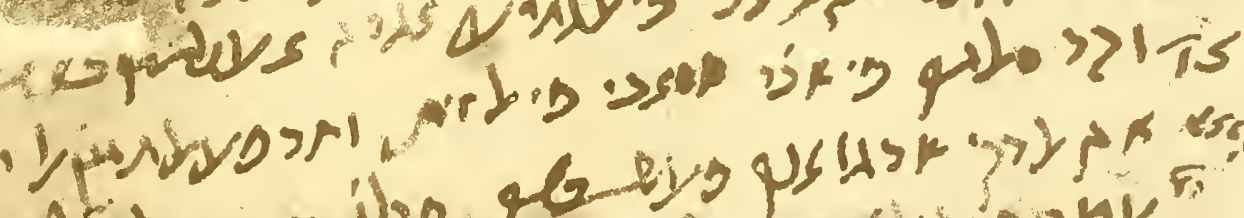

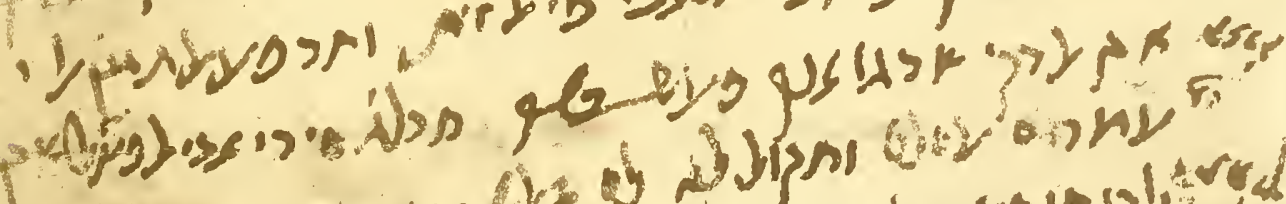

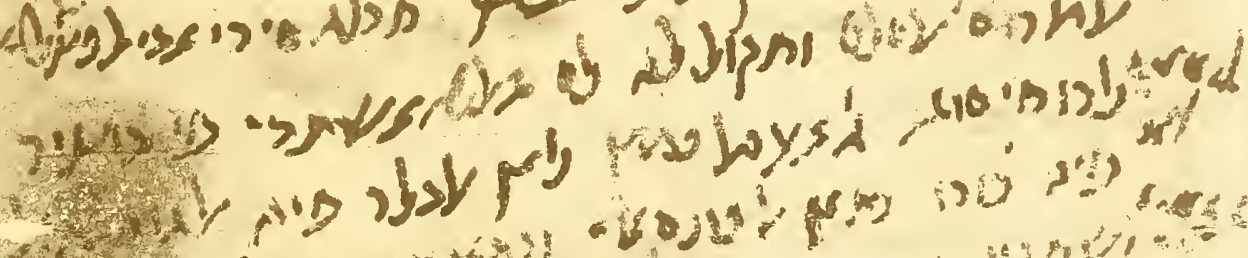

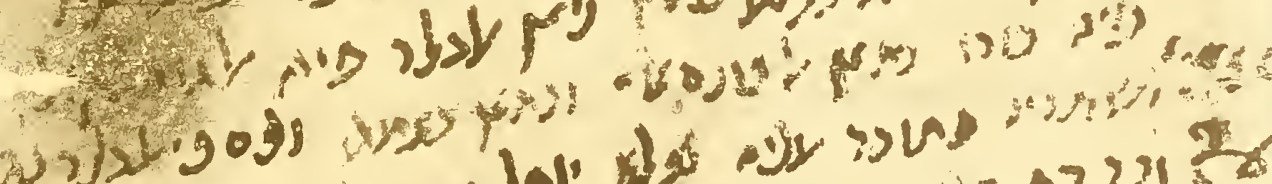
(N)

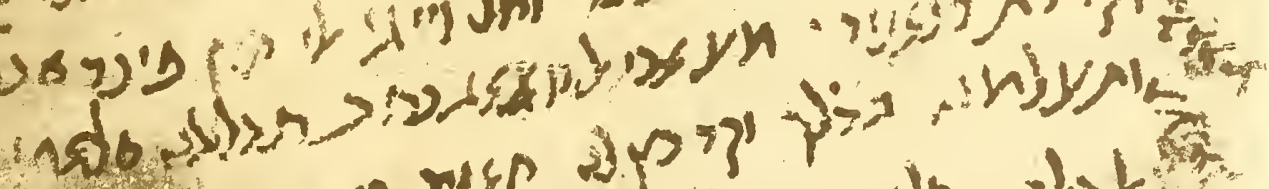

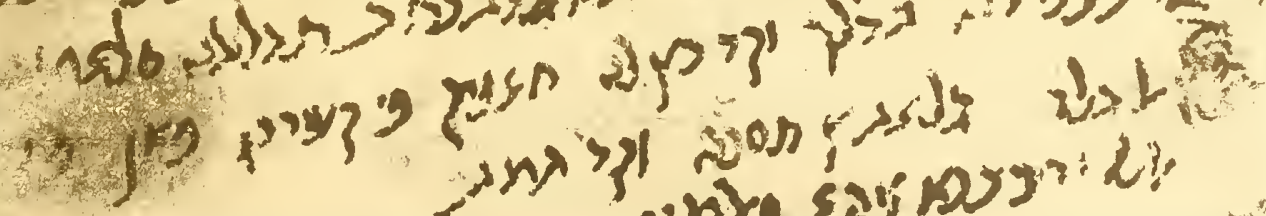
orito sisporid? 


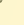




\section{A BUSINESS LETTER}

A letter from Hasan (or Hassūn) Ibn Isaac to his "brother and friend," Abū Joseph Malūl(?) Ibn Moses, dealing in flax or linen.

The Jews are having trouble in Būṣir where flax from France(?) is sold. Directions are given about various business operations.

On the verso are notes in two other hands about bales of flax or linen. They may not refer to the contents of the recto.

Recto:

I My letter goes to you, dear Brother. May God prolong your existence and lengthen your safety ${ }^{1}$

2 and well-being! I [beg to] inform you in it of the condition of Būșīr ${ }^{2}$ and its pain ${ }^{3}$ and travail; and that it is

3 a city ${ }^{4}$ of great trouble and travail. And as for me: I swear to you that I, from the day when ${ }^{5}$ I arrived

${ }_{4}$ from Jerusalem ${ }^{6}$, neither night nor day [have had opportunity] to write ${ }^{7}$. [What I say is] true! And I secured the.........

5 and I sent to you a bale ${ }^{8}$ of flax with 'Ațtāiñ ${ }^{9}$ al-Yãzūrì, on which was written :

6 "Isaac Ibn Khalf." You have no charges to pay in the matter. Accept it. And I sent [you]

7 two bales on which was written: "Hassūn Ibn Isaac" and "Ață' Ibn Jacob" [respectively].

8 And I asked Abū al-Hasan Salāmah to deliver ${ }^{10}$ them $^{11}$ with them ${ }^{12}$, and to bring them ${ }^{11}$

9 to Alexandria in their shipment ${ }^{13}$. Please show them [every] attention and help them ${ }^{12}$

ro in this [matter]. And [I sent you] a bale in my shipment ${ }^{13}$ on which was written: "Nissīm Ibn Banāyah ".........

If in my shipment ${ }^{13}$. And there remain no charges against me for any of it. Of this I inform you [explicitly].

s 2 And I asked you in the latter part of my accounting concerning the oil, [to] pay the price [of it] to

${ }_{3}$ Ibn al-Rakṣị. I hope you have done this. Convey [to] Abū al-Faḍl Ibn

${ }_{4}$ 'Umrān [my] greetings; and say to him : "By Allah, I shall not buy in Būṣir

${ }^{15}$ for myself [anything] but three bales ${ }^{8}$ of flax. Because the neighbors ${ }^{14}$ in the city say(?)

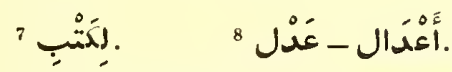

"Or " " 10 רפע for grocer."

11 I.e. the bales. 12 I.e. the addressees in person.

13 álo: 14 I.e. "gentiles"? 


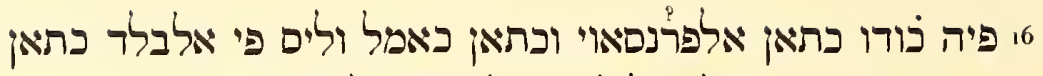

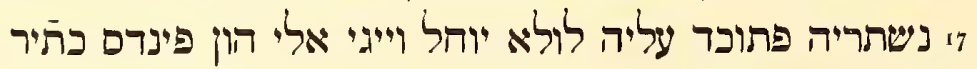

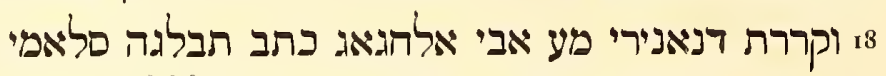

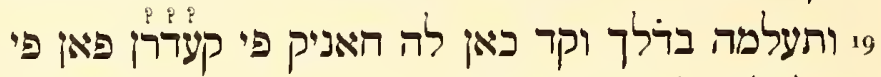

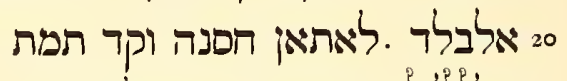

Margin:

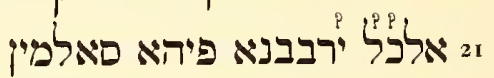

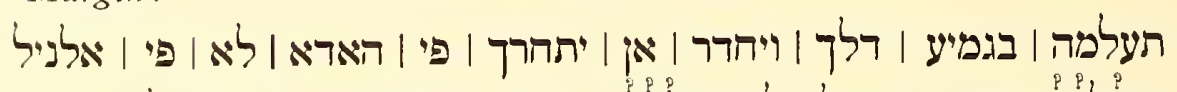

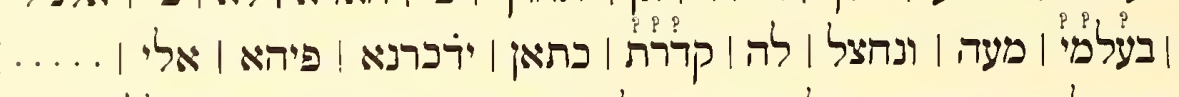

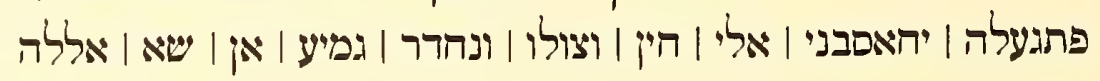

Address on verso:

לאכי ואלעזייו עליי אבי יוסף פִלול בן מן צהבה הסן אבו יצחק פניע

Notes on verso:

אטאל [אללה בקאה] וא[ראם תאיידה

$$
\text { ברההון הרל פברה ברהון }
$$

Note at left:

גמלה מא עלי חנגאג

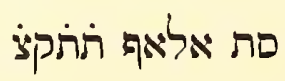

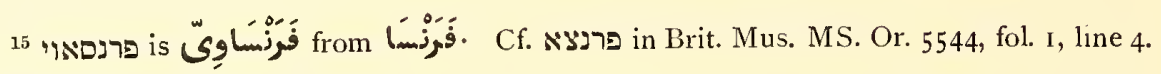
Mann, op. cit., vol. ii, p. 191 .

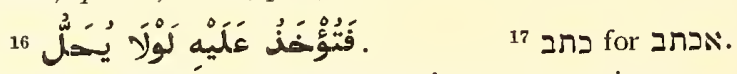

${ }_{18}$ The reference is possibly again to persecutions. 
16 about it: "Take the flax of France ${ }^{15}$, and perfect(?) flax [it is]." But there is no flax in the city that

I 7 we would buy. And you are blamed for it unnecessarily ${ }^{\mathbf{1 6}}$. And one comes [back] here and is very sorry.

18 And I have come to a definite agreement with Abū al-Hajjāj [about] my dīnārs. Write ${ }^{17}$ and convey to him my greetings,

19 and inform him of this. For he has had.........in...... were in

2o the city beautiful........ But all of it has come to an end. May [God] complete our benefit thereby in safety ${ }^{\mathbf{1 8}}$.

\section{Margin:}

${ }^{19}$ Tell him all about this. And let him guard against being excited by this; not about the indigo...... with it. And we shall recover for him a quantity of linen about which he told us......... and have him settle with me when he arrives; and we shall......all, if it please God.

Address on verso:

To my Brother and Friend [more powerful] ${ }^{20}$ than I, Abū Joseph Malūl(?) Ibn Moses. May [God] prolong [his existence] and lengthen [his safety and prosperity!] From his friend Hasan(?) Ibn Isaac.

Notes on verso:

$\begin{array}{llll}\text { Brhōn }{ }^{21} & 35 & \text { Bale } & 40 \text { with address of Joseph } \\ \text { Brhōn } & 40 & \begin{array}{l}\text { Bale } \\ \text { Brhōn }\end{array} & 35 \\ & & \text { Brhōn } & 25 \\ \text { Brhōn } & 45 & \text { Brhōn } & 35 \\ \text { Brhōn } & 45 & & \\ \text { Brhōn } & 90 & & \\ \text { Brhōn } & 40 & \end{array}$

Note at left:

Total of what Hajjāj owes : six thousand 990

\footnotetext{
19 Most uncertain. عَزْيز 20 A pun on the word.
}

21 We do not know the vocalization of this nor its meaning. The same word occurs as a proper name twice in No. XII, lines 22 and 24 . In the present case it might be برهُونون, "by pledges." Cf. Dozy, op. cit., sub voce. Nor do we know the meaning of the letters הتפ, ה־ , הכת, for which of course much might be imagined. Are they numerals with the order reversed? 


\section{NOTES ON THE BACK OF A LETTER}

Paper $18 \frac{3}{8} \times 3 \frac{1}{8}$ inches.

A strip of paper cut from a letter, upon which some hazzān or other person has written in a large cursive hand, as if for posting on the wall, what seems to be the first word or the first two words of certain prayers and pizmōnīm.

A peculiarity of the script is the different ways in which the letter $\boldsymbol{N}$ is written. Cf. lines $\mathrm{I}$ and 2 with lines 3 and 8.

\section{Recto:}

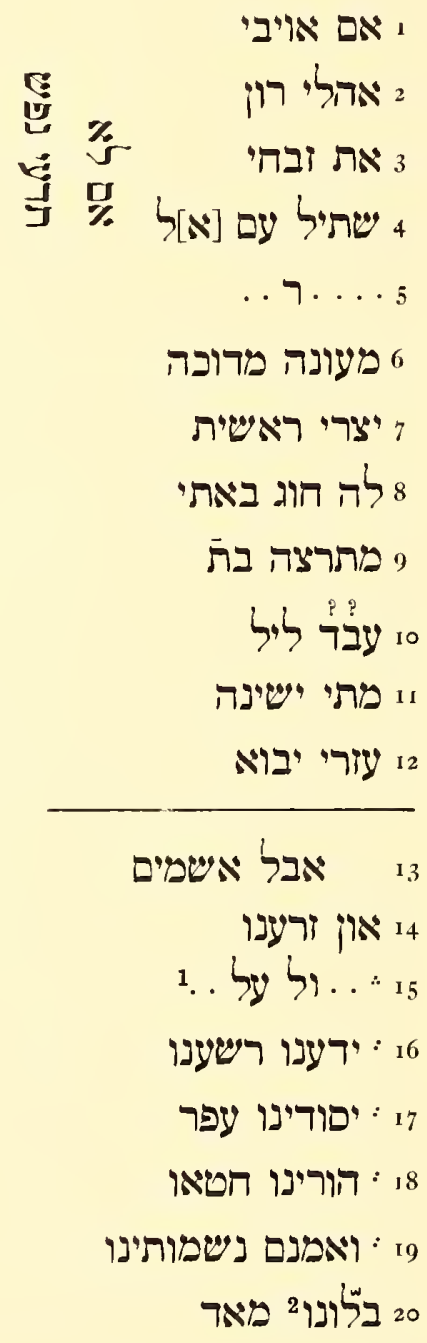

1 The dots at the beginning of this line and of the following ones are in the MS. 


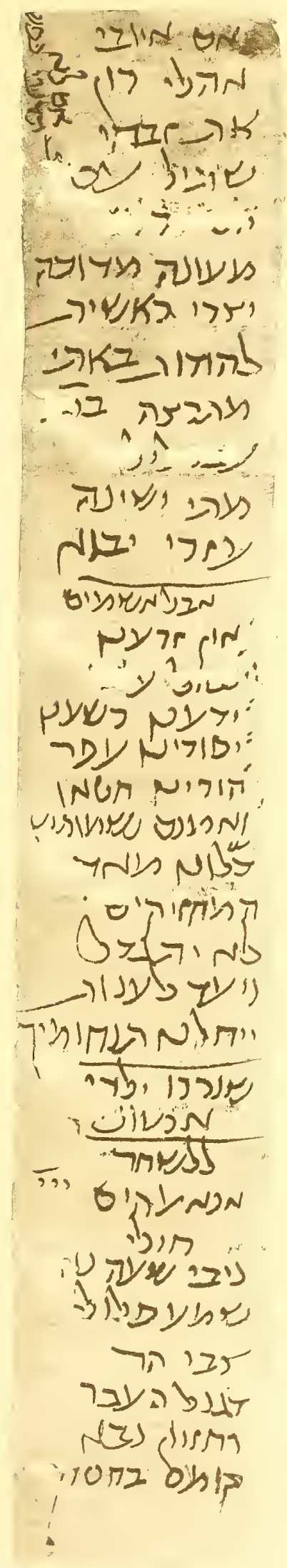





\section{NOTES ON THE BACK OF A LETTER}

The verso, in Arabic, in a very different, blacker, smaller, more regular, Hebrew hand, represents the older document from which this strip was torn before the recto was written upon it.

Recto:

I If mine adversary.

2 Tents of rejoicing.

3 My sacrifice.

4 Planted with ....

Margin:

If thou (fem.) knowest not.......

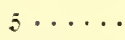

6 Dwelling, seat.

7 First $m y$ being.

8 She hath a horizon....

9 Gracious is the daughter [of].

10 He hath made night (?).

I When ....

12 My help cometh.

I3 The grief of guilt.

${ }_{14}$ The vanity of our seed.

$15 \ldots+\cdots$

16 Our wickedness knoweth us.

${ }_{17}$ We are covered with dust.

18 His $\sin$ hath cast us.

I9 And certainly our waste places.

2o They have consumed us greatly.

${ }^{2}$ Between $ב$ and $\zeta$ there seems to be the Arabic sign tashdid. 
Verso:

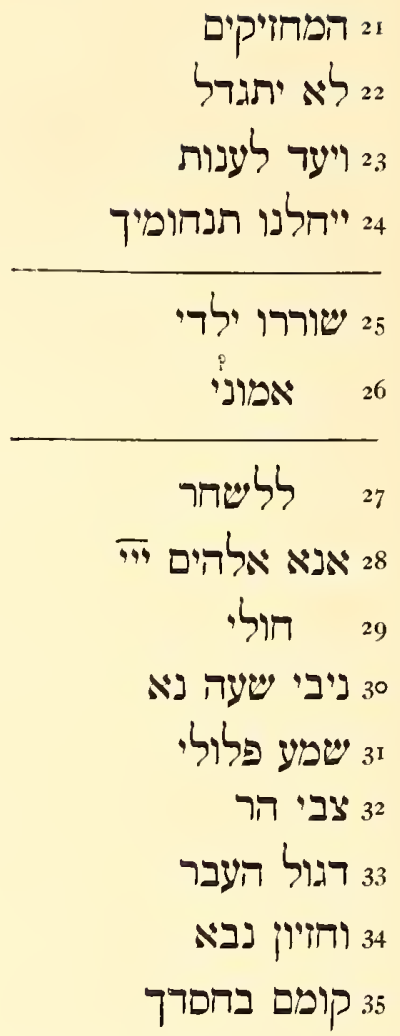

יחתי רחמה אל פאלק . . . . . . . . . . . . . . . . . . . . . . . .

2 טיביב אלסלטיאן ויאב

• 3

4 5

6 כתאב יקצור בה -

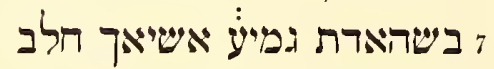

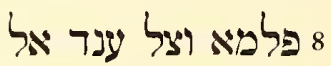

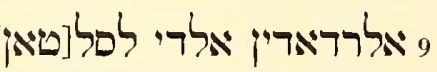

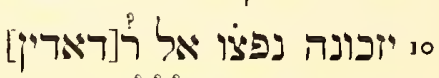

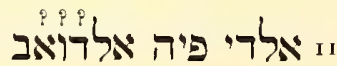

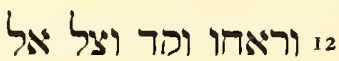

${ }^{3}$ Or "For the Morning Service." In the following we have, perhaps, the remnants of a verse : אניא אלהים ייד חולי ניבי שעה נא שמאע פדולי 
2r Those that strengthen.

22 Let him not inflate himself.

23 And he knew the bitterness.

24 Thy consolations hearten us.

$25 \ldots$ my children.

26 My faithful one (?).

27 For the morning ${ }^{3}$.

$28 \mathrm{I}$ am the Lord God.

$29 \ldots \ldots \ldots \ldots$

$3 \circ$ Attend to the fruit [of my lips].

3г Hear my prayer.

$3^{2}$ The glory of the mountain of.

33 Excellent is the.....

34 And prophecy of a vision.

35 Establish in Thy favor.

Verso:

1 till the Creator has mercy on him ....

2 the physician of the Sultan, and....

3 value of a hundred dirhams....

4 and a thousand, then produce the property ....

5 he goes to the girl to sell it....

6 a writing in which he purposes....

7 in testimony ${ }^{4}$ all $^{5}$ the sheikhs of Aleppo.....

8 and after he arrived in the presence of the...

9 the bone-setters who wait upon the Sul[tan]... .

ro the bone-setters(?) diagnosed his trembling ....

I in which the animals(?) were...

I 2 and they went away. And the... had already arrived....

${ }^{4}$ Line inserted in the original.

5 Two dots over the $\boldsymbol{V}$ seem to stand for fathatain. 


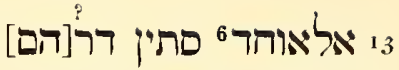
14

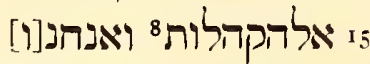

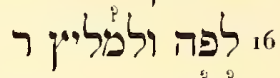
18 18 81 ובסיתו ומבשרך [לא תתעלם]

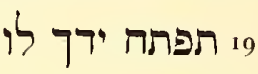

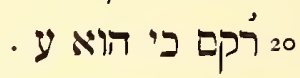

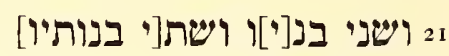
22 ידל לעדי עד ולנ[צה נצחים] וכ; [יהי רצון] 2.3

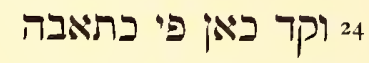

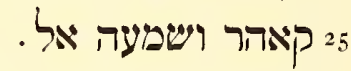
62 ו"אל נפים אבין אל ס[לטאי]

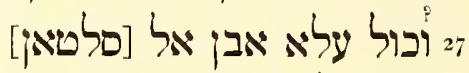

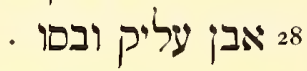

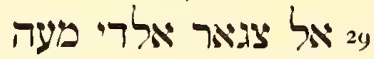

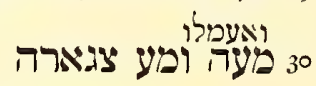

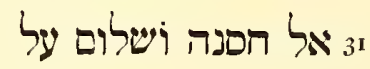

אליאוחד 6 אלואחד mistake for.

${ }^{7}$ Two letters follow which have been crossed out. 
r3 sixty dirhams apiece...

if unto the Creator and the....

I5 the congregations. But we.......

I6 wrapped him up. And .......

${ }_{7} 7$ in the pame.... might...9

18 and cover him; and hide not thyself from thine own flesh ${ }^{10}$.

19 Thou wilt open Thy hand unto him.

so their spittle, for he.....

$2 \mathrm{r}$ and two of his sons and two of his daughters....

22 he shall be weak for ever and ever.....

23 and this was the purpose [of the writing ?]...

${ }_{24}$ and there was in his letter....

${ }_{25}$ conqueror. And the ..... heard him ....

26 and the excellent son of the S[ultan ?] ......

${ }_{27}$ and every disease of the son of the [Sultan?]....

28 Ibn 'Ulaik, and.......

29 the little...... which with him

$3^{\circ}$ and they employed with him and with his little ones....

$3^{\text {I }}$ the good. And Peace be upon.....

${ }^{8}$ Note the Arabic and the Hebrew articles.

${ }^{9}$ Lines $17-23$ are in Hebrew.

${ }^{10}$ Isaiah lviii, 7 . 


\section{CHARM}

A strip of paper $15 \frac{1}{4} \times 1 \frac{5}{8}$ inches.

It is written in cursive Hebrew characters, and contains part of a charm against all manner of diseases and distempers.

ו .... ירהלולי ליליא ונוםיא ואשתא וערויתא ועיק רע וקלא ומרם מעיא

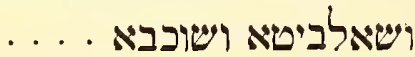

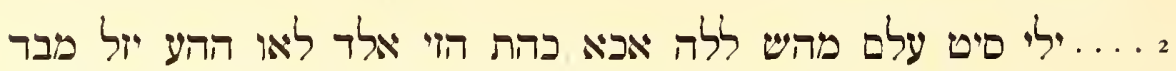

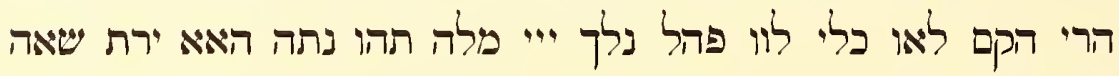
... אייי

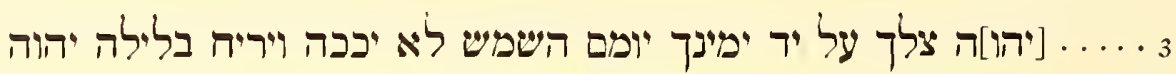
ישמרך מכל רע ישמור את נפשך יהוה ישמר צתך ובאיך מעתה יעד ... [ [ably] 4 ההור הותיק הוך הטהור היחיר הקרוש ועד אגיקורא את שמות מליאכי[

${ }^{1}$ Ink border-lines show that the strip was never any wider. The letters ודחלולי began the first line, which is written in characters small and cramped, though hardly as an afterthought to the remaining lines.

2 I.e. "spectres."

${ }^{3}$ The form נוסיא remains unexplained, but the word is related perhaps to Aramaic נִִֵַ, which has been connected with Greek vóros.

${ }^{4} \mathrm{Cf}$. the Syriac $\left\langle\triangle{ }^{\mathrm{x}} \mathrm{O}_{\mathrm{i}} \mathrm{s}\right.$.

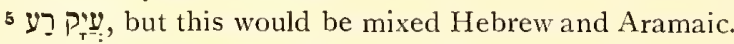

${ }^{6}$ I.e. "incantations." Cf. Montgomery, op. cit., p. 30 I.

"Cf. Targum to Levit. xxi, 20.

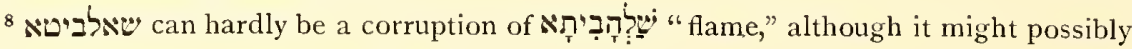
be a similar formation from the root לביבטי 


\section{CHARM}

The literature on Jewish magic is extensive. See Blau, Das altjüdische Zauberwesen, Strassburg, I 898 ; Davies, Magic, Divination and Demonology among the Hebrews and their Neighbors, London, 1898; Montgomery, Aramaic Incantation Texts from Nippur, Philadelphia, I9I3.

${ }_{1}{ }^{1}$ and scare-crows of the night ${ }^{2}$, and afflictions ${ }^{3}$, and fever, and ague ${ }^{4}$, and fear of evil ${ }^{5}$, and the voice ${ }^{6}$, and crushing of the viscera ${ }^{7}$, and $\ldots \ldots{ }^{8}$, and the Succuba ${ }^{9} \ldots \ldots$

3 [Jehov]ah is thy shade upon thy right hand. The sun shall not smite thee by day, nor the moon by night ${ }^{11}$. Jehovah will keep thee from all evil. He will keep thy soul. Jehovah will keep thy going out and thy coming in from this time forth and for $\left[\right.$ evermore $\left.^{12}\right] \ldots \ldots \ldots$

+ [shall] be with me in a circle ${ }^{13}$. In the name of God, the Mighty, the Powerful, the Creator, the Heroic, that speaketh righteousness, the Glory, the Able, the Pure, the Spotless, the Unique, the Holy! And also I shall recite the names of the an[gels] . . . . .

${ }^{9}$ אב may be connected with the root שכב "to lie" (sexually, of demons: cf. Montgomery, op. cit., p. 304). It seems actually to spell out the Latin word succuba, except that we should then have a $\square$, not a $\mathcal{~}$. At any rate, we fancy that this word is very close to the intended meaning. Amulets not uncommonly contain allusions to the incubussuccuba superstition.

${ }^{10}$ Here follow the Cabbalistic names which are untranslatable. They are derived from Exodus xiv, I9-2I, in such manner that the first letter of each name comes from verse I9, the middle letter from verse 20 , the last letter from verse $2 x$. The following names com-

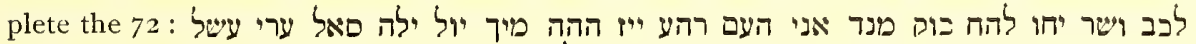

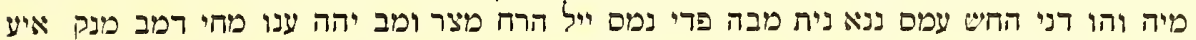
הבו ראה יבם היי מום. (So explained by M. Chapira to Professor Gottheil.)

11 Cf. Worrell, "The Demon of Noonday," in Joumal of the American Oriental Society, I9I8, xxxviii, I6off.

12 Psalm cxxi, 5-8.

${ }^{13}$ A magic circle. Cf. Worrell, "Ink, Oil and Mirror Gazing Ceremonies in Modern Egypt," in the same Journal, I9I6, xxxvi, 37 ff., particularly p. 52. 


\section{A SCRAP OF PAPER}

Paper about $\mathrm{I} 3 \times 3 \frac{1}{8}$ inches, tapering towards the top.

Hebrew and Arabic, in cursive Hebrew characters.

This fragment is perfectly described in the introduction to our No. XXIII. It is a strip, cut from the same letter and used in the same manner.

But unfortunately it is not a part of the same leaf as No. XXIII; so that comparison gives us no help with the mutilated verso, nor with the sketchy recto.

Recto:

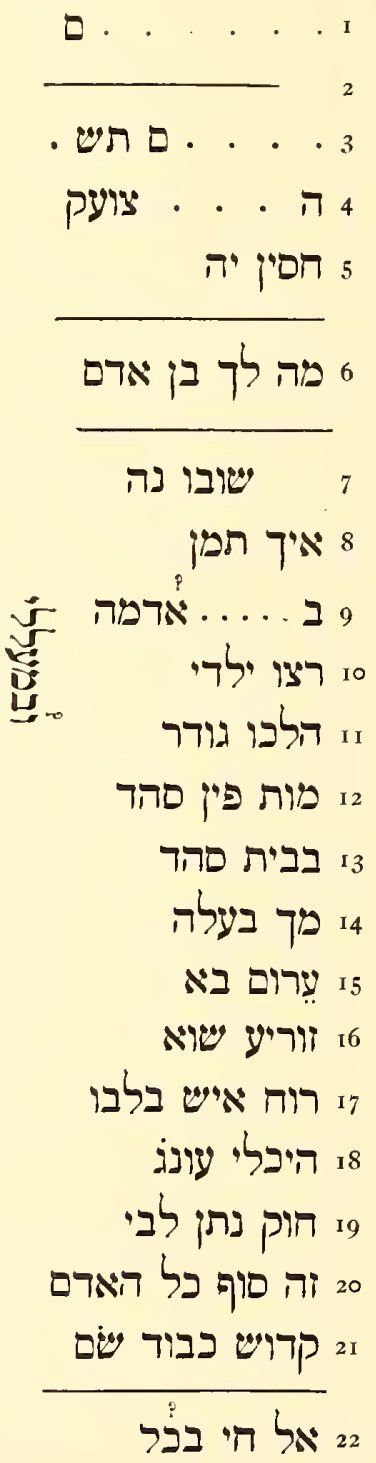




\section{A SCRAP OF PAPER}

As we do not pretend to know what either text is about, we confine ourselves to rendering a few groups of words here and there.

The recto and the verso to line $\mathrm{I} 8$ seem to refer to religious matters. From line I9 of the verso the subject is business, and the language is Arabic.

\section{Recto:}

I

2

3

4 ......crying out

5 Strong .....

6 What aileth thee, son of man?

7 Return ye.

8 As there.

9 ........the ground

ıo Consent, my children.

1 They have gone, carpenter.

I2 Death...testimony(?)

I3 In the house of testimony(?)

${ }_{4}$.........mistress.

I5 Naked he came.

I6 The sower of iniquity.

I7 The spirit of a man in his heart.

I8 My temple is delight.

I9 My heart gave a law.

20 This is the end of all mankind.

2T The Holy One has settled honor.

22 The living God in all. 
Verso:

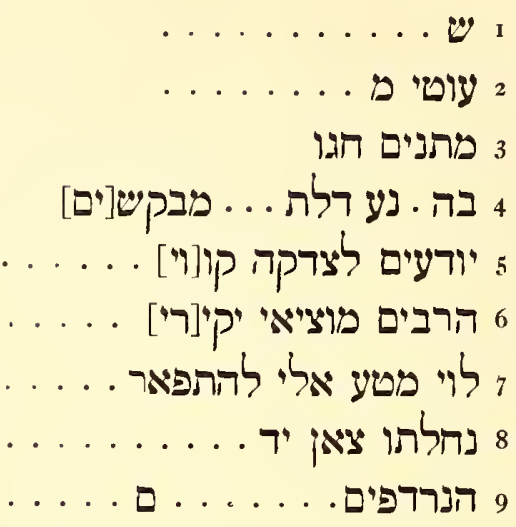

ס בכל מקומות מושב[ותיהם]

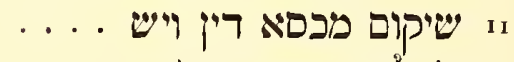

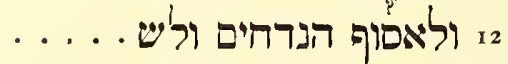

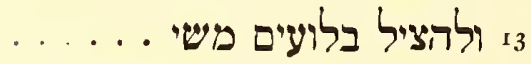

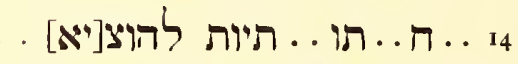

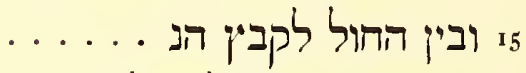

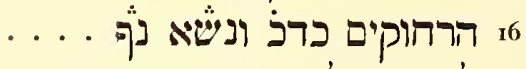
8 18 מקומות מושבותיהם להורית

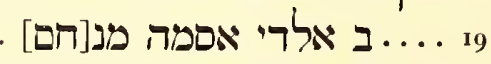

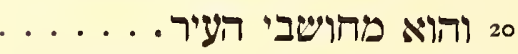

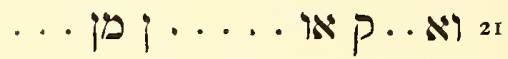

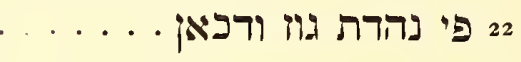

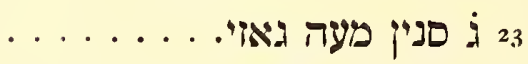

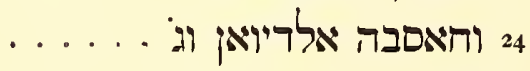

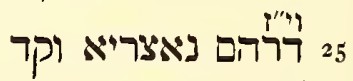
26 לtיה ולציגארה ואלדי. 28 לם יבקא פעה פלם. 28 . . . • על עיה תמן מאי . 29 
${ }_{23}$ When will the spirits.....

${ }_{24}$ For the multitude of my deeds

Vertical: And when I do.

Verso:

I

3 gifts

+......door...seekers

5 those knowing righteousness, hoping for

6 the great ones, producers of - dignitaries of - ......

${ }_{7} \mathrm{O}$, that I had a couch, to glorify myself...........

8 his inheritance the sheep of...........

9 the persecuted ones.

Io in all the places where they dwell...........

I that he arise from the chair of judgment, and.....

I2 and to gather the repudiated ones and....

13 and to deliver, those swallowed up......

$1+\ldots \ldots \ldots \ldots \ldots \ldots$.......... to bring out

15 and between the sand, to collect the.....

16 those that are far away, even as it is written" " and it shall bring forth boughs ${ }^{2} . "$

17 To make known to our teachers the places(?)......

I8 their places of residence.........

19 about him whose name is $\mathrm{M}$ [enahem]

20 and he is one of the honored men of ${ }^{3}$ the city $\ldots . .$.

21 .............

22 in. and shop...

233 years with him....

${ }_{24}$ and the tribunal called him to account, and ${ }_{25}$ and 17 Nāsirī ${ }^{4}$ dirhams...... And already.....

26 to him and to his little ones and that which...

${ }_{27}$ did not remain with him. And not......

$28 \ldots .$. he owed the price of a hund[red]

29 to the most excellent Sitt.

\footnotetext{
${ }^{3}$ For $1{ }^{4}$ See Dozy, op. cit., vol. ii, p. 679.
} 


\section{LETTER}

An irregularly shaped strip of paper, tapering a little towards the top, about $8 \frac{3}{4} \times 2 \frac{7}{8}$ inches.

Arabic, in half-square Hebrew characters.

The script is bad, and the language used is not literary. There are several mistakes in spelling.

Recto:

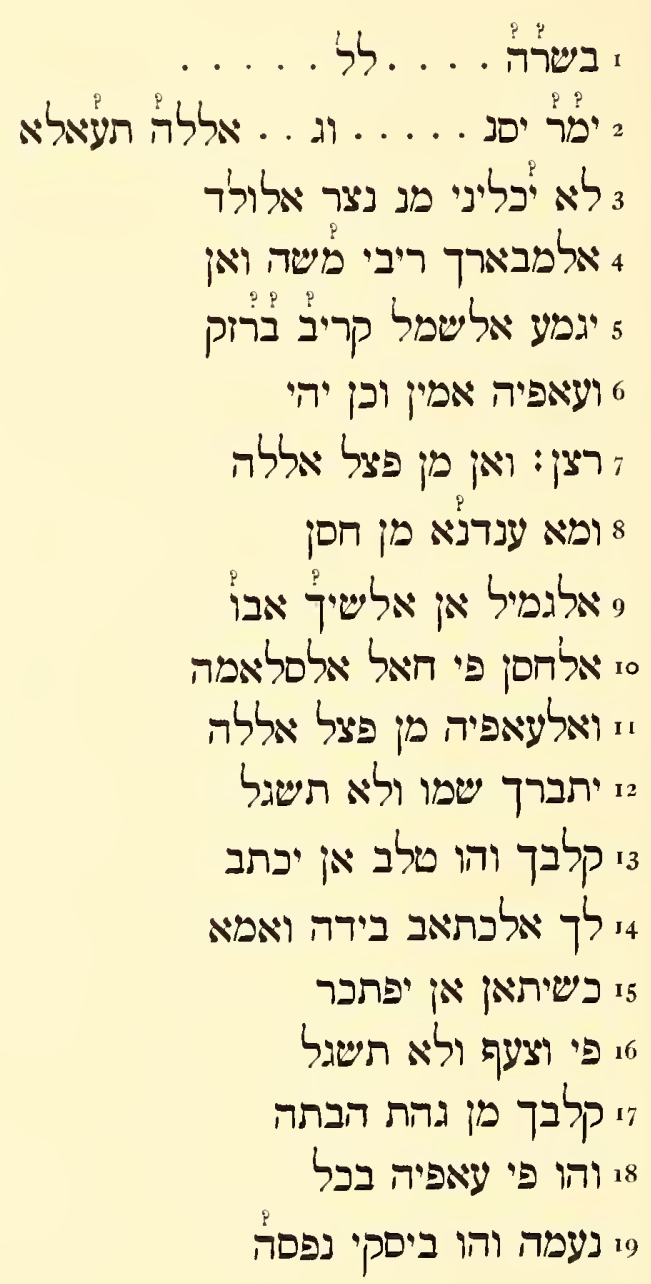

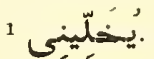

2 The text is perfectly plain here. Perhaps "progeny."

3 Must refer to the preceding word "boy" or "child" rather than to the following "Rabbi Moses." $\quad$ "Rabbi."

${ }^{5}$ We should have عن قريب in either literary or colloquial Arabic.

6 "grace."

7 This phrase is in Hebrew.

8 "busy." 


$$
\begin{aligned}
& 3=(1) \text { y } \\
& \text { तfyont if } 10: 45
\end{aligned}
$$

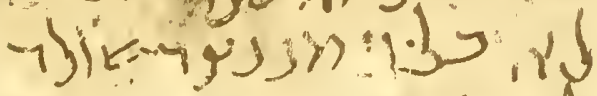

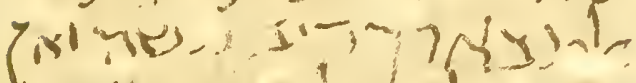

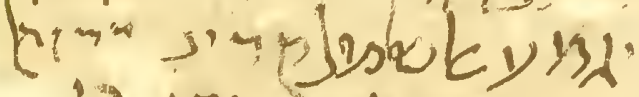

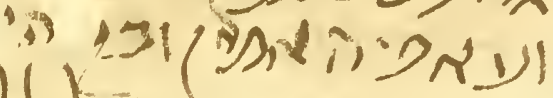

$$
\begin{aligned}
& \text { Delogy } \\
& \text { (Ot } 2 x^{2} \text { त) } \\
& 1 \pm \therefore \text { का कर Jण्यू } \\
& \text { mpalokkm g gomk }
\end{aligned}
$$

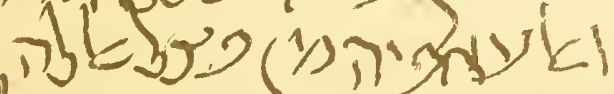

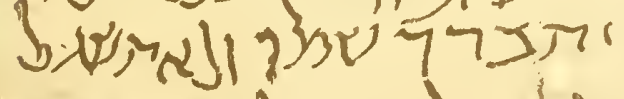

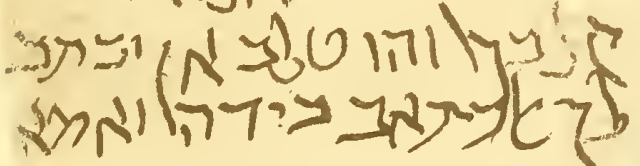

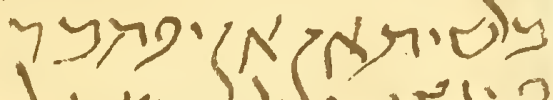

$$
\begin{aligned}
& \text { ग्रणत्री }
\end{aligned}
$$

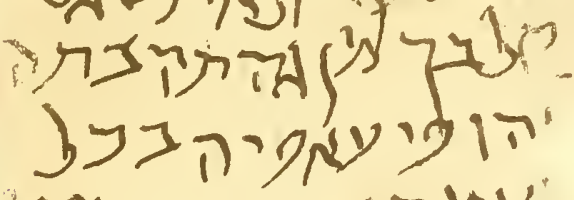

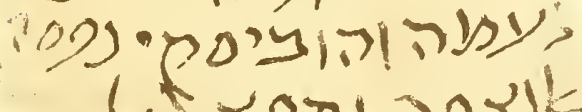

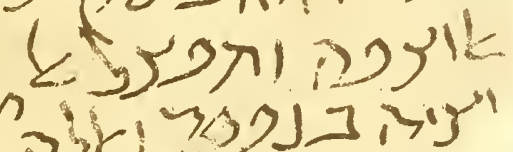

$$
\begin{aligned}
& \text { कut }
\end{aligned}
$$

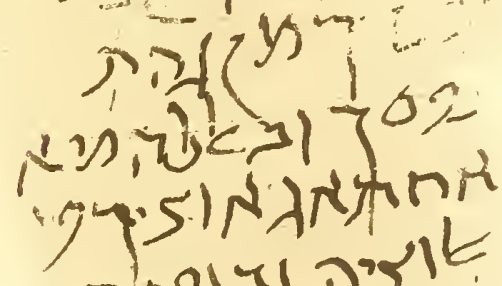

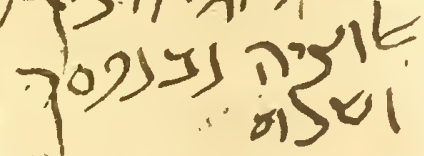





\section{LETTER}

It is a letter written to a certain Rabbi Moses in the name of an old man, Abū al-Hasan.

There is no information in it. It is purely "une lettre de politesse."

Recto :

I good news (?).....

2 .........God the Exalted

3 will not deprive $\mathrm{me}^{1}$ of the help of the boy ${ }^{2}$,

4 the blessed ${ }^{3}$ Ribbi $^{4}$ Moses, and that

5 he order his affairs $\operatorname{soon}^{5}$ with prosperity

6 and health ${ }^{6}$. Amen! Thus be

7 the will [of God] 7 ! And that by the grace of God

8 and whatever we have in the way of beauty of

9 behaviour ${ }^{6}$. Verily the Sheikh Abū

10 al-Hasan is in a condition of prosperity

I and health, by the grace of God,

I 2 blessed be His Name ${ }^{7}$ ! So do not trouble ${ }^{8}$

I 3 your heart. $\mathrm{He}^{9}$ sought ${ }^{10}$ to write

I4 to you the letter with his [own] hand, but

${ }_{15}$ like a devil ${ }^{11}$ he [only?] thought

16 about it ${ }^{12}$; and he did not do it. But do not trouble ${ }^{8}$

17 your heart about his gift

I8 since he is in good health ${ }^{6}$, in all

19 well-being, and he is treating himself ${ }^{13}$

${ }^{9}$ I.e. the Sheikh Abū al-Hasan.

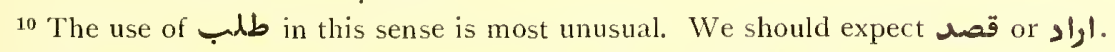

11 Probably a forgotten twelfth century vulgarism. A شيطان now-a-days in Egypt is a "clever fellow," full of tricks. In the text we have $\Omega$ instead of $ט$.

12 פ 12 the vulgar fi or fih for fini.

13 ביסקי bas the bi-prefix of the present tense imperfect in vulgar Arabic. Cf. Spitta, Grammatik des urabischen Vulgärdialektes von Ägypten, Leipzig, I88o, pp. 193, 203. أسقىى is used in three ways: (I) Of filling a cup with wine, or other drink. (2) Of watering cattle. (3) Of irrigating the soil. I think we might translate "is watering himself," "is soaking himself." Abū al-Hasan is taking a lot of this medicine, or he is enjoying it, or both, if we are not mistaken. 
[ה

20 אלוצפה ותפצל אל

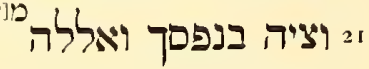
22

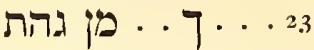

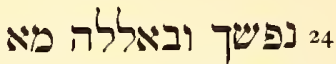
פ 25 26 אלוציה ובנפסך פושיר 27

Verso:

14 وَضْفَة is the regular term for a prescription.

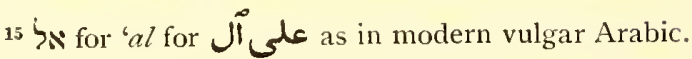

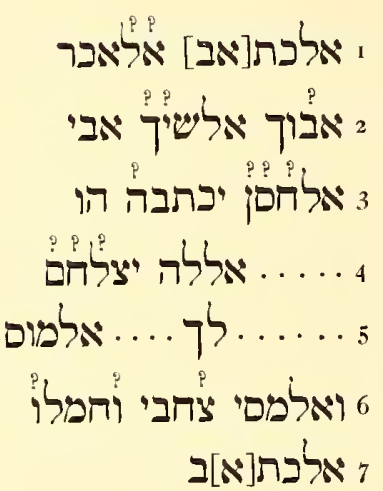

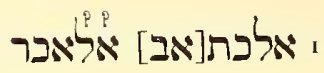

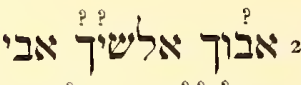

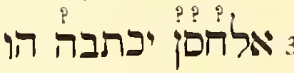
4... . . . . . .

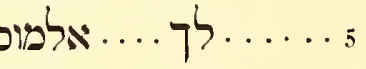

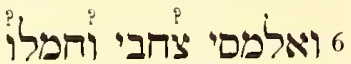

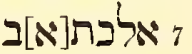


20 to the prescription ${ }^{14}$. And pray [attend] to ${ }^{15}$

2r the order in your own person. By Allah! Not

22 have I needed [to do any more] than to.........

23 .on account of

24 yourself ${ }^{16}$, and, by Allah, not

${ }_{25}$ do I need to direct you in regard to

26 the commission and yourself.

27 Greeting !

Verso:

I The other letter.

2 Your father, the Sheikh $A b \bar{u}^{17}$

3 al-Hasan will write, he

4 ........God restore them!

5 ........to to you......the.....

6 and the..... is my master (?) and they carried

7 the letter.

16 here instead of $\square$. The writer has Hebrew

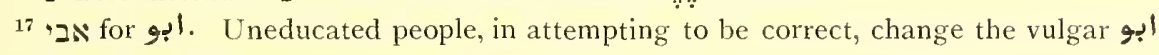
to إبى even where it is not needed. 


\section{LETTER}

Paper $\operatorname{II} \frac{5}{8} \times 7 \frac{1}{2}$ inches, water-marked with a mailed torso.

Arabic in half-square Hebrew characters.

A letter from Abū Zubair Șadaḳah al-Maghribī, in Jerusalem, to Abū Yahyyā Nurāi Ibn Nissīm, in Fusțât (Cairo). It is a prolix epistle, taking up the margins as well as the body of the page and a half upon which it is written.

Abū Zubair is a man of poor health, narrow life, and many troubles. His family was originally from Morocco or some one of the other Barbary States. He writes Arabic, in Hebrew letters-as Jews have done with many languages-but in such a manner as to betray his familiarity with the Arabic script and orthography. His language is no doubt the slightly

Recto :

י וצל כתאב מוליאי אלישיך אטאל אללה בקאה ואדאם סלאמתה וסעאדתה : ישה אמס

ביופי הדא [1]הו וֹ איאם בקין פי אלול אעיאר אללה עליה הדה אל מועדים אלמקביה

3 סנין טאילה וגעלהא עליה מיפונה מבארכה בקבול אלתורה ואל פ[צו]ה ואשהדנא

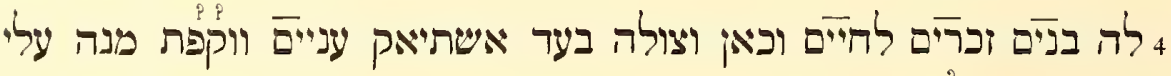

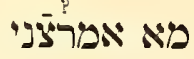

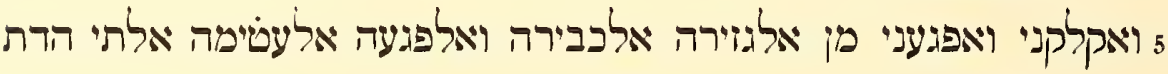
קואניא מין

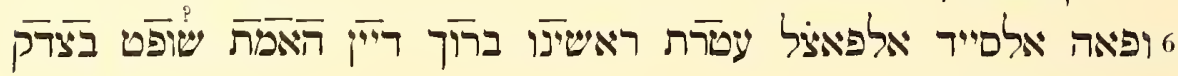

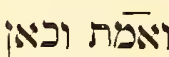
ז הרא אלסבת ענדי וענד אהלי מתל סבת תשעדה באב ומא וגדניא עוא וכאי ומיא לקלובניה איסות

8.יר אנה ארויל לנא נחי אלרי עשניא להרה אלפצאיב ונשרבו הדה

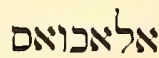
9 יאל מרה וקר עמית אבצארניא ו"אנקטעת קואנא ונחין באכייץ עליה טול חיאתניא

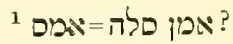

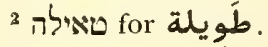

בירה is Hebrew. 


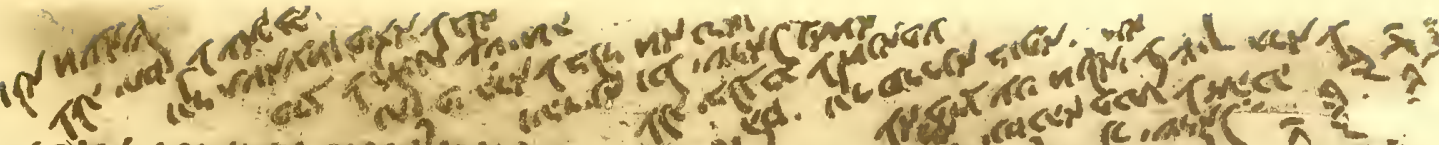

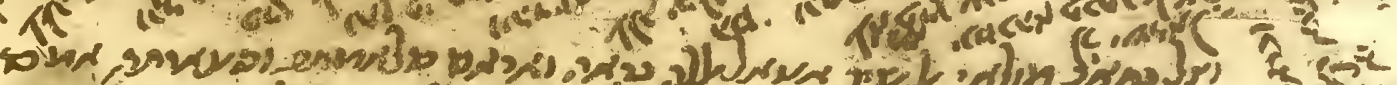

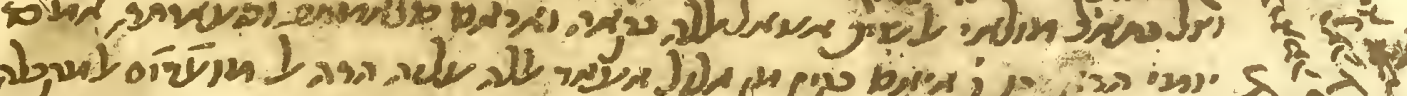

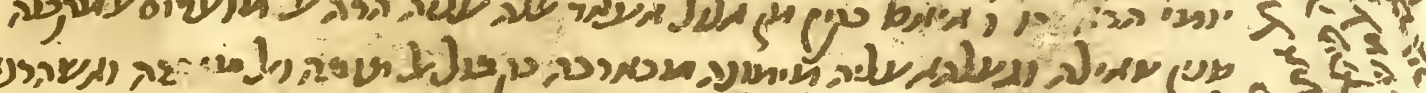

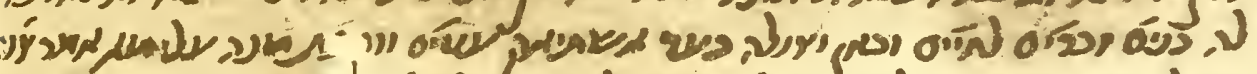

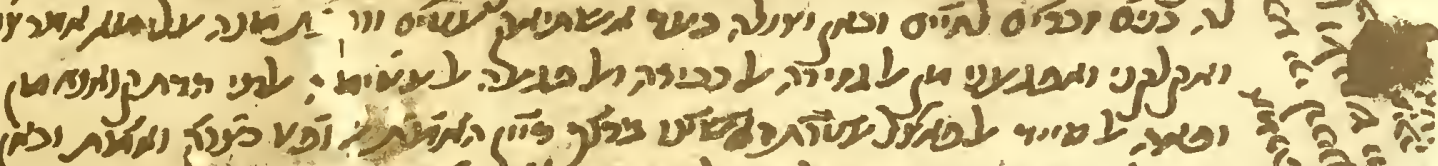

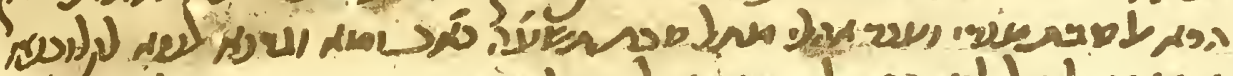

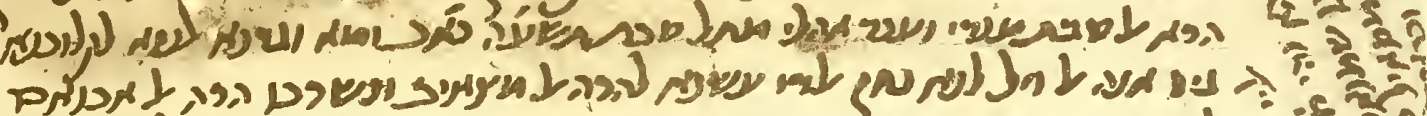

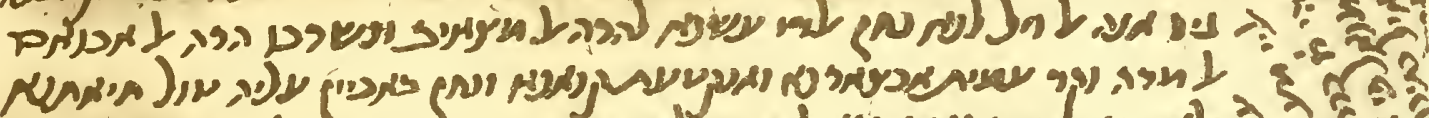
A

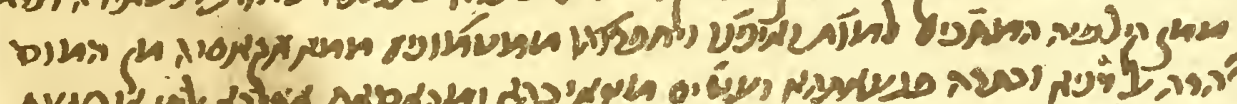

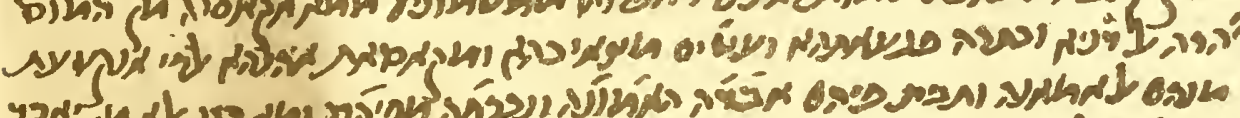

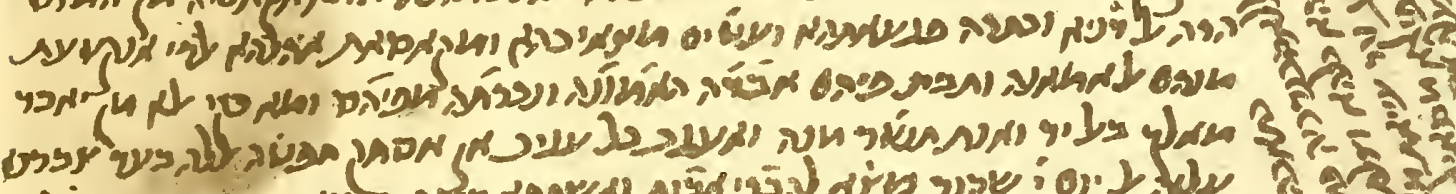
Aives ver

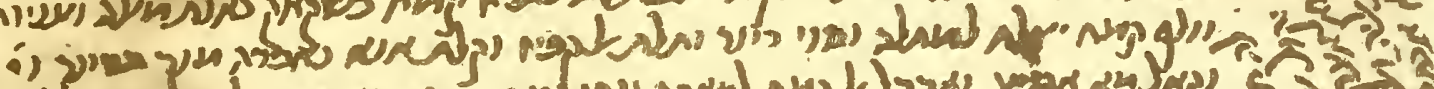

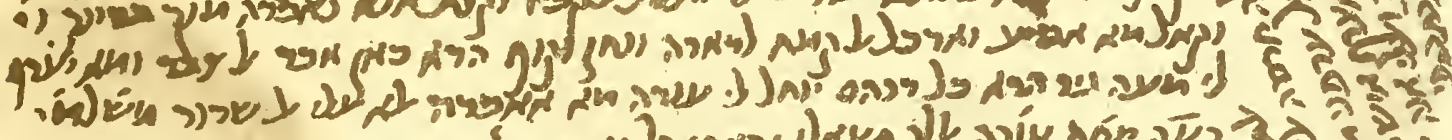

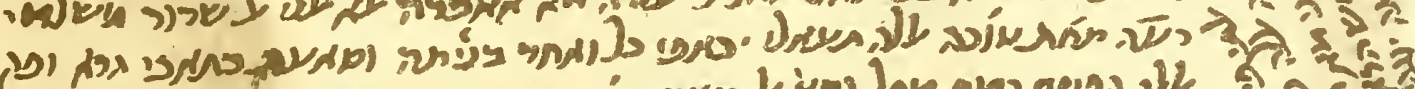

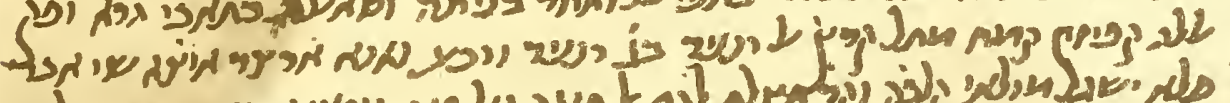

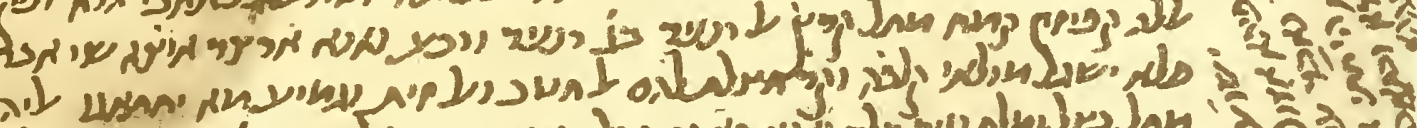

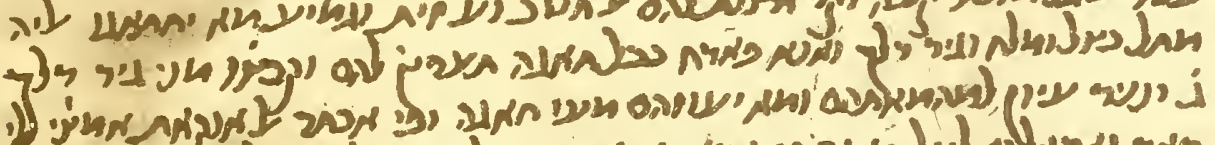

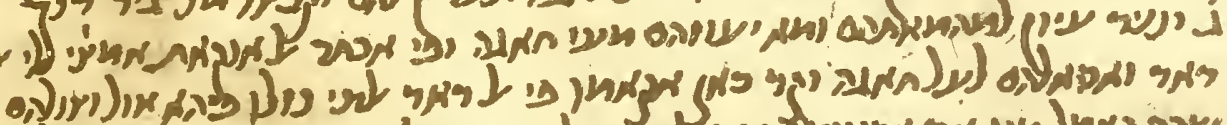

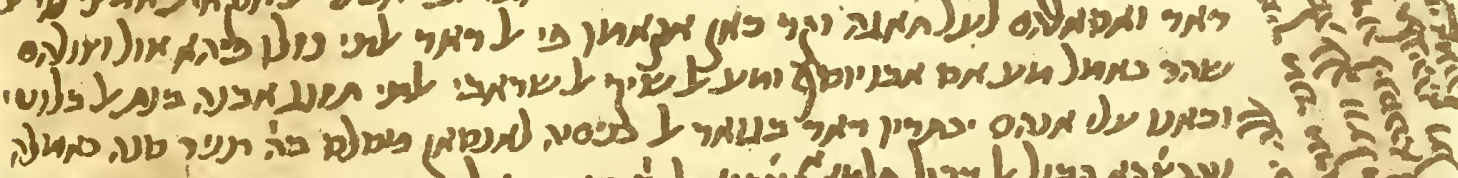

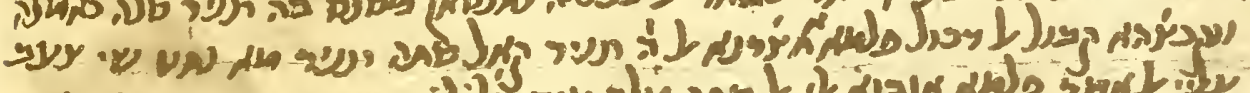

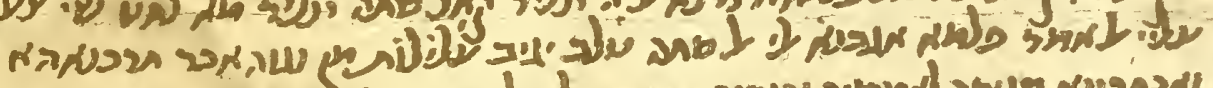

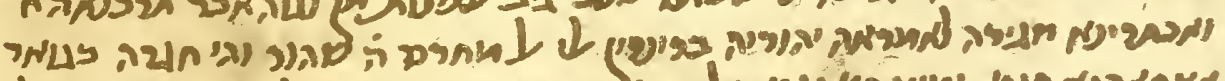

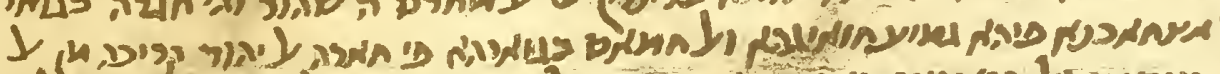

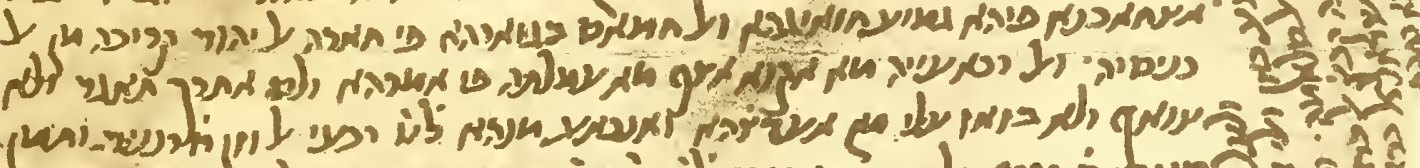

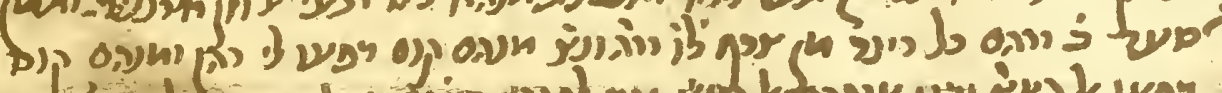

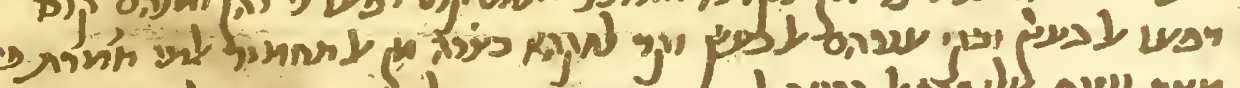

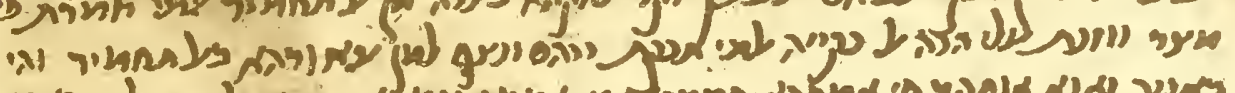

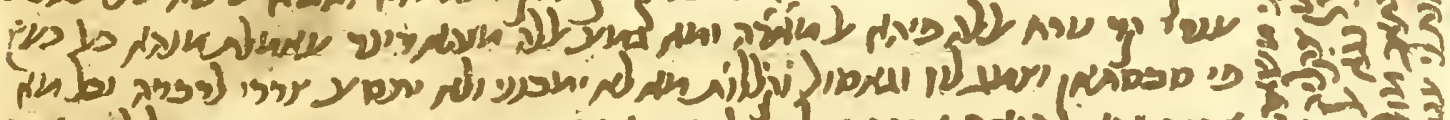

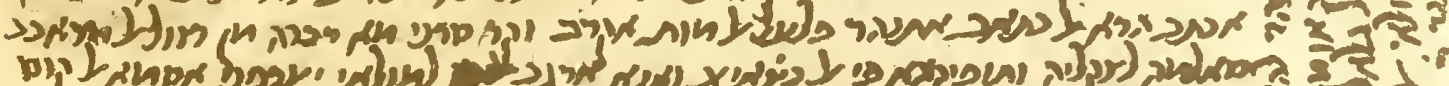

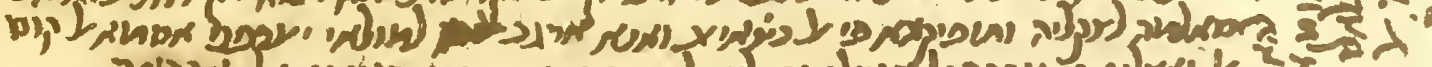

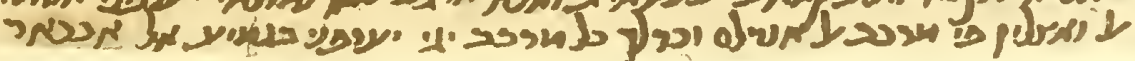




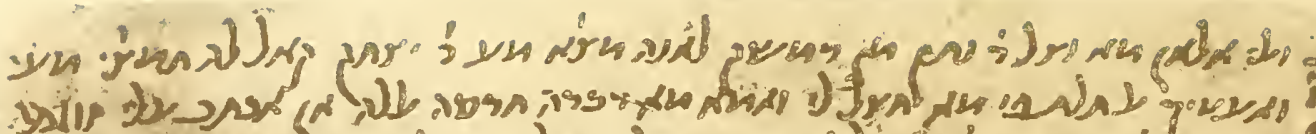

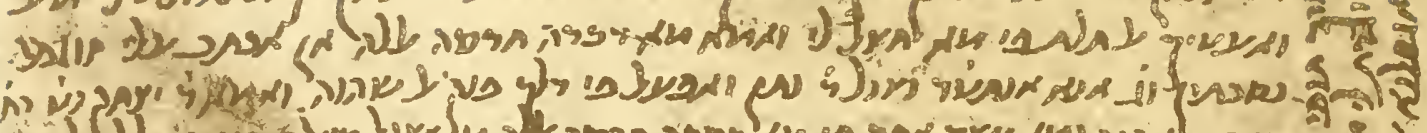

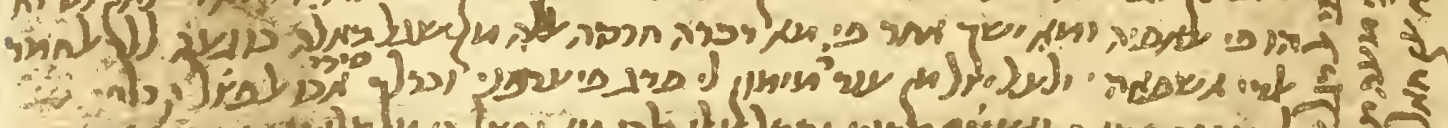

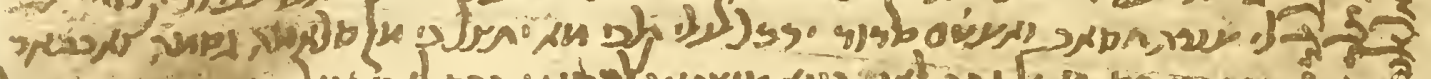

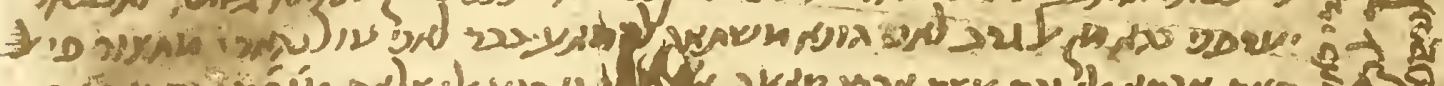

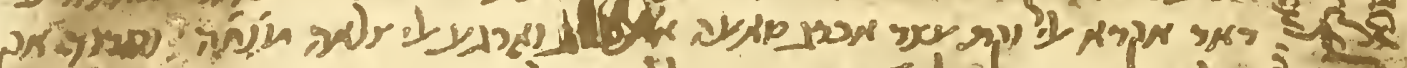
So

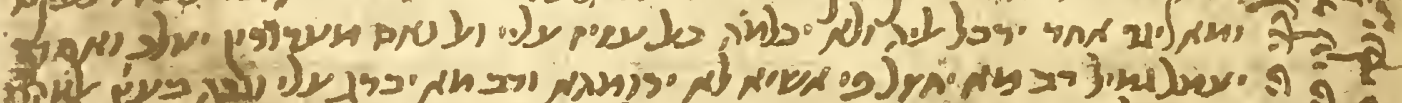

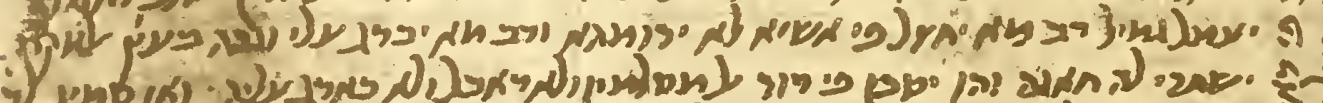

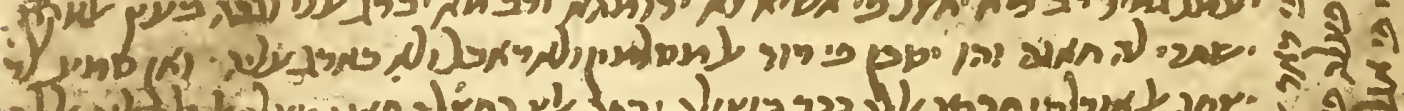

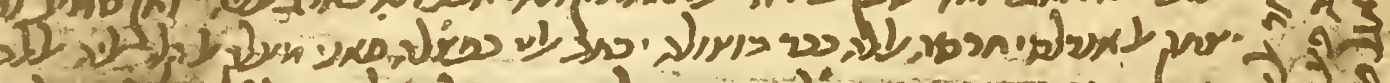

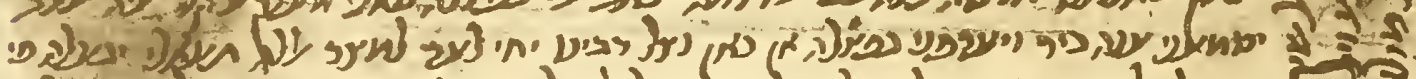

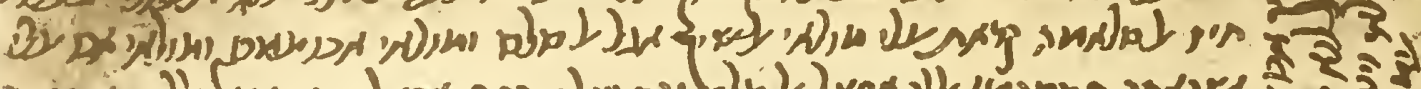

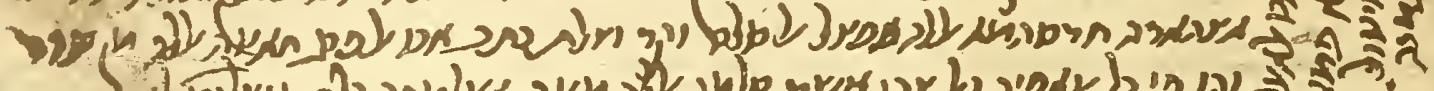

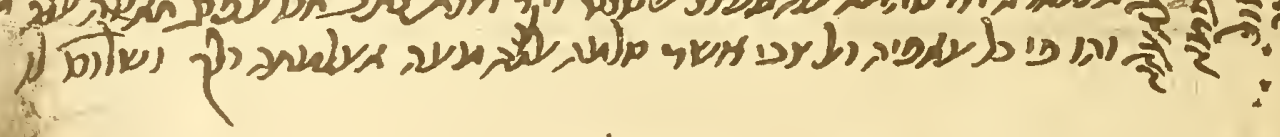
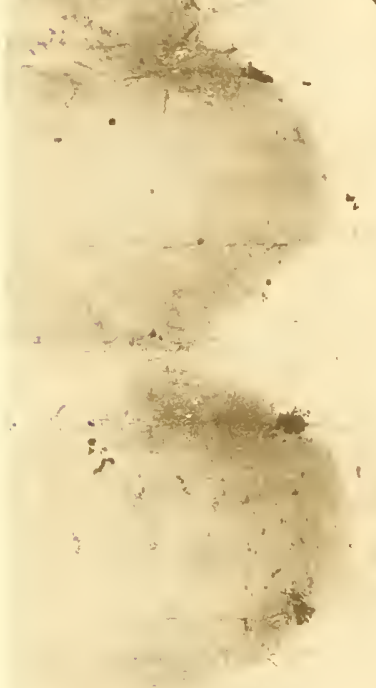

ค. कम

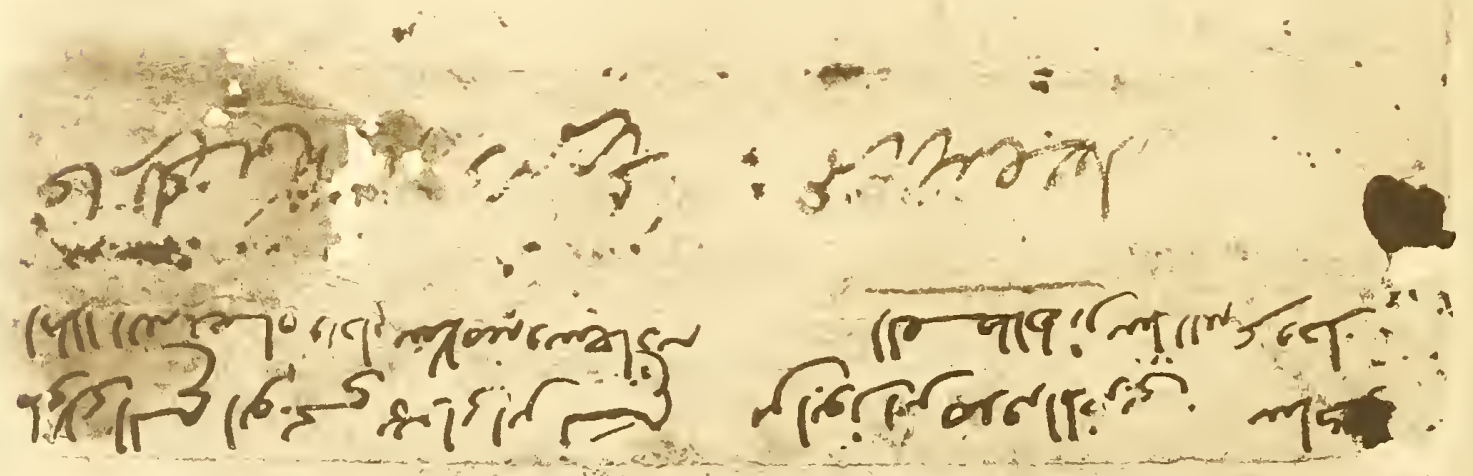




\section{LETTER}

classicised vernacular of his own day. It already exhibits many of the peculiarities of the spoken Arabic of modern Cairo. The difficult passages are no doubt in the slang of his time. Other peculiarities, such as the occasional omission of the article, the redundant "it," the strange use of 'y and other prepositions, and of common verbs, are not so easily explained. He is especially prone to mix forms and turns of expression while putting them on paper.

Unfortunately the letter bears no date. It was written, however, before I050-I098, when the addressee died.

Below the address there is a line of Arabic script which cannot be made out.

\section{Recto:}

I The letter of my Lord the Sheikh has come. May God lengthen his existence and prolong his health and his happiness! Amen! Selah ${ }^{1}$ !

2 Today - and there are six days remaining of Elul-may God add unto him these feast-days that are to come

3 for many ${ }^{2}$ years! And may He make them for him fortunate and blessed in the acceptance of the Law and the Commandment! And we wish ${ }_{4}$ for him [that he shall have] living male offspring! The arrival [of the letter] occurred after [we] poor ones had yearned for it, and had been deprived of it by delay, in addition to my having been made ill 5 and uneasy and sad by the great calamity ${ }^{3}$ and the heavy affliction which

has crushed our strength ${ }^{4}$ : namely the

6 death of the excellent master ${ }^{5}$, the Crown of our Head. Blessed be the honest judge who judges in righteousness and truth! This

7 Sabbath Day has been, with me and with my people, like the Sabbath Day falling upon the Ninth of $\mathrm{Ab}^{6}$; and we have not found any strength for our spirits.

8 [We are conscious of nothing] save that we are victims of calamity, we who have lived to [see] these misfortunes. And these bitter 9 cups $^{7}$ have been drained, and our sight has been blinded, and our strength cut off: and we shall continue to weep for him as long as we live.

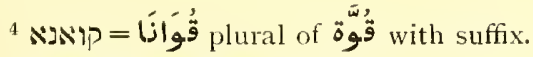

5 Identity not established.

${ }^{6}$ When Nebuchadnezzar destroyed the First Temple, and when Titus destroyed the Last Temple, according to Jewish tradition.

7 An unusual plural of Sَ: 
ס ולא עוא בערה ווחק הדא אלקדם לקד מראר כתירה נתפנא אלפית וצית ונשתהיה יצרת עיתוה

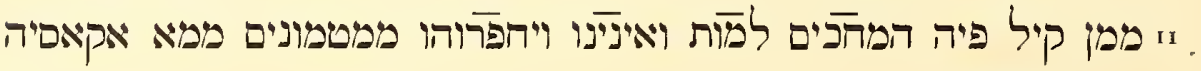

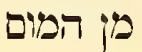

2 הרה אלדניא וכתרה פגעיאתהא ועטים מציאיבהא ופזקאםאת אהלהא אלדי

ryops:

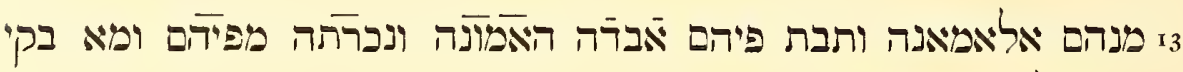

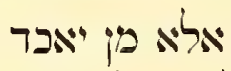

4 פיאלך באל יד ואנת תנטר פנה ואעיב כל עיניב יאי אסחק הפטה אללה

בער צברניא

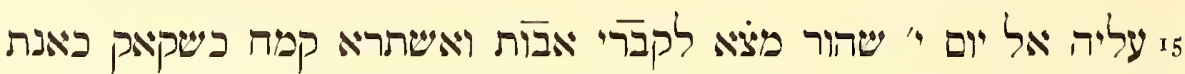

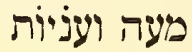

6 וולף קמה יצלה למהלה יםוי דינר ותלת אלקפיי וקלת אניא ניאכדה מנך

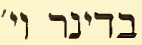

7 וקאל פיא אביע ואדכל אל קמה לדיארה ונחן וקוף. הדא כיאן אכר אלצבר

ומיט

8ו לי מעה גיר הדא פל דרהם יודיל לי ענדה פיא איאברה אליא עלי אל שרור

ishers

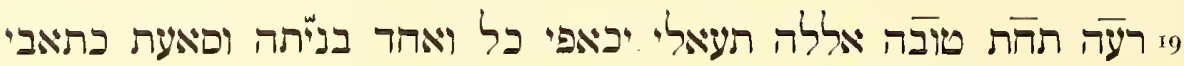

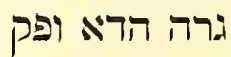

20 אללה קפיץין קפז מתל קרין אלדנניר בג' דפניר ורבע ויאנא ארצר איצטא שי יהכר יות

ז2 פליא ישנל פולאי קלבה וקר חצלת להם אלחטב יאלזית ונפיע מא יהתאיגו היליה

8 With only one $?$.

9 This quotation, Job iii, $2 \mathrm{I}$, is in Hebrew, as indicated by the overlining in the manuscript and in our text. All Hebrew words are thus marked.

10 Jeremiah vii, 28.

11 In the Arabic form.

12 I.e. to pay a debt?

13 "Graves of the Fathers" are probably Hebron, though we can not find any other instance of this title. At Hebron the "Fathers," Adam, Abraham, Isaac and Jacob, were supposed to be buried. The vicinity is fruitful, and one might have bought grain there perhaps. Cf. Baedeker, Palästina u. Syrien, I910, pp. Io5 ff.

14 Or "grain" merely.

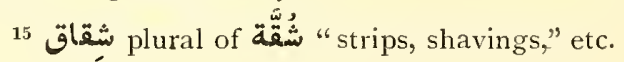


ıo There is no strength now that he is gone. $\mathrm{By}^{8}$ this Jerusalem! Many times we have desired death and longed for it. And I have become I one of those concerning whom it is said": "Who long for death, but it cometh not, and dig for it more than for hidden treasures," because of what I endure in the way of cares of

I 2 this world and the multitude of its sorrows, and the might of its calamities, and the hard-heartedness of its people from whom sincerity ${ }^{3} 3$ has been cut off. And concerning them [the saying] ${ }^{10}$ holds: "Truth is perished, and is cut off from their mouth." And nothing remains now but that someone should take

It your property by force, while you look the other way. Most wonderful of wonders! Isaac ${ }^{11}$-God keep him !-after we had waited

${ }_{15}$ for him ${ }^{12}$ these ten months, went off to Kibhrē Abhōth ${ }^{13}$, and bought wheat ${ }^{14}$ in which was [something] like chaff $(\text { ? })^{15}$ and......... ${ }^{16}$

I 6 and collected ${ }^{17}$ wheat $^{14}$ suitable for his place, worth a dinnār and a third the kafāz. And I said: "We will take it off your hands for a dīnār and Io [carats the kafĩz] $]^{18}$."

iz But he said: "I am not selling." And he put the wheat into his house, while we were standing by ${ }^{19}$. This was the extremity of [our] patience. And nothing is known

I 8 to me about ${ }^{20}$ him except this: Not a dirham which he owes ${ }^{21}$ me and has in his possession shall I take except [as] against the base "that render

I9 evil for good 22 ." God-He is exalted !- requites every man according to his intention! But the hour of this writing has elapsed ${ }^{23}$. May 2o God make suitable ${ }^{24}$ two ķafiz of grain as the equivalent of the return of the dinnārs ${ }^{25}$, at three dīnārs and a quarter ${ }^{26}$. But I am also looking out for something else.

2. But let not my Lord worry. For they have received the fuel-wood, and the olive oil and everything they need,

16 תy Hebrew. It was very poor wheat?

17 ورأَّنَ for for Dozy, Supplément aux Dictionnaires Arabes, ii, p. 892.

${ }^{18}$ If the carat is one twenty-fourth of the dinār (cf. Mann, op. cit., ii, p. 195, n. I3), Isaac bought the grain at $I_{3}^{1}$ dīnārs and was offered $1 \frac{5}{12}$ dīnārs, or two carats more than the cost. They wished to shame him into paying them on the spot when he received the cash from them. The dinār is, of course, at this time the large gold coin, and not the denarius.

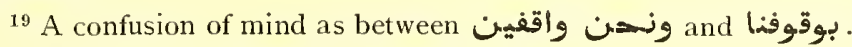

20 \&o does not usually have this meaning.

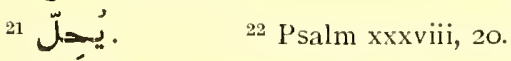

23 "My letter has become long enough." Then he makes it four times as long.

24 وَّنَ.

${ }^{25}$ The modern dananir for silis. Cf. Willmore, The Spoken Arabic of Egypt, and ed., pp. $8,80,8$ I.

${ }^{26}$ I.e. for two k̦afīz, or 1.625 dīnārs the kafīz. He offered Isaac only $\frac{5}{1} \frac{5}{2}$ before. 
22 מתל בצל ומלה וגיר דלך ואנא פארה בכל האגה תערין להם וקבצו מני גיר דליר

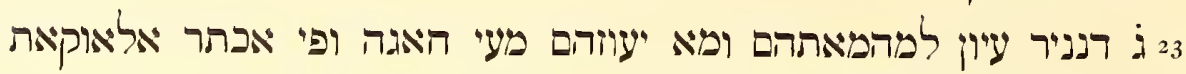

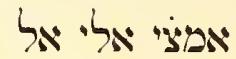

24 ראר ואסאלהם לעל האגה וקד כאן אקאמו פי אל ראר אלתי נילו פיהא איל

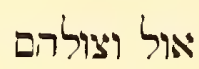

25 שהר כאמל מע אם אבו יוסף ומע אל שיך אל שראבי אלתי תזוג אבנה בנת אלבלוטי כמל משי

26 וכאנו עלי אנהם יכתריו דאר בגואר אל בניםיה לאנםאי מםלם בה רניטיר סנה כאמלה עלי אנרם יכלה

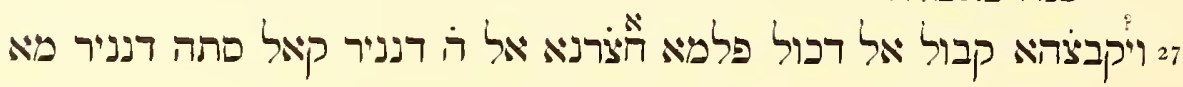
נחט שי צעב

28 עלי" אלאמר פלמא אגבנא אלי אל סתה טלב ייגיב עלילוֹת טן וגוה אבר תרכנאהאי אלאר

29 ויאכתרינא הגירה לאמראה יהודיה ברינרין אלי אלמהרם ה שהור והי חגרה בגואר

3 אצהאבנא פיהא גמיע הואיגהא ואל המאם בגוארהא פי הארה אל יהור

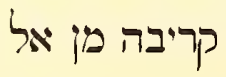

זי כניםיה ואל רבאעייה מא אקוא אצף מא עמלתה פי אמרהא ולם אתרך תאגר ולא

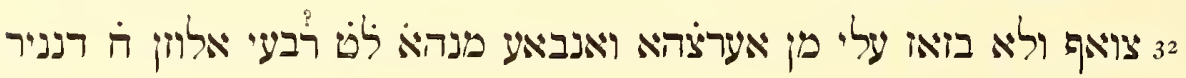
ותמן

27 a cthing" is modern Egyptian colloquial. In 1. 20 he has used the classical and Palestinian شى"

28 "وبضض "grabbed," but in the dialect of Cairo, "received." This is still Isaac's case, we take it.

${ }^{29}$ ¿. C. . note 20.

${ }_{30}$ The relative pronoun is feminine but the verb is masculine. The writer has both the mother of Abū Yüsuf and the Sheikh al-Sharābī in mind, but he means the latter.

31 יכתריו is colloquial, from 5 . The' is merely a graphic reminiscence of the singular.

32 בניסיה (Dozy, op. cit., ii, p. 493), the Spanish (1 5th century), Moroccan and Tunisian form of the same word. Is this the Church of the Holy Sepulchre? Perhaps we are to read ${ }^{-\bar{w}}$ "Place of the Church of the Holy Sepulchre."
33 "belonging to."
${ }^{34}$ قa for 
22 such as onions, and salt and other things. And I am rejoiced at everything ${ }^{27}$ that turns up for them. And they have received ${ }^{28}$ from me in addition

${ }_{23}$ three dīnārs cash for their pressing needs. And they do not need anything from ${ }^{29}$ me. And at most times I go out to the

${ }_{24}$ house and ask them whether [they] need [anything]. And they have remained in the house in which they stayed when they first arrived25 a full month-with the mother of Abū Yūsuf and with the Sheikh alSharābī who married ${ }^{\mathbf{3 0}}$ his son to the daughter of al-Ballūtī.

26 And, although they had rented ${ }^{31}$ a house in the vicinity of the Church ${ }^{32}$, from $^{33}$ a Muslim man for five dīnārs for a whole year,

${ }_{27}$ and he was to receive the money before ${ }^{34}$ we took possession. But when we had brought the five dīnārs, he said : "Six dīnārs! We shan't make it less ${ }^{35}$." The matter was

28 hard for $\mathrm{me}^{36}$. And when we had agreed to the six, he sought ${ }^{37}$ to bring $^{38}$ troubles from other directions. We dropped the matter.

29 And we hired a little room ${ }^{39}$ of ${ }^{33}$ a Jewish woman for two dīnārs until [the month of] al-Muharram-five months. And it is a room, in the neighbourhood

zo of our friends, in which are all things necessary to it. And the bath is in the neighbourhood of it in the Jewish Quarter, near to the

${ }_{31}$ Church $^{32}$ and the Rubā'iyah ${ }^{40}$. I cannot describe ${ }^{41}$ what 1 have done in regard to it. And I neglected no tradesman

32 nor wool-merchant, nor cloth-merchant-according to whoever offered [things] for sale ${ }^{42}$. And there were sold from $\mathrm{it}^{43} 39$ quarters $^{44}$ of a wazn ${ }^{45}$ [for] eight dīnārs, and [the] price

is colloquial ma nalutttshe from classical at all."

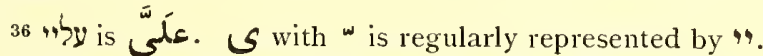

37 b in this sense is found in No. XXVI, recto, 1. 13.

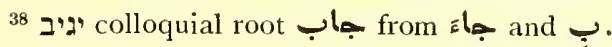

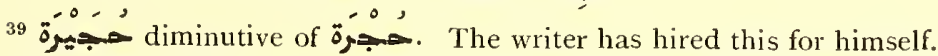

40 The "fourfold" or "quadrilateral" place, but not "city square" to our knowledge. Perhaps this name was applied to the site of the Mediaeval lodgings and hospitals of the Knights of St John, which passed into the hands of the Moslems in II87, and became known as the Mūristān. The room in question was probably in the block of buildings between the present Ḥārat Bab al-Silsileh, Ṭārīk Bab al-Silsileh and Sūk al-Laḥhāmīn.

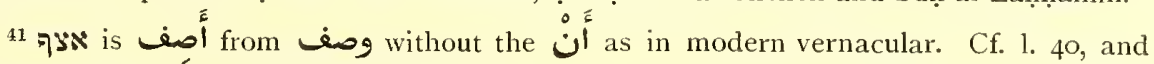
other instances.

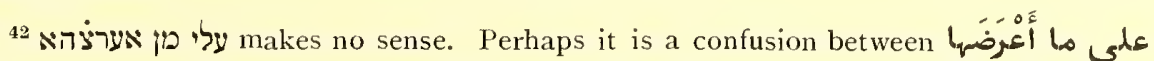
"according to what they offered for sale," and على "according to whoever presented himself." The writer of the letter is subject to these confusions.

${ }^{43}$ I.e. this room, which seems to have been used as a shop.

44 ربع with a connecting vowel.

45 The waźn seems to be here a definite weight. 
33 סער ذ דרהם כל דינר מן צרף לו דרה וניץ מנהם קום דפעו לי רהן ומנהם קום 34 דפעו אלבעץ ובקי ענדהם אלבעץ וקד לחקהא כצרה מן אל תחמיר אלתי

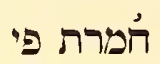

35 מצר ווזנת עלי הדה אלבקייה אלתי תבקת דרהם ונצף למן עאודהא

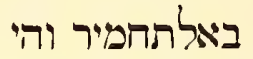

63 באקיה ואנא אגתהד פי אמרהא פסבהאי פין אסקט נגמהא ואפה אל צרה

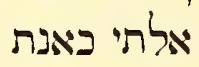

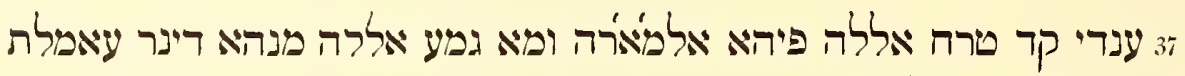
מנרה באל בעיץ

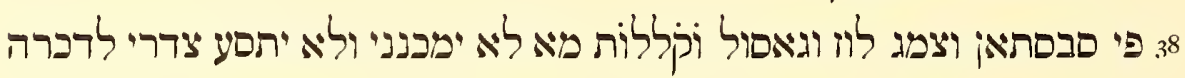

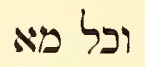

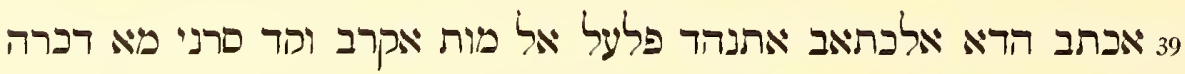

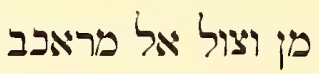
04 סאלמה לצקליה ותופיקדא פי אלבצטיע ויאניא ארגב למוליאי יערפני אסמאה אל קום ז4 הלויאצלין פי מרכב אל אנדלם וכדלך כל מרכב יני יערפני בגמיע אלאכבאר Margin :

באנני משאהר להא | ולעל יגיני פתאב פן צקליה או מן אי | מוצע כאן ואלי

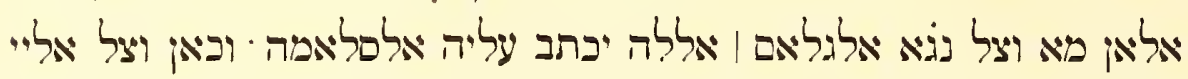

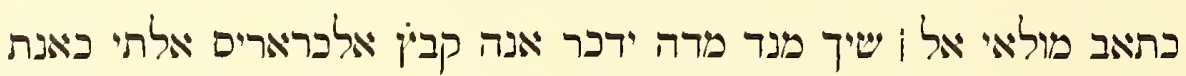

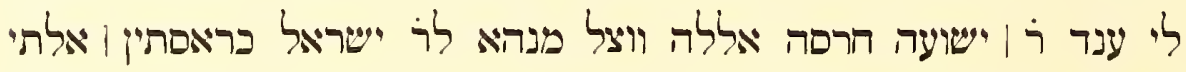

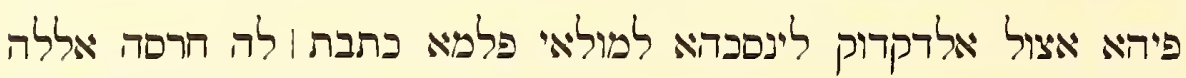

${ }^{46}$ The writer sold 39 quarter wazns for 8 dinārs. or 292 dirhams, which was at the rate of $7 \frac{19}{39}$ dirhams the quarter, or $29 \frac{37}{9}$ dirhams the wazn. After he had sold out at about 30 dirhams, the price sank to 20 dirhams the wazn.

47 The vernacular muss for نصن.

48 بُضْ "greenness."

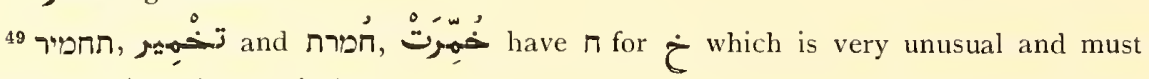
point to a dialectic peculiarity.

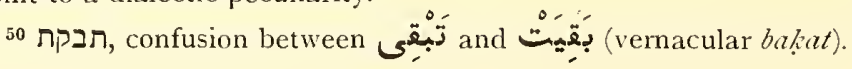


33 became 20 dirhams ${ }^{46}$, every dīnār being by exchange 36 dirhams and a half ${ }^{47}$. And of the [buyers] some people paid me [with] a note, and of them some people

34 paid a part, and a part remained with them [unpaid for]. And mouldiness ${ }^{48}$ had attacked it in consequence of the fermentation ${ }^{49}$ which had developed in

$3 \approx$ Egypt. And I weighed out, in addition to this remainder which remained ${ }^{50}$ [in their possession, unpaid for], a dirham and a half to such as brought it back ${ }^{51}$ in a fermented condition, while it

36 remained [in their possession, unpaid for]. And I am diligent in this matter. But Praise to Him who made its star to $\operatorname{sink}^{52}$ ! And as for the row which occurred

37 at my place: God has taken away its bitterness ${ }^{53}$. And where God has made [me] to profit ${ }^{54}$ from it ${ }^{55}$ by a dīnār, I have done business by means of it ${ }^{55}$ partly

$3^{8}$ in prunes $^{56}$ and gum-arabic, almonds and soap ${ }^{57}$ and earthen pots ${ }^{58}$ such as I am unable, and am not in the mood ${ }^{59}$, to mention. For even as

39 I write this letter, I sigh: "Perhaps death is very near"60." But I was pleased by what it ${ }^{61}$ said about the arrival of the ships

4o safely in Sicily, and their success with the cargoes. And I desire of my Lord that he inform me of the names of the people

4 arriving in the Spanish ship; and likewise, [of] every ship which comes let him inform me of all the news,

\section{Margin:}

as though I were an eye-witness of it. And perhaps there may come to me a letter from Sicily, or from some place or other. But up to the present [news of] the escape of the youth has not reached me. May God decree "safety" for him! And there arrived to me the letter of my Lord the Sheikh a little while ago, mentioning that he had got the pamphlets which belonged to me [and were] with Rabbi Joshua-May God keep him! And of these there reached Rabbi Israel two pamphlets in which were the elements of [Hebrew] grammar, for him to copy off for my Lord. And after I had

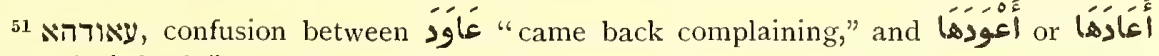
"brought it back."

52 l.e. made the price to sink; or, caused the natter to be forgotten.

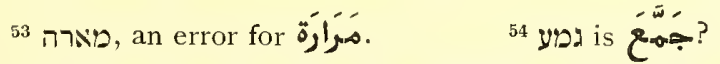

55 We doubt that the writer has anything in mind when he uses "it" so carelessly.

56 סבסתא. Cf. Dozy, op. cit., vol. ii, p. 625.

57 לסו is "cleanser."

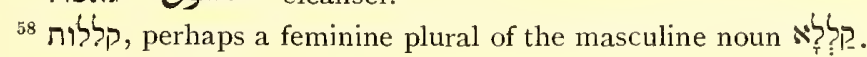

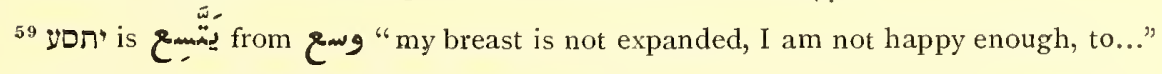

${ }^{60}$ I.e. "Oh that death were near!"

61 I.e. the letter he has received from Egypt.
} 
נאכַד עליה פי תוגיההא וצל אליי| כתאבה יקול ערפני פיא הי חתי אכתב

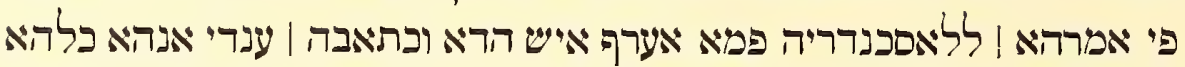

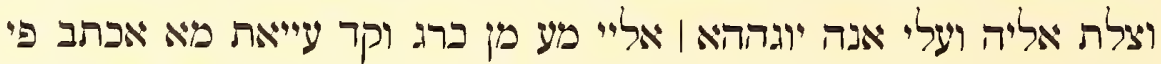

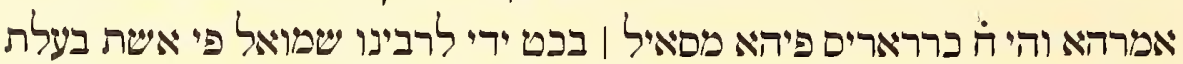

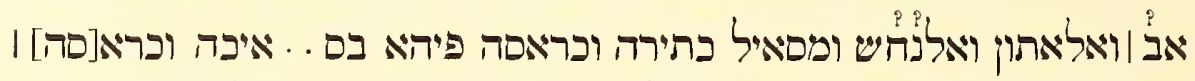

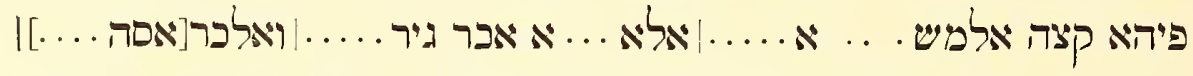

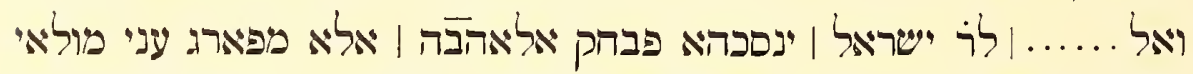

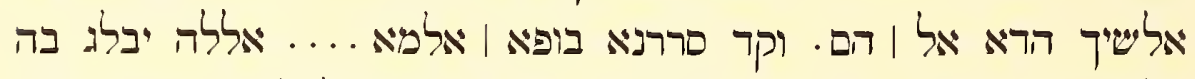

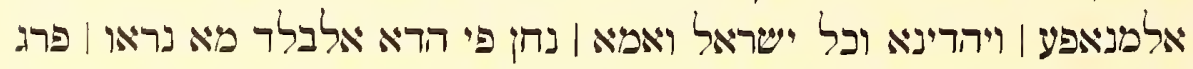

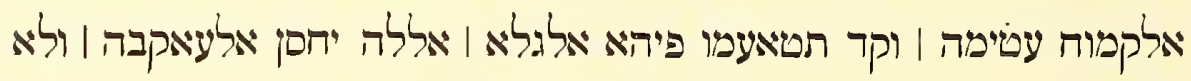
Verso:

מעאש משיט

ו וארי אליאן מיא וצל ר נתן פן דמשק לאנה מציא מע ר יצחק קאל לה

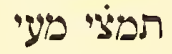

2 ואעטיך אלתלת פי מא יהצל לי ואמא מא רכרה חרסה אללה אין אבתב

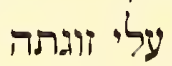

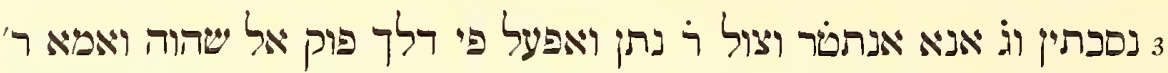

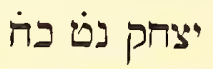

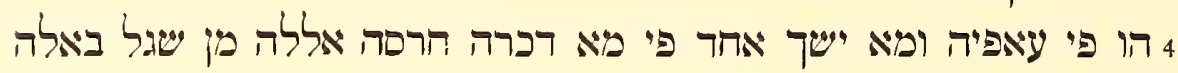

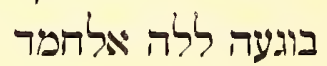

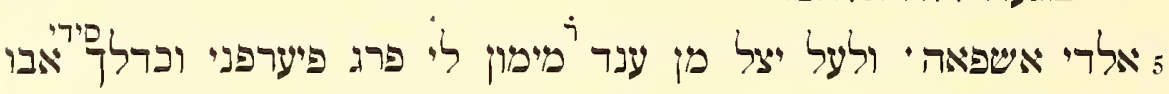

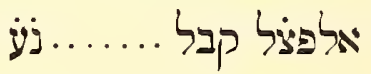

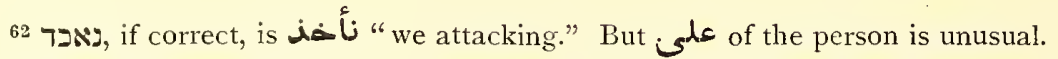

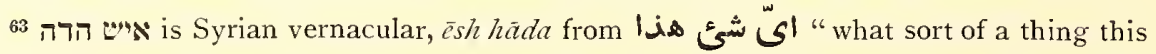
is."

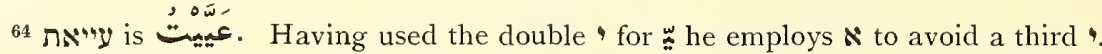

65 פררזארים 65 with an extra 7 due to confusion with the singular form.

${ }^{66}$ The correct title was אשרת בעלת אוב. Cf. I Samuel xxviii, 7 .

${ }^{67}$ Numbers xxii, 28, about the ass of Balaam that spoke.

${ }^{68}$ Genesis iii, I, about the serpent that spoke.

69 Possibly "the Messiah." $\quad 7^{0}$ I.e. "that exists between us"?

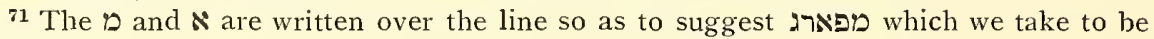

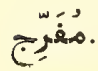

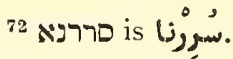


written to him-May God keep him!-taking him to task ${ }^{62}$ about [not] sending them, there arrived to me his letter, saying: "Inform me of what they are, so that I may write about them to Alexandria." So, I don't know what to make of this ${ }^{63}$; for his letter is [on file] with me that all of them reached him, and to the effect that he would send them to me with whomever left [there for here]. But I am tired ${ }^{64}$. I shall not write about it. But they are eight pamphlets ${ }^{65}$, among them [some treating of debatable] questions-in my own hand-writing-[namely:] by Rabbi Samuel on "A woman, Possessor of a Soothsaying Spirit "66," and "The She-Ass ${ }^{67}$," and "The Serpent68"(?) and many questions. And [there is] a pamphlet in which........ Lamentations, and a pamphlet in which [there is] the story of the......69.......other, not...... and the pamphlet...... and the........to Rabbi Israel for him to copy them. And, by the Love ${ }^{70 !}$ May my Lord the Sheikh dispel ${ }^{71}$ this care from me! And we were pleased ${ }^{72}$ at the success of the........... ${ }^{33}$ May God increase the profits by means of it, and guide us aright and all Israel! And as for us in this country, we do not think there will be ${ }^{74}$ any enormous ${ }^{75}$ relief ${ }^{76}$ in grain. And they have added profiteering ${ }^{77}$ to [shortage]. May God make favorable the outcome, or else ${ }^{78}$ [grant at least] subsistence!

Verso:

I And up to the present Rabbi Nathan has not arrived from Damascus, because he went away with Rabbi Isaac. He said to him: "Go away with me

2 and I will give you the third of what I make." And as for what he saysGod keep him ! - that I should write at his wife's expense

3 two or three ${ }^{79}$ amulets: I am expecting the arrival of Rabbi Nathan, and I shall do in this matter more than he could desire. And as for Rabbi Isaac,

${ }_{4}$ he is in good health. And let no one doubt what he has said-God keep him from his worrying ${ }^{80}$ over his bodily suffering. Unto God [be] the praise,

5 who cured him! And perhaps there will arrive from Rabbi Maimūn some relief for me, and he will inform $\mathrm{me}^{81}$. And so also my Lord Abū alFadl.........

${ }^{3}$ Perhaps هَأْخدن "mine," or "source of supply."

74 , גראי 7 , perhaps a confusion of [do not] think," and colloquial yarau, "they [do not] think."

75 עטימה should be masculine.

فَرَّج is a break in the grain market, or a relief in the stringency of public need.

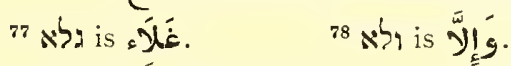

$79 \dot{y}$ is is ${ }^{\prime}$. The $a u$ was pronounced $\bar{o}$.

${ }^{80}$ Cf. No. XXVI, 1l. I2, I6.

${ }^{81}$ I.e. "about what to do for my own sickness." 
6לי ענדה חסאב ואעטם סרור ידכל עלי קלבי מא יתצל בי מן סלאמה גסמה ואכבאר

ד "ערפני בהא מן אלגרב לאני הונא משתאי לאבאי לסמאע כבר לאני טול נהאר. מחצור פי אל פי איגר

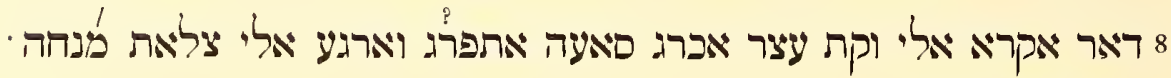

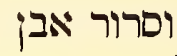
9 סהלאן הו ענדנא פי אלקדם וגע אללה תעאלי ישפיה וידכר אנה תעוזה נפקה ס ומא יגד אחד ידכל אליה ולא יכלמה באל עויו עליי ואלנאם מעדורין יטלב ואחד יטר ירור יטרי וייעמל גמיל רבמא יחצל פי אשיא לא ירומהא ורבמא יכרג עלי וגבה

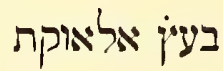
12 ישתרי לה האגה והו יסכן פי דור אל מסלמין ולא דאכל ולא כארג עליה.

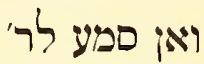
13 יצחק אלאנדלםי חרסה אללה כבר בוצולה יכתב אלי" בפצללה פאני מעלק

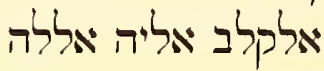

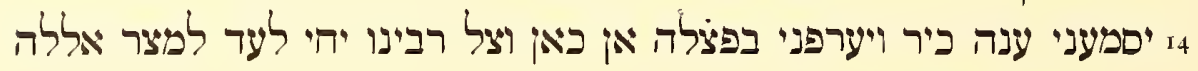

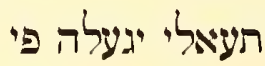
5י חיו אל סלאמה קראת עלי מולאי אלשיך אגל אלסלם ומולאי אבו אליאיטן פי פלי

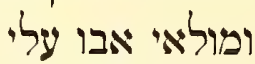
16 אצהארה חרסהמא אללה אפצל אלסלם וקד וצלת כתב אבו אלפרג האטה

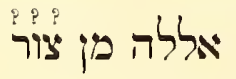
7י והו פי כל עאפיה ואל צבי אשר סלמה אללה מעה אעלמתה דלך ושלום לן Margin :

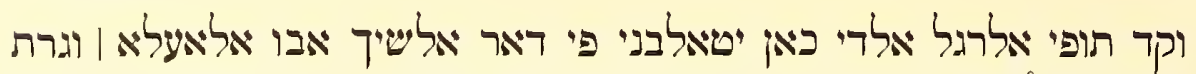

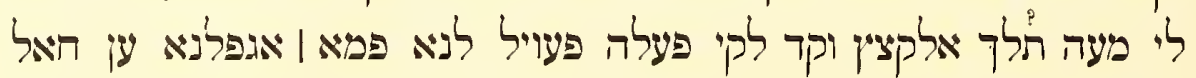

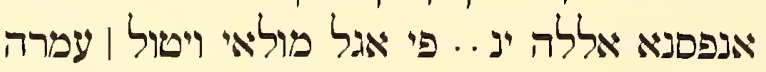

82 I.e. events.

${ }^{83}$ Article needed.

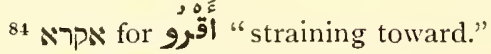

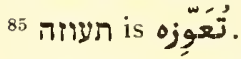

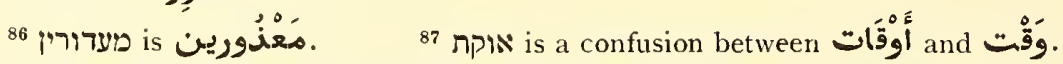

${ }^{88}$ I.e. He makes no distinction between close friends and mere acquaintances, between Jews and Muslims. 89 I.e. "do you." 
6 I have an account against him; but the greatest happiness will enter my heart if there should reach me [news] of the health of his body, and news

7 informing me of it ${ }^{82}$ in the West. For here I yearn to hear news, because I all day ${ }^{83}$ long am shut up in the

8 house, waiting impatiently for ${ }^{84}$ the time of afternoon [when] I can go out for an hour and take a walk and return for the Minhah prayers. And Sarūr Ibn

9 Sahlān is with us in Jerusalem. He has been ill. May God the Exalted heal him! And he says that his losses are reducing him to poverty ${ }^{85}$.

ro And he finds no one visiting him that he does not speak to him violently against me. And people are disappointed ${ }^{86}$. One tries

1 to do a kindness-often it results in things which one does not like. And often it leads to a crash on certain occasions ${ }^{87}$.

12 [One] buys him something, and he [goes and] lives in the houses of the Muslims. To him there is no inside or outside ${ }^{88}$. And if there is heard of Rabbi

13 Isaac the Spaniard-God keep him!--any news about his arrival, let him ${ }^{89}$ kindly write to me, for I hold him in great affection ${ }^{90}$. May God ${ }_{14}$ cause me to hear from him good news! And let him kindly inform me if the Rabbi ${ }^{91}$ - May he live forever!-reaches Cairo. May God the Exalted put him on

$I_{5}$ the side of safety! I am writing to my Lord the Sheikh the most distinguished peace ${ }^{92}$, and [to] my Lord Abū al-Ētān ${ }^{93}$, and [to] my Lord Abū 'Ulā 94

I6 his relations-God keep them both !-The most excellent of greeting! And the letters of Abū al-Faraj-God watch over him!-have arrived from Tyre.

${ }_{17}$ And he is in all [good] health. And the boy, Asher,-God preserve him ! —is with him. I am letting him ${ }^{95}$ know that. Peace be unto him ${ }^{95}$ !

\section{Margin:}

And the man has died who used to importune me in the house of the Sheikh Abū al-A'lā. And these doings ${ }^{96}$ went on between us. And he has received his deserts ${ }^{97}$. But woe ${ }^{98}$ unto us! For we are not unmindful of our own condition ${ }^{99}$. May God........(?) my Lord most abundantly and extend his life!

${ }^{90}$ I.e. "I am dependent upon him as to heart."

91 The bearer of the letter itself?

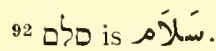

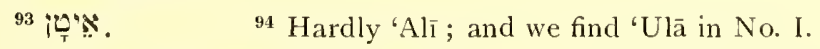

95 I.e. the addressee of the letter.

قوصَص is. Cf. Friedländer, Der Sprachgebrauch des Maimonides, p. 92.

97 Cf. Dozy, op.cit., ii, p. 546.

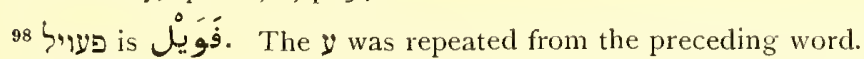

${ }^{99}$ He remembers that he also may die, as well as the man whom he disliked. 
Address:

شاكره
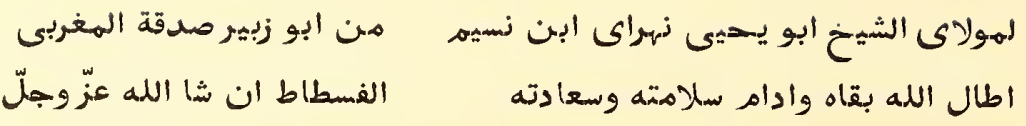

${ }^{100}$ As there are scarcely any points to distinguish similar letters from one another in these proper names, it is almost useless to try to make them out. But the Arabic type commits one to some definite reading. 
Address ${ }^{100}$ :

To my lord the Sheikh Abū Yaḥyā Nahrāīior Ibn Nissīm,

From his grateful Abũ Zubair Șadaḳah al-Maghribĩ.

May God extend his [earthly] sojourn, and protract his health and happiness!

Al-Fustāt-If it please God ${ }^{102}$, the Powerful and Exalted!

101 Aramaic.

102 I.e. that it should arrive safely. 


\section{PART OF A LETTER}

Paper I I $\frac{5}{8} \times 5 \frac{1}{8}$ inches.

Arabic in Hebrew characters.

The beginning, perhaps a considerable portion, of this letter, is wanting; but what we have is well preserved. The cursive Hebrew hand is neat and legible, and continues so to the end; and the margin has not been filled with added scrawls. A blank space has unaccountably been left near the bottom. After the conclusion, line 25, several postscripts have been added. A cryptic signature or date stands at the lower right-hand corner.

This fragment may be the ending of a letter of which No. XXX is the beginning.

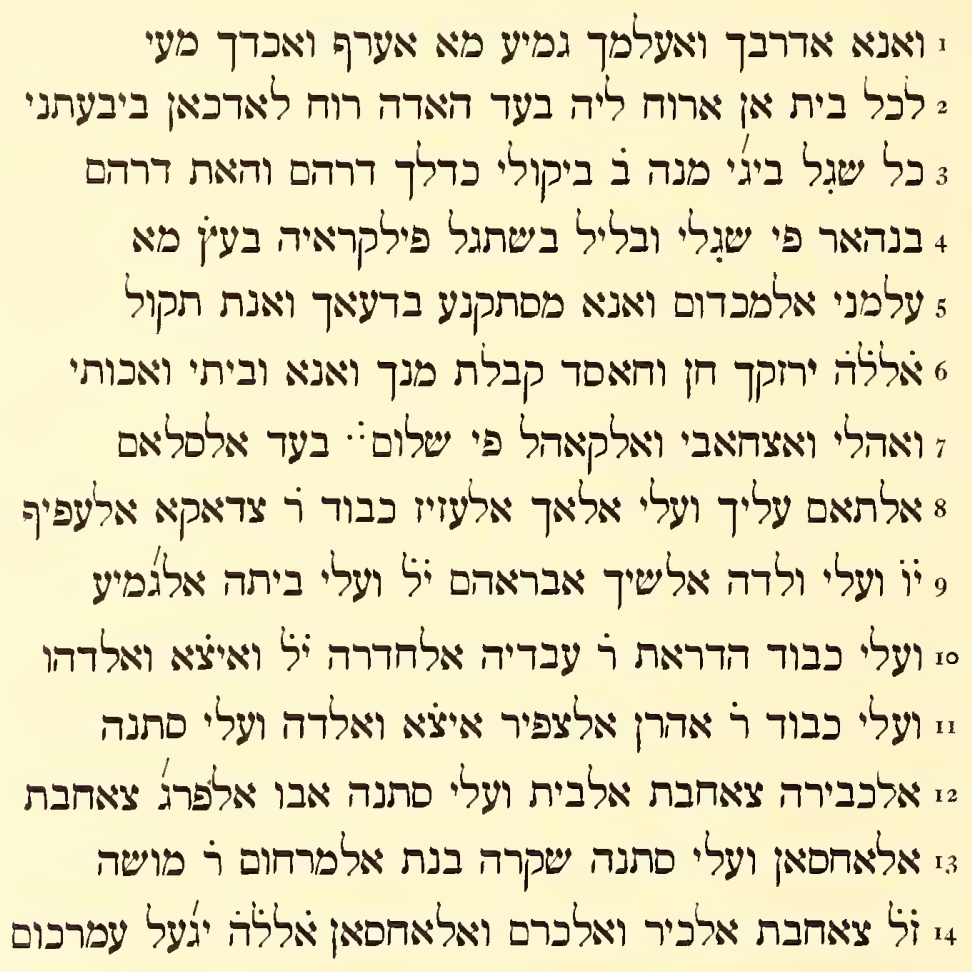

1 iN used as an indefinite relative, quite clearly in this case ; less clearly in other instances among our fragments. This is not modern vernacular, and appears to be a characteristic feature of Judeo-Arabic of the time. We also have in our fragments $\checkmark$ ⿶ill in the sense of أنَ, a semantic change illustrated by English "that": first the demonstrative pronoun, then the relative pronoun, then the conjunction. This use of $\sqrt{ } \boldsymbol{U l}^{\text {is }}$ the same as that of the modern colloquial illi: ana mabsitt illi mā gäsh, "I am glad that he did not come." Cf. Spiro, Arabic-English Vocabulary, Ist ed., I895, p. 17.

${ }^{2} l \bar{e}$ for $l \bar{o}$ is Palestinian. $\quad 3$ The Hebrew words. $\quad 4$ I.e. "wife."

5 بَré, ind not seems.

${ }^{6}$ The writer is spelling almost phonetically both his Arabic and his Hebrew :

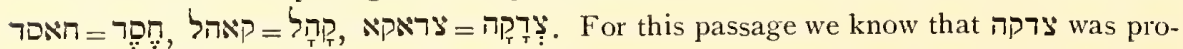
nounced in the Hebrew way by Jews. 


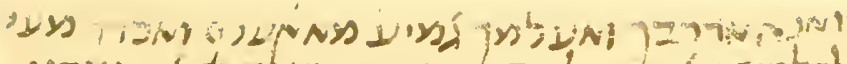

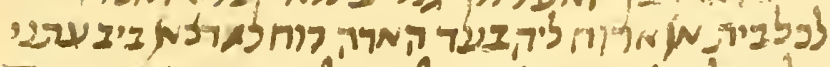
כד

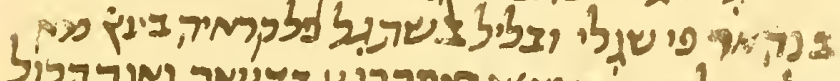
S

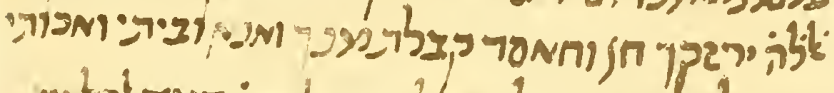

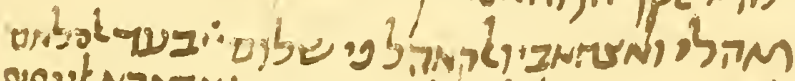
הפو

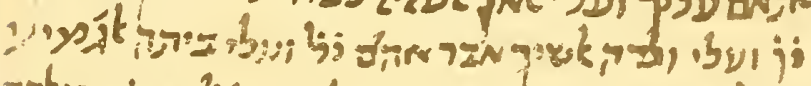

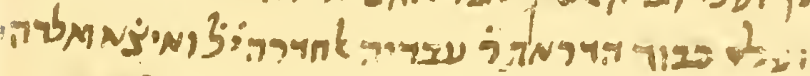

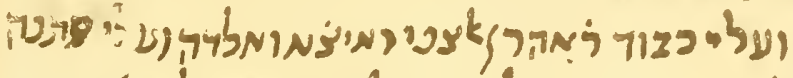

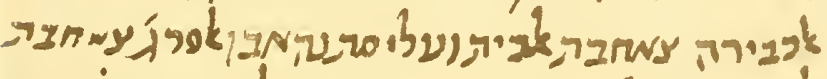

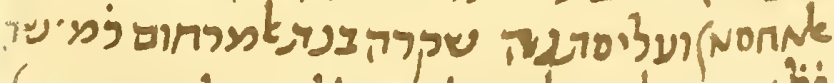

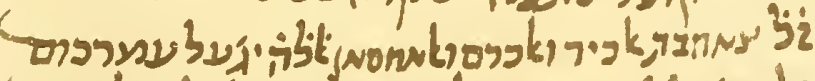

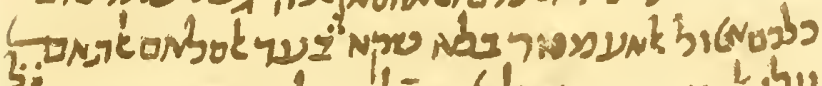

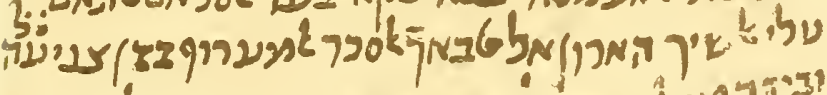

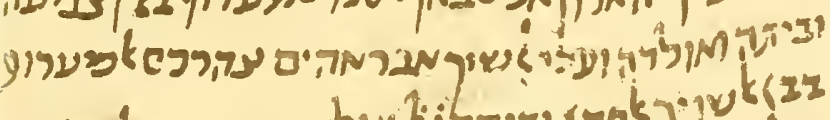

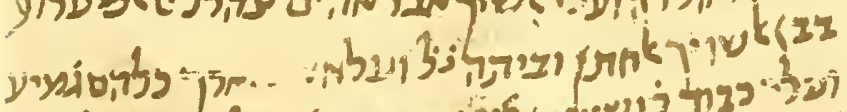

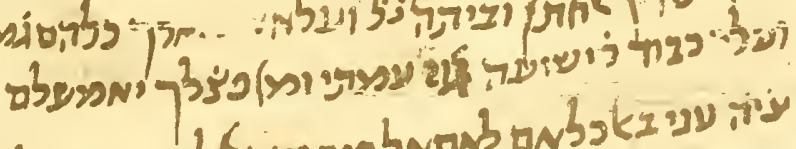

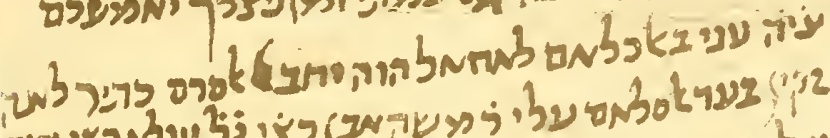
.

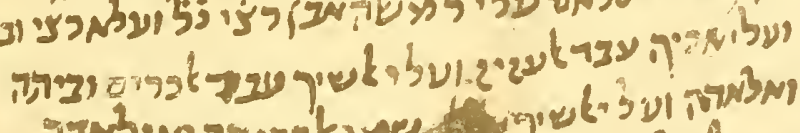
ivrbim.

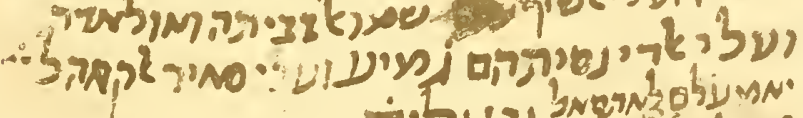

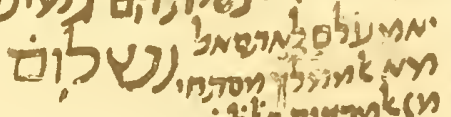
ititi $20145 n^{2}(n)$ " פצ'

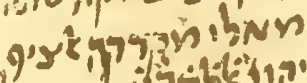

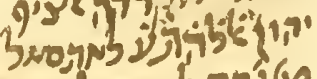

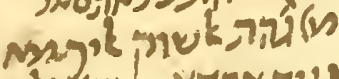

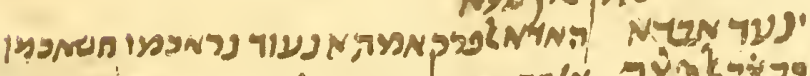

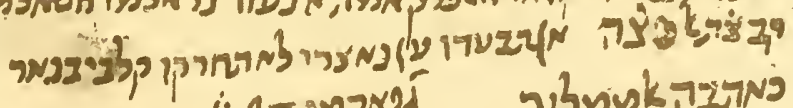
$\therefore e$ ipnכoxá

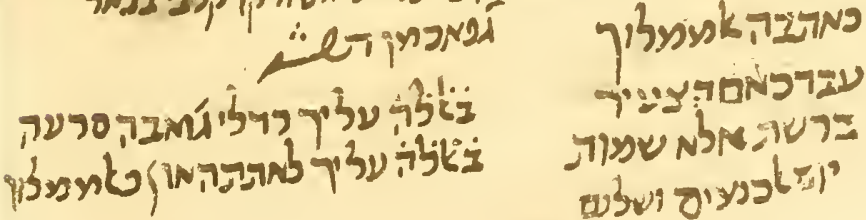

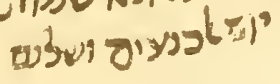





\section{PART OF A LETTER}

This text, with No. XXX, is extremely interesting, not only because it has been plainly written and perfectly preserved, but because it antedates by possibly two hundred and fifty years the next oldest specimen which we have of colloquial Arabic : Hazz al-Kultüf by al-Shirbīnī, A.D. i687. (Cf. Brockelmann, Geschichte der Arabischen Literatur, vol. ii, p. 278.) In marked contrast to our texts Nos. III, XII, XXII, XXXIII, XXXIV and XXXV, we find here a Jew writing, probably in the early fifteenth century, almost what is spoken in Cairo today. Was the writer a slave?

I And I shall acquaint you with and inform you of all that I know. And I shall take you with me [in fancy]

2 to every house to which ${ }^{1} \mathrm{I}_{\mathrm{go}^{2}}$. After this go [in fancy with me] to the shop. [The proprietor] sends me

3 all business. From this there are two [shares]. He says to me: "There is a dirham!" and "Give [me] a dirham!"

${ }_{4}$ Every day there is my business; and at night I work at reading some of the things which

5 the Master has taught me. And I am content with your prayer; for you say:

6 "May God grant you grace ${ }^{3}$ and favor 3 !" I have received [it] from you. And I and my household ${ }^{4}$ and my sisters

7 and my people, and my companions, and the congregation ${ }^{3}$ are at peace ${ }^{3}$. Then ${ }^{5}$ the perfect

8 salutation, to yourself and your dear people: the honorable ${ }^{3}$ Rabbi Ședhāḳāh ${ }^{6}$ al-'Afīf 7 ,

9 and to his son, the Sheikh Abraham ${ }^{7}$, and to all his household;

to and to his Honor, his Excellency ${ }^{8}$, Rabbi Obadiah, his Excellency ${ }^{8,7}$, and also his father,

I and to the honorable ${ }^{5}$ Rabbi Aaron al-Safīr ${ }^{9}$, also his father; and to our great

I2 lady, the mistress of the house ${ }^{10}$; and to our lady [wife of] Abū al-Faraj, mistress of

${ }_{13}$ benevolence; and to our lady Shukrah ${ }^{11}$, daughter of the deceased Rabbi Moses?,

${ }_{4}$ mistress of good fortune, and generosity, and benevolence. May God make your lives

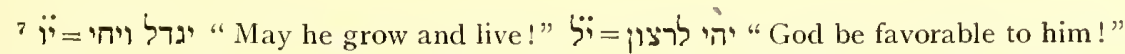

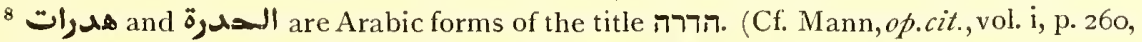
line 8.) $\pi$ and $\boldsymbol{n}$ interchange. (Cf. Dalman, Aramäisch Neuhabräisches Wörterbuch, and ed., I922, p. I38, col. I, lines I9-20.)

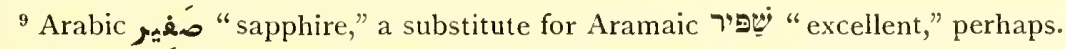

${ }^{10}$ I.e. the wife of the addressee. $\quad 11$ I.e. "bright red." 
5 1 בלכם אטול אלאעמאר בלא שקא בער אלםליאם אלתאם

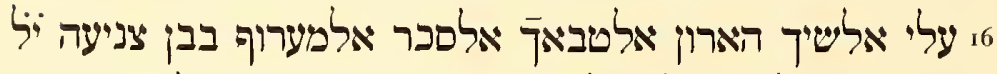
78 וביתה ואלי אלשירה ועלי אלשיך אבראהים צהרכם אלמערוך

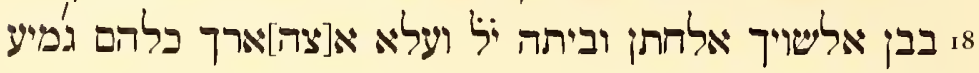

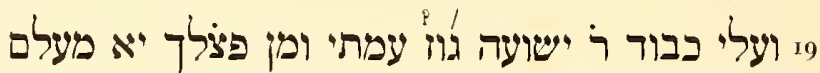
20

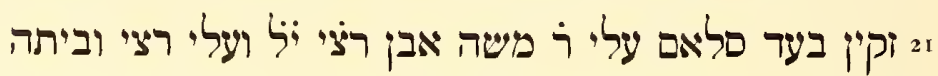

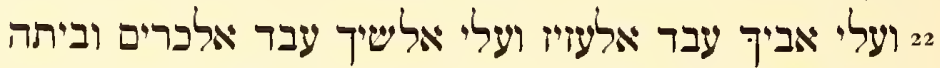

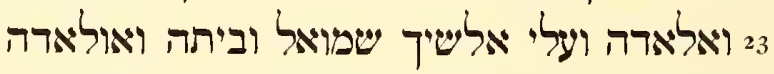

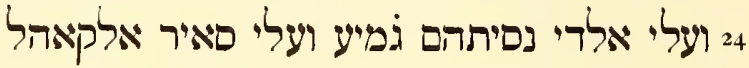
ועלום

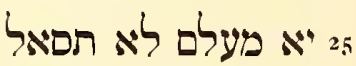

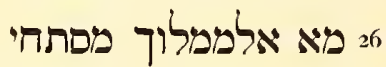

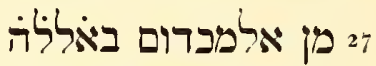
28

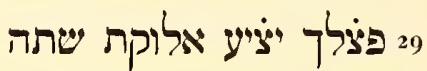

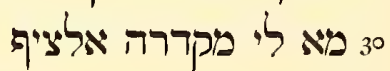

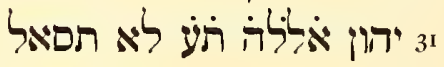
32

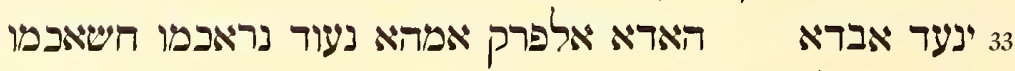

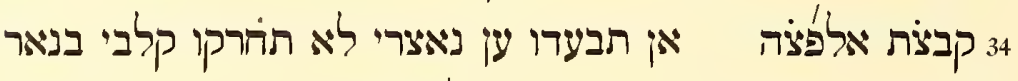

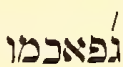

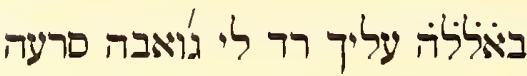

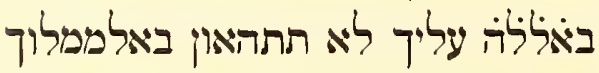

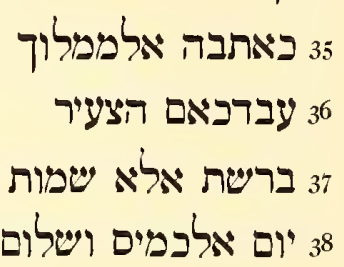

12 I.e. "sugar." Cf. Zuckermann, etc.

${ }^{13}$ I.e. "son of invention."

14 I.e. "son of the little Sheikh."

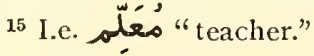

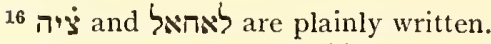

17 هר מُرس etc.: Spitta, Grammatik des Arabischen Vulgärdialectes von Aegypten, I88o, p. 18.

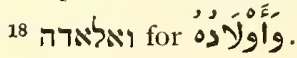


I5 -all of you-the longest of lives, without want! Then ${ }^{5}$ the perfect salutation

I 6 to the Sheikh Aaron, the cook al-Sukkar ${ }^{12}$, known by [the name of] Ibn Sanī'ah ${ }^{13,7}$,

I 7 and his house and his children; and to the Sheikh Abraham, your sonin-law, known by [the name of]

I8 Ibn al-Shuwaikh ${ }^{14}$, the son-in-law ${ }^{3}$ and his household ${ }^{4,7}$; and to all your wife's relatives, all ;

I9 and to the honorable ${ }^{3}$ Rabbi Joshua, husband of my paternal aunt. And please, Master ${ }^{15}$,

20 ......from me in conversation for ${ }^{16}$...... he loves much to quarrel ${ }^{17}$, because 2r he is an old $\operatorname{man}^{3}$. Then ${ }^{5}$ [the] salutation to Rabbi Moses Ibn Raḍi, and to Radi and his household ${ }^{4}$,

22 and to your father, 'Abd al-'Azīz, and to the Sheikh 'Abd al-Karim and his household ${ }^{4}$,

${ }_{23}$ and his children ${ }^{18}$; and the Sheikh Samuel and his household ${ }^{4}$ and his children,

${ }_{24}$ and to those whom I have forgotten, all [of them]; and to the rest of the congregation ${ }^{3,6}$.

$25-26$ So, Farewell!

${ }_{25} \mathrm{O}$ Master ${ }^{15}$, do not ask [for reassurances]!

26 The slave is not ashamed

27 of the Master. Allah!

28 It excites me [to think of] how I have made

29 your Excellency waste time! [In the] winter

30 I have no provision. [In] the summer

${ }_{31}$ God the Exalted ${ }^{19}$ will help. Do not ask [for reassurances]

32 in regard to the affection [which I bear] toward you. It

33 shall not be counted ${ }^{20}$ at all.

$3+$ I got the silver.

35. The writer of it is the slave,

36 your insignificant servant,

37 "Genesis--Exodus ${ }^{21}$ "

${ }_{3} 8$ Thursday. Farewell!

$33^{\text {bis }}$ This is the separation. But we shall see you again. Far be it from you $34^{\text {bis }}$ to hold aloof from my helper! Do not consume my heart with the fire ${ }^{22}$ of

$35^{\text {bis }}$ your cruelty ${ }^{23}$.

$3^{6 \text { bis }}$ I implore you by Allah! Return me a speedy answer!

$37^{\text {bis }}$ I implore you by Allah! Do not neglect the slave!

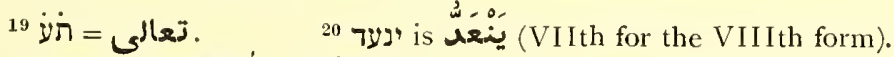

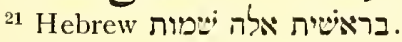

22 These two lines, with the curious -kumu, could almost be scanned as rajaz verses.

${ }^{23}$ Followed by a curious scrawl, half Hebrew and half Arabic. 


\section{PIZMONIM}

Paper $10 \frac{5}{8} \times 4 \frac{7}{8}$ inches.

Hebrew in cursive Hebrew characters.

Since the paper and ink are well preserved, and the writing is very plain, almost every letter can be certainly read. The language is an attempt at classical Hebrew, often distorted for the sake of the meter, and not always giving clear sense. Vowel points are inserted in places, and for the most part correctly.

The meter of the first nineteen verses appears to be a sort of rajaz trimeter. The remainder does not scan. In this first section of nineteen verses the second hemistichs are all rimed, with some difficulty, on the first hemistich of the poem; this hemistich appears again as the closing one of the section. In verses $2 \mathrm{I}-24$ the same rime is continued; it appears finally in the last verse of the entire poem.

The fragment can perhaps be dated not long before or after the death of the Abraham to whom it is addressed, in A.D. I 237.

Recto:

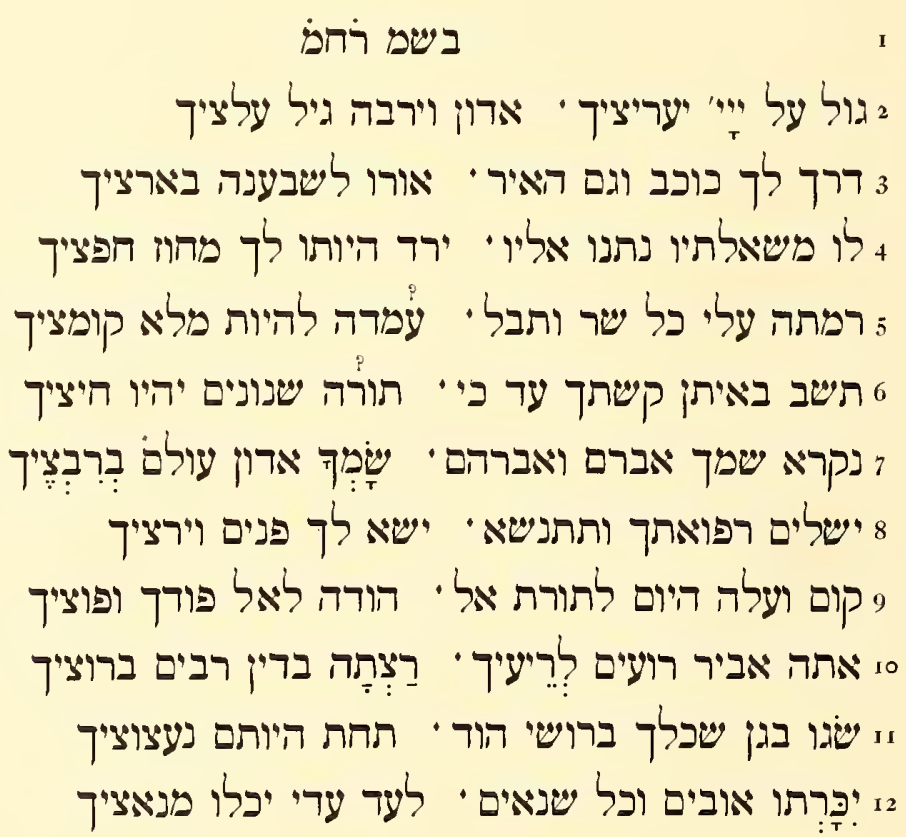

${ }^{1}$ Perhaps influenced by the Muslim formula.

2 Cf. Psalm xxxvii, 5.

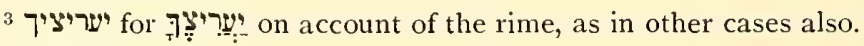

${ }^{4}$ Cf. Numbers xxiv, I7. $\quad{ }^{5}$ Cf. Genesis xlix, 24.

${ }^{6}$ Cf. Isaiah v, 28, as nāgīd.

7 Cf. Genesis xvii, 5 .

${ }^{8}$ Abraham Maimūnī was physician to the Sultan. 


\section{PIZMONIM}

This poem of praise, consolation and encouragement, is addressed by some unknown person to a certain Abraham, who is a physician, a man in high position in the world, and greatly respected by the Jewish community of which he is the champion. He has been attacked by certain enemies, and perhaps even by a mob. The person meant is presumably Abraham Maimūnī, the son of the great Maimonides. He was born June I7, i I 86, and died in the year 1237. He became nägīd, probably in 1205, and was physician to the Sultan. See Mann, op. cit., vol. i, pp. $248 \mathrm{ff}$; vol. ii, pp. 326 ff. Eppenstein, Ahraham Maimnni sein Leben and seine Schriften, I9I4 (cited by Mann); Steinschneider, Geschichte der arabischen Literatur

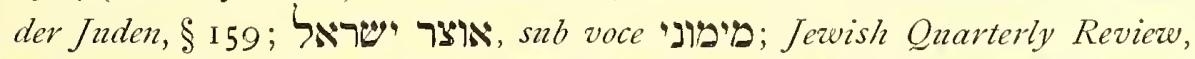
2nd series, vol. v, p. 463 ; Zeitschrift für hebräische Bibliographie, vol. iv, p. 24; Monatsschrift für die Geschichte und Wissenschaft des Judentums,

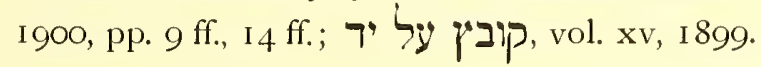

\section{Recto:}

I In the Name of the Compassionate ${ }^{1}$

2 Commit [your ways] unto the Lord ${ }^{2}$. The company of your rejoicers shall praise you in awe ${ }^{3}$, my Lord, and it shall increase.

3 A star ${ }^{4}$ has gone forth for you ; and its light has shone to our satisfaction in your land.

+ If they gave it what it asks, it would come down [from the sky, to] become the city of your desire.

5 You are exalted above every prince. And the world is about to be filled with your abundance.

6 Your bow remains strong ${ }^{5}$ until you shoot. Your arrows are sharp ${ }^{6}$.

7 You were called "Abram"; but the Lord of the World has made you an "Abraham" in your resting places". [For]

8 He makes your cures succeed, and you are exalted ${ }^{8}$. He lifts up [His] countenance upon you, and is gracious to you.

9 Arise and go up today for the Law of God. Give thanks unto God, your redeemer and your deliverer.

10 You are the mightiest of shepherds unto your companions. You have hastened [to help] many in court with your ready [help] ${ }^{9}$.

I Splendid cypresses have grown in the garden of your intelligence, instead of (their being) thorn-hedges (of yours ${ }^{10}$ ).

12 All enemies ${ }^{11}$ and haters shall be cut off for ever, until your revilers come to an end.

\footnotetext{
$9 \mathrm{His}$ position made it possible for him to come to the aid of his brethren.

${ }^{10} \mathrm{Cf}$. Isaiah $\mathrm{I} v, 13$.

${ }^{11}$ אובים. The syllable? having no full vowel does not count with the meter, and has

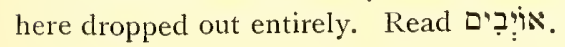


3. ידגו וגם יפרו שתיליך' האל ויפריח לנצ׳יך

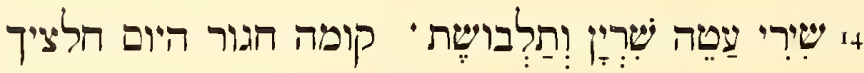

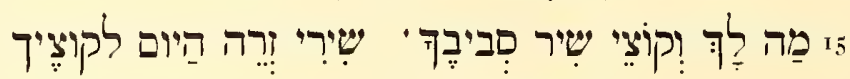

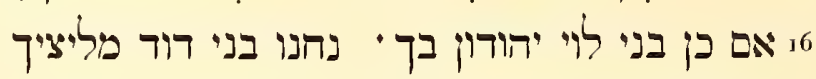

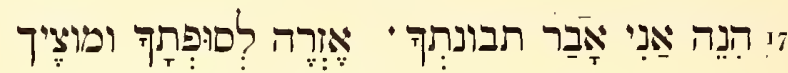
18

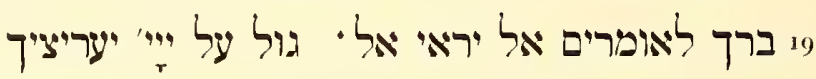

[פig]

20

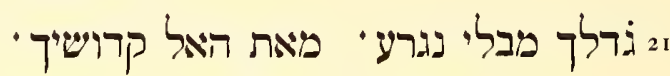

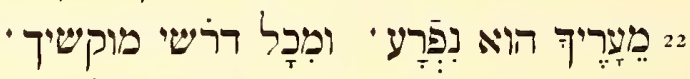

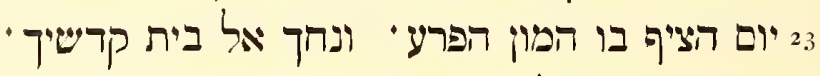

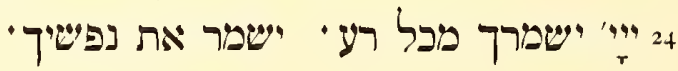

פופט 25

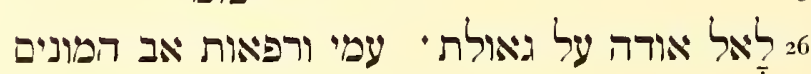

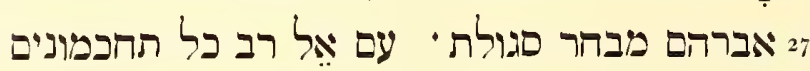

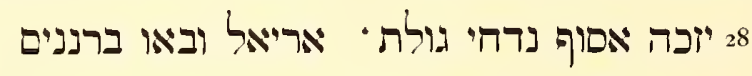

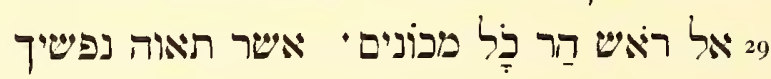

Verso:

פופו 2 אל הי לעמו חיש יקרא' גיל ובאברתו יסך לך

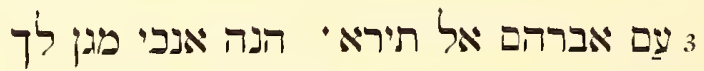

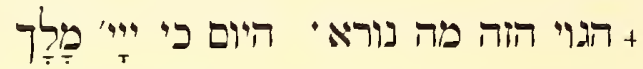

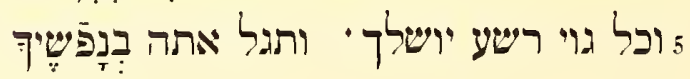
פופ

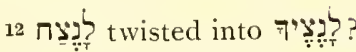

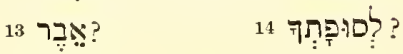

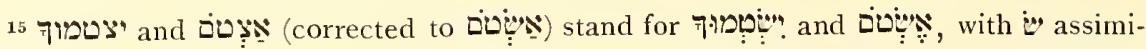
lated to $ט$, and , then assimilated to $\rightrightarrows$. Cf. Genesis xlix, 23 .

16 국?

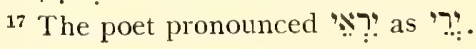


${ }_{13}$ Thy cuttings, O God, shall multiply, and increase, and flourish for ever ${ }^{12}$. ${ }_{14} \mathrm{O}$ my Song, cover yourself with armor and raiment! Arise and gird your loins today!

r5 What have you to do with suppressors of song about you? Scatter my song today to those who would cut you off!

I6 If thus the sons of Levi praise you, we sons of David are your interpreters.

${ }_{17}$ Behold I am the pinion ${ }^{13}$ of your intelligence. I will winnow your whirlwind ${ }^{14}$ and your chaff.

Is If the people with arrows attack you ${ }^{15}$, I will attack ${ }^{15}$ them that contend with you ${ }^{16}$. And [had I only] your arrows!

ig Bless those who say unto those who fear" ${ }^{17}$ God: "Commit [your ways] unto the Lord?".

20

[Pizmōn $\left.{ }^{18}\right]$

2 Y Your greatness is not at all diminished. From God is your holiness,

22 He will demand satisfaction from your oppressors and from all those who seek to ensnare you.

${ }_{23}$ On the day of the pouring out of [the] mob [there was] the leadership [of God] and your resting secure upon your holy house ${ }^{19}$ !

${ }_{24}$ The Lord will keep you from every ill. He will keep your soul ${ }^{20}$.

25

Pizmōn

26 To the Lord I will give thanks for the redemption of my people, and the healing of the Father of Multitudes,

2. Abraham, the chosen possession of the people of God, the chief of all the Tahchemonites ${ }^{21}$.

28 May the gathering of the outcasts of the exiles of Ariel ${ }^{22}$ be pure. And they shall come with joy ${ }^{23}$

29 to the top of the Mountain ${ }^{22}$, [the place of] all places which your soul desires.

Verso:

I Pizmōn

2 The Living God calls to His people: "Hasten, Rejoice!" For with His pinion He covers you, [saying:]

3 "O people of Abraham, fear not! Behold I am a shield unto you!"

+ How dreadful is this people today! For the Lord is King,

5 and every evil nation shall be destroyed; but you yourself shall rejoice.

6

Pizmōn

18 Instead of פיפ occurs the cursive Coptic numeral for 500, derived from the CopticGreek numeral $\bar{\phi}$. This may merely be intended for an ornament, dividing the introduction from the three stanzas.

19 Referring to some experience of Abraham Maimūn̄̄?

20 Psalm cxxi, 7.

21 l.e. "mighty men." Cf. II Samuel xxiii, 8.

22 "Jerusalem." Cf. Isaiah xxix, I.

23 ברנפית. The masculine plural would mean "female ostriches." 


\section{PART OF A LETTER}

Paper $9 \frac{1}{2} \times 5 \frac{1}{8}$ inches.

Arabic in cursive Hebrew characters.

This is possibly a part of the same letter as No. XXVIII. Both fragments are of the same paper, cut to the same width, written in the same hand and in the same unusual Arabic (cf. Introd. No. XXVIII). Possibly a page has been lost between No. XXX and No. XXVIII. The first two lines of No. XXX unfortunately are defective, and we do not know the name of either of the correspondents, nor the date.

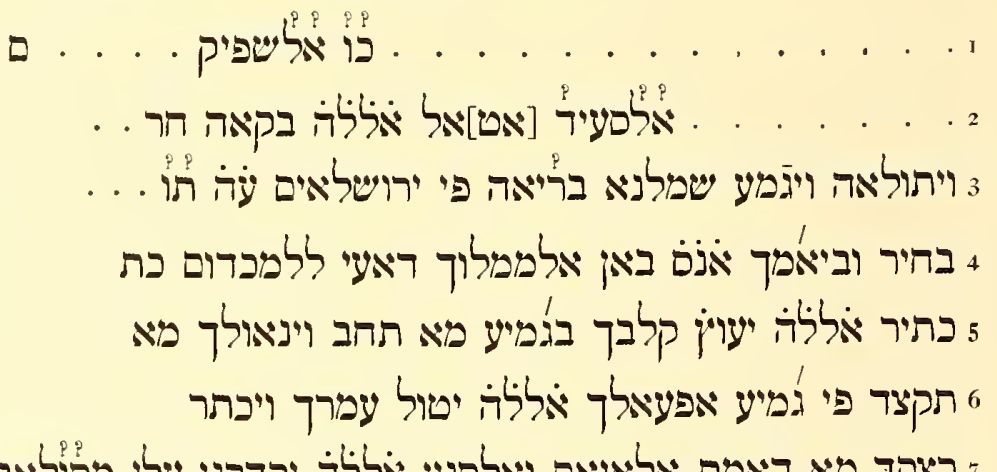
ז רצקך מא ראפת אלאיאם ואלסנין אלללה יקררני עלי מסוליאת 8 יא פעלם לא תסאל מא ג'רא לי פי יום אי טלעת פי מצר 9

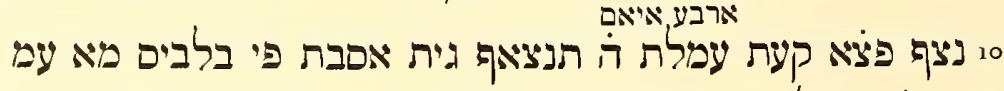

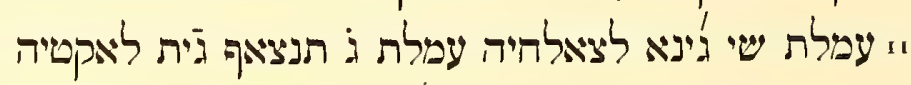

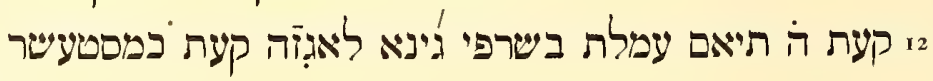

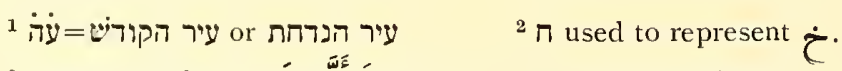

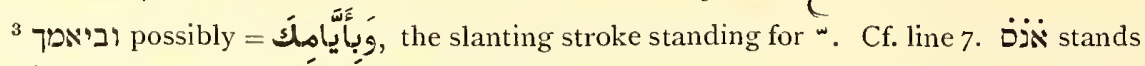

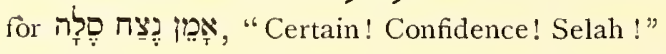

"I.e. "I." $\quad{ }^{5}$ I.e. "the one who is served."

${ }^{6}$ The first two letters of בתיר occur also at the end of the preceding line.

7 g forj. $8{ }^{2}$.

9 (ח) = vernacular hiasálli.

${ }^{10}$ A village about twenty kilometers north and east of Cairo, on the old caravan route to Syria הליאואל is a confusion of ila and vernacular li al, the $\mathbf{N}$ representing the vowel $i$.

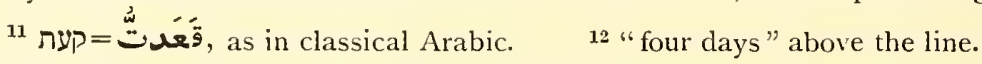

13 is the vernacular khámastansáf. So also, line I I, taláttansạ́f, lines I2, I 3, khámastīyám; line $\mathbf{I}_{4}$, árba'tansăáf, and other instances.

14 السَّ:ت 


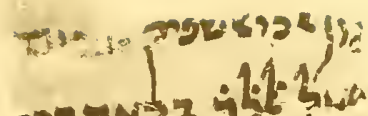

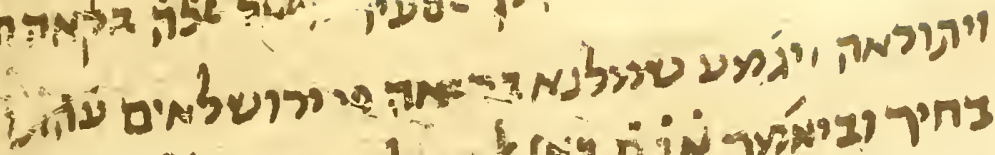

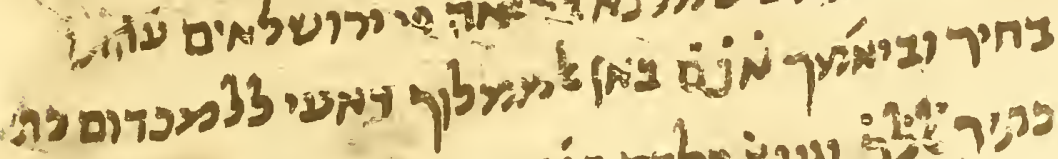

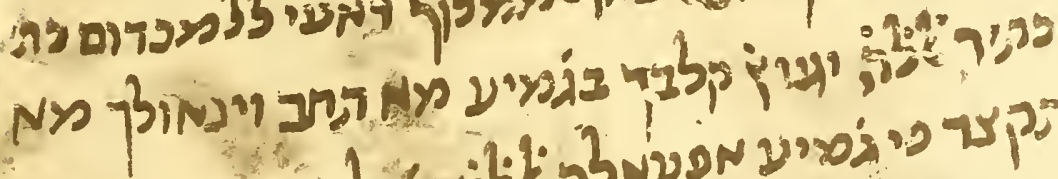

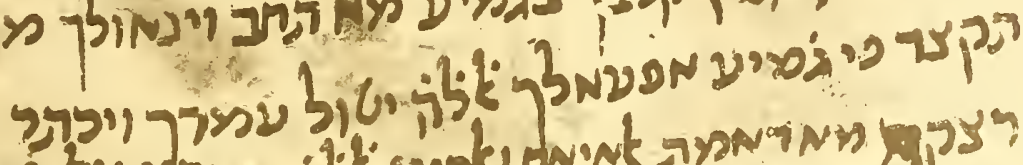

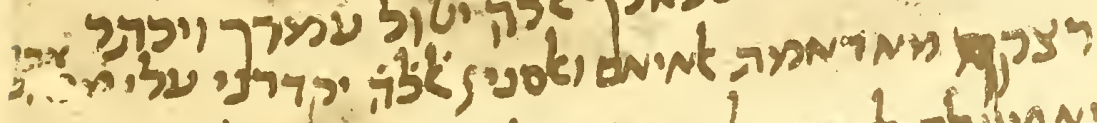

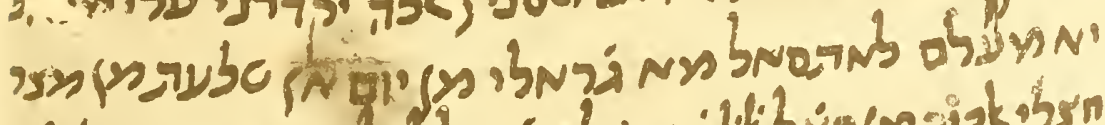

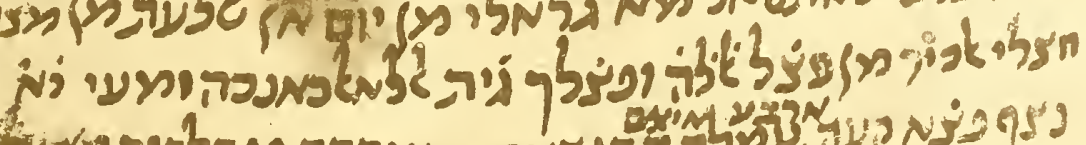

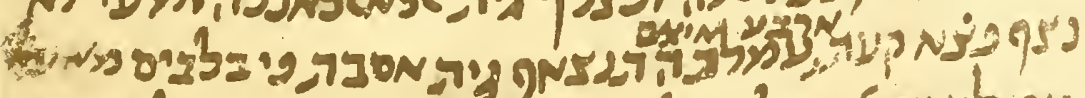

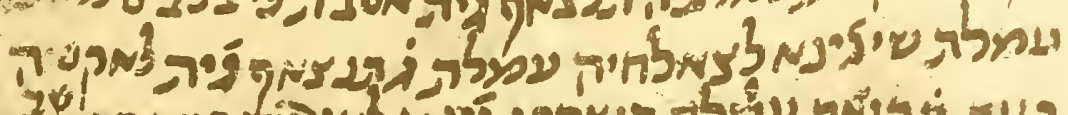
स

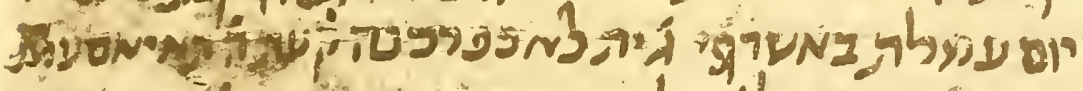

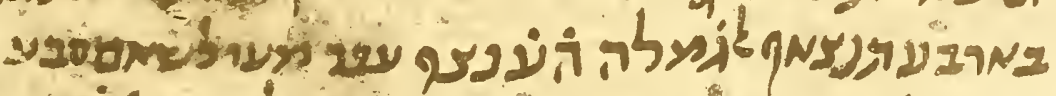
ם)

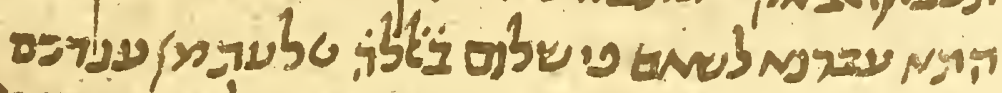

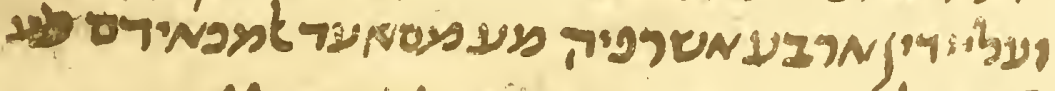

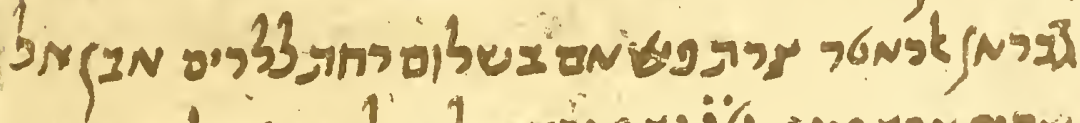

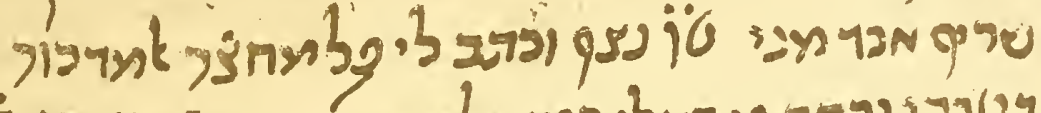
ה. .

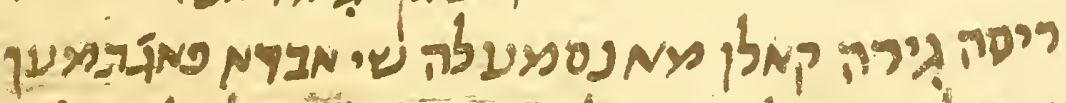

"ל על r q52

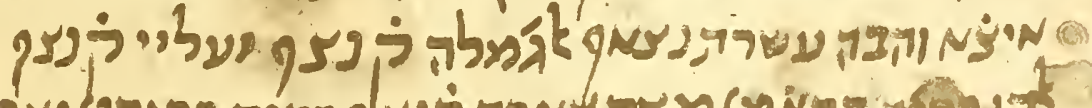

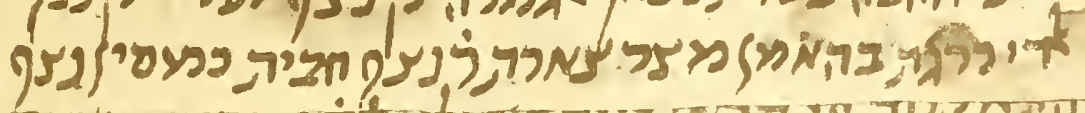

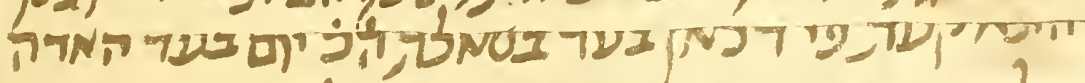

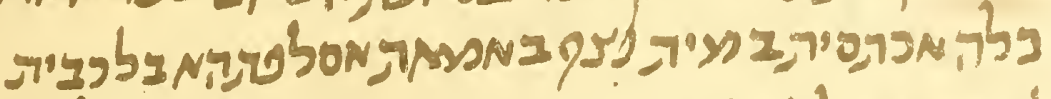

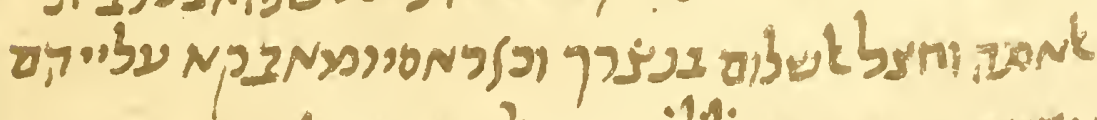
"

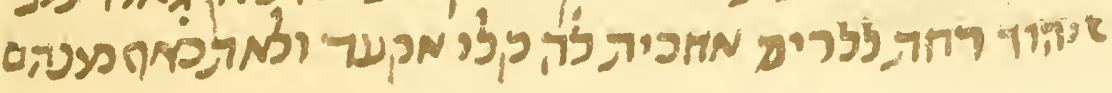





\section{PART OF A LETTER}

We have here the beginning of a breezy letter written by someone in Damascus to someone in Fustạt. The writer has recently made the journey from the latter to the former place, earning or begging money from (Jewish?) communities on the way. Arriving at Damascus he is mulcted by both Muslims and Jews, but especially the latter, who are jealous of him. After establishing himself in business he has more trouble of the same sort, and is befriended by the Muslim ra'îs. Here the text breaks off.

The use of "ashrafī" and "nuṣf faḍah," instead of "dīnār" and "dirham," is found in No. XLI also. The "nusf" was not used before the days of the sultan al-Mu'ayyad (A.D. I 4I 2-I42 I). Our fragment may therefore be dated in the early i 5 th century.

al-Shafik ......

2 .........al-Sa'īd. May God prolong his life........

3 and direct him, and reunite us by seeing him in Jerusalem ${ }^{1} \ldots .$.

4 in good condition ${ }^{2}$. And in your days: A!N!S! ${ }^{3}$; since the slave ${ }^{4}$ prays for the Master ${ }^{5}$

5 often $1^{6}$ : God requite your heart with all that you desire, and give you what 6 you seek in all your undertakings! God prolong your life and multiply

7 your sustenance ${ }^{7}$ as long as days and years continue!" God enable me to [answer your] questions!

$8 \mathrm{O}, \mathrm{Master}^{8}$, do not ask what happened to me from the day when I came up from Cairo!

9 I had ${ }^{9}$ good luck by the grace of God and your grace. I came to alKhānḳah ${ }^{10}$, having with me eleven

1o half pieces of silver. I stayed ${ }^{11}$ four days ${ }^{12}$. I made five half ${ }^{13}$ [pieces of silver]. I arrived on a Sabbath ${ }^{14}$ in Bilbais $^{15}$, [and so] I made ${ }^{16}$

in nothing. We went to al-Ṣāliḥiyah ${ }^{17}$. I made three half ${ }^{13}$ [pieces of silver]. I came to Katyah ${ }^{18}$.

12 I stayed $^{11}$ five days ${ }^{13}$. I earned an ashrafī19. We came to Gaza ${ }^{20}$. I stayed $^{11}$ fifteen $^{21}$

${ }^{15}$ About 35 kilometers from al-Khānkăh further along the caravan route.

16 The first two letters of עמלת occur also at the end of the preceding line.

17 About 55 kilometers from Bilbais, further along the caravan route.

${ }_{18}$ About 75 kilometers from al-Șālihịyah, further along the caravan route, in Sinai. Cf. Wüstenfeld's edition of Iakzut, vol. iv, p. I44, where the article is omitted as here in our fragment. The $x$ in לאגול (1. 12), לאבפרבנה (1. 13), represents the vowel of the preposition.

19 A gold-piece worth a dīnār, or somewhat less than a dīnār. Cf. Dozy, Suppl., sub voce and our note 23 . The preposition $b i$ is here properly used with the verb. Cf. Spiro, Vocab., p. 4 I 3 .

20 לאגיל, cf. note I8. About 190 kilometers from Katyāh, further along the caravan route, in Palestine.

21 in khamasta'sher is an interesting form with transposed 'still retained, and $t$ changed to $t$ by the '. The modern form is khámastásher. 
3י יום עמלת באשרפי ג'ית לאכפרכנה קעת ה תאיאם עמל]ת]

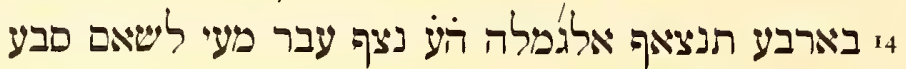

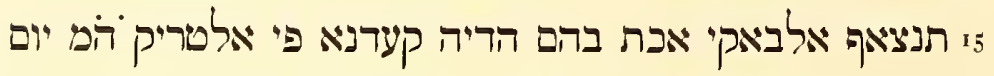

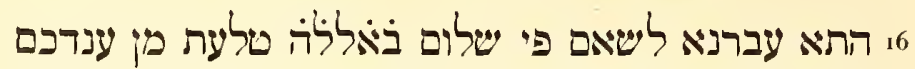

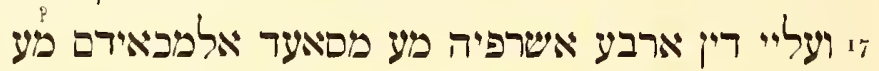

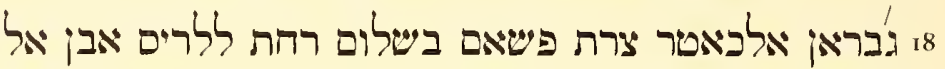

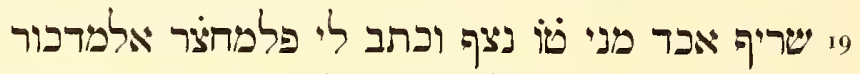

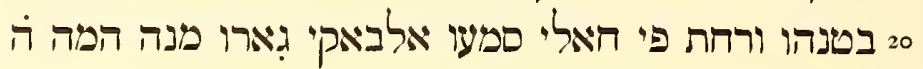

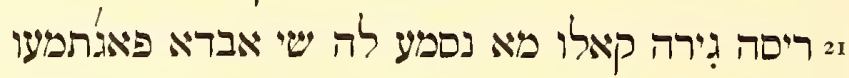

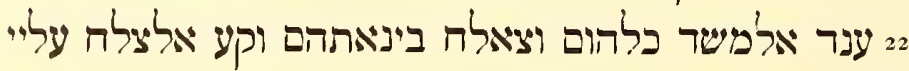

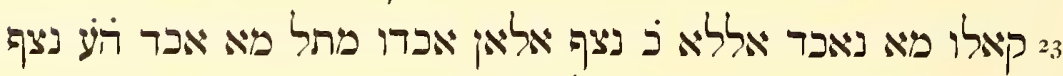

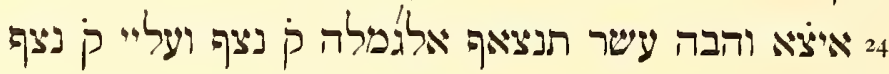

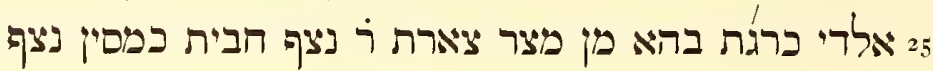

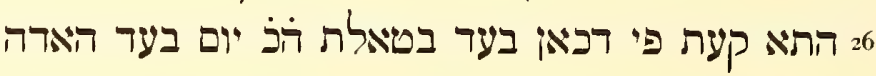

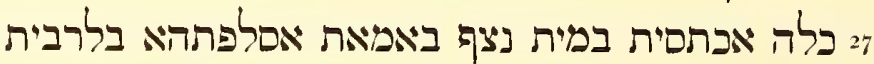

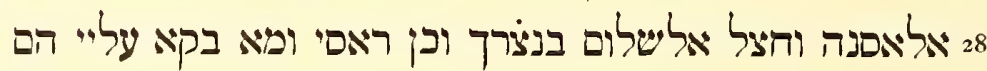

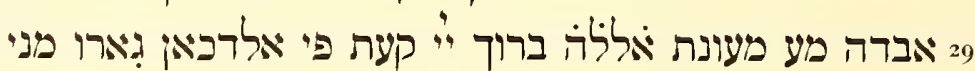

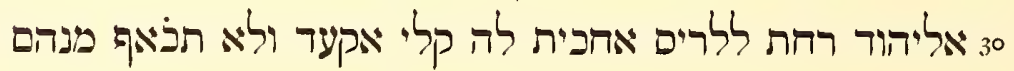

${ }^{22}$ Cana of Galilee, north and east of Nazareth.

${ }^{23}$ If the ashrafī was worth I $5 \frac{3}{4}$ dirhams (cf. Le Strange, Palestine under the Moslems, p. 43), 75 half-dirhams or half-faḍdahs would be the correct total of the collections in the various towns.

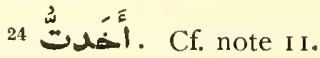

25 He put aside-though where and how?-68 half pieces, and took seven along to Damascus.

26 i for $\pi$.

27 possibly for מסאעד אלמכאירם. The singular, is elsewhere used of the addressee of this letter. The plural is here used of the Damascus Jews.

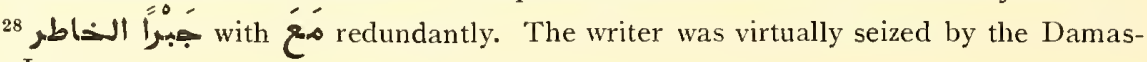
cus Jews.

${ }^{29}$ I.e. the Damascus Jews.

31 המה. Cf. the Maghrabi form himma.

32 The vernacular negative, $m a \vec{a} . . . . . . . .-s h$ abadan.

33 هُشَّن See Dozy, op. cit., vol. i, p. 736, "inspecteur."

34 Since in line 9 he says that he had only eleven half pieces upon reaching his first station from Cairo; and in lines $16-17$ he says that he left owing four ashrafīs $(=\mathrm{I} 26$ half pieces according to line $\mathbf{I} 4$. Cf, note 23 ). 
${ }_{\mathbf{1} 3}$ days. I earned an ashrafí ${ }^{\mathbf{1 9}}$. I came to Kafr Kannah ${ }^{22}$. I stayed $^{\mathbf{1 1}}$ five days ${ }^{13}$. I earned

${ }_{4}$ four half ${ }^{13}$ [pieces of silver]. The total [was] 75 half [pieces of silver] ${ }^{23}$. There crossed over with me to Damascus seven

I 5 half ${ }^{13}$ [pieces of silver]. The remainder I held onto ${ }^{24}$ as a present [to myself ? $]^{25}$. We remained on the road 45 days

I6 unti1 ${ }^{26}$ we crossed over to Damascus safely ${ }^{1}$ _ By Allah! I went out from among you

${ }_{17}$ owing a debt of four ashrafis ! - with the help of the gentlemen ${ }^{27}$,

18 against my will ${ }^{28}$ I came to Damascus safely! I went to the ra'îs, the son of the

rg sharif. He took from me 15 half [pieces of silver] and he gave me a receipt in the [presence of the] aforementioned assemblage ${ }^{29}$,

20 [in the very] midst of it. And I went about my business ${ }^{30}$. The rest heard [of this]. They were jealous about it. Five of them ${ }^{31}$,

${ }_{21}$ the ra'îs (of it) [and] others, said: "We shan't listen to this at all"32." And they gathered in a crowd

22 at the house of the mushidd ${ }^{33}$, all of them; and he tried to make peace between them. The peace turned out to my disadvantage.

${ }_{23}$ They said: "We shall not take more than 20 half [pieces of silver]."

Now they have taken what he took, [and] 75 half [pieces of silver]

${ }_{24}$ also, and a gratuity of ten half [pieces] ${ }^{13}$, the total being roo half [pieces].

But I owed Ioo half [pieces] with [the debt

25 of] which I set out from Cairo ${ }^{34}$. That made 200 half [pieces]. I desired fifty half [pieces]

26 before ${ }^{26}$ I should take my seat ${ }^{11}$ in a shop. After an idleness of 25 days, after all

27 this, I clothed myself for Ioo half [pieces] from sums (? $)^{35}$ which I borrowed ${ }^{36}$ at interest ${ }^{37}$

28 payable the next year ${ }^{38}$. And peace ${ }^{1}$ reigned, with your favor ${ }^{39}$; and so $^{1}$ [also I] myself ${ }^{40}$ [was at peace], and I had no more anxiety

29 at all ${ }^{41}$, with the help of God. Blessed be the Lord ${ }^{1}$ ! I sat ${ }^{11}$ in the shop. The Jews

zo were jealous of me. I went to the ra'îs. I told ${ }^{42}$ him. He said to me ${ }^{43}$ : "Stay where you are, and don't be afraid of them."

${ }^{35}$ I.e. "sources."

${ }^{36}$ For this sense, see Dozy, Suppl., sub voce.

37 Hebrew רִבִּית.

38 أسَْنَ, an adjective of defect, derived secondarily from "year," and meaning usually "skipping alternate years."

39 Vernacular binazrak.

40 I.e. "my head." Cf. روح وجه عين نفس, and the Ethiopic re'es, "head," "self."

41 هَ

42 ił̌két. Cf. Spitta, Gram., p. 232.

43 lállt. 


\section{PART OF A LETTER}

Paper $7 \frac{1}{8} \times 5 \frac{7}{8}$ inches.

Hebrew in elegant square Hebrew characters. Lines were drawn with a hard point before writing. Some of the worn spots are difficult to read.

This letter originally consisted of two pages (cf. line 23), probably represented by our two fragments XXXI and XXXII. But evidently one line has been lost at the bottom of XXXI, and several at the bottom of XXXII. Note the persistent rime.

$$
\begin{aligned}
& \text { אשרי שמרי משפט עושה צדקה בכל עת: } \\
& \text { אשרי פישכיל אל דל ביום רעה ימלטה]: יהוד]: }
\end{aligned}
$$

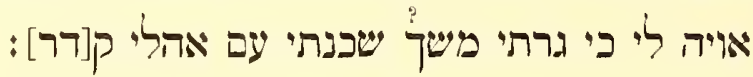

$$
\begin{aligned}
& \text { והכיתי ל'יי המםתיר פנים וקו[ית]י לו: }
\end{aligned}
$$

5 הדרת יקרת אריר שרי המלאכת • כבוד הוד אציל הורי בו לכת:

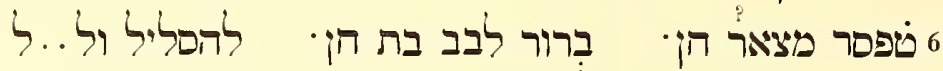

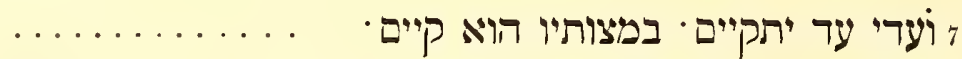

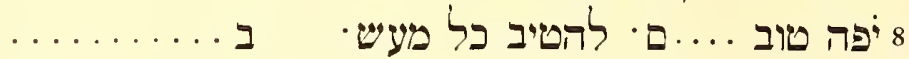

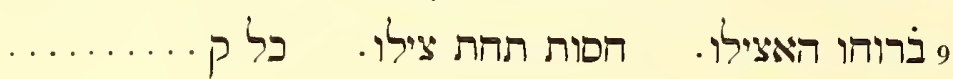
$\ldots \ldots \ldots \ldots \ldots$................ זו כבור גרולת תהלת • יקר קהלת • הפונת מעלת • הררת יקרת.

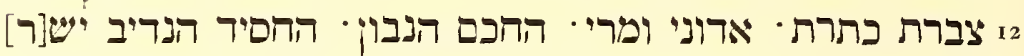

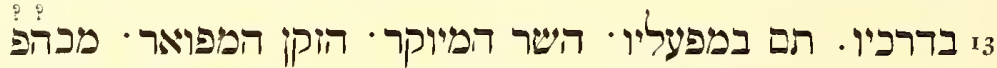

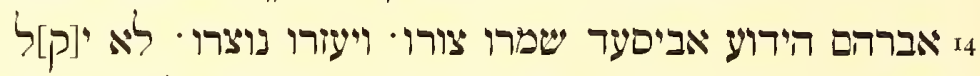

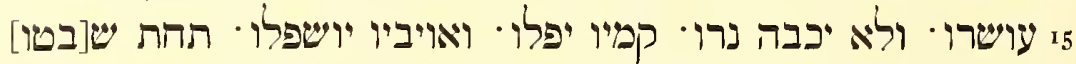

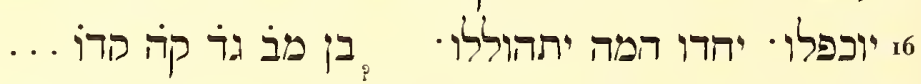

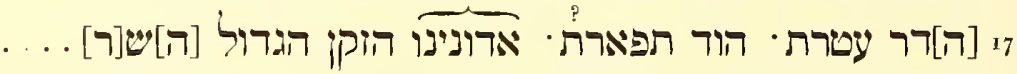

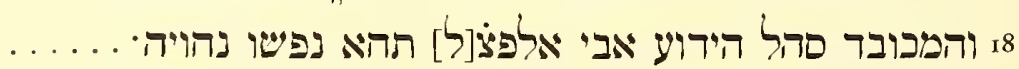

\footnotetext{
1 Psalm cri, 3. $\quad 2$ Psalm xli, 2.

${ }^{3}$ Psalm cxx, 5 .

4 Isaiah viii, I7.

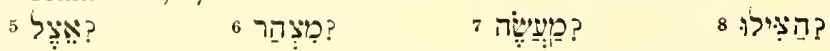

9 Isaiah $\mathrm{xxx}, 3$.

${ }^{10}$ Feminine endings forming a sort of abstract noun.

11 The Arabic name, with Abū changed to Abī, to make it seem Hebrew (cf. Abimelek).
} 


$$
\text { May 10, } 1954
$$

Mr. J. D. Goldstein (Dropsie College) and Zvi Ankori (Research Fellow of Colunbia. University)

say that nos. 31 and 32 are the same letter which has become unglued before reproduction and that the note at the top of page 142 is in part in error. 



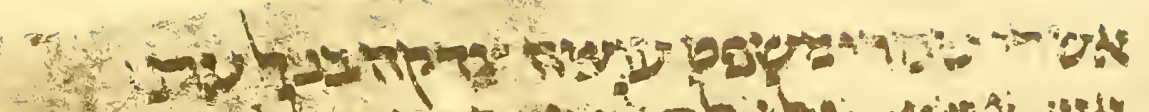

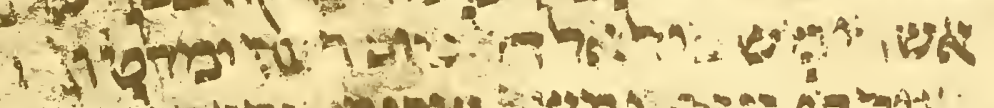

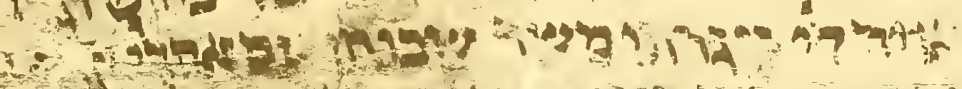

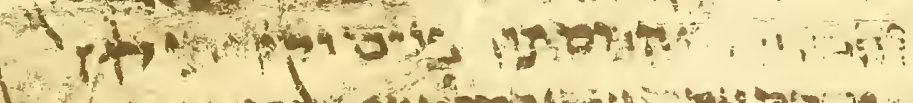

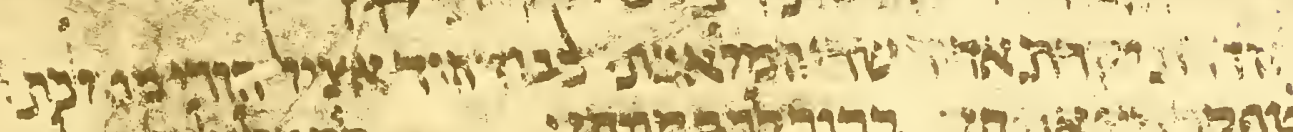

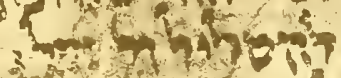

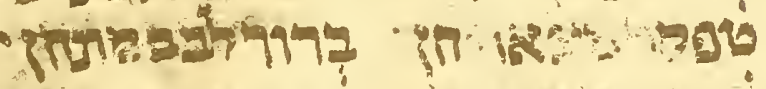

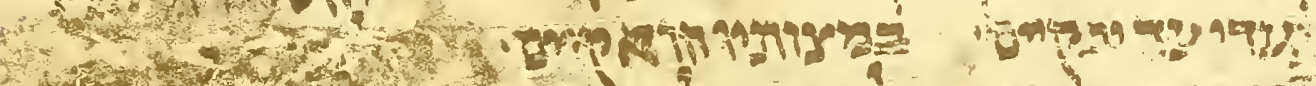

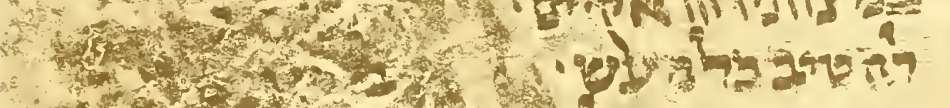

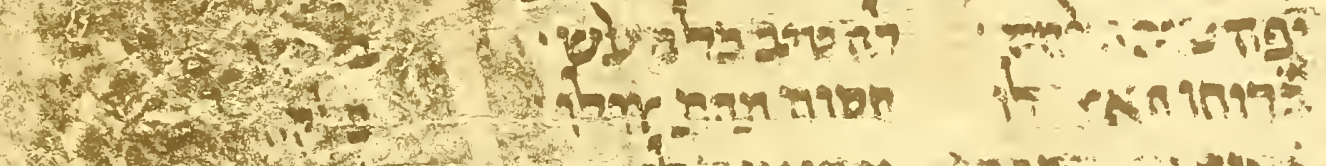

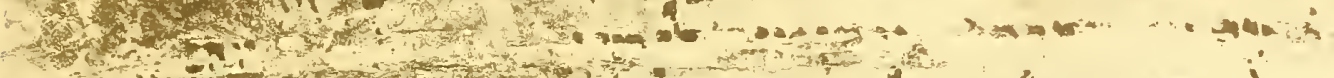

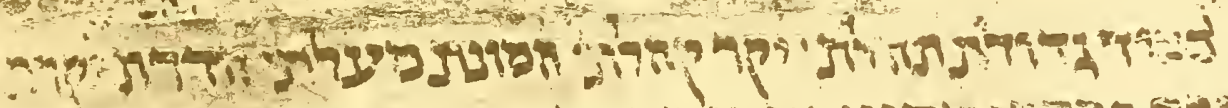

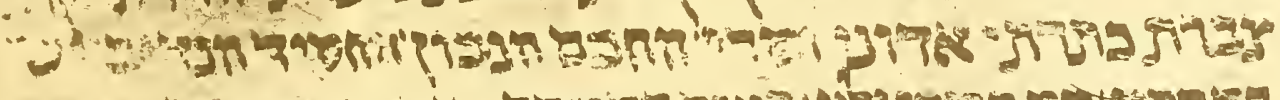

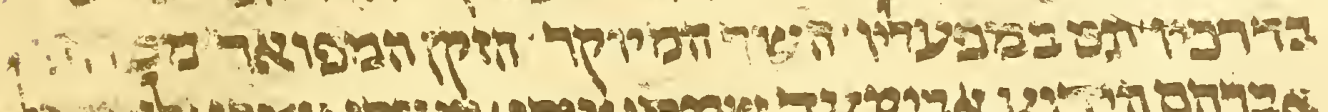

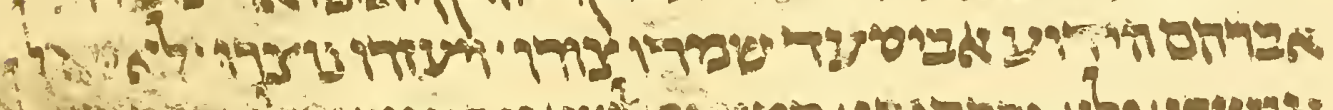

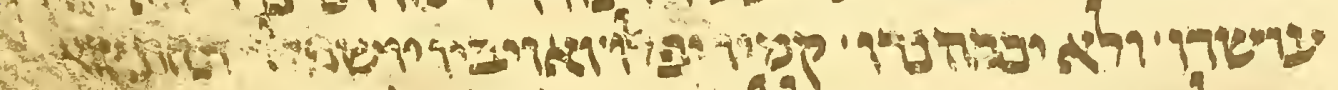

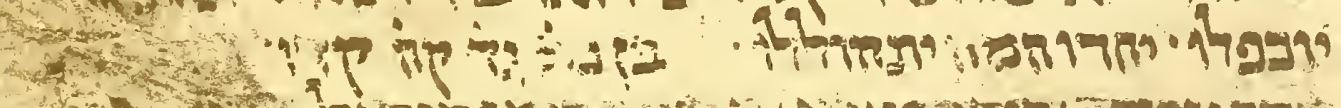

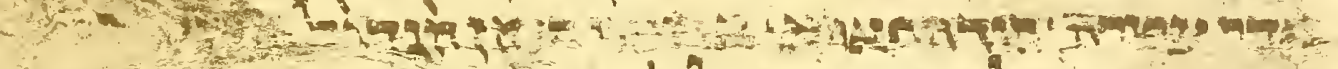

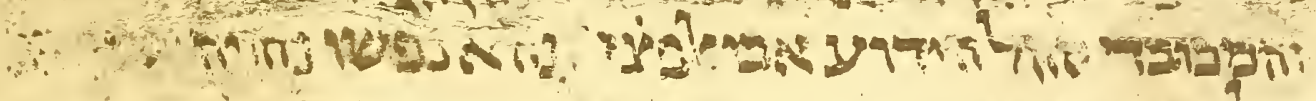

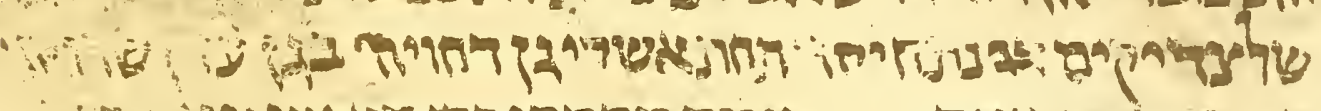

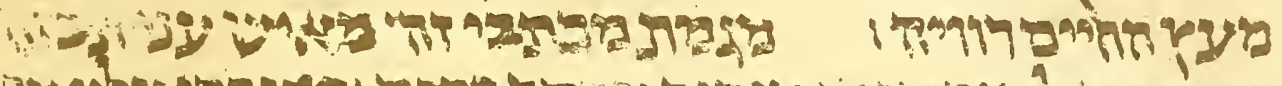

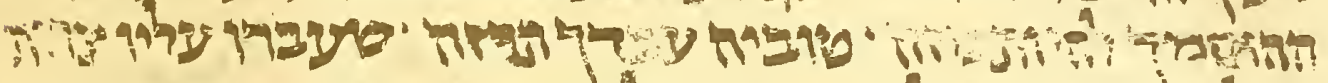

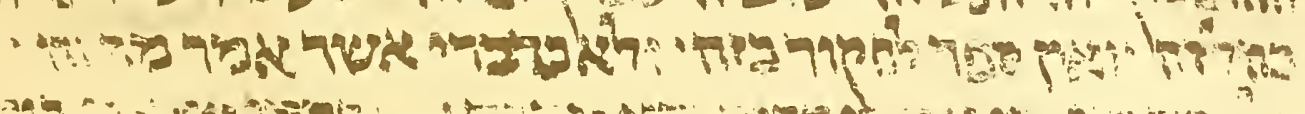
is $\begin{gathered}0 \\ y\end{gathered}$

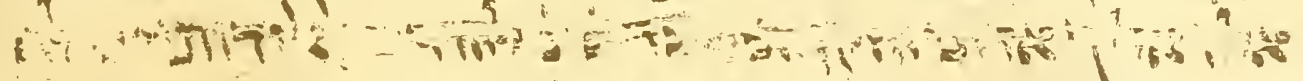

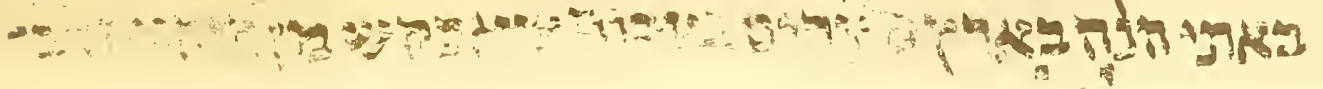





\section{PART OF A LETTER}

A letter from one, Tobiah, to Abū Sa'd Abraham Ibn Abū al-Faḍl Sahl al-Tustarī, the wealthy dealer in rarities who through the mother of the Sultan Ma'add, a slave-girl from his market, exercised great influence at court until his assassination in A.D. I048. See Mann, op. cit., vol. i, pp. 76 ff., and Index; Gottheil, Jewish Encyclopedia, vol. v, p. 62. Our fragment is without address or date, but can safely be dated at about A.D. IO48.

Tobiah has had great misfortune. He explains that he did not come to Egypt in order to obtain assistance.

I Blessed are they that keep justice, and [blessed is] he that doeth righteousness at all times'.

2 Blessed is he that considereth the poor. The Lord will deliver him in the day of evil 2 .

3 Woe is me that I sojourn in Meshech, that I dwell among the tents of $\mathrm{Kedar}^{3}$ !

+ And I will wait for the Lord, that hideth [His] face, and I will look for $\mathrm{Him}^{4}$.

5 [To] the Beauty of the Dignity ${ }^{10}$ of the Mighty One of the Princes of Commerce! Honor, Glory with ${ }^{5}$ those who teach walking therein!

6 The Courtier, the Gracious Countenance 6 ! Illustrious, Merciful of Heart, to...... and to......

7 And for ever and ever he shall be established. In His commands he is enduring.

8 Beautiful, Good, ......to do every thing well ?.....

9 In his spirit escape ${ }^{8}$. Asylum under His shadow ${ }^{9}$. Every.....

ro ...........................................

II To the Honor of the Majesty of the Praise of the Dignity of the Congregation of the Multitude of the Height of the Beauty of the Dignity ${ }^{10}$

12 of the Abundance ${ }^{10}$ of the Crown ${ }^{10}$ of my Lord and Master the $W$ ise, the Intelligent, the Pious, the Generous, Upright

${ }_{3} 3$ in his ways, Perfect in his deeds, the Honored Prince, the Glorified Elder,

14 Abraham, known as $\mathrm{Abu} \mathrm{Sa}^{\prime} \mathrm{d}^{11}$ - May his Rock ${ }^{12}$ be his preservation, and may his Protector help him ${ }^{13}$ ! May his wealth not

I5 decrease, and may his light not be extinguished! May they fall that rose against him, and his enemies be brought low, under his rod!

I6 May they be confounded! One and all, may they be confounded! Son of the Honor of the Majesty of the.

${ }_{1} 7$ Beauty of the Crown of the Glory of the Beauty of our Lord, the Elder, the Great, the Prince.........

I8 and the Honored Sahl, known as Abū al-Faḍl. May his soul live ${ }^{14}$, quickened.

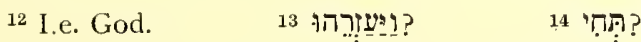




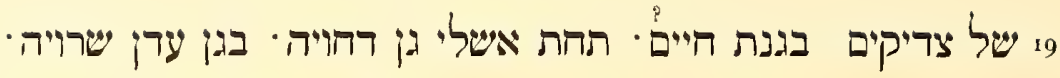
20 מעיץ החיים רוויה: מגמת מכתבי והי מיאיש עני ונבוה.

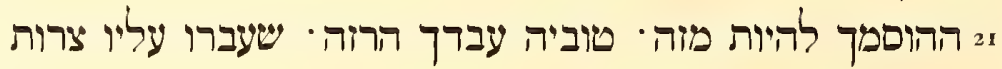
22 כהליוהי ואין ספר לחקור בזה. ולא כדברי אישר אמר פה ז̊ה.

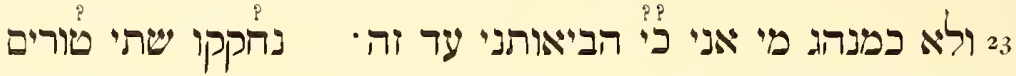
24 אלה אליך. אדוני הוק; הנכבר שיצ להודיע אודות כי ליא 25 באתי הנה באריץ מצרים בעבור שאבקט צין הוקנים דבר

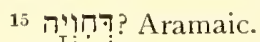

16 טוּר 16 , "pages," literally "rows," "series." The letter originally consisted of two pages, our fragments XXXI and XXXII. 
19 of the righteous, in the Garden of Life, under the tamarisks of the Garden of the Serpent ${ }^{15}$, planted in the Garden of Eden,

so saturated from the Tree of Life! The purpose of this, my letter, from a man poor and despised, [and]

21 the establishing [of fact] to result from this [letter is that] there have passed, over Tobiah, your servant, the lean, troubles

22 like this. And there is no book on this [subject] for [you to] study. Nor [is there anything] like my words when I say: "What is this!"

${ }_{23}$ Nor am I like another man when Thou [O God] hast brought me to this!" These two pages ${ }^{16}$ have been drawn up ${ }^{17}$

${ }_{2}$ for you, my Lord, the honored Elder-May God preserve him !--to make known the causes [of my plight]. For I did not

25 come here to the land of Egypt in order that I might seek anything from the elders.

17 נדהקוּ 


\section{PART OF A LETTER}

Paper $7 \frac{7}{8} \times 6$ inches.

Hebrew in elegant square Hebrew characters. Lines were drawn with a hard point before writing. Some of the worn spots are difficult to read.

This letter originally consisted of two pages (cf. XXXI, line 23), represented by our two fragments XXXI and XXXII. But evidently one line has been lost at the bottom of XXXI, and several at the bottom of XXXII.

ש שאתכרכר ואתפרנםُ • אבל באתי הנה בעבור דבר אחר

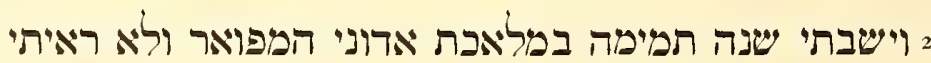

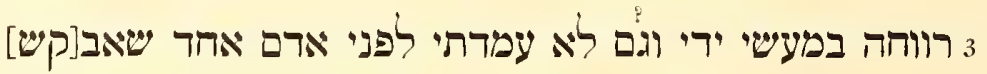

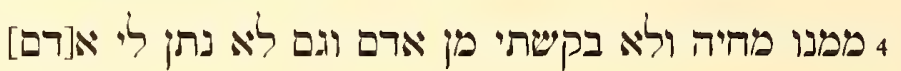

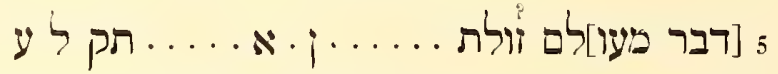

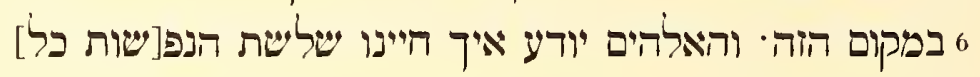

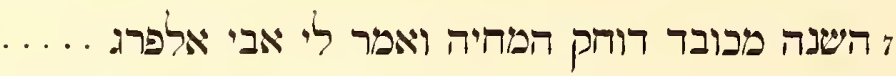

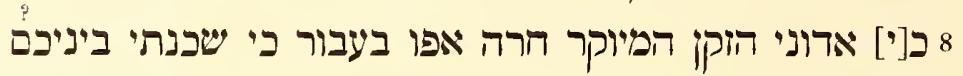

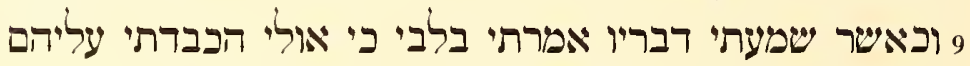

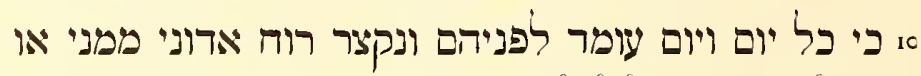

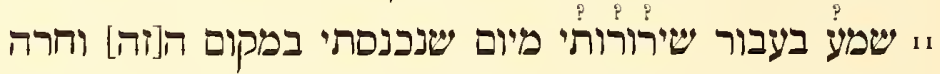

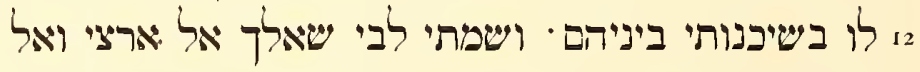

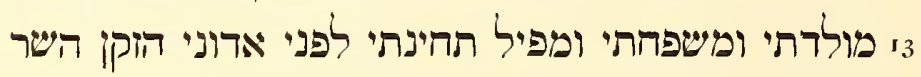

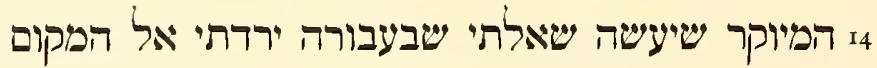

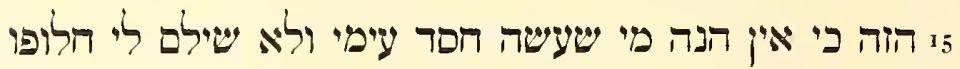

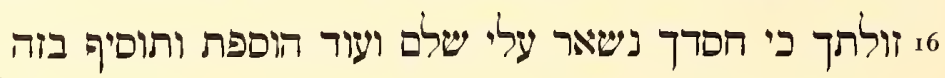

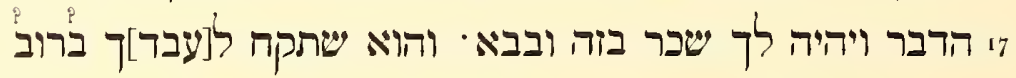

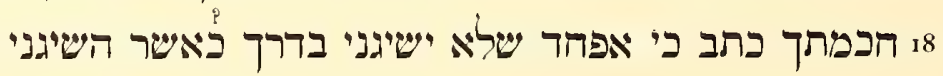

\footnotetext{
${ }^{1}$ Read perhaps: זוללת [מה] שהבאתי אתי [הכ]ל ע[ר], "except what I brought with me. All is gone."

2 See No. XXXI, note IJ.

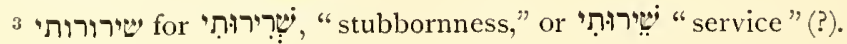




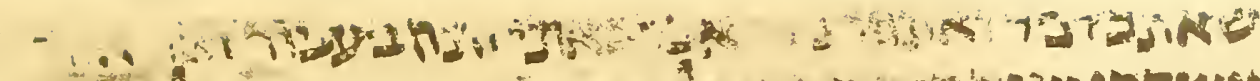

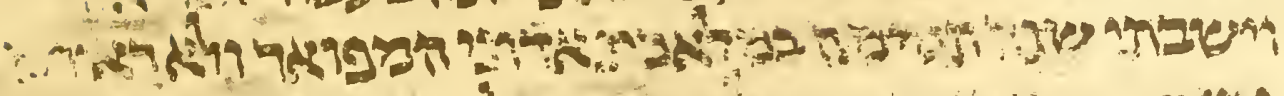

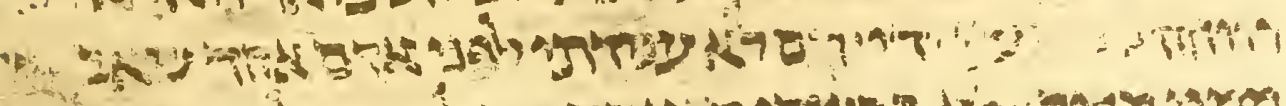

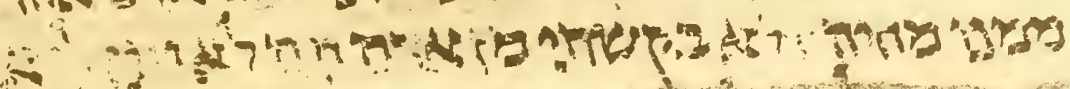

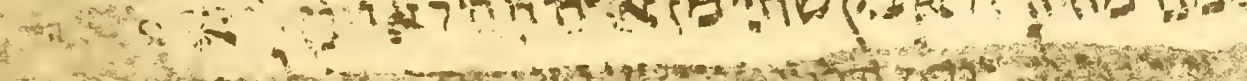

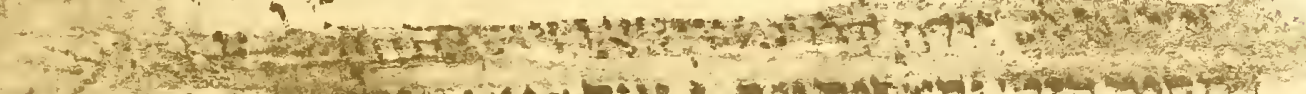
स. W:32.

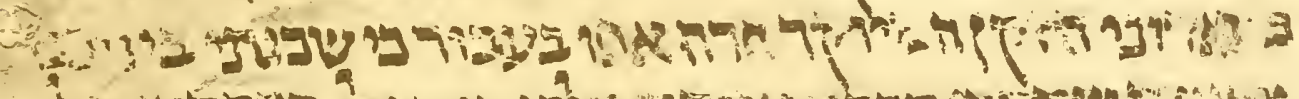

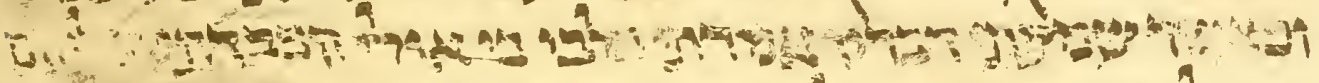

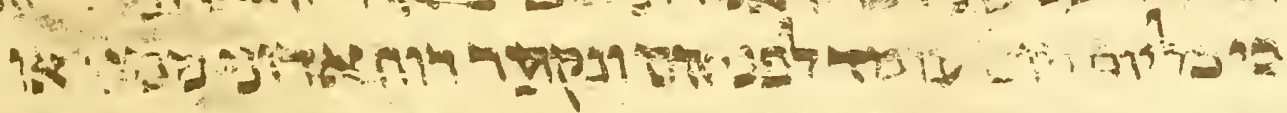

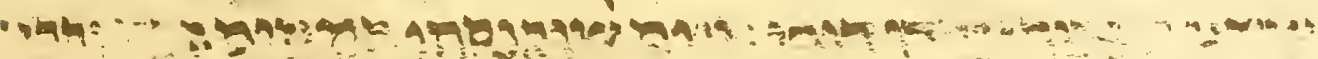

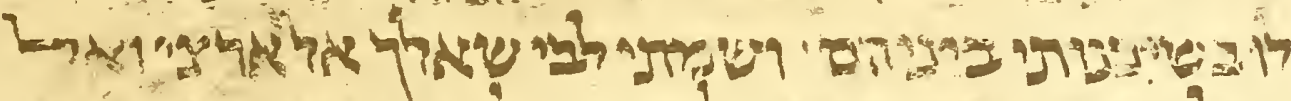

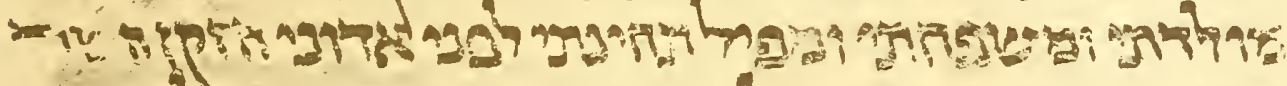
$\therefore$ :

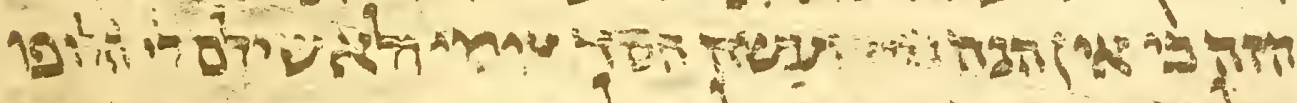

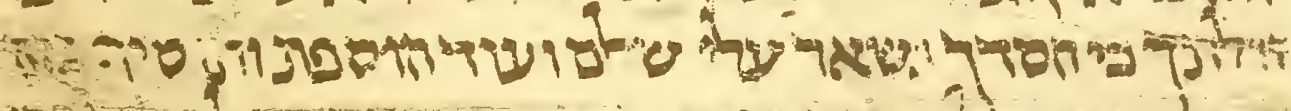
is

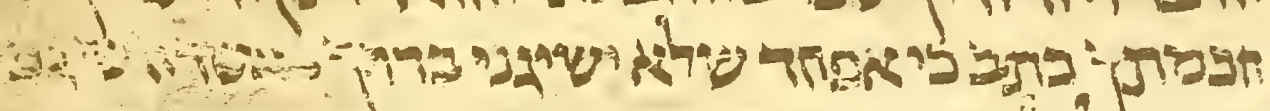

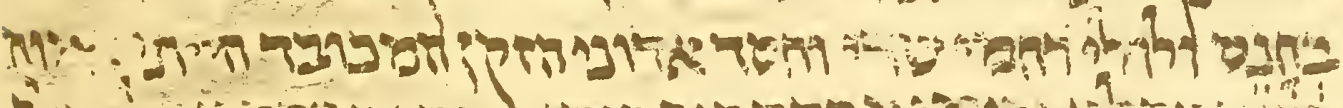

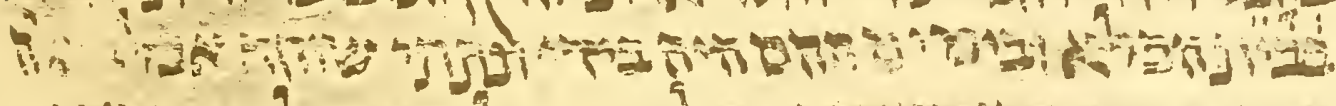
A. aq 57.

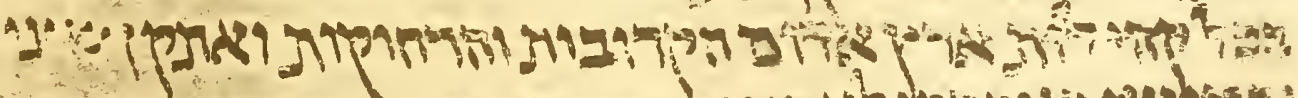

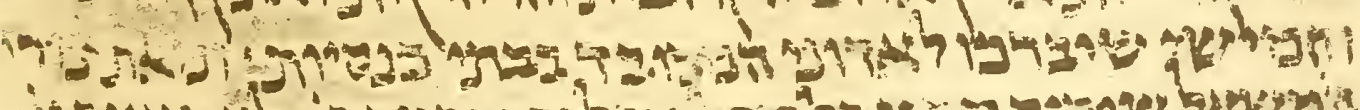
- 



\section{PART OF A LETTER}

As the context shows, hardly more than one line has been lost between XXXI and XXXII.

Tobiah has become a burden to the Egyptian community through his failure to support himself. He desires to return to his home, somewhere in the "Roman Empire," and asks Abraham to give him a letter which will protect him from molestation.

I to go to and fro and get a living; but I came here for another reason.

2 And I remained a whole year [engaged] in the business of my honored

Master. But I have not beheld

3 any profit through the work of my hands. Yet I have not stood before any man to beg

+ of him support; nor have I begged of [any] man; nor has any man given me

5 [anything,] from time out of mind except...............

6 in this place. And God knows how we lived-three persons-all

7 the year, burdened [with] the need of sustenance. And $\mathrm{Abu}^{2}$ al-Faraj... ......told me

8 that my Lord, the honored Elder, was angry because I have dwelt among you.

9 And when I heard his words, I said to myself that perhaps I had become a burden to them.

10 For day after day I stand before them; and my Lord's patience is exhausted; or

If he has heard(?) about my stubbornness (? $)^{3}$ from the day when I became a member of the community in this place; and he became angry

$x_{2}$ at my dwelling among them. And I made up my mind to go to my own country and to

I3 my birth-place and my kindred; and [I am] placing my petition ${ }^{4}$ before my Lord, the Elder, the honored Prince,

I4 that he perform my request, on account of which I came down to this place.

${ }_{15}$ For here there is no one who has been gracious to me, or requited me [with good]-Quite the contrary ${ }^{5}$ !-

16 save only you. For your favor has remained for me perfect ${ }^{6}$; and you have even added and will add [favor] in this

17 matter. And you will have a reward in this and in the coming world. And [my request is] that you prepare for [me,] your servant in the abundance(?)

I8 of your wisdom, a letter. For I fear that [evil] may overtake ${ }^{7}$ me on the way, even as it overtook ${ }^{7}$ me

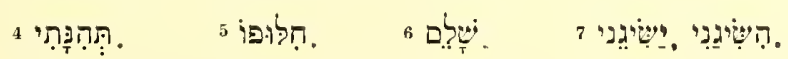




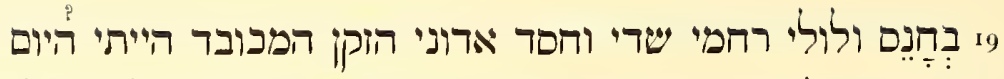
20 בבית הבלא ובימים ההם היה בידי ונתתי שוחד אבל ב[א]לה ז2 הימים אין בירי מאומה ועל זה מפיל תחינתי לפני אדוני

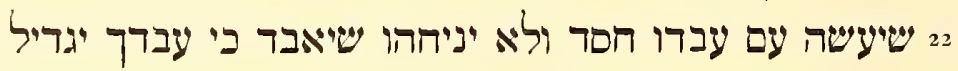

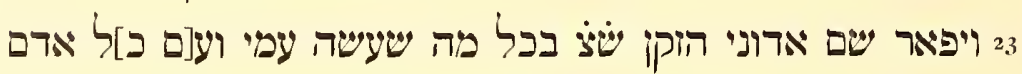

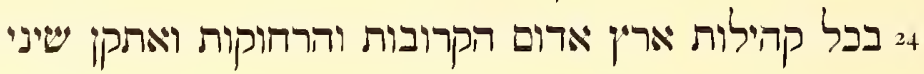

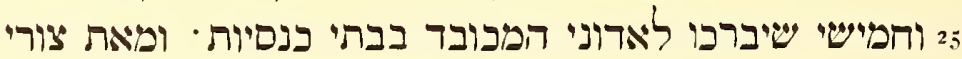
62 הפשאל שיםיר ממנו פל מהלה ופל גזרה רעד כב ליא תאונה וגו

${ }^{8}$ Probably the modern Henassīyeh near Benisueif. See Baedeker, Egypt and the Sudan, 1908, p. 206.

${ }^{9}$ See No. XXXI, line 14.

${ }^{10}$ I.e. the Roman Empire. 
I9 at Hānēs ${ }^{8}$. Had it not been for the mercies of the Almighty and the favor of my Lord, the honored Elder, I should be today

20 in prison. In those days I had [money] in my hand, and I gave a bribe. But

21 in these days there is not in my hand anything; and on account of this [I am] placing my petition ${ }^{4}$ before my Lord,

22 that he may deal graciously with his servant, and not leave him to perish. For your servant will magnify

23 and glorify the name of my Lord, the Elder-May the Rock preserve him $^{9}$ ! - for all that he has done for me, and for every man

${ }_{2}+$ in all the congregations of the land of Edom ${ }^{10}$, near and far. And I will order [the] second ${ }^{\mathbf{1 1}}$

25 and [the] fifth ${ }^{11}$ to pronounce a blessing for my honored Lord in the synagogues. And from my $\operatorname{Rock}^{9}$ [I shall make]

26 the request that $\mathrm{He}$ turn aside from him every disease, and every evil decree [of fortune:]12 even as it is written ${ }^{13}$ : "Not shall befall "..... ${ }^{14}$

11 I.e. שיני בחבורה, etc. There were the or head of the school, and the members, חברים, arranged in a certain order. See Mann, op. cit., vol. i, pp. 54, 264.

12 גירום

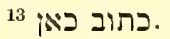

14 Psalm xci, Io. 


\section{LETTER}

Paper $7 \frac{3}{4} \times 5 \frac{5}{8}$ inches.

Arabic in cursive Hebrew characters.

See the introductions to Nos. III, XII, XXII, XXXIV, XXXV, which it closely resembles in writing and language. All of these were possibly dictated to the same scribe by members of one community. Cf. also the similar writing in Fïhrer durch die Ausstellung (Sammlung Erzherzog Rainer), Wien 1894, opposite p. 262. Many characters are completely assimilated to one form; yet the same character may have different forms. The language shows strong foreign influence.

Recto :

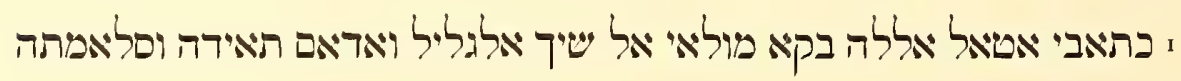
וצעת

2 וכבת אעראה פן אל מסתקר ליג כלין פן שבט רחמה אללה עליך ועליניא 3 באחסן ביאתפה ייזין אליך קרב אללה אל אגתפמאי אלסאר בפנה וגורה אנה 4 אלי ראלך אעלם מולאי אי וצללת בער פשקת בחר ובר עוגדת אלכל עלי 5 דזאל אלסלאפה נחפר אללה לאי אלאמר אלדי ביה נקול לך וכיא; קל]בי]

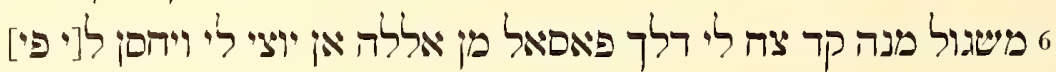
ד פיא אניא פיד אנה ספיע פיגיב ופטא יפבני אשרה לך אפ . ... 8 דלך וקר אנפרה דלך אל אהל צאנהם ארלה וכרגת ארכרתך וקר ית ... 9 . . הם וקאלו מא ציעניא לה ש וראיתהם יקולו וסאפרו אליד ארא שה

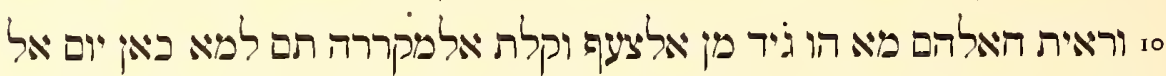

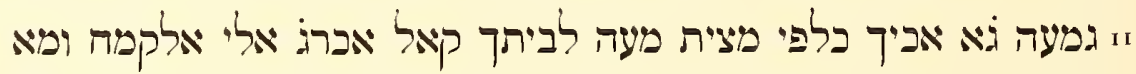

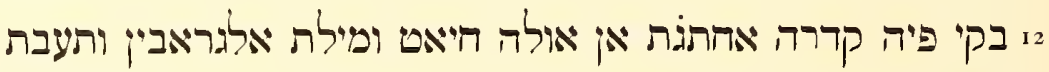

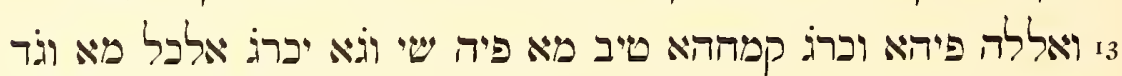

1 Cf. No. XII, line I, where the complete expression is used. For this sense of see Dozy, Suppl., vol. ii, p. 3r9, line 6 from below.

2 यें

${ }^{3}$ Much of the difficulty of translating these letters lies in the intentional vagueness with which they were written. There was danger of their being intercepted.

4 See Dozy, Suppl., vol. ii, p. 697, col, ii, middle.

${ }^{5}$ Vernacular mà dayya'na $l \bar{o} s h$. But the $-s h$ is still objective; not yet adverbial as it now is.
6 هُقَرِّرة

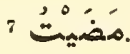




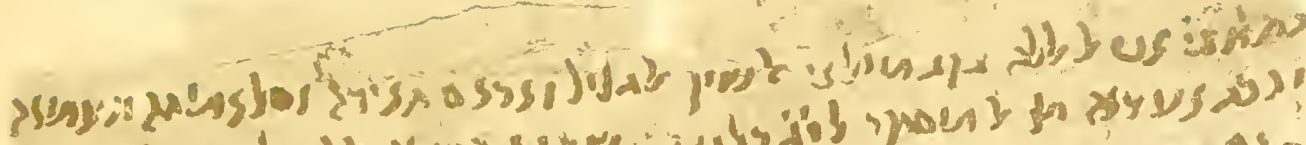

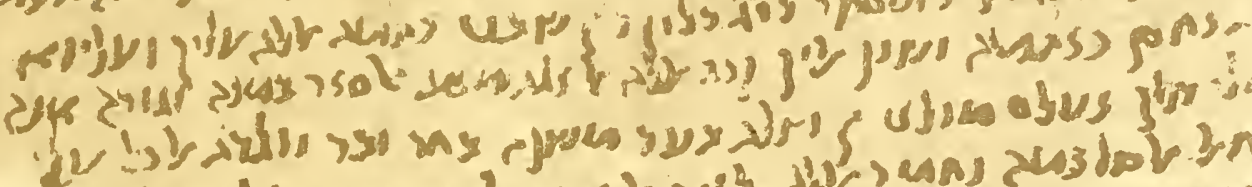

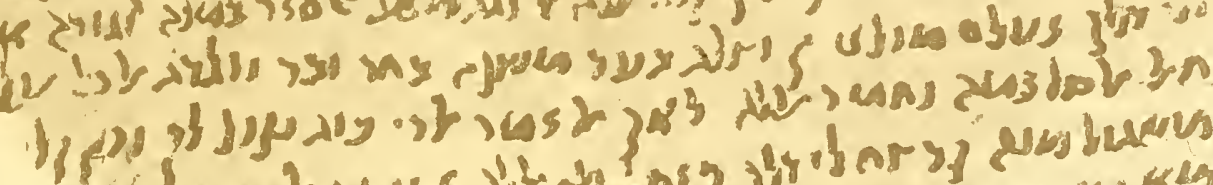

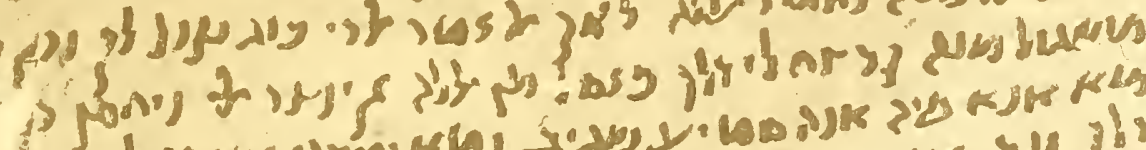

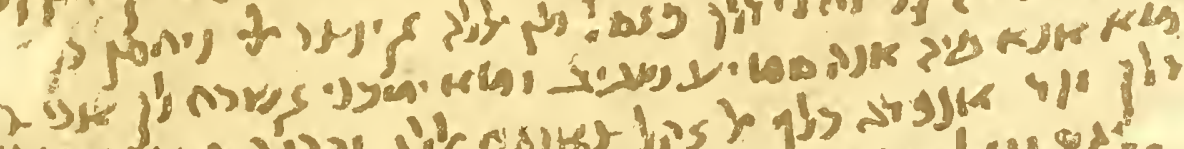

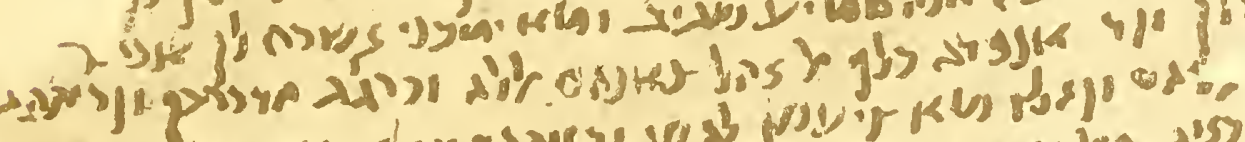
IEA

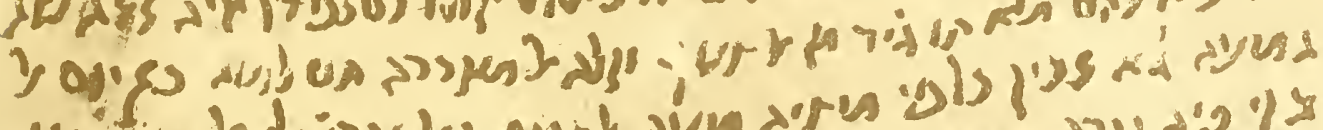

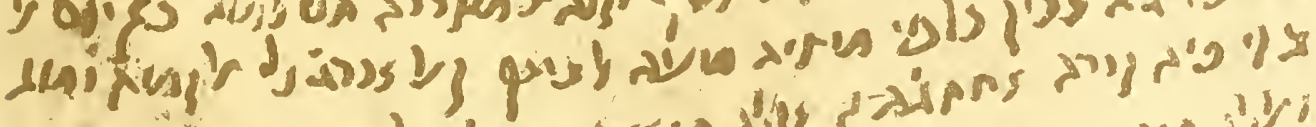

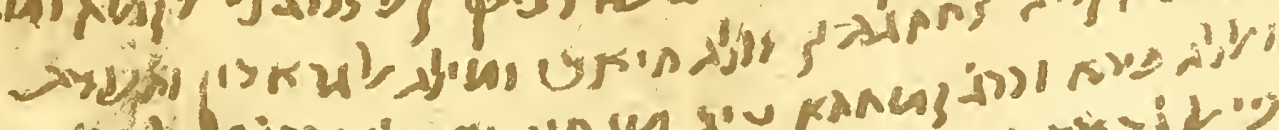

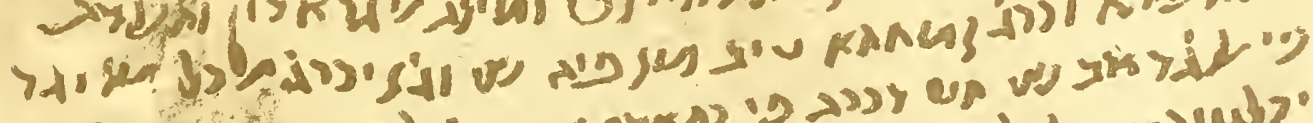

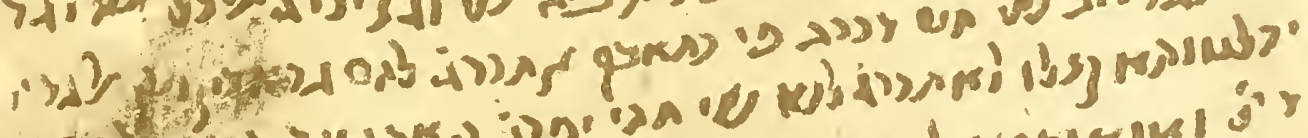
g)

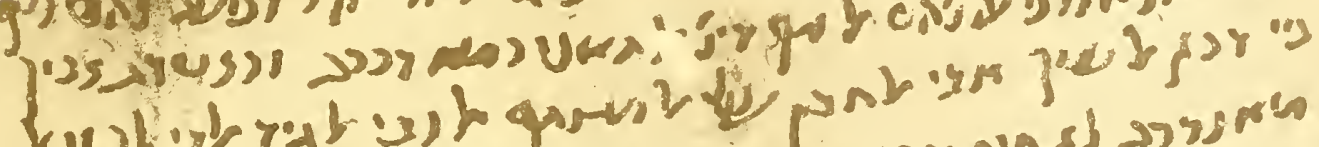

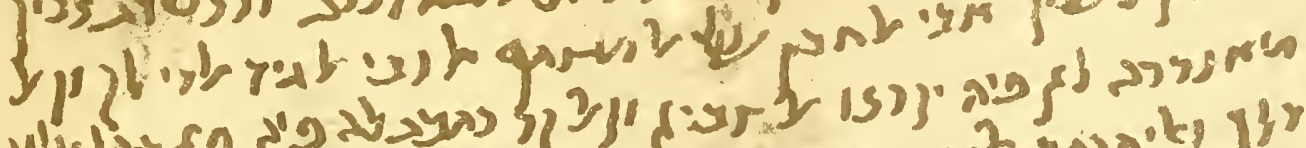

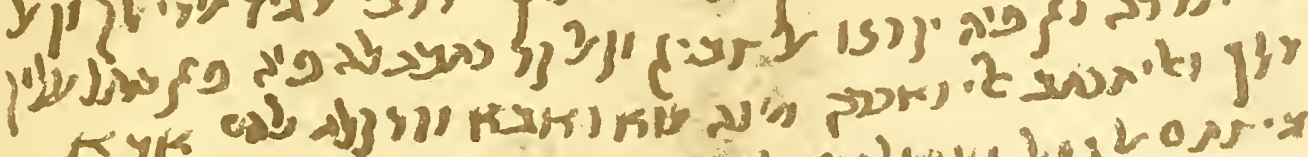

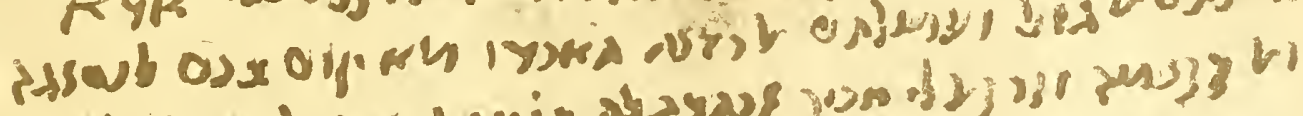

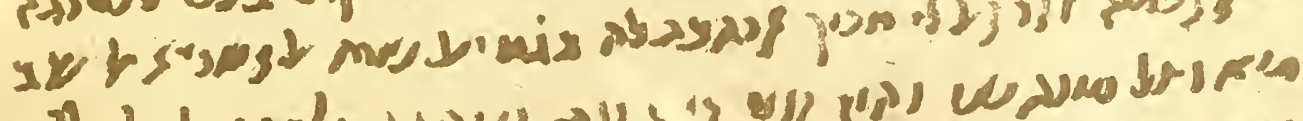

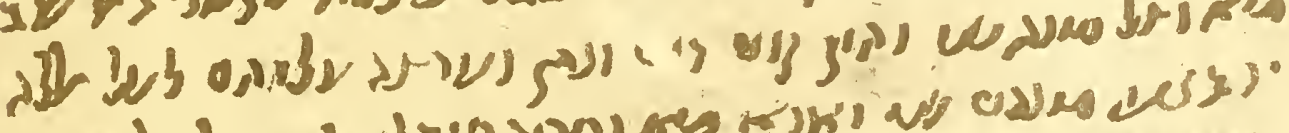
w (Drjir Wr)

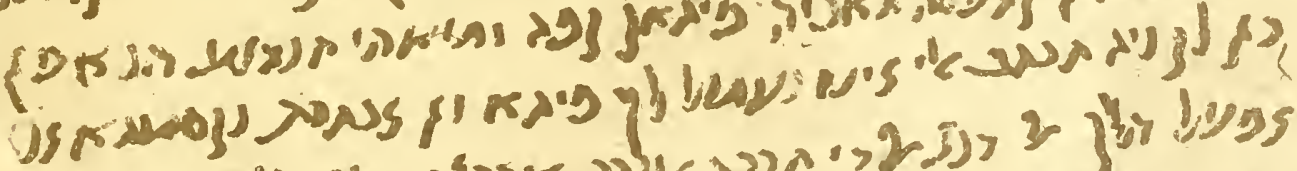
Jy 5 cale de

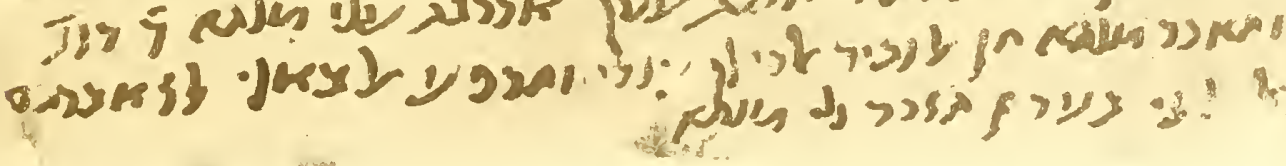




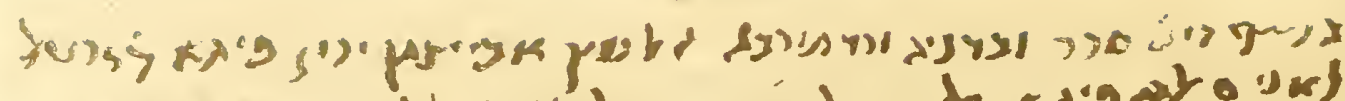

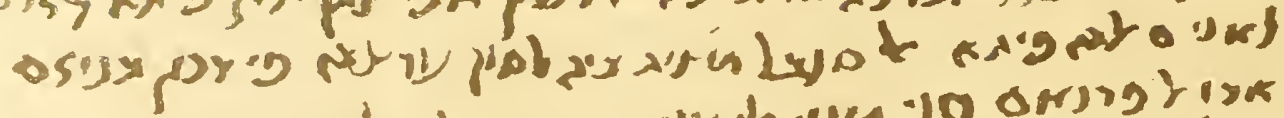

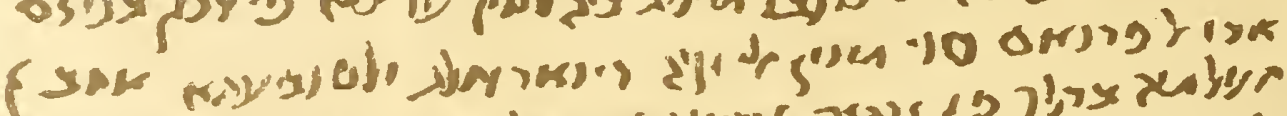

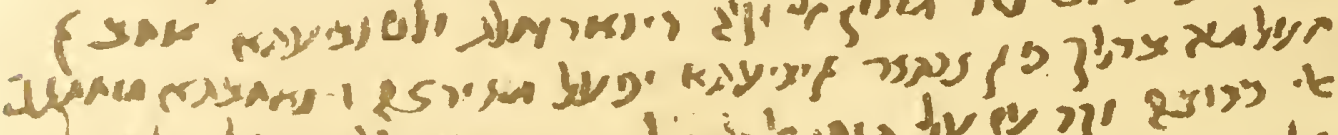

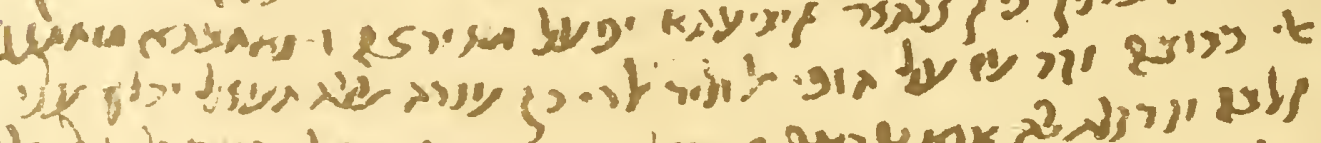

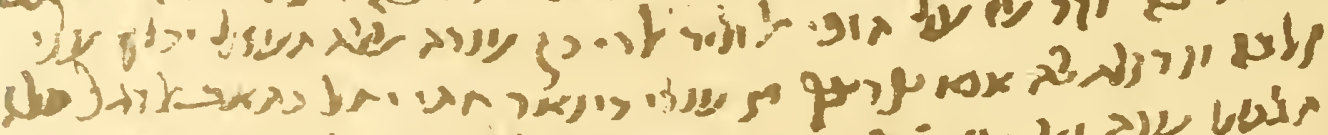

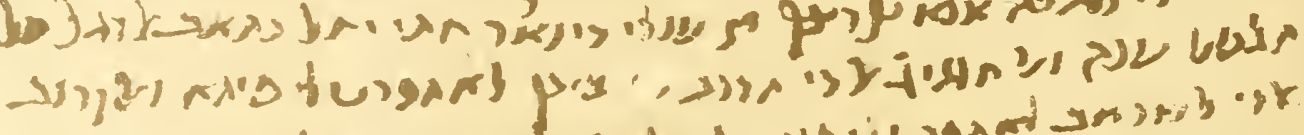

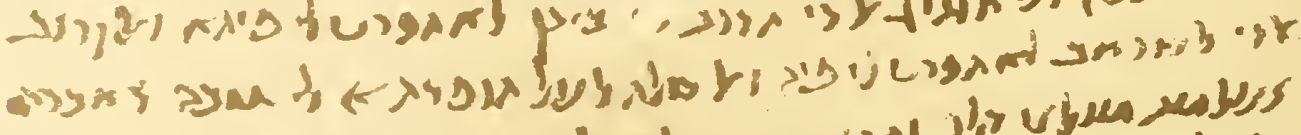

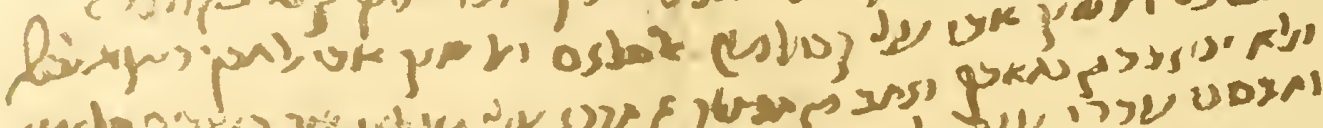

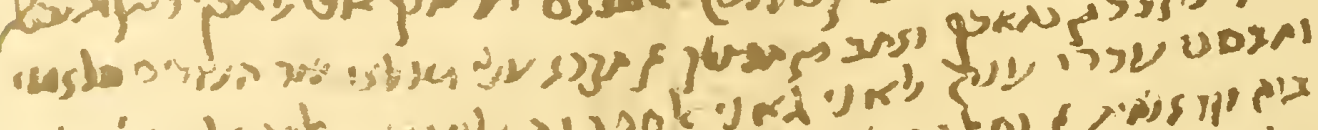
I U

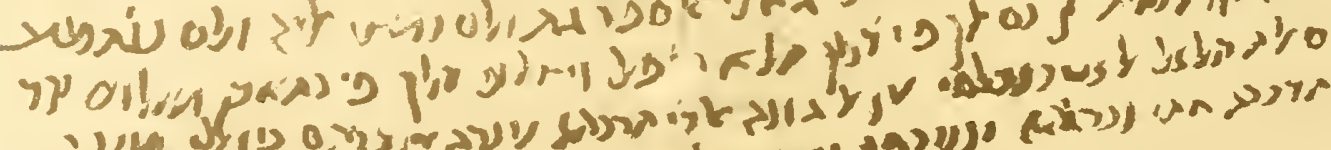

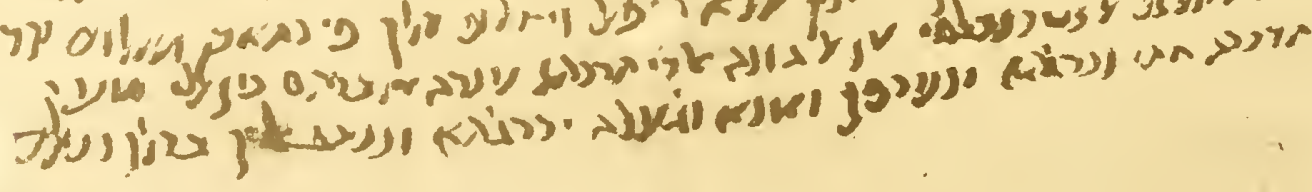

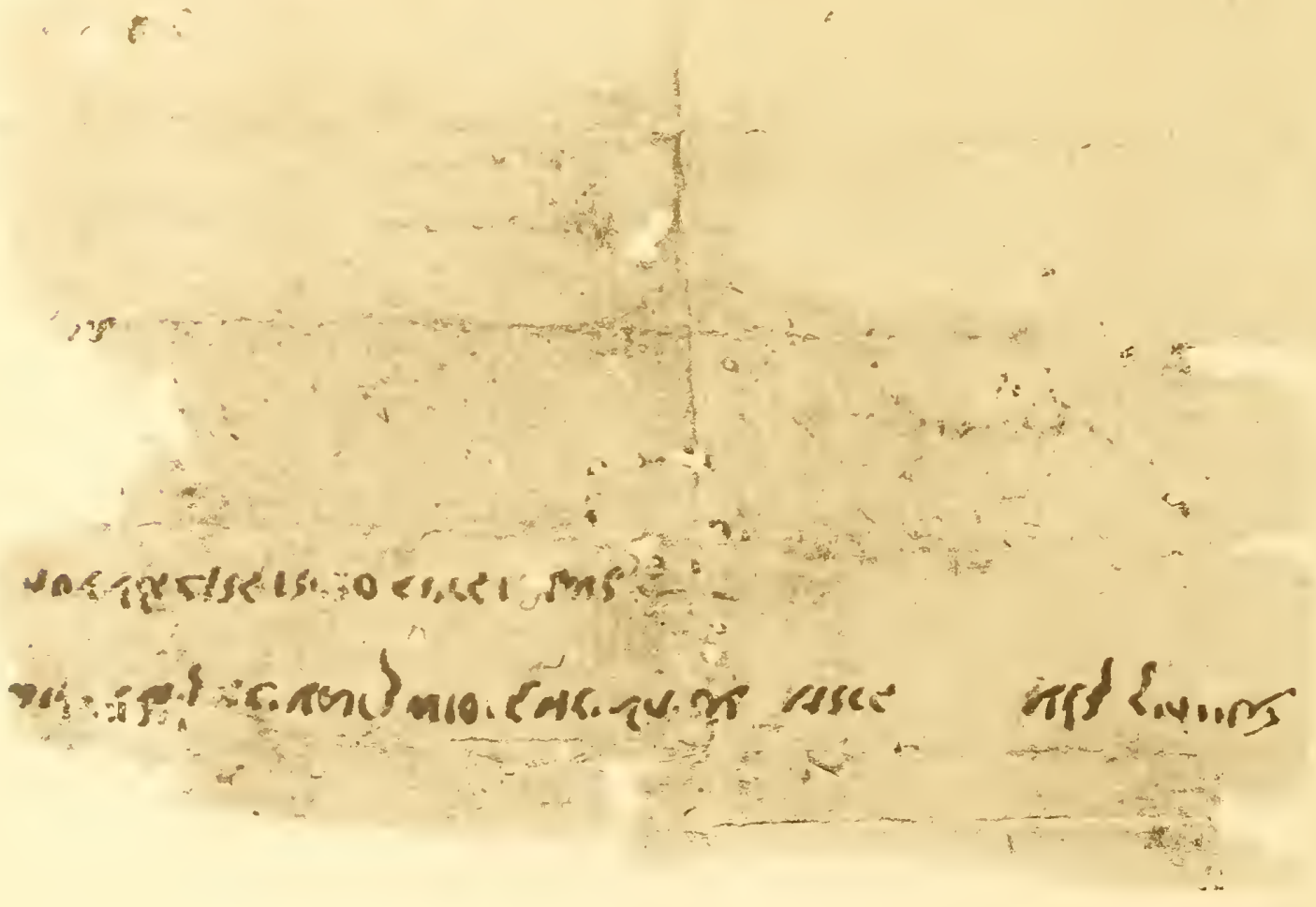




\section{LETTER}

A letter from 'Allān(?) Ibn Yahyā to Abū 'Umrān Moses Ibn Abū alHayy. The former has left the latter and gone to a distant city, whence he writes back concerning a number of business and personal matters. Both are engaged in handling miscellaneous merchandise. One is strongly reminded of II Timothy iv, I3-I4.

Where the context is lost translation becomes uncertain. Interrogation marks might have been used more plentifully.

There is no date.

Recto:

I [This is] my letter [to you]. May God prolong the life of my Lord, the glorious Sheikh, and continue his safety and his health and his prosperity, 2 and confound his enemies! [This letter is] from one who inquires ${ }^{1}$ [after his health. Written] when I 3 days of Shebhāt had passed. The mercy of God be upon you and upon us

3 through its most favorable termination, and make [it] acceptable to you! May God hasten the happy ${ }^{2}$ reunion in His goodness and His abundant kindness. He is [sufficient]

4 for that. Know, my Lord, that I arrived after tribulation by sea and land, and found everything in

5 a condition of safety. We praise God that the matter, about which we told you, and about which my heart

6 was troubled-that matter has turned out rightly for me. And I ask God to direct me and prosper me in [the business]

$r$ in which I am [now engaged]. Verily He hears and answers. And it is not possible for me to explain ${ }^{3}$ to you......

8 this. And those people had already paid ${ }^{4} \mathrm{it}^{3}$ - May God protect them ! And I went out, and [then] I remembered you. And already.........

9 their......And they said: "We have not wasted ${ }^{5}$ [anything] of his." And I saw them talking. And they journeyed to him when he wished.

ro And I saw their condition. It was not good, on account of weakness and insufficient nourishment ${ }^{6}$. Then, when it was

I Friday, your brother came, after I [had come]. I went ${ }^{7}$ with him to your house. He said: "Bring out to me the grain." But there was no 12 strength left in him [for such a task]. I needed first of all a tailor ${ }^{8}$. And I turned the sacks on their sides, and I worked hard,

${ }_{13}$ by Allah, at it. And that ${ }^{9}$ grain poured out [of the sacks in] good [condition]. There was ${ }^{10}$ not anything [the matter with it]. But he went to work and hauled out the whole business. [And still] he didn't find

\& This line is in very bad Arabic.

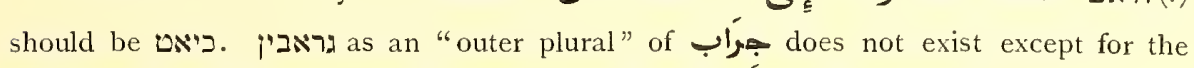
foreigner. One can only guess the sense: He tore his clothes, working (?).

9 I.e. "the grain of those sacks."

${ }^{10}$ Vernacular $m \vec{a}$ fĭh shê. But the $-s h \vec{e}$ is still subjective; not yet adverbial. Cf. note 5 . 
4י פי אלגראב שי חט דכרת פי כתאבך אין תכר: להם גראבין מן אלגריד

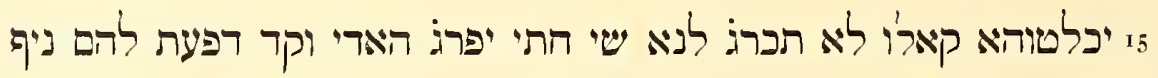

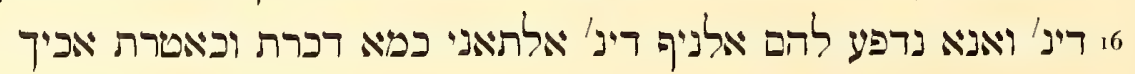

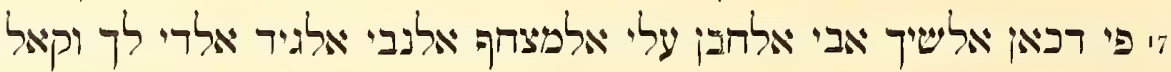

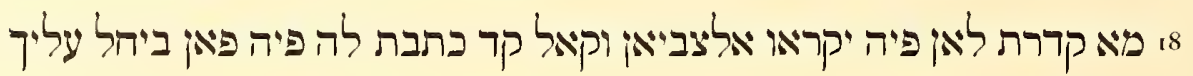

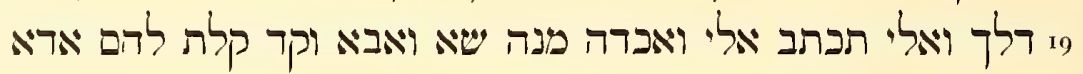

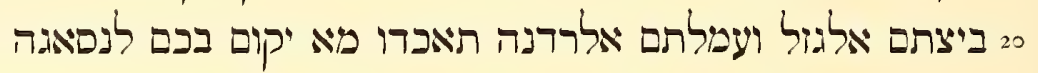

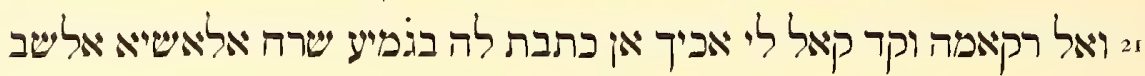

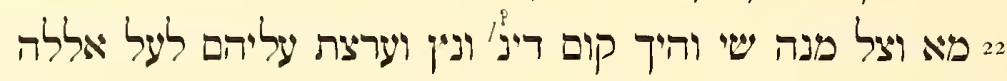

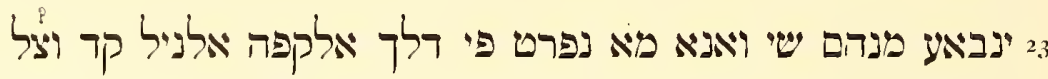

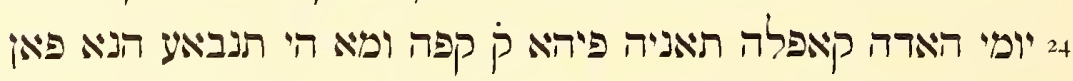

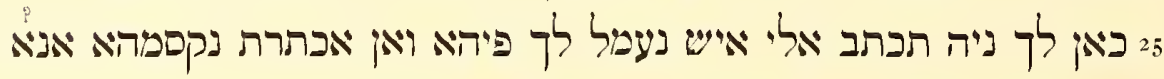

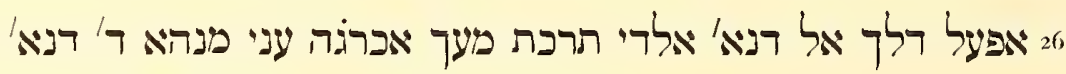

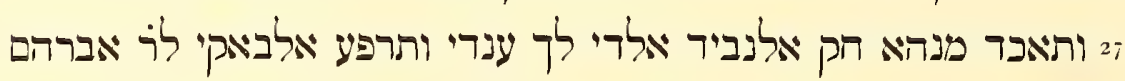

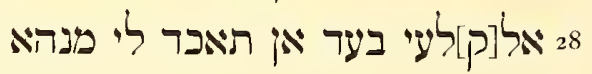

Verso:

ו בנצף דיצ' סכר וברניה ורד מרבה ל' אל שיך אבי יצחק יפון פ'הא ד ארטיאל

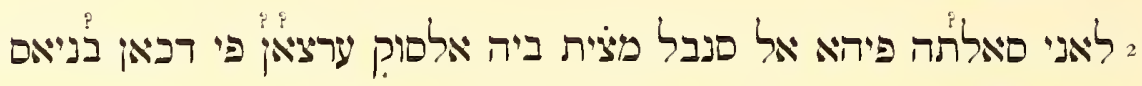

11 Here he avoids the plural entirely. Cf. note 8 .

12 ط̌ ?

${ }^{13}$ Cf. note 8.

14 Palestinian vernacular form.

15 Not $\%$, see line 22.

16 The Maghribī vernacular form.

17 " 17 ordinarily means "to bet with someone about."

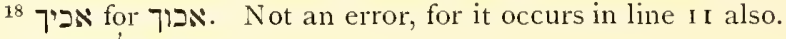

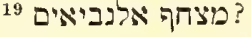

20 Vernacular' in biḥill 'aleke.

21 Dele הלי 22.

23 See Dozy, Suppl., vol. i, p. 549.

21 Confusion between terruptions in dictation.

25 Palestinian vernacular hêt for liśsis. 
${ }{ }_{t}$ in the sack[s]11 anything [wrong] at all12. You said in your letter: "If you bring out for them sacks ${ }^{13}$ of the new [grain],

15 they will mix them up [with sacks of old grain." To this] they replied: "Do not bring out to us anything until this ${ }^{14}$ [old] is exhausted." And I paid them more than ${ }^{15}$

${ }^{6} 6$ a dinār. But $I^{16}$ will pay them the second dinnār and more ${ }^{15}$ as you directed. And I risked ${ }^{17}$ asking your brother ${ }^{18}$,

${ }_{17}$ in the shop of the Sheikh Abū al-Habn(?), about the good manuscript copy of the Prophets ${ }^{19}$ which belongs to you. And he said:

18 "I haven't been able to [give it up], because the boys read in it." And he said [further that] you had already written to him about it. So, if it is permitted ${ }^{20}$ you [to do]

ig this ${ }^{21}$, write to me, and I will take it away from him, willing or unwilling. And I said to them: "When

so you have bleached the yarn and finished reeling it, take whatever you can get among yourselves for weaving [it]

21 and for ${ }^{22}$ embroiciering it ${ }^{23}$." And your brother ${ }^{18}$ said to me that you had written to him an explanation of everything ${ }^{24}$. [As for] the alum :

22 None of it has arrived, and so $^{25}$ prices ${ }^{26}$ [are] a dīnār and a half; and I have offered [mine] for sale to them. Perhaps, by Allah!

23 some of [the things] will be sold ${ }^{27}$; and in [doing] that I shall not forget $^{16}$ the basket. [As for] the indigo: There has arrived

${ }_{24}$ today a second caravan, in which are 100 baskets; and they were not sold here. So if

25 you have the inclination, write to me what ${ }^{28}$ I should do for you in the matter. And if they are too much we can divide them. I

26 will do that. [As for] the dinārs which I left with you: Subtract (it ${ }^{29}$ ) from $\mathrm{my}^{30}$ [credit by taking] from ${ }^{30}$ them four dīnārs.

${ }_{27}$ And take from them the value of the wine of yours which I have; and turn over the balance to Rabbi Abraham

28 al-Kala'î'? ${ }^{31}$, after you have bought for me from it

Verso:

x for half a dīnār sugar, and a pot of candied roses ${ }^{32}$ for(?) the Sheikh Abū Isaac, in which there are four roțls;

2 because I asked him about [that point. As to] the spikenard ${ }^{33}$ : I took it to the Market : by chance ${ }^{34}$ into the shop of Banyās(?),

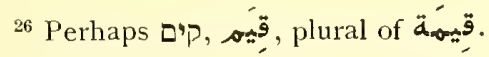

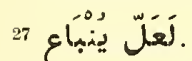

28 Vernacular. 29 Redundant.

$30 \stackrel{ن}{*}$ ef the person,

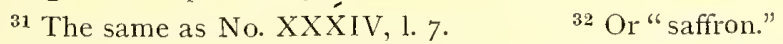

${ }^{33}$ Andropogon nurdus, or nardus Celtica. See Hava, Arabic-English Dictionary, I 899 p. 331 . 


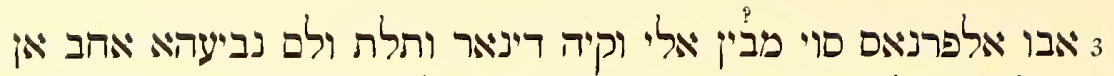

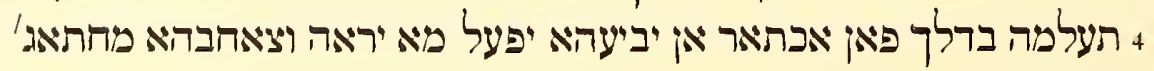

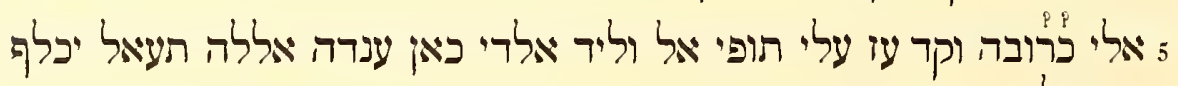
על לירור 6 קלבה וקד קלת לה אנא נקרצُך אן ענדי דינאר התי ימצל כתהב אלרוגל פליא

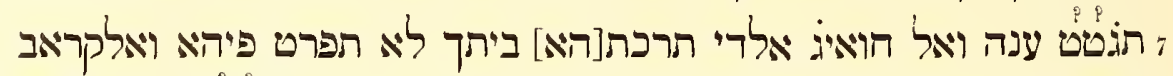

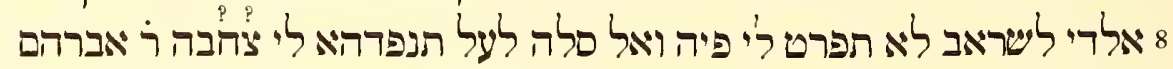

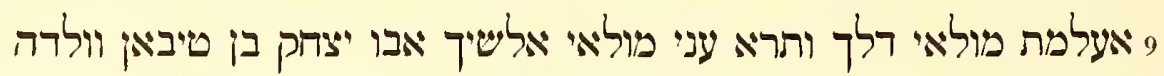

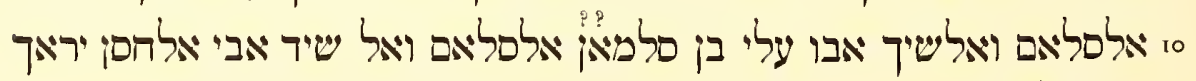

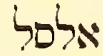
יי ולא יכון בר מן כתאבך ואהב מן תפצלך אי תקרא עלי מולאי שר השרים סלאמי ברי

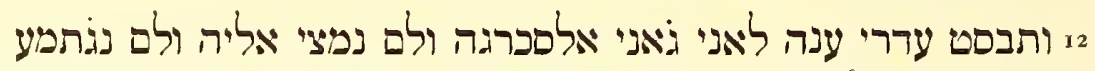

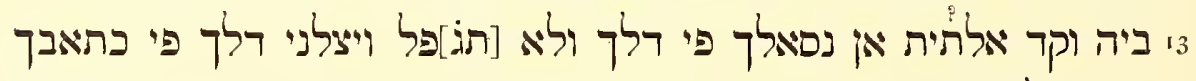
ושלום וקד וקר אלתית

14 סאלת הלאל אלאטרובלםי ען אל גונה אלדי תרכהא ענדה אברהם פקאל וקר לי מעי ריל

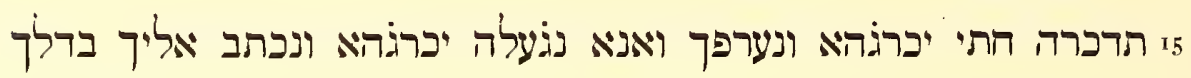
ושלום - ינרית

\section{Address:}

[ל] מולאי אלשיך אבי עמראן מוסי בן אבי אלהי נ丶 שארה עלאי בן יהיי נעו

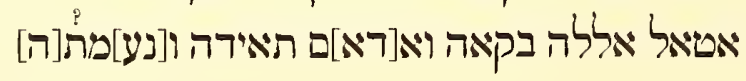

\footnotetext{
34 عَرضِ

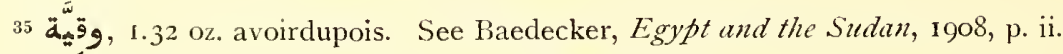

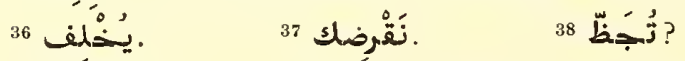

${ }^{39}$ Egyptian vernacular.

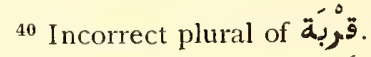

${ }^{41}$ I.e. ותקרא, with omitted. Cf. No. IX, many times. The p has been omitted here and in line ro because it has become a hamzah, as in modern vernacular.

${ }^{42}$ See No. XIII, verso, line 45.
} 
3 the father of the parnās. It was worth evidently(?) up to a dīnār and a third the wikinaha ${ }^{35}$. So $I^{16}$ didn't sell it. I desire that

+ you inform him of that; and if he prefers to sell it, let him do what he thinks best. And the owner of it has reason

5 to be concerned(?). And the death of the boy who lived with him affected me deeply. May God the Exalted recompense ${ }^{36}$

6 his heart! And I said to him : " $I^{16}$ will lend ${ }^{37}$ you-I have a dinnār [for you]-until the man's letter arrives." But

7 do not be concerned ${ }^{38}$ (?) about him. And [as for] the things ${ }^{39}$ which I left [at] your house: Do not forget about them. And [as for] the water-skins ${ }^{40}$

8 which [are] for drinking-water: Do not forget about them. And [as for] the basket: Perhaps you will send it to me in the care of Rabbi Abraham.

9 [So] I have informed my Lord of this. And give my greetings ${ }^{41}$ [to] my Lord the Sheikh Abū Isaac Ibn Tayyibān ${ }^{42}$, and his son.

10 And the Sheikh 'Alī Ibn Salmān(?) and the Sheikh Abū al-Hasan send"1 you greetings ${ }^{43}$.

I A And you will surely have to write. And I would like, if you please ${ }^{44}$, to have you give my greetings to my Lord the Prince of Princes ${ }^{45}$,

12 and to present my apologies for [the circumstance] that the saucer reached me, and $I^{16}$ did not go to him, nor did $I^{16}$ meet

${ }_{13} \mathrm{him}$. And I have bothered [you] to ask ${ }^{46,16}$ about that; and do not be heedless, but let [news of its accomplishment] reach me in your [next] letter. So farewell! And

It I asked Hilāl ${ }^{47}$ al-Atrūblusīis ${ }^{48}$ about the leather box which Abraham left at his house; and he said to me: "I have it."

15 Remind him to bring it. And $\mathrm{I}^{16}$ will let you know [if he fails], and make ${ }^{16}$ him bring it, and write ${ }^{16}$ to you about that. So farewell!

Address:

[To] my Lord the Sheikh Abū 'Umrān Moses, son of Abū al-Hayy ${ }^{49}$, whose rest [is in] Eden

God lengthen his life and continue his safety and prosperity!

[From] 'Allān, son of Yahyā, whose rest [is in] Eden.

\footnotetext{
43 I.e. יקראך אלסלאם.
}

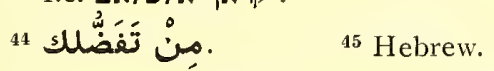

${ }_{46}$ Vernacular altēt, for classical $\stackrel{3}{=}$

47 "new moon." 48 "of Tripoli."

${ }^{49} \mathrm{~A}$ certain Abū al-Ḥayy was still alive but suffering from some skin disease, when lines 8-Io, No. III, verso were written. 


\section{LETTER}

Paper $6 \frac{7}{8} \times 5$ inches.

Arabic in cursive Hebrew characters.

Both the language and the writing are similar to those of Nos. III, XII, XXII, XXXIII, and XXXV; and what has before been said need not here be repeated. On the recto the scribe uses some care; but he grows more careless, and on the verso his slovenliness is extreme.

Recto:

י כתאבי אטאל אללה בקא פוליאי אלשיך אלאגל ואראם תאירה ופלאמתה

กงมy

2 וכבת אעראה מן אלמסתקר לך פן שבט כתמה אללה עלי מולאי באהסן

כאפה

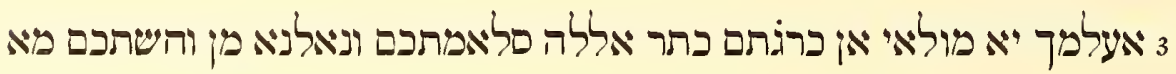
+ אללה יעלפה וכל פן פי אלבית ואמא נהריאי ולרי אחיאה אליך תכלק

עליניט

5 ייקול פתא יני רבנו יאבו סער ויקיל אדיוני ענדנא יאלי אלסעה נהן

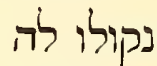

6 הם פי אל כניםיה אפעה יגי וכיאנת קלובנא בכם פש:נולה כיף כאי וציאלכם ד אלי אי יצל יום אלכעים באל עשי ר אברהם אל קלעי ואל כדן ואעל יצונא

בוציאלכם

8 עלי גפלת אל סלאמה פהפדנא אללה ופאלנאה תפיאם באחסאן פאהב

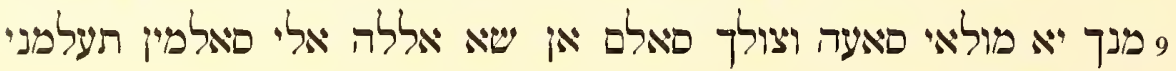

בוצולכם

ס אלי קרארכם עיאחפר אללה עלי דלך וכל פן פי אםכרריה פי אצהאבניא

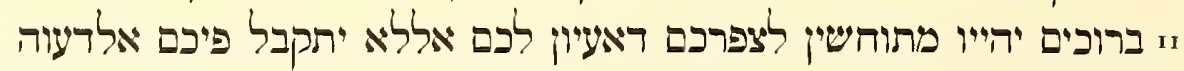

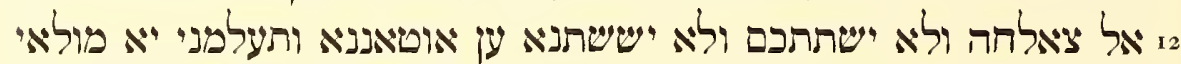

${ }^{1}$ See XXXIII, note I. The opening formulae of the two letters are almost identical.

2 Read כאתמה.

${ }^{3}$ Vernacular nallána for نَالَ

4 "Since you have gone God only knows how we have missed you."

${ }^{5}$ Aramaic.

${ }^{6}$ Hebrew.

אדיוני 7 , if not a mistake, represents a childish pronunciation.

8 النساعة 8 . 


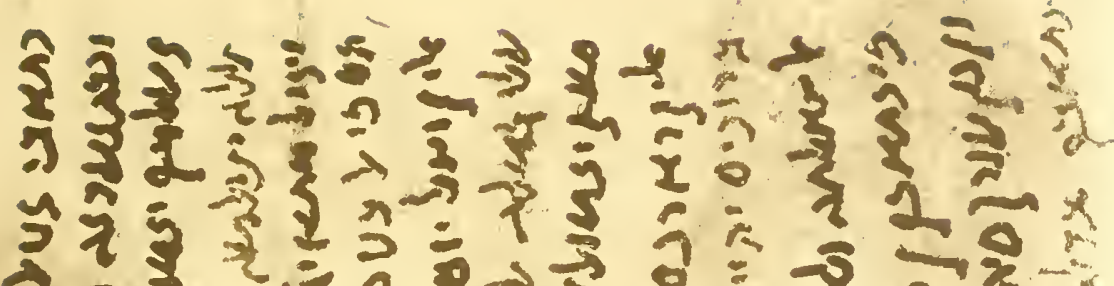

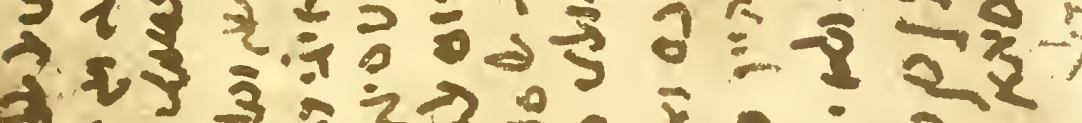

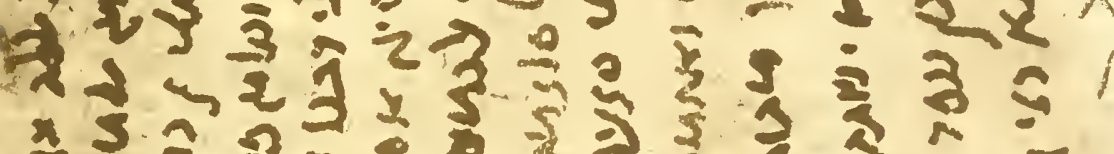

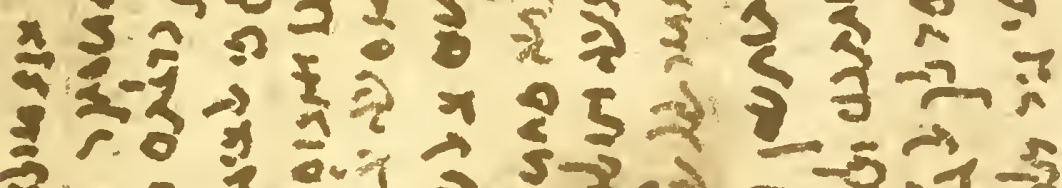

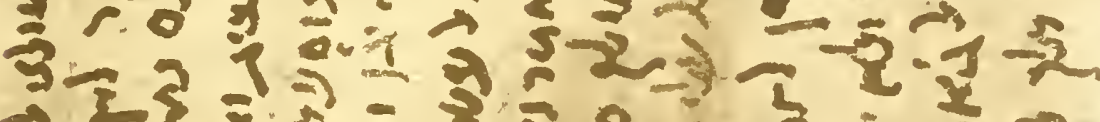

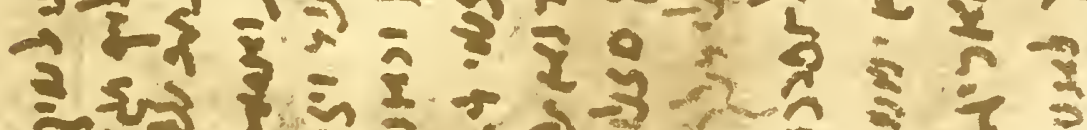

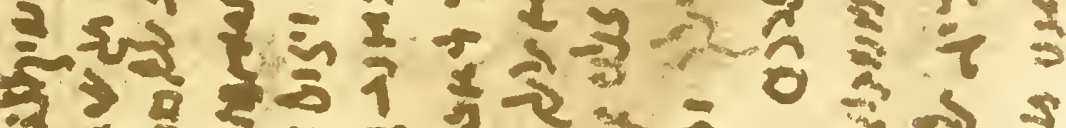
येग

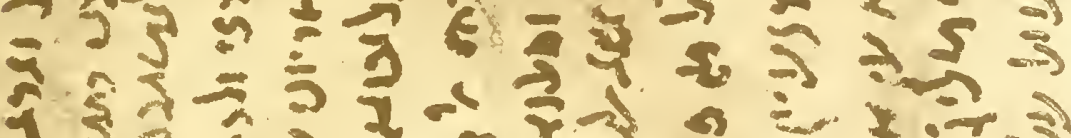

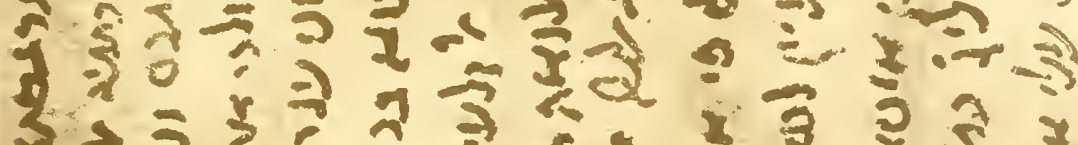

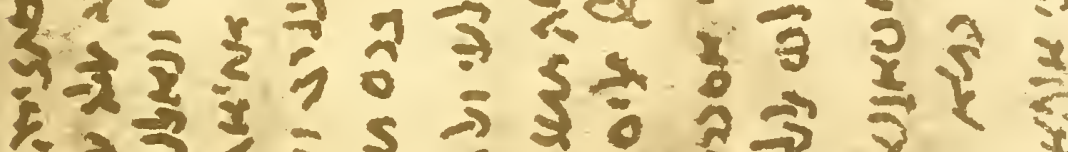

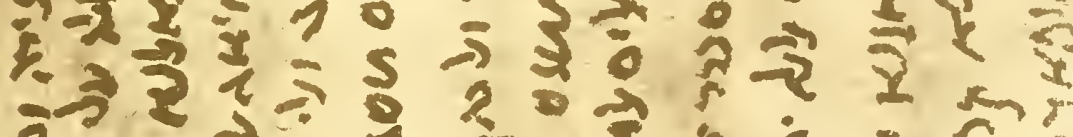

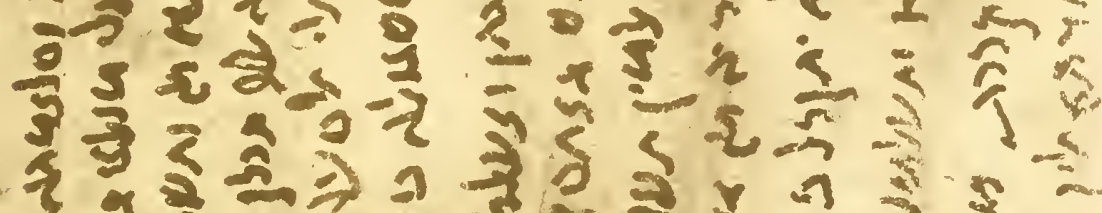

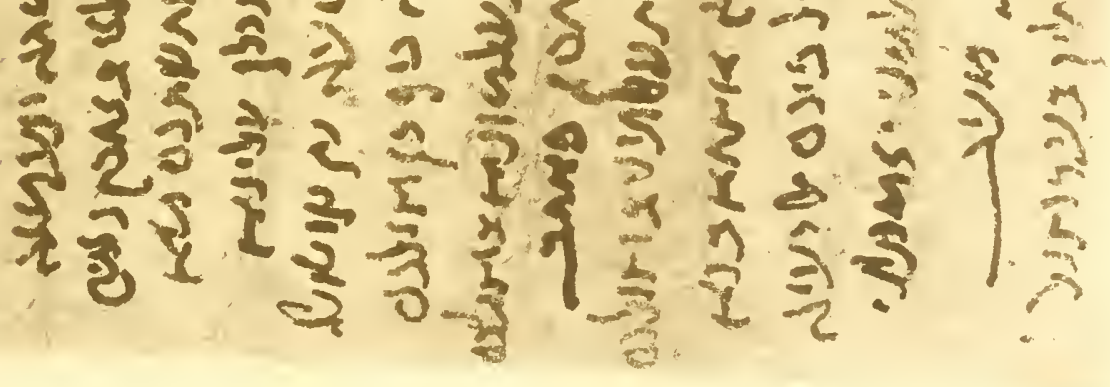




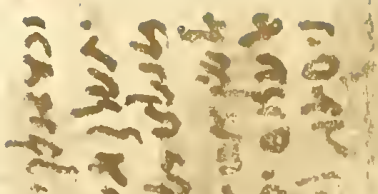

$-2+5$

y.m on of

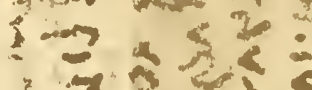

$\because 2 k+12$

$\left.3 \rightarrow \frac{1}{2}\right)^{2}$

$0-3-3-5=$

$23-902=$

$\leqslant+2$ \& 3

$\frac{1}{4}>0=-5$

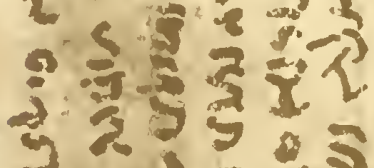

$-7=-123$

$\rightarrow 20-5$

1245

- $3 x$ is 5

$3 \geq-\frac{1}{2}=3$

-2.2 iे 32

$+3 x+2=$

$\rightarrow 2-15=5$

$5-4$ मे 3 ह

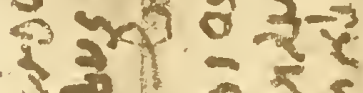

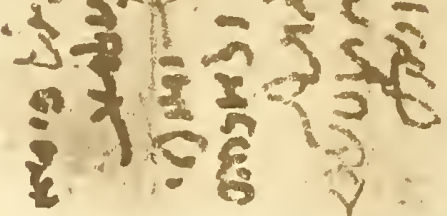

?

E:

;

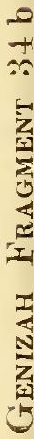




\section{LETTER}

A letter from Nathan Ben Nahrāi, in Alexandria, to Nahrāi Ben Nissīm, head of the Babylonian community in Fusțāt (See Mann, op. cit., vol. i, p. 206 ; vol. ii, p. 248), who is temporarily in Malīj(?). The addressee and a certain Abū Sa'd have recently visited the writer in Alexandria.

Translation is difficult at times, because the writer's constructions were mixed in his own mind before they reached the paper.

Recto:

I [This is] my letter [to you]. May God prolong the life of my Lord, the most glorious Sheikh, and continue his safety and his health and his prosperity,

2 and confound his enemies! [This letter is] from one who inquires ${ }^{1}$ [after his health. Written] when 20 [days] of Shebhăt [had passed]. May God complete [the month] for my Lord with the best [sort] of completion $^{2 !}$

3 I inform you, $\mathrm{O}$ my Lord: Behold you have gone-God increase your health!-and we have had ${ }^{3}$ [in the way of] bereavement of you what

+ God [only] knows ${ }^{4}$. And everyone in the household [feels likewise]. And as for Nahrāi ${ }^{5}$, my [little] boy-[God] preserve his life to you!-he is angry with us ;

5 and says: "When will our Rabbi ${ }^{6}$ come, and Abu Sa'd ?" And he says : "Is the 'dentleman'7 here?" And up to now ${ }^{8}$ we have been saying to him :

6 "They are in the synagogue". They are coming directly 8 ." And we worried [about] how you arrived,

7 until Thursday at evening Rabbi Abraham al-Kala ${ }^{10}{ }^{10}$ and the Kōhēn arrived, and informed us of your arrival

8 with all safety. And we praised God and asked Him for a completion [of your plans] with [His] benevolence. And I desire

9 of you, O my Lord, when you arrive safely, if God will, among [your people who are likewise] safe, that you inform me of your arrival

10 at your place of residence; and I shall praise God for that. And everyone in Alexandria ${ }^{11}$, from among our friends

I - May they be blessed ${ }^{6}$ ! - is grieved at your departure ${ }^{12}$, praying ${ }^{13}$ God for you [that He will] grant of you the pious prayer,

I 2 and not scatter you nor scatter ${ }^{14}$ us from our native cities. And inform me, O my Lord,

\footnotetext{
${ }^{9}$ See No. XXVII, note 32. Dozy, op. cit., vol. ii, p. 493.

${ }^{10}$ See No. XXXIII, recto, line 28 .

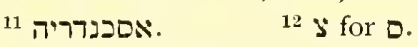

${ }^{13}$ Vernacular form.

14 יי"שתתגי".
} 


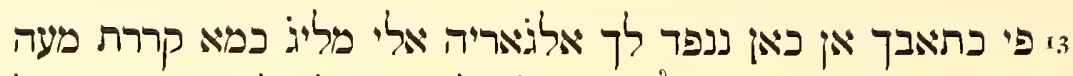

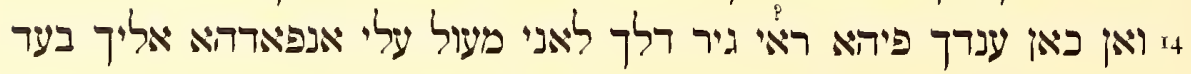

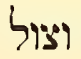

Verso:

5 כתאבך ברלך וצול

ז וכראלך ...... מא סאלת חצרתך פי אלאגתמאע מע אלשיך אבו : מאו

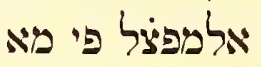

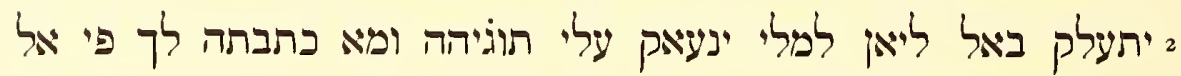
תרכרה אעלמת באיאו

3 מולאי דלך תכתין אפצל אלםלאם למולאי אל שיך אביד אבו סער

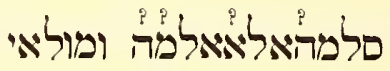

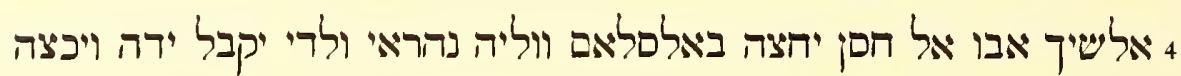

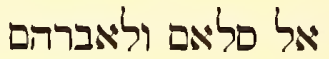

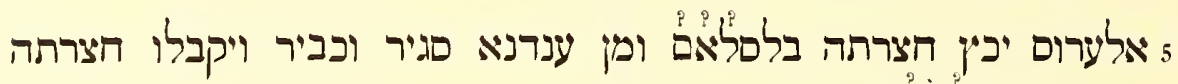

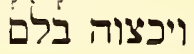

6 ויסאלה לא ינםאנא מן דעוה צ'אלחה ושלום וחיים טובים אמן ונחבך לא ושלום

תקטענא

Address:

מחבהא ושאכרהא נתן בן יחצרה מולאי החבר גדול [הי[שיבה נהראי נפיע

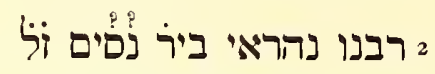

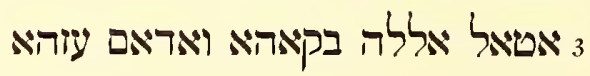

\footnotetext{
15 Maghribī form.

${ }^{16}$ See Yăkutut, ed. Wüstenfeld, vol. iv, p. 639, But near which Mahallah ?

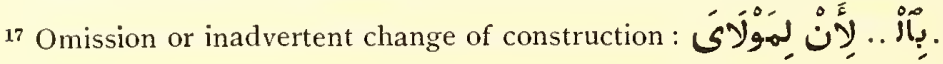


13 in your [next] letter whether $I^{15}$ shall send you the female slave to Malīj ${ }^{16}$ as I agreed with him,

If or whether you have in regard to her another opinion, for I had made

up my mind to send her to you after the arrival of

I 5 your letter in regard to that [matter];

Verso:

I and so......I did not ask your Excellency about the meeting with the Sheikh Abū al-Mufadụal concerning the matter which

2 depends upon the ${ }^{17}$ - because my Lord was prevented from sending him $^{18}$; and I did not write it to you in the memorandum. I have informed

3 my Lord of this. [Please] give [my] most distinguished salutations especially ${ }^{19}$ to my Lord the Sheikh $\mathrm{Abu} \mathrm{Sa}^{\mathrm{c}} \mathrm{d}^{20} \ldots \ldots . . .{ }^{21}$, and my Lord + the Sheikh A bū al-Hasan Isaac, with greetings, and his parents ${ }^{22}$. Nahrāi, my boy, kisses his hand, and sends him special greetings. And to Abraham,

5 the bridegroom, his Excellency, he sends especial greetings. And so do we, great and small, kiss his Excellency and send him especial greetings,

6 and beg him not to forget us, by way of a pious wish. So, Peace and good health, Amen ${ }^{6}$ ! And we wish you not to cut us off. Farewell ${ }^{6}$ !

\section{Address:}

[To] his Excellency, my Lord, the Hābēr, the Great One of the Yashībhah, our Rabbi Nahrāi, son of Rabbi Nissīm ${ }^{23}$. May God prolong his ${ }^{24}$ life and continue his ${ }^{24}$ strength!

[From] his ${ }^{24}$ affectionate and grateful Nathan, son of Nahrāi, whose rest [is in] Eden.

\footnotetext{
18 The same person as in recto, line 13 ?

19 تَخْتِتَصَّ 10 See recto, line 5.

21 Is this a twice unsuccessful attempt to write

22 ווואירדיה.

${ }^{23}$ See Mann, op. cit., vol. i, p. 206 ; vol. ii, p. 248.

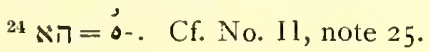




\section{LETTER}

Paper $6 \frac{7}{8} \times 5 \frac{1}{4}$ inches.

Arabic in cursive Hebrew characters.

See the introductions to Nos. III, XII, XXII, XXXIII and XXXIV, which this fragment resembles in writing and language. Although the hand is careless, it is not quite so bad as that of the other fragments mentioned; and some of the characters have a different form. The language also is better. Verso bears earlier Arabic writing.

Recto :

י כתאבי יםידי ופולאי וריםי אטאל אללה בקאך ו"אראם עיך סלך צפר עין oss ו וארחפר ללה רב אל עיארפין וכיאן קר וצל אל חהיך אלי הונה וסט ארליר וג'ות

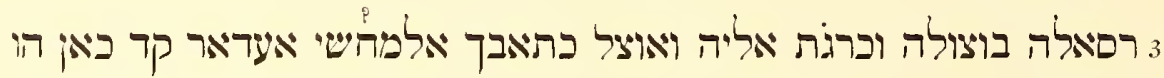
4 "אשטר מני ראי אניך מתואני ואנת תריד פין יגיך אלי דכאנך עלם [אין

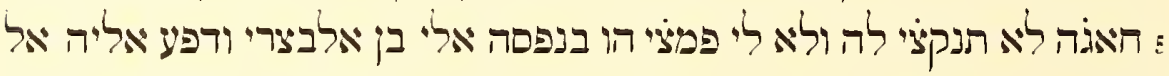

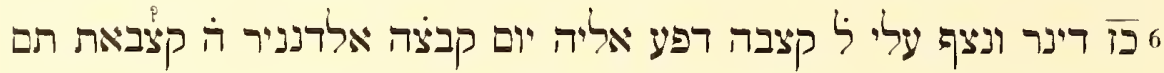
7 זםתגר אל באקי קליל וקליל ותכלין ולם יערפך בפא עמל בל ידאפעך

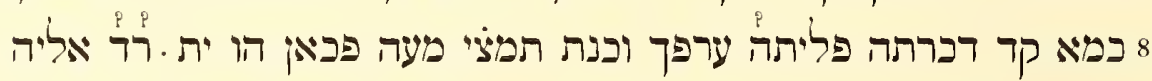
9 וייאכר כל יום וכל וקת מיא םהל התי תנקטי אל חאגה ואמא אלקעוד

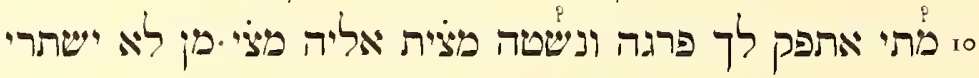

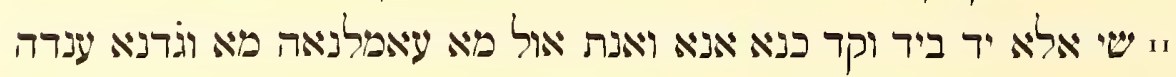

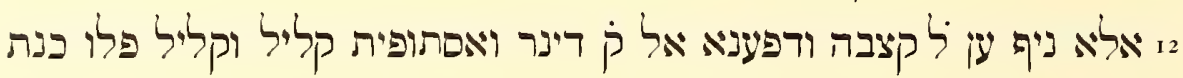

תуบา

3. איליה אלדנפיר פי וקת וצולה וקאל לך תצבר שהר לכיאן אנפיצך פי אקרב 41 וקת ליכנך פעלת אנת פעל פי יכאף יכרג אלדאר פן ידה פליא ״עור

\footnotetext{
1 Koran, Sürah i, v. I. 2 Lُهُ.

${ }^{3}$ Vernacular. Literally: "He was cleverer than 1."

* Vernacular. $\quad{ }^{5}$ al-Būșīiñ? $\quad{ }^{6}$ A k̦așabah =about i I ft. $7 \frac{3}{4}$ in.

T Vernacular dánanìr.

${ }^{8}$ The missing letter is perhaps a deleted '. The form was then yitrádd, Egyptian vernacular for يَرْتَدْ
} 


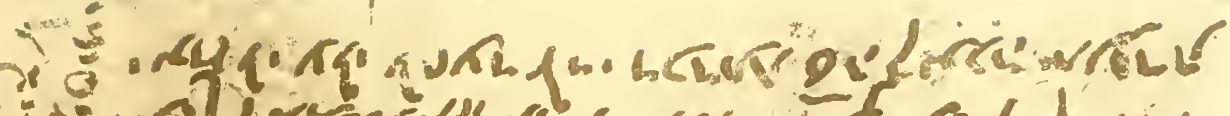
St

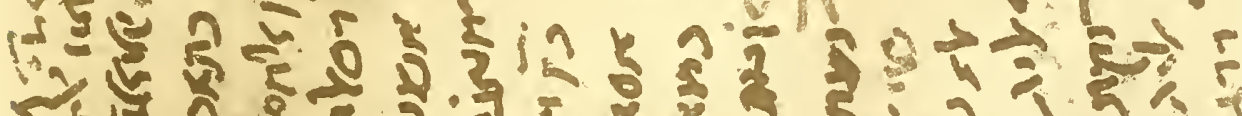
एद है 5

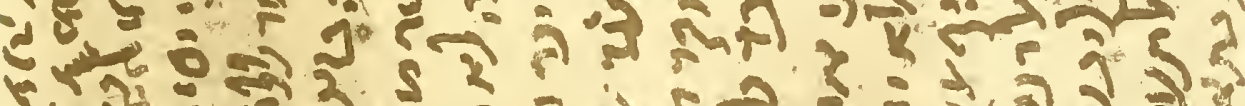

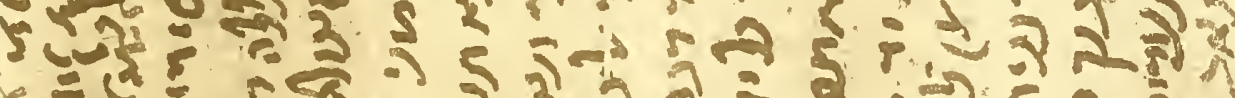

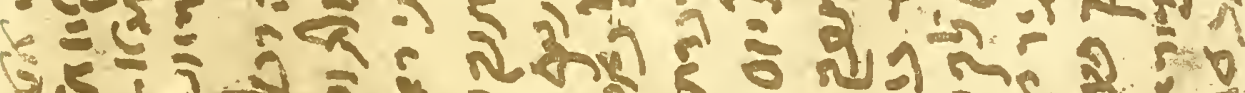

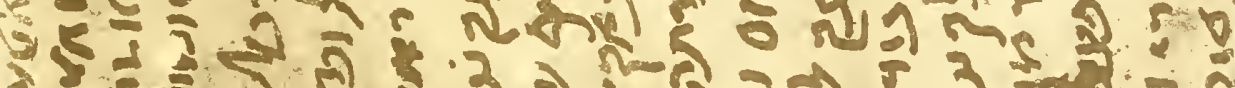

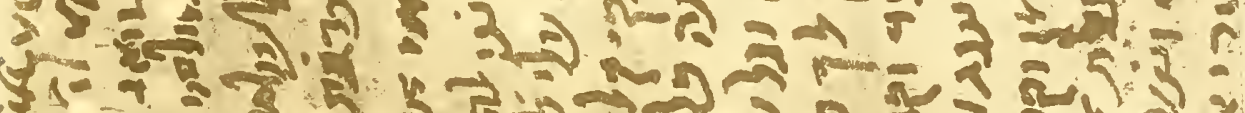

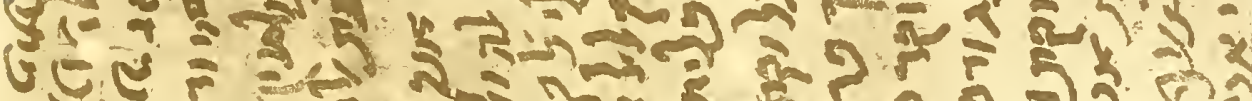

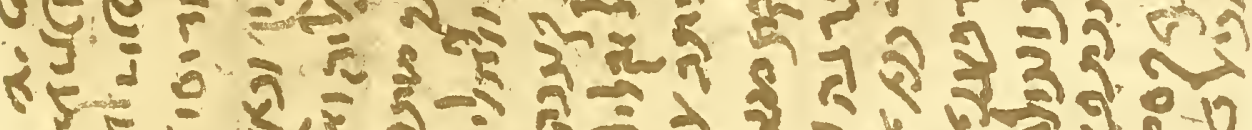

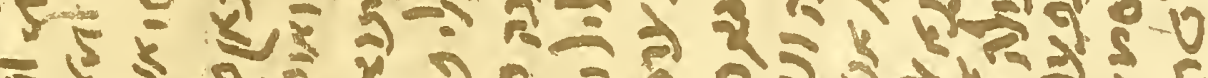

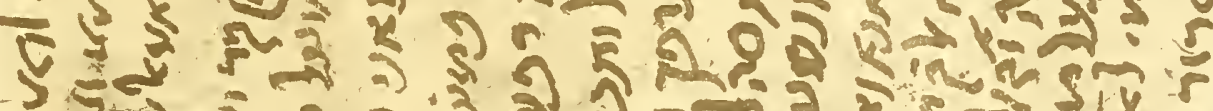

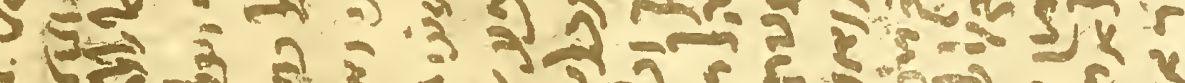

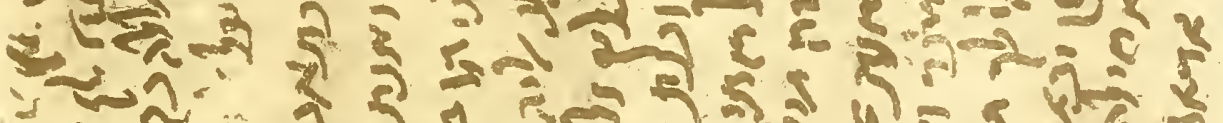

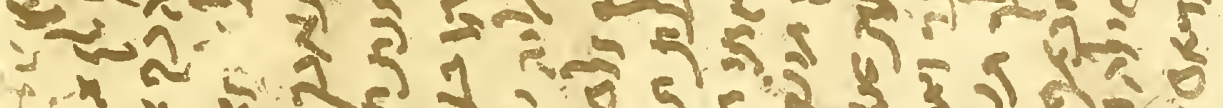
(E)

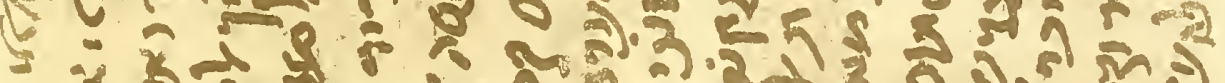

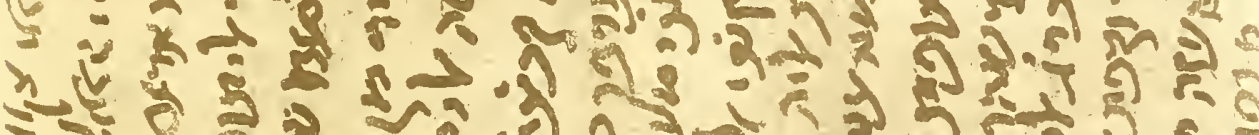

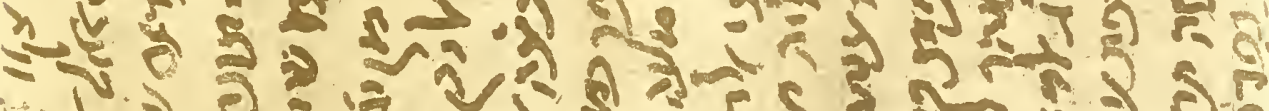

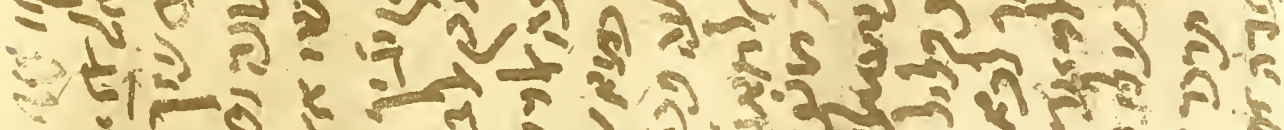

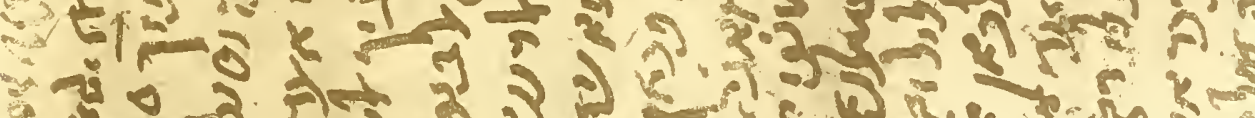
सम

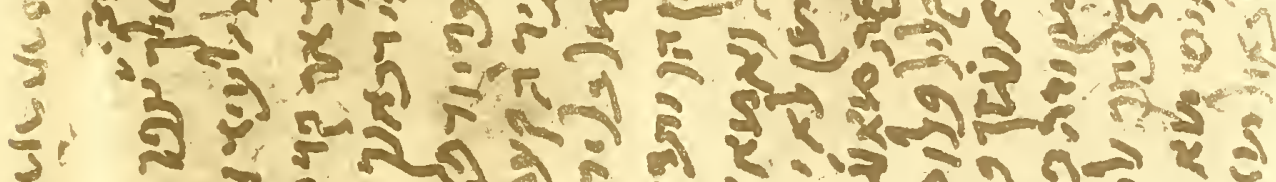

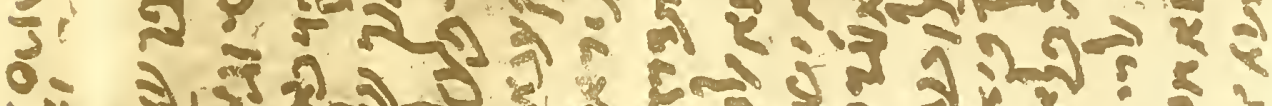

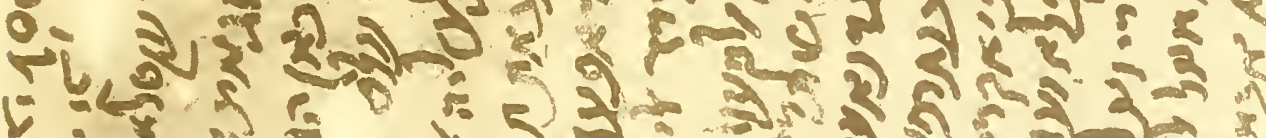

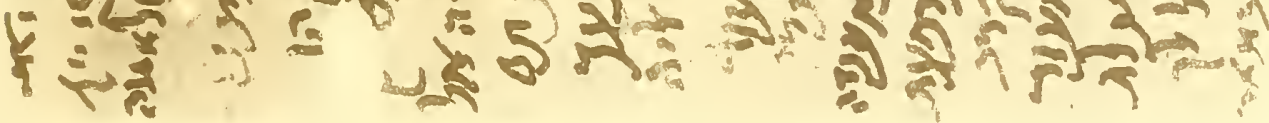




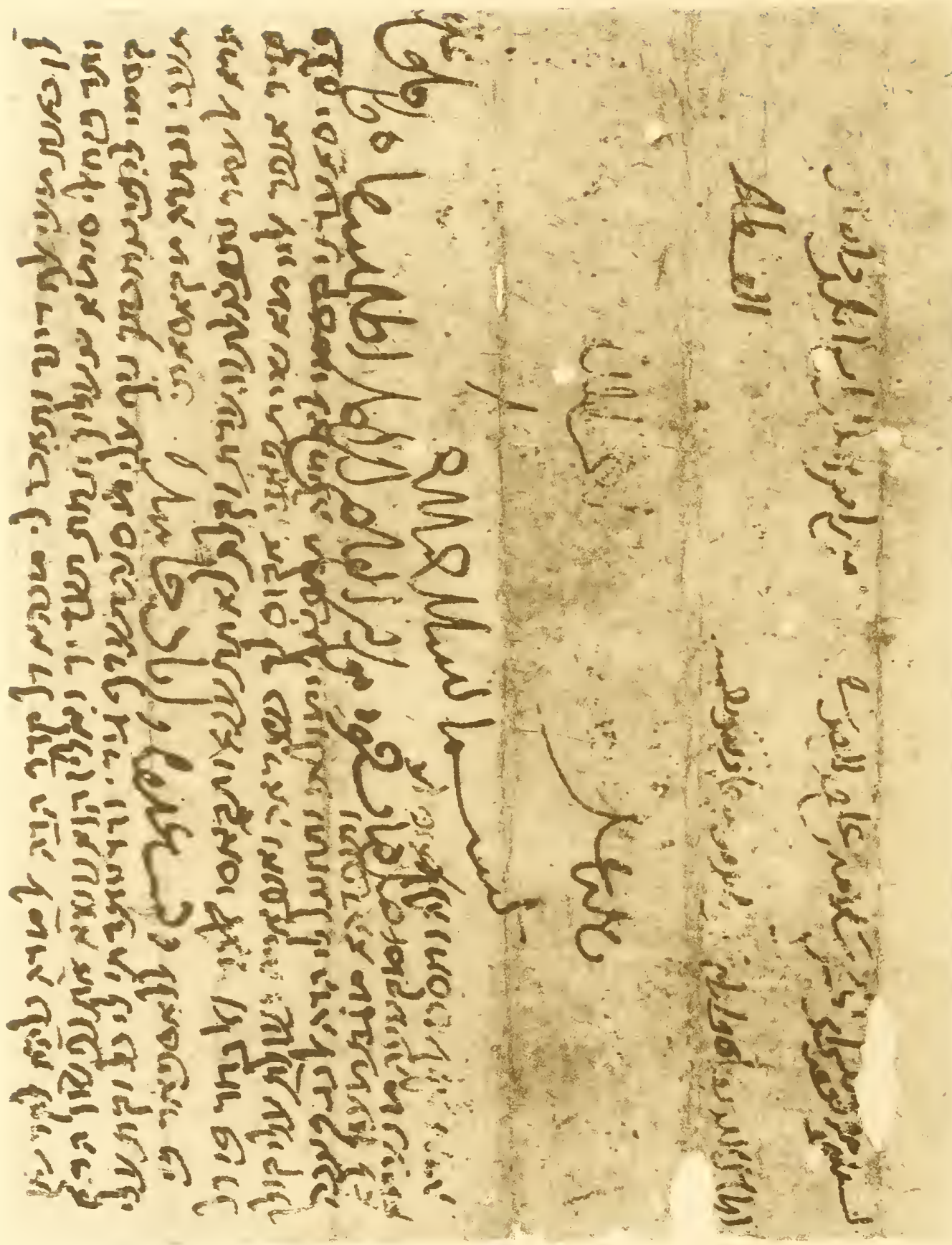




\section{LETTER}

Two men, both Jews, have for more than forty years engaged in business together; one of them, the writer of this letter, travelling about, the other remaining at home, as indeed was often the case in partnerships. They handled general merchandise, but especially cloth. They advanced money to weavers, and took the cloth as it was produced.

The writer now complains of his partner's inertia and timidity, and of his own exertions and losses: perhaps merely the business usage of the time.

\section{Recto:}

I [This is] my letter [to you], O my Lord and Master and Chief. May God prolong your life, and continue your strength! [The month of] Șafar has come in peace;

2 and praise belongs to God, the Lord of the Worlds! The weaver has arrived here ${ }^{2}$ in the midst of the Festival, and a letter

3 has come to me through his arrival. I went out to [meet] him, and he delivered your letter, stuffed with excuses. [You write:] "He has

+ taken advantage of $\mathrm{me}^{3}$." My opinion is that you are shiftless, and want people to come to you in your shop. He knew that

5 nothing ${ }^{4}$ would be done for him or for me [through you]; so, he went to Ibn al-Bașri $\overline{1}^{5}$ in person, and [the latter] paid him the

6 twenty-seven dinārs and a half on 30 kașabahs ${ }^{6}$. He delivered to [the latter] on the day when he received the dinārs ${ }^{7}, 5$ kașabahs [of cloth]. Then

7 he did the same thing with the rest [of the cloth], little by little, and at last it was finished. And he did not tell you how he was getting along. On the contrary, he kept putting you off,

8 as I have said. If he had only told you, and you had gone along with him! But he went back ${ }^{8}$ to [Ibn al-Bașrī ${ }^{5}$,

9 and [the latter] took every day and each time what was convenient, until the business ${ }^{4}$ was settled. And as for sitting idle :

10 [ Tell me,] when have relief and joy ${ }^{9}$ ever come to you by chance? You went to [the weaver] as one goes who does not buy

i anything except for $\operatorname{cash}^{10}$. Now, you and I, the first time we did business with him, found [that] he had no

12 more than a little in excess of 30 kasabahs. Yet we paid the 100 dinnārs, and you got all the rest [of the cloth] little by little. But if you had paid

${ }_{13}$ him the dinārs ${ }^{7}$ at the time of his arrival, and he had said to you "Wait a month," it would have troubled you in a very short

${ }_{1}$ time, because you ${ }^{11}$ would have acted as one who fears that the house will walk away under one's very eyes, so that the profit does not

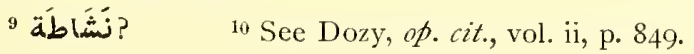

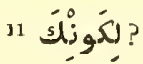




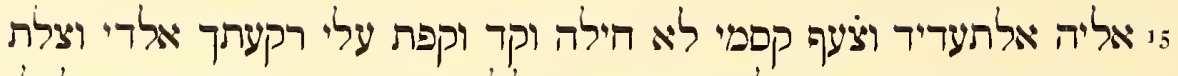

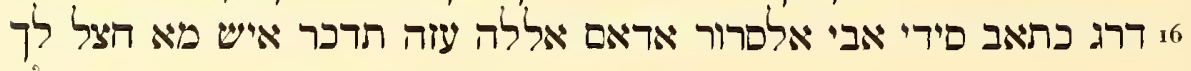
תנפרה אול באול מא אכתאר?

Margin: (a)

יכון אלא גמלתה ארא פהלה אללה וכף עלי קלבך אלדי |יצה לי עלי

Margin: (b)

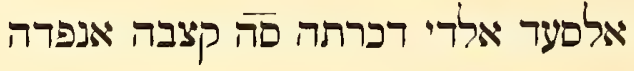

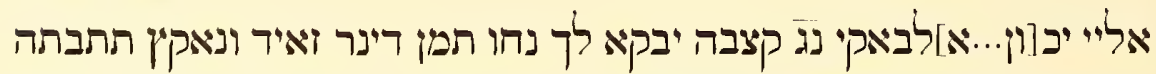

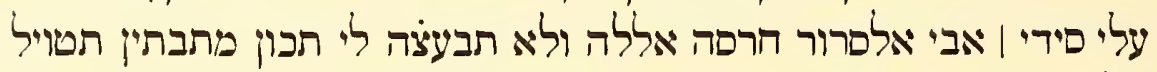

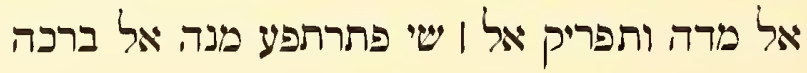

Verso:

ולו כאנת מעי אלף דינר ותאכר לי מנהא דל קדר הדה אלמדה כלהא

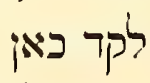

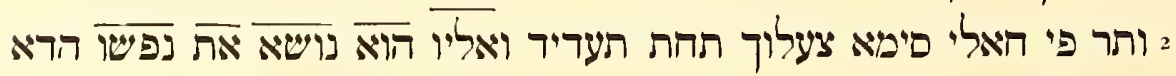

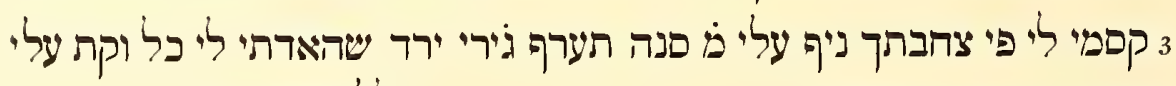

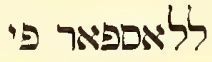
4

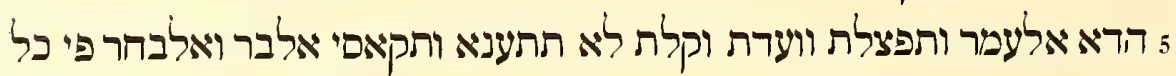

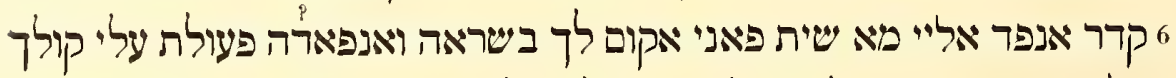

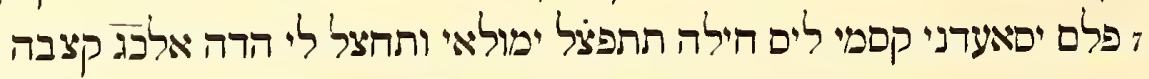

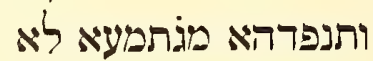

\section{מקטעה מנעמה}

אן שא אללה וחסבי אללה וחרה מעמה

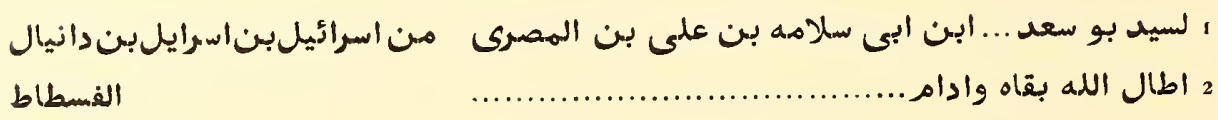

$$
\begin{aligned}
& \text { أli } \\
& \text { بسم الله الرحمن الرحيم } \\
& \text { وصل كتاب هضرة مولاى القاضى اللاماه اطال الله بقاه وادام عزه الرهم }
\end{aligned}
$$$$
\text { وكثبت عدوه واباد حاسنده }
$$ 
I5 return to him. My share has decreased-no deception [about it]. And

I have called attention to your epistle, which has arrived at the [same] moment [as]

16 the letter of my Lord Abū al-Sarūr-May God continue his strength !-

You say: "What ${ }^{4}$ has happened ${ }^{4}$ to you?"

${ }_{17}$ Send first of all what he prefers:

Margin: $(a)$

Let it be [anything] except the whole of it. When God has made it easy [to do so], and you are not worried about what I am entitled to from al-Sa'd-[the matter] which I mentioned : 65 k kașabahs-send it

Margin: (b)

to me. Let the remainder, 53 k kașabahs......, remain yours-about the value of a dīnār, more or less. Charge it against my Lord Abū al-Sarūr-May God protect him!-and do not divide it with me. Let the two [things] agreed upon be: extension of the term, and distribution of the thing. So there will arise from it a blessing ${ }^{12}$.

Verso.

I If I had had a thousand dīnārs, and you had taken this ${ }^{13}$ amount [from] me for all this length of time, the

2 ruin in my condition would have been like [the ruin of] a beggar, instead of ${ }^{14}$ profit: "And upon it he setteth his heart ${ }^{15}$." This [has been]

3 my lot in partnership [with] you [during] more than 40 years. You know

others besides me who will bear out my testimony at any time as to

+ my bitter toil ${ }^{17}$ and the greatness of my patience to [undertake] journeys 5 at my age ${ }^{16}$. You were most kind to promise and say: "Do not distress $^{17}$ yourself and endure [hardship] on ${ }^{18}$ land and sea without

6 limit. Send me whatever you like, and I will see to selling it and sending it off for you." So I relied upon your word.

7 But my share did not help me-no deception [about it]. Be so good, my Lord, and let me have 23 kasabahs.

8 And send them together; not

9 cut up, chopped up-

1o if it please God. God only is my sufficiency!

\section{In Arabic letters ${ }^{19}$ :}

I To the Sayyid Bū Sa‘d...... Ibn Abū Salāmah Ibn 'Alī Ibn al-Maṣrī.

From Israel Ibn Israel Ibn Daniel.

2 May God lengthen his life and continue....... Fustāṭ.

3........... May God strengthen!

+ In the Name of God, the Merciful, the Compassionate ${ }^{20}$ !

5 The letter of his Excellency my Lord the Kadi the Imām has arrived.

May God lengthen his life and prolong his strength

6 and confound his enemy, and destroy him who envies him!

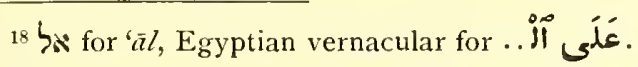

${ }^{19}$ Extremely uncertain. $\quad 20$ Muslim formula.
} 


\section{AN ACCOUNTING}

Paper $10 \frac{1}{2} \times 3 \frac{5}{8}$ inches.

Arabic in cursive Hebrew characters, distinctly written and well preserved. Decipherment would be easy, were it not for the peculiar nature of the contents.

On the verso are notes, in another hand, like that of No. XVIII, and apparently in Arabic; but they are badly written and badly preserved. The words "gold" and "silver" can occasionally be made out.

Recto :

בשמי

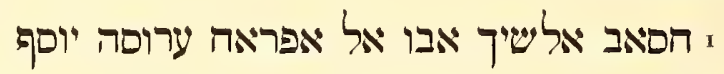

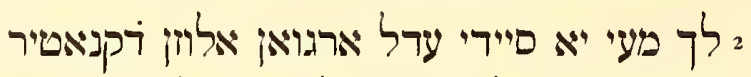

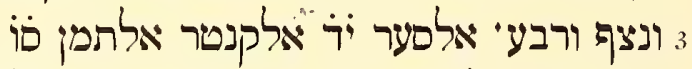

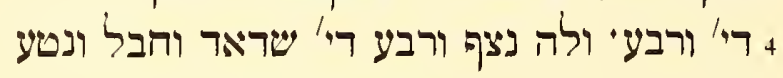

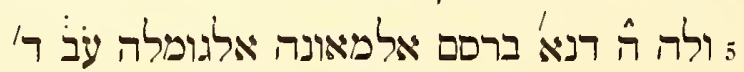

6 אלדי כרi מאונה ען רלך חמל אלמרכב א

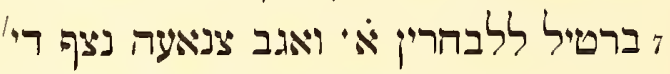

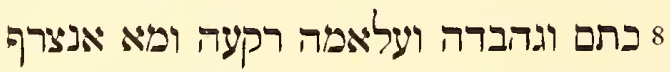

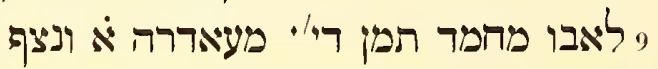

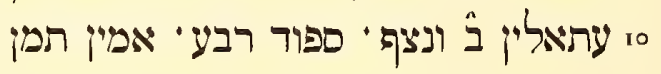

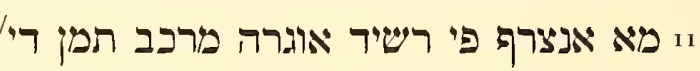

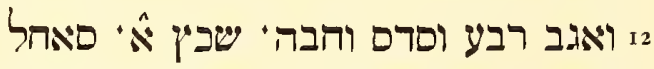

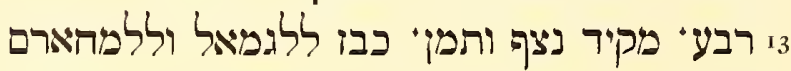

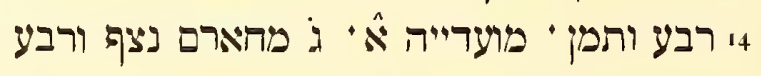

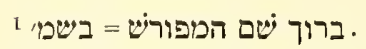

${ }^{2}$ I.e. "three-quarters." All fractions, except two-thirds, were expressed in Egypt by unit-fractions. Thus $\frac{7}{8}=\frac{1}{2}+\frac{1}{4}+\frac{1}{8}$. See L. C. Karpinski, The History of Mathematics, I925, p. 121 .

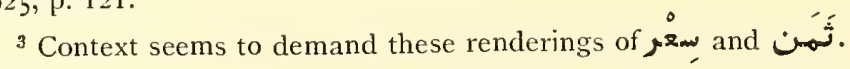

${ }^{4}$ I.e. "you."

${ }^{5}$ Without the article and with הבל this word must mean some commodity viewed collectively, though there is no authority for this rendering.

${ }^{6} \mathrm{Cf}$. the plural of this word in a similar accounting, No. XIV, verso b, line 3. 


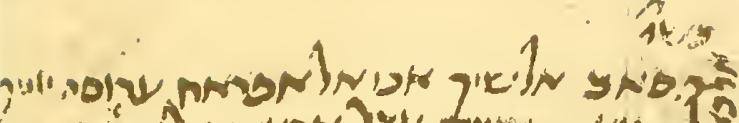

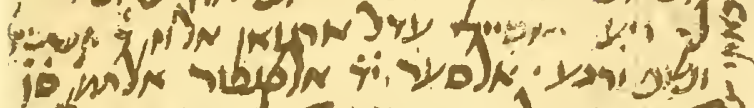

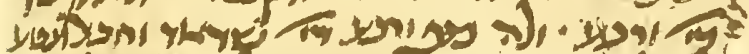

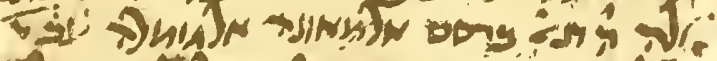

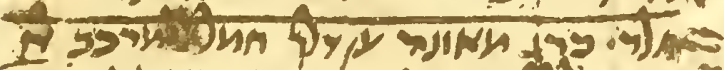

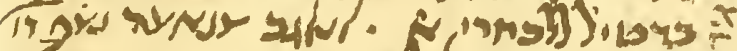

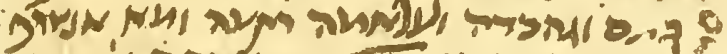

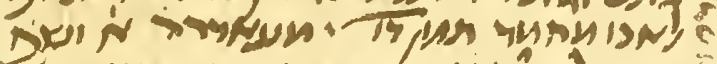

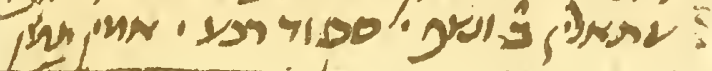

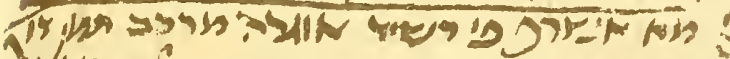

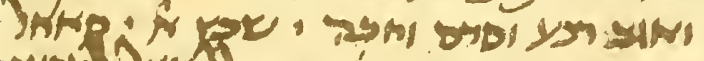

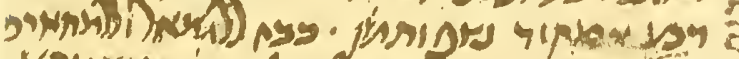

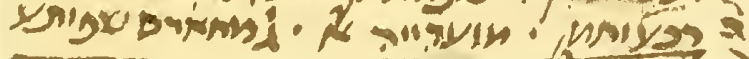

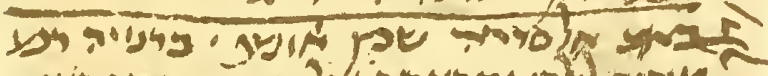

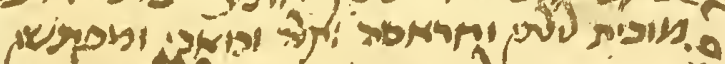
1)

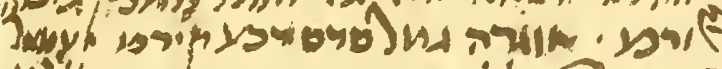

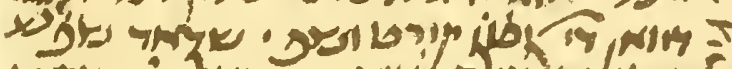

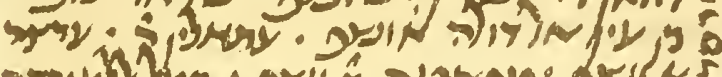

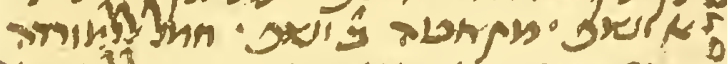

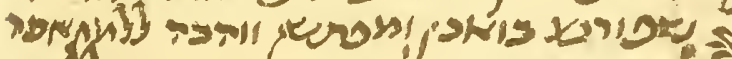

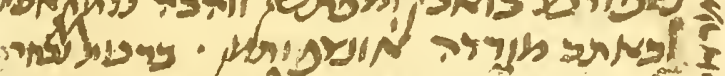

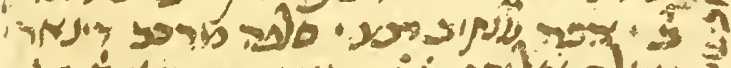

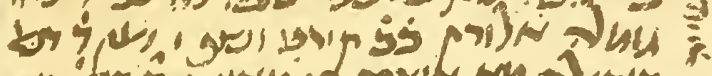

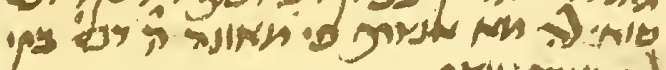
Devilus $x$

JNA Joi..

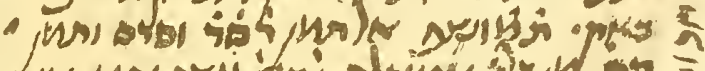

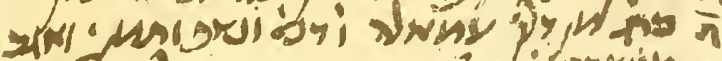

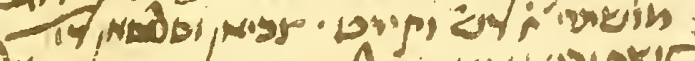

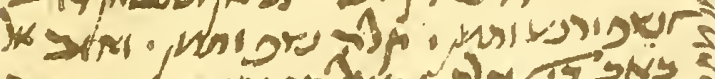

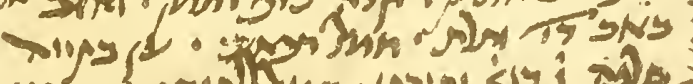
wos prob) Yh

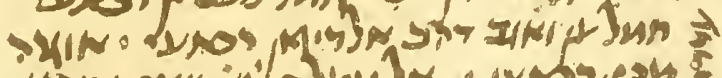

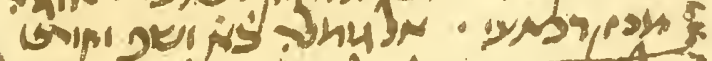

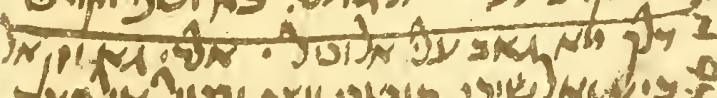

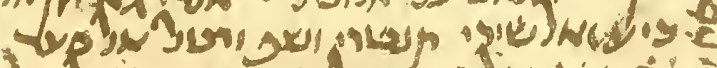

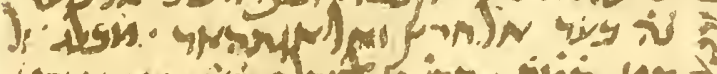

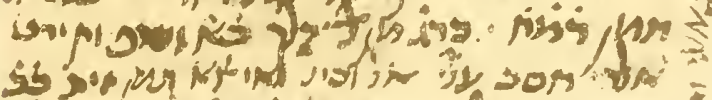

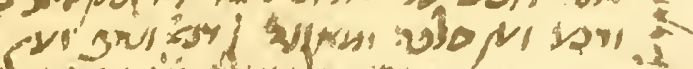

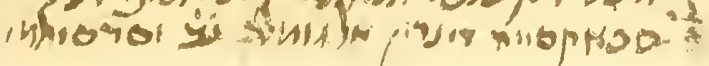





\section{AN ACCOUNTING}

This is an account rendered by some unnamed person to Abū al-Afrāh 'Arūsah Joseph. No dates nor places are named.

Many different sorts of expenses, charges, officials and commodities are mentioned. One cannot be sure of the meaning of such contemporary technical terms. Also, the amounts are not always followed by the name of the coin. If the dinār were everywhere assumed, the sums would often be too large.

Recto:

\section{Blessed be the Name ${ }^{1}$ !}

I Account of the Sheikh Abū al-Afrāh 'Arūsah Joseph :

2 You have in my keeping, Sir, a bale of purple [goods], the weight [of which is] 4 linintārs

3 and a half and a quarter ${ }^{2}$, the [purchase] price $^{3}$ [of which is] I4 the kintāar, [and] the value ${ }^{3}$ [of which is] 66

4 dīnārs and a quarter. And he ${ }^{4}$ has a half and a quarter ${ }^{2}$ dīnār ['s worth of] twine ${ }^{5}$ and rope and leather matting ${ }^{6}$.

5 And he ${ }^{4}$ has five dinārs[' worth of] clover [for] the provisioning ${ }^{7}$ [of the animals], the sum total [being] 72 dinnārs ${ }^{8}$.

6 What is deducted [for] provisioning from this: Ship's porterage, I.

7 Pourboires for the sailors, I. Obligation of the craft ${ }^{9}$, a half dinnār.

8 [Fee for] seal, and revenue-tax ${ }^{10}$, and [for] signature [on] papers, and what was paid

9 to Abū Muhammad: an eighth of a dinār. Apology ${ }^{11}$, one and a half. Io Porters, two and a half. Spit ${ }^{11}$, a quarter. Inspector, an eighth.

11 What was expended in Rosetta: Ship's hire, an eighth of a dinnār.

${ }_{22}$ Obligation $^{9}$, a quarter and a sixth, and a habbah ${ }^{12}$. [One] person, I. Sea-shore ${ }^{11}$,

I3 a quarter. Registrar, a half and an eighth ${ }^{2}$. Bread for the camel-driver and for the women ${ }^{13}$,

it a quarter and an eighth. Ferry ${ }^{14}$, I. Three women ${ }^{13}$, a half and a quarter.

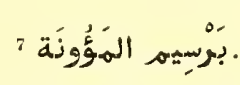

$8661+\frac{3}{4}+5=72$.

${ }^{9}$ Fee paid to some guild? Fee paid for the privilege of doing business?

1)

11 Plainly written common words, but evidently in some technical or cryptic sense.

12 I.e. "grain," "tritle." This seems to be a unit of weight and a coin. Its value is uncertain.

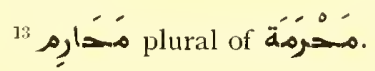

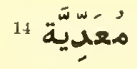


15 באב אלסדריה שכץ ז' ונצך' ברנייה רבע

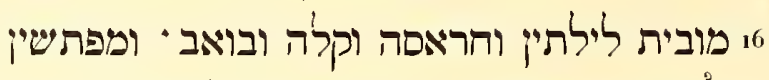

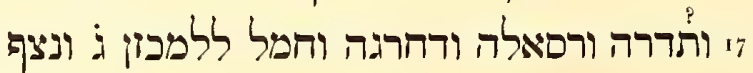

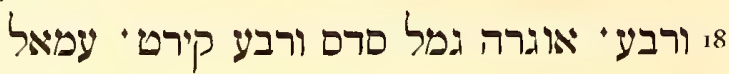

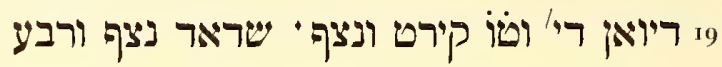

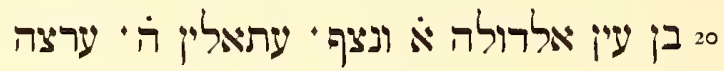

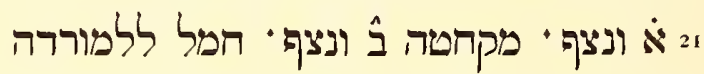

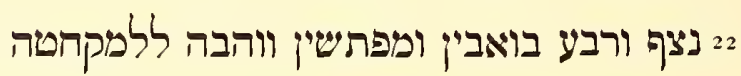

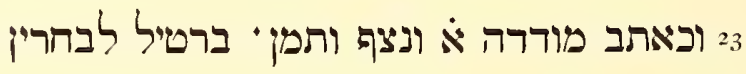

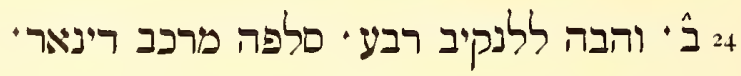
25 גומלה אלורק ذב קירט ונצף · יעין ד דנא

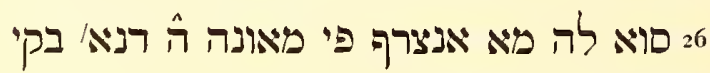

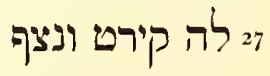

28 חסאב אלמבייע ערל ארגואן. אנבאע

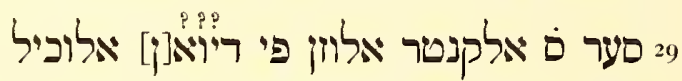

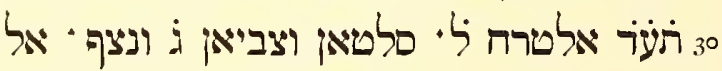

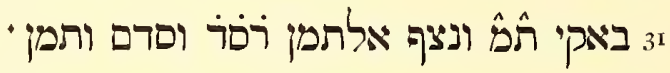

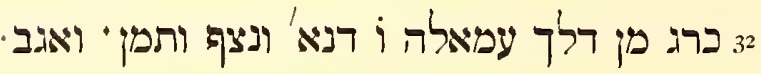

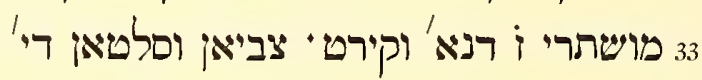

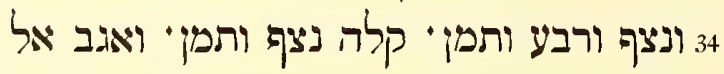

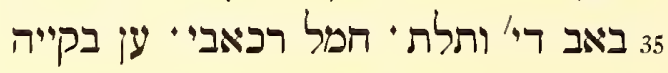

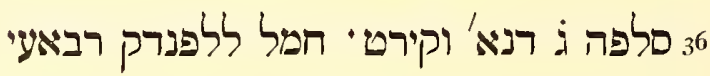

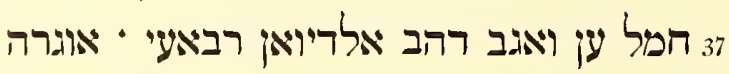

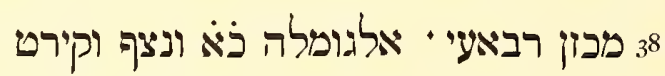

15 Abbreviated. Or perhaps another place name.

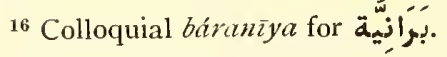

17 مُربِيَت for for

18 ותר ו 
$I_{5}[\mathrm{At}]$ the gate of Alexandria ${ }^{15}$ : [One] person, one and a half. External ${ }^{16}$, a quarter.

16 Lodging ${ }^{17}$ for two nights, and guard, and a water-bottle, and door-keeper, and inspectors,

${ }_{7}$ and ticket ${ }^{18}$, and letter, and rolling and carrying [of bales] to the warehouse, three and a half

is and a quarter. Hire of camel, a sixth and a quarter kịnāṭ. Agent

19 of the office, a dinār and 15 kìrāts and a half. Twine ${ }^{5}$, a half and a quarter.

so [To] Ibn 'Ain al-Daulah, one and a half. Porters, 5. Exhibition, 2r one and a half. Scraper ${ }^{11}$, two and a half. Carrying to the place of embarkation,

22 a half and a quarter. Porters, and inspectors, and gift ${ }^{19}$ to the scraper ${ }^{11}$, 23 and the scribe of the place of embarkation, one and a half and an eighth.

Pourboires for sailors,

${ }_{2+}$ two. And gift ${ }^{19}$ to the chief, a quarter. Breakfast [for] the ship['s crew], a dīnār.

${ }_{25}$ Total of the paper, 22 kịināts and a half. And cash, 4 dīnārs.

26 Equalled by ${ }^{20}$ what was spent in provisioning, 5 dinnārs. Balance 27 to his ${ }^{4}$ credit, a kīrât and a half.

28 Account of the sale ${ }^{21}$ of the bale of purple [goods]. It was sold, 29 price 60 the lințār, the weighing in the office of the representative.

30 Four hundred and seventy-four, tribute to the Sultan; and [to] the youths, three and a half. The

${ }_{31}$ balance, 430 and a half. The value, 264 and a sixth and an eighth.

32 There were deducted from this: Wages, six dinārs and a half and an eighth. Obligation

33 of the seller ${ }^{22}$, seven dīnārs and a kīināt. Youths and Sultan, a dīnār $3+$ and a half and a quarter and an eighth. Water-bottle, a half and an eighth. Obligation of the

35 gate, a dīnār and a third. Hauling, a rubāis ${ }^{23}$. From the balance:

$3^{6}$ Breakfast, three dīnārs and a kiirăț. Carrying to the hostelry ${ }^{24}$, a rubā'i ${ }^{23}$.

37 Favor to the gold obligation of the office, a rubā's' Hire of 38 place, a rubầi $\bar{i}$. The total: 2 I and a half and a kịiāṭ.

\begin{tabular}{|c|c|}
\hline 19 هَهِبَة for وهَبَة. & 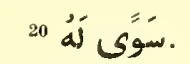 \\
\hline
\end{tabular}

${ }^{23}$ I.e. a quarter of a dīnār. See Dozy, op. cit., vol. i, p. 504.

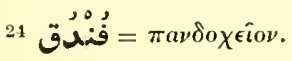


39 דלך מא גיאב עלי אלופילי אלדי גא וון אל

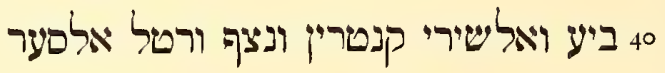

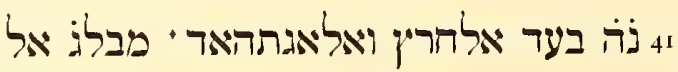

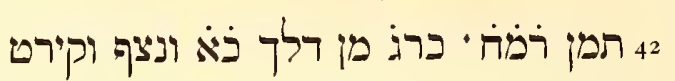

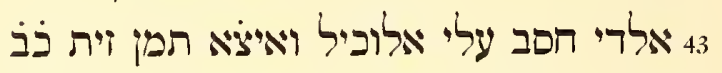
44

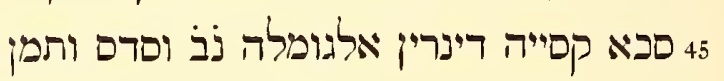

Margin :

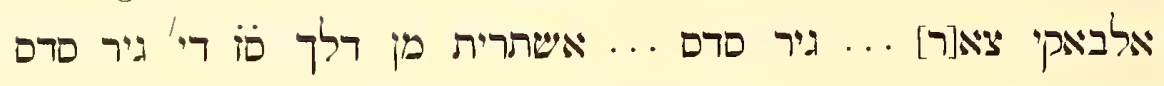
מראבשייה סער תגיר i הבוב אלמתקאל עדרהא טה ורבאעי וקרצי. 25 شعرى 
39 This is what the representative brought me. The result was: Weight of the

to selling and the buying ${ }^{25}$, two kințārs and a half and a roṭl. The price,

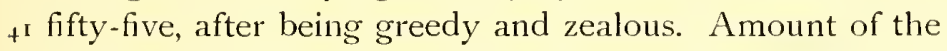
$t^{2}$ value, 248 . Deducted from this ${ }^{26}, 2 \mathrm{I}$ and a half and a kịrāt.

${ }_{43}$ What the representative charged against me, and also value of oil, 22 +4 and a quarter. And in the way of breakfast and provisions, six dinārs and a half. And in the way of

45 generosity, though hard, two dīnārs. The total, 52 and a sixth and an eighth.

\section{Margin:}

The remainder amounted to ... less a sixth...... I bought from that, 67 dinārs less a sixth, [in] Moroccan money. Price of the exchange ${ }^{27}$, 5 habbahs ${ }^{12}$ to the mithḳāl. The number of them was 68 and a rubā'i and............

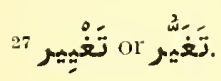




\section{LETTER}

Paper $8 \frac{1}{8} \times 4$ inches.

Hebrew in cursive Hebrew characters.

The language is exceptionally good. The writing, though apparently plain, gives some difficulty because of the unusual forms of some of the letters, and the way in which they are combined.

There is no date; but the occurrence of a watermark places the fragment certainly after A.D. I 282. See Briquet, Les Filigranes, 1907. Unfortunately the watermark is indistinct.

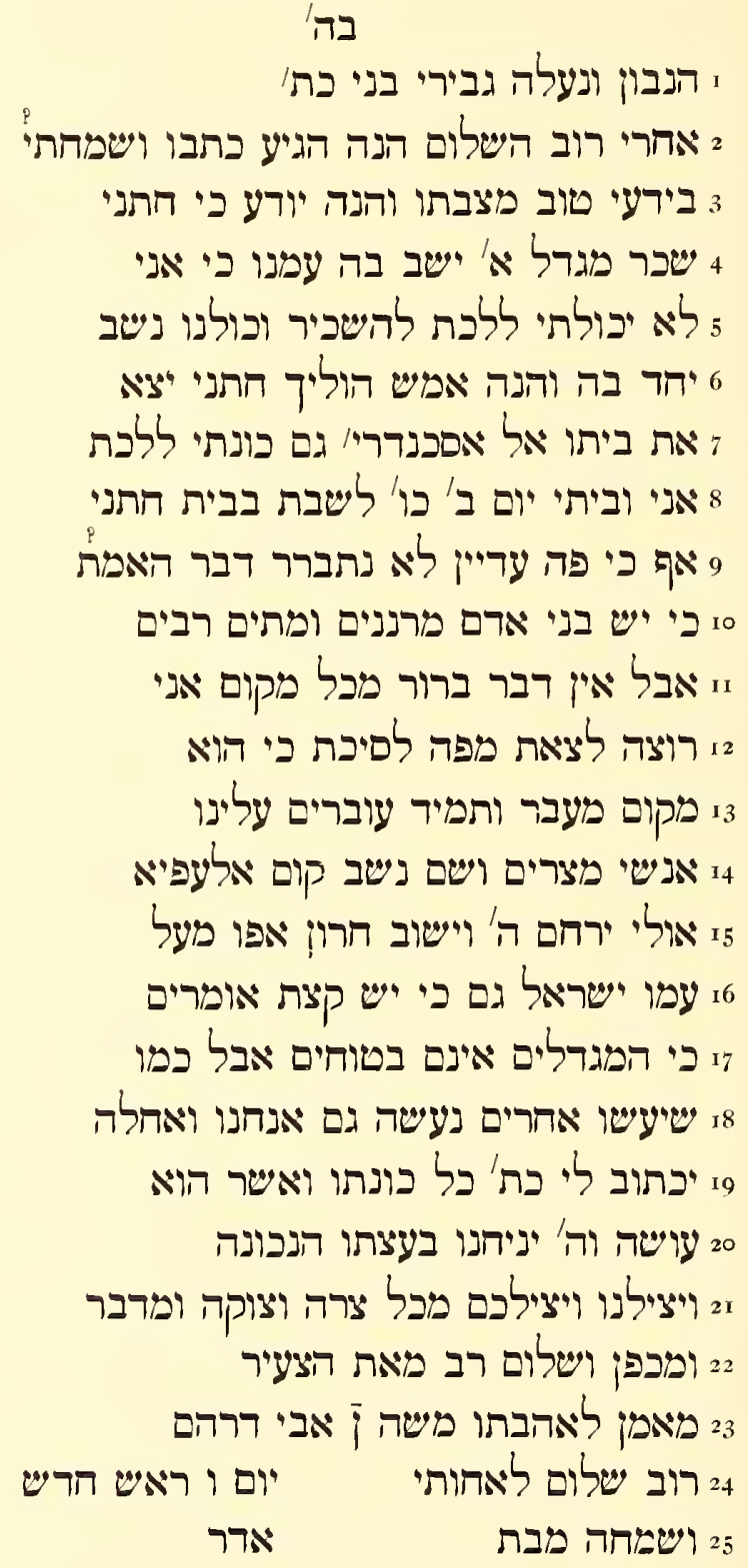




\section{$>$}

Tos

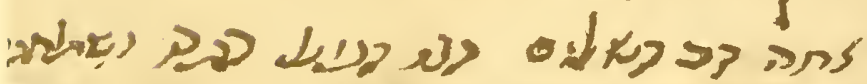
प्र

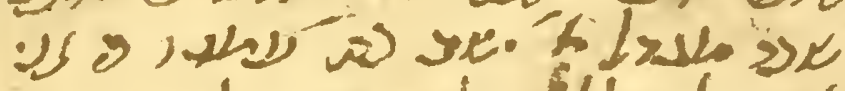

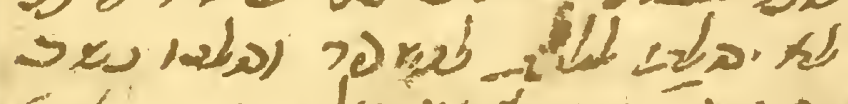
"N की

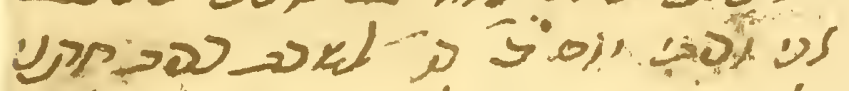
रل

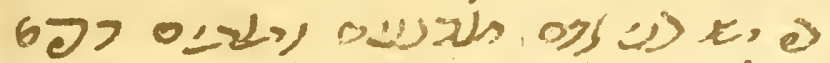
以 s 10र्य

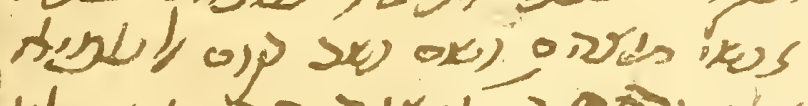
belo

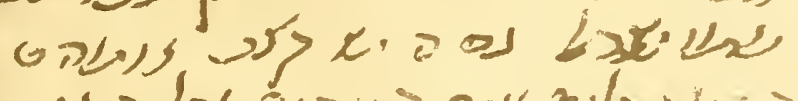

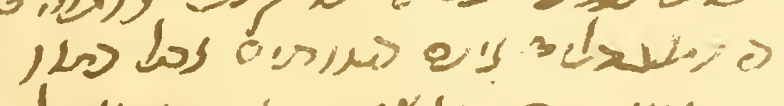
ש מ

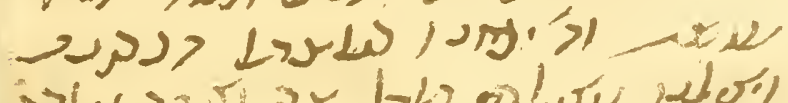
j)

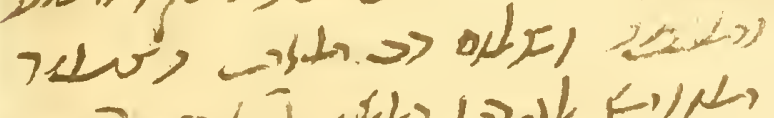

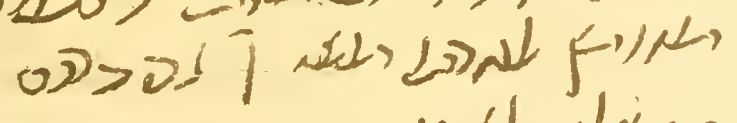
ק) i) 2 ationt 



\section{LETTER}

From Moses Ibn Abū Dirham, to a younger man who is unnamed.

The writer is about to leave his present place of residence, and remove to Sikat", near Alexandria, where he will live with his son-in-law in a "tower." There he will be safe from the present persecution, and enjoy a prosperous business upon the highway of travel.

Blessed be the Name ${ }^{1}$ !

I O Intelligent and Exalted Sir, my Son, Crown of the Law ${ }^{2}$ !

2 After many greetings ${ }^{3}$ : His $^{4}$ letter has arrived; and I am glad

3 to know ${ }^{5}$ of his ${ }^{4}$ good condition. And know that my son-in-law ${ }^{6}$

+ has rented $\mathrm{a}^{7}$ tower $^{8}$ to live in with us. For I

5 cannot go to rent [one]; so, all of us are to live

6 together in it. And last night my son-in-law went down

7 with his household to Alexandria. [It is] my intention also to go,

8 I and my household, Monday, the 26th, to dwell in the house of my son-in-law ${ }^{6}$,

9 even though no trustworthy information has reached here as yet:

ro for there are people rejoicing, and many people dead-

is yet there is no trustworthy information. At all events I

12 should like to go away from here to Sikat ${ }^{9}$, for it [is]

13 a place of passage ; and [there will be] passing by us continually

14 people of Egypt; so that we shall dwell there like prosperous folk ${ }^{10}$.

${ }_{15}$ Perhaps God ${ }^{11}$ will have mercy and His anger will depart from

i6 His people Israel ${ }^{12}$ - even though there are some who say

${ }_{17}$ that the towers ${ }^{8}$ are untrustworthy. But as

18 others have done, [so] we also shall do. And I hope

19 that he ${ }^{4}$ will write me a letter ${ }^{13}$ [expressing] all of his intention, and what he

20 [is going to] do. And may God ${ }^{11}$ give us peace with His wise counsel; $2_{\mathrm{I}}$ and deliver us and you from every anxiety and oppression, and from pestilence ${ }^{14}$,

22 and from famine! Many greetings from [my] unimportant [self who]

23 rely upon his ${ }^{4}$ love, Moses Ibn Abū Dirham ${ }^{15}$.

24) (Many greetings to my sister, and joy from [my] household!

$\left.{ }_{25}\right\}$ Friday, first day of the month of Adar.

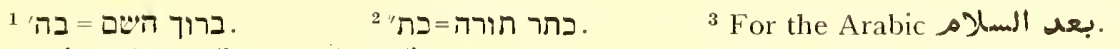

4 "his"="your," "he"= "you." 5 "Inf. with ב and suffix.

${ }^{6}$ Or "father-in-law." "

8 I.e. "strongly built house"?

9 Some place near Alexandria? Perhaps "س "road," the second element of the

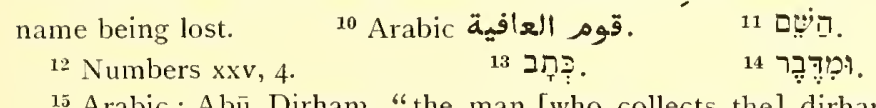

${ }^{15}$ Arabic: Abū Dirham, "the man [who collects the] dirham." On this celebrated Spanish family see the Jewish Encyclopedia, sub roce.
} 


\section{POETIC BIBLICAL PARAPHRASES}

Paper $6 \frac{7}{8} \times 5 \frac{1}{8}$ inches, folded so as to form four pages all of which are filled with writing.

Hebrew in a large square Hebrew hand, very much effaced on three of the pages.

The original verse division has been all but lost by the copyist. On recto $(b)$ and verso $(a)$ it can only occasionally be discovered, but on the other two pages it is quite evident, although it is not followed.

Recto $:(b)$

Verso: $(a)$

$$
\begin{aligned}
& \text { זלביתו ורש . . . . . . . . . . . . . . . . . . }
\end{aligned}
$$

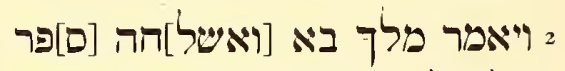

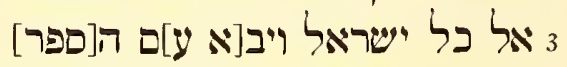

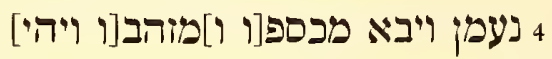

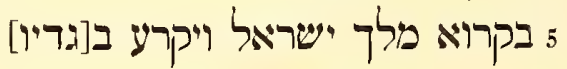

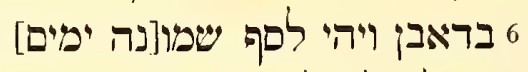

$$
\begin{aligned}
& \text { ז וישלה לו [לאמר את] יי ירא. וי[בא] }
\end{aligned}
$$

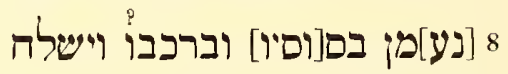

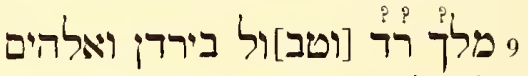

$$
\begin{aligned}
& \text { סו לך למחםהי ויקצף נעמן ויניאין }
\end{aligned}
$$

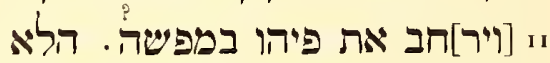

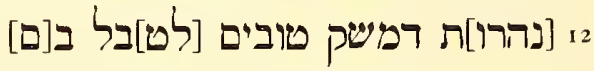

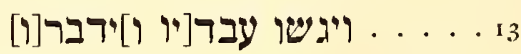

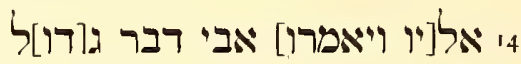

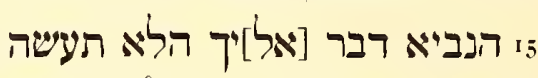

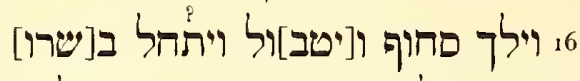

$$
\begin{aligned}
& \text { 6י [ש]בוב לה]יות כדבר] איש האלהים }
\end{aligned}
$$

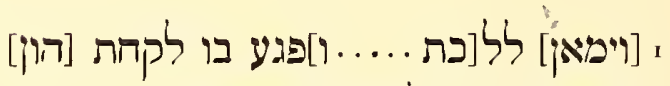

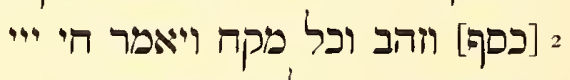

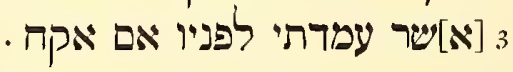

4

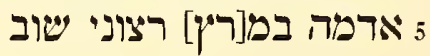

1 Cf. al-Harīzī, Tahkemōni, Chapter iii. 


\section{POETIC BIBLICAL PARAPHRASES}

This fragment seems to contain remnants of poetic paraphrases of Biblical passages ${ }^{1}$, at times with rime and division into verses, but with no apparent meter.

Verso $(b)$ and recto $(a)$ have been rearranged so as to display the intended verse division and rime. This was not possible with the other two pages. Conjectural text supplied between brackets by Professor Gottheil has been translated without brackets.

\section{Recto $:(b)$}

I to his house and............

$2^{2}$ And the King said: "Go now, and I will send a letter

3 unto all Israel." So there went with the letter

+ Naaman. And he took of his silver and of his gold. And it came to pass,

5 when the King of Israel read, that he rent his garments

6 in sorrow. And it came to pass at the end of eight days

; that he sent to him, saying: "Fear the Lord!" And Naaman

8 came with his horses and his chariot. And [the] King

9 sent [word, saying]: "Go down and dip [thyself] in the Jordan; and God [will be]

so for thee a refuge." And Naaman became angry, and spurned [him],

II and he opened his mouth, making it wide, [and he said]: "Are not the rivers of

12 Damascus good to dip [oneself] in?"

$13 \ldots \ldots \ldots$...... And his servants drew near and spake

${ }_{14}$ unto him and said: "My Father, a great thing

15 the Prophet hath spoken unto thee. Wilt thou not do [it] ?"

i6 And he went humbly, and dipped [himself]; and his flesh began

iz to return to being as the Man of God had spoken.

\section{Verso: $(a)$}

I And he refused to go....... and he begged him to accept goods:

2 silver and gold and every [sort of] gift. And he said: "As Jehovah liveth, 3 before whom I stand, I will receive none." + And he said: "I cried out: 'Approach me with presents 5 of earth. Earnestly ${ }^{3}$ I wish to repent.

2 The following is based upon II Kings, Chap. v.

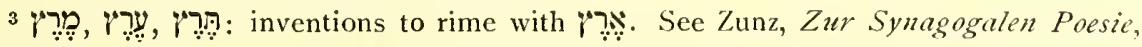
pp. 314,385 ; Literaturgeschichte d. S. P. 
6 אפתה לאל שוכן שמי ערץ.

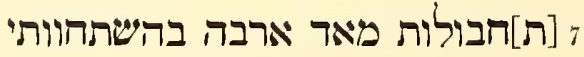

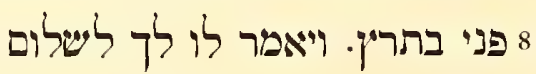

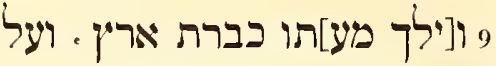

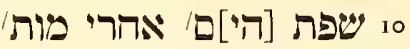

ני אוכרה היום יום ההמה והחרון. 21 [ב]השרף השרפה מול פני הארון.

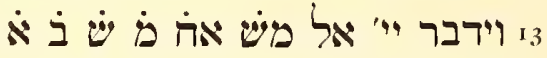

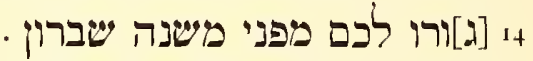

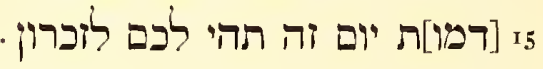

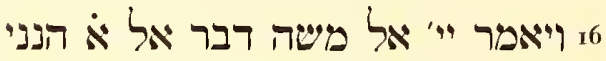
זי מעלה לך ארוכה שימנה לַעְניק

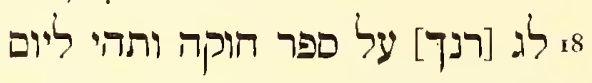

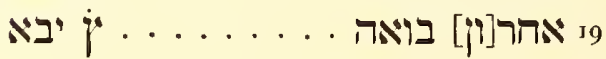

I'erso: (b)

ו תפנה מרשות . . . . . תך היה דורש וחוק]ר לא תעש]ק את

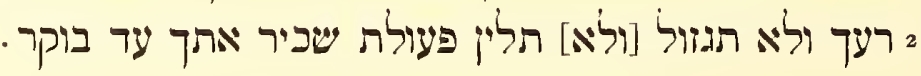
s ביטה במדרש שלשה חדשים וסור ממתי מהשול

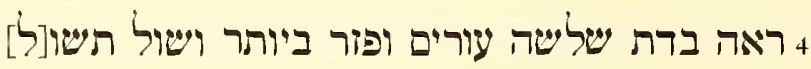

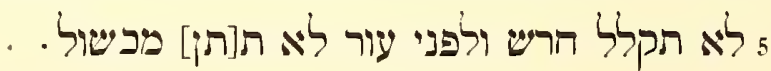

6 בעשרה דברים שב[הם] אין לדין תבין ומעול חדל מח[דול].

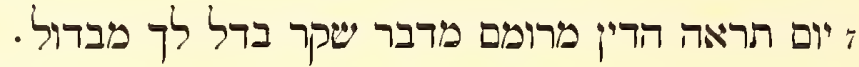

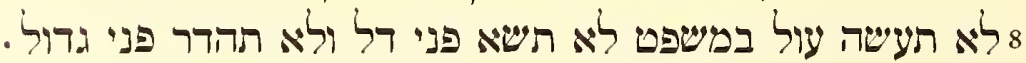

9 ירא את "י" ואל תהי רכיל מגלה סוד הבריך ויודעיך.

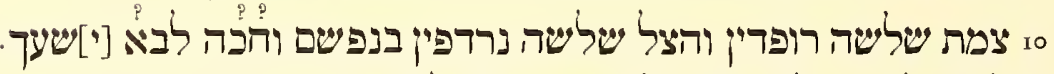
וי לא תלך רכיל בעמך ולא תעמוד [על] דם רעך .

4 The portion of the law (Leviticus xvi, I-I 8, 30) read upon the Day of Atonement.

5 Job xix, 29.

${ }^{6}$ Jeremiah xvii, 18.

${ }^{7}$ Exodus xii, I 4.

${ }^{8}$ Isaiah $\mathrm{xxx} 8$.

${ }^{9}$ Leviticus xix, $13 \mathrm{ff}$.

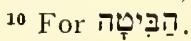


6 I will return to God, who dwells in [the] awful ${ }^{3}$ heavens.

7 I will greatly multiply deceptions when I bow

8 my face in reverence ${ }^{3}$." And he said to him: "Go in peace."

9 And he departed from him a little way.-And [add here the poem which

begins with the words]: "On

ro the shore of the sea "; and "After the death of [the two sons of Aaron"]":

i Let me remember today the Day of Fury and Anger,

22 when a great burning appeared before the Ark,

${ }_{13}$ and Jehovah spake unto Moses, after the death of the two sons of Aaron ${ }^{4}$.

${ }_{14}$ Be ye afraid of ${ }^{5}$ a repeated disaster ${ }^{6}$.

15 Let the like of this day be unto you a reminder?

ı6 And Jehovah said unto Moses: "Speak unto Aaron: 'Behold I

${ }_{17}$ bring unto you a healing; make of it a necklace,

18 around thy neck; in a law book, and that it may remain unto [the] last day 8 !'”

I9

Verso: $(b)$

I Turn thou away from the possessions of thy. has sought and inquired after. ${ }^{9}$ Thou shalt not oppress

2 thy neighbor, nor rob him: the wages of a hired servant shall not abide with thee all night until the morning.

3 Examine ${ }^{10}$ [the Scriptures] by exegesis three months, and turn from men of weakness (?) ${ }^{11}$.

${ }_{4}$ Regard the law of three blind men, and scatter more widely, and draw out ${ }^{11}$.

5 Thou shalt not curse the deaf, nor put a stumbling block before the blind.

6 [The] Ten Commandments-concerning which no one is entitled to judge-shalt thou examine; and from the unrighteous [shalt thou] turn away ${ }^{11}$.

${ }_{7}$ On the day when thou seest [pretended] justice exalting itself, speaking lies, separate thyself with a separation ${ }^{11}$.

8 Thou shalt do no unrighteousness in judgment. Thou shalt not respect the person of the poor, nor honor the person of the mighty.

9 Fear Jehovah, and be not a [carrier of] slander, revealing the secrets ${ }^{12}$ of thy neighbors and thy friends.

เo Destroy three pursuers ${ }^{13}$, and deliver three pursued in their persons, and await the coming of thy salvation.

it Thou shalt not go up and down as a talebearer among thy people, neither shalt thou stand against the blood of thy neighbor.

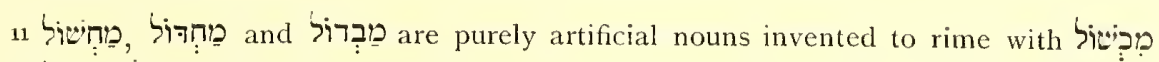

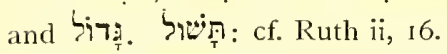

12 Proverbs xi, I3. רודפין ${ }^{13}$ Read. 
2. חדל לך משנא[ה] והוכיה תוכיה את עמיתיך.

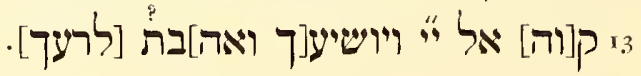

Recto: $(\alpha)$

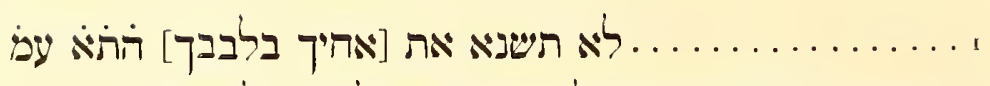
2 מנקמה ונ[ט]ירה פרוש לך והוי זהיר לשיוך לתמוכה.

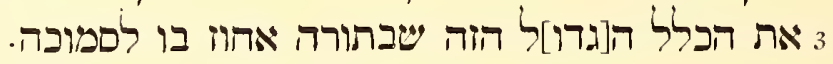

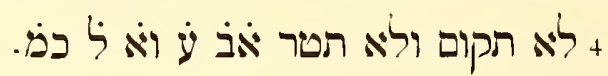

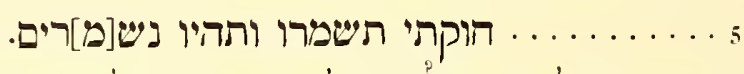

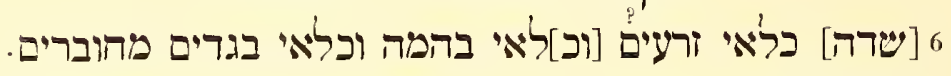

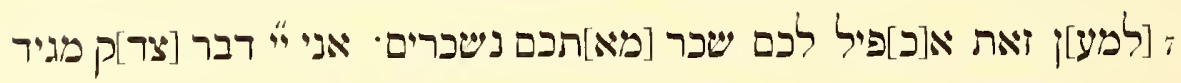
מישרים. 8 ק[בל] את שכרה יום זה אתפ .. בית [יש] כהשמיע נביא להמוני תמט

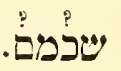

9 ויהי בשנה [השביעית ב]תמישי בעשור [להדש] באו אנשים מזקני [יש]

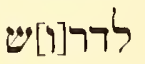
ס את " "וישבו [לפני]"

${ }^{14}$ Leviticus xix, 17 ff. 15 Not the expected לערך.

\section{FRAGMENT OF MAIMONIDES}

Paper $6 \times 4 \frac{1}{4}$ inches.

Hebrew in cursive Hebrew characters.

A portion of the $Y \bar{a} d h h \alpha-H a z \bar{a} k \bar{a} h$ of Maimonides, corresponding to chapter vi, sections I 7-2 I of the edition of Jessnitz, I 739. Of section 2 I the first three words only are written. 
12 Cease thou from hatred, [yet] thou shalt surely rebuke thy neighbors.

${ }_{13}$ Hope in Jehovah and He will save thee, and love thy neighbor.

Recto: (a)

$1 \ldots \ldots \ldots \ldots \ldots \ldots{ }^{14}$ Thou shalt not hate thy brother in thy heart : thou shalt surely rebuke thy neighbor.

2 From vengeance and spite shut thyself off. And be thou attentive to thy...... ${ }^{15}$ to uphold [him].

3 This great command which is in the Law, take hold of it [as something] steadfast :

+ Thou shalt not take vengeance, nor bear any grudge against the children of thy people; but thou shalt love thy neighbor as thyself.

5 ..........my laws ye shall keep, and ye shall be kept.

6 A field with two sorts of seed, and two sorts of cattle; and two sorts of garments, combined, [are forbidden].

7 Because of this I shall multiply unto you the produce of those [fields which are] rented by you. ${ }^{16} \mathrm{I}$, Jehovah, speak righteousness, I declare things that are right.

8 The house of Israel received its reward this day............ when a prophet made the multitude around me...........hear...........their shoulders(?). $9^{17}$ And it came to pass in the seventh year, in the fifth [month], the tenth [day] of the month, that certain of the elders of Israel came to inquire ıo of Jehovah, and sat before me.

\footnotetext{
${ }^{16}$ Isaiah xlv, I9. ${ }^{17}$ Ezekiel xx, I.
}

\section{FRAGMENT OF MAIMONIDES}

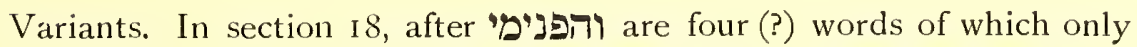

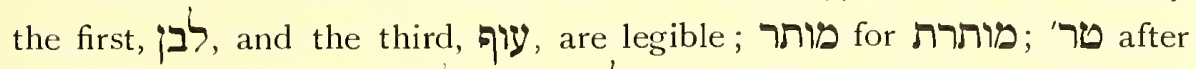

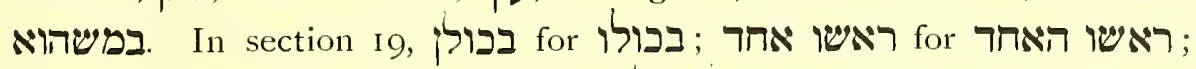

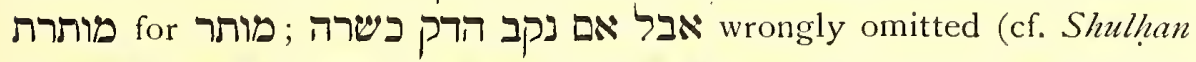
'Arūkh, Yōrēh De'āh, Hilkhōth Terēphōth, section 43). In section 20,

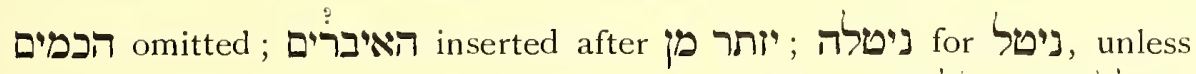

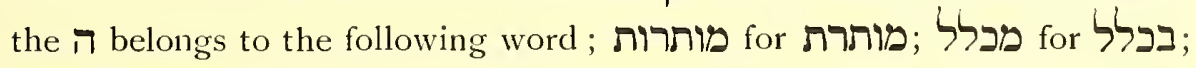
היתר for. 


\section{LEAVES FROM THE NOTE-BOOK OF A MARRIAGE BROKER}

Paper $8 \frac{3}{4} \times 6 \frac{3}{8}$ inches, folded lengthwise so as to form four pages, all of which are filled with writing in the jumbled fashion of a note-book.

Arabic and Hebrew in half-square Hebrew characters.

This Jewish text has, quite uniquely, in addition to the usual Hebrew alphabetic numerals, Coptic numerals, arranged in a column, and scattered throughout the text. It is often impossible to see their relation to the adjacent words. They are Greek alphabetic numerals, in the cursive form employed by Christian Copts after they had given up Coptic for Arabic. In the absence of special type they must here be represented by the usual Coptic alphabetic numerals with the superior stroke. Except where the figures have a direct relation to the text they have been omitted in the Translation, because they cannot be reproduced typographically without making the page unintelligible.

The date is A.D. I 5 I I.

\section{Recto: (a) Nילוס}

יהורה אבין

באטצנר יחיי

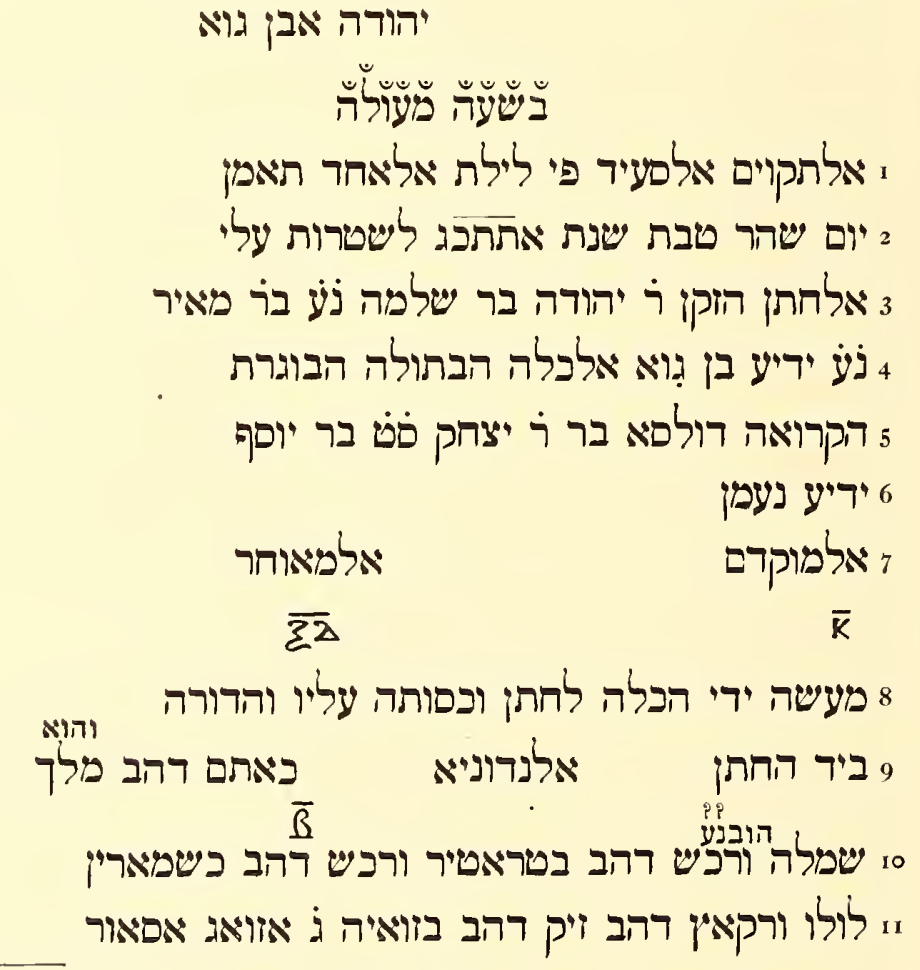

1 Evidently Spanish for "sweet." The girl seems to have had no Jewish name.

2 In a different hand. The name occurs in line 4 . Very uncertain vocalisation.

${ }^{3}$ Seleucid Era, beginning 3I 2 B.C., which makes I $823=$ A.D. I 5 I I. 


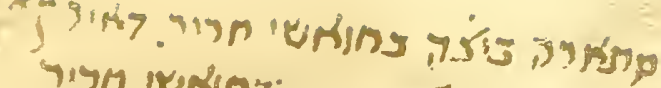

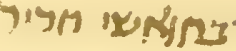

22 a

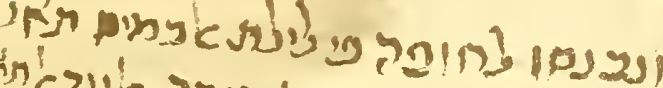

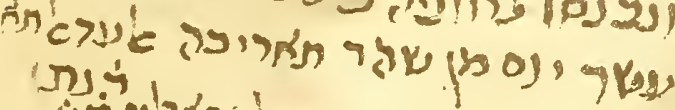

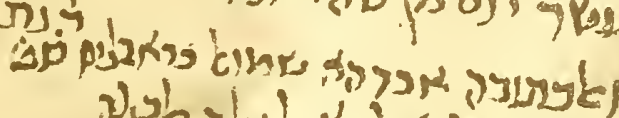

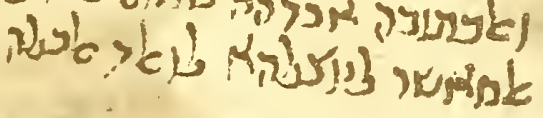

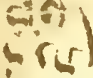

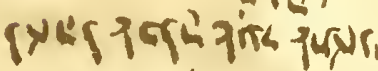

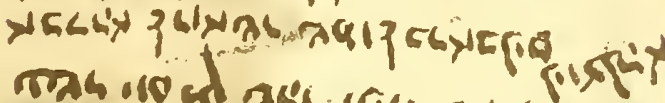

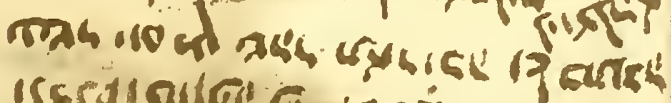

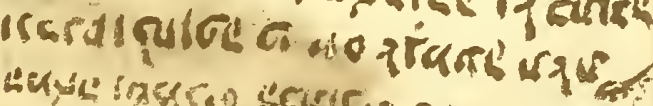

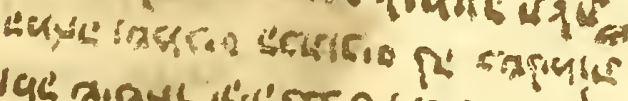

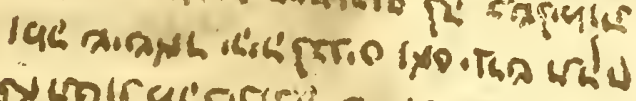

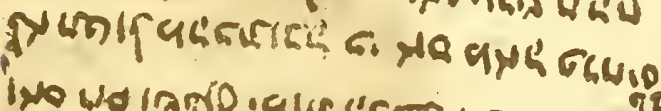

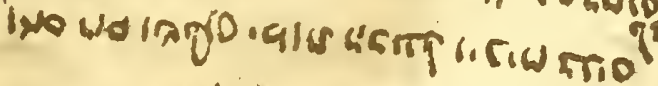

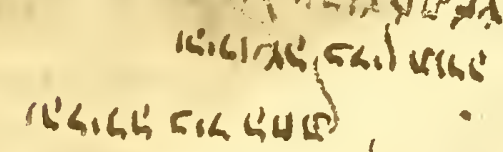

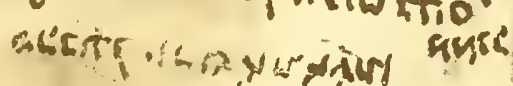

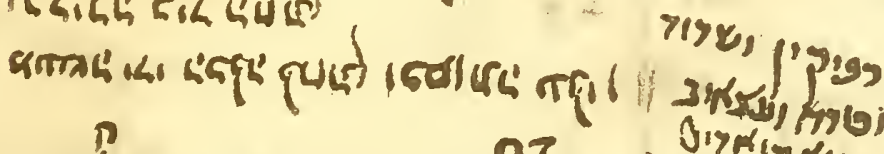

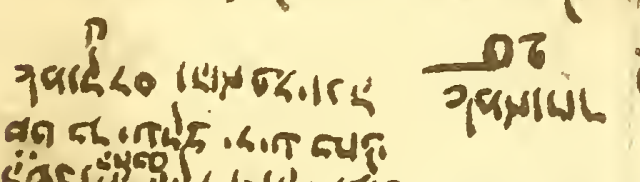

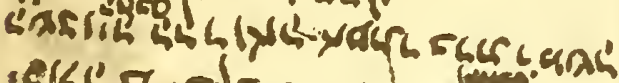

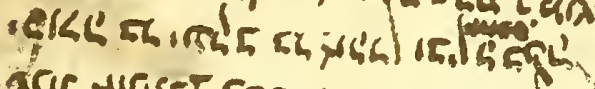

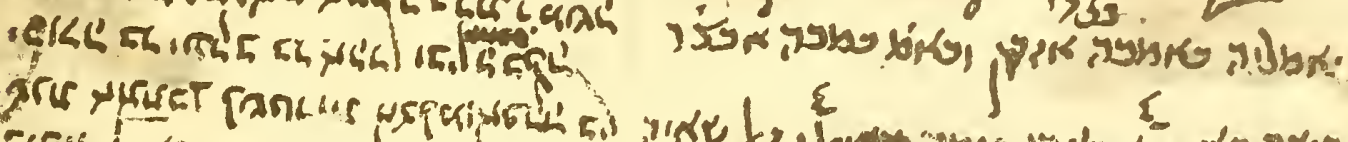

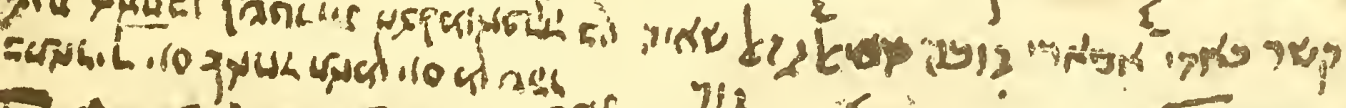

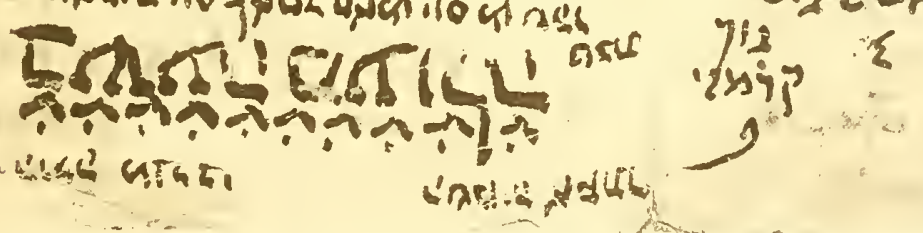

\section{7 $20,77 \%$}

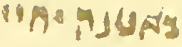

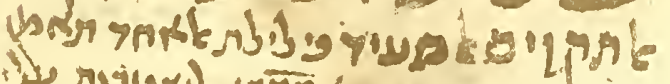

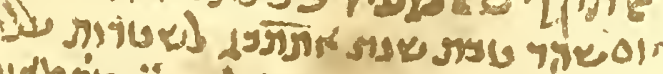
"rats is

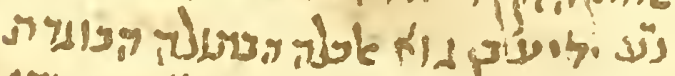
J50 Trintes

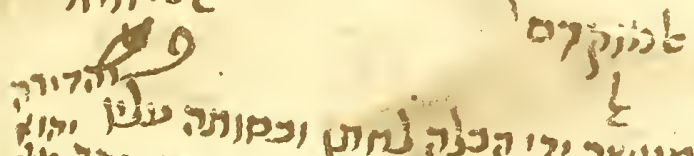
נמיר

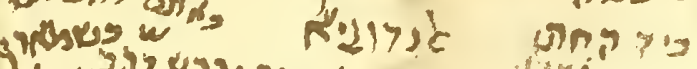
intor

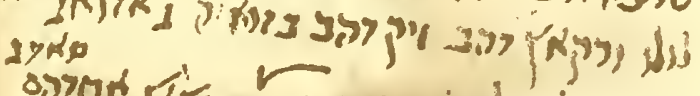
קm

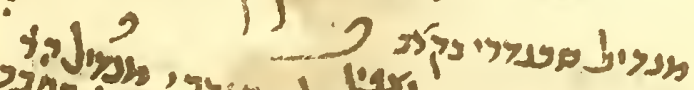

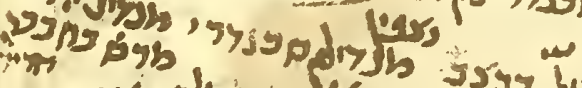

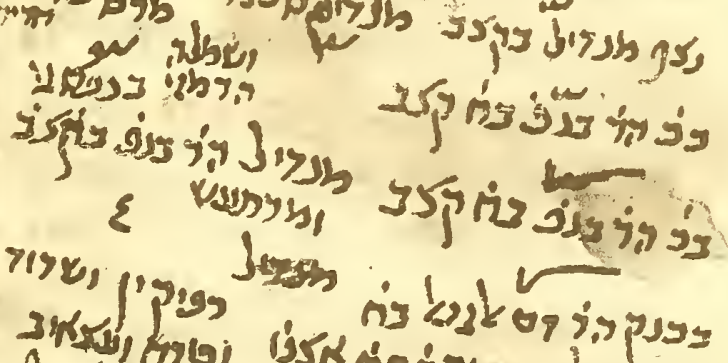

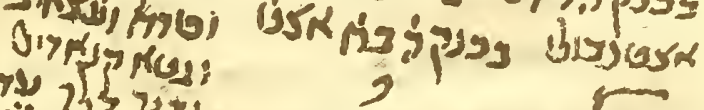

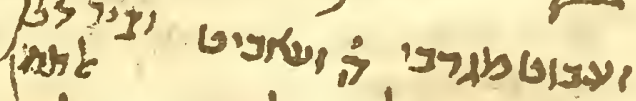

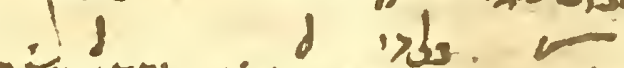


$7 \div 3$

zytyos

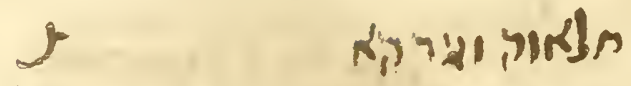

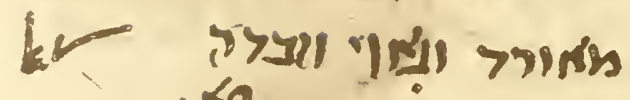
75)

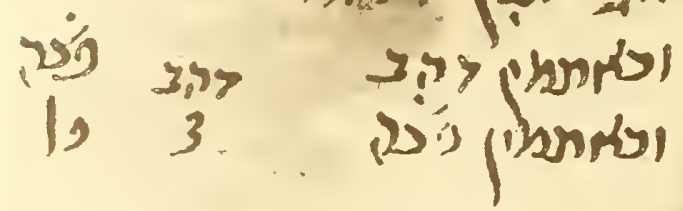

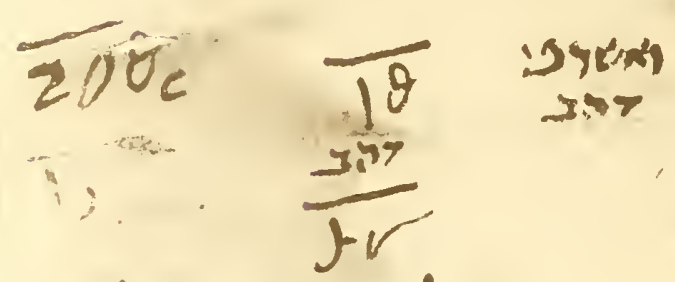

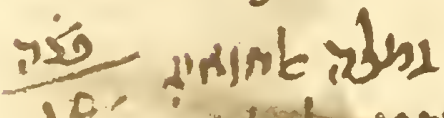

19: "radtengyexts us

$$
\text { 4aviver }
$$

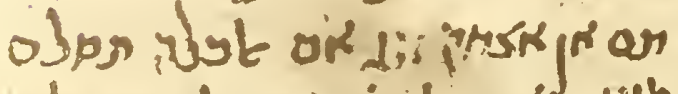

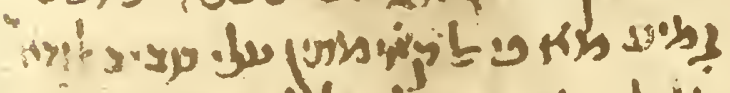

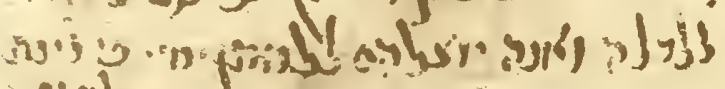

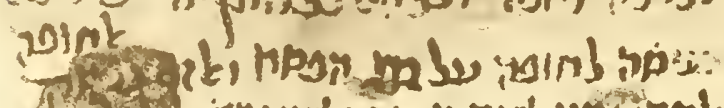

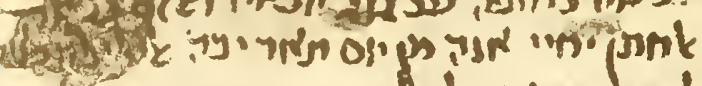

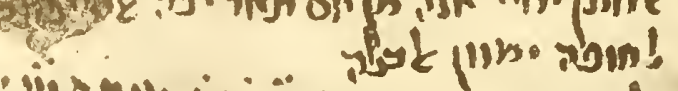

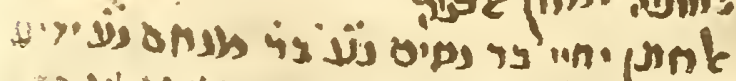

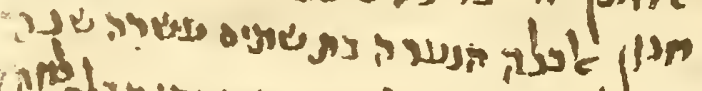

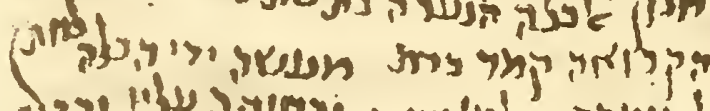

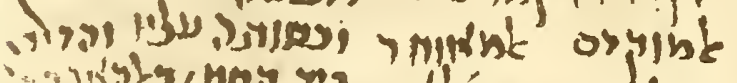

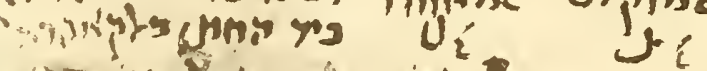

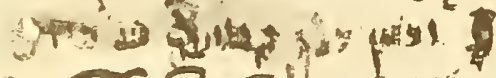

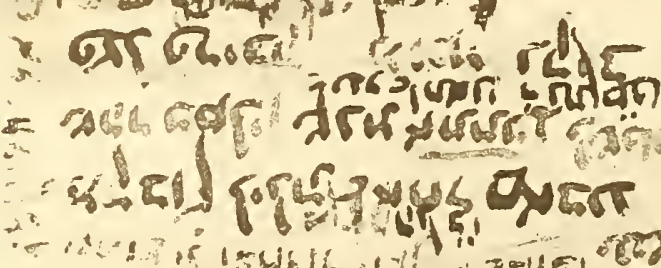

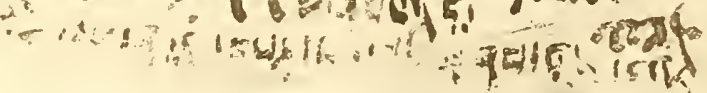

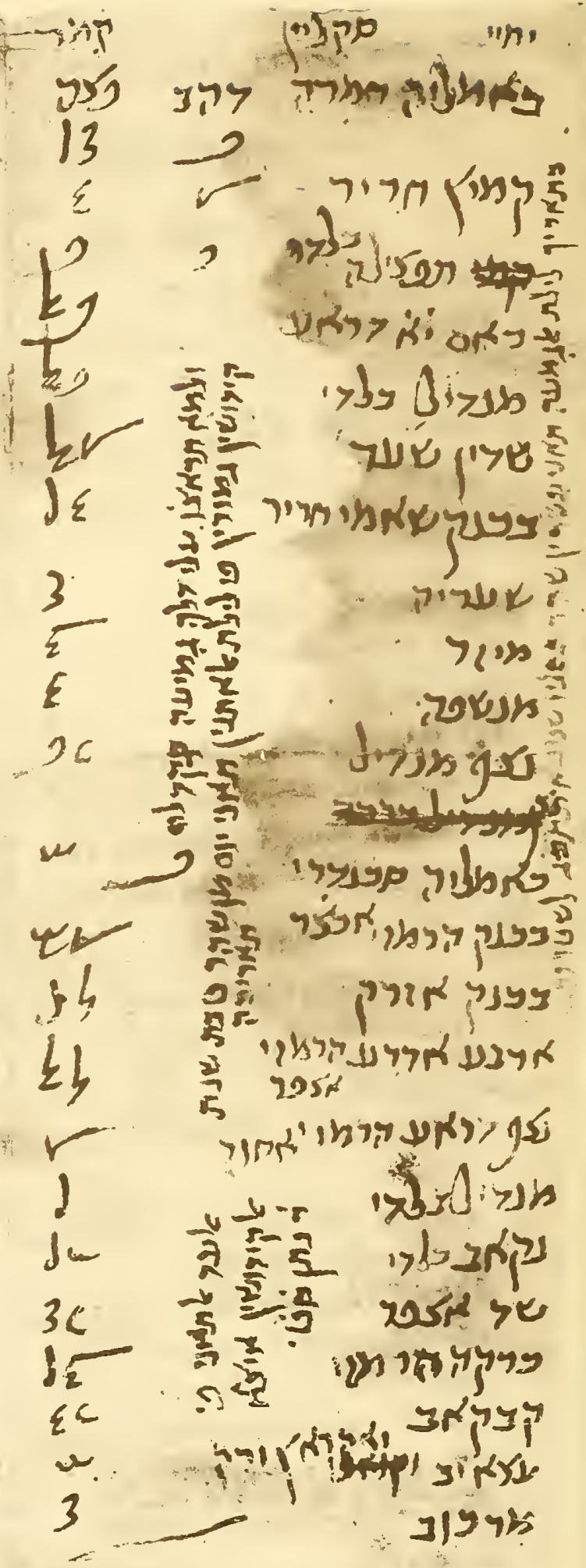




\section{LEAVES FROM THE NOTE-BOOK OF A MARRIAGE BROKER}

In spite of the large square Hebrew titles, this is not a document nor a series of documents. The lack of legal precision and the jumbled condition of the pages show that it is a double leaf out of the note-book of some marriage broker, possibly a rabbi. It is simply a memorandum of the circumstances attending the marriage of certain persons, named; and is chiefly concerned with the invoicing of the brides' paraphernalia.

The mukdam and the me'uhis seem to refer to the old formal betrothal and the marriage proper, which at this time were beginning to be celebrated in quick succession. See Aaron Ben Elia of Nicomedia (ca. A.D. I 300-1 369), Gan Eden, ed. Goslava, 1865, p. 142b, on Exodus xxi, 2. Professor Gottheil believes that, unless the Rabbinites had accepted the Karaite formula, it will be necessary to suppose that we are dealing with Karaite documents.

Recto : (a)

Confidential [memorandum of] Yahyāa $\quad$ [as to] Dulce ${ }^{1}$

[and] Judah Ibn Jiwä'²

In a Propitious Hour!

r This auspicious invoice [has been made] on the first night [of the week, the] eighth

2 day of the month of Teebhèth, [of] the year of documents $1823^{3}$, with reference to

3 the bridegroom ${ }^{4}$, the Elder, Rabbi Judah Bar Solomon Bar Mē'îr,

4 known as Ibn Jiwa' ', [and] the bride ${ }^{4}$, the marriageable virgin

5 called Dulce, daughter ${ }^{5}$ of Rabbi Isaac Bar Joseph-A good omen!-

6 known as Naaman.

7 The advanced $\left[\right.$ gift $^{6}, 20$. The delayed $\left[\right.$ gift ${ }^{6}, 64^{7}$.

8 The bride's handiwork [shall belong] to the bridegroom, but her clothing

[is to be supplied] at his expense. And her ornamentation

9 the bridegroom has received. The dowry ${ }^{8}$ is a ring of royal gold,

ıo a garment, and a clasp ${ }^{9}$ of gold with conical caps, and a clasp of gold, two Cashmere shawls ${ }^{\mathbf{1 0}}$,

i a pearl, and a dancer of gold, a collar [with] gold at the corners ${ }^{11}$, three pairs of bracelets

\footnotetext{
${ }^{4}$ Hebrew and Aramaic words creep in; and Hebrew words are often used with the Arabic article.

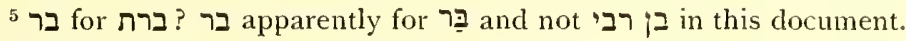

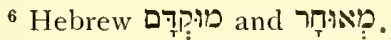

7 The sign for 60 seems to have been deleted.

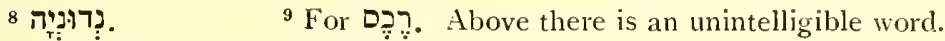

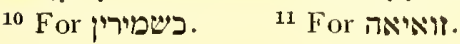


2י פצה אחר מטלה ה בואתם פצה בפציץי אחרהם סארג 3.

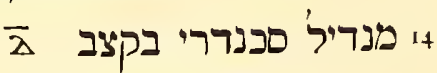

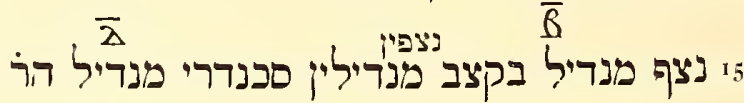
ערס בחבבה

חריר

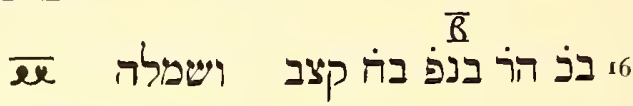

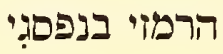

17 בذ הר בנפ בה קצב מנריל הר בנذ בקצذ $\bar{\epsilon}$ ยบการ

8 בבנק הר רם אלגנואיל בה

רפיקין ושרוד

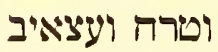

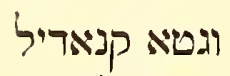

וגיט ריל $\ddot{g}$

isת פו אצטנבולי בכנק ה בה אצטי

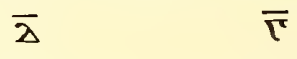

זעיטוט מגרבי ה ועאביט $\bar{\tau}$

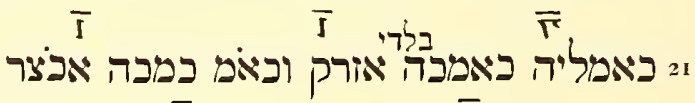

$$
\begin{aligned}
& \bar{\epsilon} \bar{\epsilon} \\
& 22 \text { קשר בארי אביארי גיובה רם אלגיל שאיה } \\
& \text { נִּד } \\
& \bar{\epsilon} \\
& \bar{\Sigma} \\
& \text { קרפו }
\end{aligned}
$$

Recto: (b)

ו סתארה ביצה בחואישי הריר דאיר קצין

בהואישי הריר

ב מלאתין ביין ומנריל אביין

$\bar{\lambda}$

3

\footnotetext{
12 سادר

13 For סכנדריה.

14 See below. Hormuz is an island in the Persian Gulf.
} 
12 of silver, one [of them] gilded, five rings of silver, one of them uncut ${ }^{12}$, 13 and an agate ring, four chains and boxes of ivory, It an Alexandrine kerchief with gold thread,

15 half a kerchief with gold thread, two halves of two Alexandrine ${ }^{13}$ kerchiefs, a Hormuzi ${ }^{14}$ striped $^{15}$ kerchief with a silk habara ${ }^{16}$,

16 a purple Hormuzi veil with a habara of gold thread ${ }^{17}$, and a purple Hormuzī garment,

i; a purple Hormuzī veil with a habara of gold thread, a purple Hormuzì kerchief with gold thread, and a trembler ${ }^{\mathbf{1 8}}$, I8 a gazelles' blood Hormuzi veil with a habara, 19 a Stamboul veil-five [of them] -with a Stamboul habara, 2o a Maghribī [woollen] smock-five [woollen] smocks, I8-20 two pairs of drawers, and shadds ${ }^{19}$, and a tarh ${ }^{20}$, and 'iṣābahs ${ }^{19}$, and a lamp-cover, and [other things] besides this, in number, I 3 , the value, Io,

2ı a kāmilīyah ${ }^{21}$ of native blue damasquette, and a kāmilīyah of green damasquette,

22 a Bedouin garment of abyārī ${ }^{22}$, a gazelles' blood jacket ${ }^{23}$, $\operatorname{articles}^{24}$ of crimson cloth,

Recto: (b)

r a white veil with borders of silk, [something to wrap] about the breast, with borders of silk,

2 two white dressing-gowns, and a white kerchief,

3 four white safārī ${ }^{25}$ combs $^{26}$.

15 مرسمَّم 16 The modern name for a sort of black veil.

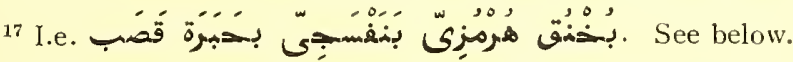

18 Perhaps the fanciful name of some ornament for the head.

${ }^{19} \mathrm{~A}$ kind of turban. For these names see the appropriate articles in Dozy, op. cit.

20 A kind of veil.

21 A kind of robe.

${ }^{22}$ A thin fabric. The phrase sounds Persian, although the first two words are of

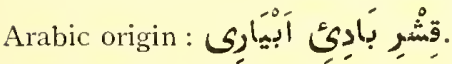

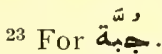

24 For أشَأَائاً

25 Some commercial or geographical term.

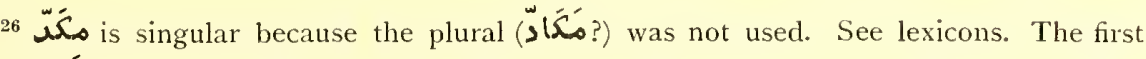
adjective then remained singular, while the second became plural under the influence of the remembered numeral. 
рॄ $\bar{B}$

4 ונכנםו לחופה פי לילת אלכפים תאני 5 עשר יום פי שרה תאריכה אלער אלתאני

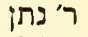

6 ואלכתובה אכרדא שמואל פראבלים סט

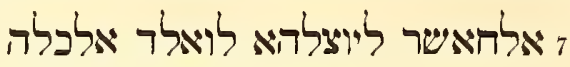

\section{Inwerted:}

השבויה אפתר

יהודה צירבי

\section{范}

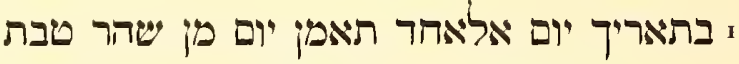
2 שנת אתתכב לשטרות הצל מואפקה בין

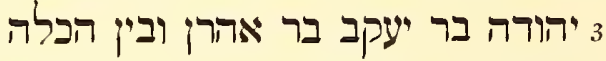
4 השבויה הקרואה יאםתר ברת ר' פטיה 5 סט בר החכים יעבב ידיע כחלי

אל איאודר

$\overline{\mathrm{p}}$

ז מעשה ידי הכלה להתן וכםותה עליט 8 ודירושה כרין תורה יוין

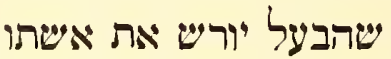

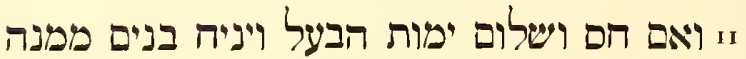
זו לא תטיל מהכתובה כי אם עאה פרחים לבר

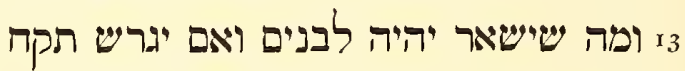
4 דמיאה ושפנים הבתובים לה בשליפות ז ונכנפו לחופה פי יום אל:מעה תאלת ושית 6 עשיר יום פי שהר תאריכה ואלכתובה זי אכרדא אלדאשר שמואל פראבלים ליוצלה יום

27 I.e. four days after the body of the memorandum. These lines, 4-7, were then added, in the same hand, though somewhat larger.

${ }^{28}$ I.e. besides the writer of the memorandum.

29 Hebrew.

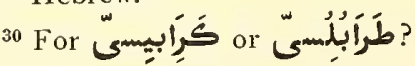


+ And they went under the marriage canopy on Thursday night, the twelfth

5 day of the month, the present year ${ }^{27}$. The other ${ }^{28}$ witness ${ }^{29}$ [was] Rabbi Nathan.

6 And [as for] the marriage writ, Samuel Karāblīs ${ }^{30}$,

i the collector, has taken charge of it, in order to bring it to the father of the bride.

\section{Inverted:}

Judah Maghribī

The captive, Esther

In a Propitious Hour!

I On the date of the first day [of the week], eighth day of the month of

Ṭèbhēth,

2 year of documents $1823^{3}$, an agreement was reached between

3 Judah Bar Jacob Bar Aaron, and the bride,

4 the captive ${ }^{4}$, [who is] called Esther, daughter of Rabbi Moses ${ }^{31}$

5 -A good omen! - son of Jacob the Wise, known as Kuhli1 ${ }^{32}$.

6 The advanced [gift] - and it is her ransom ${ }^{4}$-50. The delayed [gift], I 80.

7 The bride's handiwork [shall belong] to the bridegroom, but her clothing [is to be supplied] at his expense.

8 And her ornamentation the bridegroom has received.

9 And the estate [is to be divided at death] according to the [Pentateuchal]

Law :

Io that the husband inherits [the goods of] his wife.

I! And if-which God forbid! - the husband should die, and leave behind sons by her,

I2 she shall not [take] from the dowry more ${ }^{33}$ than a hundred perāhīm ${ }^{34}$;

$I_{3}$ and what remains shall belong to the sons. And if he should divorce [her], she shall take

${ }_{4}$ the hundred and eighty credited to her in the marriage writ, in [their] entirety ${ }^{35}$.

${ }_{15}$ And they went under the marriage canopy on Friday, the thir-

I6 teenth day of the month, the present $y^{2} \mathrm{rr}^{36}$. And [as for] the marriage writ,

is Samuel Karāblīs ${ }^{30}$, the collector, has taken charge of it, in order to bring it

31 Above the line, but deleted, החבם.

32 I.e. "dealer in collyrium," or "dark about the eyes."

${ }^{33}$ An arabism?

34 I.e. "blossoms." Name of some coin?

35 For תiּ?

${ }^{36}$ I.e. five days after the body of the memorandum. These lines, 15-19, were added, in the same hand, though somewhat larger. 
8. לאהל אלכלה אלער אלתאני ר' נתן פט

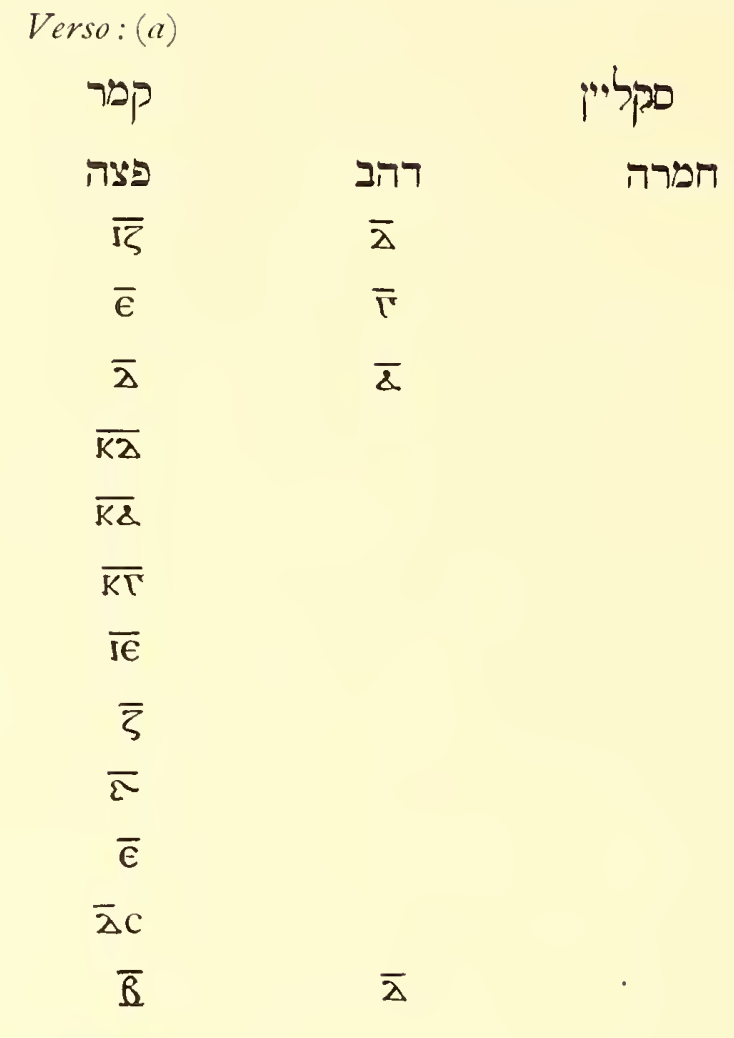

$\overline{\text { eeT }}$

$\overline{\lambda H}$

$\overline{\mathrm{KH}}$

$\bar{\tau}$

了

$\bar{I}$

$\bar{\zeta} \mathrm{C}$

I2

$\bar{\epsilon} \mathrm{C}$

$\bar{B}$

22 עצאיב ואקראיץ ורק

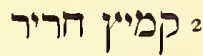
3 תפצילה בלרי + כיאם יאי רריאע 5 מנריל בלרי דיאי 6 7 בכנק שיאפי חריר

8 9 סו מנישהה וי נציך פנריל 2. כאמליה סכנררי 13 בכנק הרמןי אכצר

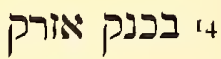
5י ארבע אדרע הרפגי אצפר 6ו נצץ דראע הרמי אסור 7ו מנריל בלרי 8 נקיאב בלרי 19 20 כרקה הרמוי ו קבקיאב 2.3

${ }^{37}$ As in the first case.

${ }^{38}$ For 3 if this is the meaning. 
18 to the bride's people. The other ${ }^{28}$ witness $^{29}$ [was] Rabbi Nathan ${ }^{37}$.

Verso: (a)

Yahyā [They are] Sicilians ${ }^{38}$

1 A red kāmilīyah ${ }^{21}$,

Gold Silver

2 a silk shirt,

3 a piece of native dress-goods, 35

4 a cut $^{40}$ [of cloth], I I cubits, I 4

5 a native kerchief,

6 two shadds ${ }^{19}$ of [camels'] hair,

7 a Syrian silk veil,

8 a sha'rīyah ${ }^{20}$, 15

9 a mi'zar ${ }^{20}$, 7

10 a towel, 6

I half a kerchief,

12 an Alexandrine ${ }^{13}$ kāmilīyah ${ }^{21}$,

13 a green Hormuzī veil,

It a blue veil, 43

I5 four cubits of yellow Hormuzī [stuff], 38

I6 half a cubit of black Hormuzī [stuff], 28

i 7 a native kerchief, 3

I8 a native niḳāb ${ }^{20}$, IO

r9 a yellow shadd ${ }^{19}$, I 2

2o an irregular piece of Hormuzī [stuff],

2i wooden sandals, I6

22 'iṣābahs, and head-discs of sheet metal,

23 shoes,

39 Arabic for "Moon." Cf. note I.

40 Cf. ${ }^{4}$ in Dozy, op. cit., vol. ii, p. 435. 


\section{Verso: (b) \\ פצי \\ $\bar{\lambda}$ \\ $\overline{K T}$}

זיאל חיאוה וגירהא 2 מא ורד וגיאו" וזברה

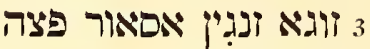

פฺ่

רהב

4

$\begin{array}{ll}\frac{\overline{18}}{\overline{\delta \circ \theta}} & \frac{\bar{\zeta}}{\overline{1 \theta}} \\ \overline{\overline{18}} & \frac{2 \pi 7}{\overline{\lambda \Gamma}}\end{array}$

פุ่ง

גמלה אלהואי:

$\overline{\mathrm{I}} \mathrm{C}$

פอาง $\overline{\lambda \epsilon}$

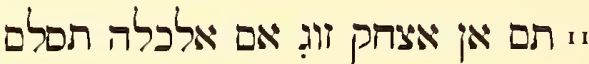

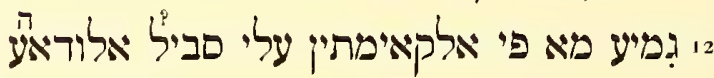

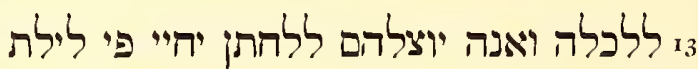

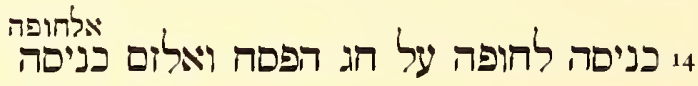

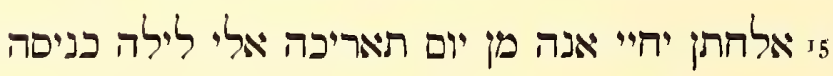
6ו לחופה ימיון אלכלה

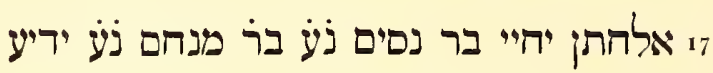
8ו חנון אלכלה הנערה בת שתים עשרה שנה

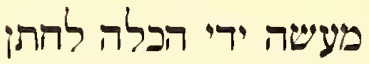
י הקרויאה קמר ברת

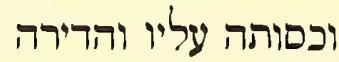
ז2 אלמוקדם אלמאודר ביר החתן באלקאהרה $\overline{\pi \epsilon}$ $\overline{\lambda \epsilon}$ 22

${ }^{41}$ Made of sesame-seed residue, with honey and sugar.

${ }^{42}$ Perhaps a pomade containing butter as a base, rose-water as a scent, and another substance. If, in spite of the dot, one may read ghāwī, then one may translate "seductive" or "fashionable." See Dozy, op. cit., vol. ii, p. 232.

${ }^{43}$ See Dozy, op. cit., vol. i, p. 605. 
Verso: $(b)$

I hilâwah ${ }^{41}$, and other [sweets],

Silver

2 rose-water and jāwī and butter ${ }^{42}$,

3 a pair of cymbals ${ }^{43}$, bracelets of silver,

+ and two rings of gold,

Gold Silver

5 and two rings of silver,

6 and an ashrafi ${ }^{44}$ of gold,

$\frac{7}{19} \quad \frac{\text { I I }}{369 \frac{1}{2}}$

Gold

$\overline{33} \quad \overline{\text { I I }}$

7 Total of the things ${ }^{45}$

Silver

8 with the ashrafi and the....

$\overline{\text { I } 9 \frac{1}{2}}$

9 and the rings

10

$\overline{35 \operatorname{ashrafis}^{46}}$

II Then Isaac, the husband of the bride's mother, handed over

Is all that is in the two lists, in the way of a deposit

13 for the bride, and in order that he should deliver them to the bridegroom, Yahyā on the night of

I4 going under the marriage canopy, during (?) the Feast of the Passover ${ }^{29}$.

And the bridegroom Yahyā made it a necessary condition of going under the marriage canopy,

I5 that from that date till the night of going under

16 the marriage canopy, he should provide food ${ }^{47}$ for the bride.

I 7 The bridegroom [is] Yahyā Bar Nissìm Bar Menahem, known as

18 Hanūn. The bride [is] the twelve year old girl,

19 called Kamar, daughter of 29,48

20

21 The advanced [gift],

$22 \quad 35$

The delayed [gift],

55

19 The handiwork of the bride [shall belong] to the bridegroom,

so but her clothing [is to be supplied] at his expense. And her ornamentation 2. the bridegroom has received, in Cairo.

4t According to the Encyclopedia of Islam, vol. i, p. 976, the old dinār (66 grains) ceased to be struck in Egypt in 1346, and the first ashrafis (53.8 grains) were struck in Egypt between A.D. I 362 and I 376 or 1421 and I438. See No. XXX, Introduction, and notes I9, 23 .

${ }^{45}$ Egyptian colloquial.

${ }^{46}$ The sums 19 and $369 \frac{1}{2}$ are correct for these columns of figures. The meanıng of the remaining figures on this page, as well as of those on recto $a$ and $b$, is not clear.

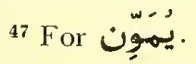

${ }^{48}$ The father's name was never filled in. 
Surrounding last four lines:

וכאין רלך גמיעה פי בית / אב הריין בר | שמואל וזל ובחצור יוסף אלסופר

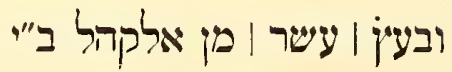

\section{Inverted:}

מקבויץ לילת אלאחר סאבע | שהר כסליו שנת אתתכג לשטרות | אלער

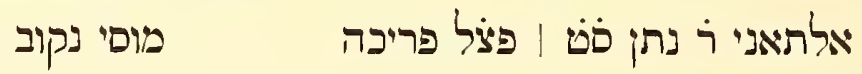
Across verso:

ולמא תראיצו עלי דלך גמיעה פקד לה | קירושין גמורין פי לילת אלאתניץ

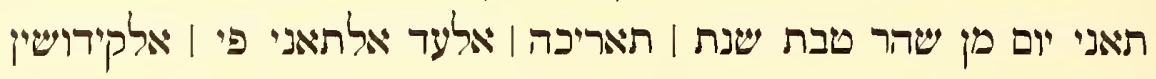

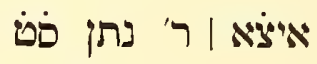

Margin of verso:

בתאריך לילת אלגמעעה תאני עשרין שהר בסליו שנת אתתכג לשטרות 
Surrounding last four lines:

And all this was [done] in the house of Abraham, the Dayyān, son of Samuel, and in the presence of Joseph the Scribe and upwards of ten [persons] from the congregation, assembled.

\section{Inverted:}

Done on the first night [of the week], seventh [day of] the month of Kislēw, [the] year of documents $1823^{3}$. The other witness ${ }^{28}$ [was] Rabbi Nathan ${ }^{37}$. [Signed :] Faḍl Farīkah(?) Moses Nāḳūb(?) ${ }^{49}$

\section{Across verso:}

And after they had reached a satisfactory agreement about all this ${ }^{4}$ [the bridegroom] arranged for her [the] final betrothal-rites, on Monday night, the second day of the month of Têbhèth, the year of the date [of this memorandum]. The other ${ }^{28}$ witness $^{29}$ at the betrothal-rites also was Rabbi Nathan ${ }^{37}$.

\section{Margin of verso:}

On the date of Friday night, twenty-second [day] of the month of Kislēw, [of] the year of documents $1823^{3}$.

\footnotetext{
${ }^{49}$ Lines $23-26$ are written in a different hand.
} 


\section{LETTER}

Paper II $\frac{3}{4} \times 4 \frac{3}{8}$ inches.

Hebrew in cursive Hebrew characters. The writing is unlike any other in this collection. A character resembling a small inverted, suspended Latin $h$ is often used for abbreviations, and in other places where its function is not clear. Cf. the muhmilah sign in MSS. and upon glass weights.

The mention of the maiyadi places the fragment certainly later than A.D. I4I2. See note 13 and No. XXX.

Recto:

בעה

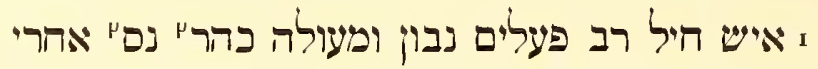

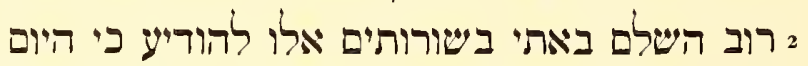

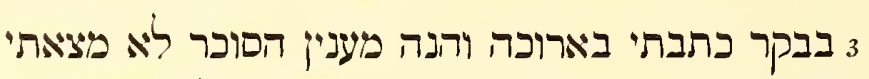

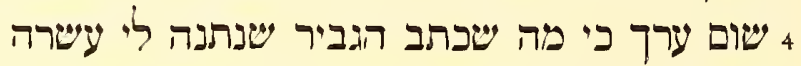

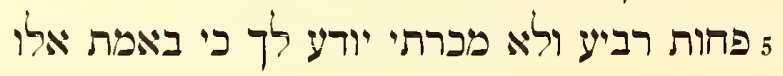

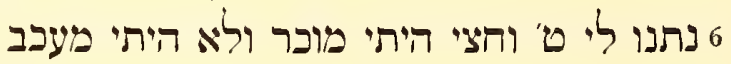

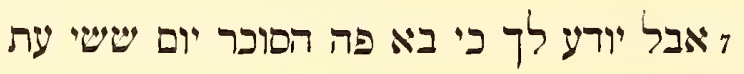

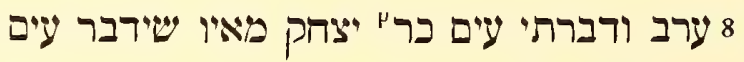

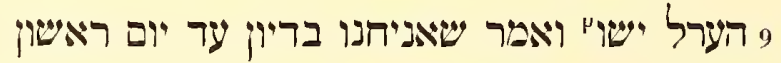

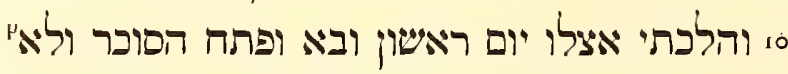

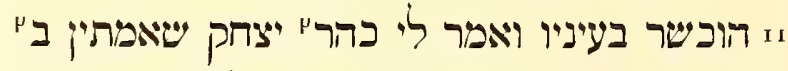

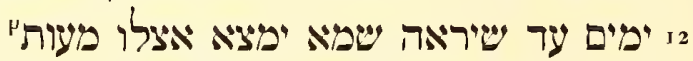

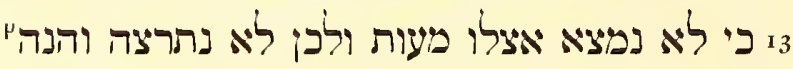

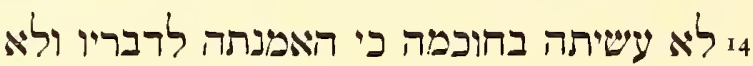

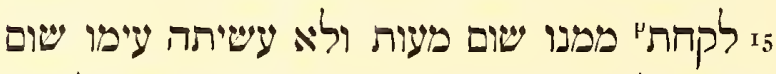

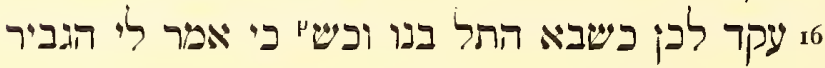

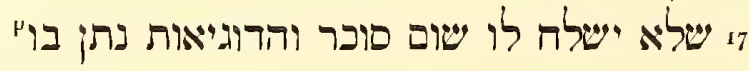

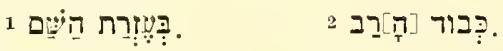

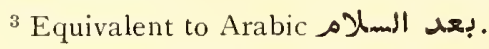

${ }^{4}$ Double plural.

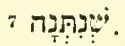
8 ערוּר.?

${ }^{6}$ I.e. "you."

9 החייחתי

${ }^{10}$ A certain Raphael Isaac Ben Aaron Mayo, or Maggio, who died in A.D. 1810, is recorded in the Jewish Encyclopedia, vol. viii, p. 392. 


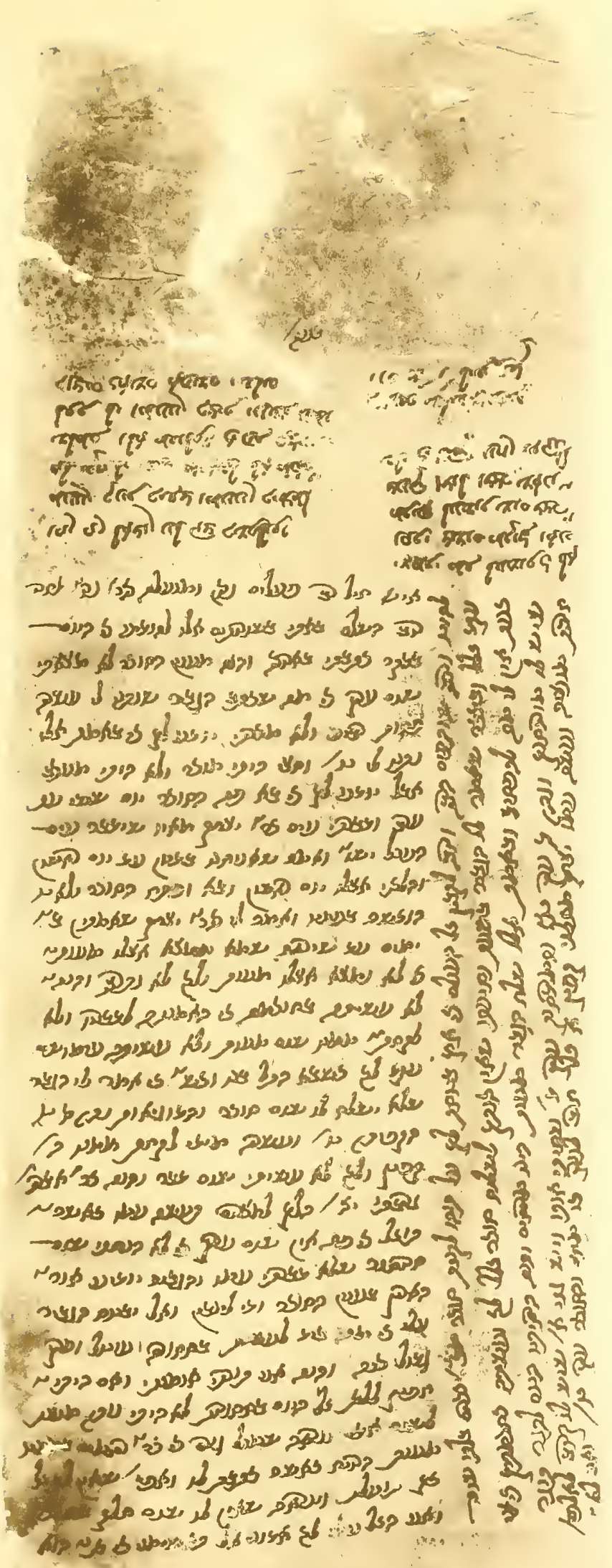





\section{LETTER}

A rambling letter from one Solomon, perhaps in Jerusalem, to one Joseph (or Nissīm?), perhaps in Cairo, about several business matters, especially the sugar trade. Solomon professes to be too much engrossed in Bible study, and too pessimistic about sugar, to undertake any business ventures.

In places it is very difficult to make satisfactory sense of the text.

Recto:

With the help of the Name [of God] ${ }^{1}$ !

I [To the] Man of Valor, Active, Intelligent and Excellent, the honored Rabbi ${ }^{2}$, Niss[īm?]. After

2 the many greetings ${ }^{3}$ : I have come with these lines ${ }^{4}$ to inform [you] that today

3 in the morning I have written at length. And now as to ${ }^{5}$ the sugar: I have not found

4 any arrangement [possible]; because what the gentleman ${ }^{6}$ wrote-- that I had been offered ${ }^{7}$ ten

5 less a quarter and did not sell- $\left[\right.$ is untrue]. Be it known ${ }^{8}$ to you that in fact if

6 they had offered me [even] nine and a half I should have ${ }^{9}$ sold and not have ${ }^{9}$ held back.

7 But be it known ${ }^{8}$ to you that the sugar arrived here on Friday at

8 evening. And I spoke with the honored Rabbi ${ }^{2}$ Isaac Māyō ${ }^{10}$, that he should speak with

9 the uncircumcised [Christian]-May his name and memory be blotted out ${ }^{11}$ ! - and he said that I should leave it in the office till Sunday.

ro So I went along with him on Sunday; and he went in[to the office] and opened the sugar; but it was not

Ir [to be] considered fit for use, in his opinion. And the honored Rabbi ${ }^{2}$ Isaac asked me to wait two

I2 days, till he should see [whether] perhaps he might have some money;

I3 for [at the moment] he had no money, and therefore we could not reach any agreement. Now really

I4 you did not act wisely; for you trusted to his word, and did not

I5 take from him any money [as guarantee], and did not make with him any I 6 binding agreement; so, when it came, he made fools of us, and so it was ${ }^{12}$. For the gentleman ${ }^{6}$ said to me

${ }_{17}$ that he ${ }^{6}$ would not send him any sugar. And [as to] the casks (? $)^{13}$ : the captain (?)

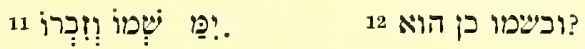

13 ת ד Tässer mit getrockneten Feigen," Jacob Levy, Wörterbuch, Berlin, 1924, sub voce; "Tiegel," Dallmann, Aramäisch-Neuhebräisches Handwörterbuch, Frankfurt, I922, sub voce. 


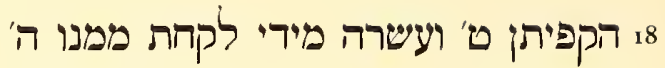

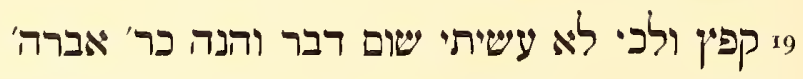

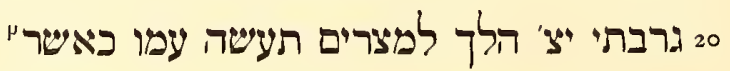

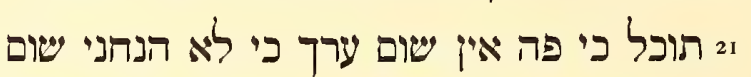

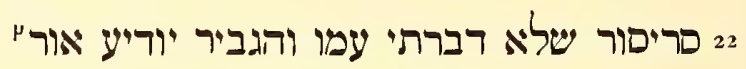

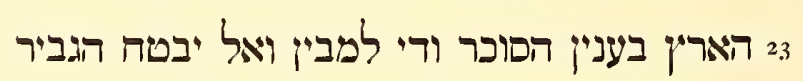

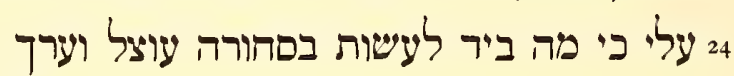

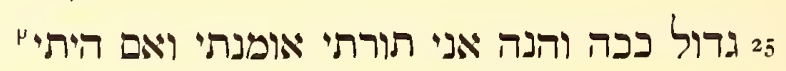

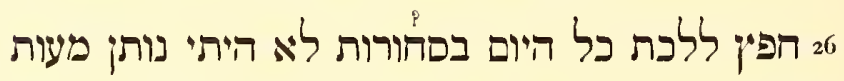

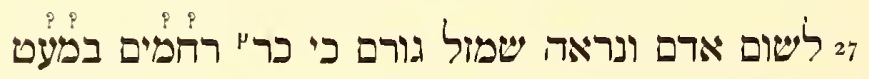

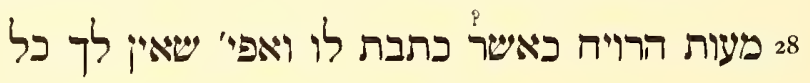

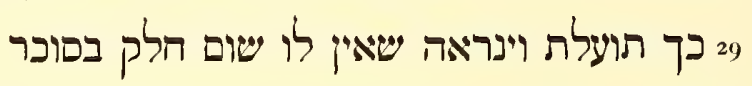

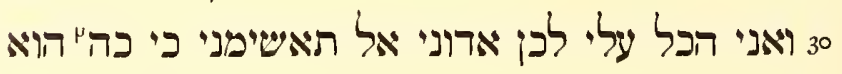

Upon the margin:

להוט ורוצה שותפים הרבה ורוצה לקביץ כל העולם כי איך בטחת לך על

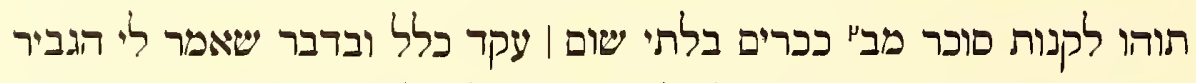

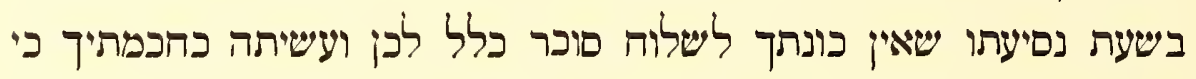

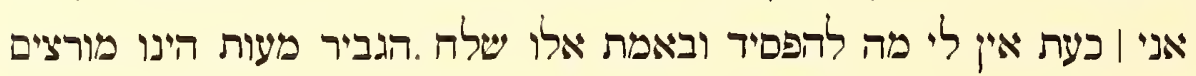

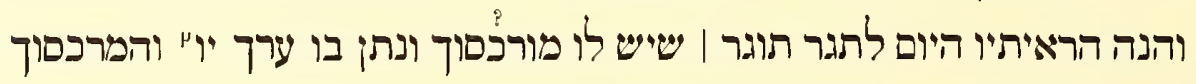

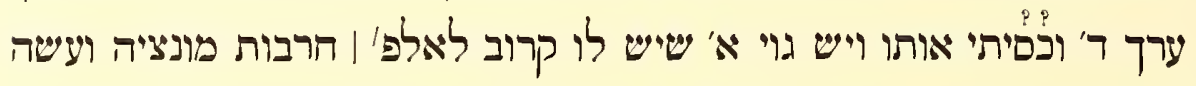

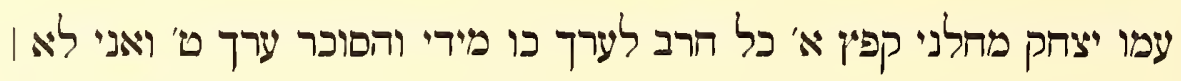

${ }^{14}$ For miaiyad, the half-dirham coined in the reign of the sultan Mu'aiyad, see Lane, The Modern Egyptians, App. B, and No. XXX. Mu'aiyad reigned from A.D. 1412 to 1421 .

15 A measure of capacity for drugs and perfumes. See Dozy, op. cit., vol. ii, p. $3^{8} 3$.

16 See al-Dhahabī, op. cit., p. 123.

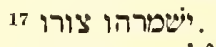

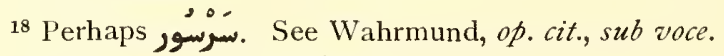

19 עִ עִ

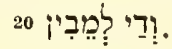

21 I.e. "What qualifications have I?"

22 It looks like עטל. Is it עָצֵל ? 
18 offered nine [ashrafīs ${ }^{14}$ ] and ten maiyadīs ${ }^{14}$ to take from him five 19 kafas ${ }^{15}$; and so I did not do any [business]. And Rabbi ${ }^{2}$ Abraham 20 Jabarti1 ${ }^{16}$, - May [God,] his Rock, preserve him ${ }^{17}$ ! - has gone to Egypt. [I hope] you will do [business] with him as much as

2I you can. Here there is no arrangement at all; for he has not appointed me in any sense

22 manager ${ }^{18}$, since I have not talked with him. The gentleman ${ }^{6}$ knows $^{19}$ the enlightenment (?)

23 of the country as to sugar; and [a word] to the wise is sufficient ${ }^{20 !}$ Let the gentleman ${ }^{6}$ not depend

${ }^{2}+$ upon me; for what [have I] in hand [with which] to operate in business ${ }^{21}$, negligent ${ }^{22}$ [as I am], and [trying to] negotiate

25 some important [transaction]? Thus it is. And as for me, my Törah is my trade ${ }^{23}$. And [even] if I $\operatorname{did}^{9}$

26 wish to take up all the day with business matters, I should not ${ }^{5}$ give money

27 to any man [for investment]. And it seems that fate determines; for Rabbi ${ }^{2}$ Rehāmìm with [only] a little

28 money has made a profit, as you wrote to him [that he would], even though ${ }^{24}$ you do not have so very

29 much advantage [from his transaction yourself]. But it appears ${ }^{25}$ that he takes no part at all in sugar [dealings],

zo and the whole thing falls on me. Therefore, my Lord, do not blame me; for he is so

\section{Upon the margin:}

greedy and desirous. He takes on more and more associates, and he would like to gather in the whole world. How could you rely upon emptinessto buy sugar [for] 42 talents ${ }^{26}$, without any security whatsoever! And as to what the gentleman said to me at the time of his departure, that it was not your intention to send sugar at all for that reason: you have acted wisely. I now have nothing to lose. Now really, if the gentleman had sent money we should have been satisfied ${ }^{27}$ ! I have shown him today how to do business ${ }^{28}$ ! He has, namely,...... and he gave for it about 16 , and the..... [is worth] about 4; and I kept the [matter] secret. There is a gentile [here] who has about a thousand swords of Mōnziah ${ }^{29}$; and Isaac Mḥlnĭ made a [bargain] with him [for] one kafaș ${ }^{15}$, each sword for about 26 maiyadis ${ }^{14}$, and the sugar [sells for] about 9. And I do not

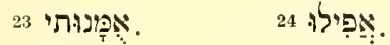

25 Confusion of

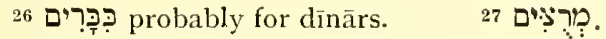

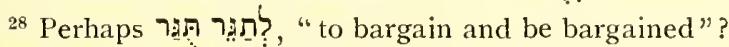

${ }^{29}$ Monza, locally Monscia, a city in Lombardy.
} 
Upon the upper part: (a)

ידעתי מה לעשות כי לא | נסתי בשום מקפה ואני | מתירה לעשות :שום

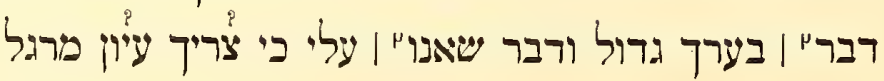

(b)

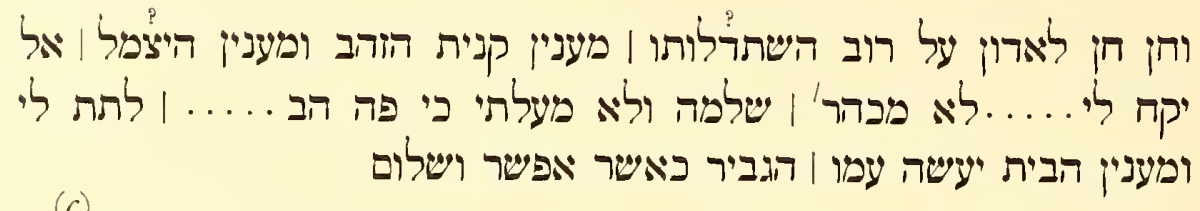

(c)

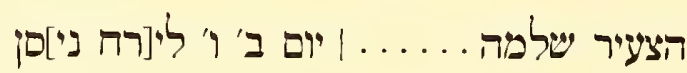

Verso:

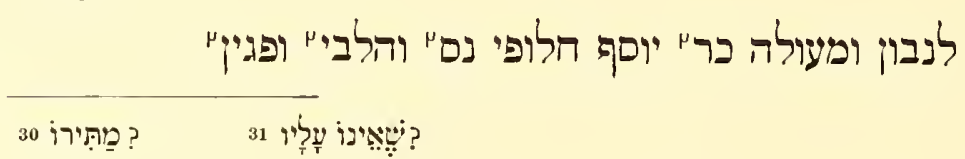

\section{LITURGICAL MEMORANDA}

Paper II $\frac{1}{4} \times 4$ inches: too long to have been a leaf from a book, and hence probably a memorandum of some sort. Number of lines : 53-62.

The language is Hebrew, with connective and directive words in

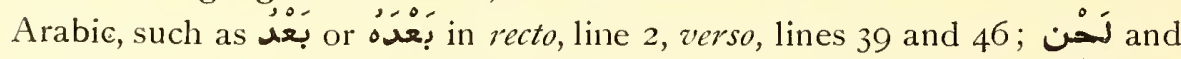

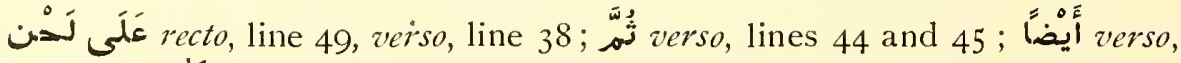
line 45 ; يَقُولى verso, line 58 ; the Arabic article in verso, line 38 .

The writing is semi-cursive Hebrew of two varieties: the first covering recto and the first five lines of verso. Both are difficult to read as the paper is worn and the ink pale. Abbreviations are so extensively used that many passages are unintelligible.

Of Biblical passages one recognises: Psalm lv, 9 in recto, line 7 ; followed by Psalm cii, I; xxv, I6; 1xxxvi, I6; 1xix, I4; 1xxiii, 22; li, I7; Proverbs xvi, I; Psalm xix, I5; Psalm xcvii, $\mathbf{I}$ in verso, line IO; Psalm lxviii, 5 in line $2 \mathrm{I}$; Psalm xxix, 9 in line 26 ; xciii, $\mathbf{I}$ in line 29.

Rimes are discoverable in three places: $7 y$ in recto up to line 7 ; various rimes in verso, lines $16-32 ; \Pi_{\tau}$ toward the end of verso. 
Ni

IN Jy की

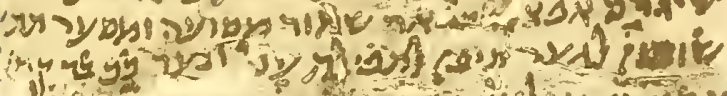
wh

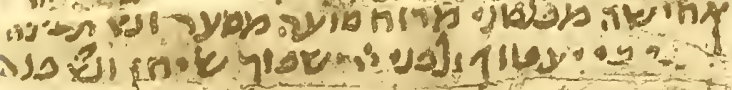

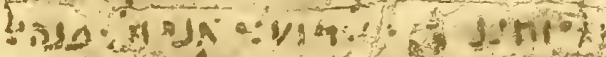

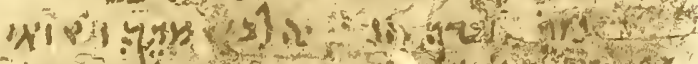

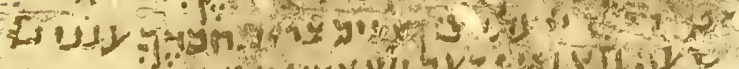

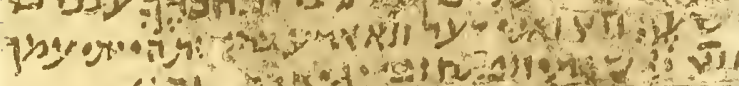

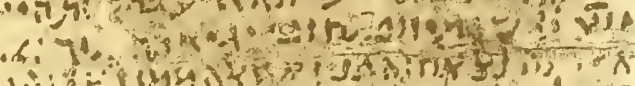
LiR j D

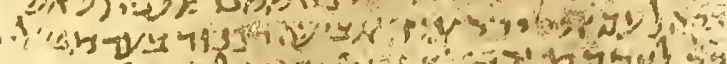

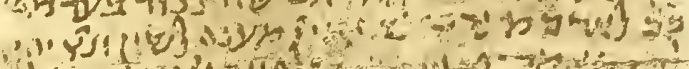

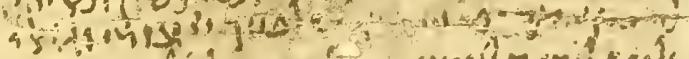

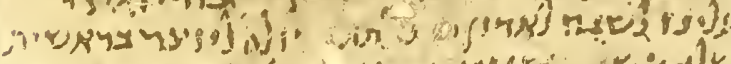

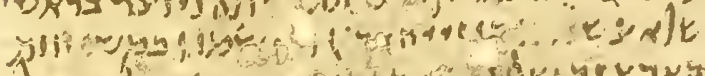

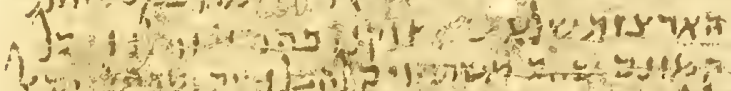
6.

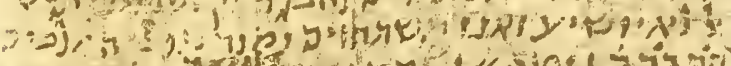

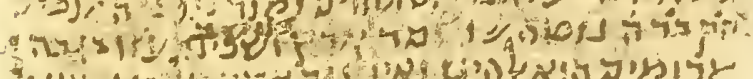

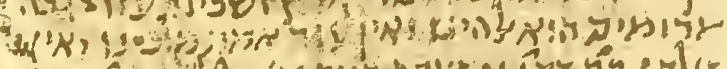

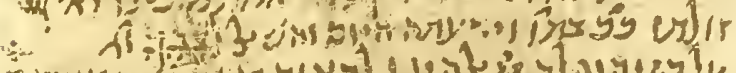

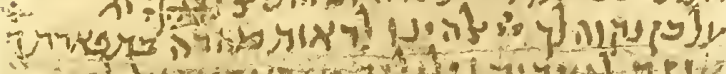
\& 3 .

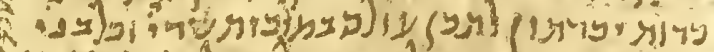

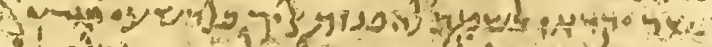

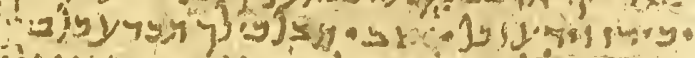

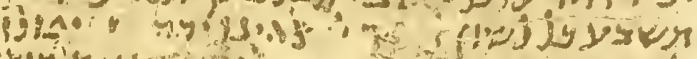

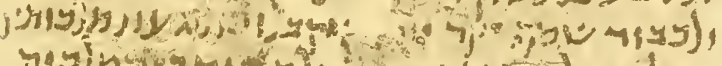

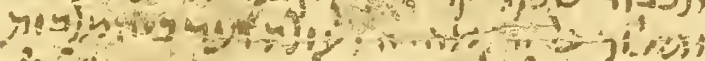

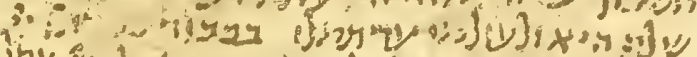
\% fi ŷn(17ge

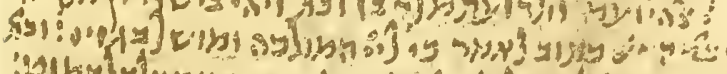

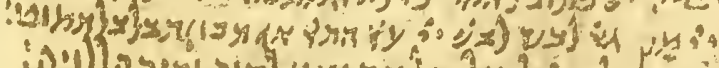
:All)

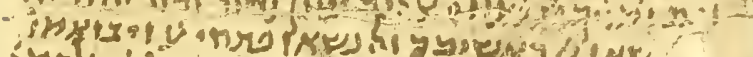

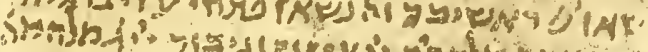

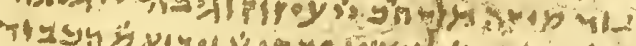
1) 8 r 1) i) "थता Yor

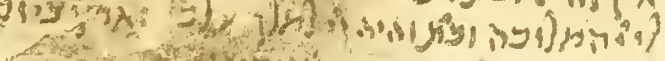

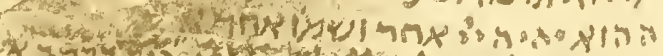

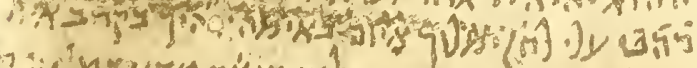

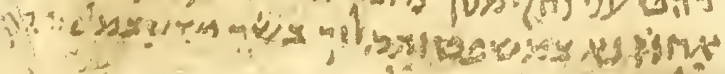

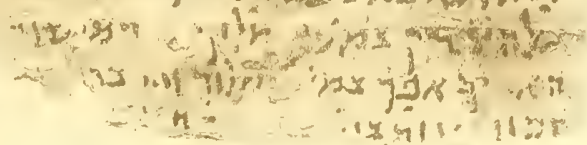


(1)

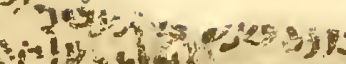

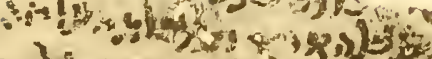

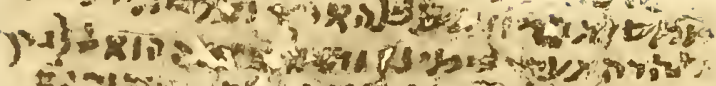

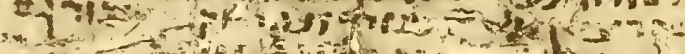

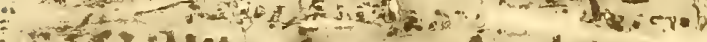

i.

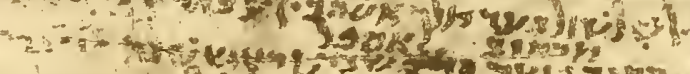

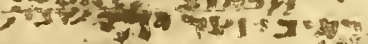

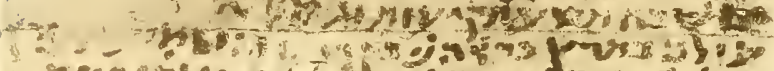

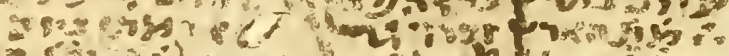

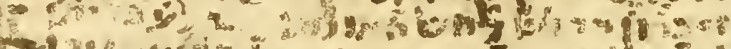

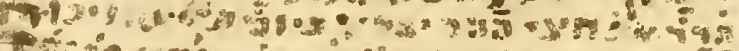

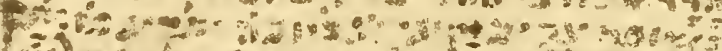

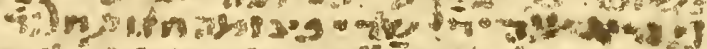

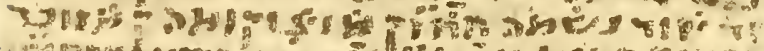

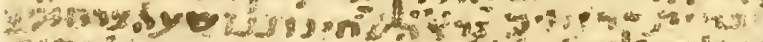

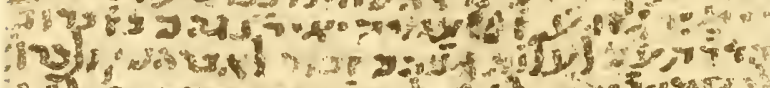

o Fon

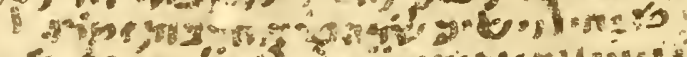

F o

TY" -1) 128.

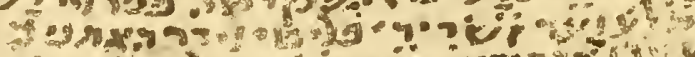

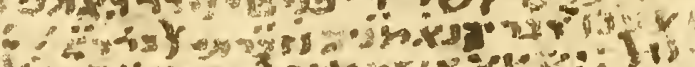

(4)

$40-3 y$ of

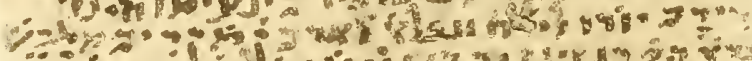

0.7. is.

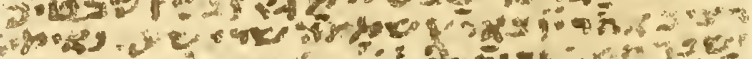

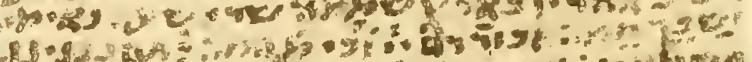

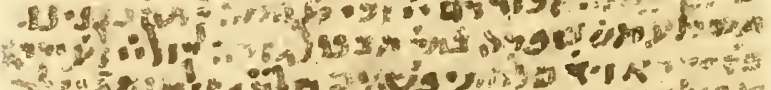

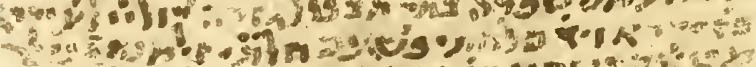
प r.

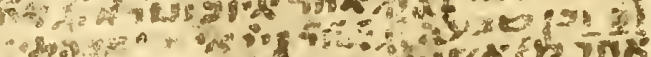

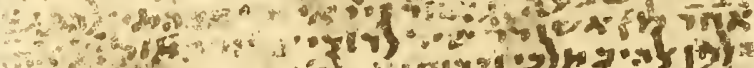

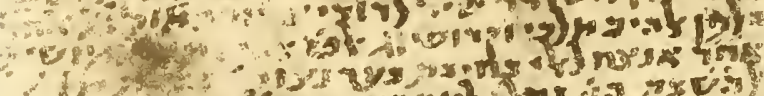

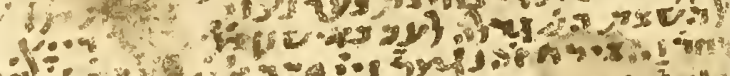

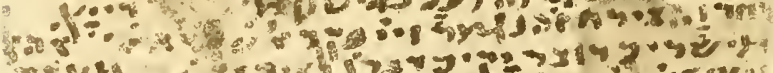

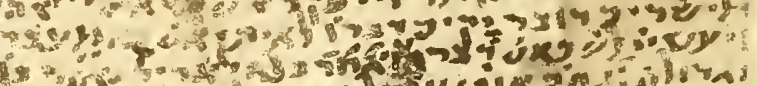

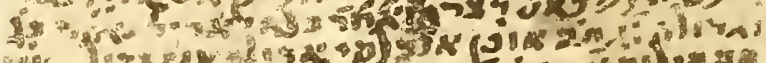

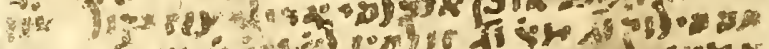
- jok

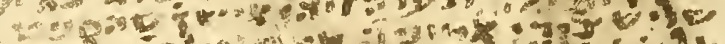

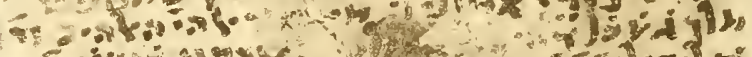

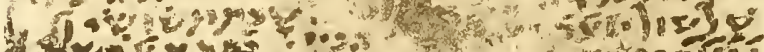

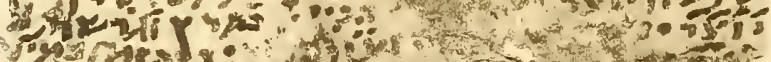

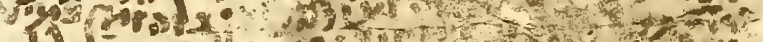

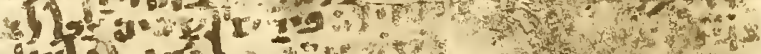

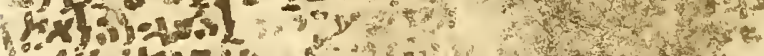

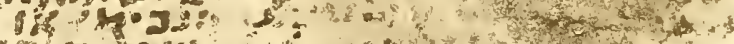

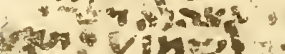

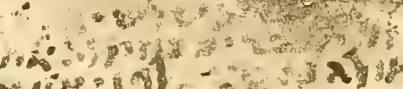

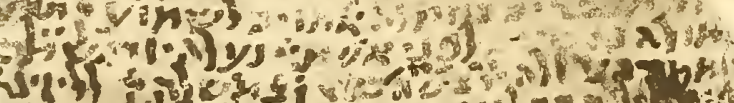

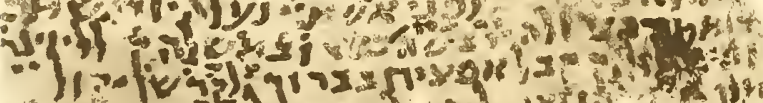

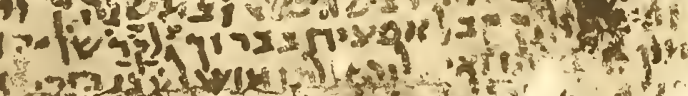

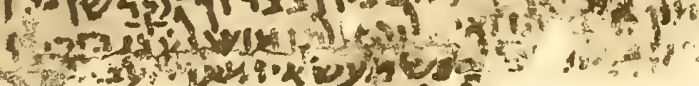
Un 
Upon the upper part: (a)

know what to do, I have not run away anywhere(?), but I [stay here and] prevent him ${ }^{30}$ from doing anything on a large scale, or anything which he does not need to $\mathrm{do}^{31}$, for inquiring thought is necessary.

(b)

And many thanks to (my) Lord for his many efforts concerning the purchase of the gold and concerning the........... Let him not take for me .............not from Rabbi ${ }^{2}$ Solomon and not on account of me(?). For here the........... to give me. And as to the house: Let the gentleman ${ }^{6}$ do with it whatever is possible. Farewell!

(c)

[From] the humble Solomon

Monday, the sixth of the month of Nīsān.

Verso:

To the Intelligent and Excellent Rabbi ${ }^{2}$ Joseph Hallüfí (?) ${ }^{32}$.

32 The last three words are apparently abbreviations.

\section{LITURGICAL MEMORANDA}

Most of the recto relates to the Mūsāph prayers of the New Year's Day service; but line 49 goes over into something else. There seems to be no particular reason for making such a selection of prayers and passages, or for arranging them in this order. Perhaps they are the notes of some pupil. Nor do the contents of this fragment appear, from any point of view, to justify transcription, translation and notes. Plates XLIII and XLIV will, however, enable the student to form his own opinion.

Professor Israel Davidson has gone over the text and has made some very valuable suggestions for which the editors wish to thank him. Bibliography: Zunz, Die Ritus des synagogalen Gottesdienstes, Berlin, I859; Jezvish Quarterly Revieru, vol. xviii, pp. 107-8; Siddur Rābh 'Amram Gä'on, Warsaw, I865; Siddur Troyes, Budapest, I905; Mahzōor Vìtrì, Berlin, I889-93; and Sêfer Abū-dirham, Prague, I784. 


\section{XLIII}

\section{AN AGREEMENT BEFORE THE COURT IN JERUSALEM IN REGARD TO PRECEDENCE IN THE ACADEMY AT AL-RAMLAH}

Paper $5 \frac{1}{2} \times 6 \frac{7}{8}$ inches.

Arabic and Hebrew, in half-square Hebrew characters.

Both the Arabic and Hebrew are fairly good; but the way in which the document passes from one language to the other, and back again, gives the impression of an imperfect command of them both, and robs the document of the dignity which it otherwise might have. The unavoidable use of Hebrew legal expressions leads the writers off into Hebrew completely for a time; and yet Hebrew cannot be sustained to the end.

The document belongs to the period of the Palestinian gaonate about which the Genizah has taught us so much, and deals with the familiar topic of discord in the Academy at al-Ramlah, evident from letters of Solomon Ben Judah, the central figure of the period, and his contemporaries, as published by Mann, op. cit. It appears to be a record of the settlement of this long controversy, alluded to by Nathan, writing in A.D. 1042 to Fustāt ț (Mann, op. cit., vol. i, p. I5I): "You have received already [the account] of how the peace came about and what we did for the sake of peace in Israel."

The date is Tishrī the 2Ist, A.M. 4803, equivalent to October 8th, A.D. 1043 .

Recto :

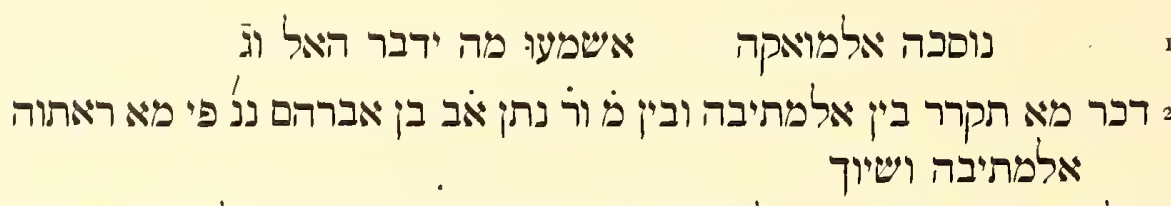

3 אלאומה ונשיאינו פן אלתקרם פי רתבה אב בית רין אלתי יפתחקהא

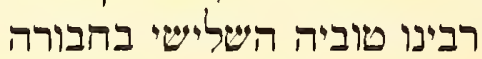

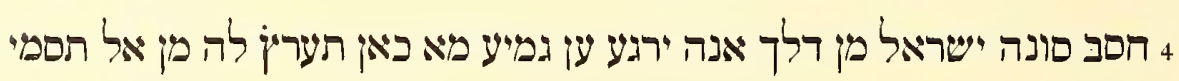

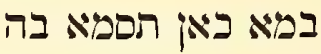

5 ומא אסמא בה סואה ואנה לא ינפרר בתקריר אמר מי אל אל אמור ולא

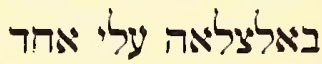

6 מן אלנאם פי מרתבה מן מראתב ישראל אלא מאיא אגתמשע עליה ראי

אדונינו שלמה גיאין

${ }^{1}$ Mistake for מואפקה.

${ }^{3}$ I.e. "school of Talmudic law."

${ }^{4}$ See Mann, op. cit., vol. i, pp. I5 I, I93-4; vol. ii, 230-I.

אית בית דין. See Mann, op. cit., pp. 265-6, 272. 
irimenta

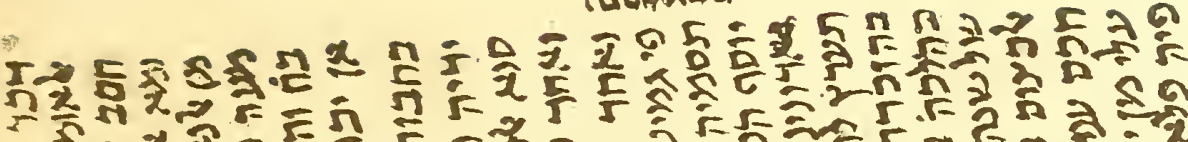

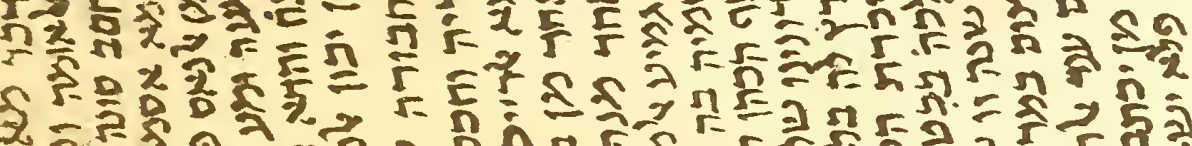
与人一. ह 5

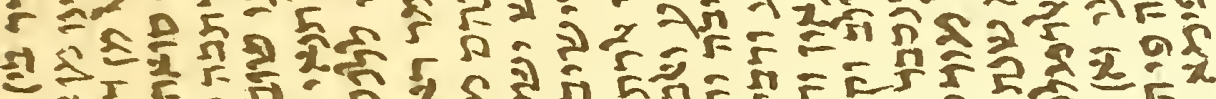

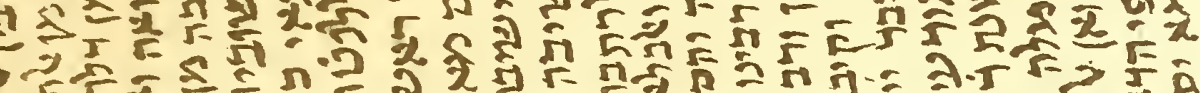

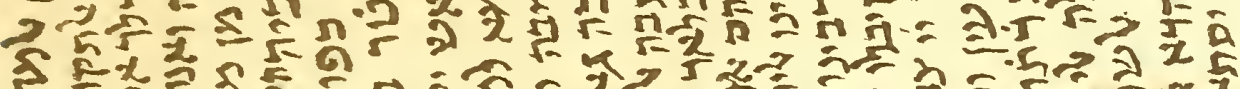
ก 1 मे

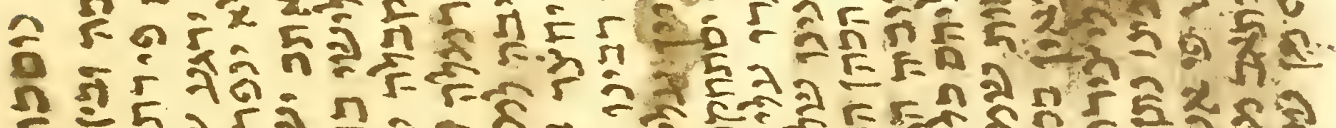

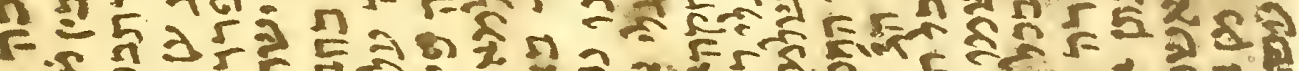
है ह d

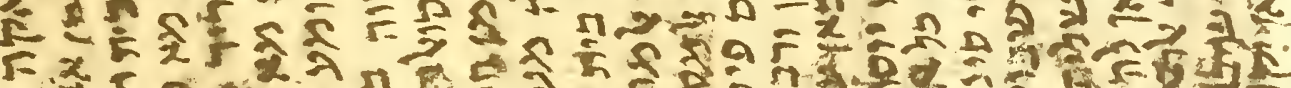

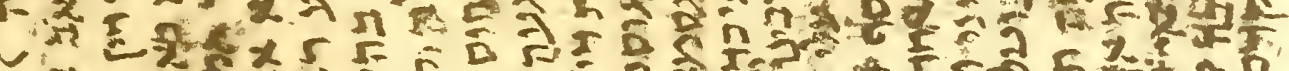

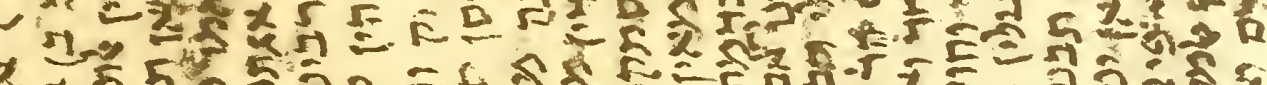
え ช

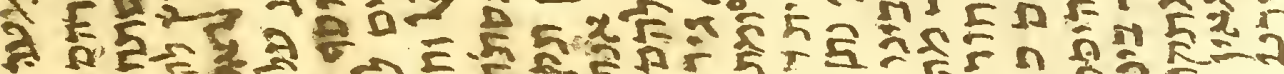
슨. a

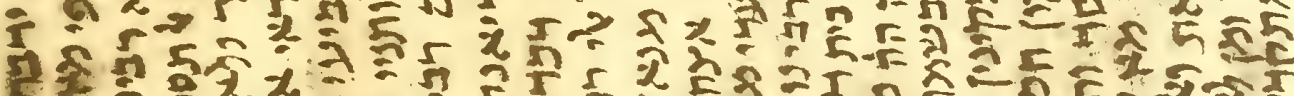

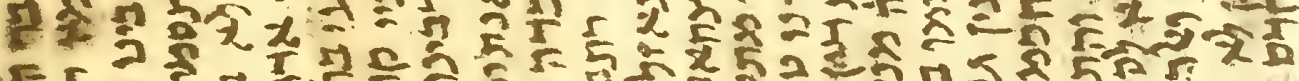

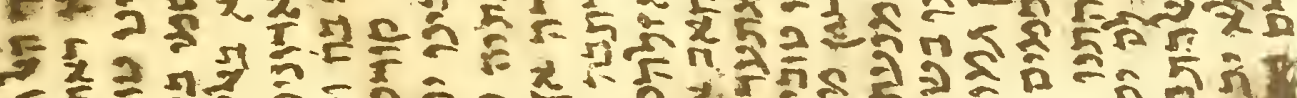

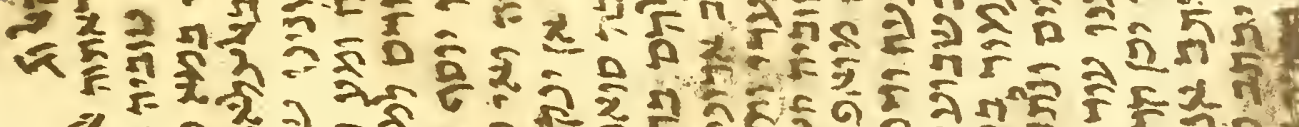

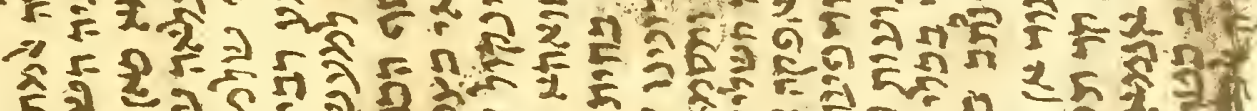
类

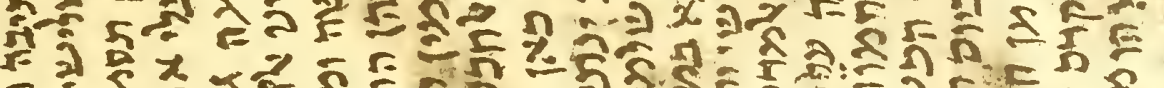

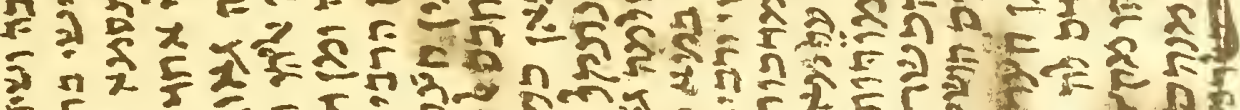

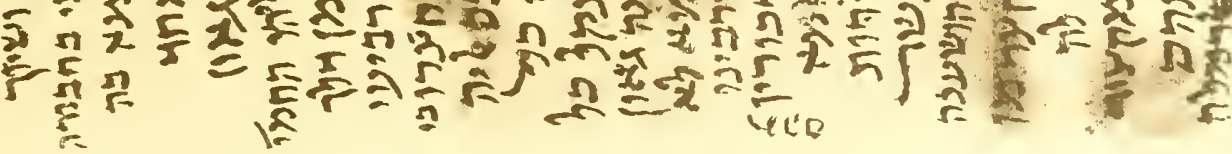




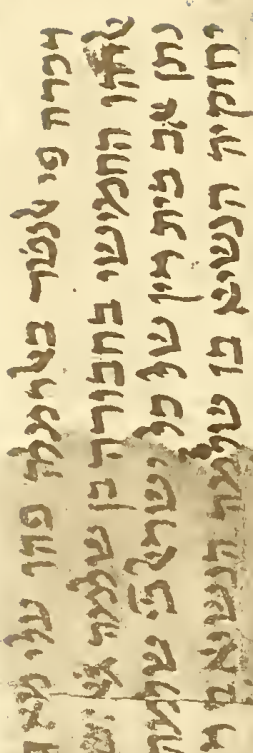

2. $5 x=$

का 5 हो a 5125 $\pi \geqslant 2$

$\Rightarrow 50$ ती

단 $\pi$

$-\pi$ ir $\Rightarrow 5$

$\frac{1}{2} \mathrm{~F}=\mathrm{I}$

n $=$ है

2 I \&

a I है

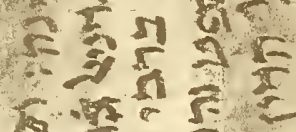

का

215 


\section{XLIII \\ AN AGREEMENT BEFORE THE COURT IN JERUSALEM IN REGARD TO PRECEDENCE IN THE ACADEMY AT AL-RAMLAH}

On the discord at al-Ramlah, see Mann, op. cit., vol. i, pp. I4I-I 52, and also pp. 7I, 75, II 5, I 29, I 30, I93, 273.

A member of the Palestinian Academy, Nathan Ben Abraham, settled in Egypt. When his uncle, the "Father of the Law Court," died, he was made "Father" by his influential Egyptian following; and the regular candidate for this office, Tobiah Ben Daniel, the "Third in the group," was pushed aside. Nathan then proceeded to undermine the authority of the Gă'ōn, Solomon Ben Judah, and at last to declare himself "Head of the Academy," the title borne by the Gā'ōn. Then began a contest between the parties behind the two rival Ge'ōnim.

Our document records the terms of the reconciliation. Nathan must renounce all assumed titles. Nathan must not decide matters of business, nor pray for anyone without the concurrence of the other four in the group. Joseph shall be judge in al-Ramlah "in imprisoning an...... and [in determining what is] permitted and forbidden." When Solomon dies and Nathan becomes Gă'ōn, the others shall be promoted accordingly, and then observe the restrictions of the offices which they shall assume. Should anyone irregularly assume a title, Nathan (sic!) shall restrain and expel him. This agreement was ratified with mighty oaths by all of the group. Thus was Nathan shorn of all power except to punish in future such as should sin as he had done.

Recto:

I Copy of the agreement ${ }^{1}$. I will hear what God will speak etc. ${ }^{2}$

2 Record of what was established between the Academy ${ }^{3}$ and our Master and Rabbi, Nathan ${ }^{4}$, [Father of the Law Court] ${ }^{5}$, son of Abraham, deceased $^{6}$, in regard to what was undertaken ${ }^{7}$ by the Academy ${ }^{3}$ and the Elders of

3 the Nation and our Princes concerning the advancement into the rank of Father of the Law Court ${ }^{5}$, which is [rightly] claimed by our Rabbi Tobiah, the Third in the group,

+ according to the custom ${ }^{8}$ of Israel in that [matter, to wit:] That he shall renounce all that he has come to possess in the way of title, in so far as he gave himself a title,

5 or was given a title ${ }^{9}$ by others, And that he shall not act as an individual in determining any matter, nor in praying ${ }^{10}$ for any

6 man in any of the classes of Israel, except [when he does] that in which the opinion of our Lord Solomon Gā'ōn concurs

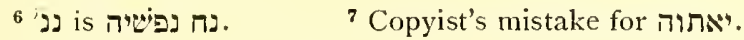

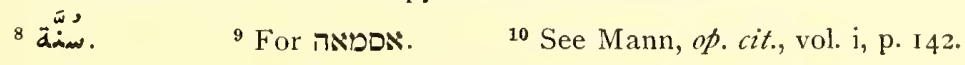


ז מעה ומע רבינו טוביה השלישי בחבורה ופע רבינו יופף הרביעי בח' ופעי רבינו אליהו החפי ולבינותי

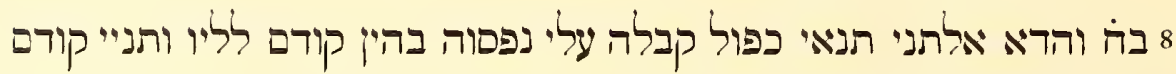

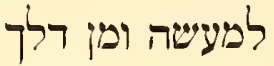

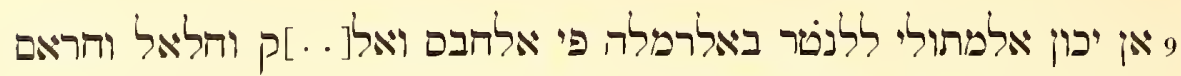

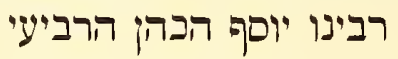

1 בחבורה ען אמר ראש ישיבה למא עלם מן חוסן סיאסתה וריאנתיה ואי

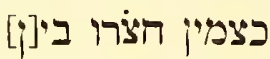

זי ידיה והכם בינהם מא למן ידצר באלרמלה מעה מצי תקרם דכרה אי כי ינקול אלדיכם אידיה

12 סוא אלריים ראש ישיבה ו"א; רבינו נתי אב בית דין מרי אנתקל אלי רתבה סואהא כאין כל

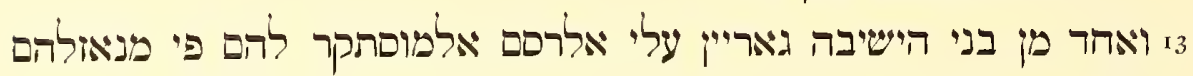

בחית ינרקל כל כיל

4ז ו"אחר מנהם אלי אררתבה אלתי יםתהקדא והם אל מספאין לא גיר ואי

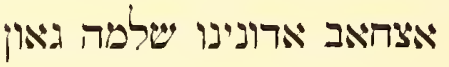

5 פי גמיע הלמוטצע ואלבליאר יגרו עלי רסומהם פי כרמהם ותקרפהם ופותי תערי מתערי ותםמטא בעיא לאיא

6 תסמיה בה אלישיבה והם ארונינו שלמה גאון ורבינו נתן אב בית רין

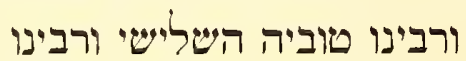

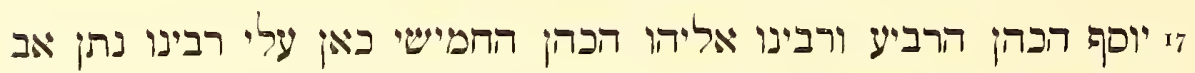
בית רין מוזאפקה אלפרכורין והם

11 I.e. Nathan.

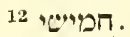

13 בהן קודם ללאי ותני קודם למעשי. See Levy, Wörterbuch, 1924, vol. iv, p. 654, quoting the Babylonian Talmud, Kiddūshīn 3, 4 (6Ia): Every conditional agreement must be twice pronounced, and must precede the transaction; and the assent must be pronounced before the dissent. This means apparently that one must first state what one will do if the condition is fulfilled, then what one will do if it is not fulfilled; and then one may act.

${ }^{19}$ Near Ludd, between Jerusalem and Jaffa.

15 One expects here "releasing." The visible remains seem to indicate pr "sustenance," or "insanity."

מתיבה מיבה the same as

$17-\bar{o}$ for $-i \hbar i$ as in modern familiar style. 
I with him ${ }^{11}$, and with our Rabbi Tobiah, the Third in the group, and with our Rabbi Joseph, the Fourth in the group, and with our Rabbi Elijah, the Fifth ${ }^{12}$

8 in the group. And this agreement is a double agreement which he has accepted for his own person, with yes before no and agreement before execution ${ }^{13}$. And similarly,

9 that the one appointed for the administration in al-Ramlah ${ }^{14}$, in imprisoning and......15 and [in determining what is] permitted and forbidden, [be] our Rabbi Joseph ha-Kōhēn, the Fourth in

so the group, by command of the Head of the Academy ${ }^{16}$, by virtue of what [the Head of the Academy'] knows of the beauty of his administration ${ }^{17}$, and his conscientiousness ${ }^{17}$. And when litigants appear be-

II fore, and judgment between them is given ${ }^{18}$ by $^{19}$, some one of those previously mentioned, who is in al-Ramlah with him, the judgment shall be referred to him,

I2 together with the ra'is, the Head of the Academy ${ }^{16}$. And when our Rabbi Nathan, Father of the Law Court, is transferred to equal rank ${ }^{20}$, all

13 of the sons of the Academy ${ }^{16}$ shall follow the ordinance laid down ${ }^{21}$ for them in their [several] stations-since each one of them

$I_{4}$ is transferred to the rank to which he is entitled; and they are the ones named $^{22}$, and not otherwise. And the associates of our Lord Solomon Gā’ōn

$1_{5}$ in all the places ${ }^{23}$ and towns shall follow their ordinances, in their service and their advancement ${ }^{24}$. And when anyone shall transgress and call himself by that

16 by which the Academy ${ }^{16}$ does not call him ${ }^{25}$,-and [these titles are:] our Lord Solomon, Gā'ōn; and our Rabbi Nathan, Father of the Law Court; and our Rabbi Tobiah, the Third; and our Rabbi

17 Joseph, ha-Kōhēn, the Fourth ${ }^{26}$; and our Rabbi Elijah, ha-Kōhēn, the Fifth-there shall be ${ }^{27}$, with respect to our Rabbi Nathan, Father of the Law Court, an agreement of the [persons] mentioned; and they $[\text { are }]^{28}$

${ }^{18}$ to ' The to is here either an adverb (German etza) or a noun ("something ").

19 Passive verb with logical subject introduced by $?$ as in Jewish Aramaic. See Margolis, Manual of the Aramaic Language of the Babylonian Talmud, Munich, I9ro, pp. 75,82 .

20 I.e. Gā'ōn, successor of Solomon.

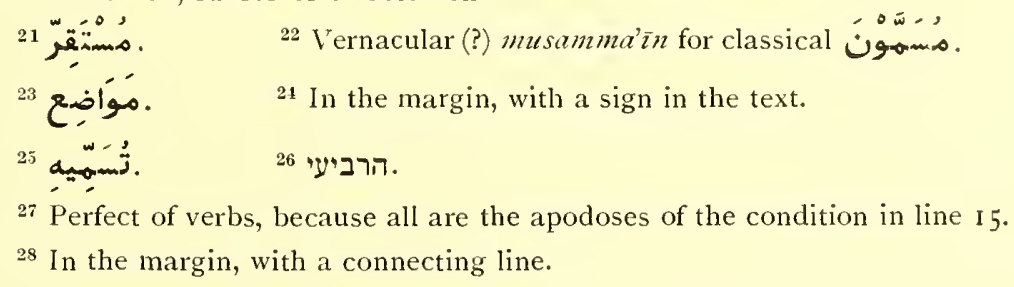


81 אדונינו שלמה גאון ורבינו טוביה הג' ורבינו יוסף הל ורבינו אליה הז מנעה ודפעה עלמא

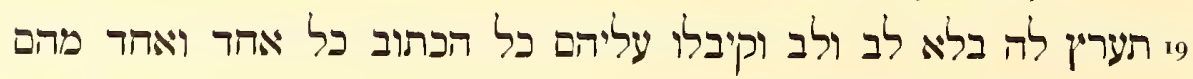

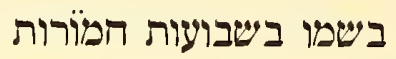

ס בהזכרת השם הנכבר "י צבאות שמו ויאמרי סיני והוקי הורב בקינין גמור בכלי הכשר השפר ז2 כהלכה בבטול כל מודעין ותנאין בכל לשון שבוטלין בהם כתיקין הכמים רנים

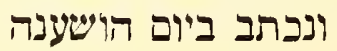

22 של שנה וו שהיא שנת דתתנג ליצירה בירושלים תבנה והיבל הפד והתנו

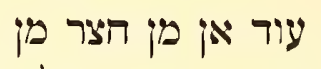

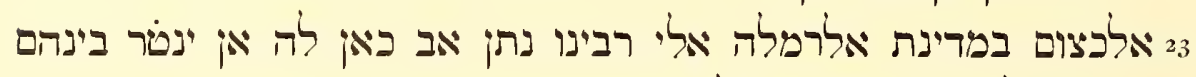

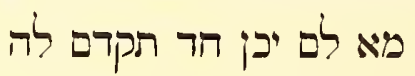

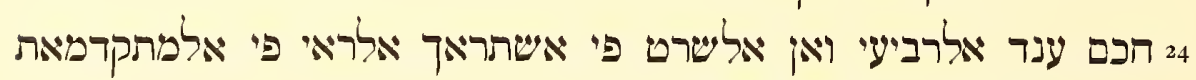

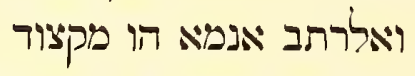

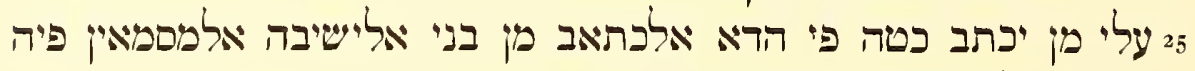

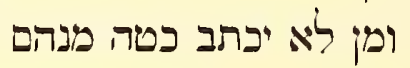

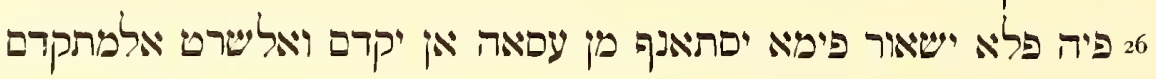
Verso:

י דכרה פי אלנטר באלרמלה פהו עלי מא תקדם בה אלשרה ללשכיץ

$$
\text { בעינה: תקוים : אלנפר באית }
$$

2 אליהו ההמישי בהבורה בן שלמה גניא: [1]טוביה השלישי בחבירה ברבי

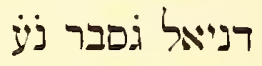

3 נתן אב בית דין של כל ישראל בי שלמה ה.. ראשי ישיבת גאון "עקב ברבי 4

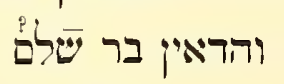

מבורך בן עלון בן משה נ丶 וקיבל עליי שאם יהזור יהיה על הדין

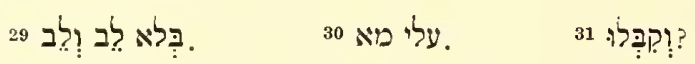

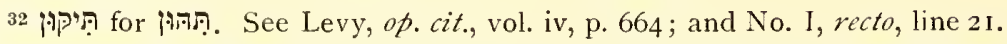

${ }^{33}$ The 2 Ist of Tishri seventh and last day of the Feast of Tabernacles, 4803 Era of the Creation, equals eighth of October, A.D. 1043.
${ }^{34}$ Rest of line scratched out.
${ }^{35}$ See line $23 . \quad{ }^{36}$ See lines $24-26$.
37 Or "rectification" or "adjustment." 
18 our Lord Solomon, Gā'ōn; and our Master Tobiah, the Third; and our Master Joseph, the Fourth; and our Master Elijah, the Fifth[Nathan] shall restrain ${ }^{27}$ [the transgressor] and expel ${ }^{26}$ him without sentimentality ${ }^{29}$, since ${ }^{30}$

19 he has opposed [them]. And all [that is] written [above] they took ${ }^{31}$ upon themselves, each one of them separately, in his own name, with mighty oaths,

2o - mentioning the "Honored Name," "Jehovah of Hosts is His Name," and "the Words of Sinai," and "the Laws of Horeb,"-by complete acquisition through a valid instrument,

2 $\mathrm{r}$ according to custom, making impossible all protests and conditions, by all the language by which men make [evasions] impossible, according to the institution ${ }^{32}$ of wise men. And we write [this document] on the Day of Hoshanah [Rabbah]

22 of this year, which is the year 4803 of the Creation ${ }^{33}$, in Jerusalem-may it be built up, and [the] Temple of Mercy! And they agreed further that when any litigants

23 appear in the city of al-Ramlah, before our Master Nathan, Father [of the Law Court], it shall be his duty to examine them as to whether some one of them have not [asked]

${ }_{24}$ judgment of the "Fourth" before [asking judgment of] him. And the condition of association in opinion [as set forth] in the foregoing [statements], and in rank applies only

${ }_{25}$ to those Sons of the Academy ${ }^{16}$, named ${ }^{23}$ therein, who affix their signatures to this document. And if any one of them shall not affix his signature

26 to it, he shall not be consulted in any [matter] which any [man] may initiate who may present [a proposal]. And the condition afore-

\section{Verso:}

I mentioned ${ }^{34}$, as to the examination ${ }^{35}$ in al-Ramlah, applies, according to the preceding comment ${ }^{36}$, to each individual in person. Summary ${ }^{37}$ :

${ }_{2}$ Elijah, the Fifth in the group, son of Solomon, Gä'ōn ${ }^{38}$, and Tobiah, the Third in the group, son of Rabbi Daniel Gsbr ${ }^{39}$.

3 Nathan, Father of the Law Court of All Israel, son of Rabbi Solomon... ....... ${ }^{40}$, Head of the Academy ${ }^{16}$, [and known as] Gā'ōn of Jacob, son of Rabbi

4 Hezekiah ha-Nasĩ. Joseph ha-Kōhēn ha-Shöfēt, the dayyānn ${ }^{41}$, son of Solomon

5 Mebörākh, son of 'Lwn, son of Moses. And [Nathan] took ${ }^{31}$ upon himself [the condition] that, if he should repent [of the agreement], he should be subject to judgment.

\footnotetext{
${ }^{38}$ Solomon ha-Kōhēn was Gā'ōn immediately preceding Solomon Ben Judah.

39 For רְִּ: "treasurer"?

${ }^{40}$ According to Mann, op. cit., chap. iii, Nathan's father was named Abraham.

41 For הדיאי?
} 


\section{HALACHIC FRAGMENT}

Recto :

זילכות 1 אוהרוּת 2 תענית יום הכפורים

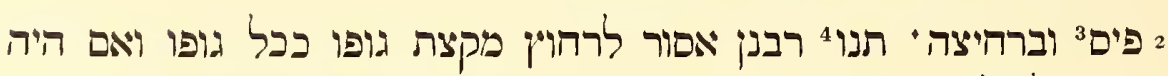
מלוכלך בטיט

3 ובצואה רוחין כררכו ואינו הושש: תאנא5 רבי מנשה רבן שמעון בן

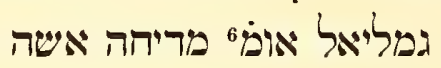

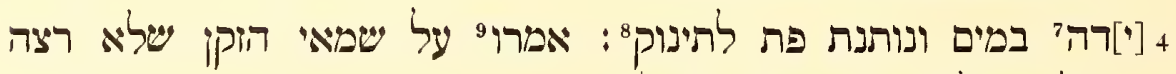

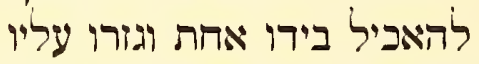

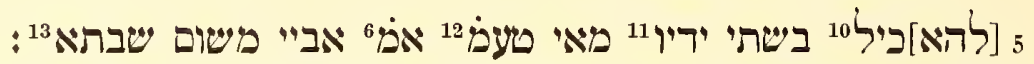

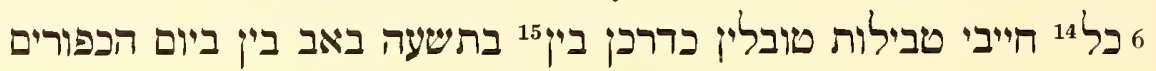

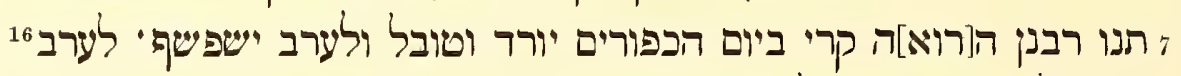

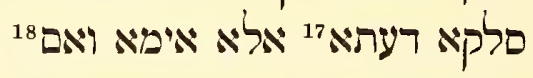

8

(Original text erased)

$9^{-15}$

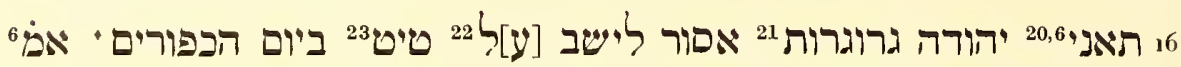

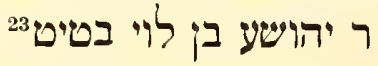

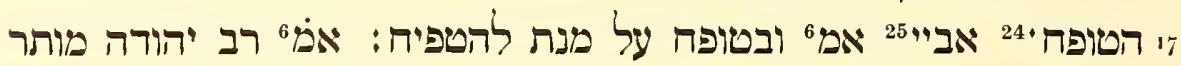

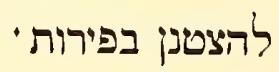

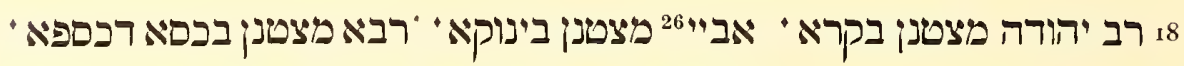

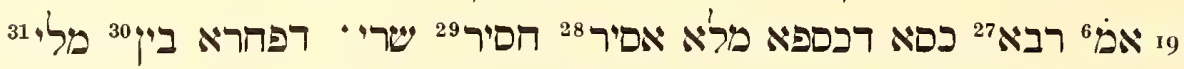

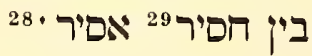

${ }^{1}$ This line is the heading to the entire subject as originally written on the fragment.

${ }^{2}$ The word can also be in the singular. The last letters are not well preserved. The meaning here is "prohibitions."

${ }^{3}$ The word 2 , for $\mathbf{N}$, is used in this fragment to designate that the following word or words are from the Mishnah. It is not usual in Talmud Bablī and Pōseḳim. The Mishnah treated in this page is found in Yōmā viii, I.

${ }^{4}$ The passage is in B. Yōmā 77 b. Compare Tōsephtā iv, 2-6.

${ }^{5}$ Participles as חאזי, באעי, ישחל, תאני, תאנא, are written with א. This may be due to Arabic influence.

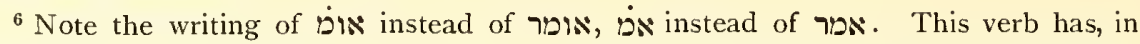
the imperfect and imperative, an $\mathbb{N}$ instead of the 7 , which was lost in pronunciation. The 7 was then apparently lost in the pronunciation of the perfect and participle. Cf. Mann, op. cit., vol. ii, p. 297, note I, quotation. 


\section{HALACHIC FRAGMENT}

Paper $7 \frac{1}{4} \times 5$ inches.

Hebrew and Arabic, in semi-cursive Hebrew characters, not all by the same hand, written in different directions, interlined, erased, smudged and otherwise defaced.

7 Talmud adds אחת. But Rabbi Hananēl, Rashī and העיטור (2nd part 44c) omit אחיר.

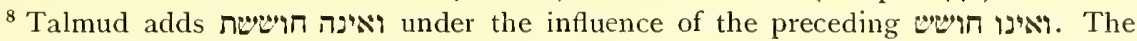
words are, however, omitted in MSSm,2,o and Hullīn Iozb. See רקרוקי סופרים to Yōmā, p. 244 , note $\%$.

9 על is omitted through a scribal error.

10 So Talmud, but ליאביל is also possible. For this text see MSS2,o (Bibliography, p. 217 ).

11 Talmud $\square$ ', but the $\square$ is due to the influence of the next word. For this text see MSS.

12 The $\mathbb{N}$ in $\boldsymbol{N}$ טעמ is omitted in this fragment, and a dot is placed upon the preceding letter.

13 This word is written everywhere also with ", The omission of the " after the $\omega$ is due apparently to a scribal error.

14 The passage is found in B. Yōmā $88 \mathrm{a}$.

15 Talmud Yōmā omits the phrase ב'ן בתשעה באב בין, but it is preserved in Shabbāth

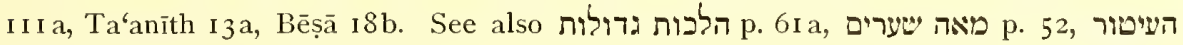
p. $44 \mathrm{~d}$.

16 Talmud מאי רהוה הוה. For the text of the fragment see MSSm,o. Cf. Rashī. See

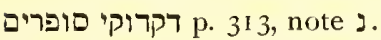

${ }^{17}$ Alf āsī and Rabbi Asher have רעתך.

${ }^{18}$ Talmud omits וצאם. The present text misled Rashî. For the correct text of the

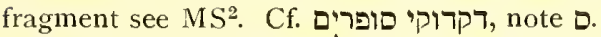

19 Talmud adds קא סבר מצוה לשפשי. But the phrase is correctly omitted in MSm. See .. . , ibid.

It seems that the passage of ההולך להקביל (B. Yōmā 77 b, in an abridged form) followed the preceding passages, but it was wiped away and replaced by an insertion. Later an addition to the preceding passage was inserted.

${ }^{20}$ Passage in B. Yōmā $78 \mathrm{a}$.

21 Talmud adds בר. For the omission see MSSo,1. Cf. •.7, p. 249, note ל.

22 Talmud adds גבי. Alfāsī omits it.

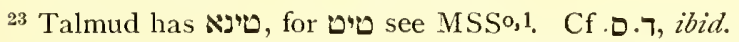

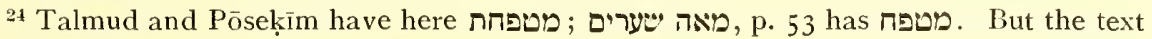
of the fragment is preferable, otherwise there is no difference in opinion between מטפחת מפטמס

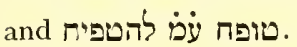

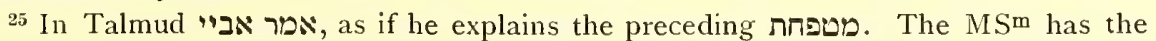

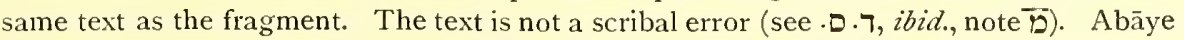
is really opposing Rabbi Yehōshua B. Lēeī, and not explaining his words.

26 Talmud has רבה. For see MSo.

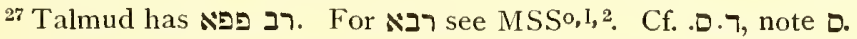

${ }^{28}$ Talmud has Hebrew הלכות גרולות put p. 62 b and Alfāsì have the Aramaic ריא.

29 Talmud writes

30 Talmud has instead אירי ואידי. For the text of the fragment see MSSO,1. Cf. ה.ד. ibid.

${ }^{31}$ We expect מלא, but see MS². Compare also Alfāsî̀ מליא. 


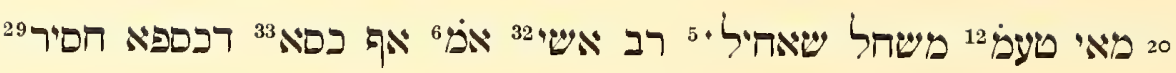

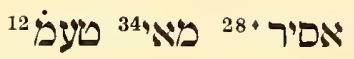

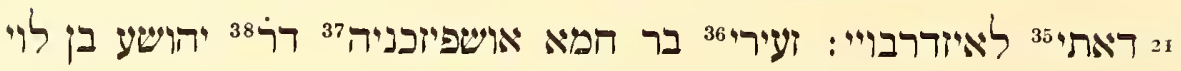

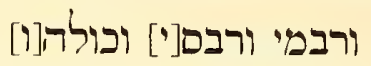

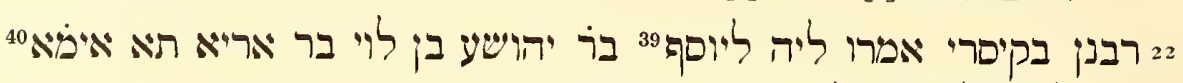

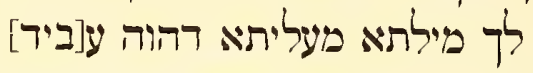

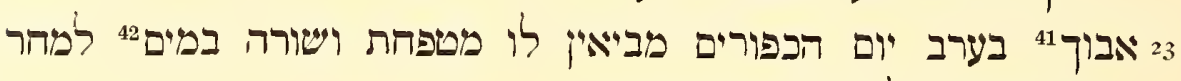

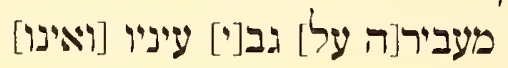

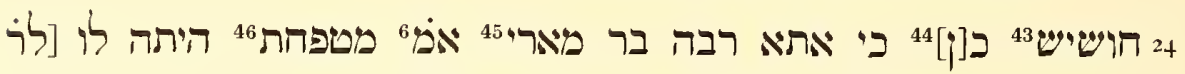

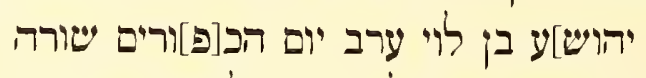

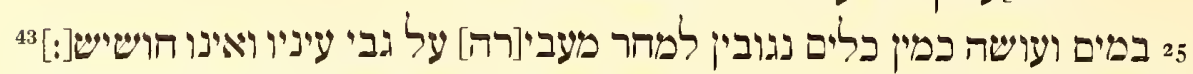

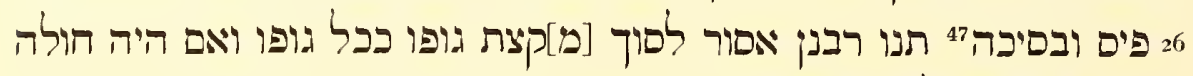

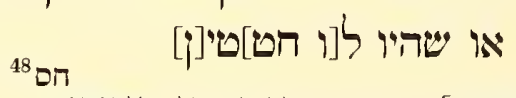
27 [בראטי] סך כדרבו ואיצו חושיש:

Right margin :

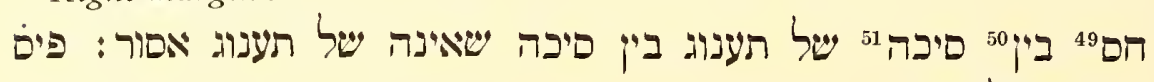

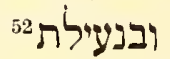

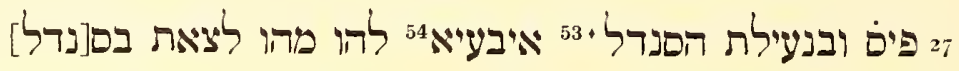

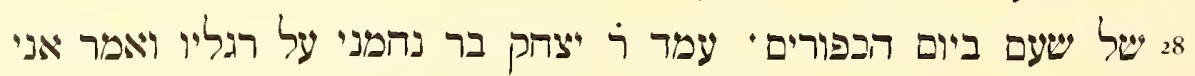

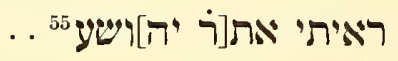

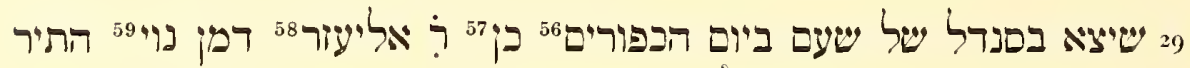

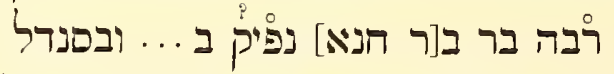

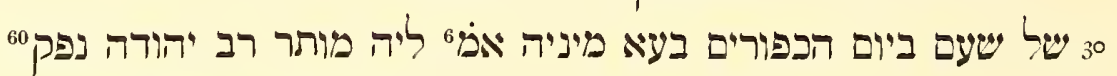
(Remainder missing)

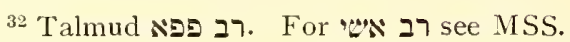

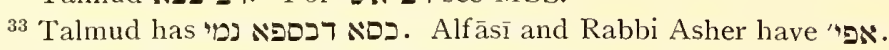

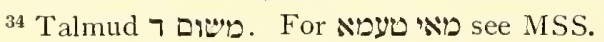

35 Talmud has here the participle רמוזרריב. For the infinitive see MSSo,1. Cf. ר.ר, note $y$.

36 Talmud אירות

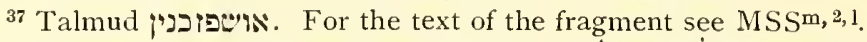

${ }^{38}$ The text in the Talmud is דרבי אמי ורבי אםי ורבי יהושע בן לוי ודכוליהו רבנן דקיפרי ... The text is surely corrupt. Rabbi Yehōshua, being of an older generation, should be mentioned first. It is not likely that Zeīra was a hotel-keeper who accommodated all the scholars of Caesarea. This statement is not important. The text of the fragment is excellent. See for its support MSm, which has and amits a 
Professor Gottheil made a preliminary examination of this fragment; but it remained for Dr Samuel Feigin to subject it to a thorough study. The rest of this article therefore is entirely his. The editors feel that,

Compare also Alfāsī and Rabbi Asher and MSSo,1,2 which mention Rabbi Yehōshua first.

Cf. . ד. מבוא הירושלמי cf. Fote p. For the writing 86.

${ }^{39}$ Talmud adds רב. For its omission see MSSo,1,2.

${ }^{40}$ היפט is written as usual in Talmud. The writer, however, intended to omit the final $\aleph$ and put a dot over the $\boldsymbol{D}$. Cf. note $\mathbf{1} 25$.

41. Here the text is very confused in the Talmud and Pōsekīm. The fragment omits entirely about the Ninth of $\mathrm{Ab}$. For the same omission see MSm. The text of the frag-

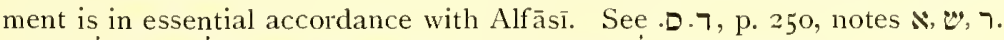

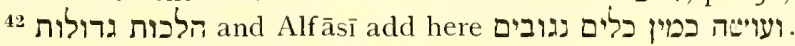

${ }^{43}$ Note the writing

44 Talmud has 10 ?.

45 Talmud writes without $\aleph$

46 The text of the fragment is exactly as that of Alfāsī.

47 The passage is found in B. Yōma $77 \mathrm{~b}$ and is connected with the statement about העיטור , The author of the fragment set them apart. Compare הלכות גדולות. The p. $44 \mathrm{~cd}$, and

48 'The word is apparently $\square \pi$, namely, "missing," and refers to the right margin.

49 We expect here ${ }^{9}$. The last letter is rather $\square$ and the word must be 0 . Th.

50 The text is from Jer. Yōmā $44 \mathrm{~d}$.

51 Jer. adds Nישי", but it is omitted in Rabbi Hananēl.

52 The words show where the margin shall be inserted.

${ }_{53}$ The text is found in B. Yōmā $78 \mathrm{~b}$.

54 Talmud has the participle the fragment.

${ }_{55}$ There is space for two more letters and we expect two more words

56 'The question about a public fast-day is omitted here.

57 The text of the fragment seems to have been mutilated in order to make it accord with the present text of the Talmud, but without success. The original text of the fragment was apparently as follows :

וכן ר אליעור רפן נוי התיר רבה בר בר דנאי נפיק ב.... ובסנדל של ישעם ביום הכפורים רב •הורה

עפיק

But this text disagrees with the text of the Talmud, according to which Rabba Bar BarHanna relates the actions of Rabbi Eleazar on a public fast-day. On this occasion he asked him about the Day of Atonement, and was answered that it makes no difference. To bring the text of the original fragment in accordance with the text of the Talmud, the editor encircled the statement of Rabbi Eleazar, put small circles around the words "Rabba Bar Bar-Hannā went out" to indicate apparently that these words precede the others, and added בעי מיפיה אפ ליה מותר. However, there was no need to ask since only יום הכפורים בעים מיפיה wasere, therefore, scratched out, and added, however, on the margin. The following passage ...p בב יהורח מפיק was moved further away.

58 Talmud אל אלעז, but compare MSm for the first statement of Rabba Bar Bar-Hannā, where it has אליעיר. These two names may be identified. See D. . p. 25I, note ח.

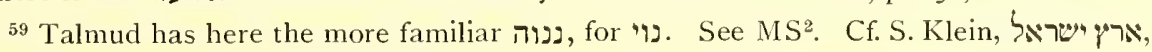
note to section 95 .

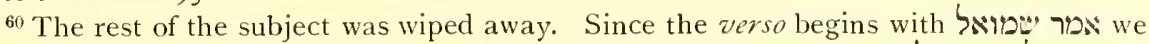
may think that a part of the passage of the Talmud, dealing with צילת הסנרל, was originally written in the space, which is now wiped away, and thus made place for the insertion. 
Left margin:

$$
\begin{aligned}
& \text { ז והלכתאי הקטע אםור לצאת } \\
& 2
\end{aligned}
$$

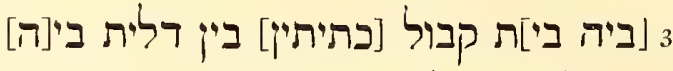

$$
\begin{aligned}
& 4
\end{aligned}
$$

Verso:

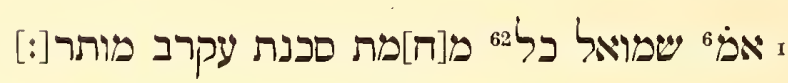

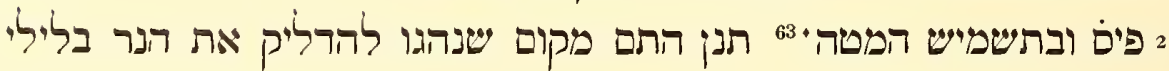
[יום ה]כפור]ים]

3 מרליק"ן מקום שנהגו שלא להדליק אין מרליקין מרליקין 64 בבתי כניםיות ובים ובבתי מ[דרשות ובמבואות]

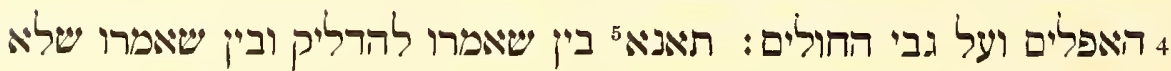

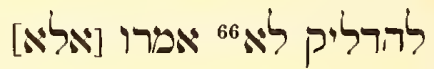

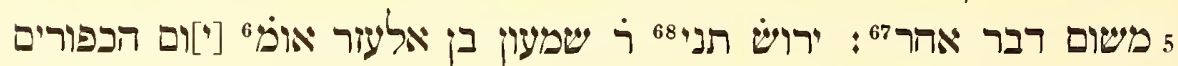

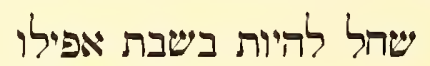

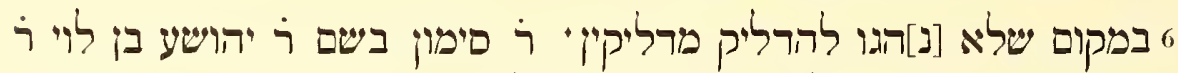

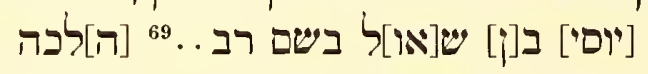

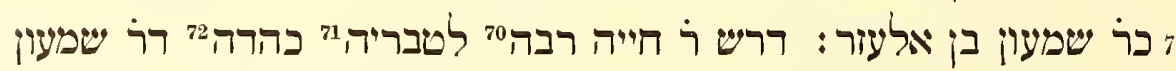

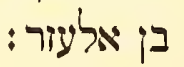

\section{Written horizontally:}

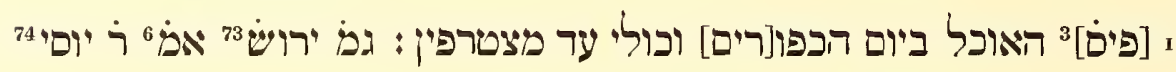

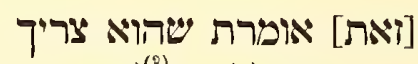

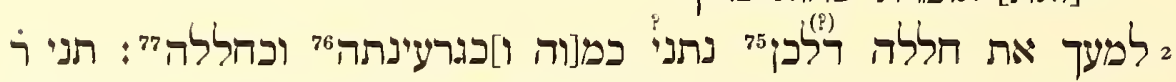

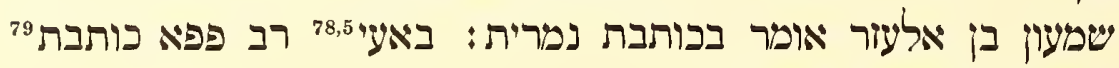

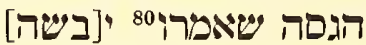

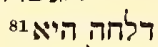

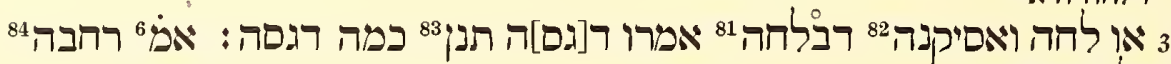
דלחה אמרו

\section{אפ்}

${ }^{61}$ The margin is not a copy from the Talmud, but is connected with the passage of the Talmud about קטע (B. Yōmā $78 \mathrm{~b}$ ). The reason someone wrote it on the margin must be that he intended to copy only extracts from the Talmud itself. A later addition was attached to this margin to modify its statement.

${ }^{62}$ The passage is in B. Yōmā $78 \mathrm{~b}$. The Talmud has אם For the text of the fragment

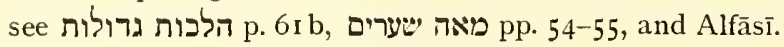

${ }^{63}$ The passage is in B. Pesāhīim 53 b. 
although no important conclusions have been reached, and although Dr Feigin presents his transcription, notes, and general remarks, with great diffidence on this account, the fragment remains a problem which might be of importance to Genizah students, and ought therefore to be presented in this volume. Dr Feigin wishes to express grateful acknowledgment to Mr S. B. Maximon, of the Jewish Institute of Religion, and Rabbi Z. W. Leiter, of Pittsburg, for the loan of needed books.

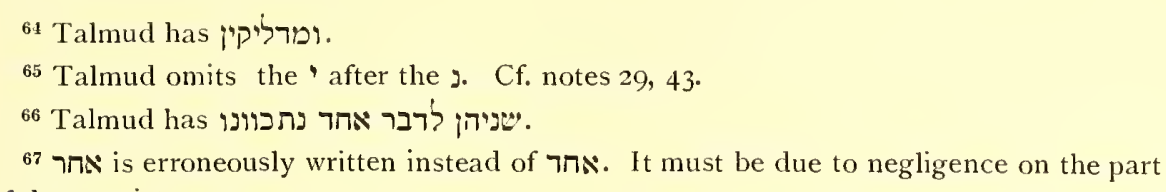
of the copyist.

${ }^{68}$ The Jerusalem Talmud, Pesāḥīm 31 a.

${ }^{69}$ Jer. has רבי. But it seems that some name is missing there. The final letter in the fragment does not seem to be a? Perhaps the name is

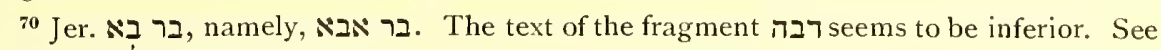

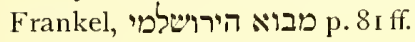

71 Jer. has a after $ט$.

72 Jer. כהרא with.

${ }^{73}$ This is copied from Jer. Yōmā ( $44 \mathrm{~d}$ near the end).

74 Jer. הוסי.

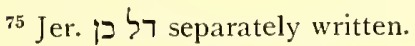

${ }^{76}$ Jer. בגלעיעתה. But compare Tōsephōth Yōmā 79a.

77 Jer. מחללה which is surely not correct. See Tōsephōth, ibid.

${ }^{78}$ The text is an extract from B. Yōmā 79-80.

79 Talmud הגבותה במתות and omits.

80 The Talmud, as well as the Pōseḳim, had a corrupted text which caused many artificial explanations. The text of the fragment has the support of MS ${ }^{2}$ which has

\section{ככותבת הגםה שיאמרו בלחה או ביבשה}

See.D.7, p. 254, note 2. According to this, the text of the Talmud should be reconstructed as follows :

בעי רב פפא כותבת הגםה שאמרו לחה או יבעה. בעי רב אישי עצם כישעורה בקליפתה או בלאי

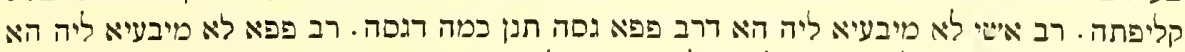

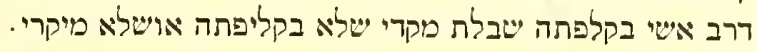

The present text of the Talmud seems to be formed by the following circumstances : בעי רב פפה כותבת הגםה ישאמדו בעי, A copyist omitted the words

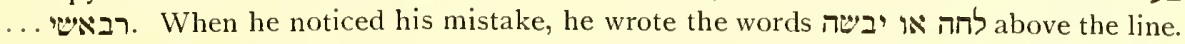
The second copyist inserted the words in the wrong place. When it was noticed that the בגדרעיצתה אי שלא although the inquiry about this is impossible. See .0.7, p. 254, note ג.

81 The copyist wrote רבלחה רלחה בnstead and placed a circle around the word to indicate that it is wrong and wrote the correct word in smaller script at the beginning of the line above (רלחה היא) and beneath it (דלחה אמרנ).

${ }^{82}$ This is a usual term in Alfāsī and Rabbi Hananēl. The fragment omits the inquiry of Rab Ashī.

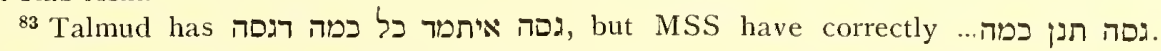
See . D.7, note $\mathrm{i}$.

84 Talmud has רבא which is impossible (Cf. I. Halevy, רודות הראיטונים, vol. ii, p. 475 f.). MS רבה $^{\mathrm{m}}$ has $\mathrm{MSS}^{0,1,2}$ have correctly, as the fragment, רחבה. 
4 יתירה מכביצה וקים להו לרבנן רבהכי מיתבא רעתאי׳ 85 ובציר 86 מהכי ליא

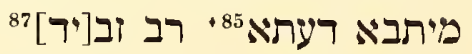

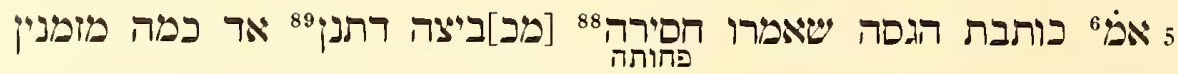
ער כזיתים

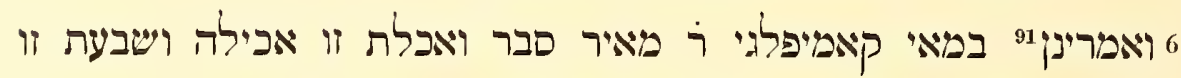
שתיה ואכילה בכית ור יהורה סבר [ואכלת]

ז ושבעת אבילה שישבה שביעה וא[־[ו זו זי92 כביצה ואי סלקא דעתא כותבת הגםה 93 יתירה מכביצה השתא כ[ביצה]

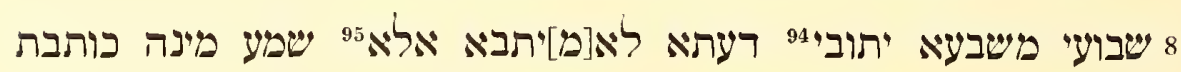

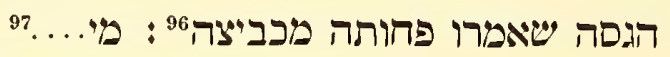

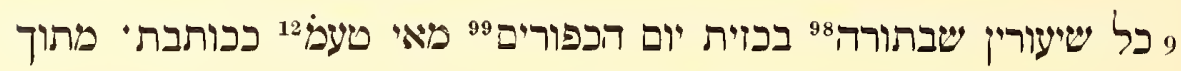

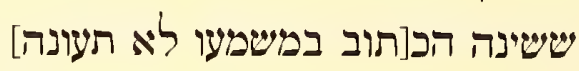
ס ולא כתוב ליא תאכל 100 שינו חכפים בשיעורו 101 ככותבת 102 ושיעורין 103

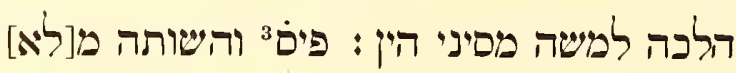

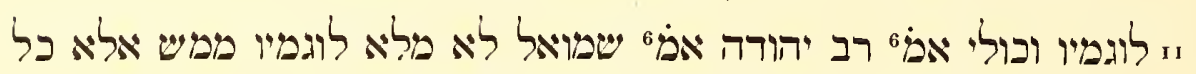

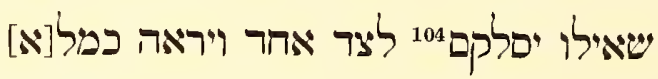

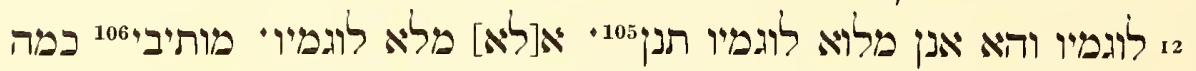
ישתה ויהא חייב [בית] שפיא אופרין [ר]בי[עית]

(Remainder missing ) .

Verso backward:

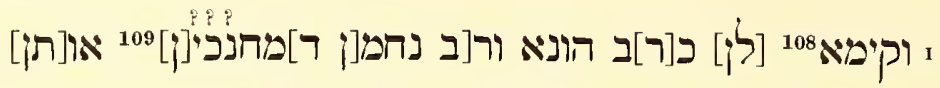

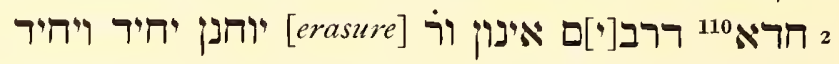
3 ורבים הלכה כרבים [ו]עור 111 רבתראי נינהו ועים יעור

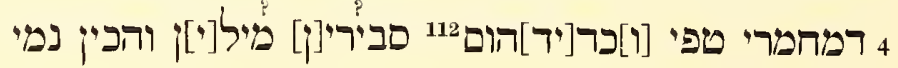

85 Talmud has רעתיה.

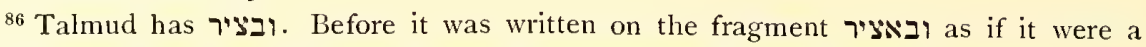
participle, but it was scratched out and written above ובציר ובציר ובציר ובירי

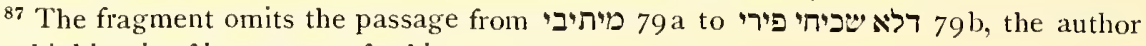
not thinking it of importance for his purpose.

${ }^{88}$ Talmud has פחסירה. In the fragment פחה is written under it, apparently, in explanation.

89 The fragment omits the passage which follows רתנן, which was rejected in the Talmud, and continues with the following passage. 
The fragment begins with a heading: "Laws [concerning] Prohibitions of the Fast of the Day of Atonement." Then follow three Talmudic extracts on Washing. Between the first two and the present third section there seems to have been another on the same subject; but at present the space is filled by an extract from Maimonides on entering into the Holy of Holies and the Temple. The last line of this insertion comes just under the first line of the passage on Washing. Between the second passage and the insertion from Maimonides is a note stating that the law permitting bathing in case of pollution, even on the Day of Atonement, is no longer in force; and the authority is a Rabbi Moses, apparently Maimonides. This note continues upside down in smaller script behind the lines. Two line-spaces below the passage on Washing there follows one on Anointing. At the end

90 Talmud adds דברי רבי מגיר. For the omission in MSS $^{\mathrm{m}, 1,2}$ see .๑.7, p. 256, note 2.

91 This word is omitted in the Talmud, but is found in MS ${ }^{2}$. See .๑.7, ibid.

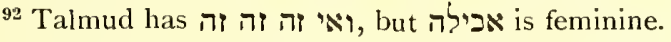

${ }_{93}$ Talmud adds 1 רמש, but it is omitted in $\operatorname{MSS}^{\mathrm{m}, \circ}$. See $\bullet .7$, p. 257.

94 The infinitive absol. is omitted in the Talmud, but it is found in MS $S^{\circ}$. See .0.7, note \&.

95 Talmud adds לאו, but it is omitted in MSS. See .0.7, ibid.

96 Talmud adds כביצה מישבעא ככותבת מיתבא רעתיה. The phrase is omitted in MS and is superfluous.

97 Talmud has תניא רבי אומרי כליא.

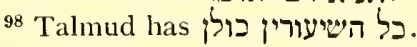

${ }^{99}$ The wording of the entire passage is not found in the Talmud, but it is extracted from it, after omitting the טמאת הוכלין about which the writer of the fragment was not concerned.

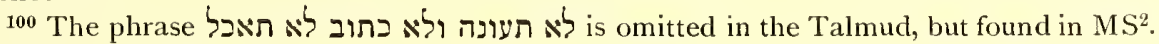
See. 0.7 , p. 257 , note $\%$

101 Talmud has Aramaic בישוריה.

102 The rest of the passage is omitted.

103 Talmud adds ועונישין.

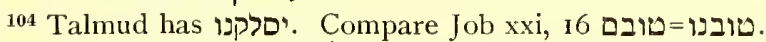

105 Talmud has והא אנן תנן מלוא לוגמיו, but MSS have the same text as the fragment.

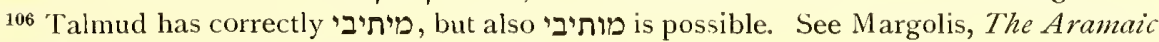
Language of the Babylonian Talmud, section 38.

107 The rest of the passage is now missing. It was wiped away in order to gain space for the passage from the Talmud which is written in smaller script. It surely contained the passage about תינוקות B. Yōmā 82a, to which the margin was attached.

108 Although the text is badly preserved, we can with certainty state that it refers to the law about תינוקות in B. Yōmā 82 a. Since its contents were not found in Talmud, they were written on the margin. Compare note $6 r$.

The author decides about the fasting of children as does Rab Huna and Rab Naḥmān, and not as Rabbi Yōḅānān. The first phrase is found in Alfāsī.

109 The words are badly preserved, but these words are fitting to the context.

110 This argument is given in 7 in', 2nd part $45 \mathrm{a}$.

111 Thıs argument is found in Rabbi Hananēl and Alfāsī.

112 The following is written in smaller script and is possibly a later addition by the man who used it. He confirms the decision of the original writer. The first phrase is doubtful. Compare the argument of Rabbi Yeshāyā for his decision against the opinion of Rabbi Yọhānān which is essentially the same as given here:

ופסק רבינו ישעיה רלית הלכתא כרבי יוחנן דהא אתותב

(See טבילי הלקט N. 3I2.) 


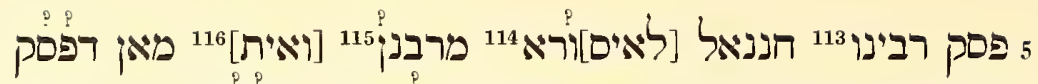

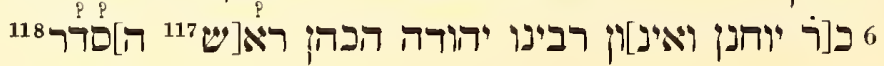
רב ..120

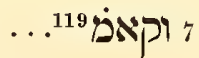
ורבינו יצחק בעל 121 ...

סי ואנן כתבי[נן נפ[י רסבירא לן רהלכה כרב הונא ורב נחמן בתינו[קות]

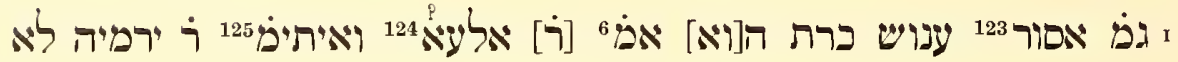

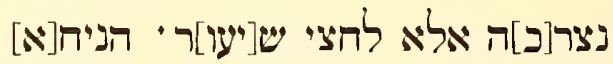

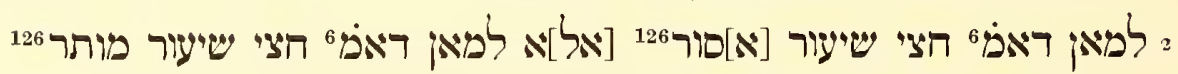

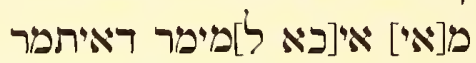

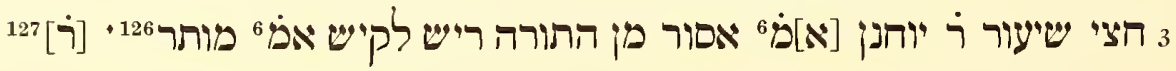
יוחני אפים

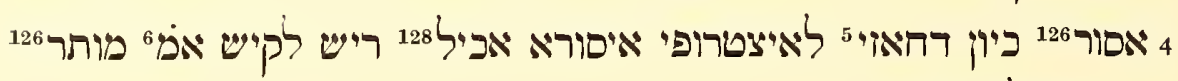

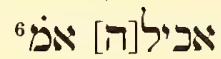
5 [רחמנא] והא לאו אבילה [היא] 129י הניחא לר יוחנן אלא לריש לקיש

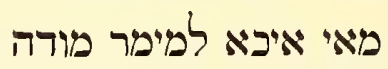

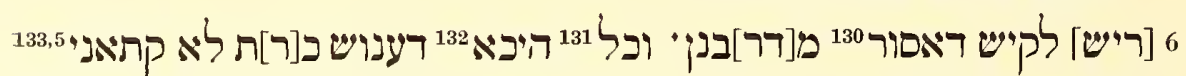
אסור [י]התניאיא ראפיא

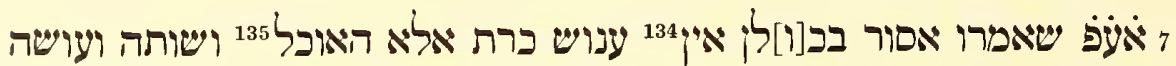
מלאכה שמרו

8 בלברי הכי קאפי6 [כש]אמרו אםור לא אמרו אלא בכחצי שיעור אבל בשיע[ור ענושי]

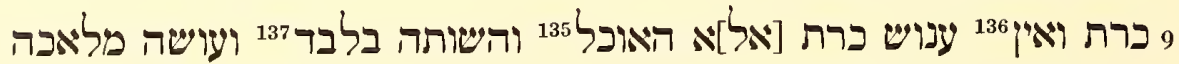

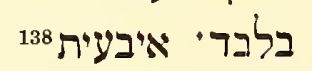

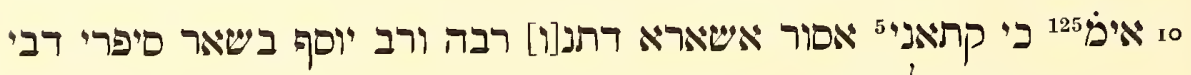
רב מנין [ל]יט[ם]

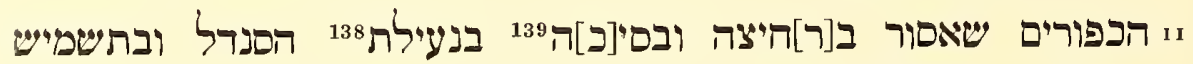

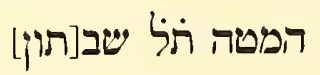

113 See note III.

114 The word is not well preserved, but there are traces of the letters. Perhaps the questioned letter was 1 .

115 The last letter is not certain, but it fits the context. 
of this a line was omitted; and this is added in the margin with marks indicating its insertion. Then follows a passage on the wearing of shoes, the ending of which is mutilated by erasures, circles, and marginal corrections. The text is interrupted in the middle. Then is inserted a law from Maimonides on salting the sacrifices. Then comes a three-fold colophon in which the writer thanks God for helping him to explain these laws. On the left-hand margin is a law about a cripple who is forbidden to use his peculiar shoe on the Day of Atonement. There must have been something about this in the original text, which was removed to accommodate the passage from Maimonides. To the decision on the margin a much confused note is attached. In the midst are a few faint words in Aramaic, relating to the subject, but belonging to an earlier entry on top of which this was written. As we see from the narrowness of the space, both notes were written after the passage from Maimonides was filled in. At the end of the recto are two lines which seem to be the remains of the original text, upside down, and which escaped the erasure. They treat of a subject apparently from Middōth. In the space between the Talmudic passage on the wearing of shoes and the insertion from Maimonides are a few unintelligible words.

116 The restoration is not certain.

117 The restoration is not beyond doubt. If this restoration is correct we may have here an allusion to the leader of the Babylonian section at Fusțāt. See for this person Jacob Mann, The Jews in Egypt and Palestine, under the Fatimids, vol. ii, p. Io , note 2, and elsewhere.

118 Here follows another illegible word or ligature.

119 The word seems to be a remainder of the former text. The rest is wiped away.

120 The word is not clear.

121 The name of the book is not clear. Perhaps we have here the Alfāsĩ referred to. The letters are pèrhaps מיפומת סתרים. Compare Mann, vol. i, p. 297, note I.

122 If the preceding suggestion is correct the text could be restored כרב הונטא ורב נחמין

123 The passage is found in B. Yōmā $73 \mathrm{~b}$.

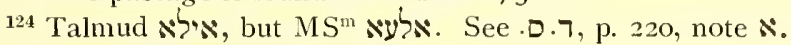

125 Here תיפ without $\mathfrak{x}$. Cf. note 40.

126 Talmud adds מין התורה. Cf. MS². See . 220, note 2, p. 22 I, note'.

127 The arguments of Rabbi Yọạanān and Rēsh Lāḳish are omitted in the Talmud in

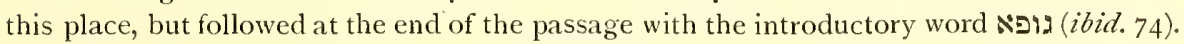

128 Talmud adds 2 .

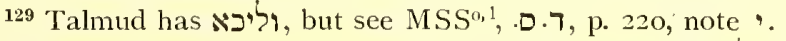

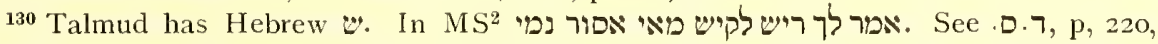
note $ב$.

131 B. Yōmā 74a. The passage which precedes this in the Talmud is omitted here since it has nothing to do with the Day of Atonement.

132 Talmud adds 'רתי, but it is omitted in the MSS. See •.. , p. 22I, note $\pi$.

133 Talmud omits the $p$.

134 Talmud has לאיא אמרו, but cf. MSS ${ }^{2,1}$ in . ד. p. 22 I, note ט.

135 Talmud adds על

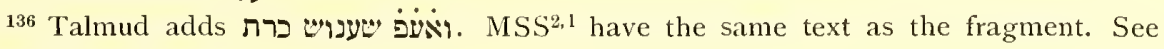
๑. T, p. $22 \mathrm{I}$, note $\bullet$.

137 The word was scratched out by the writer as soon as he realised his mistake.

138 Talmud adds 9 .

139 Talmud omits the $?$. 
2 שבות : תנו1140 רבנן תענו את נפשותיכם

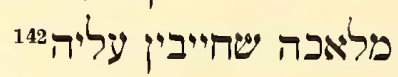

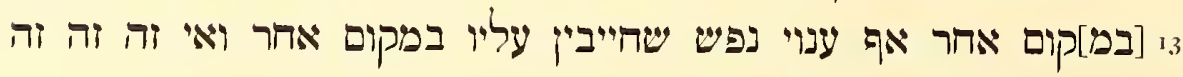

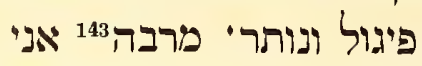

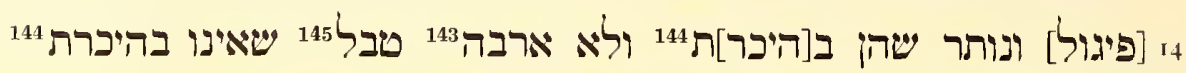

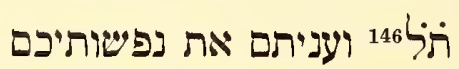

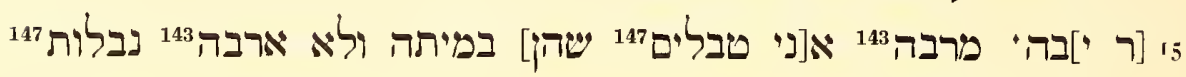

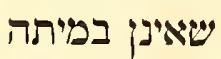
6י נלל ולא ארבה

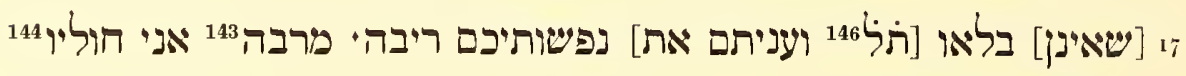
שאינן בעמור 148

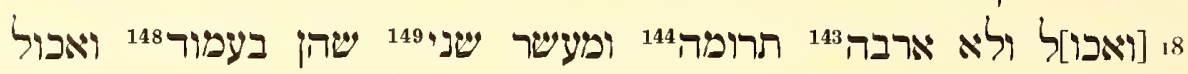
זלל

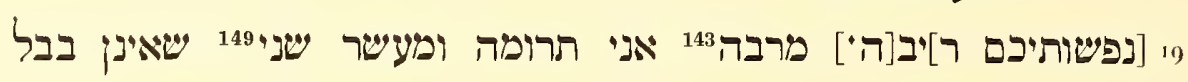
תותירו ולאי ריכם

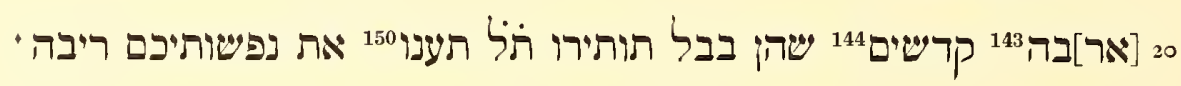
Insertions: No. I : Recto:

ולא להיכלי ביאי ס הילכות 151 ביאת [המקר]

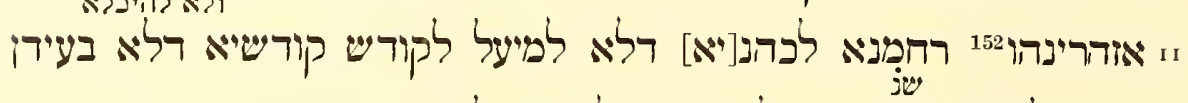

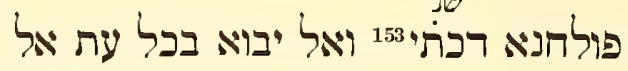

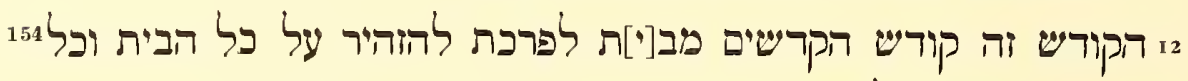

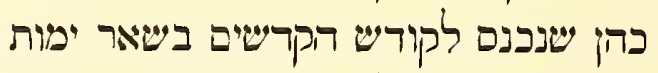

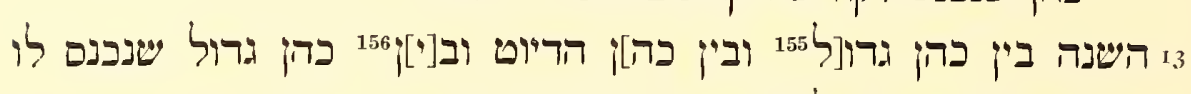

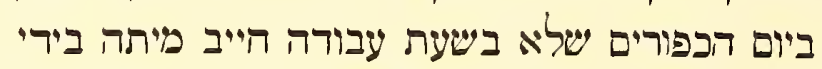

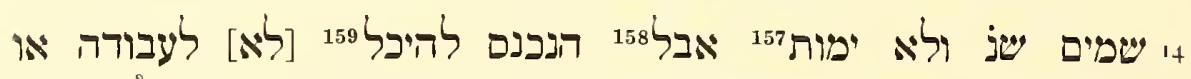

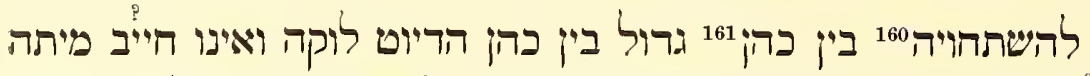

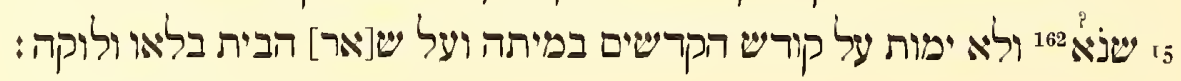
Under line 16 : 
The verso begins with a final sentence on the wearing of shoes. Then follows a passage from the Babylonian Talmud on the lighting of candles on the Day of Atonement, and another from the Jerusalem Talmud on the same act when it occurs on the Sabbath. After this there is a blank space and a marginal note. The next passage, on the side, contains passages from both Talmuds, on Eating-that from the Babylonian shortened considerably. This is followed by something about Drinking, interrupted in the middle by an erasure, in which is inserted a Talmudic excerpt in smaller script. On the margin, from the bottom up, is a note on the fasting of children, referring probably to the original text here erased. It seems to be by a later writer, and bears the name of Rabbi Hananēl, as well as the names of authorities otherwise minded, though the names and the analysis are uncertain. There is some illegible writing behind and above.

There are thus four elements in the fragment: I. A main text, dealing with laws on the Day of Atonement, and taken from the Talmud. 2. Marginal notes on decisions touching such lavs. 3. Inaccurate extracts from Maimonides. 4. Additions to the main text.

${ }^{140}$ B. Yōmā $74 \mathrm{~b}$. Talmud has another apocryphal Mishnah, but it is omitted in Jer. Yōmā 44 d.

${ }^{141}$ Talmud adds יכול ישב בהמה ובצינה ויצטער הילי. For the text of the fragment see $M S^{m i}$ in .๑.7, p. 222. Cf. note ע.

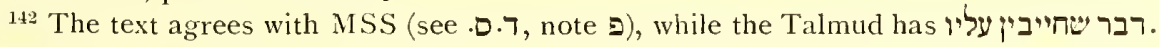

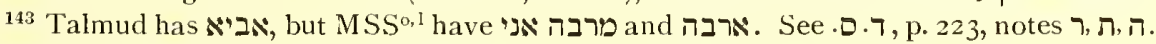

144 We have here the origin of כרת. See Levy, Wörterbuch, vol. ii, p. 420.

145 Talmud adds..... אה הע.

${ }^{146}$ Talmud adds תענו. Some MSS ${ }^{m, 0,1}$ have only this and omit ועניתם. However MS ${ }^{2}$ has the same text as the fragment. See 0.7 , notes $p, \boldsymbol{W}, \mathbf{N}$.

147 Thus MSS ${ }^{\circ, 1}$, but Talmud הטפל....

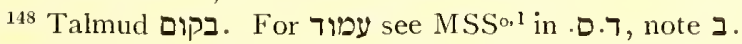

${ }^{149}$ This is omitted in Talmud and has consequently the singular. For the text of the fragment compare . $\square . T$, notes $\lambda$. ב.

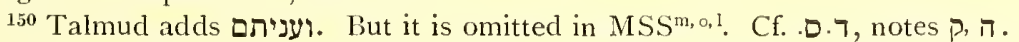

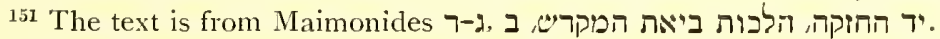

152 The first sentence is changed here from Hebrew into Aramaic. The original has והוזהרו כל הכהנים שלא יכנסו לקרש או לקדש הקרשים שלא בשעת עבורה

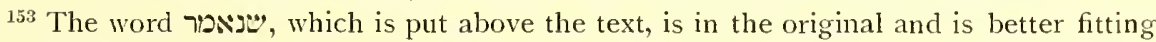
than דכתיב

154 Original omits $\$$.

155 Original has reversed order.

156 Original $ו$.

157 Original has here וכמה פעמים הויא נכנם. In the fragment it is at the end.

158 Original only $\%$

159 Original has instead לקרש חויץ לקדש הקדשים.

160 Original לפישתחוות.

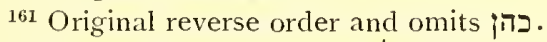

162. Original adds אל פני הכפרת.

${ }^{163}$ See note 157.

164 Original adds ביום הכפורים.

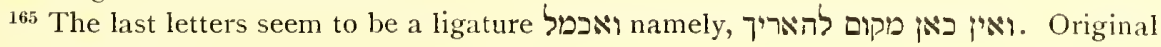
has וכבר בארנו... 
No. 2: Recto:

32. הילבות 166 פליה 33

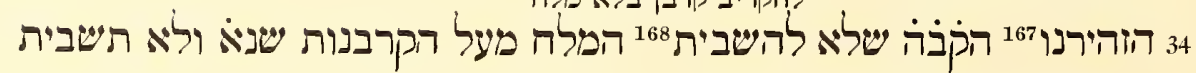
מלד ברית

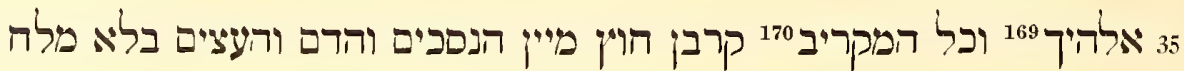

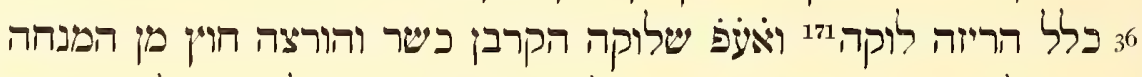

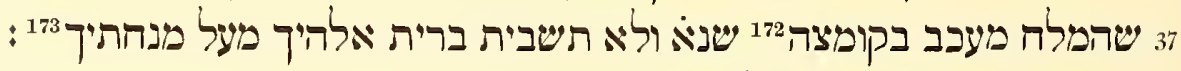

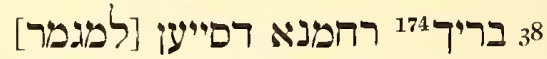

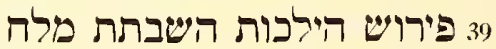

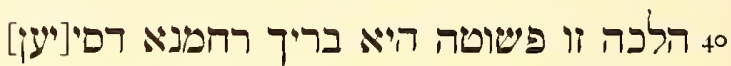
ז4 סליקו להו הילכות השבתת מלה גיפה גירסא ופירושיא.... Addition ${ }^{175}$ to recto, lines $7-8$ (הרואה קרי):

8 פי אלפירושא176... האי177 דתניא הא פילתא הזיא ליה לרבינו משה הרב דגדול דיאוקפ

9 האי שמעת איאי178 אוקמה רבינו פישה הגדול נ.180 בהיבורא ריליה 181

בשעה שתיקנו

Verso:

ו טבילה לבעלי קריאיִין וכבר ביטלוה לטבילותא ריא

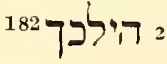

3 4 Addition to yup (left margin of recto):

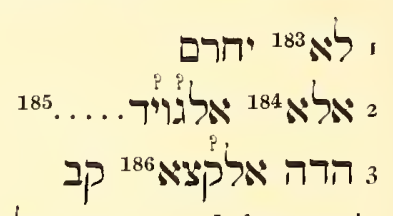

${ }^{166}$ The original is in Maimonides יד החזקה, הלכות אסורי מובחה ה, יא-י It has two inadequate headings.

${ }^{167}$ It is a free rendering of the original: מצות עשה למלוח כל הקרבנות קודם שיעלו למזבה.

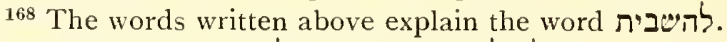

169 Original quotes על כל קרבנך תקריב מלחים

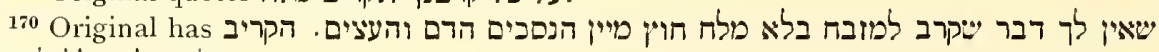
בלא מלח כלל לוקה.

${ }^{171}$ Here is added שלח כלהמר ולא תשבית מלח ברית אלהיך.

172 Original has בקלמיד

${ }^{173}$ Omitted in original.

${ }^{174}$ This is a colophon, which is written in three different ways in order to fill in the space. 
The main body of the text is not simply copied from the Talmud. It does not follow the same order as the latter, even including a passage from Pesăhìm; it omits portions of passages when irrelevant to the purpose in hand; it combines both Talmuds; and it uses the Talmudic expression for a Mishnah from another treatise. Our fragment is thus clearly a codification, perhaps from some pōsēk, though different from those commonly know11. It reminds one of Alfāsī and other African scholars. It uses the technical term ואסיקנה; regards both Talmuds as equally authoritative; omits unnecessary text; and agrees on the fasting of children. On the other hand there is no explanation of words and phrases; and the text itself contains no decisions. We may conclude that this codification could dispense with explanations and decisions, because it was to be used by a teacher, or with the help of a teacher. The character of the erasures and additions, as above described, point rather to the conclusion that we have here a teacher's notes. It seems not to have been taken from an existing pōsēk, but to have been composed independently for teaching purposes, and there may have been other pages of the same sort, covering the other holy days. The spiritual leaders of communities were accustomed to teach them the laws concerning each holy day thirty days in advance. Our fragment might be the memorandum of such a teacher; and it might even have

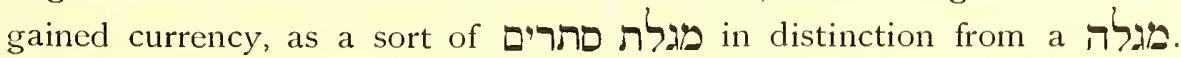
(Cf. Levy, Wörterbuch, vol. iii, p. I7.) The Mishnah was not included, because it was already known to the pupils, or more easily available. Possibly Alfāsī's work was called מגל מגת סתרים for the same reason. Cf. Mann, op. cit., vol. ii, p. 297, note I.

175 The addition seems to have been put in after the space was filled with the insertion copied from Maimonides.

${ }^{176}$ It seems to be Arabic. The rest is not clear. "In explanation"...

177 The line was partly crossed out.

178 The word מימער מעת was explained by.

${ }^{179}$ Here reference is surely made to Maimonides.

180 The first letter seems to be certainly a 2 . The second letter, unfortunately, is not clear. The word is apparently a ligature. It was either $\ddot{j}$, in which case Maimonides was alive, or $\dot{y}$, in which case he had already died. The lack of space urged the writer not to be extravagant in titles. הרב הגדול is the usual title for Maimonides.

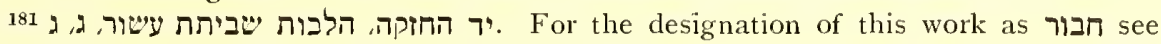
Kobeș I, 25c. (Cf. Mann, vol. ii, p. 316.)

182 Some words are omitted, namely .... אסור לטבול.

183 The addition to 2 ? was written after the insertion from Maimonides was made and thus there was no space left for it, and therefore filled in the space in wedge form. The beginning is in Arabic, the end in Hebrew and in the middle are some words in Aramaic.

184 The glossator intends apparently to define what קב is prohibited. And he states: "lt is forbidden only....."

185 The word is badly written and the letters are indistinguishable. From the context we may assume that it designates the form of the phich is forbidden to be used on the Day of Atonement. This must be in the form of a shoe, otherwise there is no reason for its being forbidden to be used on the Day of Atonement. Cf. Tōsephōth to Yōmā 78 b.

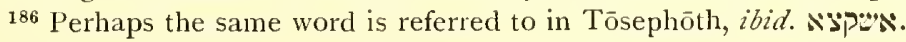




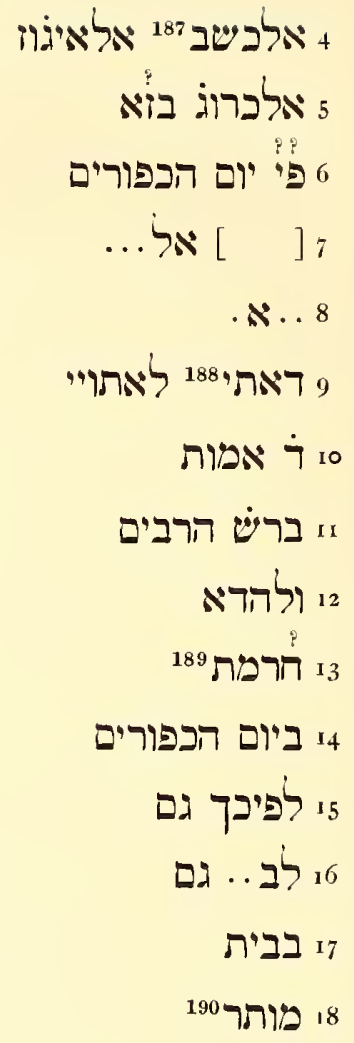

Recto backward:

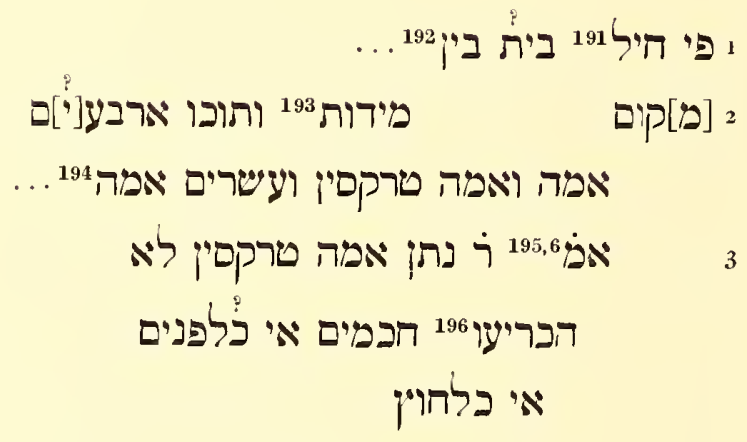

\footnotetext{
187 The words are the Arabic الخشب العجوز الخروج.

188 These few words are a remainder of an earlier note in Aramaic.

${ }^{189}$ This is apparently the end of the Arabic note.

190 This seems to be the end of the note from which few words remained in Aramaic. Cf. note 188 .

191 It seems that we have here an explanation of
} 
The fragment in its present state contains the names of Maimonides, Rabbi Hananēl, Rabbi Judah ha-Kōhēn, and Rabbi Isaac. But the last one is uncertain, and all four are probably younger than the text, Maimonides at any rate. The text itself is a copy, as may be seen from errors, corrections, omissions and inconsistencies, of a sort very unlikely in an original. No conclusion as to date is possible.

If we look for a likely author, someone from the country of Rabbi Hananēl, a teacher, to whom a פגל פתר שרים was attributed, we may choose

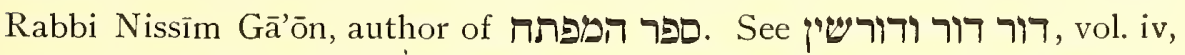
pp. 236-238. By פמגלת סתרים was meant, however, particularly the teacher's comments, preserved by the pupils, and not intended by the teacher for publication. See Jervish Encyclopedia, vol. ix, 3 I 5 ff. The present fragment is the text-book, to which the comments and their results were attached. Thus the present fragment contains a passage from the Jerusalem Talmud about כורתבת which is quoted from Rabbi Nissīm by the 'Ārūkh, apparently from his מגלת פתרים.

מעלת פתרים, or even from some text-book. In any case it has a text superior to that of the printed edition of the Talmud, in the sense that it combines the best of the known variant readings; and it may well be the old African recension of this time.

192 The phrase is not well preserved and is not clear.

193 Mishnah Middōth 4, 7.

194 In the Mishnah בית קדש הקרשים. There is not enough space for all these. Perhaps we have here a ligature.

195 B. Yōmā 52 a.

196 Talmud adds 1.

\section{BIBLIOGRAPHY}

Talmūd Bablī, meaning the printed Talmud, Wilna, I88 I : Text, Rashī, Tōsephōth, Rabbi Hananēl, Tōsephōth Yeshānīm, Rabbi Asher.

Talmūd Jerūshalmī, Louis Lamm, Berlin, 1920. (Photographic reproduction of Krotoschin edition.)

For the MSS : דקרוקי סופרים (abbreviated : •.7) of Raphael Rabbinowicz, I87I. The Munich MS is designated by a small $\mathrm{m}$, the second MS of the same place by 2, the Oxford by $\mathrm{o}$, the British Museum by 1 (London), following the Hebrew marks used by Rabbinowicz.

The following Pōsekìm, which partly share the methods of the writer of the fragment, were compared :

הלכות גרוליות Warsaw, I874, pp. 6I-62.

Rabbi Hananēl, Wilna, ı 88 I.

Alfāsī, Wilna, I88ı.

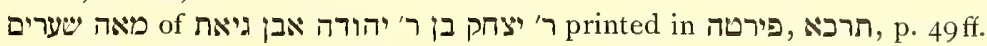

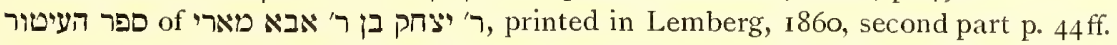
from Vienna, printed in Zitomir, I862, second part p. I62ff. Rabbi Asher, printed in Wilna, I88I.

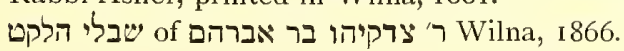




\section{LEAVES FROM A NOTE-BOOK}

Paper $6 \frac{3}{16} \times 6 \frac{1}{8}$ inches, folded down the middle so as to form two leaves and four pages, all of which are covered with writing in the same difficult cursive Hebrew hand. On verso (b) the postscripts have been written diagonally.

The language is Arabic, with a colloquial tinge, at times very difficult, not only because of the strange constructions, but also on account of the many technical terms relating to wearing apparel and the like.

The date is A.D. I I4I-I I 42.

\section{Recto: $(a)$}

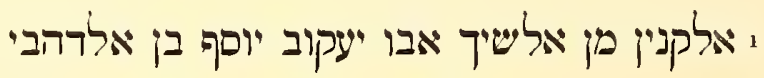

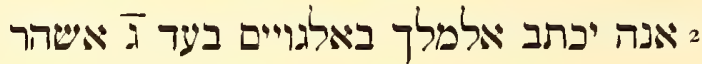

3

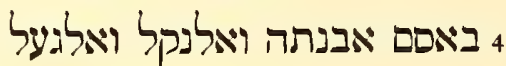

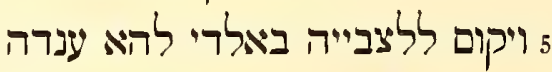

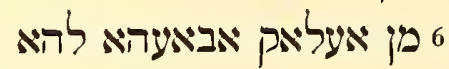
יקום מן רלך

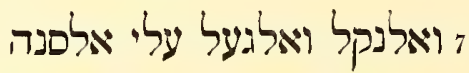

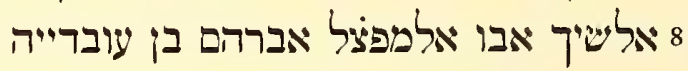

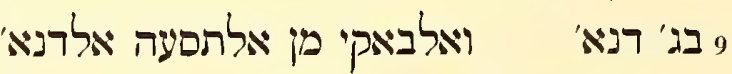

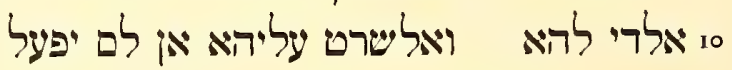

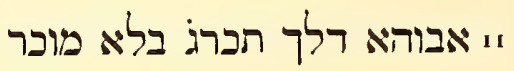

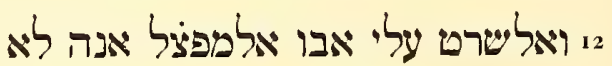

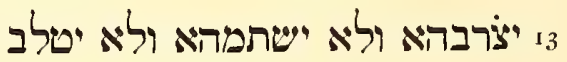

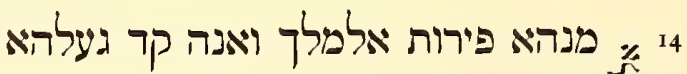
15

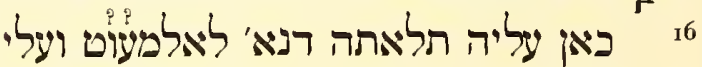

7

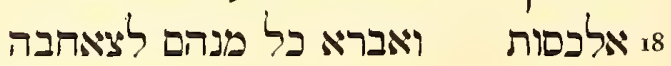

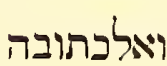
פו אליאב ואלאבנה ו"הלזוני

\footnotetext{
${ }^{1}$ I.e. "he will write in the name of."

${ }^{2}$ Era of Documents: Tammūz I $453=$ July A.D. I I 4 I.

${ }^{3}$ I.e. "turnover and make."

${ }^{4}$ See No. XL, Introduction and note 8 .
} 


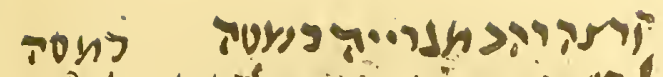

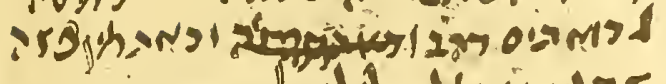

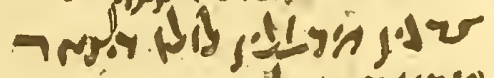

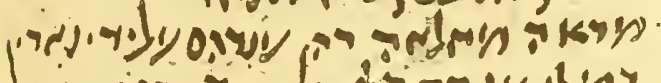

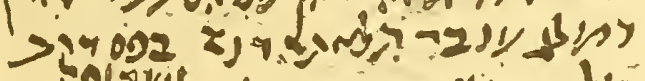

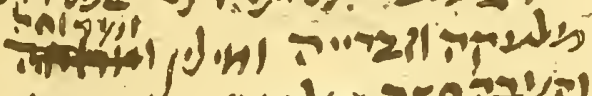

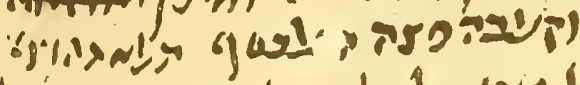

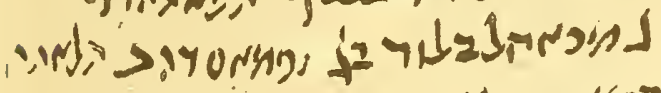

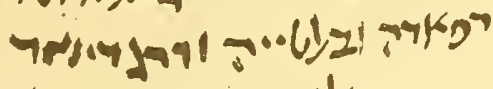

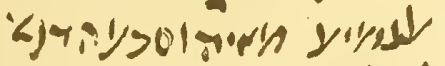

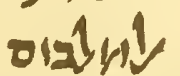
בוl

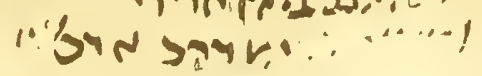
"7n,

|

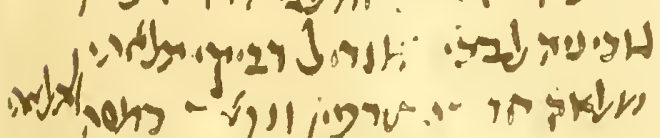

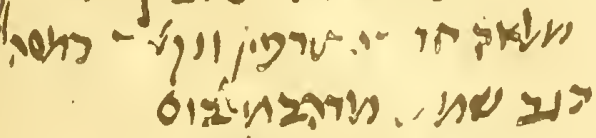

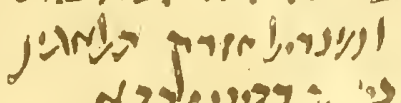

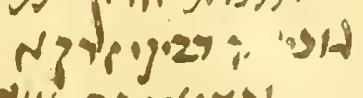

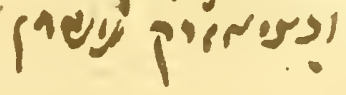

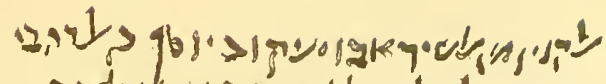

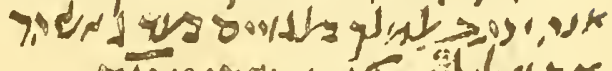

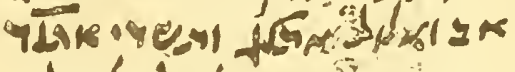

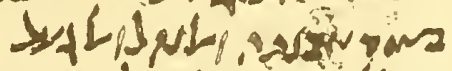

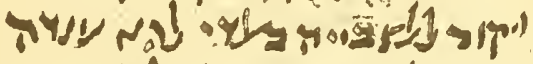

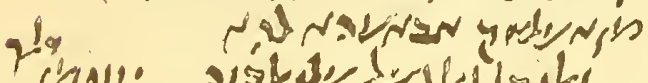

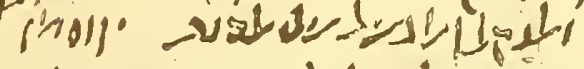

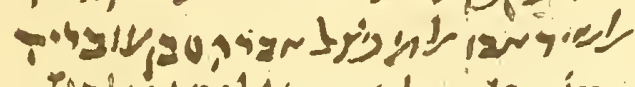

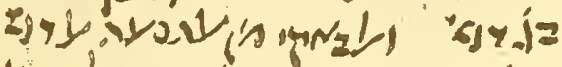

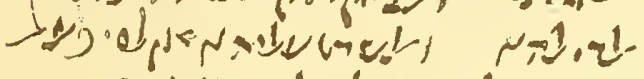

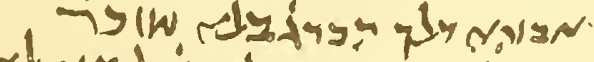

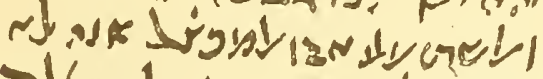

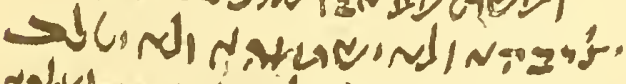

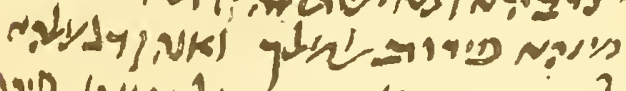

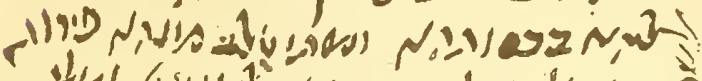

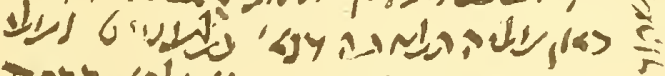

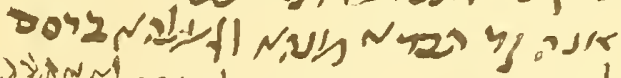

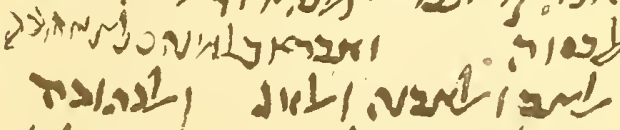

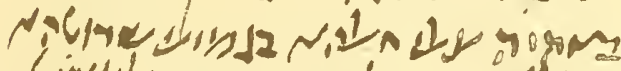

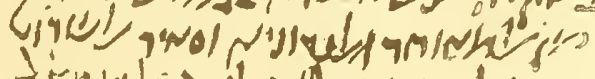

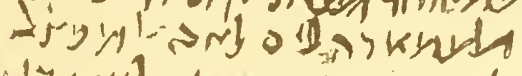

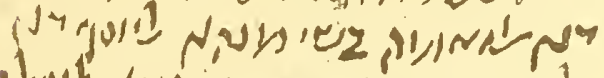

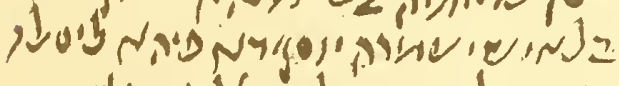

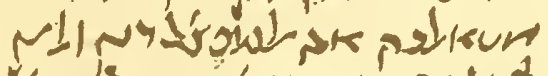
Uasho ILANin 
rods z y

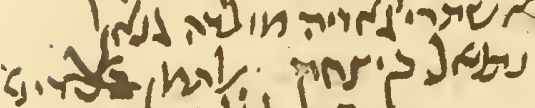

\section{vdroblembryad}

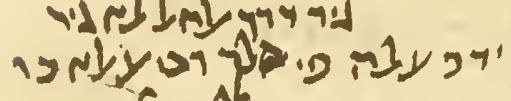

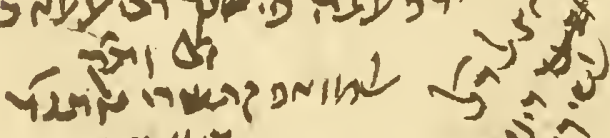

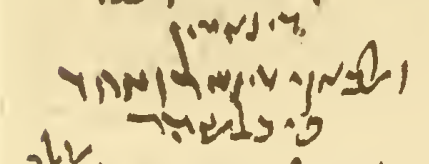

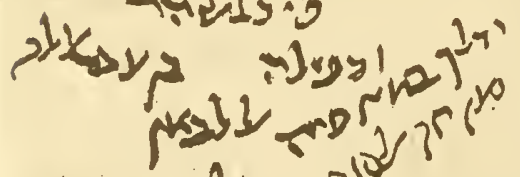

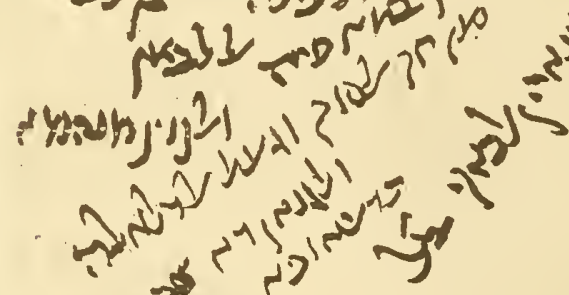

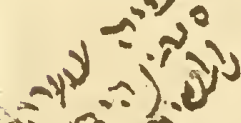

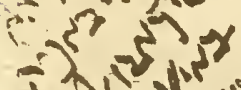

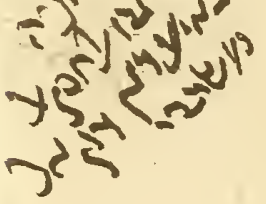

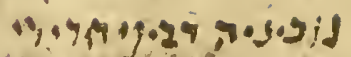

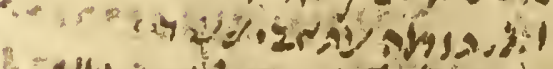

Jy

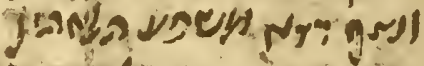

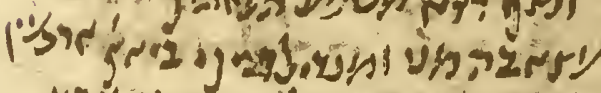

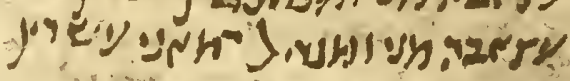

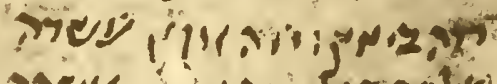

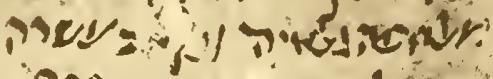

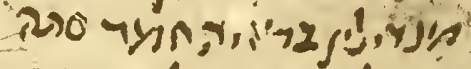
Pky blisshicodirst

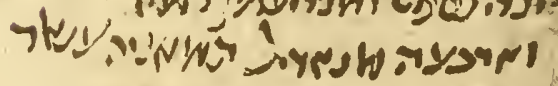
- polso - 2.2 $24+5 y$

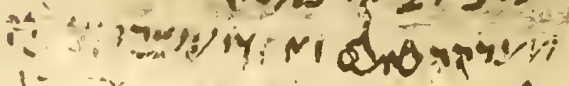

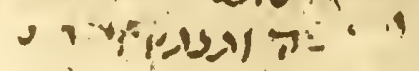

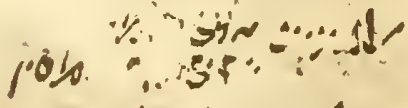
4. $\because x+1$

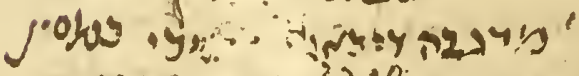
J185in a PYey joid

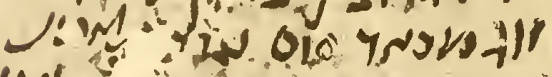

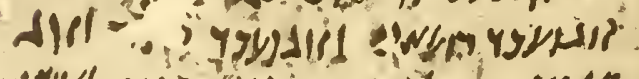

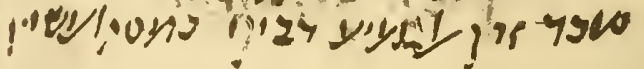




\section{LEAVES FROM A NOTE-BOOK}

The contents of the four pages seem to be unrelated. Recto $(a)$ and $(b)$ and verso $(a)$ refer to marriage settlements, similar to those in No. XL. Verso (b) deals with a case, very interesting but not very clear. Mufaddal, under the suretyship of al-Labbān, buys of Abū al-Hasan-Muslims, all of them--the "offspring" of Janān Nathan Ben Isaac, the Jew; and another daughter of Nathan becomes the property of Abū al-Hasan. Nathan seems to have died or to have been forced in some unknown manner to permit such a transaction.

\section{Recto: $(a)$}

I The possessions of the Sheikh Abū Jacob Joseph Ibn al-Dhahabì:

$2 \mathrm{He}$ will convey ${ }^{1}$ the property [which is invested] among the gentiles after three months-

${ }_{3} \bar{A} \mathrm{~b}$ and Elūl I453, and Tishrī I $454^{2}$ -

${ }_{4}$ to his daughter, together with the profit and gain ${ }^{3}$ [accruing from its investment].

5 And he will give to the girl what he has of hers, [accruing]

6 from apparel which he caused to be sold for her,

$\tau$ and the profit and gain ${ }^{3}$ by the year. Of this [marriage settlement the bridegroom, ]

8 the Sheikh Abū al-Mufaḍal Abraham Ben Obadiah, shall provide

9 three dīnārs [muḷ̣dām, ${ }^{4}$ and [six dīnārs, me'ūhār, $]^{4}$ the rest of the nine dīnārs

ro which belong to her. And the condition [laid] upon her [is that], if her father

Ir shall not do this, she shall go forth [from her father's house] without any purchase price ${ }^{5}$ [from the bridegroom].

12 And the condition laid upon Abĩ al-Mufaddal [is that] he shall not

${ }_{3} 3$ beat her, nor insult her, nor demand

${ }_{14}$ from her the fruits ${ }^{5}$ of [her invested] property; for he has promised them to Is her through her [investments in] apparel. And if he shall demand of her the fruits ${ }^{6}$ [of her investment],

is he shall be liable for three dinārs for the ........?

${ }_{17}$ and on condition that he has ..........(? $)^{8}$ from her, whereas he promised them [to her] in the agreement

r8 [about] the apparel. And each of them absolves his companions [from all liability]:

ig the father, and the daughter, and the husband. And the marriage contract

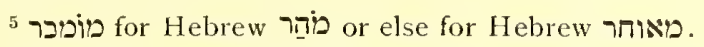

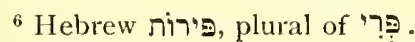

? Hebrew מִּעוּ?

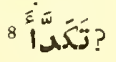


20 באקיה עלי חאלהא בגפיע שרוטהא

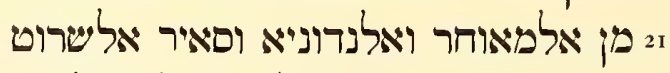
22 23 דא אלזיאמה בשי מנהא ליוסף דאי לאי לאים

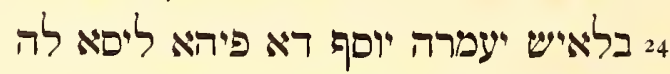
65 מטאלבה אבו אלמפצל דא ולאיא

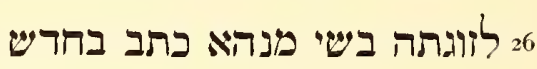
תמון אתנג בחרש

Recto $:(b)$

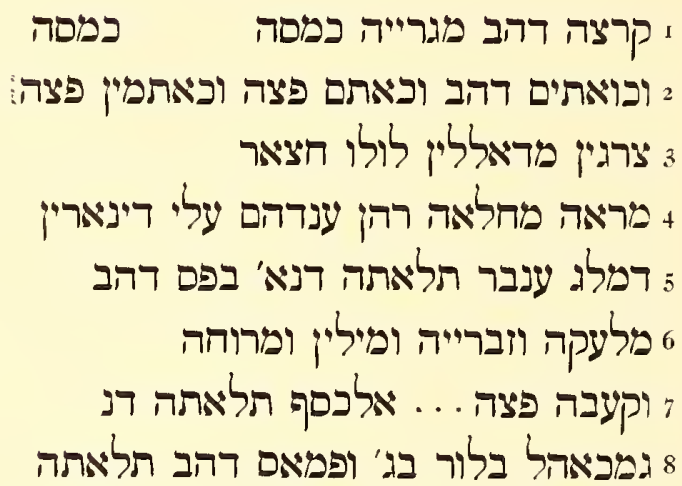

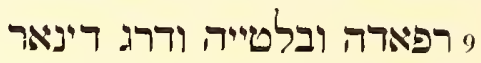
10 אלמלבום

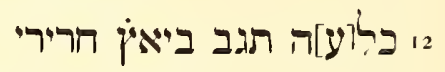

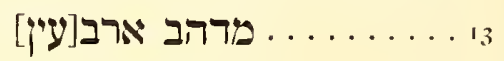

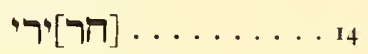

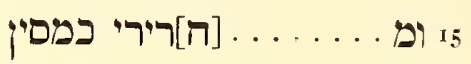
16 כלעה יאהו"די] ומעגרהא ארבעין

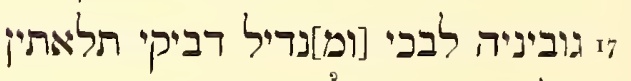

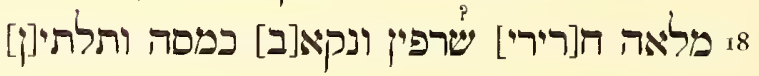
9ו תגב שמ[ם] מרדב מלבום

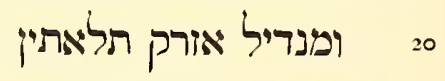
21 22

${ }^{9}$ Vernacular Egyptian Arabic, the postpositive demonstrative $d a$. 
20 remains as it is in all its stipulations

2r as to the me'ūhār and the nedunyāh ${ }^{4}$, and the remaining conditions.

22 And [as to] the housekeeping: This ${ }^{9}$ Abü al-Mufaḍal has no

23 responsibility for any part of it. This ${ }^{9}$ Joseph has [the responsibility].

${ }_{2+}$ Without $\operatorname{cost}^{10}$ he shall maintain [Abū al-Mufaḍal] in it. He has no

[right to make any]

25 request of this Abū al-Mufaḍdal, nor

26 of his wife for any part of it. Written in the month of

27 Tammūz I 453 ? 2

Recto: (b)

I A Hungarian (?) gold disc-five.

2 And gold rings ${ }^{11}$, and a silver ring ${ }^{12}$, and two silver rings-five.

${ }_{3}$ Two saddles ${ }^{13}$.......pearls, a saddle cushion.

+ A mirror.........said to be worth about two diñārs.

5 A large amber armband [worth] three dīnārs, with a gold bezel (?) ${ }^{14}$.

6 A spoon, and a deep bowl, and two collyrium sticks, and a fan ${ }^{15}$.

7 And a silver cup......16 ${ }^{16}$ three dīnārs.

8 A crystal........ for three [dīnārs], and a gold.........-three [dīnārs].

9 A saddle cushion and a...... and a jewel-box-[one] dīnār.

ıo The whole [equals] a hundred and seven dīnārs.

II

The clothing:

I2 A silk of white.

13 .............gilded-forty.

It $\ldots \ldots \ldots \ldots . . . .$. silk,

${ }_{5}$ and ........... silk-fifty.

16 A Jewish......... and its hood-forty.

I7 A Labakī (?)......... and a Dabịkīin kerchief-thirty.

I8 A silk cloak...... and nikābe ${ }^{18}$ - thirty-five.

19 A gilded sun.........19 garment.

20 A blue kerchief-thirty.

2. A blue Dabī $\hat{k}_{1}^{17} \ldots . . . .^{20}$

22 and a blue...........-twenty.

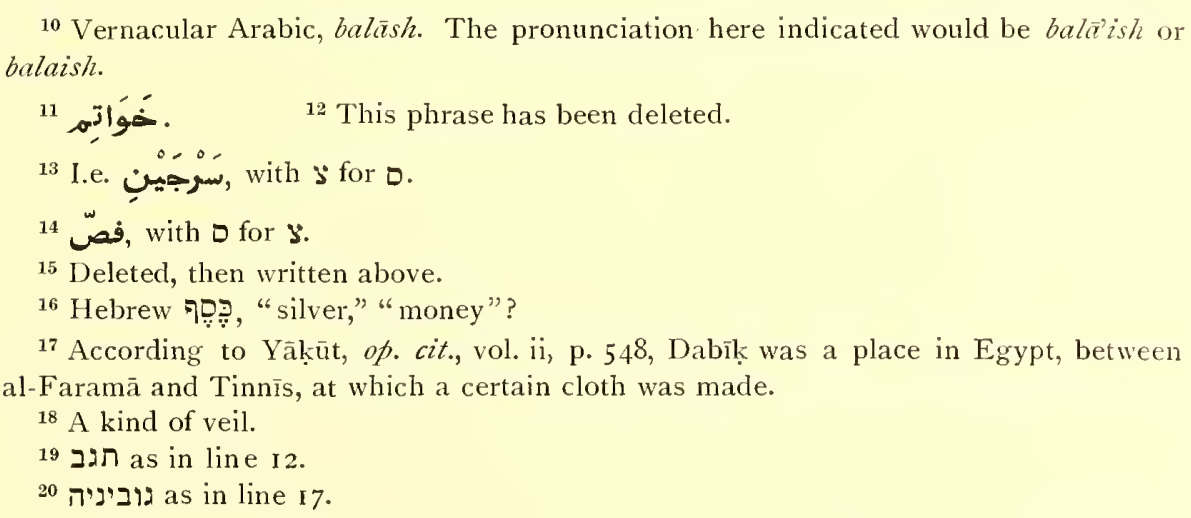


Verso: (a)

יגוביניה רביקי הרירי

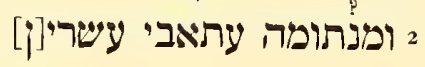

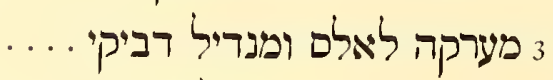

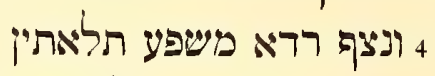

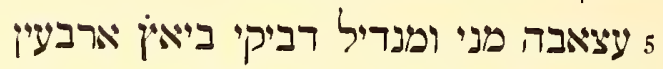

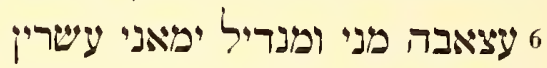

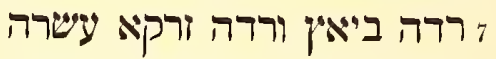

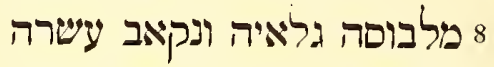

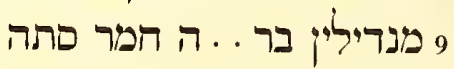

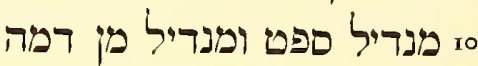

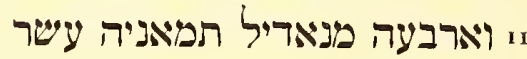

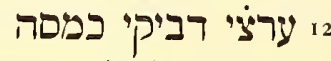

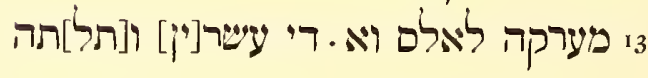

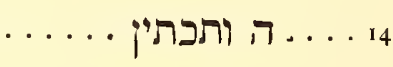
5 [ח.....

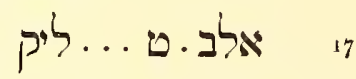
8 מרגבה ריבאג ... י"פי כמסין

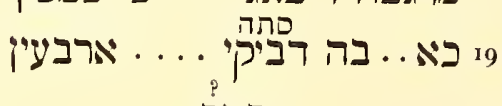
20

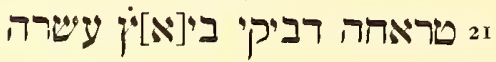

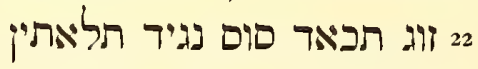
23 זווג מכר רמאני וזוג מכד ... וזוג

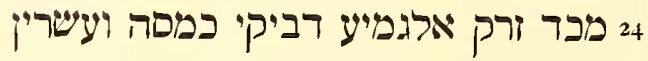

Verso: (b)

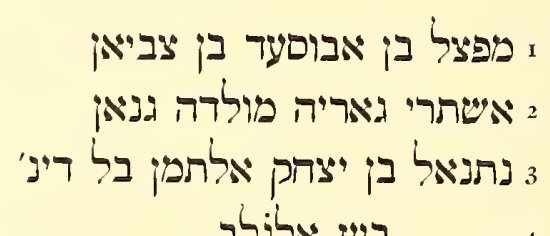

21 According to Dozy, op. cit., sub voce, a kind of taffeta originally of Bagdad.

22 Persian لَّ. 
Verso: (a)

1 A silk Dabīḳīin. 19

2 and an 'Attābī ${ }^{21}$. -twenty.

${ }_{3}$ A red silk ${ }^{22}$ skull-cap, and a Dabīkī kerchief.

4 and a half cloak, doubled-thirty.

5 A Munyī ${ }^{23}$ 'ișābah ${ }^{24}$ and a Dabiḳi kerchief of white ${ }^{25}$ - forty.

6 A Munyī 'ișābah and a Yemenite kerchief-twenty.

7. A white ${ }^{25}$ cloak $^{26}$ and a blue cloak ${ }^{26}$ - ten.

8 A........garment and a niḳāb ${ }^{18}$-ten.

9 Two kerchiefs, with a......... of red ${ }^{25}$ - six.

10 A kerchief of Saft ${ }^{27}$ and a kerchief from........

II and four kerchiefs-eighteen.

12 A Dabīḳi 'arḍāen_five.

${ }_{3}$ A red silk ${ }^{22}$ skull-cap and......-twenty-three.

$14 \ldots . . .$. and two waist-bands......

15 The total, four hundred.

s6 .........fifty

17 .............

is A...... of brocade.........-fifty.

I9 A Dabịịi................. forty.

20 ............

2r A Dabīkị coverlet of white-ten.

22 A pair of pillows: "Prince's Horse ${ }^{30}$ "- thirty.

${ }_{23} \mathrm{~A}$ pair of pomegranate-red pillows ${ }^{31}$, and a pair of.........pillows ${ }^{31}$, and a pair of

${ }_{2}$ blue pillows $^{3 t}$. The total of Dabịkị [goods], twenty-five.

\section{Verso: (b)}

I Mufaḍdal Ibn Abū Sa‘d Ibn Șubyãn

2 has bought a slave-girl, the child ${ }^{32}$ of Janān ${ }^{33}$

3 Nathaniel Ibn Isaac, the price [being] 32 dīnärs ${ }^{34}$.

+ The sale of slaves

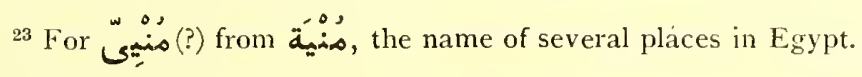

${ }^{24}$ A kind of turban.

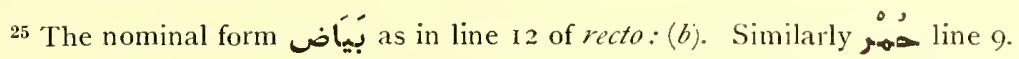

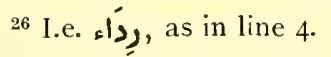

${ }^{27}$ Cf. Safṭ Abī Jirjā, Safṭ al-'Urfā and Safṭ al-Ḳ̂udūr, Yạ̦̃ūt, op. cit., vol. iii, pp. 97-98.

${ }^{28}$ According to Wahrmund, Handwörterbuch, sub voce "a kind of cloth."

29 Above the line : "six."

${ }^{30}$ Hebrew סוס נגיר.

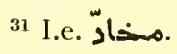

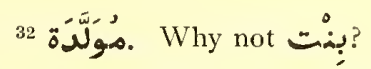

${ }^{33}$ I.e. "dark." Janān is not the seller. He is the father of the girl.

${ }^{34}$ There is a strange mark over the $ב$, and both numerals seen to have been deleted. 
5

6 $\overline{\text { i }}$

8 אלמואפק תשרי אתנד ותקי

9

1 ו ואלבאקי דיניאר ואחר

וי י פי כל שהר

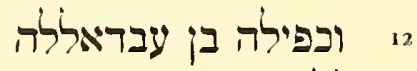

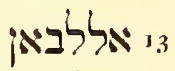

4 - ואיקלין מנהמאי

י ודלך במא פיה ימאי

2 פן חק אלסוק ונעשאל אלדלאלה במאה

י ולגנאי רא צבייה עמרהא

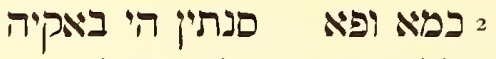

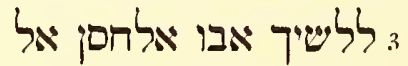

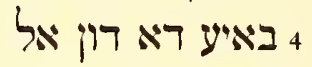

5

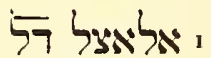

2 קכאי בער רינארין

3 יאלשיך אבואלחסן בער רינין

4 מנהא דינהרין אלבאין ביואסי בל

35 רביע should have the article.

${ }^{36}$ The Muslim dating is unusual, and is due to the circumstance that the seller, purchaser and surety were Muhammadans. Both dates equal exactly Oct.-Nov., A.D. I 42. 
5 at present [is] not otherwise than thus (?).

6 He [now] pays him in this [month of] $\mathrm{Rabi}^{-35}$ al-Ākhir,

7537 [A.H. $]^{36}$,

8 corresponding to Tishrī, I 454, [Era of Documents] ${ }^{36}$,

9 two dīnārs,

to and the remaining [thirty dinārs he will pay at the rate of] one dinnār

II every month.

12 And his security is Ibn 'Abd Allāh ${ }^{36}$

13 al-Labbān ${ }^{37}$,

It and the property of them both.

I And this [has been agreed upon] together with what it involves

2 in the way of market-fees and auctioneer's commissions.

1 And this ${ }^{38}$ Janān has a girl, aged-

2 according to settlement-two years. She remains [the property]

3 of this Sheikh Abū al-Hasan ${ }^{39}$, the

4 seller, instead of [becoming the property of] the

5 buyer.

I The basic [price is] 34 .

2 ..........after ${ }^{40}$ two dīnārs.

${ }_{3}$ The Sheikh Abū al-Hasan ${ }^{39}$ [takes]

+ from it two dinārs. The remainder is [therefore] 32.

${ }^{37}$ I.e. "seller of sour milk," or "brick-maker."

${ }^{38}$ Vernacular Egyptian Arabic.

${ }^{39}$ This shows that Janān is not the seller. See note 33 . The younger child is not "thrown in," but goes to the seller as a consideration.

40 בער 4 has been deleted. 


\section{A PAGE FROM A PRAYER-BOOK}

Paper $6 \frac{7}{8} \times 4 \frac{1}{8}$ inches, with writing on one side only.

Hebrew, in cursive Hebrew characters, pointed in a most unusual way which can be due only partly to ignorance. The vowels are here printed as they stand, regardless of the translation.

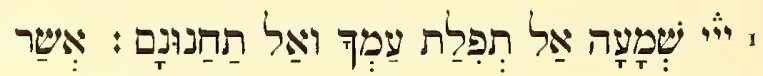

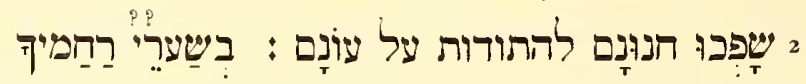

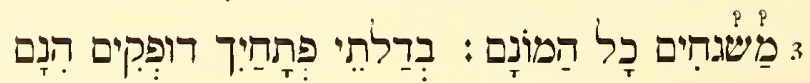
4

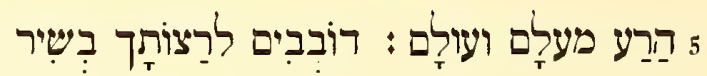

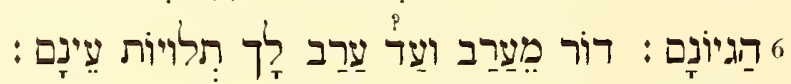

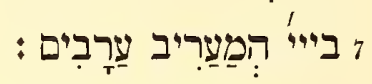

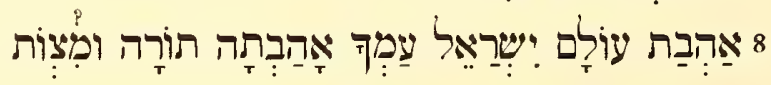

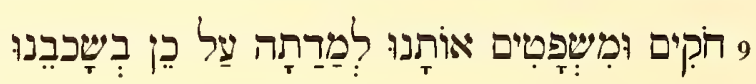

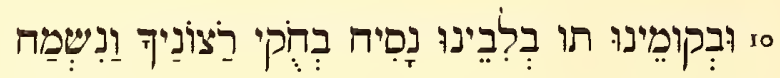

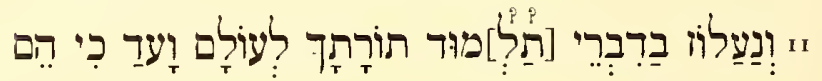

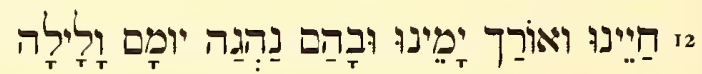

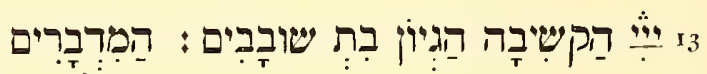

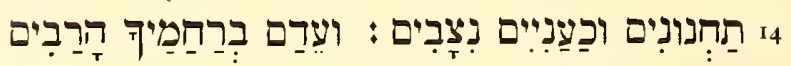

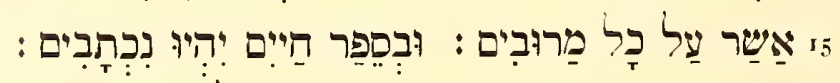
16

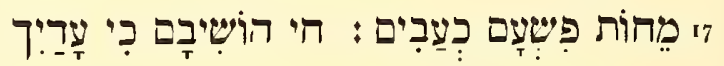

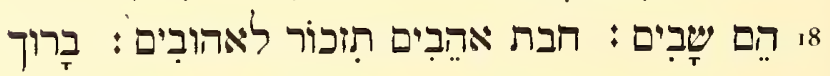

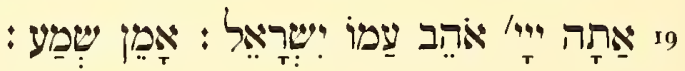




\section{A PAGE FROM A PRAYER-BOOK}

A portion of the Yōm Kippūr service.

The copyist las disregarded the verse division indicated by the rime. There are traces of an initial acrostic extending from $\boldsymbol{\aleph}$ to $\pi$.

I Lord, hearken unto the prayer of Thy people, and unto their supplication, who

2 pour out their entreaty, to confess their sins in the gates of Thy mercy,

3 watching, all the multitude of them, at the doors of Thy portals, knocking, behold them!

${ }_{4}$ Lord, forgive their shame, their sin, and their wickedness, the mote of their evil

5 judgments, for ever and ever. [They] appeal to Thy favor (?) with the song 6 of their music. A generation whose eyes are raised to Thee from the evening unto the evening.

7 Blessed art Thou, O Lord, that bringest the evenings!

8 [With] a perpetual love hast Thou loved Israel, Thy people. With Law and commandments,

9 statutes and judgments, [hast Thou loved] us therefore accordingly, when we lie down

to and when we arise. Also in our hearts........ by the statutes of Thy will, and happy

II and rejoicing in the words of the study of Thy Law, forever and ever. For they

12 [are] our life, and the lengthening (?) of our days; and in them we meditate day and night.

13 Lord, give ear to the music of the house of wanderers (?), who speak

It prayers, and, like the poor, stand up [before Thee]. Admonish (?) in Thy great mercy,

I5 which is plentious, over everything. And in the Book of Life let them be written down.

16 Often do they cry out, thirsty and hungry, to put aside their wickednessif the blotting out of their sins, like clouds. [O] Living [God] bring them back; for unto Thee

I8 [would] they return. Remember Thou the love of lovers toward [their] beloved [ones]. Blessed [art]

ig Thou, Lord, that lovest Thy people, Israel! Amen! Hear! 


\section{LETTER}

Paper $8 \frac{5}{8} \times 4 \frac{3}{4}$ inches.

Hebrew in cursive Hebrew characters, small but distinct, like those of Nos. XLI and XLVIII, though not identical with either.

The text is written in several directions, in order that the various postscripts and afterthoughts may not be confused. Two of these shorter additions are to be inserted into the text, and are here so printed, with asterisks.

The date is Wednesday, 7 th of Tammūz; and the 23 rd of Rajab, A.H. 460 (May 28, A.D. I067), is in the immediate past.

Recto : (a)

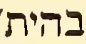

י השר והטפסר נשא ופיאר נעלה לשם ולתהלה ארוני כפהר פב'

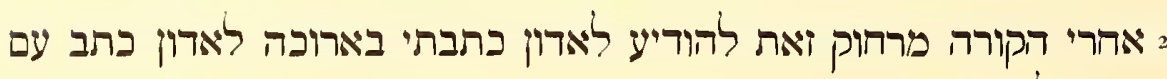

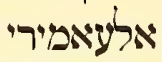

3. מתםאפיר הרבאעה שרלפה בחברת החכם כהר' יעקב בירב יצ' פי ת'

หาะทย

4

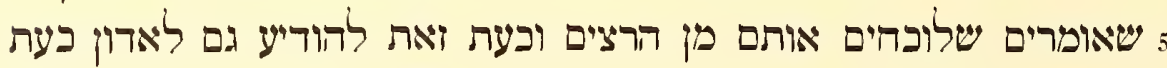

דיום

6 יום רביעי i' לחרש תמוי הגיעה רבאעה כמו קפ' חמל גמאל ואפגאל

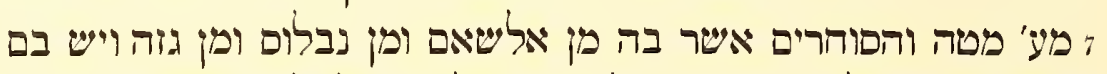

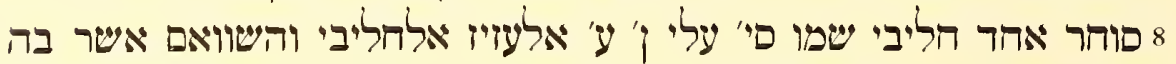

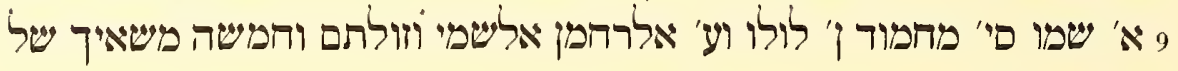

יהורים

ס והשיאר בפו שהולך בקאיפה הרבאעה בפרטית ודגירו לנו הפוהרים

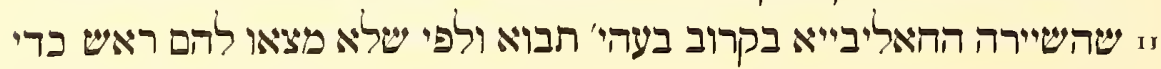

1 בצכת בת בת.

2 Apparently an epistolary formula, meaning "after the greeting." Perhaps קורת דרוח = הקורה

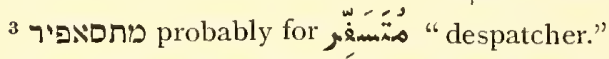

${ }^{4}$ Arabic עושר suggests a vernacular form: "ushrin, unless the $q$ is transposed from before the $y$ where there should indeed be a 1 . Hebrew.

5 l.e. of the Hijrah, which equals May 28th, A.D. I067. The $\pi$ would then stand for 400 , nor for 3 , as above. 'سنَّةُ

6 The letters, though plain, yield no sense.

7 Arabic. 

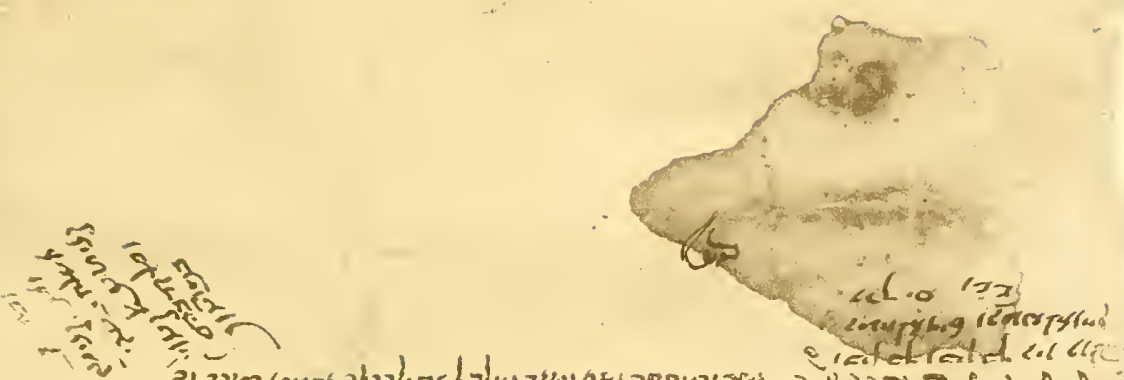

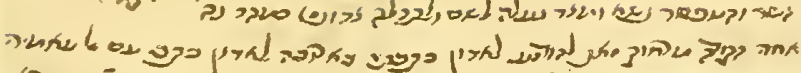

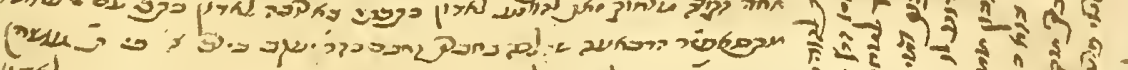
हैं के

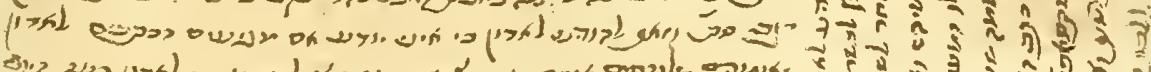

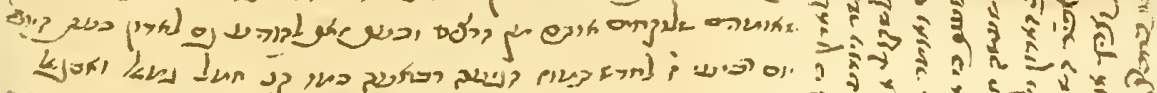

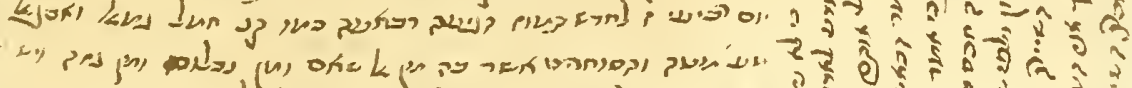

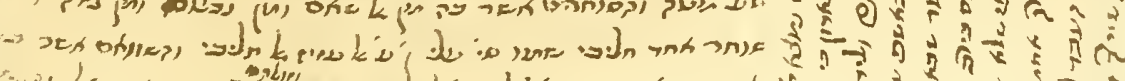

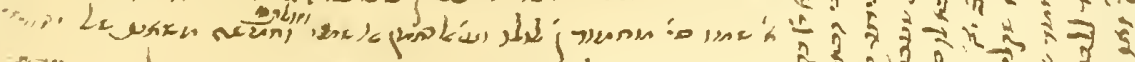

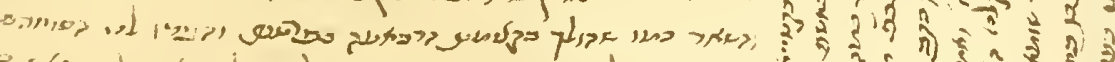

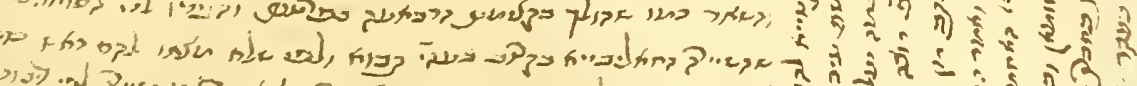

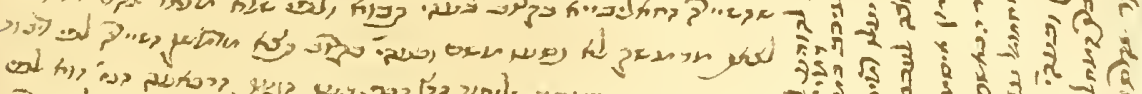
然

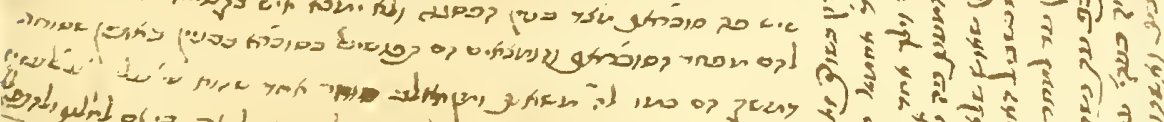

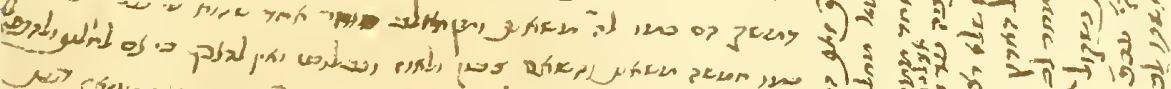

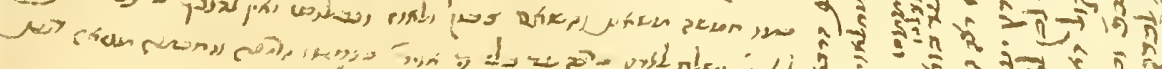

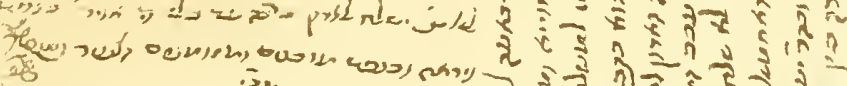

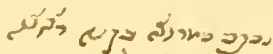
sweal's is a d

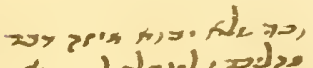

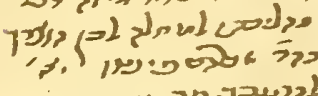
Ex; ; $=7$ ind on cost, al

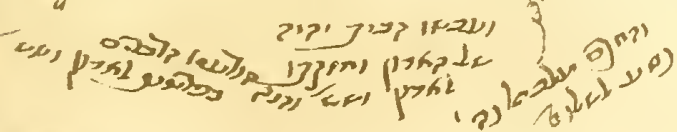

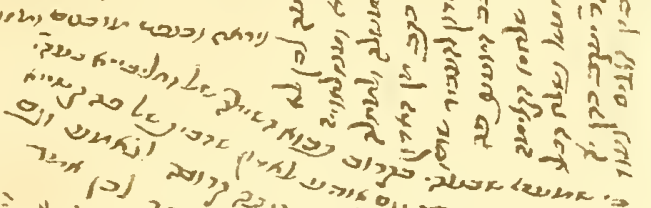

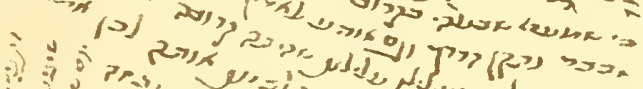

a d a

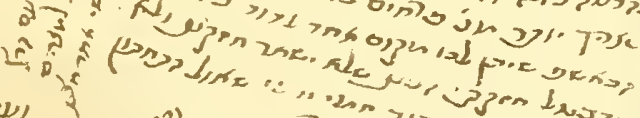

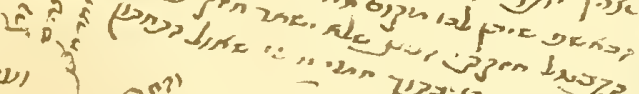

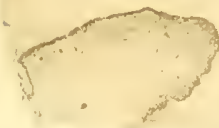





\section{LETTER}

A letter from one named Nissīm, in Katyah, Sinai, to a certain Rabbi Solomon Iskanderānī, in Cairo or Fusțāṭ.

It is a rambling and repetitious account of conditions in the small and turbulent caravan station on the Cairo-Damascus highway. There is much about caravans. Robbers infest the way. The Muslims have demolished a synagogue (?) and a private house of the Jews. It is as hot as the nethermost Sheol, and the writer's pen is broken.

Recto: $(a)$

\section{Blessed be the Name [of God]!}

r [To] the Prince, the Dignitary, Exalted and very Eminent, in Name and Reputation, my Lord, his Exalted Honor, the Rabbi [whose name is] written at the side [of this letter] ${ }^{1}$ !

2 After the solace ${ }^{2}$ from afar: This [is] to inform the Gentleman [that] I have written at length to the Gentleman a letter, [sent] from al-'Āmīrī, 3 the mutasaffir ${ }^{3}$ of the caravan which went [from here] in the company of the wise, the honored Rabbi Jacob, son of Rabbi Is[aac], on the twentythird ${ }^{4}$ of

${ }_{4}$ Rajab, $460[\text { A.H. }]^{5}$. And this is to inform the Gentleman-for I do not know whether the letters reach the Gentleman-

5 that [people] say that they take them away from the runners. And now this [is] also to inform the Gentleman, now, today,

6 Wednesday, the 7 th of Tammuzz, of the arrival of a caravan of about I 50 camel-loads and.

7 ........6. And the merchants who are in it [are] from Damascus ${ }^{7}$, and from Nablus ${ }^{7}$, and from Gaza? ${ }^{7}$. And there is in it

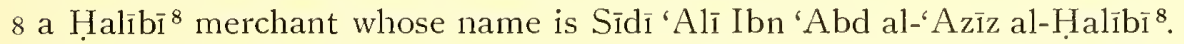
And the Syrians ${ }^{9}$ who are in it:

9 One whose name is Sìdĩ Mahmūd Ibn Lu'lu', and [another,] 'Abd alRaḥmān the Syrian ${ }^{\mathbf{1 0}}$, and [a few others] aside [from these], and five sheikhs ${ }^{7}$ of the Jews;

so and the rest [are] individually like what travels in the lists of a caravan. And the merchants told us

I that the caravan ${ }^{11}$ of Halibīis ${ }^{12}$ would soon arrive, with the help of GodHis Name be blessed ${ }^{13}$ ! - And because they have not found for themselves any leader, so

\footnotetext{
8 The context indicates Aleppo, but there appears to be no authority for such a form.

9 Modern vernacular Arabic form.

10 For "שs"

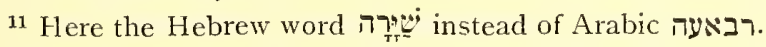

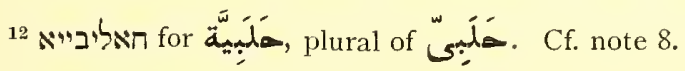

13 בעורת השם יתברך.
} 
2י לצאת מדמשק לא נסעו משם ובעהי' בקרוב תצא מדמשק השיירה לפי דיבור

31 הסוחרים ומה שנתעכב שליחות הריץ תכף בעת הגעת הרבאעיה הנז' הוא לפי ריפ

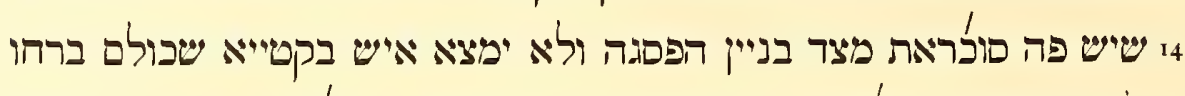

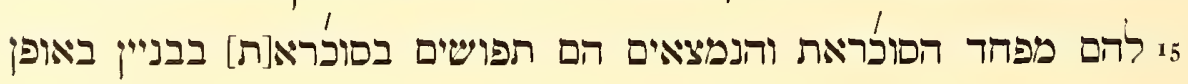
שם שוחרי

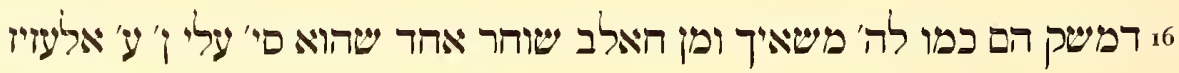

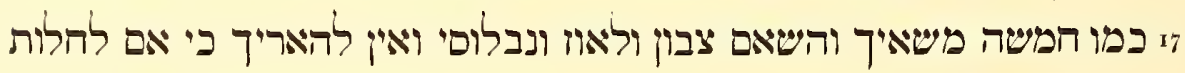

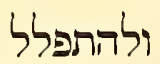
8 ליאלית' ישלח לאדון ברכה ער בלי די אויר בנפשי הרהבה והחכמה

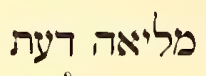

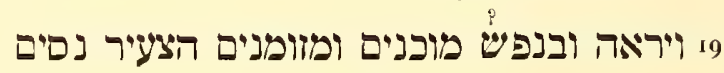
20 נכת במרוצה בקנה רצוצה.

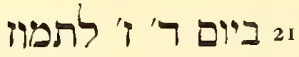

Recto: (b)

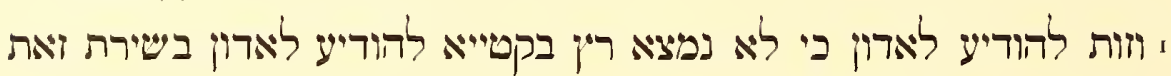

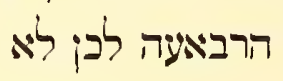

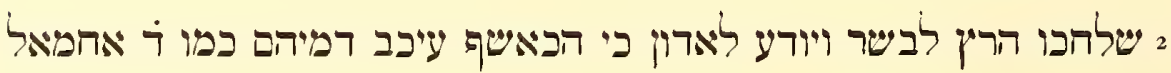

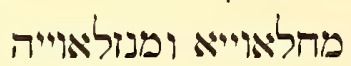

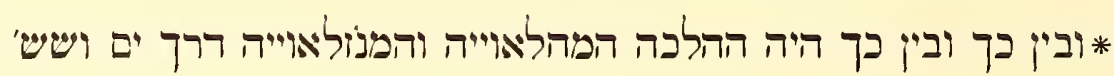

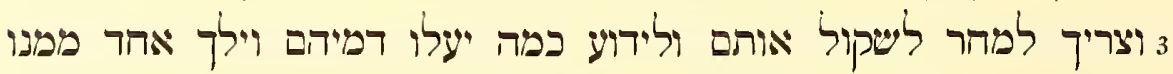

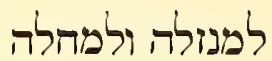

4 ללבות דמיהם ואומר הכאשך שעכף רוצה לעכב המעוזת פה עד בוא כתב מין האדון

14 See No. XXX, line I 1 , and note 18 . About 75 kilometers from al-Ṣālihīyah on the caravan route, in Sinai. The spelling קטייא does not necessarily indicate Kațiyah, for the ' is doubled in בפ" in the same line and next.

$15 \mathrm{Cf}$. note 8.

${ }^{16}$ Mentioned above in line 8 . He seems to have made a great impression upon the writer, or else the writer is suffering from the heat. Cif. recto (c), line 7 .

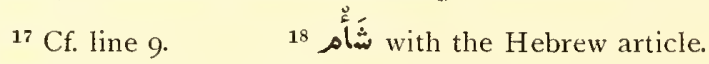

19 لو 19.

20 ברוך חישם יתברך : Cf. the title above line I יתברך. 
I2 that [they may] depart from Damascus, they have, not journeyed from there ; but with the help of God-His Name be blessed!- the caravan ${ }^{\mathbf{1 1}}$ will soon depart from Damascus according to the report

${ }_{3} 3$ of the merchants. And what prevented sending the runner immediately upon the arrival of the caravan mentioned: [It was] because

It there are here labor requisitions on account of building the hill (?), and not a man can be found in Katyah ${ }^{\mathbf{1 4}}$; for they have fled

$x_{5}$ for fear of the labor requisitions. And those who were found were seized in the labor requisitions in building. In the way of merchants

16 of Damascus, there are about 35 sheikhs. And from Aleppo ${ }^{15}$ there is

a merchant who is [named] Sīdī 'Alī Ibn 'Abd al-'Azïz'i .

${ }_{17}\left[\right.$ There are] about five sheikhs ${ }^{7}$ [of the Jews] ${ }^{12}$ ! And [from] Syria ${ }^{18}$ [they bring] soap and almonds ${ }^{19}$. And [the] Nablus [party]-There is no [use] in continuing [this letter], except to supplicate and to pray

I8 to God-His Name be blessed ${ }^{20}$ !- [that] He will send unto the Gentleman a blessing, until no breath is left in his soul ${ }^{21}$, broad, and wise, and full of knowledge,

19 and fear [of God], and in the soul of [those who are] prepared and summoned. [Signed:] The insignificant Nissim.

20 Written in haste, with a broken reed,

2 I on Wednesday, 7 th of Tammūz.

Recto: $(b)$

I And this is to inform the Gentleman that no runner was found in Katyah to inform the Gentleman about the persons ${ }^{\mathbf{1 1}}$ of this caravan. Therefore we have not

2 sent the runner to bring news. And be it known to the Gentleman that the inspector ${ }^{7}$ has held back ${ }^{22}$ about the equivalent of ${ }^{23}$ four loads ${ }^{7}$ of Mahallah and Manzalah ${ }^{24}$. * But, however that may be, the Mahallah and Manzalah way is a sea-way. So farewell ${ }^{25}$.

3. And it [will be] necessary tomorrow to weigh them and know what their value is. And one of us will go to Manzalah and to Mahallah to + collect their value. And the inspector is saying that he is holding ${ }^{26}$ wishing to hold-the money here until ${ }^{27}$ the arrival of a letter from the Gentleman [directing him]

21 1.e. "until he dies."

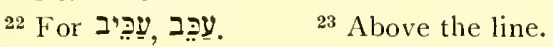

21 There are several Mahallahs, the most important of which lies at the center of the Delta. Manzalah is perhaps the village on the lake of that name.

25 Obscure, like the preceding passage. This sentence is written on the margin, and its insertion may be intended here. There is a sign before this sentence, but none after איזלים

${ }^{26}$ For מעכבי?

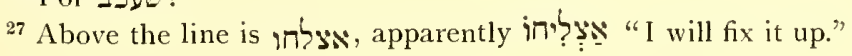


5 לפרוע לו האנות כי אמר שבא לו כתב מן איסמעין שאוש שלא רצה

6 הארון להעביר שום

דמעות פה

7 עד בוא כתב האדון ולפי שלא שקל .. דאחמאל עדיין עיר למחר לכן לא

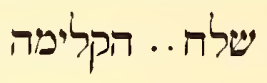

8 בחרת מתסאפיר השיירה אהמר שומאן ובעהי תכף עת נשקול האחמאל

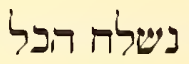

* ובאמת זות הקלמה אשלה בעהי קליפת אלקטויי וכל הרברים בפרטות

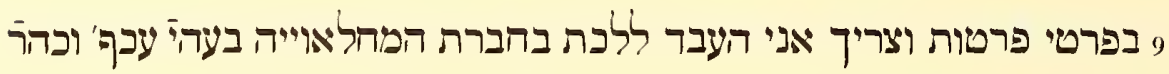

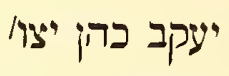

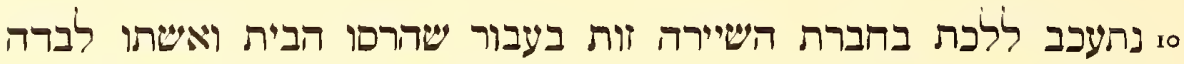
בין הגוים ועוד לכדת בערות

Recto: $(c)$

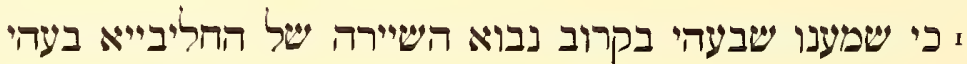

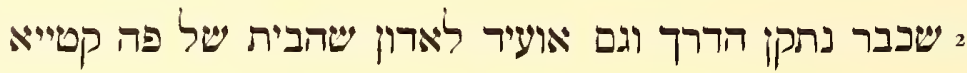

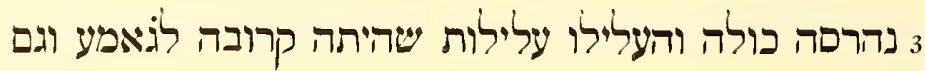

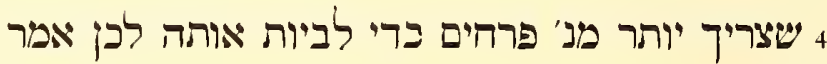

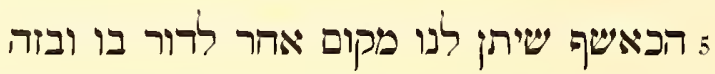

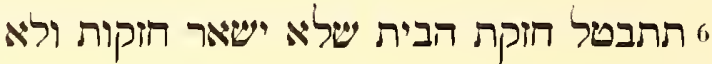
7 רברים ואנחנו בתוך המי חמי שאול התחתון

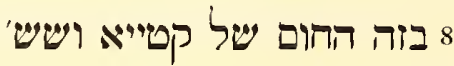

${ }^{28}$ The modern colloquial Cairene form of Isma‘īl. See Willmore, The Spoken Arabic of Egypt, 2nd ed., p. 27.

29 These forms seem to have 1 - for $:$ -

30 This substance, קלימה, is mentioned three times.

${ }^{31}$ For אלקטוייה?

32 This sentence is written in the upper left-hand corner of the fragment, and its insertion may be intended here. There is a sign > after, but none before this sentence.

33 על כל פנים 33.

34 כבוד הרב.

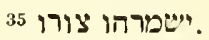

${ }^{36}$ Quite plainly with prefix 9, as in Syriac. 
5 to pay him the money. For he said that a letter had come to him from Isma'inn ${ }^{28}$ Shāwish [saying] that the Gentleman did not wish to send over any

6 reckoning of what Hākhām, the son of Rabbi Isaac, had done. And the inspector said that on account of the Gentleman he would hold the money here

7 until the arrival of the letter of the Gentleman. And because they had not weighed (? $)^{29}$ the loads, [and would not do so] till tomorrow, therefore they would not send (? ${ }^{29}$ the ${ }^{30}$

8 in the company of the mutasaffir ${ }^{3}$ of the caravan ${ }^{11}$, Ahmad Shūmān. But with the help of God-His Name be blessed!-as soon as we weigh the loads, we shall send all —*But truly I shall send this......... ${ }^{30}$, with the help of God-His Name be blessed !- the......... ${ }^{30}$ of Katyah ${ }^{31}$, and everything with special care- ${ }^{32}$

9 with very special care. And I, the [humble] servant, must go in the company of the Mahallah [caravan] with the help of God-His Name be blessed! - in any event ${ }^{33}$. And the honorable Rabbi ${ }^{34}$ Jacob Kōhēn - May God keep him ${ }^{35}$ ! —

Io is prevented ${ }^{36}$ from going in the company of this caravan, because they have torn down the house, and his wife [would be] alone among gentiles. And furthermore:

\section{Recto: $(c)$}

I Now we have heard that with the help of God-His Name be blessed ! the caravan of the Aleppo ${ }^{12}$ [company] will soon arrive ${ }^{36}$, with the help of God-His Name be blessed :-

2 that already the road has been put in order ${ }^{36}$. And also I inform the Gentleman that the house ${ }^{37}$ which is here [in] Katyah

3 has been torn down, all of it; and [that] they have brought accusations that it was near to a mosque ${ }^{38}$; and also

${ }_{4}$ that more than 50 perāhīm ${ }^{39}$ [will be] necessary in order to [re]build it. Therefore

5 the inspector has said that he would give us another place in which to live. And in this [way all question as to]

6 the confiscation of the house ${ }^{37}$ will be prevented; so that there will be no longer [any] confiscations, nor [any]

7 troubles $^{40}$. And we are in the midst of the greatest heat of the lowest Sheol,

8 in this heat of Katyah. So farewell.

\footnotetext{
${ }^{37}$ Here at least the word means "synagogue." Cf. line Io, just above. The expression is intentionally cryptic.

${ }^{38}$ Arabic \&ole.

${ }^{39}$ I.e. "dīnārs"?

${ }^{40}$ Literally: "words," "affairs."
} 
Recto : (additions)

וכדי שליא יבוא איזה דבר|בהליכתי למחלה לכ; הוצרך| כהרَ אברהם

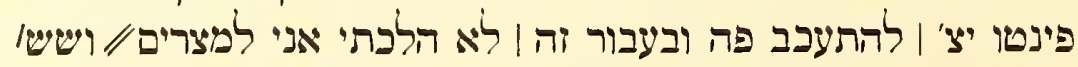

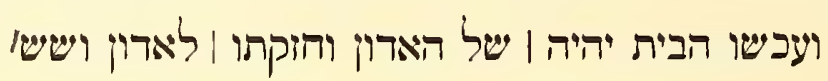

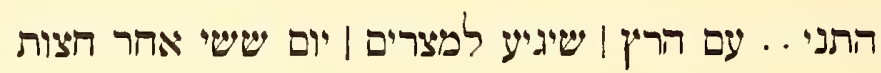

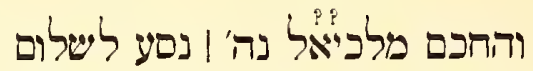

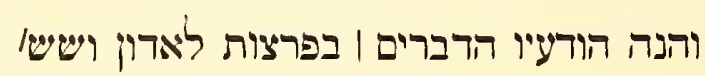

Verso:

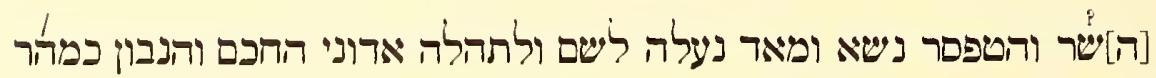

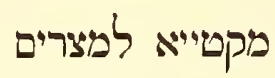

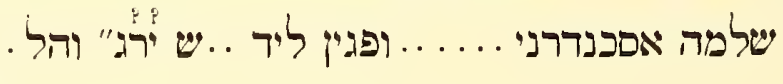

41 הוצורך for.

${ }^{42}$ A very numerous and able Portuguese-Jewish family. See Jewish Encyclopedia, sub roce. 
Recto: (additions)

And, in order that nothing may happen | while I am going to Mahallah, it is necessary ${ }^{41}$ that Rabbi Abraham Pinto ${ }^{42}$ - May God keep him ${ }^{35}$ ! - | should be kept here. And on account of this / I have not gone to Cairo. So farewell.

And now the house shall belong | to the Gentleman, and the possession [shall be] | the Gentleman's. So farewell.

I (?) have stipulated ${ }^{43}$ with the runner | that he shall reach Cairo | Friday, after midnight.

And the wise Malkî̀'èl(?), pure soul ${ }^{44}$, has gone to his [everlasting] peace. So farewell.

And behold I have made known ${ }^{45}$ the matters | in detail to the Gentleman. So farewell.

\section{Verso:}

[To the Pr]ince, the Dignitary, Exalted and very Eminent, in Name and Reputation, my Lord, the Wise and Intelligent, his Exalted Honor, Rabbi Solomon Iskandarānī

From Kaṭyah to Cairo.
43 ההניתי.
44 נישמוז טהורה.
45 הורעתיו 


\section{LETTER}

Paper $8 \frac{3}{4} \times 4 \frac{1}{2}$ inches.

Hebrew in cursive Hebrew characters.

The first marginal addition is in the same hand as that of the body of the letter, and merely continues the same. The second, in a different hand, protests against the unwarranted presumption of the letter. The third, in an extremely difficult cursive hand, and in Arabic, unintelligible save for a word or two, closes with the signature אברהם קאםטרו, "Abraham Castro." This is therefore the writer's own language and script, the body of the letter having been composed and penned by a scribe. In two other places there are brief combinations of letters, the purpose of which is not apparent.

Unfortunately there is no date.

י השר הנעלה לשם ותהלה גבירנו כהרב שלמה ני' 2 מאלהא רבא שלמא כולא אדון השלם ישפת שלם לכם ולנו אמן 3. להיות מחק השלמים לרדוף השלם נכפל בספרי הנביאים עיה דבר השלם + ושבחנהו שבה לאין תכלית ואם הוייביו לרדוף השלם עם פל הארם

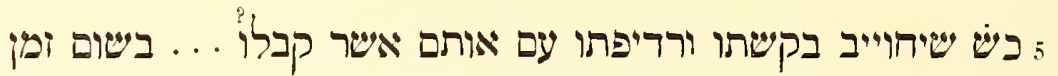

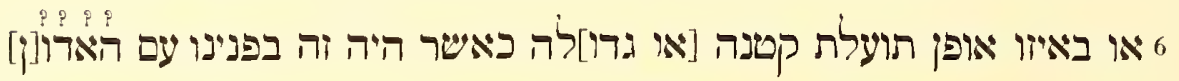

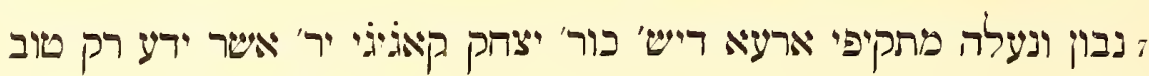

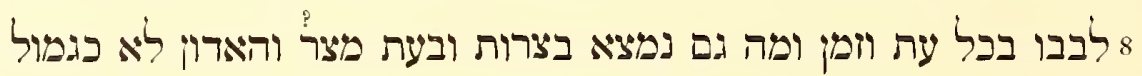
9 השיב בכל הרברים אם בהיותו נחוין בלקיהת מעותיו אשר היו ביד האדון ס כרי לשוב לדרכו ובהיותו מתמהמה נתגלגל לו נוק רב באותם

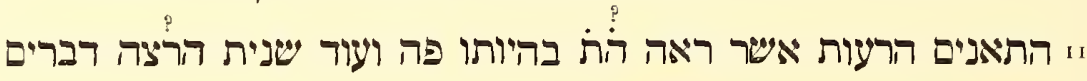

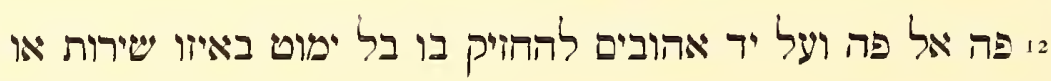

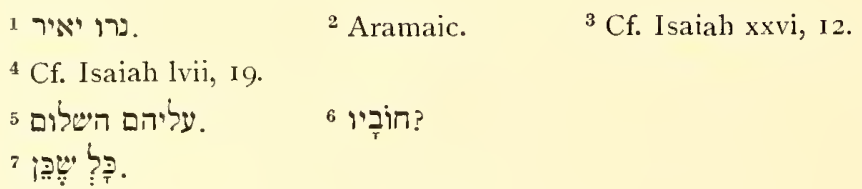




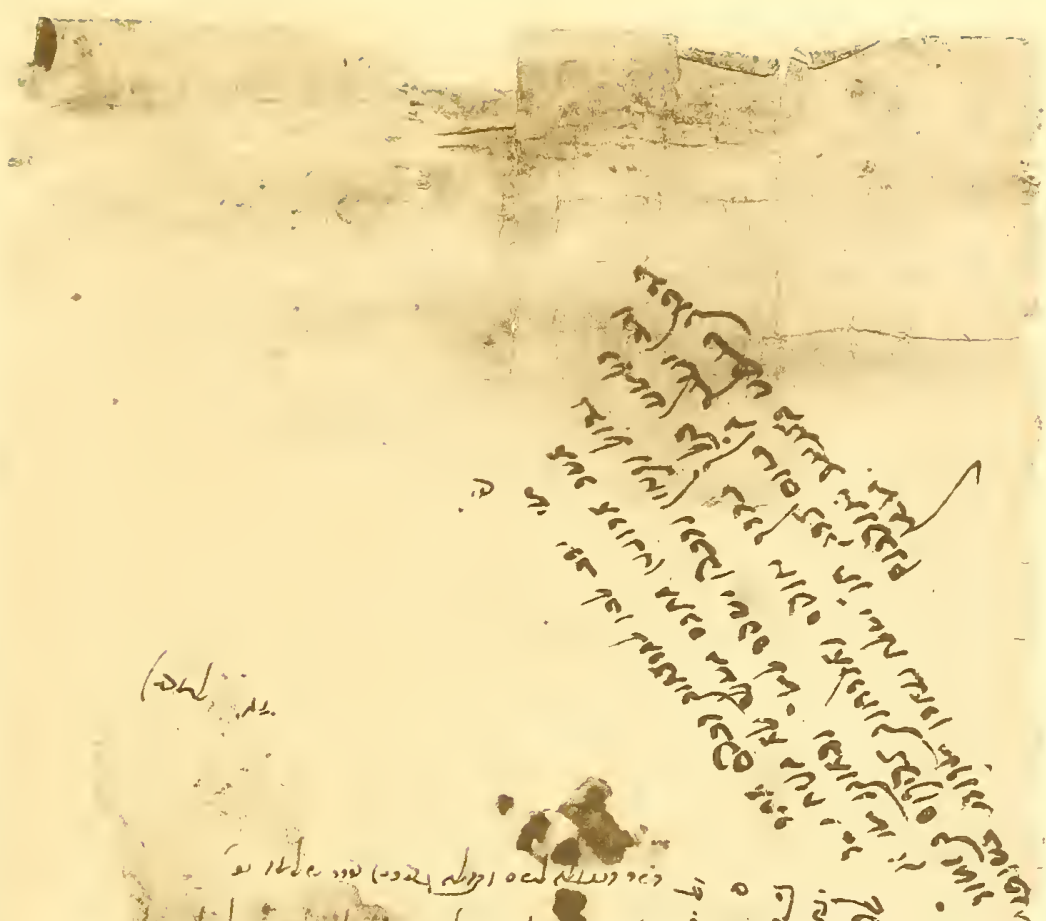

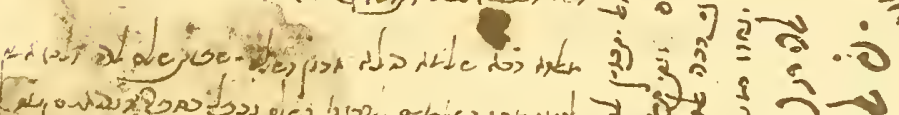

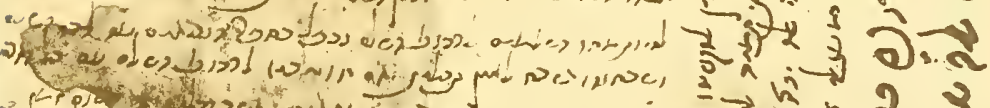

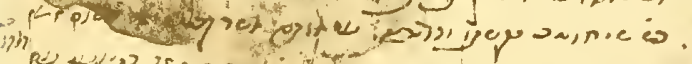
RU $2-\frac{1}{2}$ i

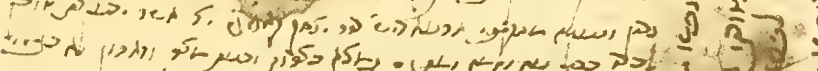

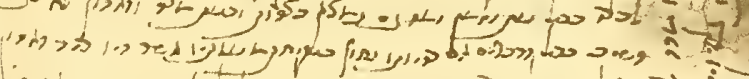

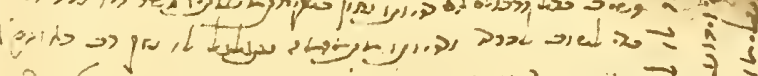
-

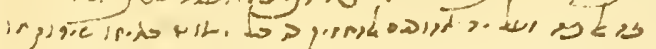

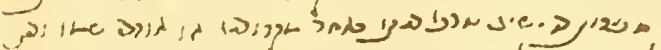

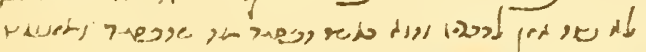

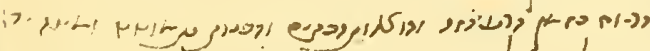

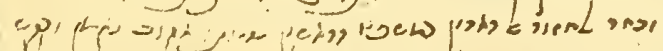
pos

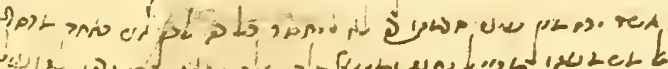

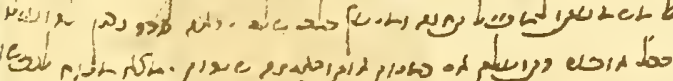

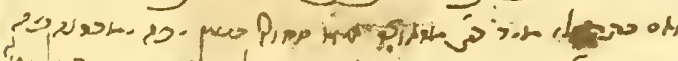

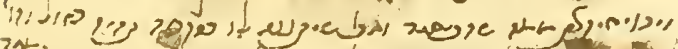

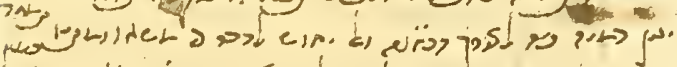

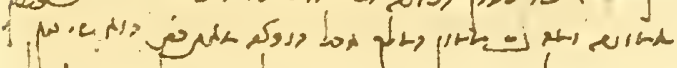

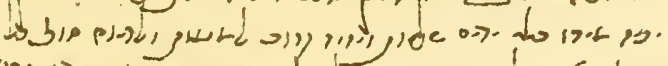

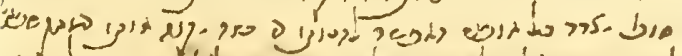

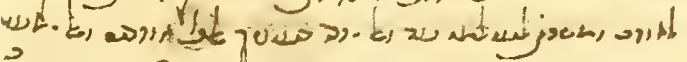

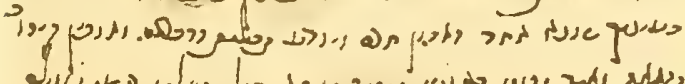

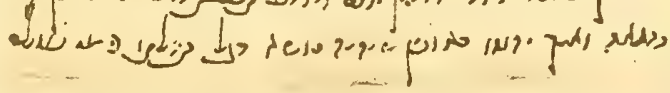

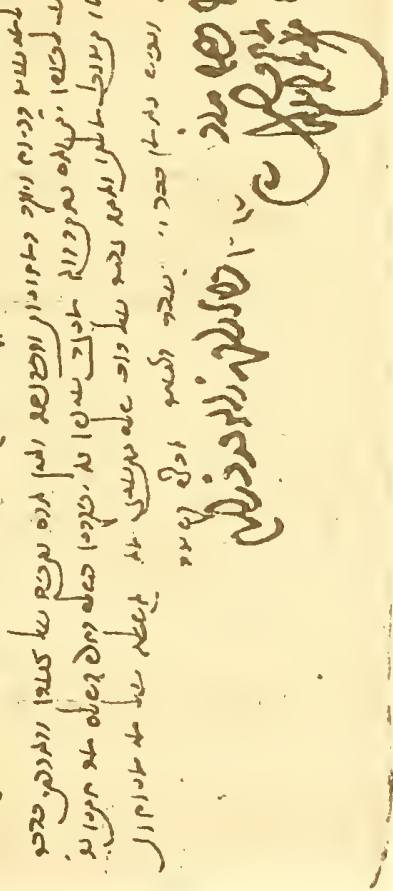





\section{LETTER}

A wheedling, reproachful, almost threatening letter from one, Abraham Castro, in Jerusalem (?), to an eminent and powerful man named Solomon, in Fusțât (?), asking him by employment or credit to aid a certain Isaac Kajìji, who seems to have become estranged from Solomon and then to have fallen upon evil days. Merchandise given Isaac from the common stock in Fustât (?) is to be paid for later by gifts to the treasury in Jerusalem (?).

The chronicler Sambari (ed. Neubauer, vol. i, p. I45) mentions an Abraham Castro in connection with a Benjamin (not Isaac) Kajijī; and Solomon Hazzān (Sêfer ho-Ma'alōth li-Shemōth, page I2) as having in his possession a document of A.D. 1606 , signed by Abraham Castro, Benjamin Kajījī and others.

r [To] the Prince, Eminent in Name and Reputation, our Master, his Exalted Honor, Solomon-May his light shine ${ }^{1}$ !

2 From the Great God [cometh] all peace ${ }^{2}$. The Lord of Peace grant peace to you and to us ${ }^{3}$ ! Amen.

3 Inasmuch as it is the custom of peaceful men to pursue peace-The word "peace" occurs twice in succession in the books of the Prophets ${ }^{4}$, upon whom be peace ${ }^{5}$ !

+ and [inasmuch as] we praise [peaceful men] with boundless praise, and if it is one's duty ${ }^{6}$ to pursue peace with all mankind,

5 how much more ${ }^{7}$ do the quest and pursuit of it become the duty of such as have received. ...at any time

6 or in any way a favor, great or small, such as we have observed to occur in the case of the intelligent

7 and eminent gentleman, [one] of the influential men of Palestine ${ }^{2}$, the honorable Rabbi ${ }^{8}$ Isaac Kajijīi-May he be acceptable !- the goodness of whose heart

8 at all times and seasons is known, and also how he found himself [involved] in troubles and in a period of difficulty. Now my Lord ${ }^{9}$ has not requited

9 good in all matters: whether because [Rabbi Isaac] was hasty in demanding his money, which was in the hands of my Lord,

Io in order to make his return journey-Indeed, because he was delayed [by you], he became involved in a great loss in connection with those is bad figs which my Lord (?) saw when he was here-[or for some other reason]. But in the second place, [Rabbi Isaac] made an appeal [to you, both]

12 in direct conversation and through the mediation of friends, to encourage him not to waver. [He asked you] by any sort of employment or

\footnotetext{
בבבוד הרב 8 I.e. "you."
} 
3י ספרות כי ישיב טרף ביתו כאחר מקרוביו או אוהבי שמו והּת' 4. לא נטה אזן לדבריו והוא כאשר הפסיד מה שהפסיד ומיעוט 15 הריות בזמן הרע הזה והוצאות הבתים והבנות נתמוטט ומטה ידו 16 ובחר לחזור אל האדון כמשפט הראשון להיותו אהוב נאמן ובקש

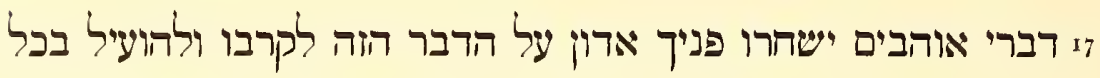
8 8 אשר ירזמון עיני חכמתו כי לא יחפר כל בו לכן אני כאחד מהם..ם 91 אל משמעתו מפיל תחנה ומיעיץ בלב שלם יראה סדר נכון להועילו 20 בכל אופני התועלת אם כמיות אותו באיזה שירות ימצא מנוח לנפשו

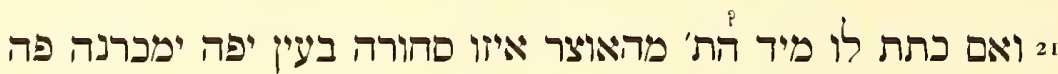
22 וירויה קצת ממה שהפטיד ויאף שיתננה לו בהקפה תהיה בזול והוא 23 ינתן רמיה פה לצורך הכتנה ואל יתוש לדבר כי משאו ומתנו תמיר 24 ממונה ומה ג?ם ממון המלך אבל הנרצה מאת הּה הוא שיתן בעין 52 יפה מירו בלי ידים שניות ויהיה קרוב למעות ולריוה סוף כל גם 26 סוף יצדר כל אופני האפשר להיותו כי כזה יקנה אותו במתן שפתיו 72 לאוהב ומשרת לעולמי עד ואל ירבו בעיניך יאלף אוהבים ואל ימעט 28 בעיניך שונא אחר האדון חכם ויודע תכלית הדברים ואופן קירוב 29 ההנאה ואיך יהנהו באופן שיהיה נושא רגל תהלתו ב'מי עולם

\section{Margin: (a)}

י ואל יתכוין להקניטו חi כי נפשו מרה לו למיעוט הריוה ויוקר המזונות והפרנםה ואין ארם נתפם על צערו והארכתי בדבר

\footnotetext{
${ }^{10}$ Cf. Leviticus xxv, 35 .

11 The second and third persons are used interchangeably.

12 Arabic.
} 
13 literary work to restore the support of his house, as one of [my Lord's] relatives and admirers. But my Lord (?)

It did not give ear to his words. Then he, [Rabbi Isaac,] when he had lost what he lost-the small

15 profits of those evil times, and the expenses of the houses and the daughters [being what they were]-collapsed, and his hand wavered ${ }^{\mathbf{1 0}}$, i6 and he chose to return to my Lord as originally planned, to be [his] beloved and trusted [friend]. And he sought to employ

17 the conversations of friends, [that] they might address themselves to you ${ }^{11}$, Sir, concerning this matter, in order that he might approach [you] and that [you] might aid him in every thing

18 which the eyes of [my Lord's] ${ }^{11}$ wisdom might indicate; for there is no lack [of ability] at all in him. Therefore I, as one of those.

ig to [my Lord's] subjects, make supplication and give counsel with a perfect heart. May [my Lord] see some proper arrangement for helping him

20 by every sort of usefulness, whether.... .him in some sort of employment by which he may find rest for his soul,

21 or else giving him, by the hand of my Lord (?), from the common stock, some sort of merchandise, in a kindly spirit, which he may sell here

22 and [thereby] gain a little of what he has lost. And even though [my Lord] gives it to him on credit, the price must be low. And he

${ }_{23}$ will deliver its equivalent here toward the needs of the treasury ${ }^{12}$. And let [my Lord] not fear anything; for his business at all times brings in ${ }_{24}$ money, and royal money too ${ }^{13}$. But the thing that is desired of my Lord (?) is that he give in a kindly

25 spirit by his own hand, without [the mediation of] other hands, and [thus] be close to [both] capital and profits. In

26 short, let [my Lord] be everything possible [to him], for thus he will gain him, by gentle speech,

27 as a friend and servant for ever and ever. And let not a thousand friends be many in your eyes; nor let one

28 enemy be a small thing in your eyes. My Lord is wise, and knows the purpose of things, and the manner of advantageous

29 approach, and how he may benefit [this man] in such a way that he will become a bearer of the flag of his praise for all eternity.

\section{Margin: (a)}

I And let [my Lord] not seek to affront him-God forbid!-for his soul is bitter by reason of the smallness of [his] profit and the costliness of food and maintenance; and no man is to be blamed for his suffering. Now I have dilated upon this matter

${ }^{13}$ From תמיר on, very uncertain. 


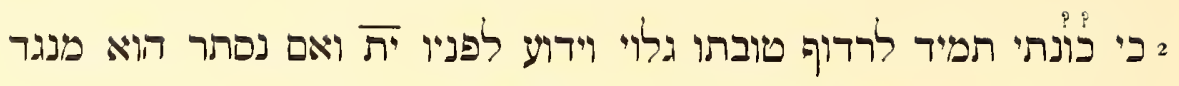

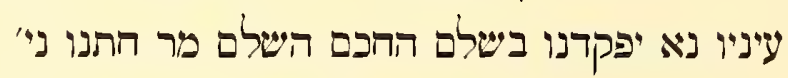

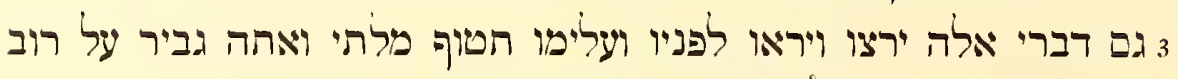

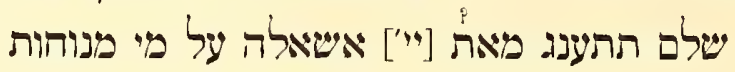

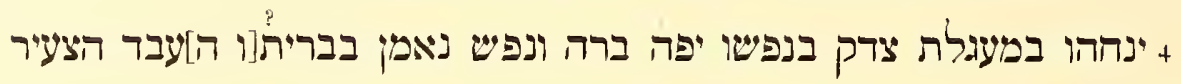

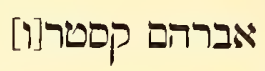

Margin : (b)

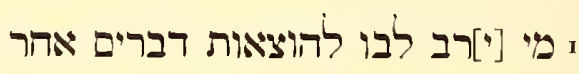

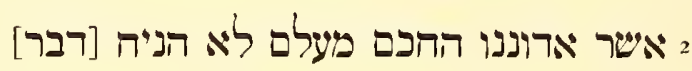

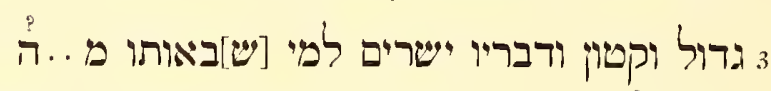

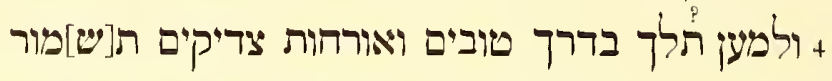

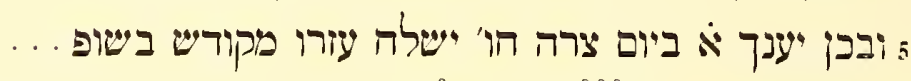

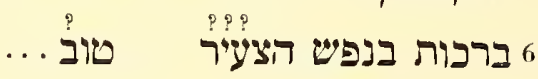
ips 7

${ }^{14}$ Or "son-in-law."

15 Job xxix, 22.

16 Psalm xxiii, 2.

17 Psalm xxiii, 3.

18 The adjectives are uncertain, and ought in any case to have the article. 
2 because my purpose to further his welfare at all times is evident and well known to [God] - Blessed be He! But if [my purpose seems to be] hidden from his eyes, then, I pray, let his father-in-law ${ }^{14}$-May his light shine ${ }^{1}$ — - the wise and peaceful, visit [Rabbi Isaac] in peace.

3 And furthermore, may these my words be acceptable, and may they receive his attention: "And my speech distilled upon them ${ }^{15}$." But [as for] you, Master: May you enjoy an abundance of peace. From [the Lord] I ask it "beside the still waters ${ }^{16}$."

+ May He guide him "in the paths of righteousness ${ }^{17}$ " because of his beautiful, pure soul ${ }^{18}$, the soul of one faithful in his covenant ${ }^{19}$. [Signed:] The insignificant slave, Abraham Castro.

Margin: (b)

- I Who dares ${ }^{20}$ to utter words [of reproach], seeing

2 that our wise Master from time out of mind has never neglected any matter,

3 great or small. And his words are just to those whom...........

4 "That thou mayest walk in the way of good men, and keep the paths of the righteous ${ }^{21} . "$

5 And thus may "the Lord answer thee in the day of trouble ${ }^{22}$ " ..... Send His help from the Sanctuary ${ }^{23}$.

6 Blessings by (?) the soul of the insignificant...........

7 Amen!

19 Psalm lxxviii, 37.

22 Psalm $\mathrm{xx}, 2$.

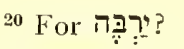

23 Psalm xx, 3.
21 Proverbs ii, 20. 


\section{LETTER FROM A LADY}

Paper $8 \times 4 \frac{1}{8}$ inches.

Hebrew in semi-cursive Hebrew characters, very regular and beautiful, but badly faded. The text could be read, however, in an especially prepared photograph, the work of Mr George R. Swain, Technical Expert in Photography at the University. It was doubtless written by a professional scribe.

Recto:

יוישב בשבת תחכמוני הוא עוזנו העצם החכם השלם ריש מתיבתא טיטי

2 מתה כמהר אברהם סבנררני נ"י

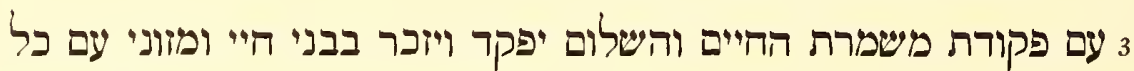

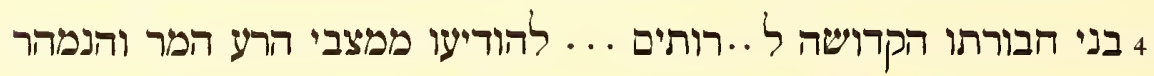

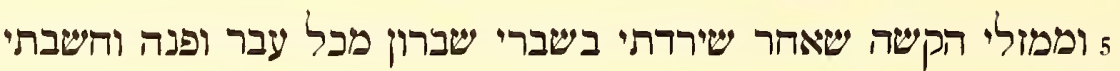

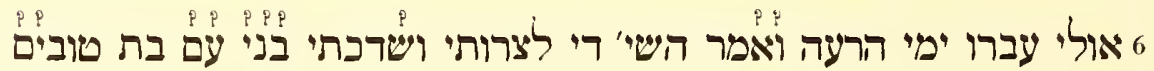

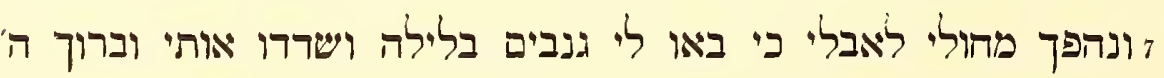
רשי

8 עלי גם בזאת לטעום טעם עוני אני ובני ערומים רעבים גם צמאים

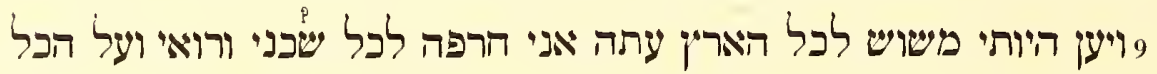
ז. יהי שם ק מבורך שהיצלני ולבני מהרבם כי כל אשר לאיש יתן בעד

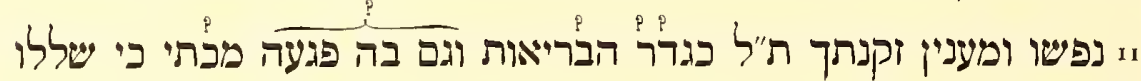

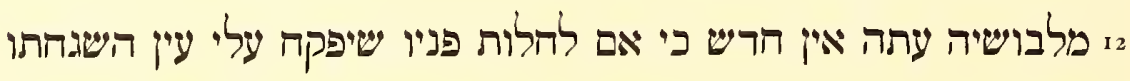

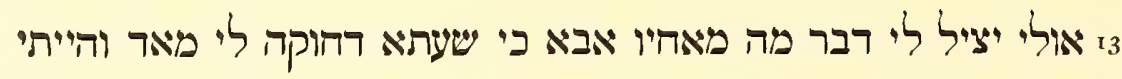

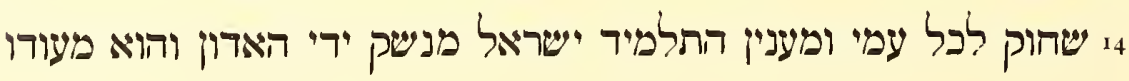

${ }^{1}$ II Samuel xxiii, 8. 2 Aramaic forms.

הטים יתברך ". 3.

${ }^{4}$ For הצילפי.

5 I.e. "you." 


\section{LETTER FROM A LADY}

A letter addressed to a certain Rabbi Abraham Skandarānī, "The Alexandrian," by his aunt, an unnamed lady who has fallen upon evil days and desires his assistance.

Many Old Testament phrases are interwoven, in the manner of one who reads the Scriptures much, and has no style of his own; but, as this is unconscious, the references have not always been given in our notes.

Recto:

Blessed be the Name [of God]!

I [To him] who sits in the seat of Tahkemōni ${ }^{1}$, him, our Refuge, Mighty, Wise, Perfect, Head of the Academy, and Head of

2 the city (?) the Exalted Honor of the Rabbi Abraham Skandarāni, Light of Israel.

3 With the granting of preservation of life and peace let him be cared for, and let him be remembered among the sons of life $^{2}$ and sustenance ${ }^{2}$, together with all

+ the people of his holy company..............to inform him of the doings of that evil, bitter and hasty man,

5 and of my cruel fate which, after I had descended into the lowest depths of destruction [which assailed me] from every side and quarter, and had imagined [that]

6 perhaps the days of evil had passed, and had said: "The Name [of God] be praised ${ }^{3}$ ! Enough of my sufferings! I have betrothed my son to a maiden of beauty!"-

7 my dancing was changed to (my) lamentation. For thieves entered my [house] by night and robbed me. But blessed [be] the Name [of God], who decreed

8 for me also this, to taste the flavor of my sin. I and my son are naked, hungry-and thirsty.

9 And instead of (?) being a delight unto all the earth, now I [am] an [object of] shame to all my neighbors and those who see me. But in spite of it all,

ro may the Holy Name [of God] be blessed, who delivered $\mathrm{me}^{4}$ and my son from their sword; for all that a man hath will he give for

I his life. And as regards your grandmother..........according to the definition of healthy women; but her also did my misfortune strike. For they carried off

12 her clothing. At present there is nothing new [to ask], except to pray his $^{5}$ presence that he will open upon me the eye of his ${ }^{5}$ oversight.

${ }_{13}$ Perhaps he ${ }^{5}$ will save for me something from his ${ }^{5}$ brethren, Sir, for it is to me an hour ${ }^{2}$ of great need. And I have become

${ }_{14}$ dust unto all my people. And as regards the pupil, Israel, he kisses the hands of the Gentleman ${ }^{5}$, and he is still (?) 


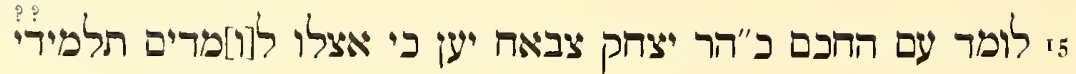

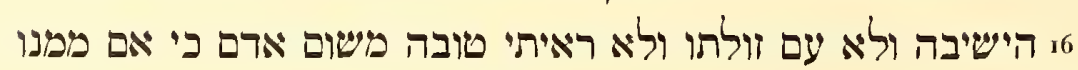

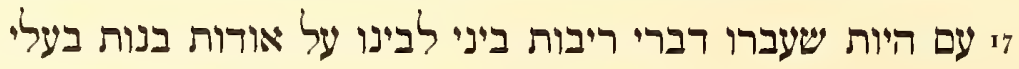

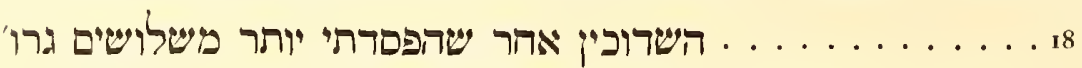

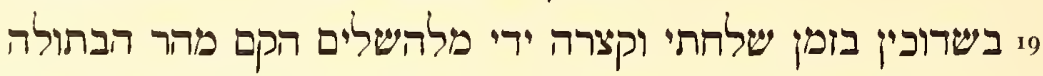

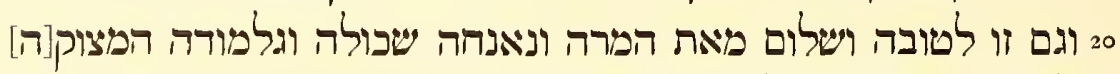

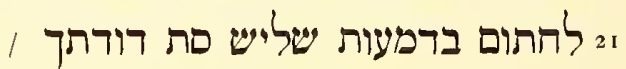

Margin:

.......

Verso:

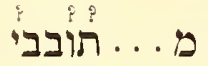

יוצל ליד אוֹצר בלוט תגא דאוריתא ודרבין הח' הש' פמהר אברהם סכנדרני ........

בבור הרב

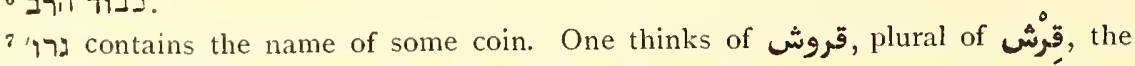
modern "piastre." But 30 piastres is too small a sum (about \$1.50) to complain of losing. Also, the word is supposed to have been borrowed from Germany or Austria (groschen) in comparatively recent times.

8 הקרם 8. 
I5 studying with the learned Rabbi Isaac ${ }^{6}$ Șabāh, because with him there are studying pupils of

I6 the Academy, and not with any other. And I have not experienced a kindness from any one but him;

I7 although, to be sure, words of strife have passed between him and me concerning the daughters of my husband

I 8 ...........the betrothal after I had lost more than thirty........

ig in the betrothal at the time when I sent [you word of it?]. And I am unable to finish putting up ${ }^{8}$ the dowry of the maiden.

20 But this also [must be] for the best. Greetings from the bitter and sighing, bereft and lonely woman, who is forced

21 to sign [this letter] with tears in large measure: the Lady ${ }^{9}$, your Aunt.

Margin:

I 5 th of Tēbhèth.

Verso:

May it reach the hand of the Most Eminent ${ }^{10}$ Oak ${ }^{11}$, Crown of the Law and the Rabbis ${ }^{12}$, the Pious, the...... Exalted Honor of the Rabbi ${ }^{9}$ Abraham Skandarān̄īis.

${ }^{9}$ Vernacular Arabic, sitt, for classical سَِّّة

10 These words in Arabic.

11 Hebrew. 12 These words in Aramaic.

13. 


\section{THREE LETTERS OF COMPLAINT}

Paper $45 \frac{5}{8} \times 6 \frac{1}{4}$ inches.

Hebrew in cursive Hebrew characters.

The three letters which the fragment contains are all in the same hand, and were doubtless written down by the same professional scribe. The first fills one hundred lines, of which lines I-34 and 4I-53 are rimed, the rimes being indicated by short diagonal strokes. The second letter occupies twenty-five lines, and the third letter forty-four lines.

Many biblical phrases are introduced, paraphrased, or hinted at. Not all have been indicated in the notes, for the reference is often remote.

The paper bears a watermark of the familiar hand-and-star variety, employed by many manufacturers, in France, Switzerland, and Sicily, between A.D. I490 and I590. See Briquet, Les Filigranes, I907. If the Moses mentioned is indeed Moses di Trani, our fragment may be accurately dated toward the close of his incumbency at Safed, I525-I535 (note 72), and may even have had something to do with his apparent removal. He did not die till I 585 , fifty years later.

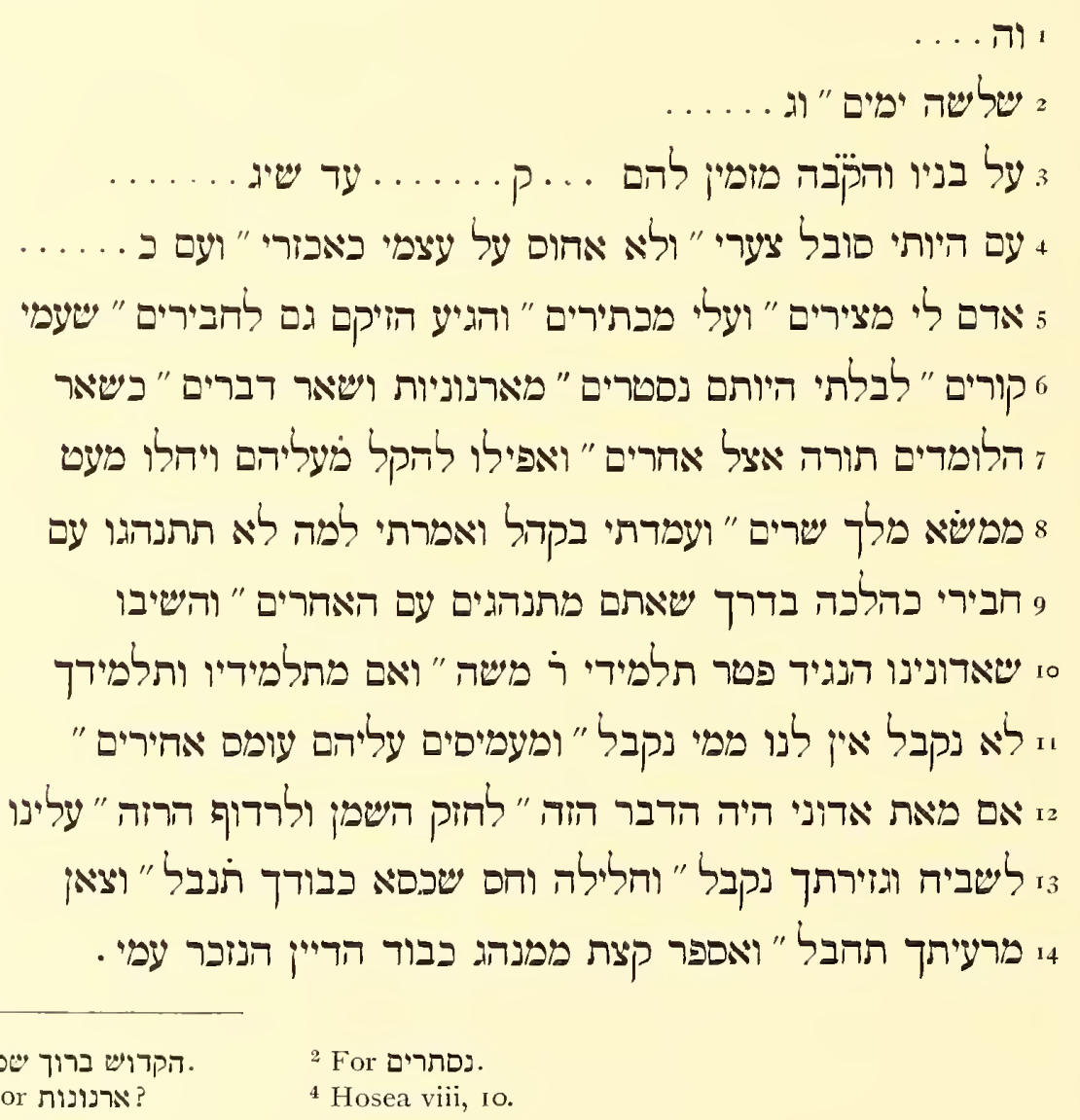


at

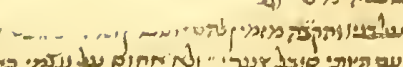

ב. "

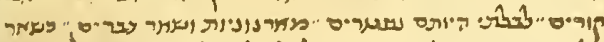

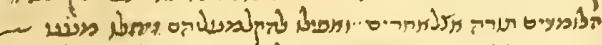

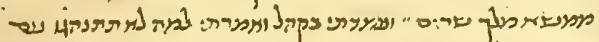

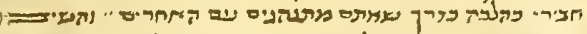

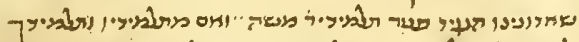

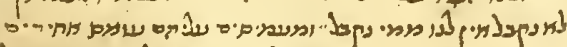

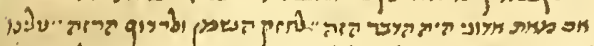

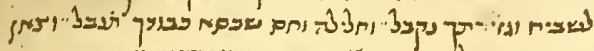

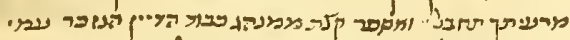

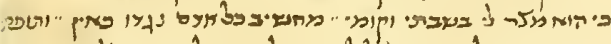

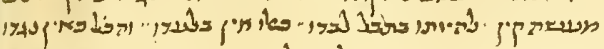

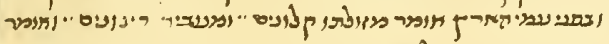

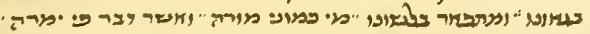

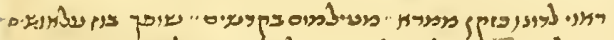

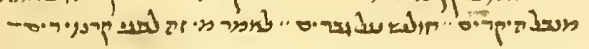

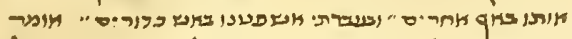

עلת:

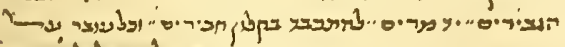

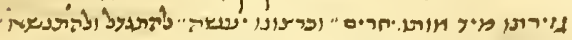

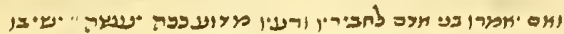

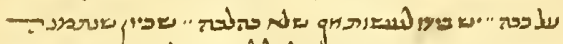

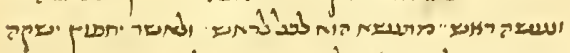

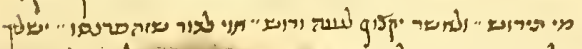

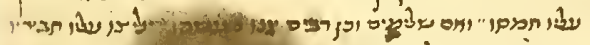

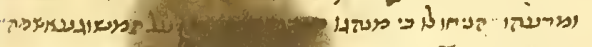

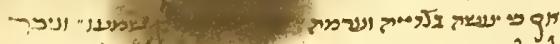

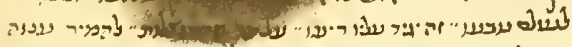

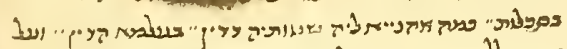

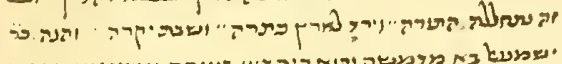

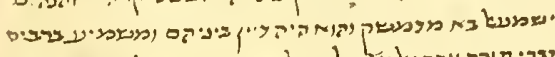

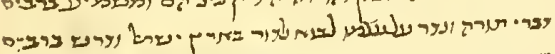

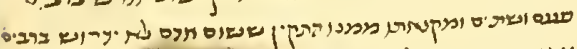

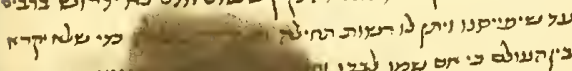

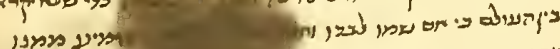

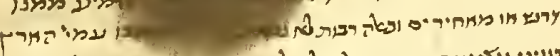

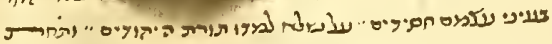

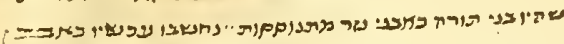

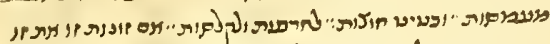

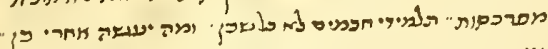

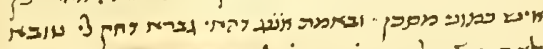
נ. Than sivas

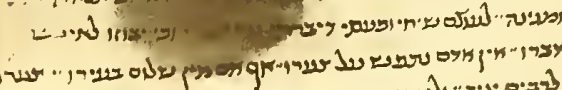

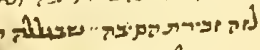

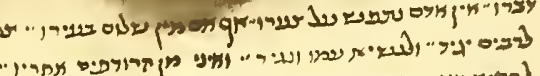

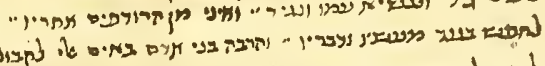

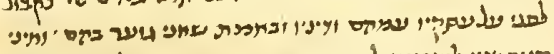

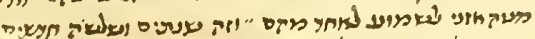

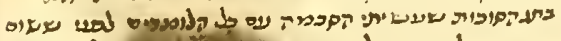

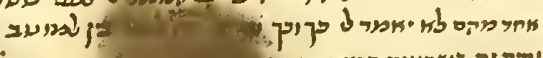

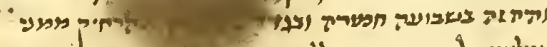
-

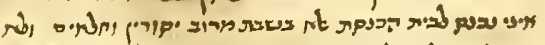

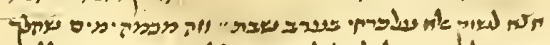

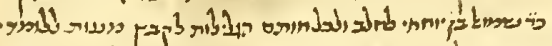

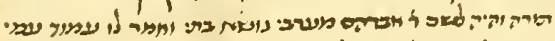

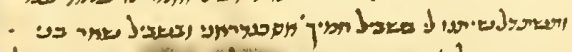

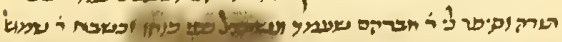

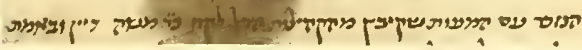





\section{THREE LETTERS OF COMPLAINT}

These three letters complain of the conduct of a certain Rabbi Moses, the dayyann of Safed in Galilee. If we are to believe the writers, he was a rather unusually vainglorious, selfish and unscrupulous person, guilty of many acts of tyranny, misappropriation and corruption, and responsible for the perennial Safed Meat Scandal.

It is difficult to recognise in this Moses, the Moses di Trani who was Rabbi of Safed from I 525 to I 535. But our Moses was the immediate successor of a certain Joseph Sarakossī (or Saragossī), as we learn from line I57; and Moses di Trani was a successor, possibly an immediate successor, of the Joseph Saragossi who organised the community of Safed in I 492 ; and the identification is thus not unlikely.

The addressee of the letter is an unnamed Egyptian nāgīd, at Fusțāt(?). The beginning of the fragment, which might have revealed his identity, is unfortunately missing. The writers are all people at Safed, whose names are duly signed. Many interesting names appear.

2 three days, and.

3 over his sons. And the Holy One-Blessed be the Name ${ }^{1}$ - - was inviting them.

+ while I bore my affliction, and did not spare myself, cruel that I was, and while.

5 men were hemming me in and surrounding me, the injury [which] they [were doing] extended even to the scholars who with me

6 [were] reading, without their being protected ${ }^{2}$ from taxes $^{3}$ and other things, as [are] the rest of

7 those who study the Law, with other [teachers], if only [to the extent of] lightening their [obligations] and relieving them a little

8 from "the burden of the King of Princes"." And I stood in the congregation and said: "Why do you not behave toward

9 my friends properly, as you behave towards the others?" and they replied:

10 "Our Master, the Nāgīd, has exempted the pupils of Rabbi Moses; and if we do not receive [taxes] from

II his pupils nor [from] your pupils ${ }^{5}$, we have no [people] from whom we may receive [taxes]. We are [thus merely] placing upon [your friends] the burden of others.

12 If this matter proceeds from our Master, to strengthen the fat and drive out the lean, it is our duty

13 to applaud; and we shall accept your decision. God forbid that the throne of your Honor should be outraged, and the sheep

${ }_{1+}$ of your pasture injured." And I shall recount something of the manner of his Honor, the dayyān, [above] mentioned, [in dealing] with me.

\footnotetext{
${ }^{5}$ For תלמיריך"pupils"?
} 
5י כי הוא מצר לי בשבתי וקומי "מהשיב כל ארם נגדו כאין"ותופם

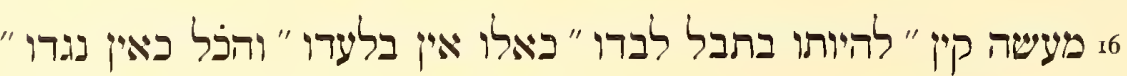
7ו ובפני עמי האריץ אומר מזולתו קלונים "ופעביר רינונים "ואומר 18 בגאונו "ומתפאר בלשונו "מי כמוני מורה ' ואשר דבר פי ימרה" פו ראיי לדונו כזקן ממרא " מטיל מים בקרשים "שופך בוּ על אנשים " 20 מנבל היקרים " חולש על גברים "לאמר מי וזה לפני קרנו ירים " ז2 אותו באף אהרים "ובעברתי אשפענו באש כרורים "אומר 22 עצצתי תקום וכל הפצי אישה "ופי הוא שלפני פיו יפצה "ובכל 2323

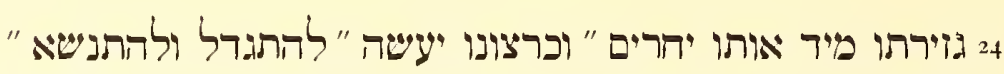

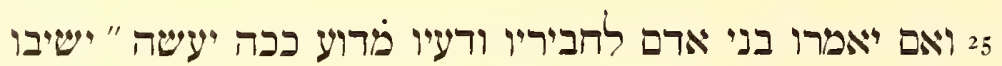

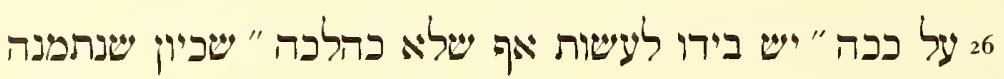

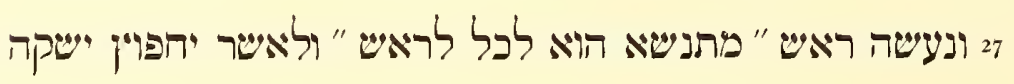
28 פי תירוש " ולאישר יקצוף לענה ורוש " אוי לדור שוה פרנפו" ישליך

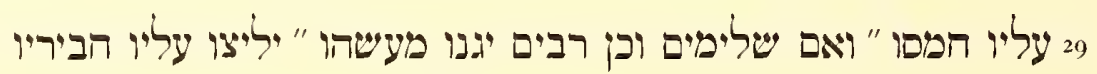

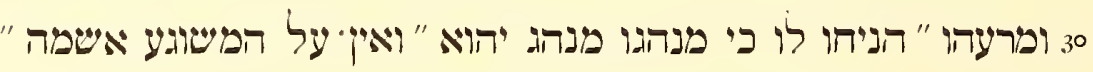
וב אף כי יעשה בצדייה וערמה "דגה יצא בארין שמעו "וניכר

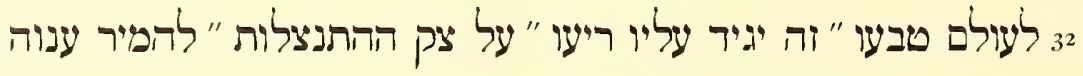
33 בפכלות " כמה אהנייא ליה שטותיה רדין" בעלמא הרין " ועל 34 וזה נתהללה התורה "וירד לאר"ץ כתרה " ושבת יקרה "והנה כך 35

\footnotetext{
6 בלעדים.

${ }^{7}$ A scholar who refuses to conform to the majority opinion.

8 Isaiah xlvi, Io. 9 For 9
} 
Is He has oppressed me in my downsitting and my uprising, reckoning as nothing every man opposed to him, having recourse to

if the deed of Cain in order to be the only one in the world, as if there were no one beside him ${ }^{6}$, and everything [were] as nothing before him.

1) And before the common people he says shameful things about [everyone] but himself, uttering slanders and speaking

is in his pride, and boasting with his tongue: "Who [is there that] teaches like me?" and "He who rebels against the word of my mouth

ig shall be treated as a disobedient elder 7." He voids water upon holy things, pours contempt upon men,

2o outrages the honorable, brings weakness upon strong men, saying: "Whosoever shall exalt his horn before me,

${ }_{21}$ him in anger shall I outlaw, and in my wrath overwhelm with the fire of battle." He says :

${ }_{22}$ "My counsel shall stand, and I will do all my pleasure"," and "Who is he that will dare open his mouth in my presence?" And against all

${ }_{23}$ the leading men he raises his hand, that he may gain honor for himself by the shame of [his] associates. And everyone who transgresses

${ }_{2+}$ his decisions he forthwith outlaws; and he does as he pleases, that he may magnify and exalt himself.

${ }_{25}$ And if people say to his companions and those that know him ${ }^{9}$ : "Why does he do this?" they reply

26 thus: "He has the power to do even what is contrary to legal custom; for as soon as he was appointed

27 and made Head [of the Academy], he exalted himself to [the dignity of being] Head of All. And to him whom he desired, he gave to drink

28 the waters of new wine; but to him against whom he was angry, [he gave] wormwood and poison. Woe unto the generation which has this for a leader! [A man] who casts

29 his injustice in its face. And although sound men-and there are many such — defend his doings, [nevertheless] his companions and his flock make sport

30 of him. They let him [do] according to his custom, the custom of Jehu. There is no blame for the madman,

3r even though he works with design and cunning. Truly, his report has gone forth in the land, and his character

$3^{2}$ is recognised ${ }^{10}$ for all time. This is what his friend says of him, about the difficulty of his justifying himself: for [him] to turn humility

33 into folly. How has the folly of this [man] profited him in this world ${ }^{11}$ ? And because of

34 this the Law has been desecrated, and its crown brought down to earth, and its honor has ceased. Behold, the honorable Rabbi

35 Ishmael came from Damascus. He had been dayyān among them [there]. And he had published abroad

\footnotetext{
10 For וינבר. 11 This sentence is in Aramaic.
} 
6ברי תורה ופרר על עצמו לבוא לדור בארץץ ישראל ודרש ברבים

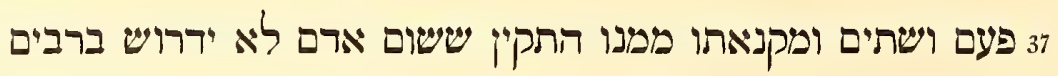

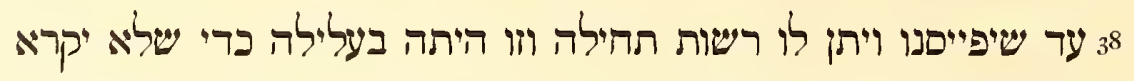

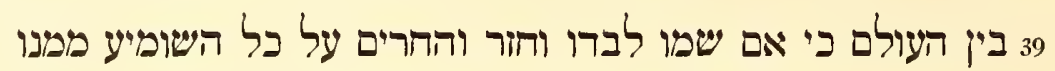

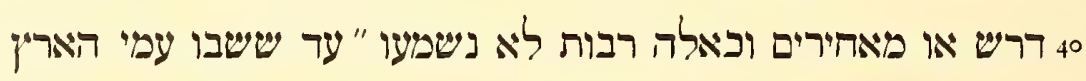

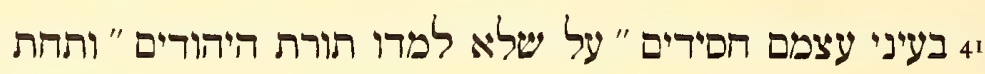
24 שהיו בני תורה כאבני נזר מתנוסםים "נחשבו עכשיו כאבן

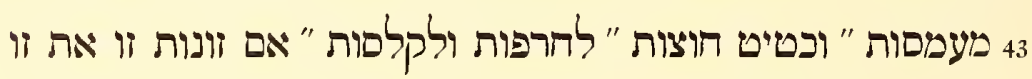

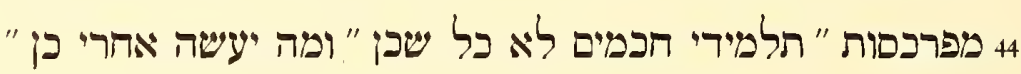

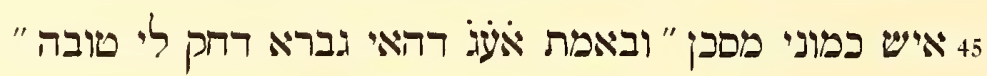

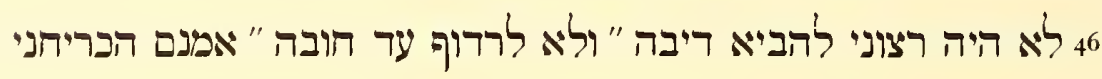

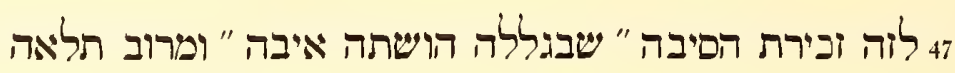

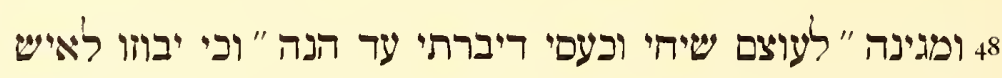

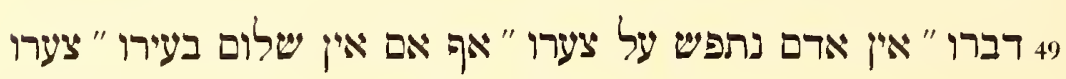

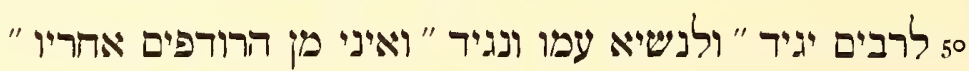

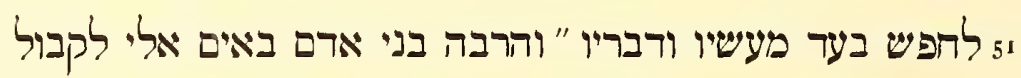

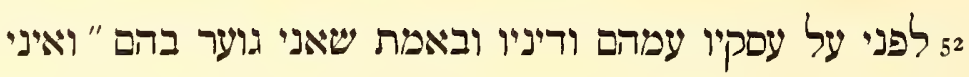

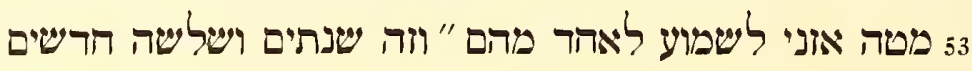

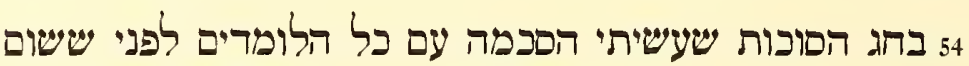

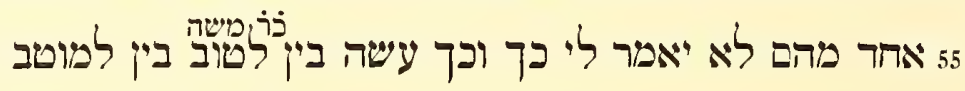

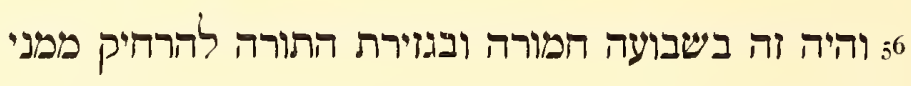
65 ומליבי כל רופי ואון זה הבלל שאני עוסק בצערי וברוב העתים

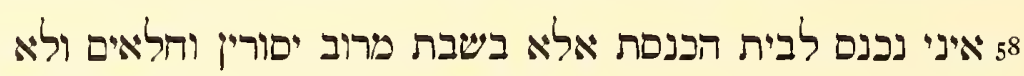

12 Zechariah ix, 16.

14 Micah vii, 10.

16 ๆ 16.

17 This clause is in Aramaic.

19 Talmud, Baba Bathra, I6b, where however we have "in the hour of his suffering":

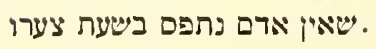

13 Zechariah xii, 3. But here correct to אבנים.

15 Talmud, Shabbāth, 34 a.

${ }^{18} \mathrm{Cf}$. Genesis iii, I 5 . 
$3^{6}$ [certain] words of the Law, and taken upon himself a vow to go and live in Palestine. And he preached publicly

37 once or twice. And, because [Rabbi Moses] was jealous of him, he commanded that no man should preach publicly

$3^{8}$ until he had made peace with him, and he had given him permission beforehand. And this was done in order that his name

39 only should be noised abroad. And he next outlawed every one who listened to instruction from him

to or from others; and many things like these, [such as] were never heard of [before]; until the common people came to be

${ }_{4} 1$ saints in their own eyes, without learning the Law of the Jews; and, instead of

$t^{2}$ the Sons of the Law being as stones of a crown lifted on high ${ }^{12}$, now they are reckoned as burdensome

${ }_{43}$ stones $^{13}$, and as mire of the streets ${ }^{14}$, [fit only] for shame and derision. If harlots paint each other's

${ }_{44}$ faces, should not the pupils of wise men [show] even more [mutual helpfulness ${ }^{15}$ ]? And after [all] this what is a poor man

${ }_{45}$ like me to do? And truly, even though ${ }^{16}$ this man has deprived me of $\operatorname{good}^{17}($ ?),

+6 I have not wished [of myself] to bring gossip, nor to pursue [him] to [the point of] accusation. Verily I was compelled

47 to [do] this by the memory of the cause by which enmity was established ${ }^{18}$. Because of much vexation

${ }_{4}^{8}$ and sorrow I have spoken thus far in my strongest language and in $\mathrm{my}$ anger. But if people despise a man [for]

${ }_{49}$ his speech, [let them remember that] no man is called to account for his suffering ${ }^{19}$. Even if there be no peace in his city, his suffering

so to the multitude he makes known: even unto the prince and leader of his people. I am not a persecutor of him,

5 I to search out his doings and sayings. Many people come to me to complain

$5^{2}$ to me about his dealings with them and his judgments. But truly I rebuke them and $I$ do not

53 lend my ear to hearing one of them. Only two or three months [ago]

$5+$ at the Feast of Tabernacles, I made an agreement with all those who were studying under me, that not

55 one of them should say: "The honorable Rabbi Moses ${ }^{20}$ has done thus and so," however good [his intentions].

${ }_{5} 6$ And this occurred in an important week and [at a time] when the Law commands [me] to put away from myself

57 and from my heart every blemish and sin. This [was] the rule which I practised in my suffering. And for the most part

58 I did not go to the synagogue except upon the Sabbath Day, by reason of $[\mathrm{my}]$ ailments and disorders; nor

${ }^{20}$ Evidently the name of the accused. It is written between lines. Cf. line 64 . 
95 אצא לשוק אלא על כרהי בערב שבת "וזה מכמה ימים שהלך

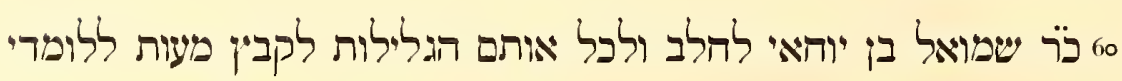

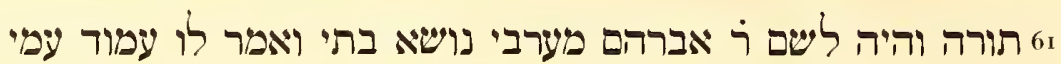
26 ותשתרל שיתני לי בשביל המיך אסכנרראני ובשביל שאר בני

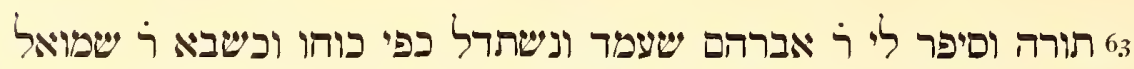
64 הנזכר עם דמעות שקיבץ מהקהילות הכל לקה ذר משה דיין ובאמת 65 שלא הגיע לי אפילו פרוטה אהת ובפנים הזאת הלך ذר שמואל הנזذ 66 לארץ תוגרמה וקיבץ מה שקיבץ וכשהגיע להלב שלה לפקוד 6 בשלומינו ומה שבא בידו הכל לכך משה ולעלם לא רדפתי אהר אלי 68 אלו הרברים ולא קיבלתי משלאהרים מלבר מה ששלהו אלי קרובי

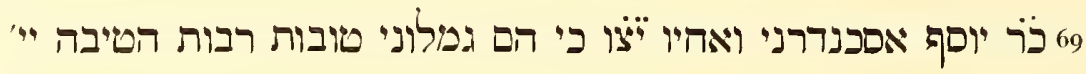

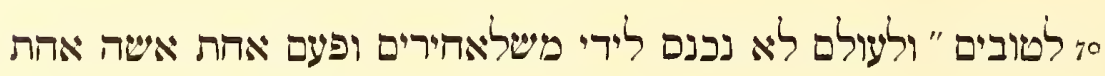
ז' היתה הולה והיה הרופא ذר יוסף המצרי זל שנקרא עפ'ף בן עורא

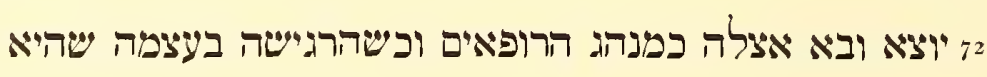
3. נפטרת לבית עולמה שלהה לקרות לי ביד הרופא הנזכר ולא הלכתי אצלה

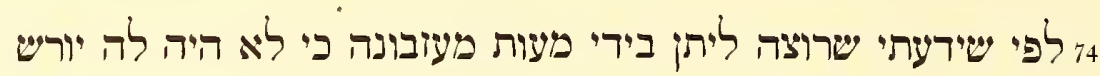
5 ויאני לא רציתי ללכת אצלה ובא ذר יוסף הרופא הנזכר אלי ויאמר לי רעי 6 שהיא נוטה למות וכל מה שיש בירה לוקהים הגוים ויאתה נשבעת דה שלא יכנם לידך שום רבר מזה תן לנו עצה מה נעשה והביא מה ניש

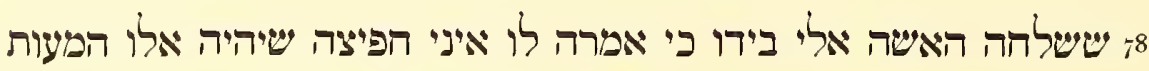
9; שנשארים אחרי מעובוני כי אם ביר יוסף אסכנדראני שיעישה

\footnotetext{
21 Hebrew for the ordinary Arabic, Maghribi.

22 For $\mathrm{D}$. A frequent form. See other examples below.

23 For 24 Or Armenia?
} 


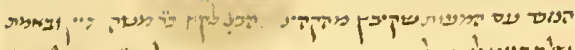

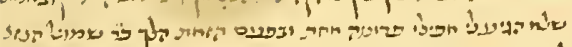

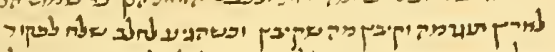

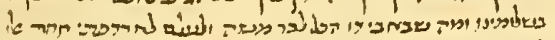

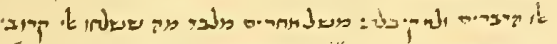
" "

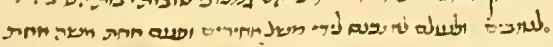

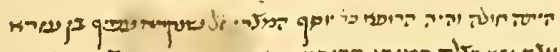

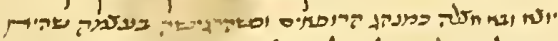

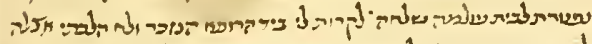

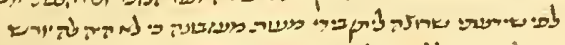

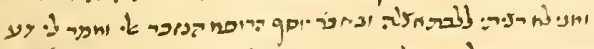

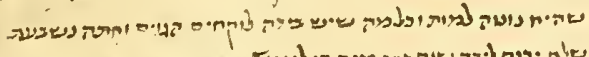

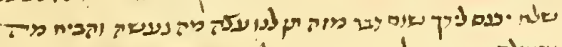

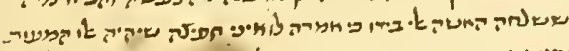

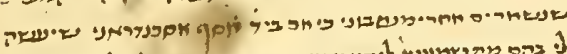

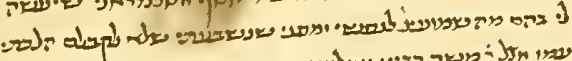

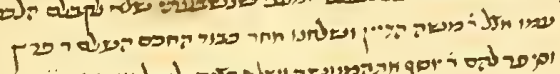

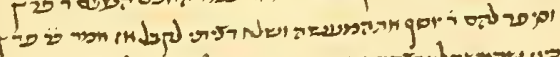

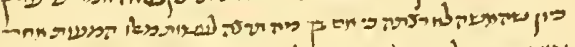

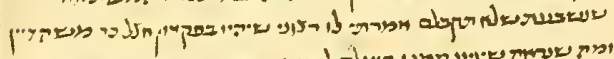

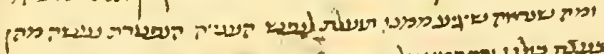

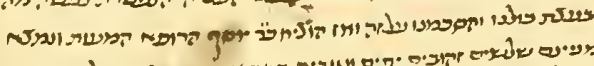

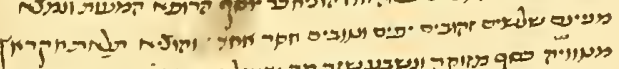

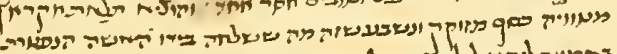

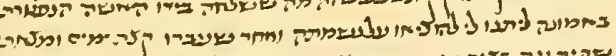

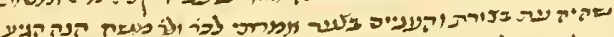

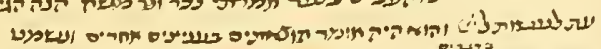

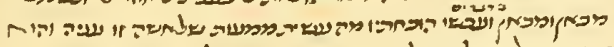

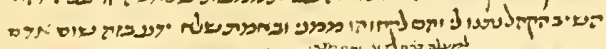

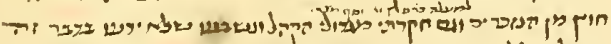

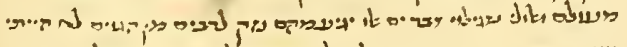

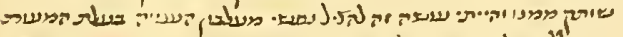

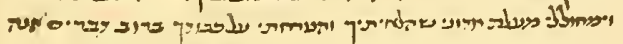

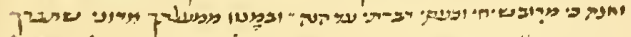

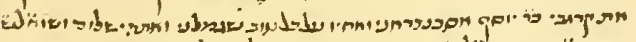

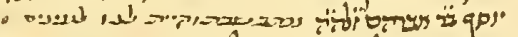

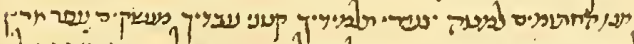

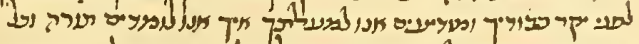

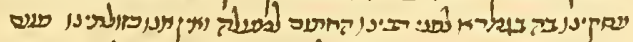

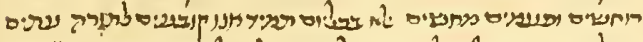
.

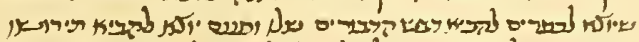

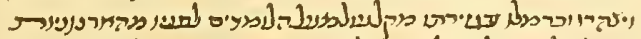

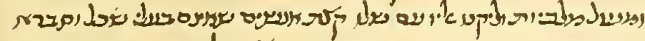
על , 40

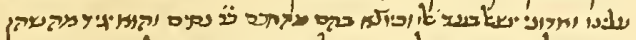

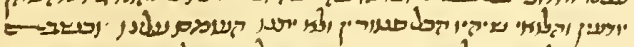

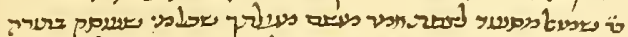

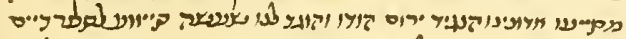

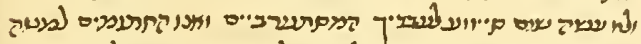

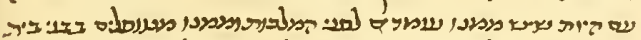
דivar

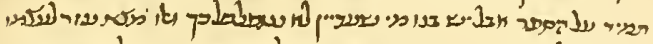

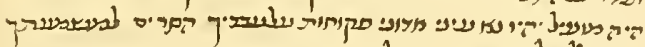

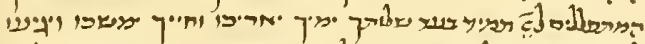

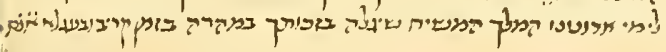

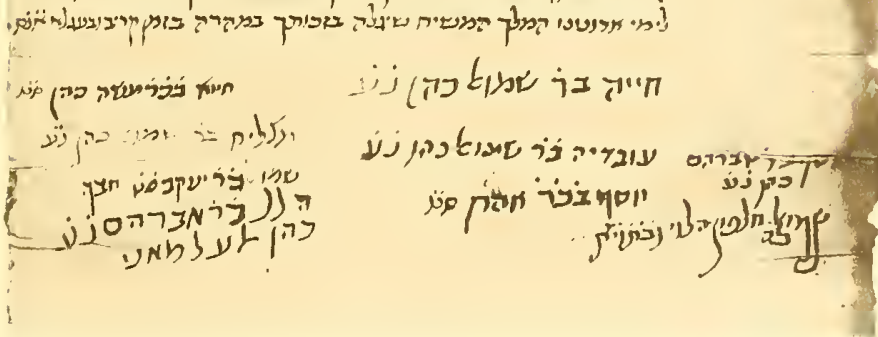




\section{-}

\section{-}


59 did I go forth to the market-place, except involuntarily, on Sabbath Eve. Only a few days ago the honorable Rabbi Samuel

6o Ben Yōhai went to Aleppo and to all those surrounding [places], to collect money for the students of

6r the Law. And it happened in the case of Rabbi Abraham Ma'rabī ${ }^{21}$, my daughter's betrothed, [that Rabbi Samuel] said to him: "Stand with me

62 and persuade them to give to me on account of your father-in-law, Iskandarāni, and on account of the other Sons of

63 the Law." And Rabbi Abraham told me ${ }^{22}$ that he stood and solicited ${ }^{23}$ as well as he was able; and that, when the [above-]mentioned Rabbi

${ }_{6}$ Samuel returned with the money which he had collected ${ }^{22}$ from the congregations, the honorable Rabbi Moses, the dayyān, took the whole [of it]. And truly

65 not even a single penny reached me. With these sentiments the honorable Rabbi Samuel, [above] mentioned, went

66 to the land of Turkey ${ }^{24}$, and collected what he could ${ }^{22}$. And when he had reached Aleppo, he sent to give

$6_{7}$ us greetings; but all that had come into his hands he turned over to the honorable Rabbi Moses. I have never run after

68 these things, nor have I received what belonged to others: save only what my kinsmen sent me,

69 the honorable Rabbi Joseph Iskandarānī and his brothers-May God preserve him!-for they have shown me many kindnesses. May God reward

7o the good! Never has there come into my hands what belonged to others. On one occasion a woman

In was ill, and the physician was the honorable Rabbi Joseph, the Egyptian, of blessed memory, who was called [in Arabic] 'Afíf Ibn Ezra.

${ }_{72} \mathrm{He}$ went in and out of her house, in the manner of physicians; and when she felt within herself that she

73 was departing to her eternal home, she sent to have me summoned by the [above-]mentioned physician. But I did not go to her [house]

74 because I knew that she wished to place in my hands the money of her estate-for she had no heir-

75 and I did not wish to go to her [house]. And the honorable Rabbi Joseph, the physician, [above] mentioned, came to me, and said to me: "Know

${ }_{7} 6$ that she is inclining toward death, and that the gentiles will take all that she has in her possession; and [yet] you have sworn

77 that nothing of this shall be gathered into your hand. Give us [therefore] advice [as to] what we are to do." And he brought what

78 the woman had sent to me by his hand; for she had said to him: "I do not wish this money,

79 which shall be left behind me in the way of an estate, to be in the hands of any but Joseph Iskandarānī, to do 
o לי בהם מה שמועיל לנפשי ומפני שנשבעתי שלא לקבלם הלכתי ז8 עמו אצל ר משה הדין ושלחנו אחר כבוד החכם השלם ר פרין 82 וסיפר להם خ' יוסף את המעשה ושלא רציתי לקבל או אמר כר פרין 83 ביןן שהאשה ליא רצתה כי אם בך מה תרצה לעשות מאלו המעות אהר 48 שנשבעת שלא תקבלם אמרתי לו רצוני שיהיי בפקרון אצל ذֹ מש הדיין 5 ומה שנראה שיגיע ממנו תועלת לנפש העיייה הנפטרת נעשה מהן 86 בעצת כולני והפכמנו על זה ואז הוציא כר יוסף הרופא המעות ונמצא

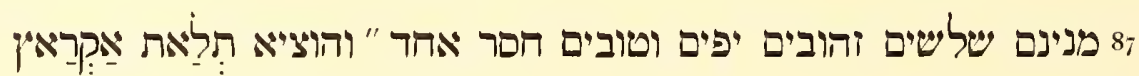
88 מטוֹייה כסף מזוקק ונשבע שזה מה ששלחה בידו האשה הנפטרת 89 באמונה ליתנו לי להוציאו על נשמתה ואהר שעברו קצת ימים ומצאתי ס9 שהיה עת בצורת והעניים בצער אמרתי לذר ולר משה הנה הגיע יו9 עת לעשות ל.) והוא היה אומר הוצאתים בעניינים אחרים ונשמט

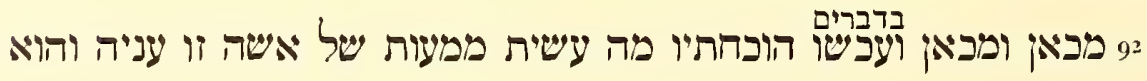
93 השיב הקהל נתנו לי והם לקחוהו ממני ובאמת שלא ידע בזה שום אדם

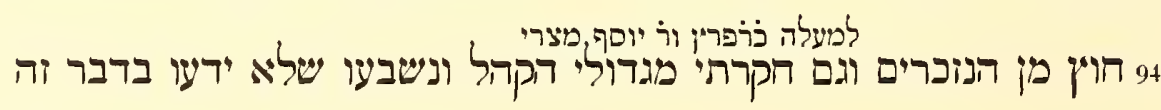

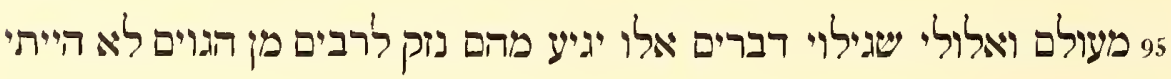
69 שותק ממנו והייתי עושה זה להציל נפשי מעלבון הענייה בעלת המעות ז9 וימחול לי מעלת אדוני שהלאיתיך והערחתי על פבודך ברוב רברים אנה

\footnotetext{
25 Supply $\pi$.

${ }_{26}$ Arabic, meaning some article of personal adornment.

27 Psalm cxix, I26. 28 This phrase is in Arabic.

${ }^{29}$ Added above the line in the same hand.

${ }^{30}$ Added above the line in a different hand.
} 
80 for me with it that which will help my soul." But, since I had sworn not to accept them, I went

8r with him to Rabbi Moses, the dayyān; and we sent for the honorable, wise [and] perfect Rabbi Perez(?);

82 and Rabbi Joseph told them of the matter, and [also] that I did not wish to accept [the money]. Then the honorable Rabbi Perez said:

$8_{3}$ "Since the woman did not wish [anyone] but you [to have the money], what do you wish to do with this money, after

$8+$ you have sworn that you will not accept it?" I said to him: "My wish is that it shall be upon deposit with the honorable Rabbi Moses, [the $]^{25}$ dayyän;

85 and whatever we shall perceive to bring profit to the soul of the poor woman who is departed, we shall do [by using some] of it,

86 with the advice of us all." And we agreed upon this. And then the honorable Rabbi Joseph, the physician, brought out the money; and their number

87 was found [to be] thirty gold-pieces, fair and good, less one. And he brought out three folded

$88 \operatorname{discs}^{26}$ [of] refined silver. And he swore that this was what the deceased woman had sent by his hand

89 in good faith, for him to give me, to expend for the sake of her soul. And after a few days had passed, and I found

90 that it was a time of scarcity and [that] the poor [were] in distress, I said to the honorable Rabbi [Perez?] and to Rabbi Moses: "Behold the time

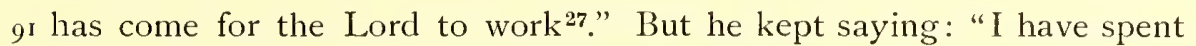
it for other poor people; and it has been expended

$9^{2}$ in this place and that ${ }^{28}$ in [different] undertakings ${ }^{29}$." And now I called him to account, [saying]: "What have you done with the money of this poor woman?" But he

93 [merely] answered: "The congregation gave it to me, and they have taken it from me." But the truth [is] that no man knew [anything] about this,

94 excepting those mentioned-beyond the honorable Rabbi Perez, and Rabbi Joseph [the] Egyptian ${ }^{30}$. And I have also made inquiry of the important persons of the congregation; and they have sworn that they never knew [anything] about this

95 matter. And had it not been that a divulgence of these matters would have brought injury to many at the hands of the gentiles, I should not have been

$9^{6}$ silent about it; but I should have done this to release myself from the reproach of the poor woman, the owner of the money.

${ }_{97}$ But his Eminence, my Lord, will forgive me that I have wearied you ${ }^{31}$ and taxed ${ }^{32}$ your Honor with [the burden of hearing] many words about various matters;

\footnotetext{
31 I.e. "him" etc. הערכתי Ashkenazic pronunciation of $\pi$ ?
} 
98 ויאנה בי מרוב שיחי וכעםי רברתי עיד הנה "ובמָטו ממעלתך ארוני שתברך

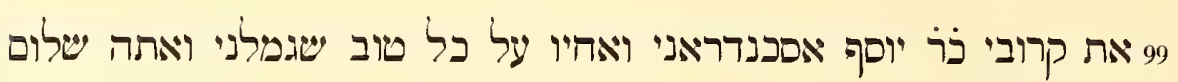

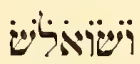

roo יוסף ذَ אברהם تללהה נכתב שבת והיית לנו לעינים

זо זנו החתומים למטה • צעירי תלמידיך קטני עבדיך מנשקים עפר אריץ

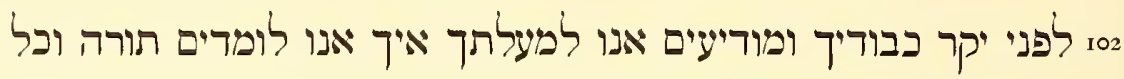

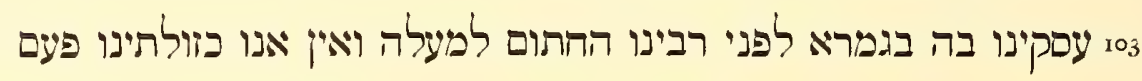

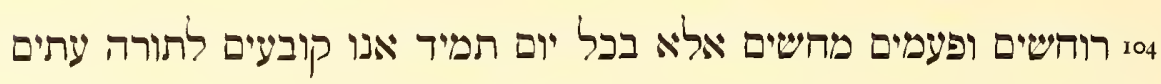

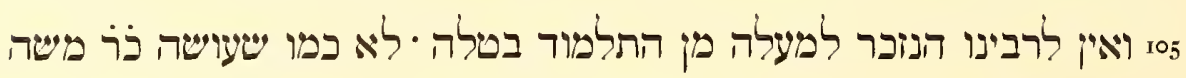

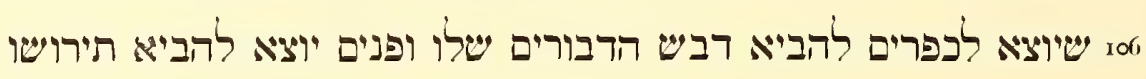

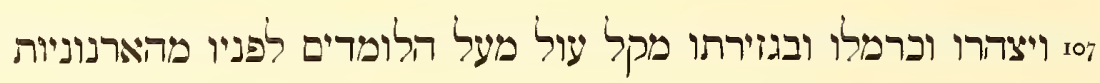

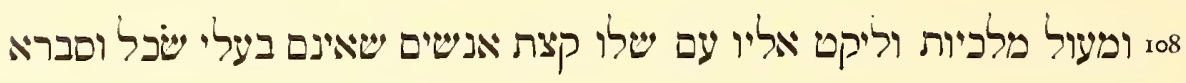

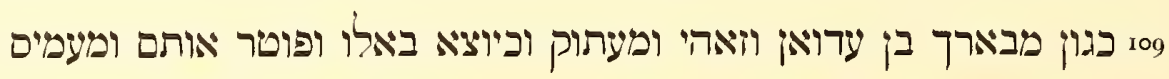

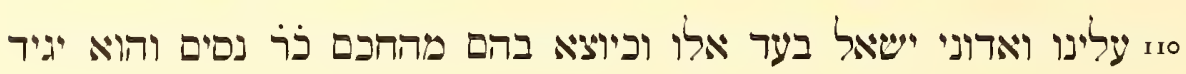

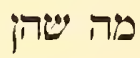

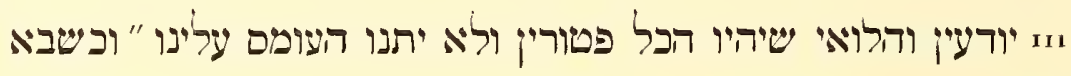

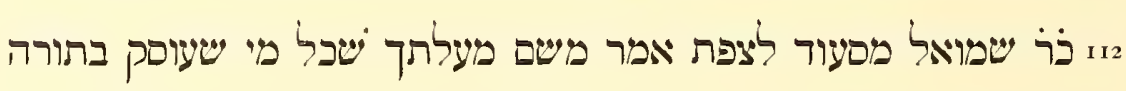

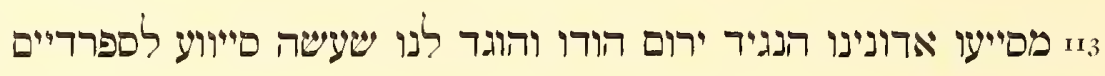

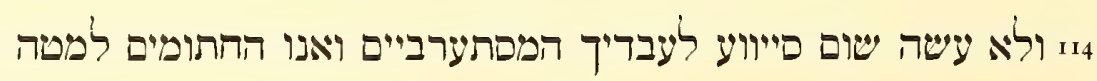

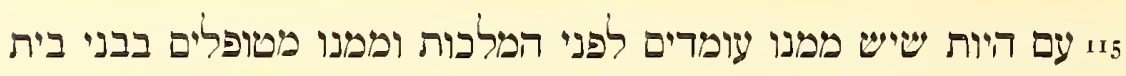

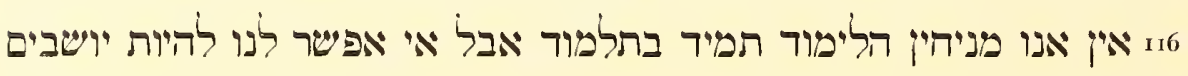

\footnotetext{
${ }^{33}$ I Samuel i, 16.

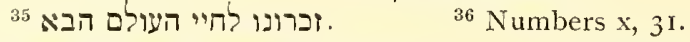

${ }^{37}$ Arabic for Baruch, "Blessed." 38 "Hostility" (?).

39 "Brilliant." Cf. Glanz, Finkelstein, etc. "40 "Freedman."

${ }^{41}$ Aramaized Hebrew, and confused. בישם 42 ?

${ }^{43}$ The 2 nd and 3 rd persons are confused.

${ }^{44}$ An Arabic word with a Hebrew plural ending.
} 
$9^{8}$ "for out of the abundance of my complaint and my provocation have I spoken hitherto ${ }^{33}$." And [I beg] as a favor from your Eminence, my Lord, that you will greet

99 my kinsman, the honorable Rabbi Joseph Iskandarānī, and his brothers, [and bless him] for every good thing which he has done for me. And [to] you: Farewell! And the one who greets you ${ }^{34}$ [is]

roo Joseph, son of Rabbi Abraham-[May] his memory [be] eternal life ${ }^{35}$ ! Written [upon] the sabbath of the [Scripture reading:] "And thou shalt be to us instead of eyes ${ }^{36}$."

ror We, whose names are signed below, the youngest of your students, the least of your servants, kiss the dust of the ground

102 before the Dignity of your Honor. And we [beg to] inform your Eminence how we are studying the Law, and of all

ro3 our activities in the Gemara, with our master whose name is signed above. We are not like the others: at one time

ro+ working, and [many] times doing nothing; but every day without exception we set apart hours for [studying] the Law.

105 Nor does our master, mentioned above, have any leisure from teaching. [He does] not [do] as the honorable Rabbi Moses does, [at one time] 106 going forth to the villages to bring in the honey of his bees, and [at another] time going forth to bring in his new wine

roy and his oil and his grain, and by his decree relieving students under his instruction from taxes ${ }^{3}$

108 and from the burden of the royal levies. And [Rabbi Moses] has selected people who belong to him: a parcel of men possessing no intelligence or understanding,

Io9 as, for example, Mubārak ${ }^{37} \mathrm{Ibn}$ ' $\mathrm{Udwān}{ }^{38}$, and Zāhīi ${ }^{39}$, and Ma'tūk ḳ and the like of these. And he lets them go free while laying burdens

ro upon us. And let my Lord inquire concerning these [men] and the like of them, from the wise, the honorable Rabbi Nissim; and he will tell what they

m $\mathrm{know}^{41}$. But oh that all [of us] were free, and that the oppressor were not placed over us! And when the honorable

In Rabbi Samuel Mas'üd came to Safed, he said, in the name ${ }^{42}$ of your Excellency, that everyone who occupied himself with the Law

Ir.3 should receive assistance from our Lord the Nāgìd-May his glory be exalted! - But we have been told that he has given help to the Spanish [Jews],

${ }_{14}$ and has given no help to his ${ }^{43}$ servants the Arabized [Jews] ${ }^{44}$. And we, the undersigned,

${ }_{1} 5$ in spite of the fact that [some] of us stand before Royalty ${ }^{45}$, and [some] of us have dependent children,

Ir6 never cease at all to study the Talmud. But it is not possible for us to be sitting

${ }^{45}$ They were in military service? 
7יו תמיר על הספר אבל ישי בנו מי שעריין לא יטפלפל כך ואלו מציא עור לעצמפו

118 היה מועיל יהיו נא עיני אדוני פקוחות על עבריך הפרים למשמעתך

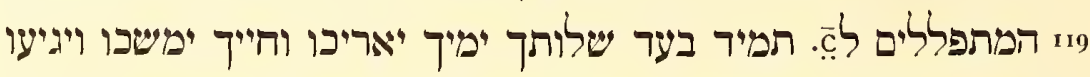
120 לימי ארונינו המלך המשיח שיגלה בזכותך במהרה בזמן קריב ובעגלה אנים. חייא ذذخר משר כהן פט

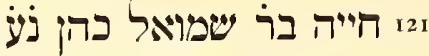

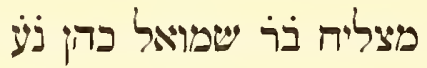
122

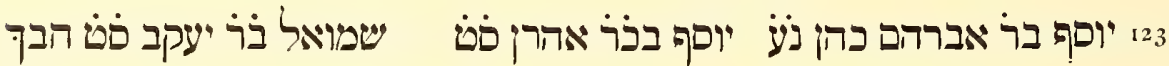

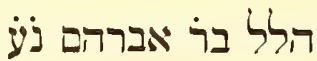
124

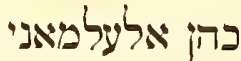

226 והנה אני החותם שמי מטה העלוב מיפורי הזמן מפני שאני נהפ: ללכת

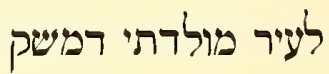

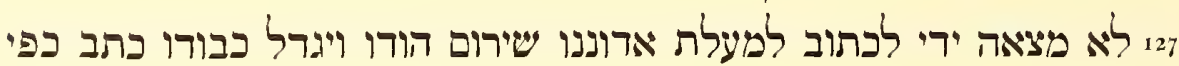
הראאי אמנם אגיד צערי

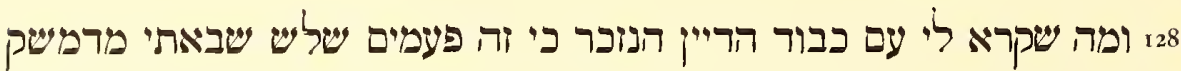

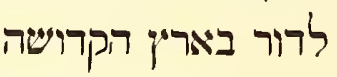

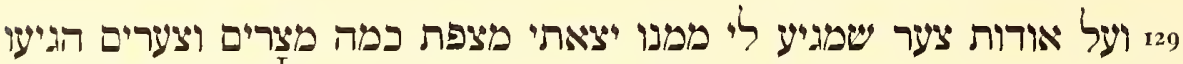

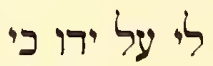

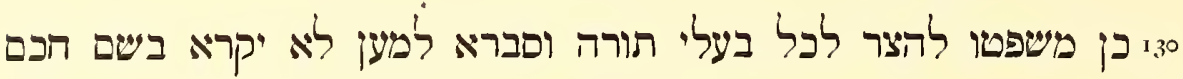

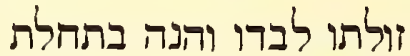

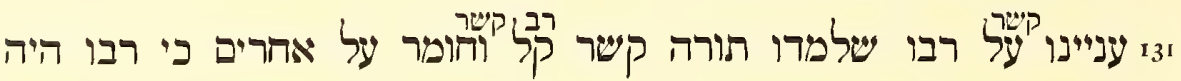

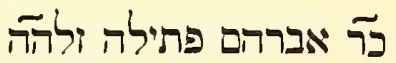

${ }^{46}$ For babeת.

${ }^{47}$ Cf. Jeremiah xxxii, 19.

${ }^{48} \mathrm{Cf}$. the unintelligible passage in I Samuel xxii, I4, which the Revised Version translates badly: "and is taken into thy council."

${ }^{49}$ A very strange sign in the text.

50 Aramaic

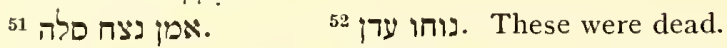

סופו טוב 53 . The were still living. The "Successful."

${ }^{55}$ Not an abbreviation, as we see from the form of 7 .

נפשו בטוב תלין ויתברך 56. 
${ }_{11} 7$ forever at the Book! There are among us some who do not yet argue ${ }^{46}$ [points] so [well]. But if [such a one] found help for himself

118 it would help others. May the eyes of my Lord be open upon his ${ }^{43}$ servants ${ }^{47}$ who turn when they hear him, ${ }^{43,48}$

119 who pray to God ${ }^{49}$ continually for his ${ }^{43}$ peace of mind: May your days be long, and may your life stretch out and touch

I 20 the days of our Lord, the King, the Messiah, who [we pray] may be revealed through your merit soon, in a time near at hand, and in haste ${ }^{50}$ ! Amen! Forever! Selah ${ }^{51 !}$ [Signed:]

I21 Hiyyāh, son of Rabbi Samuel Kōhēn-[May] his rest [be in] Eden ${ }^{52}$ ! Hiyya, son of the honorable Rabbi Moses Kohēn-[May] his end [be] good $^{53}$ !

122 Obadiah, son of Rabbi Samuel Kōhēn-[May] his rest [be in] Eden! Maṣlīạ ${ }^{54}$, son of Rabbi Samuel Kōhēn-[May] his rest [be in] Eden! 123 Joseph, son of Rabbi Abraham Kōhēn-[May] his rest [be in] Eden! Joseph, son of Rabbi Aaron-[May] his end [be] good! Samuel, son of Rabbi Jacob-[May] his end [be] good !......... ${ }^{55}$

I24 Samuel, son of Rabbi Halfōn ha-Lēvi- May his soul rest in good, and be blessed ${ }^{56}$ ! Hillēl, son of Rabbi Abraham-[May] his rest [be] in Eden!

${ }_{125}$ Kōhèn the German ${ }^{57}$.

I 26 Behold I, who have signed my name below, [a man] afflicted by the visitations of the times, because I was in haste to go to Damascus, the city of my nativity,

${ }_{127}$ did not find [opportunity] to write to the Eminence of our Lord-May his glory be exalted, and his honor be magnified-a letter according to propriety. [Yet now] in truth I shall tell of my suffering

128 and of what befell me in connection with the honorable dayyān [above] mentioned: for it [is now] three times that I have come from Damascus to dwell in the Holy Land,

129 and have left Safed because of trouble which overtook me through him. How many troubles and afflictions have overtaken me at his hands! For

130 such is his manner of oppressing all the masters of the Law and of tradition to the end that [no one] shall be called by the appellation "wise" except himself only. And behold, in the beginning of

131 his affair ${ }^{58}$ he conspired against his rabbi, who had taught him the Law, in a great conspiracy. How much more then did he conspire against others! For his rabbi was the honorable Rabbi Abraham Pethīanh ${ }^{59}$ May his memory endure unto the life of the World to Come ${ }^{60}$ !-

57 The modern Arabic word for "German," with the Arabic article. He is not merely an "אישבנז, but comes from Germany itself. He does not give his father's name, and may be a recent arrival.

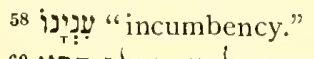

59 "Wick."

זכרונו לחיי העולם הבאי 60 
132 יצא מן העולם והוא מצטער ממנו על זה יאמר אשרי מי שרוה הבריות נוחה הימנו וישאל

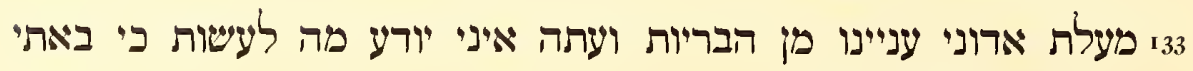

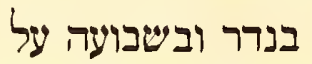

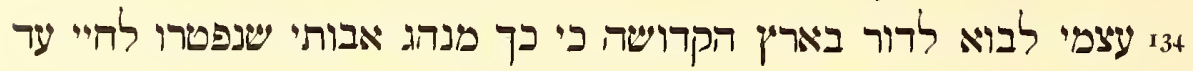

\section{בשמזקינים באים לורים}

135 באים לאריץ ישראל להיות באים קולטתן מהיים וזה רוצה לגרשני ממנה

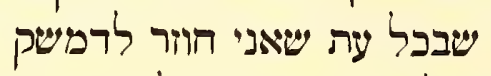

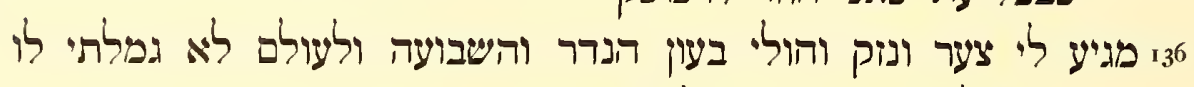
רעה אלא אררבה נשתרלתי וניתי

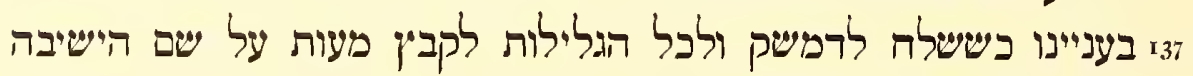

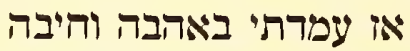

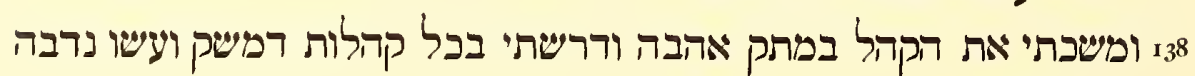
בשביל ומשתי

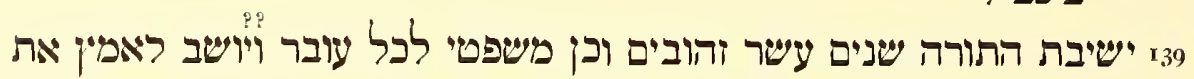
דנכבשל וכן

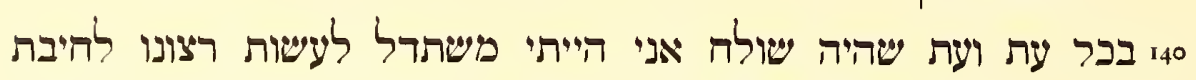
התורה ולומריה ולחיבת ועת שתיה

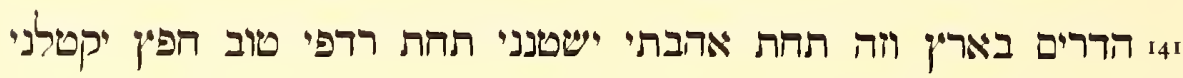
ואיטפ שבני ארם ברים

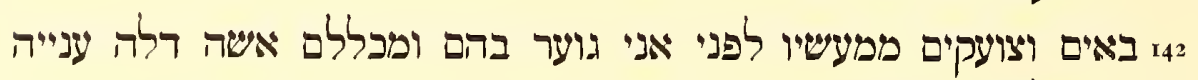

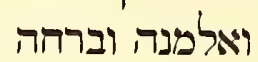

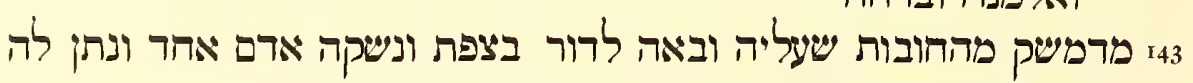
המשים נספים מדות שמות

144 ממטבע רמשק ולא עלה ויווגם יפה וגרשה בימים מעטים קיבל ממנה ר' מכשי

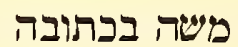

145 ובגט ששה ושלשים כספים וחבל בגר האלמנה ער שקיבל השישה ושלשים בכרים

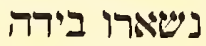

\footnotetext{
${ }^{61}$ Mishnah iii, IO: "Every [man] in whom the spirit of men [finds] its rest, in him the spirit of God [finds] its rest. And every [man] in whom the spirit of men [finds] not its rest, in him the spirit of God [finds] not its rest." In the present case : Blessed is the man who is beloved on earth, for he is assuredly beloved in Heaven." Rabbi Moses was not one of these.

${ }^{62}$ Word repeated.
} 
132 [Rabbi Abraham] departed this world [much] grieved with him. To this [the Mishna] says: "Blessed is he in whom the spirit of men [finds] its rest ${ }^{61 . "}$ And his Eminence, my Lord,

${ }_{33}$ asks [about] his dealings with men: I know not what to do now; for I came, under a vow and an oath [which I had taken] upon

134 myself, to go to dwell in the Holy Land-for thus [was] the custom of my fathers who have gone to eternal life, that when they became old they went ${ }^{62}$

135 to the Land of Israel in order that it might receive us [under its protection] while still living ${ }^{63}$. And this [man] wishes to drive me from it. For every time I return to Damascus

${ }_{1} 3^{6}$ trouble and misfortune and sickness overtake me because of the $\sin$ of the [unfulfilled] vow and oath. And yet I never did him any wrong; but, on the contrary, I exerted myself ${ }^{64}$

137 in his undertaking, when he sent to Damascus and to all the [neighboring] districts, to collect funds in the name of the Academy. At that time I stood in love and affection,

${ }_{13} 8$ and I drew the congregation [after me] with the sweetness of love ${ }^{65}$; and I preached in all the congregations of Damascus; and they gave alms in the cause of

139 the Academy of the Law: twelve gold-pieces. And this is my manner toward everyone transient and resident: to strengthen him who has stumbled. And thus,

I 40 on each occasion when he sent [solicitors], I exerted myself to do his will, for love of the Law and its teachers, and for love

I +1 of those who dwell in the [Holy] Land. But this man, instead of [requiting] my love, antagonised me; instead of [emulating] my pursuit of good, desired to kill me. And although ${ }^{66}$ men

$1_{42}$ come and cry aloud of his deeds before me, I rebuke them. And of all [the complaints, I mention particularly] a woman, poor, destitute, and widowed, a fugitive

${ }_{143}$ from Damascus, on account of the debts which she owed. And she had come to dwell in Safed; and a certain man kissed her ${ }^{67}$ and gave her fifty pieces of silver

It+ of the Damascus mint. But their marriage did not turn out well, and he divorced her after a few days. Rabbi Moses took from her for the marriage contract

$I_{45}$ and for the letter of divorce thirty-six pieces of silver. And he took the widow's clothing as security ${ }^{68}$, until he should receive the thirtysix. [Thus] she had left

\footnotetext{
"אינו רומה קותטתו מחיים לקולטתו לאחר מיתה : Kethübhōth Ir I a, cited by Levy, op. cit. "He whom [Palestine] receives while living, is not to be compared to him whom it receives after his death."

${ }^{61}$ For המת was written, but deleted.

${ }^{67}$ I.e. "married her"? The word has been corrected by the scribe.

${ }^{68} \mathrm{Cf}$. Deuteronomy xxiv, 17 .
} 
146 ארבעה עשר כספים למוקרם ולמאוחר הן אלה קצות ררכיו וכאלה רבים ועם כל וזה לעולם

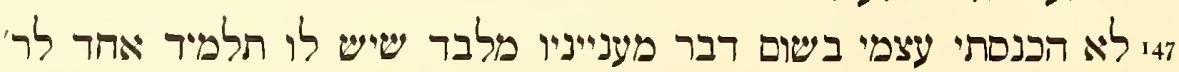
משה הנז

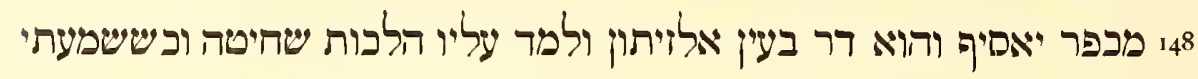

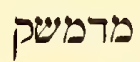

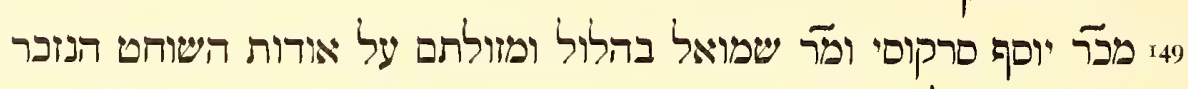

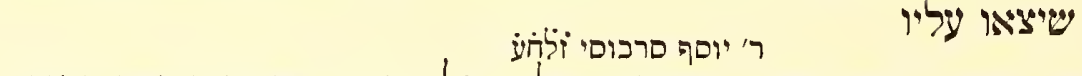
150 רבות רבות ועמר החכם והפכים עליוי שלאי יהאי שוחט ובודק ופוכר

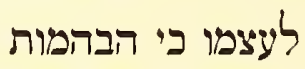

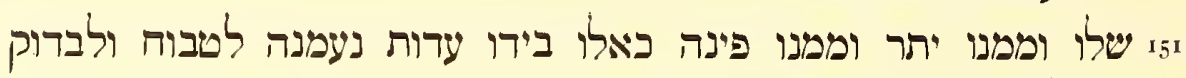

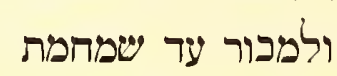

2515 וה כל אנשי עין אלויתון ואנשי ביריא וצפת מרננים עליו ומרברים אחריו

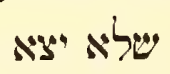

153 מבהמותיו כי אם מעט טרפות וכשראה החבם ר' יופק: סרכוסי הנזכר עניינו גזור

154 שלא יאכל שום אדם משחיטתו ער שיעמידו עליו איש נאמן על השחיטה

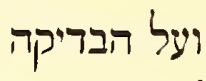

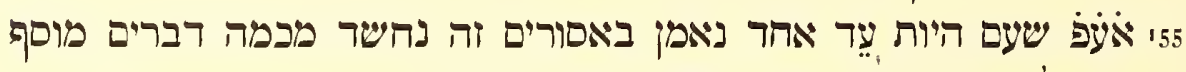

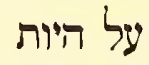

6ים שמיע לו נזק בעת שתעלה הבהמה טרפה שאינו מובר אותה בהצי דמי הכשרה

157 אחר שנפטר החכם ר' יוסף סרכוסי זללה החזירו ר' משה להיותו נאמן על עצממו פברלי

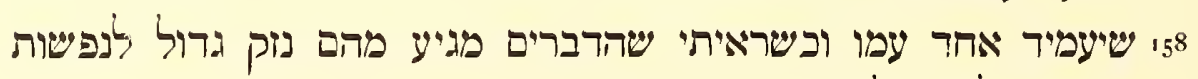

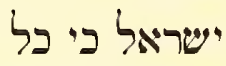

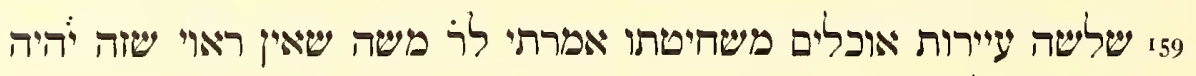

ניאמן לעצמו כי עירות יכוי

69 הניכר.

70 See Baedeker, Palästina (I9Io), p. 250.

71 See ibid. p. 242.

72 " of Saragossa." A Rabbi Joseph Saragossī reorganised the Safed community in I 492 (see Jervish Encyclopedia, s.v. Safed). Our Moses succeeded Joseph (line I 57), and must have been the elder Moses di Trani, Rabbi of Safed, I 525-I535, according to J. E., s. $\%$. Trani. 
${ }_{1}+6$ [only] fourteen pieces of silver as the former and latter [marriage gifts]. Behold, these are some of his ways; and [there are] many [others] like them. And in spite of all this never

I 47 have I involved myself in any of his affairs, except [in one case]. The [above-]mentioned ${ }^{69}$ Rabbi Moses had a student

${ }_{1}{ }^{8}$ from Kafr Yāsīf ${ }^{70}$, and he lives in 'Ain al-Zaitūn ${ }^{71}$, and he taught him the laws of slaughtering [animals]. And according to what I have heard from Damascus,

I 49 from the honorable Rabbi Joseph Sarakossī ${ }^{72}$ and from Rabbi Samuel

Bahlūl ${ }^{73}$ and from others, about the [above-]mentioned butcher, there went forth against him

150 many evil reports; and the wise Rabbi Joseph Sarakossi-_ [May] his memory [be] for everlasting life! — stood up and agreed [with those] against him, that he should not be ${ }^{74}$ butcher and inspector and retailer for himself. For the cattle

151 [were] his own; and he sometimes allowed to pass, and sometimes condemned-as if [indeed] he possessed "sure testimony ${ }^{75}$ " to slaughter, and inspect, and sell-until, on account of

152 this, all the men of 'Ain al-Zaitūn and the men of Bīria (? ${ }^{76}$ and Safed spoke evil against him, and said concerning him that only a few

I53 of his animals turned out [to be ritually] unclean. And when the wise Rabbi Joseph Sarakossī, [above] mentioned, saw his doings, he decreed ${ }_{15+}$ that no man should eat of his slaughter[ed animals] until [the authorities] appointed over him a trustworthy man for the slaughtering and for the inspection.

${ }_{155}$ And, although ${ }^{66}$ for prohibitions ${ }^{77}$ one witness is trusted, this [man] was suspected, for many reasons, even of being [such that],

I 56 when a loss accrued to him on the occasion of an animal's turning out [to be ritually] unclean, that he would ${ }^{78}$ sell it for half the price of a [ritually] clean [one].

${ }_{157}$ After the wise Rabbi Joseph Sarakossi departed [this life] - [May] his memory [be] for [everlasting] life!-Rabbi Moses again made him responsible for himself, without

${ }_{58}$ his appointing anyone [to serve] with him. And when I saw that great loss would result to the souls of Israel-for all

139 three cities ${ }^{79}$ eat of his slaughter[ed animals] - I said to Rabbi Moses that it is not proper that this [man] should be responsible for himself; for

73 "Laughing." 74 For 'הי?

75 Cf. Psalm xix, 8.

${ }^{76}$ Some unidentified village very near to Safed. It could not, of course, be al-Bīrah near Rāmallāh, in the south.

77 The community could usually trust anyone to report uncleanliness in the common food supply, and one objection was sufficient to cause prohibition.

78 Literally: "was suspected......that he would not."

79 I.e. Safed, 'Ain al-Zaitūn, and Bīria (?). 


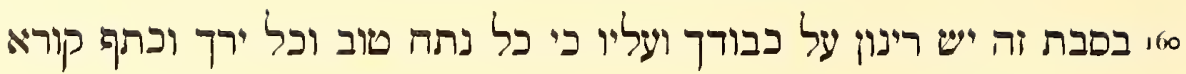
אותו על שמך

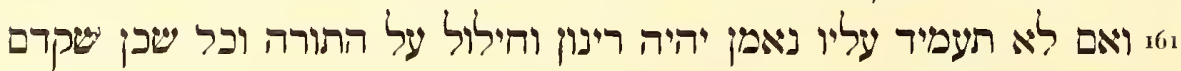
ליזה תקנה

26 מרבי יוסף סרכוסי מבשיר שהאואי מוכר עד שיעמידו עליו בודק נאמן ואיך องา

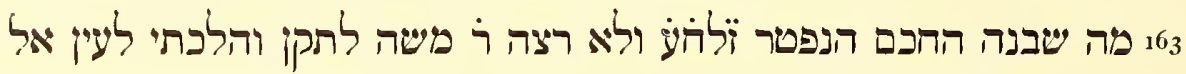
זיתון וחקרתי

461 על הענין ושלח ר משה הםכמה בכה כל פי שישי יודע לשוחט הנזכר

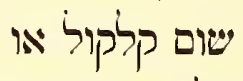

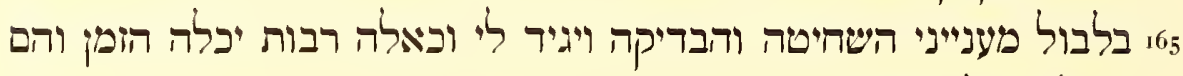
לא יכלו ומפני 166 שאני נחפו ללכת לדפשי לא ספרתי אהת מני אלף ואם יישר "בעיני

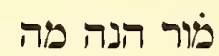
167 טוב אבל הלילה וחם ומצד קנאתו ממני מנעצי מרברי תורה אני ווולתי ועכשיו אם טוב 168 בעיני אדוני שיבטלני מדברי תורה אני וזולתי עלי לקבל גורתך ויאין

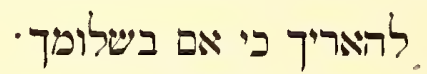
169 שיגרל לעד ואל יחדל בחפצך וחפין הנרצע לאהבתך ומתפלל תמיד בעד שלומך

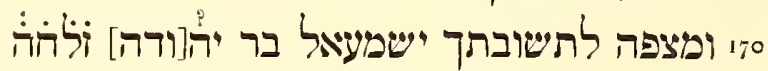

\footnotetext{
${ }^{80}$ Cf. Ezekiel xxiv, 4 .

81 At the beginning of line 166 there is a $\Gamma$ or an $\mathbf{~}$.

82 The word was misspelled, deleted, and then written above the line.
} 
I6o on account of this there is evil comment against your Honor and against him, since he names "every good piece," and every "thigh and shoulder ${ }^{80}$ " with your name.

r6I And, if you do not appoint over him a trustworthy [person] there will be criticism and desecration of the Law-all the more, [indeed], since an order from Rabbi Joseph

162 Sarakossī has already been [issued], which forbids [us] to eat of the flesh which that [man] sells, until [the authorities] appoint over him a trustworthy inspector. How shall we destroy

163 what the wise [man] has built, [who is] departed!-[May] his memory [be] for everlasting [life]! But Rabbi Moses did not wish to restore [order]; so, I went to 'Ain al-Zaitūn, and I investigated

${ }_{1} \sigma_{4}$ the affair. And Rabbi Moses sent out an opinion with [some] vehemence:

"Anyone who knew, [with reference] to the [above-]mentioned butcher, any injuri[ous rumor] or

165 slander, respecting the matters of slaughter and inspection, and told [it] to me-!" And [there are] many [other cases] like these. Time may pass away, but they will not pass away. But because ${ }^{81}$

I66 I am in haste to go to Damascus, I have not recounted one out of a thousand. And if this [conduct] is right in the eyes of my Lord and Master ${ }^{82}$, then what [is the]

r67 good [of my protest]! But God forbid! Because of his jealousy of me [this man] has prevented $\mathrm{me}^{83}$ from [preaching the] words of [the]

Law-me and others besides me. And now, if [it be] good

$\mathbf{r} 68$ in the eyes of my Lord that [this man] keep me from [preaching the] words of [the] Law-me and others besides me-it is for me to accept your decision, and not to continue [this letter] except in [wishing] your prosperity.

I69 That it may increase forever, and languish never, as is your wish, and the wish of [him who is] the object of your affection, and who prays unceasingly for your prosperity,

170 and who awaits your answer, Ishmael, son of Rabbi J[udah? $]^{84}$ - [May] his memory [be] for everlasting life!

\footnotetext{
83 מרי וארוני.

${ }^{84}$ The last name is written as a monogram, and there is a break in the paper just at this point.
} 



\section{INDEX OF SUBJECTS ${ }^{1}$}

Academy, 245

address, elaborate, 143

forms of, 62

adulter'y, $53 \mathrm{ff}$.

almonds, 231

amulets, 125

animals, speaking, 125

anointing, 209

aphrodisiac amulet, 23

"apology," I 65

"Appointed," $26 \mathrm{ff}$.

Arabic, bad or peculiar, I I 2, I 5 I

classical, I 33

Maghribī, VI I

script, II, XVI, XIX, XXVII,

XXXV, i 6

vernacular, IX, XII, XXVI,

XXVII, XXVIII, XXX, XXXIII,

XXXIV, XLV, XLV11

arabised Jews, 257

Aramaic, I, 58

arbitration, $5 \mathrm{ff}$., 43

article, Arabic and Hebrew, $\mathrm{IO}_{4}$

banker, 25

betrothal, 179

Bible paraphrases, XXXVIII

books, borrowing of, 125

purchase of, 65

used by children, 153

bribes, 149

bride, twelve year old, 187

business, methods, I6 I

overhead, 75

risks, 33, 51, I65

cabbalistic names, 107

canal, 54

captive, marriage of a, $\mathbf{I}_{3}$

captivity, 52

caravan route, Cairo-Damascus, I $39 \mathrm{ff}$.

caravan station, XLVII

Cashmere shawls, I79

charm, XV, XXIV children, I 53, I 57

circumcision of illegitimate, 55

colors of dyes, 73

commodities, $25,73,75,99,123,153$

confiscation of synagogue, 233

confusion of construction, $36,46,119-126$,

I 38, I 52 f., I 58

controversy, theological, I 25

Coptic numerals, XL

coral, 75

-gatherer, 75

corruption in office, $\mathrm{L}$

credit, transfer of, 237,239

cryptic style, $18 \mathrm{f} ., 50,95,99,133,15 \mathrm{I}$, $165 \mathrm{ff}$.

"dancer," I 79

dating, 4, 35

Day of Atonement, 57, 209, 21 3

debt, $\mathbf{I}-5,25$

divorce, $27 \mathrm{ff}$, $58 \mathrm{ff}$., $26 \mathrm{I}$

documents, $3 \mathrm{ff}$.

"dogs," I 9

dowry, I $79 \mathrm{ff.}$, I 85

drinking, 2 I 3

dyeing business, XIV

earthquake, 3 I

"elephant," 94

expenses, XXXVI

fear of the supernatural, $106 \mathrm{f}$.

fees, XXXVI

festivals, 23

"Fifth," I 49

foreign influence upon Arabic, XXXIII

fractions, Egyptian, I64

"gazelles' blood," I 8 I

ghosts, $106 \mathrm{f}$.

"Glorious Place," $26 \mathrm{ff}$.

"gold"-names, 70

grammar, Hebrew, 123

halachic fragment, XLIV

1 Roman numerals refer to the documents, and Arabic numerals to the pages of this volume. The Indices do not cover the Introduction. 
handicrafts, I 53, I6 I

handiwork, bride's, I 79

hebraisms in Arabic, I62

Hebrew grammar, I 23

honey, 59

Hormuzī goods, I 80 , I 85

illegitimacy, 55

inheritance, laws of, 183

inspector, 165

i'rāb, 4 I

Jewish Quarter, Jerusalem, I2 I

Karaite document, I 79

Koranic expressions, I6o, I63

labor, requisitions of, $23 \mathrm{I}$

"lion"-names, 32, $66 \mathrm{ff}$.

liturgical memoranda (?), XLII

magic, 23, IO7 circle, $106 \mathrm{f}$.

mail, $45 \mathrm{ff}$.

Market of Exchange, 49

marriage-broker, XL, XLVII -settlement, XLV

maxims, I27, I75, 26I

meat-inspection, abuses in, 263

misappropriation of funds, 253, 255, 26 I

money-changer, 25

Monizah, swords of, 193

Moroccan money, I69

Muslims, relations with, I 27

names of God in magic, Io6 ff.

"obligation," I65

pamphlets, I $23 \mathrm{ff}$.

participle for imperfect, $5 \mathrm{I}$

partnership, 7 ff., 33, I9I

penitential hymn, $84 \mathrm{ff}$.

pepper, 87

persecution, 97, I 7 I

petition, XXXI, XXXII, XLVIII, XLIX

phonetic spelling, I 30

pirates, 50

pizmōnim, XVII, XIX, XX, XXXVIII

plene writing of vowels, 63

poll-tax, 23

pōseḳim, XLIV

prayer-book, X, XLVI

prepositions, XXVII "princes," $76 \mathrm{ff}$.

prohibitions, 209

pronunciation, $76 \mathrm{ff}$.

property settlement, XL

proverbs, I27, 26 I

quotations on money, 63

rajaz verses, 133

ransom, $5^{\circ}$

renting houses, 23, I 2 I

revenue-tax, 165

risks in business, $25 \mathrm{ff}$., $33 \mathrm{ff}$.

"runners," XLVII

saffron, I 53

salting of sacrifices, 2 I I

scrying, XV

"Second," I 49

Seleucid Era, 4, 35, I78

shoe, of a cripple, 2 I 5

"silver"-names, 7 I

skin diseases, 23

slavery, 50, I 59, $223 \mathrm{f}$.

soap, 23 I

speech mixture, 39,76

spell, for finding gold, 79

succuba, I06 $\mathrm{f}$.

sugar, I9I

"sugar"-names 66

sultan, 4 I, IO3

synagogue, destroyed by Muslims, 233

Talmud, XLIV

tartar, 25

tax-list, XII I

testament, IX

theft, 33

"tower," I 7 I

"trembler," I 79

ultima-accent, 82, 4I, 69

"uncircumcised" (Christian), I9I

vernacular forms of numerals, I 38

vow to live in Palestine, 25I, 26I

washing, 209

watermarks, XXVII, L

weaving business, I6 I

women, position of, 39

clothing of, XL

yeshībhāh, 26, I 59 


\section{INDEX OF PROPER NAMES ${ }^{1}$}

Aaron al-Șafīr, I 3 I

'Abd Allah aI-Labbān, 225

'Abd al-'Azīz, I 33, 229, 23 I

'Abd al-Karīm, I 33

'Abd al-Raḥmān, 229

Abraham Barakāt, $8_{3}$

Abraham Castro, 237, 24 I

Abraham Ben Ezra, 90

Abraham the Hazzän, $27 \mathrm{ff}$.

Abraham Jabartī, 193

Abraham aI-K̦ala $\mathfrak{t}$, I 53, 157

Abraham Maimūnī, I 35

Abraham Ma'rābī, 253

Abraham Ben Obadiah, 2 I 9

Abraham Pethīlāh, 259

Abraham, "Reader of the Law," I9 ff.

Abraham Ben Ședhāḳāh, al-'Afīf, I 3 I

Abraham Ben Shema'yäh, 7

Abraham Ibn al-Shuwaikh, 133

Abraham Skandarān̄̄ , 243

Abū Abraham Ismāìl Kạwḥ (?), 63

Abū Abraham Ibn Shbt, 95

Abū al-Afrāḥ al-Arjawan̄i, I ff.

Abū al-Afrāḥ 'Arūsah, Joseph, I65

Abū al-A'lā, I 27

Abū al-A'lā Ibn al-Bahwarī, 67

Abū al-'Alā Sā'id, 'Ulāh, I ff.

Abū al-A'lā Ibn Sha'yā, 67

Abū al-Bahā of Damascus, I3, I7

Abū al-Ētān, 127

Abū al-Faḍl, 125

Abū al-Faḍl al-Nūr Ibn al-Nūrr, I 5

Abū al-Faḍl Ibn 'Umrān, 97

Abū al-Faraj, 23, 25, 53, I 47

Abū al-Faraj Nissìm, 69

Abū al-Faraj of Tyre, I 27

Abū al-Habn (?), I 53

Abū al-Hajjāj, 99

Abū al-Hasan, 53, I 12 ff., I 55

Abū al-Hasan Isaac, I 59

Abū al-Hasan Șadaḳah, 69

Abū al-Hasan Sadaḳah Ibn Simon, 7 I

Abū aI-Ḥasan Salāmah, 97

Abū al-Hasan Sibā', 67
Abū al-Hayy, 23, 69, I 55

Abū al-Husain (?), 65

Abū al-Husain Ibn al-'`̄bid, 69

Abū al-Husain al-Dhahabī, 70

Abū Isaac Ibn al-'Assāl, 7 I

Abū Isaac Brhōn (?), 65

Abū Isaac Ibn Hujaij, 7 I

Abū Isaac al-Iskandarān̄i, 73

Abū Isaac Ibn Ṭayyibān, I 55

Abū 'Iț̣r Ibn Sufrāwī, 65

Abü Joseph MalüI Ibn Moses, $97 \mathrm{ff}$.

Abū al-Khair, 69

Abū al-Khair al-Bmārīn (?), 67

Abū al-Khair, the Proselyte, 69

Abū Manșūr, 69

Abū Manșūr, the Registrar, 67

Abū Manșūr Ibn Abū al-Faraj al-Ḳalyūbī, $36 \mathrm{ff}$.

Abū Manșūr Ibn Hayyīm, 67

Abū Moses Aaron, the Money-Changer, 7 I

Abū al-Mufaḍdal, I 59

Abü aI-Mufạ̣ḍaI Abraham Ibn Obadiah, 2 I $9 \mathrm{ff}$.

Abū Muḥammad, I66

Abū al-Munajjah, I 5

Abū Nașr, 69

Abū Nașr Ibn Mukhtāri, 69

Abū Sa'd, I 57

Abū Sa'd Abraham Ibn Abū al-Faḍl, Sahl al-Tustarī, I 43, I47

Abū (Bū) Sa'd Ibn Abū Salāmah Ibn 'Alī

Ibn al-Mașrī, I63

Abü Sa'd Ibn al-Kābisi, 67

Abū Sa'd Ibn al-Katā'if, 69

Abū Sa'd Ibn al-Sukkarī, 67

Abū $\mathrm{Sa}^{6} \overline{\mathrm{T}} \mathrm{d}(?), 65$

Abū Sa'īd, 94

Abü al-Sarūr, 53, 87, I63

Abū aI-Sarūr Ibn Ma‘ānī, 36 ff.

Abū al-Sarūr Sidr al-Maghribī, 7 I

Abūșīr, 96

Abū Sudūr (sic!) Farah, 67

Abū Thanā, 37 ff.

Abū 'Ulā, 23

1 Arranged according to the order of the Latin alphabet. Incomplete names, such as "Jacob," have not been included. Names have their English forms whenever possible. 
Abū al-'Ulā Bin Bū al-Faraj Bin 'Ayyārah, $32 \mathrm{ff}$.

Abū 'Umrān, 23

Abū "Umrān, "with the police," 69

Abū 'Umrān Moses lbn Abū al-Ḥayy, I 5 I ff.

Abū 'Umrān I bn Saghīr, 69

Abū Yaḥyā Nahrāi lbn Nissīm, I I6, I 29

Abū Yahyyā(?) Nathaniel lbn Nissìm lbn Mahabbah (?) lbn Mașrūf(?) lbn Moses, $63 \mathrm{ff}$.

Abū Zachariah, 87

Abū Zekharāi lbn Manasseh, 69

Abū Zekharāi Sūjmār, 69

Abü Zubair Șadaḳah al-Maghribī, I 6 , I 29

Aden, $45 \mathrm{ff}$.

al-'Afïf, Abraham Ibn Șadakah, I 3 I

'Afï Ibn Ezra, 253

Aḥmad Shūmān, 233

Aḥmad Ibn Sulaimān 1 bn Ibrāhīm, 83

'Ain al-Zaitūn, 263, 265

Aleppo, 26, 103, 229, 253

Alexandria, I4, I9, 33, $157 \mathrm{ff}$.

Alfāsī, $203 \mathrm{ff}$.

'Alî lbn Salmān (?), I 55

(Mar) 'Allān, 9, I I, I9

'Allān (?) l bn Yaḥyā, I 5 I, I 55

al-'Āmirī, 229

al-Anșārī, 5 I

Ariel, I 37

'Arūs, I ff.

Asher, I 27, 205

Ashī, 207

'Ațā', Jacob, 97

'Ațāllāh, 53

al-Athĩr, the Kādì, of Alexandria, $33 \mathrm{ff}$.

'Aț̣āirī al-Yāzūīī, 97

'Awwād al-Dīn, I 3

Azhar Bin Azhar, 7 I

al-Azhar Ibn Jonah, the Spaniard, $27 \mathrm{ff}$.

al-Ballūțī, I 2 I

Banyās (?), I 53

Barakāt, 5 I

Bayyān, the Hazzān, 53

Benari, 32

Benha al-'Asal, 59

Berākhōth Ibn Abū al-Manșūr, 39

Bilbais, I 3 ff., I 39

Bïria, 263

Brhōn (?), 65, 99

Būk, 27

Būṣìr, 96 f.

Būzār, 68

Byzantine Jews, 55

Cana of Galilee, I 4 I

Castro, Abraham, 237, $24 \mathrm{I}$

Ceylon, $45 \mathrm{ff}$.

Colombo, $45 \mathrm{ff}$.

Dabbāḥ, I7

Damascus, I39 ff., 23r, $249 \mathrm{ff}$.

Damietta, I 4

Dulce Bint lsaac lbn Joseph, Naaman, I 79

Edom, 84, I 49

Eleazar, 205

Elijah, Judge in Kalyūb(?), V111

Elijah ha-Kōhēn Ben Solomon, the "Fifth," I 99

Esther Bint Moses Ben Jacob he-Ḥākhām, Kuḷlī, I 83

Faḍl Farikah (?), I 89

Faraj Bin Nahum, $7 \mathrm{I}$

al-Fidḍ̄ī, Abū Isaac, 7 I

Finkelstein, 7 I

France(?), 99

Fusțāt, passim

Futūh the Egyptian, 53

Gā'ōn Ya'kōb (Yeshībhāh), 26

Gaza, I 39, 229

German, Kōhēn the, 259

Glanz, 7 I

Hākhām Ben lsaac, 233

Halākhōth Gedhōlōth, VI, XLIV

Halfōn ha-Lēvī, 95

Halfōn ha-Lèvī Ben Menasseh, I I

Hananēl, 203, 2 I 7

Hānēs, I 49

Hanūn, Yahyyā Bar Nissīm, I 87

Hassūn, I 9, 23

Hassūn 1 bn Isaac, 97 ff.

Hebron, i 8

Henassīyeh, I 48

Herz, 32

Hibah, 27, 69

Hilāl al-Atrūblusī, I 55

Hiyyā (sic ') Ben Moses Kōhēn, 259

Hiyyah Ben Samuel Kōhēn, 259

Holy Sepulchre, Church of the(?), 12 I

Huna, 209

Hurmuz, I 8 I, I 85

al-Husain, 2 I

1 bn Abūh, 67

lbn 'Ain al-Daulah, I 67

Ibn 'Ammō, 66 
Ibn (Bin) Asad Ibn Samuel Ibn Judah $32 \mathrm{ff}$.

Ibn 'Azūr (?), 95

Ibn al-Bașrī, I6I

Ibn Bushair, 69

Ibn Elias, 53

Ibn Ghurāb, 25

I bn (Bin) al-Kal'ī, 33

Ibn aI-Kuzdīrī, Hājj 'Alī, 45 ff.

Ibn Mufarrij al-Ubzārī, 69

Ibn Rahmah, 69

Ibn al-Rakkī, 97

Ibn al-Rifā, 67

Ibn Sahl, 69

I bn Sandabīsî̀, 4I

Ibn al-Shuwaikh, Abraham, I33

Ibn al-Tirmidhī, 67

Ibn 'Ulaik, I05

Ibn 'Umrān, 67

Ibn al-Zaiyāt, 47

Immanuel Ben Yehīēl, 6I

India, $47 \mathrm{ff}$.

Indian Ocean, 45

Isaac Ibn Abū Sa'd Ibn Muḷāsin, $8_{3}$

Isaac Ibn Khalf(?), 97

Isaac Kurshānt (?), 95

Isaac Māyō, I9I

Isaac Mḥln̄î, I93

Isaac Ibn Obadiah, 95

Isaac Șabāḥ, 245

Isaac Ben Samuel ha-Sephārdī, 7

Isaac the Spaniard, I 27

Isma'īn Shāwish (Shawīsh ?), 233

Israel Ben Israel Ben Daniel, I63

Jacob Ben Joseph, Father of the Law Court, 26

Jacob Ben Joseph ha-Hasīdh, Gā'ōn, 26 ff.

Janān, 2 I9

Jehu, 249

Jerusalem, $26 \mathrm{ff}$.

Joseph, the Scribe, I 89

Joseph Ben Aaron, 259

Joseph Hallūfī(?), I95

Joseph Ibn al-Dhahabī, Abū Jacob, 2 I9

Joseph Iskandarān̄i, 253

Joseph al-Jadid, 53

Joseph ha-Kōhēn ha-Shōfẹt Ben Solomon

Mebhōrākh Ben 'Lwn Ben Moses, the

"Fourth," XLIII

Joseph ha-Lêvir, 9

Joseph al-Maghribì, 53

Joseph Ibn Sadōk, 55

Joseph Sarakossī (Saragossĩ), L

Joshua Ben Shemaryah, 35
Josiah, Gā'ōn, 26

Judah, Rabbi in Cairo, 38

Judah Ben Jacob Ben Aaron, I 83

Judah ha-Kōhēn Ben Eleazar, Dayyān at Bilbais, I 3

Judah Maghribì, I 83

Judah Bar Solomon Bar Mēîr, Ibn Jiwā', I79

Kafr Kannah, I 4 I

Kafr Yasīf, 263

Kajījī, Benjamin, 237

Kajījî, Isaac, 237

Kalaf, oil-dealer, 7 I

Kalyūb, 37

Kamar, Sicilian, I 85

Kāmil, the Ayyubid, 38

Kațah, I 39, XLVII

Khalìj, Cairo, 54

al-Khānḳah, I 39

Kibhrē Abhōth (Hebron ?), I 19

Kifā', 37 ff.

Ḳuzdīr (Küuzdār?), 44

Lākish, 2 I I

Leben, 32

Lèvi, 33 et passim

Lfyj (?), 63

"lion"-names, 32, 66, 67

Lmāṭ (?), 67

Ma'add, Sultan, 143

al-Maghribī, I 5

al-Mahallah, I 5, 23 I

Maimonides, I 35, 177

Malīj, I 57 ff.

Malkīēl (?), 235

Manșür Ibn al-Khabīth, Byzantine Jew, 55

Manșür I bn Khalaf, 53

Manșūr Ibn Moses, Byzantine Jew, 55

Manzalah, 23 I

Market of Exchange, Cairo, 49

Maṣlīạ̣ Ben Samuel Kōhēn, 259

Ma'tūk, 257

Māyō, Isaac, I9I

Mebōrākh Ben Nathan, I I

Mē's̄r, Judah Bar Solomon Bar, I 79

Memūḥamān Ben Yapheth, 29

al-Mihdāwī, 3

Minyat Ziftah, I $3 \mathrm{ff}$.

Mishnah, 26I

Mīṭațrōn, angel, 77

Monza, Monscia, I93

Morocco, 94, I I6

Moses Ibn Abū Dirham, I 7 I 
Moses lbn al-Majānī, 69

Moses Nālẹūb(?), I 89

Moses lbn Radīi, I33

Moses di Trani (?), L

Mu'ayyad, Sultan, 192

Mubārak Ibn 'Udwān, 257

Muḥammad lbn Husain Ibn 'Alī Ibn Manșūr, 83

Muḥammad lbn Lu'lu', 229

Muḥammad Ibn Muṣtaphā Ibn 'Abd Allāh, 83

al-Muharrab, 25

Mūristān, I2 I

Musayyar lbn Jārah, 47

Naaman, XXXVIII

Nablus, 229

Nahrāi Ben Nathan, I $57 \mathrm{ff}$.

Nahrāi Ben Nissīm, $157 \mathrm{ff}$.

Nahrāi Ibn Nissīm, XXVII

Nathan-Hibah, 27, 69

Nathan, "the other witness," I 83, I85, I89

Nathan Ben Abraham, Nathan Ben Solomon, Father of the Law Court, "Second," I 99

Nathan ha-Kōhēn Ben Joseph ha-Kōhēn, 35

Nathan Ben Nahrāi, $157 \mathrm{ff}$.

Nathan Ben Samuel, Scribe of the Jewish Court, 35

Nathan Ben Solomon, I96

Nathan Ben Zachariah, $27 \mathrm{ff}$.

Nissīm Ben Banāyah, 97

Nissīm al-Maghribī, 69

Obadiah, His Excellency, I3I •

Obadiah Ben Samuel Kōhēn, 259

Perez, Rabbi, 255

Persia, 68

Pinto, Abraham, 235

Rabba Bar Bar-Hannā, 205

Raḍī, I 33

al-Rainlah, Academy at, $196 \mathrm{ff}$.

Raphael Isaac Ben Aaron Mayo, or Maggio, I 90

Rosetta, 165

Rubā'îyah, 12 I

Șadak̦ah, the Glazier, 7 I

Șadaḳah al-'Afïf, I 3 I

Șadakah Bin Jacob Bin al-Kal' ${ }^{\star}, 32 \mathrm{ff}$.

Șadak̦ah al-Ṣafinn, 7 I

Ṣadaḳah (Ṣedhāḳāh) lbn Sitt al-Ahl, 77 ff.
Șafīr, 13 I

al-Sa'îd, 139

al-Sa'īd al-Muwaffik, $15 \mathrm{ft}$.

Șalāḥ al-Dīn, I 3

al-Ṣālị̣īyah, I 39

Samuel, I33

Samuel Bahlūl, 263

Samuel Ben Halfōn ha-Lēvī, 259

Samuel Ben Jacob, 259

Samuel Karāblìs, I83

Samuel Mas'ūd, 257

Samuel Ben Yōḥai, 253

Sandabīs, 4 I

lbn Șaníah, I33

Saragossa, L

Sarūr Ben Sahlān, I 27

Sayyid Bū Sa‘d...Ibn Abū Salāmah Ibn 'Alī Ibn al-Mașrī, I63

Shabbatai Ben Abraham, of Minyat Ziftah, $13 \mathrm{ff}$.

al-Shafīk, I 39

Shapiro, I 3 I

al-Sharābī, I 2 I

Shbl al-Daulah, 5 I

Shēlāh Bar 'Amram, 6I

Shēlāh Bar Yakīn, 35

Shema'ya Gā'ōn, 7

Shilyā, $59 \mathrm{ff}$.

Shuḳrah lbn Moses, I3I

Sicilians, 75

Sicily, 123

Sikat, I 7 I

Sitt al-Ahl, $77 \mathrm{ff}$.

Sitt al-Dār Bint Isaac, 59

Sitt Nissim, 5 I

Solomon Ben Abraham Ben Ezra, 29

Solomon Ben David, 29

Solomon Iskandarān̄ , 235

Solomon Ben Judah, Gā'ōn, "First," 199

Solomon Ben Khalaf al-Būkēi, $27 \mathrm{ff}$.

Solomon ha-Kōhēn, 20 I

Solomon Ibn Yahyā, 3 I

Song of Solomon, cure for boils, $19 \mathrm{ff}$.

Spanish ship, I 23

Stamboul, I 8 I

al-Sukkar, Ibn Șanī‘ah, I 33

Sutait Bint Abraham, $37 \mathrm{ff}$.

Tahchemonites, I 37

Tamīm Bar Joseph, $37 \mathrm{ff}$.

Taposiris Magna, 96

Ṭayyibān, 7 I

al-Thiḳah, I 5

Tiberias, 23

Tirmidh, 67 
Tobiah, I $43 \mathrm{ff}$.

Tobiah Ben Daniel Gsbr, "Third," 201

Tripoli, I 55

Turkey, 253

Tyre, 127

'Ulāh ha-Lēvī Ben Joseph ha-Lēvī, I I

'Ulā Abū 'Umrān Moses, Reader of the Law, I $9 \mathrm{ff}$.

'Umrān the Sicilian, 75

Walad Isaac Abū Farah, 67

Yaḥyā, I 79
Yaḥyā Bar Nissīm Bar Menahem, İanūn, I 87

Yehōshua, $204 \mathrm{f}$.

Yehudah ha-Lēvī, poet, 9I

al-Yemen, i ff.

Yepheth Ben David Ben Shekhanya, 7

Yepheth the Hazzān, 7

Yeshāyā, 209

Yōḥānān, 2 I I

Zāhī, 257

Zeira, 204

Zuckermann, I 32

ARABIC AND HEBREW

See pp. xvi-xxii of the Introduction. 
Printed by W. Leivis, M.A. At the University Press CAMBRIDGE 


\section{University of Michigan Studies}

HUMANISTIC SERIES

General Editors : FRANCIS W. KELSEY and HENRY A. SANDERS

Size, $22.7 \times 15.2 \mathrm{~cm} .8^{\circ}$. Bound in cloth

Vol. I. Roman Historical Sources and Institutions. Edited by Henry A. Sanders, University of Michigan. Pp. vii +402. (Out of print.)

\section{CONTENTS}

i. The Myth about Tarpeia: Henry A. Sanders.

2. The Movements of the Chorus Chanting the Carmen Saeculare: Walter Dennison.

3. Studies in the Lives of Roman Empresses, Julia Mamaea: Mary Gilmore Williams, Mt. Holyoke College.

4. The Attitude of Dio Cassius toward Epigraphic Sources: Duane Reed Stuart, Princeton University.

5. The Lost Epitome of Livy: Henry A. Sanders.

6. The Principales of the Early Empire: Joseph H. Drake, University of Michigan.

7. Centurions as Substitute Commanders of Auxiliary Corps: George H. Allen.

Vol. II. Word Formation in Provençal. By Edward L. Adams, University of Michigan. Pp. xvii +607 . \$4.oo net.

Vol. III. Latin Philology. Edited by Clarence Linton Meader, University of Michigan. Pp. vii + 290. (Out of print.)

Parts Sold Separately in Paper Covers:

Part I. The Use of iden, ipse, and Words of Related Meaning. By Clarence L. Meader. Pp. I-I I 2. \$0.75.

Part II. A Study in Latin Abstract Substantives. By Manson A. Stewart, Yankton College. Pp. I I $3-78$. \$0.40.

Part III. The Use of the Adjective as a Substantive in the De Rerum Natura of Lucretius. By Frederick T. Swan. Pp. I79-214. \$o.40.

Part IV. Autobiographic Elements in Latin Inscriptions. By Henty H. Armstrong, Beloit College. P. 2r 5-86. \$0.40.

UNIVERSITY LIBRARY, ANN ARBOR, MICHIGAN OR

THE MACMILLAN COMPANY

Publishers 64-66 Fifth Avenue New York 


\section{University of Michigan Studies-Continued}

Vol. IV. Roman History and Mythology. Edited by Henry A. Sanders. Pp. viii +427 . (Out of print.)

Parts Sold Separately in Paper Covers:

Part I. Studies in the Life of Heliogabalus. By Orma Fitch Butler, University of Michigan. Pp. I-I69. \$I.25 net.

Part II. The Myth of Hercules at Rone. By John G. Winter, University of Michigan. Pp. I 7 I-273. \$0.50 net.

Part III. Roman Law Studies in Livy. By Alvin E. Evans. Pp. 275-354. $\$ 0.40$ net.

Part IV. Reminiscences of Ennius in Silius Italicus. By Loura B. Woodruff. Pp. 355-424. \$0.40 net.

Vol. V. Sources of the Synoptic Gospels. By Rev. Dr Carl S. Patton. Pp. xiii +263 . \$1.30 net.

$$
\text { Size, } 28 \times 18.5 \mathrm{~cm} .4 \text { to. }
$$

Vol. Vi. Athenian Lekythoi with Outline Drawing in Glaze VArnish on A White Ground. By Arthur Fairbanks, Director of the Museum of Fine Arts, Boston. With I 5 plates, and 57 illustrations in the text. Pp. viii $+37 \mathrm{I}$. Bound in cloth. $\$ 4.00$ net.

Vol. VII. Athenian Lekythol witi Outline Drawing in Matt Colok on a White Ground, and an Appendix: Additional, Lekythoi with Outline Drawing in Glaze Varnish on A White Ground. By Arthur Fairbanks. With 4I plates. Pp. $x+275$. Bound in cloth. $\$ 3.50$ net.

Vol. Vill. The Old Testament Manuscripts in the Freer Collection. By Henry A. Sanders, University of Michigan. With 9 plates showing pages of the Manuscripts in facsimile. Pp. viii +357 . Bound in cloth. $\$ 3.50$ net.

Parts Sold Separately in Paper Covers :

Part I. The Washington Manuscript of Deuteronomy and Joshua. With 3 folding plates. Pp. vi + I $04 . \$ 1.25$ net.

Part II. The Washington Manuscript of the Psalms. With i single plate and 5 folding plates. Pp. viii $+105-357$. \$2.00 net.

UNIVERSITY LIBRARY, ANN ARBOR, MICHIGAN OR

$$
\begin{aligned}
& \text { THE M A C M I L L A N C O M P A N Y } \\
& \text { Publishers } \quad \text { 64-66 Fifth Avenue New York }
\end{aligned}
$$




\section{University of Michigan Studies-Contimued}

Vol. IX. The New Testament Manuscripts in the Freer Collection. By Henry A. Sanders, University of Michigan. With 8 plates showing pages of the Manuscripts in facsimile. Pp. $x+323$. Bound in cloth. $\$ 3.50$ net.

Parts Sold Separately in Paper Covers:

Part I. The Washington Manuscript of the Four Gospels. With 5 plates. Pp. vii $+247 . \$ 2.00$ net.

Part II. The Washington Manuscript of the Eistles of Paul. With 3 plates. Pp. vii $+249-3$ I $5 . \$$ I.25 net.

Vol. X. The Coptic Manuscripts in the Freer Collection. By

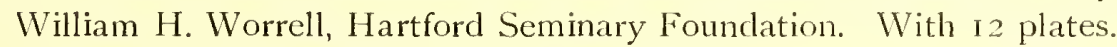
Pp. xxvi +396 . Bound in cloth. $\$ 4.75$ net.

Parts Sold Separately in Paper Covers:

Part I. The Coptic Psalter. The Coptic text in the Sahidic Dialect, with an Introduction, and with 6 plates showing pages of the Manuscript and Fragments in Facsimile. Pp. xxvi + I I 2. \$2.00 net.

Part II. A Homily on the Archangel Gabriel by Celestinus, Archeishop of Rome, and a Homily on the Virgin by 'Theophilus, Archbishop of Alexandria, from Manuscript Fragments in the Freer CollecTion and the British Museum. The Coptic Text, with an Introduction and Translation, and with 6 plates showing pages of the Manuscripts in facsimile. Pp. I I $3-396$. \$2.50 net.

Vol. XI. Contributions to the History of Science. (Parts I and II ready.)

Part I. Robert of Chester's latin Translation of the Algebra of AL-Khowarizm. With an Introduction, Critical Notes, and an English Version. By Louis C. Karpinski, University of Michigan. With 4 plates showing pages of the Manuscripts in facsimile, and 25 diagrams in the text. Pp. vii + I64. Paper covers. \$2.00 net.

Part II. The Prodromus of Nicolaus Steno's Latin Dissertation on a Solid Body Enclosed ey Process of Nature within a Solid. Translated into English by John G. Winter, University of Michigan, with a Foreword by William H. Hobbs. With 7 plates. Pp. vii $+\mathrm{I} 69-283$. Paper covers. \$I.30 net.

Part III. Vesuvius in Antiquity. Passages of Ancient Authors, with a Translation and Elucidations. By Francis W. Kelsey. Illustrated. (In preparation.)

UNIVERSITY LIBRARY, ANN ARBOR, MICHIGAN $O R$

THE MACMILLAN COMPANY

Publishers 64-66 Fifth Avenue New York 


\section{University of Michigan Studies-Contimued}

Vol. Xit. Studies in East Christian and Roman Art. By Charles R. Morey, Princeton University, and Walter Dennison. With 67 plates (IO colored) and 9I illustrations in the text. Pp. xiii +175 . Bound in cloth. \$4.75 net.

\section{Parts Sold Separately:}

Part I. East Christian Paintings in the Freer Collection. By Charles R. Morey. With I 3 plates (Io colored) and 34 illustrations in the text. Pp. xiii +86 . Bound in cloth. $\$ 2.50$ net.

Part II. A Gold Treasure of the Late Roman Period from Egypt. By Walter Dennison. With 54 plates and 57 illustrations in the text. Pp. 89-1 75. Bound in cloth. $\$ 2.50$ net.

Vol. Xili. Fragments from the Cairo Genizah in tile Freer Collection. By Richard Gottheil, Columbia University, and William H. Worrell, University of Michigan. Text, with Translation, Notes and an Introduction. With 52 plates showing the different styles of writing in facsimile. Pp. xxxi +273 . Bound in cloth. $\$ 4.00$ net.

Vol. XiV. Two Studies in Later Roman and Byzantine AdminIstration. By Arthur E. R. Boak and James E. Dunlap, University of Michigan. Pp. $\mathrm{x}+324$. Bound in cloth. \$2.25 net.

$$
\text { Parts Sold Separately in Paper Covers: }
$$

Part I. The Master of the Offices in the Later Roman and Byzantine Empires. By Arthur E. R. Boak. Pp. $\mathrm{x}+\mathrm{i} 60$. \$i.oo net.

Part II. The Office of the Grand Chamberlain in the Later Roman and Brzantine Empires. By James E. Dunlap. Pp. I6I-324. $\$ 1.00$ net.

Vol. XV. Greek Themes in Modern Musical Settings. By Albert A. Stanley, University of Michigan, With Io plates. Pp. xxii +385 . Bound in cloth. \$4.00 net.

$$
\text { Parts Sold Separately in Paper Covers: }
$$

Part I. Incidental Music to Percy Mackaye's Drama of Sappho and Phaon. Pp. I-68. \$.90 net.

Part II. Music to the Alcestis of Euripides with English Text. Pp. 7 I - I $20 . \$ .80$ net.

Part III. Music for the Iphigenia anong the Taurians by Euripides, with Greek Text. Pp. I23-2I4. \$.75 net.

Part IV. Two Fragments of Ancient Greek Music. Pp. 217-225. $\$ .3 \circ$ net.

Part V. Music to Cantica of the Menaechmi of Plautus. Pp. 229-263. $\$ .50$ net.

Part VI. Attis: A Symphonic Poem. Pp. 265-384. \$i.oo net.

UNIVERSITY LIBRARY, ANN ARBOR, MICHIGAN $O R$

THE MACMILLAN COMPANY Publishers 64-66 Fifth Avenue New York 


\section{University of Michigan Studies-Continued}

Vol. XVI. Nicomaciuss of Gerasa : Introduction to Arithmetic. Translated into English by Martin Luther D'Ooge, with Studies in Greek Arithmetic by Frank Egleston Robbins and Louis C. Karpinski. Pp. vii $+3 \mathrm{I} 8$. Bound in cloth. $\$ 3.50$ net.

Vols. XVII, XVIII, XIX, XX. Royal. Correspondence of tie ASSVRIAN EMPIRE. Translated into English, with a transliteration of the Text and a Commentary. By Leroy Waterman, University of Michigan. (In press.)

Vol. XXI. The Minor Prophets in tile Freer Collection and the Berlin Fragment of Genesis. By Henry A. Sanders, University of Michigan, and Carl Schmidt, University of Berlin. With plates. (In press.)

Vol. XXII. A Papyrus Codex of the Shepherd of Hermas. By Campbell Bonner, University of Michigan. (In press.)

\section{FACSIMILES OF MANUSCRIPTS}

Size, $40.5 \times 35 \mathrm{~cm}$.

Facsimile of the Washington Manuscript of Deuteronomy and JosiluA IN TIIE FREer COLLECTION. With an Introduction by Henry A. Sanders. Pp. x; 201 heliotype plates. The University of Michigan. Ann Arbor, Michigan, I9Io.

Limited edition, distributed only to Libraries, under certain conditions. A list of Libraries containing this Facsimile is printed in University of Michigan Studies, Humanistic Series, Volume VIII, pp. 351-53.

\section{Size, $34 \times 26 \mathrm{~cm}$.}

Facsimile of the Washington Manuscript of the Four Gospels In THE FREER Collection. With an Introduction by Henry A. Sanders. Pp. x; 372 heliotype plates and 2 colored plates. The University of Michigan. Ann Arbor, Michigan, I9I 2.

Limited edition, distributed only to Libraries, under certain conditions. A list of Libraries containing this Facsimile is printed in University of Michigan Studies, Humanistic Series, Volume IX, pp. 317-20.

$$
\text { Size, } 30.5 \times 40.6 \mathrm{~cm} \text {. }
$$

Facsimile of the Washington Manuscript of the Minor ProPHETS In the Freer Collection and the Berlin Fragment of Genesis. With an Introduction by Henry A. Sanders. With I 30 heliotype plates. (In press.)

\section{UNIVERSITY LIBRARY, ANN ARBOR, MICHIGAN}

OR

\section{THE MACMILLAN COMPANY}

Publishers 64-66 Fifth Avenue New York 


\section{University of Michigan Studies-Contimued}

\section{SCIENTIFIC SERIES}

Size, $28 \times 18.5 \mathrm{~cm} .4^{\circ}$. Bound in cloth

Vol. I. The Circulation and Sleep. By John F. Shepard, University of Michigan. I'p. ix +83 , with an Atlas of 63 plates, bound separately. Text and Atlas, $\$ 2.50$ net.

Vol. II. Studies on Divergent Series and Summaility. By Walter B. Ford, University of Michigan. Pp. xi + I94. \$2.50.

$$
\text { Size, } 23.5 \times 15.5 \mathrm{~cm} \text {. }
$$

Vol. III. The Geology of the Netherlands EAST Indies. By H. A. Brouwer. With I 8 plates and I 7 text figures. Pp. xii + I6o. $\$ 3.00$.

Vol. IV. The Glacial Anticyclones: The Poles of time AtmoSpheric Circulation. By William Herbert Hobbs. With 3 plates and 53 figures. Pp. xxiv + I98. \$2.75.

\section{University of Michigan Publications}

\section{HUMANISTIC PAPERS}

General Editor: EUGENE S. McCARTNEY

Size, $22.7 \times 15.2 \mathrm{~cm} .8^{\circ}$. Bound in cloth

The Life and Work of George Sylvester Morris: A Chapter in the History of American Thougit in the Nineteenth Century. By Robert M. Wenley, University of Michigan. Pp. xv + 332. \$1.50 net.

Latin and Greek in American Education, witi Symposia on the Value of Humanistic Studies. Edited by Francis W. Kelsey. Pp. $x+396$. \$I.50. (Out of print; new edition in preparation.)

The Present Position of Latin and Greek, the Value of Latin and Greek as Educational Instruments, the Nature of Culture Studies.

Symposia on the Value of Humanistic, Particularly Classical, Studies as a Preparation for the Study of Medicine, Engineering, Law and Theology.

A Symposium on the Value of Humanistic, particularly Classical, Studies as a Training for Men of Affairs.

A Symposium on the Classics and the New Education.

A Symposium on the Doctrine of Formal Discipline in the light of Contemporary Psychology.

UNIVERSITY LIBRARY, ANN ARBOR, MICHIGAN $O R$

THE MACMILLAN COMPANY Publishers 64-66 Fifth Avenue New York 


\section{University of Michigan Publications-Continued}

Size, $18 \times 12 \mathrm{~cm}$.

The Menaechin of Plautus. The Latin 'Text, with a Translation by Joseph II. Drake, University of Michigan. Pp. xi + I29. \$.6o net.

This edition of the Menaechmi was prepared, with stage directions, as a libretto for the presentation of the play at the University of Michigan in 1890 . It was revised and republished in 1916.

\section{LANGUAGE AND LITERATURE}

Vol. I. Studies in Shakespeare, Milton and Donne. By Members of the English Department of the University of Michigan. Pp. viii + 232. Cloth. $\$ 2.50$.

Vol. II. Elizabethan Proverb Lore in Lyly's 'Euphues' and in Pettie's 'Petite Palace, with Parallels from Shakespeare. By Morris P. Tilley. Pp. $x+46 I$. Cloth. $\$ 3.50$.

Vol. III. The Social Mode of Restoration Comedy. By Kathleen M. Lynch. Pp. $\mathrm{x}+242$. Cloth. \$2.50.

\section{HISTORY AND POLITICAL SCIENCE}

The first three volumes of this series were published as "Historical Studies" under the direction of the Department of History. Volumes IV and V were published without numbers.

Vol. I. A History of tile President's Cabinet. By Mary Louise Hinsdale. Pp. ix +355 . Cloth. \$2.00.

Vol. II. Englisit RUle in Gascony, I 199-1259, With Special ReFerence to tile Towns. By Frank Burr Marsh. Pp. xi +178. Cloth. \$1.25.

Vol. III. The Color line in Ohio; A History of Race Prejudice in A Typical Northekn State. By Frank Uriah Quillan. Pp. xvi + I 78 . Cloth. $\$$ I.50.

Vol. IV. Tile Senate and Treaties, i789-18i7 : The Development of the Treaty-Making Functions of the United States Senate during Their Formative Period. By Ralston Hayden, University of Michigan. Pp. xvi +237 . Cloth. \$1.50 net.

Vol. V. William Plumer's Memorandum of Proceedings in the United States Senate, i 803-1807. Edited by Everett Somerville Brown, University of Michigan. Pp. xi +673 . Cloth. $\$ 3.50$.

Vol, VI. The Grain Suprly of England during the Napoleonic PERIOD. By W. F. Galpin, University of Oklahoma. Pp. xi +305. Cloth. $\$ 3.00$.

UNIVERSITY LIBRARY, ANN ARBOR, MICHIGAN OR THE M A CM I L L A N COMPAN Y Publishers 64-66 Fifth Avenne New York 


\section{University of Michigan Publications-Contimued}

CONTRIBUTIONS FROM THE MUSEUM OF GEOLOGY

Vol. I. The Stratigraphy ani Fauna of the Hackberry Stage of THE Upper Devonian. By Carroll Lane Fenton and Mildred Adams Fenton. With 45 plates, 9 text figures and one map. Pp. $\mathrm{xi}+260$. Cloth. $\$ 2.75$.

All communications relative to the Numbers of Volume II should be addressed to the Librarian, General Library, University of Michigan.

Vol. II. No. I. A Possible Explanation of Fenestration in the Primitive Reptilian Skull, with Notes on the Temporal Region of the Genus Dimetrodon. By E. C. Case. Pp. I-I2, with five illustrations. \$O.3O.

No. 2. Occurrence of the Collingwood Formation in Michigan. By R. Ruedemann and G. M. Ehlers. Pp. I3-I8. \$O.I 5.

No. 3. Silurian Cephalopods of Northern Michigan. By Aug. F. Foerste. Pp. 19-\$6, with I7 plates. \$I.00.

No. 4. A Specimen of Stylemys nebrascensis Leidy, with the Skull Preserved. By E. C. Case. Pp. 87-9I, with 7 text figures. \$0.20.

No. 5. Note on a New Species of the Eocene Crocodilian Allognathosuchus $A$. wartheni. By E. C. Case. Pp. 93-97, with I plate and I text figure. $\$ 0.20$.

No. 6. Two New Crinoids from the Devonian of Michigan. By G. M. Ehlers. Pp. 99-I04, with I plate. \$o.20.

No. 7. New Brachiopods from the Warsaw Formation of Wayne County. By G. M. Ehlers and M. S. Chang. Pp. IO5-I I I, with I plate. \$o.2O.

No. 8. The Richmond Formation of Michigan. By R. C. Hussey. Pp. I I 3-I 87, with I I plates, I 2 text figures and I map. \$0.75.

\section{UNIVERSITY OF MICHIGAN COLLECTIONS}

Catalogue of the Stearns Collection of Musical Instruments (Second Edition). By Albert A. Stanley. With 40 plates. Pp. 276. $\$ 4.00$.

\section{PAPERS OF THE MICHIGAN ACADEMY OF SCIENCE, ARTS AND LETTERS}

(Containing Papers submitted at Annual Meetings)

Editors: EUGENE S. McCARTNEY AND PETER OKKELBERG

Size, $24.2 \times 16.5 \mathrm{~cm}$. $8^{\circ}$. Bound in cloth

VOL. I. (I92I). With 38 plates, I text figure and 5 maps. Pp. xi +424 . $\$ 2.00$ net.

VOL. IJ. (I922). With I I plates and 7 text figures. Pp. xi $+226 . \$ 2.00$ net. Bound in paper, \$I.5O net.

VoL. III (I923). With 26 plates, I 5 text figures and 3 maps. Pp. xii + 473. \$3.0o net. Bound in paper, \$2.25 net.

VOL. IV (I924), PART I. With 27 plates, 22 text figures and 3 maps. Pp. xii $+63 \mathrm{I} . \$ 3.00$ net. Bound in paper, $\$ 2.25$ net.

Vol. IV (I924), Part II. A Key to the SNakes of the United States, Canada And Lower California. By Frank N. Blanchard. With 78 text figures. Pp. xiii +65 . \$1.75.

VOL. V (1925). Pp. xii + 479. With 27 plates, 26 text figures and I map. $\$ 3.00$ net. Bound in paper, $\$ 2.25$ net.

VoLs. VI, VII (1926). (In press.)

UNIVERSITY: LIBRARY, ANN ARBOR, MICHIGAN $O R$

THE MACMILLAN COMPANY

Publishers 64-66 Fifth Avenue New York 


\title{
HELLENIC HISTORY
}

By George Willis Botsford

A survey of Greek life from its primitive beginnings to the year $3 \circ$ B.C., with an account of the political, social, economic, artistic, intellectual, and religious development. The book is abundantly illustrated.

\section{TABLE OF CONTENTS}

CHAPTER

I. Country and People

I1. The Minoan Age

II The Middle Age. Transition from Minoan to Hellenic Life

IV. Economic Growth and Colonial Expansion

V. Evolution of the City-State, Amphictyonies, and Lcagues

VI. Crete, Lacedaemon, and the Pelopounesian League

VII. Athens: From Monarchy to Democracy

VIII. Intellectual Awalsening: (I) Social and Literary Progress

IX. Intellectual Awakening: (II) Religious, Moral, and Scientific Progress

X. Conquest of the Asiatic Greeks by the Lydians and the Persians

XI. The War with Persia and Carthage

XII. The Age of the War Heroes: (I) Political and Economic

XIII. The Age of the War Heroes: (II) Society and Culture

XIV. The Age of Pericles: (I) Imperialism

XV. The Age of Pericles:(II) The Athenian Democracy

\section{CHAPTER}

XVI. The Age of Pericles: (III) Society and Public Works

XVII. The Age of Pericles: (IV) Thought, Culture, and Character

XVIII. The Peloponnesian War to the Beginning of the Sicilian Expedition

XIX. The Sicilian Expedition and the Last Years of the WVar

XX. A Cultural Revolution

XXI. The Lacedaemonian Empire and the Ascendency of Thebes

XXII. Sicily and Magna Graecia

XXIII. The Rise of Macedon to 337

XXIV. Economy and Society

XXV. Social Aspects of the State

XXVI. Art and Intelligence in the Fourth Century

XXVII. Alexander's Empire and the Hellenistic Kingdoms

XXVIII. The Organization and Administration of the Hcllenistic States

XXIX. Hellenistic Culture: (I) City Construction and Art

XXX. Hellenistic Culture: (II) Philosophy, Science, and Literature

\section{A HISTORY OF ROME TO 565 A.D.}

By ARThur E. R. BOAk, Professor of Ancient History in the University of Michigan

A well-proportioned and accurately written history of Rome from the beginning of civilization in Italy to 565 A.D.

\author{
TABLE OF CONTENTS \\ INTRODUCTION \\ The Sources for the Study of Early Roman History \\ PART I \\ The Forerunners of Rome in Italy \\ PART II
}

The Early Monarchy and the Republic, from Prehistoric

Times to 27 B.C.

PART III

The Principate or Early Empire: 27 B.C. -285 A.D.

PART IV

The Autocracy or Late Empire : $285-565$ A.D.

Epilogue Chronological Table Bibliographical Note Index

Price $\$ 3.25$

On sale wherever books are sold

THE MACMILLAN COMPANY

Publishers 64-66 Fifth Avenue New York 


\title{
HANDBOOKS OF ARCHAEOLOGY AND ANTIQUITIES
}

\author{
EdTED BY PERCY GARDNFR AND FRANCIS W. KELSEY
}

\section{THE PRINCIPLES OF GREEK ART}

By Percy Gardner, Litt.D., Lincoln and Merton Professor of Classical Archaeology in the University of Oxford.

Makes clear the artistic and psychological principles underlying Greek art, especially sculpture, which is treated as a characteristic manifestation of the Greck spirit, a development parallel to that of Greek literature and religion. While there are many handbooks of Greek archaeology, this volume holds a unique place.

Nean Edition. Illustrated. Cloth $\$ 3.25$

\section{HANDBOOK OF GREEK SCULPTURE}

By Ernest A. Gardner, M.A., Professor of Archaeology in University College, London.

A comprehensive outline of our present knowledge of Greek sculpture, distinguishing the different schools and periods, and showing the development of each. This volume, fully illustrated, fills an important gap and is widely used as a text-book.

Illustrated. Cloth $\$ 4.25$

\section{ATHENS AND ITS MONUMEN'TS}

By Charles Heal, Weller, of the University of Iowa.

This book embodies the results of many years of study and of direct observation during different periods of residence in Athens. It presents in concise and readable form a description of the ancient city in the light of the most recent investigations. Profusely illustrated with Half-tones and Line Engravings.

Illustrated. Cloth $\$ 4.00$

\section{ROMAN FESTIVALS}

By W. WARde Fowler, M.A., Fellow and Sub-Rector of Lincoln College, Oxford.

This book covers in a concise form almost all phases of the public worship of the Roman state, as well as certain ceremonies which, strictly speaking, lay outside that public worship. It will be found very useful to students of Roman literature and history as well as to students of anthropology and the history of religion.

Cloth $\$ 2.5^{\circ}$

On sale wherever books are sold

\section{THE MACMILLAN COMPANY}

Publishers 64-66 Fifth Avenue New York 



